University of Nebraska - Lincoln

DigitalCommons@University of Nebraska - Lincoln

2000

\title{
Managing for Enhancement of Riparian and Wetland Areas of the Western United States: An Annotated Bibliography
}

David A. Koehler

United States Department of Agriculture

Allan E. Thomas

United States Department of Agriculture

Follow this and additional works at: https://digitalcommons.unl.edu/usblmpub

Part of the Environmental Sciences Commons

Koehler, David A. and Thomas, Allan E., "Managing for Enhancement of Riparian and Wetland Areas of the Western United States: An Annotated Bibliography" (2000). U.S. Bureau of Land Management Papers. 16. https://digitalcommons.unl.edu/usblmpub/16

This Article is brought to you for free and open access by the U.S. Department of the Interior at DigitalCommons@University of Nebraska - Lincoln. It has been accepted for inclusion in U.S. Bureau of Land Management Papers by an authorized administrator of DigitalCommons@University of Nebraska - Lincoln. 

Department of Agriculture

Forest Service

Rocky Mountain

Research Station

General Technical

Report RMRS-GTR-54

June 2000

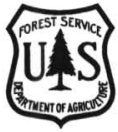

Managing for Enhancement of Riparian and Wetland Areas of the Western United States: An Annotated Bibliography

Compilers:

David A. Koehler

Allan E. Thomas

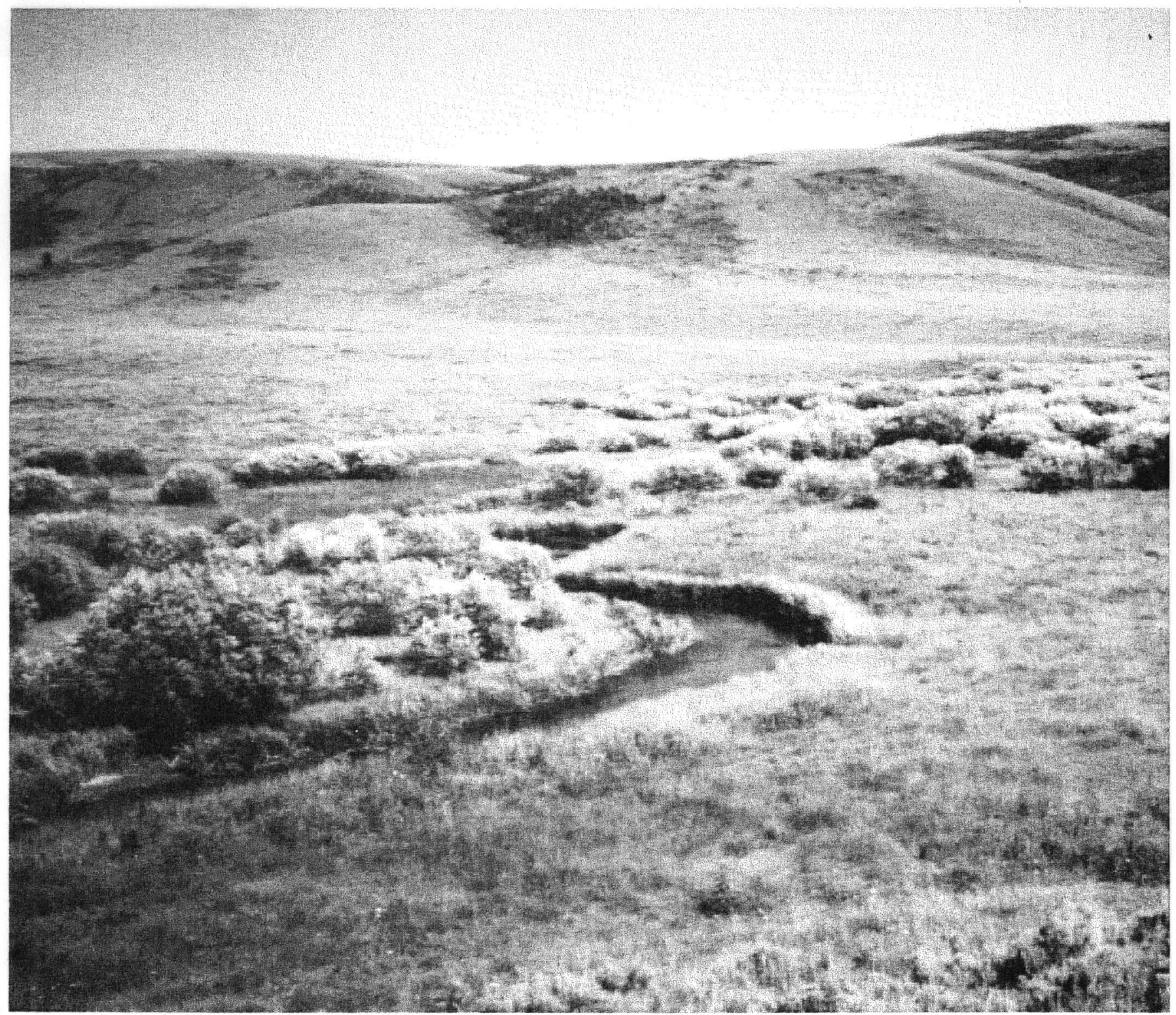




\section{Abstract}

Koehler, David A.; Thomas, Allan E., comps. 2000. Managing for enhancement of riparian and wetland areas of the Western United States: an annotated bibliography. Gen. Tech. Rep. RMRS-GTR-54. Ogden, UT: U.S. Department of Agriculture, Forest Service, Rocky Mountain Research Station. 369 p.

This annotated bibliography contains 1,905 citations from professional journals, symposia, workshops, proceedings, technical reports, and other sources. The intent of this compilation was to: (1) assemble, to the extent possible, all available and accessible publications relating to riparian management within a single source or document; (2) provide managers, field biologists, researchers, and others, a point of access for locating scientific literature relevent to their specific interest; and (3) provide, under one cover, a comprehensive collection of annotated publications that could dessiminate basic information relative to the status of our knowledge.

Key words: fisheries, geomorphology, grazing impacts, hydrology, riparian habitat, riparian restoration, riparian vegetation, watersheds, wetlands.

\section{The Compilers}

Davld A Koehler and Allan E. Thomas both recently retired from the Idaho State Office of the Bureau of Land Management, U.S. Department of the Interior. Koehler was a Rangeland Ecologist and Thomas was a Senior Wild life Biologist. Both are now pursuing second careers as environmental consultants in the private sector.

\section{Contents}

page
Introduction $\ldots \ldots \ldots \ldots \ldots \ldots \ldots \ldots \ldots \ldots \ldots \ldots \ldots$
Keyrnals List
Bibliography
Keyword Index




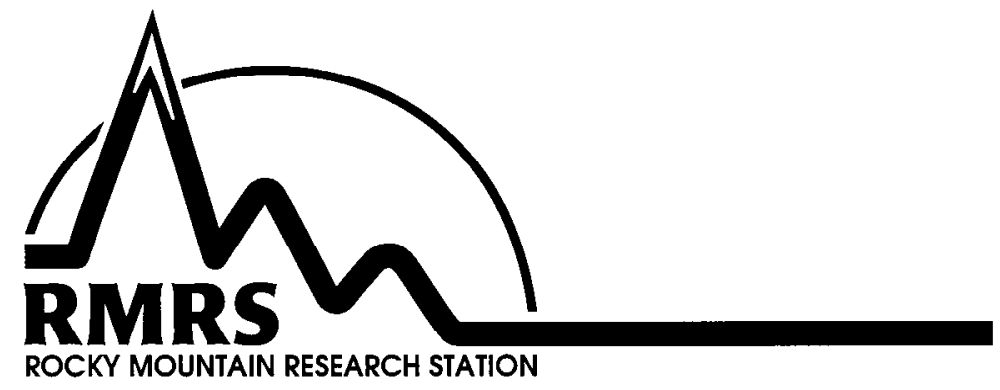

The Rocky Mountain Research Station develops scientific information and technology to improve management, protection, and use of the forests and rangelands. Research is designed to meet the needs of National Forest managers, Federal and State agencies, public and private organizations, academic institutions, industry, and individuals.

Studies accelerate solutions to problems involving ecosystems, range, forests, water, recreation, fire, resource inventory, land reclamation, community sustainability, forest engineering technology, multiple use economics, wildlife and fish habitat, and forest insects and diseases. Studies are conducted cooperatively, and applications may be found worldwide.

\section{Research Locations}

Flagstaff, Arizona

Fort Collins, Colorado*

Boise, Idaho

Moscow, Idaho

Bozeman, Montana

Missoula, Montana

Lincoln, Nebraska
Reno, Nevada

Albuquerque, New Mexico

Rapid City, South Dakota

Logan, Utah

Ogden, Utah

Provo, Utah

Laramie, Wyoming

*Station Headquarters, Natural Resources Research Center, 2150 Centre Avenue, Building A, Fort Collins, CO 80526

The U.S. Department of Agriculture (USDA) prohibits discrimination in all its programs and activities on the basis of race, color, national origin, sex, religion, age, disability, political beliefs, sexual orientation, or marital or family status. (Not all prohibited bases apply to all programs.) Persons with disabilities who require alternative means for communication of program information (Braille, large print, audiotape, etc.) should contact USDA's TARGET Center at (202) 720-2600 (voice and TDD).

To file a complaint of discrimination, write USDA, Director, Office of Civil Rights, Room 326-W, Whitten Building, 1400 Independence Avenue, SW, Washington, DC 20250-9410 or call (202) 720-5964 (voice or TDD). USDA is an equal opportunity provider and employer. 


\title{
Managing for Enhancement of Riparian and Wetland Areas of the Western United States: An Annotated Bibliography
}

\author{
Compilers: David A. Koehler and Allan E. Thomas
}

\section{INTRODUCTION}

The manuscript that follows has been a work-in-progress for nearly 20 years. In 1979, the Idaho State Office (ISO) of the Bureau of Land Management, United States Department of the Interior, began the process of collecting relevant publications and technical references to riparian and wetland sites and their management. Over that term, many colleagues and employees have contributed to the collection after encountering articles in the technical literature, copying them, and sending them to the central collection point. At this point in time, the assemblage of material fills almost two complete file cabinets and technical citations continue to proliferate. Periodically, ISO has attempted to publish and distribute bibliographies of the contemporary literature; technical bulletins containing these listing were published: Thomas and Wentzell (1986); Cuplin (1987); Clifton and Thomas (1988); Fisher and Thomas (1990). By 1995, when we conceived the idea of consolidating all of the assembled material into a comprehensive annotated bibliography, the subject area had become an extremely popular one. Symposia addressing riparian/wetland problems and solutions were being scheduled in many locations and professional journals offered increasingly more pertinent information. Our project, which seemed straightforward and simple at its inception, became a matter of pursuing a moving target. That target was not only moving, but accelerating.
This report makes no claims to represent a comprehensive or regionally complete collection of available citations. We recognized that logistical parameters would limit the scope and entirety of our efforts. Almost certainly, there are dozens --if not hundreds-- of other sources and papers that we were not able to access from our base of operations. Our apologies are extended to contributors to the collective literature if their efforts are not acknowledged here. Given time, resources, and access to other databases, this report could have been expandcd considerably. However, there is a point beyond which it is no longer is practical to proceed, at which additional efforts yield diminishing results. This product is not without limitations but is as complete and thorough as circumstances would allow.

The annotations included in the body of this report are aimed at a primary audience of ecologists, biologists, students, scientists, and natural resource managers who may employ the information for basic knowledge or utilize the material as building blocks for management strategies, resource dccisions, planning documents, and expanded research. A review of the literature reveals many overlaps among issues common to agriculture, landscape ecology, engineering, land use planning, biology, and other disciplines. The content of the abstracts and annotations has been tailored to interpret the biological implications of the various citations, even though the source document frequently had an engineering or other orientation. In short, the emphasis of this report 
was to provide a biological perspective to the issues and problems facing riparian areas and wetlands along with an ecosystem-based foundation for management and remedial actions.

There are 1,905 citations contained in this review, of which 1,837 are annotated. These vary considerably in length, based on the critical issues expounded in the original article or paper and also on the complexity of these. Papers which contained a single subject of observation or examination were obviously given less space than complex studies addressing multiple issues.

Papers that extended beyond our scope of interest were similarly abbreviated to restrict our citation to the essential information that directly regarded our relatively narrow focus.

Frequently papers originating in other regions of the United States, or even other countries, were included if they were perceived to be of general interest. In no way does the annotated information chosen for this document reflect the general merit or substance of the papers represented within.

A list of professional journals follows this introduction, some of which contributed multiple entries and others that offered relatively few, in some cases only a single citation. The list length, however, testifies to the rapid expansion of general interest in riparianwctlands management that has been generated in recent years.

The journals list, in turn, is followed by a keywords list, arranged alphabetically. This list has been consolidated and trimmed from the original draft, which contained various permutations of the same terms or subjects. Various authors employed different terms, depending on their own personal preference or professional discipline. Many of these terms were redundant or reiterative and were eliminated for the sake of simplicity. Conversely, a certain degree of specificity was admittedly lost during these reductions. Initially, we also considered arranging keywords under a primary ordination of general subject or search terms, with relevant keywords listed in a secondary ranking. This consideration was rejected, however, because of an emphasis on simplicity and the self explanatory nature of most keywords. Within the main text, all references have been assigned keywords. During the course of several editorial reviews, some keywords were added and some deleted. Those that remain were selected to adequately represent the subject matter without redundancy, overlap, or esoteric language

Finally, the citations with annotations are contained in the main body of the text and these are arranged alphabetically. There are a few of these that were submitted without journal references by our contributors and in all but a few of these we were able to locate the originating journal through secondary sources. When that was not possible, the citations were allowed to remain with a "unspecified" attribution. Keywords are assigned to all citations and in an addendum to the text, keywords are listed with all of the citations and entries that relate to them in order to facilitate any search for subject material.

Many people contributed time and efforts to the compilation of this manuscript. These include, but are not limited to the following, whom we gratefully acknowledge:

Paul Cuplin, Lucinda Eslick, Dr. Helen Fisher, Karl Gebhardt, Harriet Thomas, Jim Klott, Charlene Vullo, Sharon Olendorff, Melinda Rittacco, Dave Brunner, and Dr. Warren Clary. Special thanks are owed to Kim Peterson, who formatted and helped edit the manuscript. 


\section{JOURNALS LIST}

Acta Theriologica

Agricultural Engineer

Agricultural History

Agricultural Research

Agriculture, Ecosystems, and Environment

American Association for the

Advancement of Science

American Geophysical Union Transactions

American Institute of Hydrology

American Journal of Science

American Journal of the Soil Science Society

American Midland Naturalist (The)

American Society of Civil

Engineering Transactions

Annals of the Association of the

American Geographer

Artic and Alpine Research

Australian Journal of Ecology

Biogeochemistry

Biological Conservation

BioScience

California Fish and Game

Cal-Neva Wildlife Transactions

Canadian Field Naturalist

Canadian Geographer

Canadian Journal of Botany

Canadian Journal of Fish Aquatic Science

Canadian Journal of Forest Resources

Condor (The)

Coniferous Forest Biome Bulletin

Conservation Biology

Desert Plants

Earth Surface Processes

Earth Surface Processes and Landforms

Ecological Applications

Ecological Modeling

Ecological Monitoring

Ecological Monographs

Ecology

Engineering Geology
Environment

Environmental Conservation

Environmental Geology

Environmental Law

Environmental Management

EPA Journal

Fisheries

Forest Ecology and Management

Forest Science

Fly Fisherman

Freshwater Biology

Geology

Geological Society of America Bulletin

Green Thumb (The)

Great Basin Naturalist

Hydrological Science and Technology

Hydrological Sciences

Holarctic Ecology

Hydraulic Engineer

Idaho Law Review

Idaho Wildlife

IEEE Transactions on Geoscience and

Remote Sensing

International Association of Sedimentologists

Journal of Applied Ecology

Journal of Arid Environments

Journal of the Arizona-Nevada

Academy of Science

Journal of Biogeography

Journal of Canadian Forest Resources

Journal of Environmental Management

Journal of Environmental Quality

Journal of Environmental Systems

Journal of Fish Biology

Journal of Fisheries Management

Journal of Forestry

Journal of Freshwater Ecology

Journal of Geomorphology

Journal of Hydrological Engineering 
Journal of Hydrological Science

Journal of Hydrology

Journal of the Idaho Academy of Science

Journal of the Institute of Water Engineers and Scientists

Journal of Irrigation and Drainage Engineering

Journal of Range Management

Journal of Research of the U.S. Geological Survey

Journal of Soil and Water Conservation

Journal of Water Resource Planning and Management

Journal of Wildlife Management

Land and Water

Landscape Ecology

Landscape and Urban Planning

Line Rider (The)

Madrono

Montana AgResearch

Murrelet (The)

National Wildlife

Natural Areas Journal

New York Fish and Game Journal

New Zealand Agricultural Science

North American Journal of Fisheries

Management

Northwest Science

Oecologia

Oikos

Photogrammetric Engineering and Remote Sensing

Prairie Naturalist

Quaternary Research

Range Magazine

Rangelands

Rangeman's Journal

Renewable Resources Journal

Restoration Ecology

Restoration \& Management Notes

Restoration: Newsletter for the
Rivers

Oregon Sea Grant

Science

Sheep Research Journal, Special

Edition:1994

Soil Science of America Society

South African Journal of Science

Southwest Habitater

Southwestern Naturalist (The)

TOPS

Transactions of the 53rd North American

Wildlife and Natural Resources Conference

Transactions of the American

Geophysical Union

Transactions of the American Fisheries

Society

Transactions of the American Society

of Agricultural Engineers

Transactions of the American Society of Civil Engineers

Tree Physiology

Trees

Tropical Ecology

Unreferenced

USDI Fish and Wildlife Service Biological Report

Verhandlung Internationale Vereinigung Limnologie

Verhandlungen der Internationalen Vereinigung fur Thcoretische und Angenwandte Limnologie

Water Resources Bulletin (American

Water Resources Association)

Water Resources Research

Weed Technology

Western Birds

Western Jounal of Applied Forestry

Western Wildlands

Wild Earth

Wildlife Society Bulletin

Wilson's Bulletin

Zeitschrift fur Geomorphlogie 
KEYWORD LIST

A

ACID MINE WASTES

ADAPTIVE MANAGEMENT

AERIAL PHOTO

AGRICULTURAL IMPACTS

AIR TEMPERATURE

ALDER

ALGAE

ALPINE LAKES

AMPHIBIANS

ANADROMOUS FISH

AQUACULTURE

AQUATIC ECOSYSTEMS

AQUATIC PLANTS

ARCVIEW

ARROYOS

ARTHROPODS

ARTIFICIAL INTELLIGENCE

ASPECT

ASPEN

ASSESSMENTS

AVIAN ECOLOGY

AVIFAUNA

B

BACKWATERS

BAT SPECIES

BEAVER

BEDLOAD

BELOW-GROUND BIOMASS

BELOW-GROUND HERBIVORY

BENTHIC BIOMASS

BEST MANAGEMENT PRACTICES

BIBLIOGRAPHY

BIOCHEMICAL PROCESSES

BIODIVERSITY

BIOENGINEERING

BIOGEOMORPHIC TECHNIQUES

BIOLOGICAL CONTROL

BIOLOGICAL INTEGRITY

BIOMASS

BIOREMEDIATION

BIOTIC INDICES

BIOTIC POTENTIAL

BITTERBRUSH

BLM

BOREAL FOREST

BOSQUE
BROWN-HEADED COWBIRD

BROWSING EFFECTS

BUFFER STRIPS

BUFFER ZONES

BULL TROUT

BUTTERFLIES

C

CANADIAN RIVER

CANOPY

CARRYING CAPACITY

CHANNEL DYNAMICS

CHANNEL MORPHOLOGY

CHECK DAMS

CHEMICAL BUDGETS

CHEMICAL RESPONSES

CHEMICAL SINKS

CLASSIFICATION

CLEAN WATER ACT

CLIMATE

COBBLE MULCH AGRICULTURE

COLD DESERT SHRUBS

COLIFORM BACTERIA

COLLABORATION

COLORADO RIVER

COLORADO SQUAWFISH

COLUMBIA RIVER

COMPACTION

CONFLICT RESOLUTION

CONNECTIVITY

CONSENSUS

CONSERVATION

CONSERVATION BIOLOGY

CONTAMINATION

COTTONWOOD

COVER

COWFISH

COWFISH MODEL

CREATED WETLANDS

CRMP

CULTURAL IMPACTS

CULTURAL VALUES

CUMULATIVE IMPACTS

CUTTHROAT TROUT

CUTTINGS

D

DAMS 
DECISION MAKING

DECISION SUPPORT SYSTEMS

DECOMPOSER FOOD CHAIN

DEER BROWSING

DEFINITIONS

DEFOLIATION

DENDROCHRONOLOGY

DESERT SCRUB

DESERT STREAMS

DESERT TORTOISE

DESIRED FUTURE CONDITIONS

DETRITUS

DEWATERING

DIFFUSE-SOURCE POLLUTION

DISTURBED WILDLANDS

DIVERSION SITES

DORMANCY

DRAINAGES

DREDGING

DROUGHT EFFECTS

DRYLAND PLANTS

\section{E}

ECOLOGICAL CONDITION

ECOLOGICAL IMPACTS

ECOLOGICAL INTEGRITY

ECOLOGICAL NICHES

ECOLOGICAL PERTURBATIONS

ECOLOGICAL SITE

ECONOMIC VALUES

ECONOMICS

ECOSYSTEM MANAGEMENT

EDGE EFFECT

EDUCATION

EFFLUENTS

ELK GRAZING

EMERGENT VEGETATION

ENDANGERED SPECIES ACT

ENVIRONMENTAL MANAGEMENT

EPHEMERAL STREAMS

EROSION

EROSION CONTROL

EUTROPHICATION

EVALUATION

EVAPOTRANSPIRATION

EVOLUTION

EXCLOSURES

EXOTICS

EXPERIMENTAL DESIGN
F

FECAL MATERIAL

FEDERAL ENERGY REGULATORY COMMISSION

FENCING

FERTILIZATION

FIELD KEY

FIRE IMPACTS

FISH DISPERSAL

FISH HABITAT

FISH MANAGEMENT

FISH POPULATIONS

FISHERIES

FLOOD IMPACTS

FLOODPLAIN MANAGEMENT

FLUVIAL PROCESSES

FOOD CHAINS

FOOD WEBS

FORAGE PRODUCTION

FOREST EDGE

FOREST LAYERS

FOREST MANAGEMENT

FOREST SUCCESSION

FOREST WETLANDS

FORESTRY MANAGEMENT

FRAGMENTATION

FRESHWATER CONSERVATION

$\boldsymbol{G}$

GALLERY FOREST

GAP ANALYSIS

GARTER SNAKES

GEOLOGY

GEOMORPHOLOGY

GILA RIVER

GIS

GLOBAL WARMING

GLOSSARY

GRAMINOIDS

GRAZING IMPACTS

GRAZING TREATMENTS

GREEN-LINE METHOD

GREENHOUSE EFFECT

GROUNDWATER

GROWING SEASONS

GROWTH RATES

GULLY CONTROL

H

HABITAT MANAGEMENT 
HEADCUTTING

HEAVY METALS

HERBICIDES

HERBIVORY

HERPETOFAUNA

HISTORIC RECORDS

HUMAN IMPACTS

HYDRAULICS

HYDROCHEMICAL INFLUENCES

HYDROELECTRIC IMPACTS

HYDROGEOMORPHIC

HYDROLOGIC UNIT AREA

HYDROLOGY

HYDROPHYTES

\section{I}

IMPACT MITIGATION

INDIAN TREATY FISHING RIGHTS

INERTIA VALUES

INFILTRATION

INSTREAM STRUCTURES

INTEGRATED USE

INTERDISCIPLINARY TEAMS

INTERESTED PUBLICS

INTERNATIONAL RELATIONS

INVENTORY

INVERTEBRATES

IRRIGATION IMPACTS

ISOTOPE ANALYSIS

\section{$L$}

LACUSTRINE ECOLOGY

LAGOMORPHS

LAND ETHICS

LAND USE

LANDSCAPE ECOLOGY

LARGE WOODY DEBRIS

LEGAL ACTIONS

LIGHT ABSORPTION

LITTER FALL

LITTORAL ZONE

LIVESTOCK EFFECTS

LOGGING IMPACTS

LOTIC ECOSYSTEMS

\section{M}

MACROFAUNA

MACROHABITAT

MACROINVERTEBRATES

MAMMALS

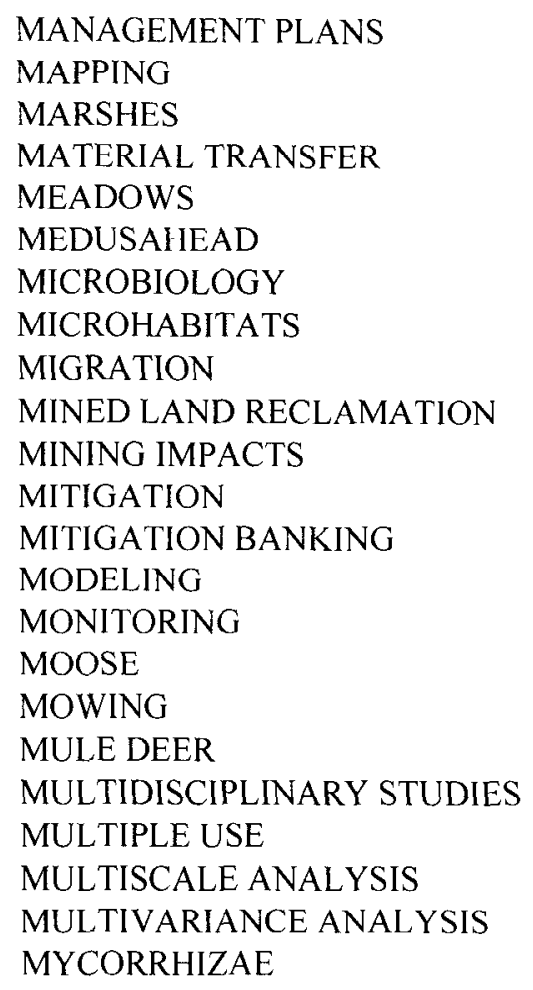

\section{$N$}

NATIONAL CONSERVATION AREA NATIVE FISHES NATIVE UNGULATES NATURAL AREAS NEOTROPICAL BIRDS NON-POINT SOURCE POLLUTION NUTRIENT CYCLES

\section{$\boldsymbol{O}$}

OIL/GAS IMPACTS

OLD-GROWTH FOREST

OPEN SPACE

ORGANIC DEBRIS

\section{$\boldsymbol{P}$}

PARASITISM

PARK MANAGEMENT

PARTICLE SIZE

PARTNERSHIPS

PASSIVE RESTORATION

PATHOGENS

PEATLANDS

PEBBLE COUNTS

PECOS RIVER

PERMITTING 
PFANKUCH STREAM CHANNEL EVALUATION

PHOTO PLOTS

PHOTOSYNTHESIS

PHREATOPHYTES

PINYON-JUNIPER

PLANNING

PLANT COMMUNITIES

PLANT IDENTIFICATION

PLANT MATERIALS

PLANT PHENOLOGY

PLANT PHYSIOLOGY

PLANT PRODUCTION

PLANT PROPAGATION

PLANT TISSUE

PLANT YIELDS

PLANT-SOIL RELATIONSHIPS

PLANTINGS

PLATTE RIVER

PLAYAS

POINT SOURCE POI LUUTION

POLICY

POLITICAL ISSUES

POLLUTION

POPULATION DYNAMICS

POTHOLES

PRECIPITATION

PREDATION

PREHISTORIC DISTURBANCE

PRESCRIBED BURNING

PRESCRIBED GRAZING

PRIMARY PRODUCTION

PROPER FUNCTIONING CONDITION

PROTECTED RIVERS

PROTOCOLS

PUBLIC COMMENT

PUBLIC LAND

PUBLIC TRUST DOCTRINE

PUEBLO INDIANS

PURPLE LOOSESTRIFE

\section{$\boldsymbol{R}$}

RANGE MANAGEMENT

RANGELAND ECOSYSTEMS

RANGELAND HEALTH

RANGELAND STREAMS

RAPTORS

RECREATION IMPACTS

RECRUITMENT

REDOX POTENTIAL

\author{
REFERENCE SITES \\ REGULATIONS \\ REMOTE SENSING \\ REPTILES \\ RESEARCH \\ RESEEDING \\ RESERVOIRS \\ RESILIENCY \\ RESOURCE CONFLICTS \\ REST ROTATION \\ RESTORATION PROJECTS \\ RIO GRANDE \\ RIPARIAN \\ RIPARIAN CONDITION \\ RIPARIAN ECOLOGY \\ RIPARIAN ENHANCEMENT \\ RIPARIAN FOREST \\ RIPARIAN HABITAT \\ RIPARIAN HEALTH \\ RIPARIAN ISSUES \\ RIPARIAN MANAGEMENT ZONE \\ RIPARIAN PASTURES \\ RIPARIAN PLANTS \\ RIPARIAN RESTORATION \\ RIPARIAN RIGHTS \\ RIPARIAN SHRUBS \\ RIPARIAN STRUCTURES \\ RIPARIAN STUDIES \\ RIPARIAN VALUES \\ RIPARIAN VEGETATION \\ RIPARIAN ZONES \\ RIPARIAN-WETLAND INITIATIVE \\ RIVER ECOLOGY \\ RIVER MEANDERS \\ ROAD IMPACTS \\ ROOT DEPTH \\ RUNOFF \\ RUSHES \\ $S$ \\ SAGEBRUSH \\ SALINITY \\ SALMON RECOVERY \\ SALMON RIVER \\ SALMONIDS \\ SALT MARSHES \\ SALT-CEDAR \\ SALT-TOLERANCE \\ SAMPLING \\ SANITARY LANDFILLS
}


SCENIC QUALITY

SCIENCE

SEASONAL POOLS

SECONDARY SUCCESSION

SEDGES

SEDIMENT TRANSPORT

SEDIMENTATION

SEED BANK

SEED PRODUCTION

SHADING

SHARP-TAILED GROUSE

SHOOT GROWTH

SHORELINES

SILT REMOVAL

SKAGIT RIVER

SMALL MAMMALS

SMZ

SNAKE RIVER

SNOW MELT

SOCIAL VALUES

SOIL TEMPERATURE

SOIL-WATER CONDITIONS

SOILS

SOLAR RADIATION

SOUTHWESTERN DESERT STREAMS

SPATIAL SCALE

SPAWNING HABITAT

SPECIES DISTRIBUIION

SPECIES RECOVERY

SPECIES RICHNESS

STANDARDS AND GUIDELINES

SIATE PARKS

STEELHEAD

STEWARDSHIP

STOCK PONDS

S'TORM EVEN'IS

STREAM ECOLOGY

STREAM FLOW

STREAM IMPROVEMENTS

STREAM TEMPERATURE

STREAM VELOCITY

STREAMBANK PROTECTION

STREAMBANK STABILITY

STREAMBEDS

STRESS

STUBBLE HEIGHT

SUCCESSION

SURFACE WATER-GROUNDWATER INTERACTION

SUSTAINABILITY

SWEETWATER RIVER
$T$

TECHNIQUES

TERRESTRIAL ECOSYSTEMS

TERRESTRIAL/AQUATIC INTERACTIONS

TOPSOIL

TOXICOLOGY

TRANSPLANTS

TREE DISTRIBUTION

TREE PRODUCTS

TREE SIZE

TREND

TRIBAL LANDS

TROUT

$U$

UPLAND VEGETATION

URBAN IMPACTS

UTILIZATION

UV RADIATION

V

VEGETATION MANAGEMENT

VEGETATION MANIPULATION

VIDEOGRAPHY

VOLUNTEERS

W

WARM WATER STREAMS

WASTEWATER

WATER ALLOCATION

WATER BALANCE

WATER BANKS

WATER CONSERVATION

WATER CYCLES

WATER FEATURES

WATER ISSUES

WATER LAW

WATER LEVELS

WATER LOSS

WATER PERMITS

WATER POTENTIAL

WATER QUALITY

WATER REGIMES

WATER RELATIONS

WATER RESOURCE MANAGEMENT

WATER RIGHTS

WATER SOURCES

WATER STRESS 


\author{
WATER SUPPLY \\ WATER TABLE EFFECTS \\ WATER TEMPERATURES \\ WATER TRAPPING \\ WATER TREATMENT \\ WATER TURBIDITY \\ WATER YIELD \\ WATERFOWL MANAGEMENT \\ WATERSHED \\ WESTERN JUNIPER \\ WETLAND LOSSES \\ WETLAND MITIGATION \\ WETLAND MITIGATION BANKING \\ WETLANDS \\ WETLANDS SEED BANK \\ WHITE-TAILED DEER \\ WHOOPING CRANES \\ WILD AND SCENIC RIVERS \\ WILD UNGULATES \\ WILDERNESS \\ WILDFIRE \\ WILLOW \\ WINDTHROW \\ WOODY DEBRIS \\ $X$ \\ XERORIPARIAN \\ $\boldsymbol{Y}$ \\ YELLOWSTONE NATIONAL PARK \\ YELLOWSTONE RIVER
}




\section{BIBLIOGRAPHY}

1. Abbruzzese, $B$; Allen, $A B$; Henderson, $S$; Kentula,ME (1988): Selecting sites for comparison with created wetlands. Un referenced, 291-297.

This paper describes a study conducted in Oregon by the US EPA to evaluate the success of wetland creation and restoration required as compensation for wetland losses permitted under Section 404 of the Clean Water Act. Methods for selecting natural wetlands to compare with created wetlands are described. Results of the sclection process and the advantages and disadvantages of the method are discussed.

[CREATED WETLANDS; RIPARIAN RESTORATION; WETLANDS]

2. Abernathy, Y; Turner,RE (1987): US forested wetlands: 1940 - 1980. BioScience 37(10), 721-727.

Forested wetlands are undergoing rapid changes from conversions to other uses. This article assesses the magnitude of those changes by summarizing USDA Forest Service field surveys from 1940 to 1980. The authors estimate that there has been a selective loss of forested wetlands up to five times higher than nonwetland forests over the past 40 years. The total loss of 2.74 million ha has occurred mostly in the Mississippi River valley floodplain where most of the forested wetlands are. Loss rates are continuing, albeit irregularly from one decade to the next.

[RIPARIAN FOREST; WETLANDS]

3. Adams,B; Fitch,L (1995): Caring for the green zone: Riparian areas and grazing management. Alberta Riparian Habitat Project. Publication No. I-581. ISBN: 0-7732-1435-6. 37 p.

Three decades of research by range managers, biologists, and hydrologists have shown us the value of riparian areas for forage production, maintenance of fish and wildlife populations and providing water to sustain human communities. It is now clear that the two percent of the rangelands which are riparian areas are disproportionately more important than their size would indicate. The key message is, riparian areas have significant importance, they are different from uplands and need to be managed differently. Research results also show us the difficulty of restoring the functions and values of these areas, after years of damage. By comparison, careful and thoughtful management has been shown to maintain riparian areas and all their functions and values.

[GRAZING IMPACTS; RIPARIAN HABITAT; RIPARIAN MANAGEMENT ZONE]
4. Adams, KR (1985): Annual phenological profiles of plants in and adjacent to two riparian habitats in southeastern Arizona. p.485-488. In: Johnson,RR; Ziebell,CD; Patton,DR; Ffolliott,PF; and Hamre, RH |tech. coord.|. Riparian ecosystems and their management: Reconciling conflicting uses. 16-18 April 1985. Tucson, AZ. USDA Forest Service. General Technical Report RM-120.

A suite of plants growing near a fresh water stream and in a cienega in southeastern Arizona at $5000-6000 \mathrm{ft}$ was observed and sludied over a 12-month period. Dates of flowering and fruiting and periods of leaf growth and stem elongation were recorded for trees, shrubs, herbaceous perennials and annuals growing in saturated and well-drained soils. Phenological profiles can provide insight into: a) animal use of wetlands, b) timing of reproductive events of closely related species, and c) the role local factors may play in phenological responses. [PLANT PHENOLOGY; RIPARIAN HABITAT; RIPARIAN PLANTS]

5. Adams,PC; Viereck,LA (1992): Multivariance analysis of woody plant succession on the Tanana River in interior Alaska. p. 4-10. In: Clary,WP; McArthur,ED; Bedunah,D; and Wambolt,CL |comp.|. Proceedings - Symposium on ecology and management of riparian shrub communities. USDA Forest Service. General Technical Report INT-289.

Woody plant succession on Alaskan floodplains was analyzed using multivariate techniques. Numerical classification results were consistent with the well-described vegetation chronosequence. Variation in community composition was high in intermediate stages, but decreased in later successional stages. Analyses support the contention that physical, fluvial controls of early succession are dampened by biotic factors in later successional stages.

[FLOODPLAIN MANAGEMENT; MULTIVARIANCE ANALYSIS; RIPARIAN HABITAT; SUCCESSION]

6. Adler, R (1996): The Clean Water Act: Has it worked? EPA Journal 20(1-2), 10-16.

In many ways, the Clean Water Act has been successful in the last twenty years. Pollution from point sources has been dramatically reduced and some threats to human health and the environment have also declined. Many problems continue, however, including the following: 1) we continue to release large amounts of toxic and other pollutants 
into our water, causing cumulative contamination of water, sediment, fish, and wildlife; 2) relatively little has been done to stop polluted runoff from farms, lawns, and city streets; and 3) the biological health of our waters is still declining. A revised CWA would address these flaws in the present law. [CLEAN WATER ACT; CONTAMINATION; NON-POINT SOURCE POLLUTION; WATER QUALITY]

\section{Agee,J (1979): Controlling water pollution} from grazing activities. p.15-17. In: Cope, $O B$ [ed.]. Forum: Grazing and riparian/stream ecosystems. 3-4 November 1978. Denver, $C O$. Trout Unlimited, Inc.

The water quality management planning for non-point sources like livestock grazing is primarily a state responsibility. The federal government, EPA, has very little regulatory authority to deal with non-point sources.

[GRAZING IMPACTS; NON-POINT SOURCE POLLUTION; WATER QUALITY]

8. Agee,JK (1987): Successional dynamics in forest riparian zones. In: Streamside management: Riparian, wildlife, and forestry interactions. An interdisciplinary symposium. 11-13 February 1987. University of Washington. Seattle, WA.

Forest riparian zones are characterized by disturbance, and maintain a reservoir of disturbance-oriented species within a matrix of usually less frequently disturbed forest. Disturbance can be high frequency/low magnitude, maintaining a stable distribution of riparian communities over time. Or, it can be low frequency/high magnitude, resulting in periods where early-successional and late-successional species alternate dominance. Disturbance is most often caused by flooding and its associated effects: sediment deposition, bank cutting, debris torrents, landslides, etc. Concurrently, edges of riparian areas are often buffered from direct effects of landscape-level disturbances such as fire, although indirect effects through water-based disturbance are likely to occur. A typical forest riparian zone will exhibit decreasing disturbance by landscape-level processes and increasing disturbance by water-based disturbance processes toward its core. The result is a zone with diverse species composition and structure.

[RIPARIAN ECOLOGY; RIPARIAN HABITAT; RIPARIAN ZONES; SPATI $A L$ SCALE]

9. Ainslic, BJ; Post,JR; Paul, AJ (1998): Effects of pulsed and continuous electrofishing on juvenile rainbow trout. North American Journal of Fisheries Management 18:905-918.

Injury rate varied from 15 to 39 percent, with PDC causing a greater number, but less severe, injuries than DC sampling. Electroshocking reduced mean growth rates of rainbow trout, but there were no statistically different differences in growth between treatment groups. Length growth was significantly reduced with increasing severity of injuries. Growth was directly impaired by the occurrence of associated spinal injury. Extrapolation of the experimental data to field studies in which 20 percent or less of the population is sampled suggested reductions of 3 percent or less in mean population growth with DC or low frequency PDC electroshocking.

[INVENTORY; MONITORING; TROUT]

10. Aitchison,SW (1977): Some effects of a campground on breeding birds in Arizona. p.175-182. In: Johnson,RR; Jones,DA [tech. coord.|. Importance, preservation, and management of riparian habitats: A symposium. 9 July 1977. Tucson, AZ. USDA Forest Service. General Technical Report RM-43.

Over a three-year period, breeding bird densities were found to be similar between a constructed campground and a relatively natural area when the campground was closed to campers. Once the campground was opened for human use, the breeding bird population decreased in density and diversity. On the control site, the population either remained the same or increased.

[AVIFAUNA; RIPARIAN HABITAT]

11. Alados,CL; Emlen,JM; Wachocki,B; Freeman,DC (1998): Instability of development and fractal architecture in dryland plants as an index of grazing pressure. .Journal of Arid Environments 38, 63-76.

Developmental instability has been used to monitor the well-being of natural populations exposed to physical, chemical, and biological stressors. Grazing pressure imposed by presumably co-adapted wild herbivores enhances developmental stability in species habituated to moderate grazing, like Oryzopsis hymenoides, but stresses plants such as Chrysothamnus greenii that prefer disturbed environments. These grazing effects are probably due to the impact grazing has on competitive relationships and not to the direct action of the herbivores on the plants.

[DRYLAND PLANTS; GRAZING IMPACTS] 
12. Alexander,EB; Kissinger,E; Huecker,RH; Cullen,P (1989): Soils of southeast Alaska as sinks for organic carbon fixed from atmospheric carbon dioxide. p.203-210. In: Alexander,EB [ed.]. Proceedings of Watershed '89: A conference on the stewardship of soil, air, and water resources. USDA Forest Service. Juneau, AK. 215 p.

More organic carbon is stored in soils than in living biomass. Most very poorly drained soils contain much more organic $\mathrm{C}$ than the vegetation on them. The average soil organic $\mathrm{C}$ on the Tongass National Forest was found to be $28 \mathrm{~km} / \mathrm{m} 2$, compared to a world mean of $10 \mathrm{~kg} / \mathrm{m} 2$. It is increasing because: 1) many glaciers in southeast Alaska are receding, exposing more land to colonization by plants, and 2) organic matter continues to accumulate in Histosols, which cover about $1 / 4$ of the land in southeast Alaska.

[RIPARIAN HABITAT; SOILS]

13. Alexander,EB [ed ]. (1989): Proceedings of Watershed '89: A conference on the stewardship of soil, air and water resources. 21-23 March 1989. Juneau, AK. USDA Forest Service. Juneau, AK. 215 p.

The proceedings of a conference in which some of the papers deal with riparian, wetland, or watershed issues. However, not all of the papers are relevant to this bibliography.

[BIODIVERSITY; RIPARIAN HABITAT; WATERSHED]

\section{Allan,DR; Marlow,CB (1992): Effects of} cattle grazing on shoot population dynamics of beaked sedge. p.89-91. In: Clary,WP;

McArthur,ED; Bedunah,D; Wamboldt,CL. [comp.|. Proceedings - Symposium on ecology and management of riparian shrub communities. USDA Forest Service. General Technical Report INT-289.

Grazing effects on number of new shoots produced by beaked sedge were examined on grazed and protected plots for two years. In the second year, grazed plots produced 27.4 percent more shoots than ungrazed plots. The greatest difference between grazed and ungrazed plots was in July. [GRAZING IMPACTS; POPULATION DYNAMICS; SEDGES; SHOOT GROWTH]

15. Allan,JD; Flecker,AS (1993): Biodiversity conservation in running waters. BioScience 43(1), 33-43.

In terms of biological diversity, streams and rivers are both rich in species and severely imperiled.
Habitat degradation and species invasion are the greatest threat to these systems. However, multiple factors frequently interact in the demise of species. In the coterminous United States, only 2 percent $(<100,000 \mathrm{~km})$ of the 5.2 million $\mathrm{km}$ of streams are of high enough quality to warrant federal protection. Present methods of protection address segment conservation instead of entire watersheds, the equivalent of forest fragments. A national policy of protected waters is urgently needed. Since habitat quality is of vital importance to biodiversity preservation, protective measures aimed at both instream and near-stream habitat conditions will benefit ecosystem functions and individual species. [BIODIVERSITY; RIPARIAN HABITAT; RIVER ECOLOGY; WATER QUALITY; WATERSHED]

16. Allan,PF; Anderson, WL (1955): More wildlife from our marshes and wetlands. p.589-596. In: Water: The yearbook of agriculture. 84th Congress. House Document No. 32.

Marshlands have been shrinking in size since colonial days as a result of industrial expansion, urbanization, agricultural drainage and development, sedimentation, and landfill of wetlands. [In 1955,] --Waterfowl and furbearers were the principal marsh products of economic value and the need to preserve marshes was becoming more urgent to maintain or expand production of those harvestable species. \{Reviewer's Note: In this early paper, there is no focus on marshes or wetlands as critical links in larger systems or scenarios. They are perceived as entities which produce specific marketable products instead of entities with important intrinsic values.\} [ECONOMICS; MARSHES; RIPARIAN HABITAT; WETLANDS]

\section{Allen,DR; Marlow,CB (1994): Shoot} population dynamics of beaked sedge following cattle grazing. Journal of Range Management 47(1), 64-69.

The authors studied the effects of cattle grazing on shoot density and flux in Montana beaked sedge stands for two years. Mean shoot density increased more in grazed than in ungrazed plots and ended 12-16 percent higher. Mean shoot emergence was 20 percent greater in the grazed than in the ungrazed plots. Mean shoot height declined similarly in grazed and ungrazed plots, indicating that shoot productivity was equal between treatments. Beaked sedge was tolerant of light to moderate grazing, given adequate regrowth between spring and fall treatments. [GRAZING IMPACTS; RIPARIAN PASTURES; 


\section{SEDGES]}

18. Allen,EB; Niering,WA (1997): Riparian restoration. Restoration Ecology 45(5), 1.

An editorial that introduces a Special

Supplement for the December 1997 volume of Restoration Ecology. Restoration research is especially needed for riparian wetlands, which are near the top of our national agenda. Papers contained in this volume will provide guidelines for riparian restoration efforts on both a national and global scale. [RIPARIAN RESTORATION]

19. Allen,EO (1968): Range use, foods, condition, and productivity of white-tailed deer in Montana. Journal of Wildlife Management 32(1), 130-141.

White-tailed deer use of vegetation types on the Missouri River floodplain and islands was surveyed. Meadows and alfalfa fields, respectively, accounted for 40 and 33 percent of summer observations, and 22 and 35 percent of fall observations. Fifty percent of winter and 19 percent of spring observations were in the cottonwood forests adjacent to the river.

Weed-infested fields accounted for 26 and 53 percent of winter and spring observations, respectively.

Western snowberry (Symphoricarpos occidentalis), occurring in the cottonwood vegetation type, was the most important food type.

[GRAZING IMPACTS; RIPARIAN HABITAT; WHITE-TAIL.FD DEER]

20. Allen,HH (1997): Bioengineering approaches to streambank stabilization at several sites within the United States. In: Proceedings of the Society of Wetland Scientists. 18th annual meeting.

Restoration and Management Notes 16:1:92.

This paper contains the findings of a four-year study of bioengineering techniques for erosion control on streambanks. Wide arrays of results are reported for techniques including dormant willow posts and emergent vegetation. The ability of planted willow posts to maintain themselves was noteworthy, even after four major flooding events.

[BIOENGINEERING; EROSION CONTROL; RIPARIAN RESTORATION; STREAMBANK STABILITY; WILLOW]

21. Allen,SD (1985): Estimating the economic value of recreation resources: A legal and policy perspective. p.426-432. In: Johnson, RR; Ziebell, CD; Patton, DR; Ffolliott, PF; Hamre, RH |tech. coord.|. Riparian ecosystems and their management: Reconciling conflicting uses. 16-18 April 1985. Tucson, $A Z$. USDA Forest Service.
General Technical Report RM-120.

Recent hearings on hydroelectric development in Montana by the Federal Energy Regulatory Commission shows that decision-makers can perceive recreation economics. A case study examines testimony presented on the estimated value of recreation at a dam site and the role and analyses of the outcomes.

[HUMAN IMPACTS; RECREATION IMPACTS; RIPARIAN HABITAT]

22. Allen-Diaz,B; Jackson,RD (1998): Cattle grazing effects on oak woodland spring ecosystems. p.146. In: Potts, DF [ed.|. Rangeland management and water resources: Proceedings of the AWRA specialty conference. American Water Resources Association. 27-29 May 1998. Reno, NV.

Three watersheds in northern California were studied to determine the effects of cattle grazing on the vegetation, channel morphology, water quality, and cold spring macroinvertebrates. With few exceptions, sites persisted as stable plant communities regardless of grazing intensity. No significant grazing treatment effects were detected in channel morphology or water quality parameters such as nitrate, orthophosphate, dissolved $\mathrm{O}$, temperature, or $\mathrm{pH}$. Repeated measures ANOVA indicated that insect family richness was significantly reduced on moderately grazed compared to lightly or ungrazed plots. The study suggests that attributes such as vegetation cover, channel morphology, or water quality which are commonly measured by rangeland and riparian systems may not be sensitive to grazing effects in this riparian ecosystem. [CHANNFI, MORPHOLOGY; GRAZING IMPACTS; LIVESTOCK EFFECTS; RIPARIAN FCOLOGY; WATER QUJAIITY; WATERSHFD]

23. Allen-Diaz,B; Jackson,RD; Fehmi,.IS (1998): Detecting channel morphology changes in California's hardwood rangeland spring ecosystems. Journal of Range Management 51(5), 514-518.

Changes in spring and subsequent creek channel morphology were estimated with permanent cross-sectional transects perpendicular to flow. Three grazing treatments (none, light, and moderate) were applied to two 5 ha pastures for five years on pastures containing a perennial spring and creek. No grazing effects on channel morphology were detected. Channel change over time appeared to be related to precipitation patterns. Cross-sectional transects on stream channels did not appear to be 
adequate to detect channel changes in low-flow spring/creek systems.

[CHANNEL MORPHOLOGY; GRAZING

IMPACTS; LIVESTOCK EFFECTS; RIPARIAN

PASTURES; STREAM ECOLOGY]

\section{Allred,MD (1993): Little Bear River} hydrologic unit area. p.359-363. In: Tellman, B; Cortner, HJ; Wallace, MG; DeBano, LF; Hamre, RH [tech. coord.]. Riparian management: Common threads and shared interests. USDA Forest Service. General Technical Report RM-226.

The Little Bear River Watershed consists of nearly 200,000 acres in northern Utah, of which 88 percent is privately owned. Since 1990 , the USDA Soil Conservation Service has undertaken planning and implementation for the Hydrologic Unit Area. The establishment of strong linkages between agencies has been critical to the implementation of water quality and riparian management applications. [HYDROLOGIC UNIT AREA; PLANNING; RIPARIAN MANAGEMENT ZONE; WATER QUALITY]

25. Almand,JD; Krohn,WR (1978): The position of the Bureau of Land Management on the protection and management of riparian ecosystems. In: Strategies for protection and management of floodplain wetlands and other riparian ecosystems. Callaway Gardens, GA. 1113 December 1978. USDA Forest Service. General Technical Report GTR-WO-12.

This paper discusses the USDI Bureau of Land Management's policy and procedures for protection and management of riparian ecosystems. Past abuses of riparian habitats are recognized as are future opportunities for improved management. Recent legislative/executive mandates require land managers to protect the natural function of riparian ecosystems. The result is a comprehensive program to adequately protect and manage components of riparian ecosystems.

[GRAZING IMPACTS; RIPARIAN MANAGEMENT ZONE]

26. Amaranthus,M; Jubas,H; Arthur,D (1989): Stream shading, summer streamflow and maximum water temperature following intense wildfire in headwater streams. p. 75-78. In: Proceedings of the symposium on fire and watershed management. 26-28 October 1988. Sacramento, CA. USDA Forest Service. Pacific Southwest Forest and Range Station. Berkeley,
CA. General Technical Report PSW-109. 164 p.

Adjacent headwater streams were monitored for post-fire shade, summer streamflow, and maximum water temperature following the Silver Complex Fire in southern Oregon. Variation in maximum water temperature increase was strongly correlated to streamflow and percent total streamside shade. [FIRE IMPACTS; RIPARIAN FOREST; RIPARIAN HABITAT; STREAM TEMPERATURE]

27. Ambasht,RS; Singh,MP; Sharma,E (1984): Soil, water and nutrient conservation by certain riparian herbs. Environmental Management 18, 99-104.

In order to assess experimentally the quantitative roles in binding the soil nutrient, nutrient conservation, and retarding runoff and soil erosion, six herbaceous species dominant on the bank of the River Gomti at Jaunpur, India, were selected. Young seedlings of these species were sown on sloping experimental plots in the Botanic Garden, Banaras Hindu University. Known quantities of water were sprayed on vegetated and bare plots, and runoff water and soil were collected in separate contained reservoirs. The physical-chemical properties of the soil of the bare plot, vegetated plots and eroded soils were compared to determine the role of these herbaceous species in maintaining soil quality and fertility.

[RIPARIAN HABITAT; RIPARIAN VEGETATION; SOILS]

28. American Fisheries Society (1997):

Watershed restoration: Principles and practices. Williams, JE; Wood,CA; Dombeck,MP [eds.]. American Fisheries Society, Sewickley, PA. [ECOSYSTEM MANAGEMENT; RIPARIAN RESTORATION; WATERSHED]

29. Ames,CR (1977): Wildlife conflicts in riparian management: Grazing. p.49-58. In: Johnson,RR; Jones,DA [tech. coord.]. Proceedings of the Symposium on importance, preservation, and management of the riparian habitat. 9 July 1977. Tucson, AZ. USDA Forest Service General Technical Report RM-43.

Grazing has a negative effect on riparian zones which constitute a small but critically important part of the overall range resource. Riparian types in southern Arizona have increased in the last 100 years due to stream eutrophication. This is most apparent where streams pass through grassland types. Effective protection of grazed riparian types can only be accomplished through fencing. 
[GRAZING IMPACTS; LIVESTOCK EFFECTS; RIPARIAN HABITAT]

30. Anderson,BW; Drake,J; Ohmart,RD (1977): Population fluctuations in nocturnal rodents in the lower Colorado River Valley. p.183-192. In: Johnson, RR; Jones, DA [tech. coord.]. Importance, preservation, and management of riparian habitats: A symposium. 9 July 1977. Tucson, AZ. USDA Forest Service. General Technical Report RM-43.

Examination of population fluctuations in a sample of over 10,000 rodents (five species) along the lower Colorado River Valley revealed distinct cycles (seasonal and annual) in (Perognathus penicillatus) and (Dipodomys merriami). There was a general population decline over the term of the study. There was significant interspecific asynchrony in different vegetation types. Significant interspecific asynchrony in population fluctuations renders the task of evaluating habitat difficult and subject to error unless carried out for prolonged periods in various vegetation types.

[RIPARIAN HABITAT; SMALL MAMMALS]

31. Anderson,BW; Engel-Wilson,RW; Wells,D; Ohmart,RD (1977): Ecological study of southwestern riparian habitats: Techniques and data applicability. p.146-155. In: Johnson,RR; Jones, DA [tech. coord.]. Proceedings of the Symposium on the importance, preservation, and management of riparian habitat. $9 \mathrm{July} 1977$. Tucson, AZ. General Technical Report RM-43.

This paper presents techniques used in a comparative ecological study of bird and rodent populations along the Lower Colorado River. Data were collected to examine faunal community relationships to various plant community types and to gain detailed knowledge of species' vegetational preference and niche within the riparian habitat. Parameters such as habitat breadth, habitat and niche overlap, and dispersal are instructive for the determination of a species' niche. [AVIAN ECOLOGY; ECOLOGICAL NICHES; RIPARIAN HABITAT; SMALL MAMMALS]

32. Anderson,BW; Higgins, A; Ohmart,RD (1977): Avian use of salt-cedar communities in the lower Colorado River Valley. p.128-136. In: Johnson, RR; Jones,DA [tech. coord.]. Importance, preservation, and management of riparian habitats: A symposium. 9 July 1977. Tucson, AZ. USDA Forest Service. General Technical Report RM-43.
Bird densities and species diversities in saltcedar (Tamarix chinensis) stands of the lower Colorado River Valley were determined on a seasonal basis. Results showed the salt-cedar community supported fewer birds than native communities, although tall, dense stands were valuable for nesting doves and rarer bird species along the lower Colorado River.

[AVIFAUNA; COLORADO RIVER; PHREATOPHYTES; RIPARIAN HABITAT; SALT-CEDAR]

33. Anderson,BW; Ohmart,RD (1977):

Vegetation structure and bird use in the Lower Colorado River Valley. p.23-33. In: Johnson,RR; Jones,DA [tech. coord.|. Importance, preservation, and management of riparian habitat: A symposium. 9 July 1977. Tucson, AZ. USDA Forest Service. General Technical Report RM-43.

Relationships between the avifauna and the structure of plant communities are presented. Correlations between bird population parameters and vegetation structural characteristics were found to vary seasonally. Mean habitat breadth of all species is narrowest with respect to vegetative structure in winter and broadest in summer. Winter requirements are different but equally as important as breeding requirements and should receive at least equal attention. The requirements of wintering visitors should receive special attention because they showed a higher degree of habitat specialization.

[AVIFAUNA; PLANT COMMUNITIES; RIPARIAN HABITAT]

34. Anderson,BW; Ohmart,RD (1977): Climatological and physical characteristics affecting avian population estimates in southwestern riparian communities using transect counts. p. 193-200. In: Johnson, RR; Jones,DA [tech. coord.]. Importance, preservation, and management of riparian habitats: A symposium. 9 July 1977. Tucson, AZ. USDA Forest Service. General Technical Report RM-43.

Strong winds $(20-50 \mathrm{~km} / \mathrm{ph})$ may reduce avian censusing accuracy but winds below $20 \mathrm{~km} / \mathrm{ph}$ appear not to affect avian estimates. During winter, optimum census time is from 1 hour after sunrise to 2.5 hours after sunrise. In summer, the optimum period is 0.25 hours before sunrise to 1 hour after. [AVIFAUNA; CLIMATE; RIPARIAN HABITAT]

35. Anderson,BW; Ohmart,RD (1979): Riparian revegetation: An approach to mitigating for a 
disappearing habitat in the Southwest. p. 481-487. In: Swanson,GA [tech. coord.]. The mitigation symposium: A national workshop on mitigating losses to fish and wildlife habitat. USDA Forest Service. General Technical Report RM-65.

Revegetation of two test plots was implemented in riparian habitats along the lower Colorado River in Arizona and California to test the feasibility of using this technique to enhance operations or mitigate habitat losses. The data base consisted of plant and vertebrate community data collected monthly for a period of six years. Significant plant and animal correlations developed through community models led to the design of plant communities that predictably would provide maximum wildlife use values. Plant community development on revegetation sites have thus far produced higher wildlife values than predicted.

[RIPARIAN HABITAT; RIPARIAN RESTORATION]

36. Anderson,BW; Ohmart,RD (1985): Managing riparian vegetation and wildlife along the Colorado River: Synthesis of data, predictive models, and management. p.123-127. In: Johnson, RR; Ziebell,CD; Patton,DR; Ffolliott,PF; Hamre, RH [tech. coord.]. Riparian ecosystems and their management: Reconciling conflicting uses. 16-18 April 1985. Tucson, AZ. USDA Forest Service. General Technical Report RM-120.

Monthly vegetative and wildlife data were used to develop predictive models over a 7-year period in order to design wildlife enhancement projects. Implementation and testing occurred during the next four years.

[MODELING; RIPARIAN HABITAT]

37. Anderson,DC (1994): Demographics of small mammals using anthropogenic desert riparian habitat in Arizona. Journal of Wildlife Management 58(3), 445-454.

Resource managers attempting to rehabilitate degraded desert riverine ecosystems must understand the effects of vegetation management on riparian wildlife. The author used capture-recapture methods to investigate demography of small mammals in the xerified Colorado River floodplain, five years after treatment to replace salt-cedar with native woody plants. The site had become a mosaic of various vegetation types, including closed canopy cottonwood/willow. The site represents source habitat for most native small mammal species. High levels of measured biomass suggest the reclaimed site has potential to be important in local ecosystem functioning.

[RIPARIAN HABITAT; RIPARIAN

RESTORATION; SMALL MAMMALS]

38. Anderson,DC (1994): Are cicadas

(Diceroprocta apache) both a "keystone" and a "critical-link" species in lower Colorado River riparian communities? The Southwestern Naturalist 39(1), 26-33.

Apache cicada densities were estimated to be 10 individuals $/ \mathrm{m} 2$ within a closed-canopy stand of Fremont cottonwood/Goodding willow in a revegetated site adjacent to the lower Colorado River. The author estimates that up to $1.3 \mathrm{~cm}$ of water may be added to the upper soil layers annually through the feeding activities of cicada nymphs. This is equivalent to 12 percent of the annual precipitation received in the study area. Apache cicadas may have significant effects on ecosystem functioning via effects on water transport and thus act as a "critical-link" species in this southwestern desert riverine ecosystem. Cicadas emerged later within the cottonwood/willow stand than in salt-cedar/mesquite stands; this difference in temporal dynamics would affect their availability to several insectivorous birds and may help explain the birds' recent decline. [BIODIVERSITY; COTTONWOOD; INVERTEBRATES; RIPARIAN HABITAT; SALT-CEDAR]

\section{Anderson,EW (1987): Riparian area} definition - a viewpoint. Rangelands 9(2), 70 .

The author offers the following definition for "riparian area": ---a distinct ecological site, or combination of sites, in which soil moisture is sufficiently in excess of that otherwise available locally, due to run-on and/or subsurface seepage, so as to result in an existing or potential soil-vegetation complex that depicts the influence of that extra soil moisture. Riparian areas may be associated with lakes; reservoirs; estuaries; potholes; springs; bogs; wet meadows; muskegs; and intermittent or perennial springs. The soil-vegetation complex is the differentiating criterion.

[RIPARIAN; RIPARIAN HABITAT]

40. Anderson,JW; Beschta,RL; Boehne,PL; Bryson,D; Gill,R; Howes,S; McIntosh,BA; Purser,MD; Rhodes,JJ; Zakel,J (1993): A comprehensive approach to restoring habitat conditions needed to protect threatened salmon species in a severely degraded river - The upper Grande Ronde River anadromous fish habitat protection, restoration, and monitoring plan. 
p.175-179. In: Tellman,B; Cortner,HJ;

Wallace,MG; DeBano,LF; Hamre, RH [tech.

coord.|. Riparian management: Common threads and shared interests. USDA Forest Service. General Technical Report RM-226.

The Grande Ronde River, a tributary to the Snake River, is the center of a 3,950 square mile watershed in northeast Oregon. It is critical habitat for spring chinook salmon and steelhead. The primary goals of the plan were to reduce sediment loads and summer water temperatures, and to re-establish natural loading of large, woody debris to the streams. It also proposed watershed management measures aimed at reducing high sediment loads caused by past activities. The plan is broadly adaptable to other northwestern watersheds that have undergone similar degradation.

[MONITORING; RIPARIAN HABITAT; RIPARIAN RESTORATION; WATERSHED]

41. Anderson,MT (1985): Riparian management of coastal Pacific ecosystems. p.364-368. In: Johnson,RR; Ziebell,CD; Patton,DR; Ffolliott,PF; Hamre, RH [tech. coord.]. Riparian ecosystems and their management: Reconciling conflicting uses. 16-18 April 1985. Tucson, AZ. USDA Forest Service. General Technical Report RM-120.

Along the Pacific coast of Oregon are riparian areas where high value conifers stand near streams bearing salmonid fisheries. Riparian areas are managed by setting objectives that allow for limited timber harvest along with stream protection. Annual timber sale quantity is reduced by 13 percent in order to protect riparian values and fishery resources. [LOGGING IMPACTS; RIPARIAN HABITAT; RIPARIAN MANAGEMENT ZONE]

42. Anderson, MW (1985): Protection of riparian lands through tax incentives. p.433-434. In: Johnson,RR; Ziebell,CD; Patton,DR; Ffolliott,PF; Hamre, RH [tech. coord.]. Riparian ecosystems and their management: Reconciling conflicting uses. 16-18 April 1985. Tucson, AZ. USDA Forest Service. General Technical Report RM-120.

Coalitions of professional societies and conservation groups sponsored legislative initiatives to protect, enhance, and manage riparian lands. Idaho House Bill 105 involves landowners in a voluntary riparian conservation program that provides a tax credit for costs of rehabilitation projects. [RIPARIAN RESTORATION; WATER LAW]

43. Anderson,PA; Brechtel,S; Ambrock,KR (1988): The Alberta landowner habitat project. p.113-120. In: Proceedings of the national symposium on the protection of wetlands from agricultural impacts. 25-29 April 1988. Ft. Collins, CO. USDI Fish and Wildlife Service. Biological Report 88(16).

A three-year pilot project aimed at providing incentives to private landowners to retain and enhance wildlife habitat on their own lands was initiated in Alberta in 1986. Through field coordinators, these incentives are offered to landowners by negotiation and include rental or habitat retention agreements as well as various habitat enhancement opportunities. Various indirect incentives are also being promoted including signage and recognition to landowners and, wherever possible, encouragement of conservation-oriented farming practices.

[AGRICULTURAL IMPACTS; RIPARIAN HABITAT; WETLANDS]

44. Anderson,S (1993): Livestock management effects on wildlife, fisheries, and riparian areas: $A$ selected literature review. USDA Forest Service. Humboldt National Forest.

This is a selected bibliography that focuses on citations, many annotated, found in the literature regarding the effects of livestock grazing on riparian habitat and aquatic and terrestrial wildlife. 102 citations are listed.

[AQUATIC FCOSYSTEMS; BIBLIOGRAPHY; GRAZING IMPACTS; RIPARIAN HABITAT]

45. Anderson, VJ; Hardin,PJ (1992): Infrared photo interpretation on non-riparian wetlands. Rangelands 14(6), 334-336.

Despite recent debates, modifications of regulations, and interpretations of wetlands policies, delineation of wetlands will likely continue to be necessary by law to conserve this critical resource. Approaches to make this evaluation logistically feasible and reasonably accurate will need further attention. Interpretation of infrared aerial photography holds promise as a useful technique. [AERIAL PHOTO; RIPARIAN HABITAT; WETLANDS]

46. Andrews,ED (1979): Hydraulic adjustment of the East Fork River, Wyoming to the supply of sediment. p.169-197. In: Rhodes,DD; Williams,GP [eds.|. Adjustments of the fluvial system. Proceedings of the tenth annual geomorphic symposium series. Binghampton, NY.

The increased sediment load of the East Fork River in western Wyoming in a single year 
downstream from the confluence with Muddy Creek was transported without an appreciable increase in water discharge. The hydraulic characteristics of the East Fork River downstream from the mouth of Muddy Creek have adjusted to the increased sediment load in order to maintain a quasi-equilibrium channel. Considerable time was required for a complete adjustment of the dependent variables. Initially, only roughness and depth adjust to accommodate a change in the independent variables. Then, after a number of years, channel width gradually changed until the hydraulic adjustment was distributed mutually among roughness, depth, width, and slope. Therefore, over a period of considerable time, the hydraulic geometry tends toward the minimum-variance condition. [CHANNEL DYNAMICS; GEOMORPHOLOGY; HYDRAULICS]

\section{Andrews, ED (1980): Effective and bankfull} discharges of streams in the Yampa River basin, Colorado and Wyoming. Journal of Hydrology 46, 311-330.

Effective discharge is defined as the increment of discharge that transports the largest fraction of the annual sediment load over a period of years.

Increments of the average annual total sediment load transported by the various discharges were calculated by the flow-duration, sediment transport-curve method for gaging stations in the Yampa River basin of Colorado and Wyoming. A total sediment-transport curve was constructed for each gaging station by adding measured instantaneous suspended-sediment discharges to bedload-sediment discharges computed from the Meyer-Peter and Mueller relation. Stream flow durations were compiled from the respective gaging station records. The quantity of sediment transported by discharges having various frequencies may be computed by combining these two relations. At all gaging stations, the effective discharge and the bankfull discharge were nearly equal. Thus, the stream channels appear to be adjusted to their effective discharge.

[FLOOD IMPACTS; GEOMORPHOLOGY; SEDIMENT TRANSPORT]

\section{Andrews, ED (1982): Bank stability and} channel width adjustment, East Fork River, Wyoming. Water Resources Research 18(4), 1184-1192.

Surveys of eight cross sections located in self-formed reaches of a Wyoming river showed a close relation between channel morphology and scour and fill. Cross sections narrower than the mean reach width filled at discharges less than bankfull and scoured at discharges greater than bankfull. Cross sections wider than the mean reach width scoured at discharges less than bankfull and filled at discharges greater than bankfull. A resurvey six years later showed that cross sections that scoured at discharges greater than bankfull had become 2-4 feet wider, whereas those cross sections that filled at discharges greater than bankfull were unchanged. Bank stability and adjustment of stream channel width appeared to be controlled by the processes of scour and fill. [CHANNEL DYNAMICS; CHANNEL MORPHOLOGY; STREAMBANK STABILITY]

49. Andrews,ED (1984): Bed-material entrainment and hydraulic geometry of gravel-bed rivers in Colorado. Geological Society of America Bulletin 95, 371-378.

In Colorado, 24 gravel-bed rivers in the Rocky Mountain region were selected for a detailed investigation of bed-material mobility and hydraulic geometry. Criteria for choosing the study reaches were: a non-braided channel with self-formed bed and banks, evidence of quasi-equilibrium, minimal flow regulation, and a streamflow gaging station of at least ten years. No significant differences between the hydraulic geometries of Colorado and British rivers with thick bank vegetation were found. The comparison of hydraulic-geometry equations for those rivers with thin bank vegetation determined that there was no difference in the width-versus-discharge relations. No significant difference was found for the exponents of the depth, velocity, and slope equations; however, the coefficient values were slightly different. [CHANNEL MORPHOLOGY; HYDRAULICS; SEDIMENT TRANSPORT]

50. Andrus, C; Froehlich,H; Summers,R; Heimann, D; Long, B (1987): Development of streamside vegetation following logging or fire in the Oregon Coast Range. In: Streamside management: Riparian wildlife and forestry interactions. An interdisciplinary symposium. 11-13 February 1987. University of Washington. Seattle, WA.

Regrowth of riparian vegetation following clearcutting and burning is rapid along coastal streams. Shading to the stream, as expressed by angular canopy density, reached 50 percent in less than five years and approached levels typical of old-growth forest by ten. Salmonberry and alder dominated the early stages of succession. Conifer seedlings were scarce, and dense brush prevented recruitment of 
conifer seedlings beyond the first years following logging and burning.

[RIPARIAN FOREST; RIPARIAN HABITAT; SHADING]

51. Angradi,T; Vinson, $M$; Contor,C; Riehle,M; Parker,J; Mende,B (1986): Fish population estimates for fenced and unfenced sections of Burnt Creek, Custer County, Idaho. Report to USDI Bureau of Land Management, Salmon District Office, Salmon, ID. 11 p.

Four sites were electrofished for trout population estimates. Three of the study sites were located in grazed areas, one in an ungrazed exclosure. One site was in a depositional area, all others were in erosional areas. Highest densities of trout were found in the ungrazed segment. Significantly greater lengths were also found in the ungrazed section. None of the sites appeared to offer over-wintering habitat for trout.

[FISH POPULATIONS; GRAZING IMPACTS; TROUT]

52. Anon. (1980): Management and protection of Western riparian stream ecosystems. Riparian Habitat Committee, position paper. American Fisheries Society, Western Division. Duff, D.[ed.]. [RIPARIAN HABITAT; RIPARIAN MANAGEMENT ZONE]

53. Anon. (1986): Beaver management program for the Wood River Resource Conservation and Development Area. (Woods River RC\&D Project assisted by USDA Soil Conservation Service. A report sponsored by the Blaine, Camas, Wood River, and Gooding Soil Conservation Districts).

A beaver management committee has been formed by public and private land managers within the Wood River Resource and Conservation and Development Project Area in central Idaho. The report outlines the goals of this committee and its beaver management policy.

[BEAVER; RIPARIAN MANAGEMENT ZONE]

54. Anon. (1990): The biodiversity challenge: By linking protected habitats, $\Lambda$ merica can aid the survival of nature's richness. Defenders of Wildlife Magazine Spccial Report.

The essay introduces concepts of island biogeography and applies these to wildlife survival on islands of natural habitat created by human conversion of landscapes. Wildlife conservation is discussed in terms of conservation of habitat types, the areal extent and continuity of habitats.
[BIODIVERSITY; GAP ANALYSIS; RIPARIAN

HABITAT]

55. Anon. (1994): Riparian road guide: Managing roads to enhance riparian areas. Terrene Institute. In cooperation with the US Environmental Protection Agency and USDA Forest Service. 33 p.

This booklet presents a number of cost-effective road construction practices that are easy to install and maintain. Their use can help local governments maintain clean water and safe roads while simultaneously enhancing and restoring the health and value of riparian areas. Solutions recommended here highlight inexpensive retrofits of roads that periodically wash out or erode during storms. Available cost information is also included. The guide was written primarily for local government personnel, elected officials, and road designers/contractors in the semi-arid southwestern United States. The general principles, however, are applicable to other regions of the country. [RIPARIAN HABITAT; ROAD IMPACTS]

56. Anthony,RG; Forsman,ED; Green,GA; Witmer,G; Nelson,SK (1987): Small mammal populations in riparian zones of different-aged coniferous forests. The Murrelet 68, 94-102.

Small mammals were trapped in riparian zones in young, mature, and old-growth coniferous forests in spring and summer of one year. More species, but fewer individuals, were captured on the streamside transects in comparison to the riparian fringe transects, $15-20 \mathrm{~m}$ from the stream. No species was solely dependent on riparian zones in old-growth forests; however, additional studies are needed. [BIODIVERSITY; RIPARIAN FOREST; RIPARIAN HABITAT; SMALL MAMMALS]

57. Anthony,RG; Forsman,ED; Green,GA; Witmer,G; Nelson,SK (1987): Small mammal populations in riparian zones of coniferous forests in western Oregon. In: Streamside management: Riparian management and forestry interactions. An interdisciplinary symposium. 11-13 February 1987. University of Washington. Seattle, WA.

Small mammal populations inhabiting low order riparian zones in three age classes of forests were compared. Contrast species composition and capture rates for streamside vs. riparian fringe transects were also compared. Deer mice were the most abundant species and comprised 76 and 83 percent, respectively. Total small mammal abundance was greater in old growth forests than in young and 
immature forests. More species but fewer individuals were captured on the streamside transects in comparison to the riparian fringe transects. [RIPARIAN HABITAT; SMALL MAMMALS]

58. Apple,LL (1983): The use of beavers in riparian/aquatic habitat restoration in a cold desert, gully-cut stream system: A case history. Proceedings of the 18th annual meeting, Colorado-Wyoming Chapter. American Fisheries Society. p. 29-35.

This paper describes another successful application of riparian restoration by transplanting beaver to a degraded ecosystem.

[BEAVER; RIPARIAN RESTORATION]

\section{Apple,LL (1984): Riparian habitat} restoration in cold desert, gully-cut stream systems: An innovative, cost effective, ecological approach. In: Proceedings of the 49th North American wildlife and natural resources conference. 23-28 March 1984. Boston, MA.

This poster paper described a case study of riparian habitat restoration in southwest Wyoming. After reintroduction of beaver and rest from livestock grazing, wildlife response to improved habitat was monitored. Bird transects, fish surveys, and wildlife observations indicated that wildlife response was substantial.

[BEAVER; RIPARIAN HABITAT; RIPARIAN RESTORATION]

60. Apple,LL (1985): Riparian habitat restoration and heavers. p.489-490. In: Johnson,RR; Ziebell,CD; Patton,DR; Ffolliott,PF; Hamre, RH [tech. coord.| Riparian ecosystems and their management: Reconciling conflicting uses. 16-18 April 1985. Tucson, AZ. USDA Forest Service. General Technical Report RM-120.

Materials were supplied to beavers in marginal habitats, resulting in habitat improvement. This practice was expanded to determine if both materials and beavers could be relocated to marginal areas. Results have been promising for stabilizing and improving riparian habitats.

[BEAVER; RIPARIAN HABITAT; RIPARIAN RESTORATION]

61. Apple,LL; Smith,BH; Dunder,JD; Baker,BW (1984): The use of beavers for riparian/aquatic habitat restoration of cold-desert, gully-cut streams in southwestern Wyoming. In: Proceedings of the American Fisheries Society/Wildlife Society joint chapter meeting.
8-10 February 1984. Logan, UT.

Several studies have been initiated in this locale to develop techniques for restoring and re-establishing degraded riparian and aquatic habitats. A major objective has been to utilize primarily "natural" systems to restore the habitat rather than use labor- and capital-intensive artificial methods. After reintroduction of beaver to fenced and unfenced study sites, aspen trees were delivered to the sites of beaver activity because large materials for stable dam construction were not available.

Newly built beaver dams are trapping sediment, reducing stream velocity, elevating the water table, and reducing the effects of seasonally fluctuating water table levels. In turn, this process is helping to encourage development of willow and other riparian plants in an expanded riparian zone, which is stabilizing banks and improving habitat. [BEAVER; RIPARIAN HABITAT; RIPARIAN RESTORATION]

62. Armacost,LV (1979): Lower Snake River fish and wildlife compensation. p.408-413. In: Swanson,GA [ed.]. The mitigation symposium: A national workshop on mitigating losses of fish and wildlife habitat. USDA Forest Service. General Technical Report RM-65.

In 1945, multipurpose water resource projects were authorized on the Lower Snake River without adequate provision for fish and wildlife compensation. With the realization of the impacts, compensation was authorized in 1976. This paper covers development of the plan and efforts to implement it.

[RIPARIAN HABITAT; SNAKE RIVER]

63. Armour,CL (1979): Critique of the Diamond Fork aquatic study. Proceedings of the Idaho water resources workshop. 27-29 November 1979. Boise, ID. USDI Bureau of Land Management. Idaho State Office.

This paper critiques a controversial study conducted at Diamond Creek, Utah. Many individuals have erroneously interpreted study results as definite proof that habitat improvement was attributable entirely to rest-rotation grazing and that rest-rotation grazing can be a management tool for solving most aquatic habitat problems. There were reportedly deficiencies in the experimental design that would have invalidated many of these conclusions.

[GRAZING IMPACTS; MONITORING; RIPARIAN HABITAT] 
64. Armour,CL (1978): Effects of deteriorated range streams on trout. Bulletin. Idaho State Office. USDI Bureau of Land Management. Boise, ID.

Improper management of domestic livestock on western ranges has caused habitat degradation of trout streams in some areas. As a result, there is either less trout production or conditions have deteriorated to such a degree that the fish cannot survive in streams. To accommodate requirements of sportsmen for additional fishing opportunities and to achieve national objectives for better balance in managing resources, it is necessary for habitat degradation problems to be solved. Livestock can alter the quality of stream habitat by damaging banks and decreasing the density of streamside vegetation. Bank damage, besides contributing to erosion and the alteration of channels, can eliminate important trout habitat associated with banks. When streamside vegetation is cropped unacceptably, erosion and sedimentation are promoted. If shading is decreased, water temperatures can elevate to levels unsuitable for trout. Sedimentation can lessen trout reproductive success and production of aquatic insects which are the predominant food base. Problem resolution will require interdisciplinary efforts and the cooperation of the livestock industry.

[FISHERIES; GRAZING IMPACTS; LIVESTOCK EFFECTS; STREAM ECOLOGY; TROUT]

65. Armour, CL (1979): Livestock management approaches and the fisheries resource. p.39. In: Cope, $O B$ [ed.]. Forum -- Grazing and riparian/stream ecosystems. 3-4 November 1978. Denver, CO. Trout Unlimited, Inc.

This presentation provided an overview of grazing and fish interactions; presented examples of management which had been implemented to enhance fish habitat; and encouraged development of innovative management practices for improving rangeland fisheries.

[FISHERIES; GRAZING IMPACTS; RIPARIAN MANAGEMENT ZONE]

66. Armour,CL; Duff,DA; EImore,W (1991): The effects of livestock grazing on riparian and stream ecosystems. Fisheries 16(1), 7-11.

Stream vegetation is most affected by grazing because riparian-aquatic zones are grazed more heavily than upland terrestrial zones. Most apparent effects on fish habitat include: reduction of shade, cover and terrestrial food, increased stream temperature, changed water quality and stream morphology, and addition of sediment. Aquatic insect food production for salmonid species is reduced by streambank vegetation removal and bank erosion causing streambed gravel sedimentation. Sediments hinder fry by covering waterfront gravel and impairing the survival and development of embryos. Damaged streams also support fewer public recreational opportunities.

[GRAZING IMPACTS; RECREATION IMPACTS; RIPARIAN HABITAT; SEDIMENTATION]

67. Arno,MK (1996): Reestablishing fire-adapted communities to riparian forests in the ponderosa pine zone. p.12-13. In: The use of fire in forest restoration. USDA Forest Service. General Technical Report INT-341.

Prior to 1900 , frequent, low-intensity fires occurred on upland forests in this forest zone at intervals of five to thirty years. With fire exclusion, dense understories and thickets of conifers developed, producing stands that are highly susceptible to a variety of insect and disease epidemics and severe wildfires. This paper describes a study in western Montana designed to create conditions that will allow a return of seral vegetation and will reduce the hazards of severe wildfire and insect and disease infestations.

[FIRE IMPACTS; RIPARIAN FOREST; RIPARIAN HABITAT; RIPARIAN VEGETATION]

68. Arnold,JG; Williams,JR (1987): Validation of SWRRB -Simulator for water resources in rural basins. Journal of Water Resource Planning and Management 113(2), 243-256.

The SWRRB model (simulator for water resources in rural basins) was developed for use in rural basins. The three major components of SWRRB are weather, hydrology, and sedimentation. Processes considered included: surface runoff, return flow, percolation, evapotranspiration, transmission losses, pond and reservoir storage, sedimentation, and crop growth. SWRRB can realistically simulate water and sediment yields under a wide range of soils, climate, land use, topography, and management conditions.

Moreover, it can provide a versatile and convenient tool for use in planning and designing water resources projects.

[HYDROLOGY; MODELING; WATER RESOURCE MANAGEMENT]

69. Aronson,JG; Ellis,SL (1979): Monitoring, maintainence, rehabilitation and enhancement of critical whooping crane habitat, Platte River, Nebraska. p. 168-180. In: Swanson,GA |ed.]. The mitigation symposium: A national workshop 
on mitigating losses of fish and wildlife habitats. USDA Forest Service. General Technical Report RM-65.

In 1978, a portion of the Platte River from Lexington to Denman, Nebraska was designated as critical habitat for the whooping crane. Changes in the flow regime of the Platte River have resulted in modification of the "pristine" riverine habitat, especially with respect to increasing vegetative encroachment on channel islands and decreasing wet meadow habitat. Desirable whooping crane roosting and feeding habitats have been adversely affected by vegetative encroachment and by decreasing groundwater levels. This paper explores the vegetative succession on Platte River islands, compares various river stretches on the basis of vegetative change over time, and discusses the potential for monitoring, maintaining, rehabilitating, and enhancing critical whooping crane habitat as means to mitigate future natural and/or man-made changes in the flow regime.

[MEADOWS; PLATTE RIVER; RIPARIAN HABITAT; STREAM FLOW; WHOOPING CRANES]

70. Ashkenas, I R (1995): Beyond walls: The myth of riparian forestry. p. 142-146. In: At the water's edge: The science of riparian forestry conference. 19-20 June 1995. Duluth, MN.

All land use practices have significant influences on landscape level patterns and processes. Forest practices such as road construction or harvest can have local influences on parameters ranging from streamflow and water quality to riparian plant and animal biodiversity. When these local, watershed-level impacts are combined with mixed ownership and mixed management objectives, the result is usually a fragmented and dysfunctional landscape. To effectively manage these landscapes, we must address both the historical practices that generated current patterns and conditions as well as how we want the ecosystem to look and function in the future. Landscape views imply that we must integrate processes and human activities across the land base.

[LANDSCAPE ECOLOGY; RIPARIAN FOREST; RIPARIAN HABITAT]

71. Ashmore,PE; Day,TJ (1988): Effective discharge for suspended sediment transport in streams of the Saskatchewan River. Water Resources Research 24, 864-870.

Sediment records for the Saskatchewan River range from 5 to 29 years. These were used to determine effective discharge for suspended sediment load for 21 sites. Drainage area for these sites range from 10 to over $300,000 \mathrm{~km} 2$. Percentage duration of the effective discharge ranged from 0.1 to 15.0 percent. There was a tendency for the percentage duration of the effective discharge to increase with the size of the drainage area downward through the drainage system.

[RUNOFF; SEDIMENT TRANSPORT; SEDIMENTATION; WATERSHED]

\section{Ashton,WS; Bredthauer,SR (1986):}

Riverbank erosion processes on the Yukon River at Galena, Alaska. p.415-423. In: Proceedings of the cold regions hydrology symposium. July 1986 . American Water Resources Association.

Periodic measurements of riverbank recession on the Yukon River at Galena, Alaska, have been made since 1946. Intensive studies of channel shape and riverbank erosion were conducted in 1959,1984 , and 1985. Erosion rates varied from $0.3 \mathrm{~m} / \mathrm{yr}$ at banks with developed vegetative protection (peat or bank debris) to $10.8 \mathrm{~m} / \mathrm{yr}$ at steep banks with active thermo-erosional niching. Comparison of channel profile measurements from June 1984 and June 1985 indicate that the thalweg did not significantly change location or elevation during a 10 -year recurrence interval flood.

[EROSION; GEOMORPHOLOGY; HYDROLOGY; STREAMBANK PROTECTION]

\section{Asplund,KK; Gooch,MT (1988):}

Geomorphology and the distributional ecology of Fremont cottonwood (Populus fremontii) in a desert riparian canyon. Desert Plants 9(1), 17-27.

Diameter Breast Height (DBH) data were collected from Fremont cottonwood in a desert riparian canyon in west-central Arizona. Recruitment was found to depend on geomorphologic features and flood "refugia" rather than on the absence of grazing. Fremont cottonwood is specifically a "strandline" streamside species, particularly of braided aggradations and their associated secondary channels, a microhabitat that ultimately depends on upstream and upslope erosion. The concept of flood-subclimax succession explains virtually nothing of the ecology of obligate riparian trees. Riparian classification based upon gcomorphology and hydrology are likely to have significant meaning for biogeography and management. [GEOMORPHOLOGY; GRAZING IMPACTS; RIPARIAN FOREST]

74. Atchley,JL (1989): Temperature, light, and 
soil effects on the establishment of Bebb's willow (Salix bebbiana). M.S. Thesis, Montana State University. Bozeman, MT. 54 p.

Bebb's willow is a common riparian shrub along Rocky Mountain foothill streams and springs. In eight-year-old grazing exclosures near Norris, Montana, decadent Bebb's willow has not reproduced by seed and its establishment requirements are uncertain. The effects of light, tempcrature, and soil type on Bebb's willow were examined in this study. Significantly more seeds germinated at 20 degrees $C$ than at any of four other temperature regimes.

Seedlings grown under the highest light intensity, 20 percent of full daylight, produced more biomass and taller shoots. There were no significant differences among soil treatments. Responses within light and soil treatments were not consistent. This species may possess a suite of reproductive strategies to establish under a variety of environmental conditions.

[RIPARIAN HABITAT; RIPARIAN SHRUBS; WILLOW]

75. Athearn, FJ (1988): Habitat in the past: Historical perspectives of riparian zones on the White River. p.73-75. In: Mutz,K; Cooper,DJ; Scott,ML; Miller,LK [eds.]. Restoration, creation, and management of wetland and riparian ecosystems in the American West. A symposium of the Rocky Mountain Chapter of the Society of Wetland Scientists. 14-16 November 1988. Denver, CU.

Beginning in 1880, much of the woody vegetation along the White River, Colorado, was removed for agricultural purposes. Elimination of vegetation resulted in increased runoff, unstable soils, and a reduction of surface vegetative cover. The present time indicates the reintroduction of cottonwoods and willows for bank stabilization. Restoration after human disturbance is occurring as landowners increasingly recognize the importance of riparian habitat.

[HISTORIC RECORDS; RIPARIAN HABITAT; RIPARIAN VEGETATION; RIPARIAN ZONES]

76. Atwill,R; Tate,KW; George,MR; McDougald,NK (1998): Transport of Cryptosporidium parvum oocysts out of fecal patties as a function of slope during simulated rainfall. p.446. In: Potts, DE [ed.]. Rangeland management and water resources: Proceedings of the AWRA specialty conference. American Water Resources Association. 27-29 May 1998. Reno, NV.

Cattle are often perceived as a primary source of the protozoal parasite, Crytosporidium parvum, and riparian green strips are advocated as one method to prevent non-point source contamination of drinking water. This study modeled the transport of $C$. parvum oocysts that leach out of cattle manure as a function of slope during simulated rainfall. Slopes of 5, 12, and 20 percent were uscd. Oocysts were rapidly transported across the one meter grass buffer strip regardless of slope. Peak concentrations of oocysts in overland flow were higher for the steeper slopes.

[FECAL MATERIAL; GRAZING IMPACTS; NON-POINT SOURCE POLLUTION]

77. Auble,GT; Hamilton,DB; Roelle, JE; Clayton,J; Fredrickson,LH (1988): A prototype expert system for moist soil management. p.137-143. In: Mutz,K; Cooper,DJ; Scott,ML; Miller,LK [eds.] Restoration, creation, and management of wetland and riparian ecosystems in the American West. A symposium of the Rocky Mountain Chapter of the Society of Wetland Scientists. 14-16 November 1988. Denver, CO. Moist soil management is an intensive management strategy for wetland wildlife habitat. It involves manipulating seasonally flooded, manmade impoundments to provide hydrologic conditions and food resources for migrating waterfowl. Effective moist soil management requires considerable expertise concerning how wetland units will respond to management actions and how multiple objectives can be met with complimentary management regimes on sets of units. This paper describes a computer program that suggests management regimes for a set of moist soil impoundments.

[RIPARIAN RESTORATION; WETLANDS]

78. Aust,WM; Mader,SF; Mitchell,LJ; Lea,R (1990): An approach to the inventory of forested wetlands for timber-harvesting impact assessment. Forest Ecology and Management 33/34, 215-225.

A methodology for assessment of timber-harvesting impacts in a tidal freshwater wetland was developed. Indices were chosen to detect changes in net primary productivity, plant nutrient assimilative capacity, soil nutrient retention and transformation, decomposition, sedimentation rate, hydrology, and the provision of wildlife habitat. Methods were chosen for data collection efficiency, interpretive simplicity, and ability to provide a relative index of the integrity and recovery rates of a disturbed ecosystem. This assessment enables wetland managers to determine which parameters are sensitive to functional changes. 
[FOREST WETLANDS; INVENTORY; RIPARIAN HABITAT]

79. Austin, TA (1986): Utilization of models in water resources. Water Resources Bulletin 22(1), 49-56.

Water resources personnel were surveyed to determine the current and future uses of mathematical models in planning, design, and operations of watered resources systems. Eighty-six percent of those responding indicated they had used mathematical models in the past year. Lack of appropriate data, inadequate time and funding to do the modeling and lack of models that represented the "real world" situation were the most frequently mentioned constraints to model use.

[HYDROLOGY; MODELING; WATER RESOURCE MANAGEMENT]

80. Baad,MF (1988): Soil-vegetation correlations within the riparian zone of Butte Sink in the Sacramento Valley of northern California. USDI Fish and Wildlife Service. Biological Report 88(25), 48.

In part of a national study, vegetation associated with known hydric and nonhydric soil series was sampled in the Sacramento Valley of California. Weighted averages, presence/absence averages, and Michener averages were calculated for vegetation in each soil series or vegetation type. Currently flooded hydric soils were designated as wetlands based on vegetation.

[CLASSIFICATION; PLANT COMMUNITIES; RIPARIAN HABITAT; SOILS]

81. Babcock,WH (1986): Ten-mile Creek: a study of stream relocation. Water Resources Bulletin 22(3), 405-415.

After intensive planning, three miles of creek were relocated to accommodate highway construction near Denver, Colorado. The project was designed to provide fish habitat of equal or enhanced value to that present before construction. After channel excavation, rock and log fish habitat structures were constructed. Two years after construction, a flood rendered 75 percent of the habitat structures ineffective. Pool-riffle ratios and quantity and quality of spawning areas remained unchanged during this period. Population estimates indicated an increase in the number of fish after construction. Fish biomass estimates, as well as aquatic invertebrates populations, were unchanged. [FISHERIES; RIPARIAN HABITAT; RIPARIAN RESTORATION]
82. Backiel,A (1993): Political factors in riparian management issues. p.124-127. In: Tellman, $B$;

Cortner,HJ; Wallace, MG;Debano,LF;

Hamre; RH [tech. coord.]. Riparian management: Common threads and shared interests. USDA Forest Service. General Technical Report RM-226.

The author believes that America today is experiencing a renewed interest in democracy and an increased political awareness. This process will most likely come to include natural resource issues. Each individual is part of that process, with the opportunity to participate in environmental and natural resource decisions.

[POLICY; RIPARIAN HABITAT; RIPARIAN MANAGEMENT ZONE]

83. Bailey,RG (1982): Classification systems for habitat and ecosystems. Research on Fish and Wildlife Habitat. US Environmental Protection Agency. p.16-26. EPA 600/8-82-022.

Systems for classifying and evaluating land as ecosystems have evolved in different agencies of the federal government over the past several years. Such systems involve the delineation, description, and analysis of relatively homogenous units of land at the local or regional scale. The concept of the ecosystem has been widely accepted as a basis for organizing our knowledge of fish and wildlife resources and for considering their interaction with other resources. Although some commonality of ideas exists at present, there is no uniform approach to ecological land classification. Cooperative efforts are underway to develop common or compatible systems. As part of these efforts, the problem of integrating wildlife data into the ecological land classification process and of integrating land/water ecosystem concepts must be resolved.

[CLASSIFICATION; ECOSYSTEM MANAGFMENT; RIPARIAN HABITAT]

84. Bain,MB; Finn,JT (1988): Streamflow regulation and fish community structure. Ecology 69(2), 382-392.

An abundant ( $>90$ percent of all fish) and diverse (nine species) group of small-fish species and size classes were restricted to microhabitat that was characterized as shallow in depth, slow in current velocity, and concentrated along stream margins (tributaries of the Connecticut River, Vermont). This group of fish was reduced in abundance in the regulated river and absent at the study site with the greatest flow fluctuation. Another fish group included species and size classes that used either a 
broad range of habitat or a microhabitat that was deep, fast, or both, and was concentrated in midstream areas. The density of fish in this group was higher in the regulated river and peaked at the sites with the greatest fluctuations in flow. Highly variable and unpredictable flow regimes appear to be a high-frequency disturbance that affects fish differently depending on the way they use stream habitat and acts to reduce community complexity. [BIODIVERSITY; FISHERIES; RIPARIAN HABITAT; STREAM FLOW]

85. Baker,BW; Cade,BS (1995): Predicting hiomass of beaver food from willow stem diameters. Journal of Range Management 48(4), 322-326.

Beaver and willow are important components of riparian restoration on degraded western rangelands. Land managers need quantitative information to evaluate carrying capacity and potential habitat quality for beavers in riparian-willow systems. This study was conducted in the shrub-steppe ecosystem of northwestern Colorado. The authors wanted to determine the best model to predict biomass components of coyote willow from basal stem diameters and compare model predictions to diameter class averages. Percentage of stem weight that was beaver food varied from 93.6 percent for the smallest stems to 12.2 percent for the largest. They concluded that the logistic model provided reliable estimates of beaver food biomass and could be used with food consumption rates and stem density data to evaluate carrying capacity for beaver.

[BEAVER; CARRYING CAPACITY; RIPARIAN HABITAT; WILLOW]

86. Baker,Jr.,MB (1996): Hydrology and watershed management in semi-arid grasslands. p.159-169. In: Tellman,B; Finch,DM; Edminster,C; and Hamre,R (eds.). 1998. The future of arid grasslands: Identifying issues, seeking solutions. Proceedings. RMRS-P-3. USDA Forest Service. 392 p.

Northern Mexico and Southwest US ecosystems are sustained by a delicate balance under limited water regimes and variable climates. Past land abuse has resulted in severe, widespread watershed degradation. Hydrologic and watershed information for the semi-arid grassland vegetation type is discussed and recommendations for riparian restoration are provided. [HYDROLOGY; RIPARIAN RESTORATION; WATERSHED]
87. Baker,Jr.,MB; Benevides-Sonorio,JDD; Talavera-Zuniga,E (1995): Relationship between precipitation and streamflow on El Carrizal watershed, Tapalpa, Jalisco. p.115-120. In: Aguirre-Bravo,C; Villa-Salas,AB [tcch. eds.]. Partnerships for sustainable forest ecosystem management: Fifth Mexico/U.S. biennial symposium; 17-20 October 1994; Guadalajara, Jalisco, Mexico. USDA Forest Service. General Technical Report RM-GTR-266.

A 789 ha watershed was gauged to study the hydrology of the area and to assist in the assessment and restoration of its riparian ecosystem. Streamflow for the 1994 season began one month after the first summer precipitation occurred. Response in daily flow was generally associated with rainfall amounts of $10 \mathrm{~mm}$ or more. Maximum daily flow of 5.27 and $4.79 \mathrm{~mm}$ occurred following rainfalls of 60 and 35 Inm, respectively. A total of $81 \mathrm{~mm}$ of runoff was produced from May through October by a total rainfall of $990 \mathrm{~mm}$. Results suggested that streamflow is basically generated by subsurface flow and will average about 10 percent of the total annual precipitation.

[CLIMATE; HYDROLOGY; STREAM FLOW; WATERSHED]

88. Baker,Jr.,MB; Debano,LF; Ffolliott,PF (1998): Riparian-watershed linkages in the Southwest. p.347-357. In: Potts,DF [ed.]. Rangeland management and water resources: Proceedings of the AWRA specialty conference. American Water Resources Association. 27-29 May 1998. Reno, NV.

Riparian ecosystems in the Southwest provide a unique setting for evaluating the linkages between them, the channel dynamics and surrounding watersheds. In a highly variable precipitation-runoff regime, erosion is a discontinuous process that transports sediment from source areas through a channel system with alternate periods of storage. Intermittent streamflow coupled with the discontinuous storage and movement of sediment through channel systems in response to fire, grazing, and vegetative manipulations is extremely complex and, therefore, can be difficult to interpret when assessing responses of southwestern riparian areas to management.

[CHANNEL DYNAMICS; EROSION; HYDROLOGY; RIPARIAN ECOLOGY; WATERSHED]

89. Baker,WL (1989): Classification of the riparian vegetation of the montane and subalpine 
zones in western Colorado. Great Basin Naturalist 49, 214-228.

A paper that offers a classification of relatively undisturbed riparian vegetation, remnant from pre-settlement vegetation, in western Colorado. Plant associations include montane riparian forests, subalpine riparian forests, lower subalpine willow carrs, upper subalpine willow carrs and a subalpine wetland.

[CLASSIFICATION; PLANT COMMUNITIES; RIPARIAN FOREST; RIPARIAN HABITAT]

\section{Baldwin,MF (1987): Wetlands: Fortifying} federal and regional cooperation. Environment 29(7), 16-20, 39-43.

Future protection of wetlands will largely depend on federal initiatives and authorities that can support and strengthen local and state programs. A two-pronged effort is essential. First, federal agencies should implement an effective, efficient wetland regulatory program under Section 404 of the Clean Water Act. Second, they must supplement that program with carefully focused planning to protect valuable and vulnerable wetlands in close cooperation with other federal, state, and local agencies, private groups, and the public.

[CLEAN WATER ACT; POLICY; RIPARIAN HABITAT; WETLANDS]

\section{Baltosser,WH (1986): Seasonal analysis of a southwestern New Mexico riparian bird community. Western Birds 17, 115-131.}

The lower Gila River Valley of southwestern New Mexico has some of the finest riparian habitat and most diverse association of wildlife in the entire lower Colorado River drainage. Over two-thirds of New Mexico's total of 449 species of birds are known from the valley. In addition, the New Mexico portion of the Gila River Valley contains the greatest diversity of raptors in the lower Colorado River drainage and the largest number of endangered, threatened, and peripheral bird species. This study was conducted to examine and quantify seasonal changes in avian composition, density, and diversity along the Gila River and the results reaffirm the richness of avian fauna in the study area.

[AVIAN ECOLOGY; GILA RIVER; RAPTORS; RIPARIAN HABITAT]

92. Baltz,DM; Vondracek,B; Brown,LR; Moyle,PB (1987): Influence of temperature on microhabitat choice by fishes in a California stream. Transactions of the American Fisheries Society 116, 12-20.
In this study, eight microhabitat variables (temperature, total depth, focal point elevation, focal point velocity, mean water column velocity, surface velocity, substrate, and cover) were used to determine their adequacy to discriminate among species' microhabitat. Two variables were especially important in discriminating among species. Focal point elevation explained between 32 and 43 percent of the variance in the models in which it was available. Temperatures made significant contributions in 12 of 14 models in which it was available. When total depth was included in a model, it was always more important than temperature. However, temperature and focal point elevation were the only two significant variables on two sampling dates. [FISHERIES; RIPARIAN HABITAT; STREAM ECOLOGY]

93. Banister, $\mathbf{R}$ (1991): Eight principles of range management. Rangelands 13(2), 85-86.

Dealing effectively with riparian problems has been hindered in the past because there has been little effort by the land management agencies to work cooperatively with ranchers in developing goals or using evaluation methods for solving streambank problems. Often the rancher has more experience and expertise in the critical aspects of the problem. Without the ranchers' input, most projects are doomed to failure.

[GRAZING IMPACTS; LIVESTOCK EFFECTS]

\section{Barclay,JS (1980): Impact of stream} alterations on riparian communities in southcentral Oklahoma. USDI Fish and Wildlife Service, Biological Services Program. FWS/OBS/17.91 p.

This report evaluates the effects on bird, mammal, amphibian, and reptile populations of stream channelization and stream impoundment in the southern grasslands region, Oklahoma. Two channelized streams and one impounded stream, all major tributaries of the Washita River, were studied. Present day land use was usually the most apparent factor determining vegetation differences between sites. Altered flood patterns reduced productivity on channelized or impounded streams, however. Bird, amphibian, reptile and small mammal species richness was reduced on channelized sites. Impoundment effects tended towards lower species diversity and higher relative abundance on downstream sites. [AMPHIBIANS; AVIFAUNA; BIODIVERSITY; CHANNEL DYNAMICS; MAMMALS; REPTILES; 
RIPARIAN HABITAT; RIPARIAN

RESTORATION]

95. Bardecki,MJ (1988): Impacts of agricultural land drainage on wetlands. p.15-21. In: Stuber,PJ [tech. coord.]. Proceedings of the national symposium on protection of wetlands from agricultural impacts. 25-29 April 1988. Ft. Collins, CO. USDI Fish and Wildlife Service. Biological Report 88(16).

A discussion of the impacts of agricultural drainage is presented based on a

municipality-specific investigation of the distribution of drainage in Ontario, Canada. This analysis forms the basis for the identification of areas of concern regarding potential impacts on wetlands and provides a regional perspective on the past and present distributions of wetlands and their relationship to agricultural drainage.

[AGRICULTURAL IMPACTS; RIPARIAN HABITAT; WETLANDS]

96. Barfield,BJ; Warner,RC (1981): Applied hydrology and sedimentology for disturbed areas. Oklahoma Technical Press, Stillwater, OK. 603 p. [CHECK DAMS; HYDROLOGY; SEDIMENT TRANSPORT; SOILS; VEGETATION MANAGEMENT]

97. Barnes,HH (1967): Roughness characteristics of natural channels. USDI Geological Survey. Water Supplement Paper 1849. 213 p. [CHANNEL DYNAMICS; CHANNEL MORPHOLOGY]

98. Barron, T (1996): Rio Grande Valley State Park maintenance, improvements, and developments. p.208-209. In: Shaw,DW; Finch,DM [tech. coord.]. Desired future conditions for Southwestern riparian ecosystems: Bringing interests and concerns together. USDA Forest Service. General Technical Report RM-GTR-272.

Managing the Rio Grande Valley State Park as a valued riparian-wetland area is very important because it encourages conditions for vegetation growth. This growth supports a riparian community consisting of various insects, animals, birds, and fishes, as well as other wildlife. Human activity in riparian areas has led to historic use patterns causing erosion, relocation of animals and birds, and a loss of some valued riparian ecosystems. Riparian areas on the urban edge present a unique management challenge and opportunity. All area residents benefit from a properly functioning riparian-wetland environment. Riparian area managers must consider all concerns when balancing uses of riparian habitat from preservation of archaeological and cultural resources to riparian recovery, improvement, and development. [RIO GRANDE; RIPARIAN ECOLOGY; RIPARIAN HABITAT; RIPARIAN MANAGEMENT ZONE]

99. Barron, T (1996): Restoration guidelines for riparian areas using dormant stock "pole" cuttings. p.260-261. In: Shaw,DW; Finch,DM [tech. coord.]. Desired future conditions for Southwestern riparian ecosystems: Bringing interests and concerns together. USDA Forest Service. General Technical Report RM-GTR-272. The Open Space Division manages seven thousand acres of riparian areas comprising the Rio Grande Valley State Park. In 1988, Open Space began experimenting with dormant stock cuttings. This paper suggests methods and procedures for establishing dormant stock cuttings, referred to as "poles".

[OPEN SPACE; RIO GRANDE; RIPARIAN RESTORATION; RIPARIAN SHRUBS]

100. Barron, $T$ (1996): Mitigation in riparian areas: $Q$ uestions, concerns, and recommendations. p.265-266. In: Shaw,DW; Finch,DM [tech. coord.]. Desired future conditions for Southwestern riparian ecosystems: Bringing interests and concerns together. USDA Forest Service. General Technical Report RM-GTR-272.

The management of seven thousand acres in the Rio Grande Valley State Park presents a unique management challenge and opportunity. The influence of permanent water or water flows produces visible vegetation and vegetative characteristics on the affected land. Management practices are designed to avoid adverse and negative impacts. Mitigation measures such as creating wetlands and land donations are encouraged. [RIO GRANDE; RIPARIAN RESTORATION]

101. Barrow,JR (1992): Use of floodwaters to disperse grass and shrub seeds on native arid lands. p.167-169 In: Clary,WP; McArthur,ED; Bedunah,D; Wamboldt,CL [comp.]. Proceedings Symposium on ecology and management of riparian shrub communities. USDA Forest Service. General Technical Report INT-289.

On the Jornada Experimental Range, seeded and native species from root-plowed and seeded strips 
were observed to establish in substantial numbers down-channel from the source. The author suggests that flood-water has good potential as a low-input method of seed dispersal for revegetation of natural waterways.

[FLOOD IMPACTS; RIPARIAN RESTORATION; SEED PRODUCTION]

102. Barry,S; Tate,KW; Atwill,R; Cullor,J; Koopman,T; Huff,T (1998): Development and use of a HACCP (Hazard analysis of critical control points) program to protect water quality in a rangeland watershed. p. 443. In: Potts, DF [ed.] Rangeland management and water resources: Proceedings of the AWRA specialty conference. American Water Resources Association. 27-29 May 1998. Reno, NV.

The Hazard Analysis of Critical Control Points (HACCP) program was developed for the US Army and NASA more than thirty years ago to identify and control food contaminants in food processing. In this application, a HACCP-based program for grazing cattle and feral pig management to guard against Crytosporidium and other potential pathogens was developed for Alameda Creek Watershed, part of the San Francisco water system. Grazing and feral pig management were defined by critical points, management measures, monitoring, critical limits, corrective actions, and recordkeeping. Further assessments and monitoring will help identify additional control points and management measures. [GRAZING IMPACTS; PATHOGENS; WATER QUALITY; WATERSHED]

103. Bartos,DL; Campbell,RB,Jr (1998): Water depletion and other ecosystem values forfeited when conifer forests displace aspen communities. p.427-434. In: Potts,DF [ed.] Rangeland management and water resources: Proceedings of the AWRA specialty conference. American Water Resources Association. 27-29 May 1998. Reno, NV.

The absence of fires on western landscapes, coupled with excessive browsing of young aspen trees by livestock and wildlife, has led to rapid displacement of aspen communities by conifer communities throughout the West. Previously aspen regenerated as clones from suckers arising from parent that survived frequent wildfires. Since European settlement, conifer trees have displaced more than 50 percent of the aspen communities in Utah. Conifer species transpire more water than aspen and have sparse undergrowth with relatively few species. Such displacement could cause the annual forfeiture of 375,000 acre-feet of water that would have been available for streamflow and the annual loss of 750,000 tons of undergrowth biomass production in the mountains of Utah. A greater loss would be the reduction of the numbers and kinds of plants and animals.

[ASPEN; BIODIVERSITY; EVAPOTRANSPIRATION; SUCCESSION]

104. Bartuska, $A$ (1993): A river ran through it. p.405-407. In: Tellman,B; Cortner,HJ; Wallace,MG; DeBano,LF; Hamre, RH |tech. coord.]. Riparian management: Common threads and shared interests. USDA Forest Service. General Technical Report RM-226.

This presentation offered highlights and concluding remarks for the symposium. Selected comments, statements, and remarks are reiterated in a summation of preceding events.

[RIPARIAN HABITAT; RIPARIAN MANAGEMENT ZONE]

105. Bartuska,AM; Buford,MA (1996): USDA Forest Service's National Wetlands Research Program. p.160-167. In: National hydrology workshop proceedings. 27 April - 1 May 1992; Phoenix, AZ. USDA Forest Service. General Technical Report RM-GTR-279.

This paper describes the genesis of the USDA Forest Service's National Wetlands Program, and gives a regional summary of some important wetlands and riparian research accomplishments of its eight research stations. Key program directions for future emphasis are also discussed.

[RESEARCH; RIPARIAN HABITAT; WETLANDS]

106. Bates,DT (1996): Development, implementation, and monitoring of riparian standards and guidelines. p.103-107. In: National hydrology workshop proceedings. 27 April - 1 May 1992; Phoenix, AZ.

This paper discusses the development and implementation and results of the first year of monitoring of the Riparian Standards and Guidelines and the Riparian Management Guide (Gregory, 1990) used on the Willamette National Forest in western Oregon.

[MONITORING; RIPARIAN HABITAT; RIPARIAN MANAGEMENT ZONE; STANDARDS AND GUIDELINES]

107. Bathurst,JC (1985): Flow resistance estimation in mountain streams. Journal of 
Hydrological Engineering 111(4), 625-643.

Examination of the flow resistance of high-gradient gravel and boulder-bed rivers, using data collected in British mountain rivers with slopes of 0.4 - 4 percent, shows that there are differences in resistance variation between mountain and lowland rivers and that between-site variations do not necessarily reflect at-a-site variations. The influences of nonuniform channel profile, sediment size distribution, channel slope and sediment transport are reviewed, but the data do not allow any quantification of these effects.

[CHANNEL DYNAMICS; HYDROLOGY; STREAM FLOW]

108. Batson,FT; Cuplin,PE; Crisco,WA (1987): The use of aerial photography to inventory and monitor riparian areas. USDI Bureau of Land Management. Technical Reference 1737-2. Aug., 1987. Denver Federal Center. Denver, CO.

The report describes technical considerations and procedures for acquisition and use of aerial photography for riparian area inventory and monitoring. Preplanning is crucial and considerations such as area selection, film type, and time of day or season of flight, and scale of photography are discussed. Other issues such as when to begin initial paperwork, specifications, and flight map preparations, leading to the procurement of aerial photography, are also discussed. Procurement options are discussed, as well as various analytical and procedural methods.

[AERIAL PHOTO; MONITORING; REMOTE SENSING; RIPARIAN HABITAT]

109. Bauer,S; Burton,T; Thomas, A (1994): Livestock grazing: Fishery concerns and recommended actions. p.105. In: Summit showcase displays and ecosystem case studies. USDI Bureau of Land Management Summit. Incline Village, NV. April, 1994.

This poster paper illustrated that livestock grazing and healthy riparian habitat are not mutually exclusive. Improved grazing strategies were shown that have had high levels of compatibility with stream/riparian habitats. Critical habitat factors for resident salmonids were presented along with proposed standards for grazing utilization. [GRAZING IMPACTS; LIVESTOCK EFFECTS; RIPARIAN HABITAT; UTILIZATION]

110. Bauer,SB; Burton,TA (1993): Monitoring protocols to evaluate water quality effects of grazing management on western rangeland streams. Submitted to: US Environmental Protection Agency, Washington, DC by Idaho Water Resources Research Institute. University of Idaho. Moscow, Idaho 83843. 179 p.

This document describes a monitoring system to assess grazing impacts on water quality in streams of the western United States. The protocols were developed to assess water quality improvement from stream restoration projects funded under the Clean Water Act Amendments of 1987 and the Coastal Zone Management Act as amended in 1990. The monitoring methods were selected for application by natural resource professionals. The project goal is to describe methods that are easy to use and cost-effective. This is achieved by using methods that reduce sample frequency, minimize the need for specialized equipment, and reduce costly laboratory analysis. The document focuses primarily on the attributes of the stream channel, stream bank, and streamside vegetation of wadeable streams that are impacted by grazing and are important to support aquatic life. These characteristics are sampled during the low flow conditions in the summer when streams can be waded. The methods require relatively inexpensive equipment compared to standard water chemistry analysis techniques. Implementation requires fielding a trained interdisciplinary team. [GRAZING IMPACTS; INTERDISCIPLINARY TEAMS; MONITORING; RIPARIAN HABITAT; WATER QUALITY; WETLANDS]

111. Bayha,K (1978): Instream flow methodologies for regional and national assessments. Instream Flow Information Paper No. 7. USDI Fish and Wildlife Service/OBS-78/61. 98 p.

[FISHERIES; HYDROLOGY; STREAM FLOW; WATER RESOURCE MANAGEMEN'T]

112. Bayley,PB (1995): Understanding large river-floodplain ecosystems. BioScience 45(3), 153-157.

Ecologists in temperate countries have not benefitted from studying relatively unperturbed systems in order to understand how their systems functioned naturally. Prevailing economic perspectives of rivers are grossly distorted by government subsidies and the inability of most economists to value natural resources unless they are currently being exploited and are thus in the market economy. Less impacted tropical river floodplains, whose ecological attributes seem to be shared among all systems, have contributed to ecological and economic knowledge; although many of these are 
also undergoing rapid development in pursuit of advanced technology. Large-scale processes and benefits common to relatively pristine systems in some tropical areas, however, are sufficiently known to indicate that significant economic advantages, in addition to benefits associated with increased biodiversity and stability would result from restoration of impaired systems. Our cultural development has caused river-floodplain ecosystems in most temperate areas to be more adversely affected than most other natural systems. It has also almost destroyed our ability to study their ecology. [BIODIVERSITY; ECONOMICS; FLOOD IMPACTS; FLOODPLAIN MANAGEMENT; HYDROLOGY]

\section{Beall,JT; Elliott,W (1994): West Eugene} wetlands project. p.175-177. In: Summit showcase displays and ecosystem case studies. USDI Bureau of Land Management Summit. Incline Village, NV. April, 1994.

The West Eugene Wetlands Partnership, composed of BLM, The Nature Conservancy, Lane Council of Governments, Lane County, and the city of Eugene, Oregon, was formed to acquire and manage wetlands and other connected open spaces. The effort has dramatically improved the relationship of the Bureau with other public entities. [COLLABORATION; PARTNERSHIPS; RIPARIAN HABITAT; WETLANDS]

114. Beaudry,PG (1989): Hydrology of the Skeena River floodplains I: Implications to herbicide use. p.165-171. In: Alexander,EB [ed.]. Proceedings of Watershed '89: A Conference on the stewardship of soil, air, and water resources. USDA Forest Service, Alaska Region, Juneau, AK.

Based on the annual groundwater regime, stratigraphy of deposits, soil characteristics, soil and air climates, and chemical/physical properties of herbicides, inferences were made about the probable herbicide fate in the coastal alluvial environment. [HERBICIDES; HYDROLOGY; WATER QUALITY]

115. Beaudry,PG (1989): Hydrology of the Skeena River Floodplains II: Flood hazard classification for silviculture. p.173-178. In: Alexander,ED [ed.]. Proceedings of Watershed '89: A conference on the stewardship of soil, air, and water resources. USDA Forest Service. Juneau, AK.

This paper describes a flood hazard classification for planning silvicultural treatments to the floodplain. To develop the classification, survival and growth of Sitka spruce were related to frequency, duration, and depth of flooding. Certain morphological and topographical features of the floodplain were identified as being unfavorable for the establishment and growth of Sitka spruce. Using aerial photography and a five-category frequency/duration classification, the user can identify site specific flooding potential. Description of each class is included along with Sitka spruce growth potential relative to flood hazard.

[AERIAL PHOTO; HYDROLOGY; PLANTINGS]

116. Becker, $R$ (1996): The citizen volunteer. p.210-211. In: Shaw,DW; Finch,DM [tech. coord.]. Desired future conditions for Southwestern riparian ecosystems: Bringing interests and concerns together. USDA Forest Service. General Technical Report RM-GTR-272.

Citizen organizations and their volunteers provide substantial resources to the land management agencies which include volunteer time, effort, and funding. Through their assistance, habitat projects are completed. Volunteers, likewise, benefit from the experience. A sense of "stewardship" evolves from this process. The mutual benefits to both agencies and volunteers are discussed in an effort to further promote the recruitment and retention of volunteers. [RIPARIAN HABITAT; RIPARIAN MANAGEMENT ZONE; VOLUNTEERS]

117. Beckman,BR; Larsen,DA; Pawlak, BL; Dickhoff, WW (1998): Relation of fish size and growth rate to migration of spring chinook salmon smelts. North American Journal of Fisheries Management 18:537-546.

Juvenile chinook salmon were separated by size into small and large categories and reared at both normal (cool) and elevated temperatures. Fish from warm water groups displayed significantly higher growth rates through the spring. Fish with relatively higher spring growth rates moved downstream sooner than fish with relatively slower growth rates. Fish with relatively higher growth rates moved downstream sooner than smaller growth fish. Smolt size and migration were also related with larger fish moving downstream sooner than smaller fish. [ANADROMOUS FISH; FISH HABITAT; STREAM TEMPERATURE]

118. Bedell,TE |ed.] (1984): Range watersheds, riparian zones and economics: interrelationships in management and use. Proceedings of the 1984 Pacific Northwest range management short 
course. 25-27 January 1984. Pendleton, OR. Oregon State University. Corvallis, $O R$.

This short course facilitated by Oregon State University included 19 presentations in three subject classes. Fifteen of the presentations were developed into formal papers. The principles represented in these proceedings were intended to provide the basis for future management decisions involving riparian areas and their resources.

[ECONOMICS; GRAZING IMPACTS; RIPARIAN HABITAT; RIPARIAN VEGETATION]

119. Beecher,HA (1990): Standards for instream flows. Rivers 1(2), 97-109.

Instream flow standards are not clearly defined in laws of most western states. Such a standard should imply a formula that would incorporate biological and hydrological information to assign a range of instream flows for a stream. Ambiguity in instream flow standards has led to unresolved controversy over water allocation. A clear policy would reduce costly delays in water resource planning. Five elements of an unambiguous instream flow standard are identified: goal, resources to be considered, unit of measurement, benchmark time period, and protection statistic. Future water management options and instream resource levels are influenced by choices pertaining to each of these elements.

[HYDROLOGY; STREAM FLOW; WATER RESOURCE MANAGEMENT]

120. Beechie,TJ; Sibley,TH (1997): Relationships between channel characteristics, woody debris, and fish habitat in northwestern Washington streams. Transactions of the American Fisheries Society 126, 217-229.

Relationships between large woody debris (LWD) and pool area spacing varied with channel slope and width for streams in second-growth forests. Pool-spacing and percent pool were correlated with an interaction between I.WD abundance and channel slope, suggesting that the influence of LWD changes with channel slope. Low-slope channels were less sensitive to LWD abundance because pools were formed by mechanisms other than LWD. There was no significant relationship between woody debris and percent gravel. Relationships among percent gravel, channel width, and channel slope were adequately explained by the channel's capacity to transport particles of various sizes.

[CHANNEL MORPHOLOGY; FISHERIES; LARGE WOODY DEBRIS]
121. Behmer,DJ; Hawkins,CP (1986): Effects of overhead canopy on macroinvertebrate production in a Utah stream. Freshwater Biology 16, 287-300.

[AQUATIC ECOSYSTEMS; MACROINVERTEBRATES; RIPARIAN HABITAT; RIPARIAN VEGETATION]

122. Behnke,RJ (1979): Value and protection of riparian ecosystems. p.164-167. In: Swanson, GA [ed.]. The mitigation symposium: A national workshop on mitigating losses of fish and wildlife habitats. USDA Forest Service. General Technical Report RM-65.

The riparian ecosystem is a zone of highly concentrated values associated with fish, wildlife, recreation, and water quality. Multiple use management on federal lands has often severely degraded riparian zones and associated values. This abuse must be corrected.

[GRAZING IMPACTS; MULTIPLE USE; RIPARIAN ECOLOGY]

123. Behnke,RJ; Raleigh,RF (1978): Grazing and the riparian zone: Impact and management perspectives. p.262-267. In: Proceedings of the symposium, Strategies for protection and management of floodplain wetlands and other riparian ecosystems. 11-13 December 1978. Callaway Gardens, GA. USDA Forest Service. General Technical Report WO-12.

Overgrazing impacts of livestock on riparian vegetation are magnified in arid and semi-arid regions. Typical stream habitat changes resulting from overgrazing of riparian vegetation, trampling of stream banks and increased erosion include: widening and shallowing of the stream bed, gradual stream channel trenching or braiding dependent upon soils and substrate composition, silt degradation of spawning and invertebrate food producing areas, loss of streamside and instream cover, increased water temperatures and velocities, decreased terrestrial food inputs, and a 3-4 fold decrease in trout biomass in grazed vs. ungrazed systems. Recommendations for reparations and management are presented.

[GRAZING IMPACTS; RIPARIAN MANAGEMENT ZONE; RIPARIAN VEGETATION]

124. Behrens-Tepper,JC; O'Leary,JT; Anderson,DC (1985): Focused recreation use in riparian ecosystems: A taxonomy of user types. p.216-218. In: Johnson,RR; Ziebell,CD; Patton,DR; Ffolliott,PF; Hamre, RH [tech. coord.]. 
Riparian ecosystems and their management: Reconciling conflicting uses. 16-18 April 1985. Tucson, AZ. USDA Forest Service. General Technical Report RM-120.

Data from a 1980 survey of recreation users provided the basis to examine anglers by amount of participation at rivers and streams, sociodemographic background and conservation activity involvement. Each factor appeared to facilitate identification of different user types that should be considered in managing/planning riparian environments.

[RECREATION IMPACTS; RIPARIAN ECOLOGY; RIPARIAN HABITAT]

125. Beier, $\mathrm{AE}$ (1998): Managing rangeland water resources - The changing legal landscape. p.271-279. In: Potts, DF [ed.]. Rangeland management and water resources: Proceedings of the AWRA specialty conference. American Water Resources Association. 27-29 May 1998. Reno, NV.

Water quality degradation associated with grazing has not, historically, been regulated. Increased high quality water demand has generated a greater interest in managing land-use activities. Public policy relating to grazing and water quality is currently being reshaped, as demonstrated by a recent Federal Court decision (Oregon Natural Desert Association v. Thomas, 946 F. Supp. 1534 $(D<O R>1996)$ ). The court found that grazing activities do cause a "discharge" and that state certification is required before a federal agency can issue a permit. [GRAZING IMPACTS; NON-POINT SOU IRCE POLLUTION; POLICY; WATER QUALITY]

\section{Beier,P; Barrett,RH (1987): Beaver habitat} use and impact in Truckee River Basin, California. Journal of Wildlife Management 51(4), 794-799.

Step-wise regression was used to identify factors for habitat use by beavers on streams. Increasing stream width and depth and decreasing gradient had the strongest positive effects on habitat use; food availability variables added little further explication. Some abandoned colony sites appeared to have been located on physically unsuitable habitat, whereas others appeared to be physically suitable sites abandoned due to resource depletion. The fact that few unused or noncolonized reaches were classified as suitable habitat suggests that suitable habitat has been saturated. Local extirpation of quaking aspen and black cottonwood occurred on $4-5$ percent of stream reaches. Willow demonstrated good vigor despite heavy use in most reaches. [BEAVER; RIPARIAN HABITAT]

127. Bell,DT; Johnson,FL; Gilmore,AR (1978): Dynamics of litter fall, decomposition, and incorporation in the streamside forest ecosystem. Oikos 30:76-82.

Dynamics of the litter stratum of a streamside forest ecosystem are described. Changes in litter fall, leaf decomposition, and soil organic matter content were determined in relation to time and to the coenocline of canopy species induced by the gradient of flood variables. Slower decomposition rates in the upland resulted in turnover rates exceeding one year. All leaf litter falling in the floodplain section of the gradient was either decomposed or washed into the stream during flood each year. Soil organic matter in the upland averaged 4.17 percent and showed an increase between autumn levels and those recorded after decomposition of leaf matter was nearly completed.

[DECOMPOSER FOOD CHAIN; LITTER FALL; ORGANIC DEBRIS; STREAM ECOLOGY]

128. Belt,GH; O'Laughlin,J; Merrill,T (1992): Design of riparian forest buffer strips for the protection of water quality: Analysis of scientific literature. Idaho Forest, Wildlife and Range Policy Analysis Group. Report No. 8. University of Idaho. Moscow, ID 83843.

This report summarizes the research-based knowledge in the current scientific literature concerning the effectiveness of streamside buffer zones in protection of water quality. More than 300 papers were located and reviewed; almost 100 were relevant and are cited in this report. Cited papers addressed the definitions of buffer strips, their effectiveness for reducing impacts of forest practices, their effect on water quality and fish habitat, issues surrounding them, and the available models for utilization.

[BUFFER STRIPS; FISHERIES; RIPARIAN FOREST; RIPARIAN MANAGEMENT ZONE; WATER QUALITY]

129. Ben-David,M; Hanley,TA; Schell,DM (1998): Fertilization of terrestrial vegetation by spawning Pacific salmon: The role of flooding and predator activity. Oikos $83,47-55$.

This study evaluated the influences of marine-derived nutrient transport by spawning Pacific salmon on terrestrial vegetation using stable isotope analysis. Collected data from 5 plant species in transects from stream to upland forests indicated a 
significant decrease in $\mathrm{N}$ values occurred with increase in distance and relative elevation from the stream in 3 of 5 species. Results indicate that salmon carcasses contribute to the nitrogen pool available to riparian vegetation. The spatial distribution of marine-derived $\mathrm{N}$ is apparently determined by flooding and the activity patterns of piscivorous predators.

[FERTILIZATION; FOOD WEBS; NUTRIENT CYCLES; RIPARIAN VEGETATION; SALMONIDS]

130. Benedict,NB (1984): Classification and dynamics of subalpine meadow ecosystems in the southern Sierra Nevada. p.92-95. In: Warner,RE; Hendrix,KM [eds.] California riparian systems: Ecology, conservation and productive management. 17-19 September 1981. Berkeley, CA.

In the Sierra Nevada, subalpine meadows are an important high elevation riparian vegetation type. The study of meadows has proceeded in two directions: classification and studies of meadow dynamics. Current research in both topics is discussed.

[CLASSIFICATION; HYDROLOGY; MEADOWS; RIPARIAN HABITAT]

131. Bengeyfield,P; Svoboda,D (1998): Determining allowable use levels for livestock movement in riparian areas. p. 243-257. In: Potts,DF [ed.]. Rangeland management and water resources: Proceedings of the AWRS specialty conference. American Water Resources Association. 27-29 May 1998. Reno, NV.

This paper offers proposed guidelines designed to restore and maintain riparian function in the presence of grazing by determining acceptable use levels for the following parameters: browse levels on riparian shrubs, stubble height, streambank alteration, and forage utilization. Use levels are determined by setting a desired future condition (DFC), and assessing the potential, sensitivity, and inherent stability of the riparian areas. This approach has seen on-the-ground applications for maintaining functioning riparian areas and to initiate recovery of functioning-at-risk riparian areas.

[DESIRED FUTURE CONDITIONS; GRAZING IMPACTS; RIPARIAN MANAGEMENT ZONE; STUBBLE HEIGHT; UTII.IZATION]

132. Bentrup,G; Hoag,JC (1998): The practical streambank bioengineering guide: User's guide for natural streambank stabilization techniques in the arid and semi-arid Great Basin and Intermountain West. USDA Natural Resources Conservation Service; Plant Materials Center. Aberdeen, Idaho.

This publication is a user's guide to natural stream stabilization techniques for the arid and semi-arid Great Basin and Intermountain West. It was produced primarily for the professional conservationist who provides technical resource assistance to individual landowners. The user should understand that riparian areas are complex ecosystems and that restoration efforts require interdisciplinary teams. This publication provides an easy to understand guide for coordinators of riparian restoration projects. The first part of the guide covers the basic principles of restoration and bioengineering. The second part consists of detailed, illustrated technique sheets for different bioengineering methods, including how to install, materials, type of use, and other special considerations.

[BIOENGINEERING; RIPARIAN ECOLOGY; RIPARIAN RESTORATION; STREAMBANK STABILITY]

133. Berg,DR (1995): Riparian silvicultural system design and assessment in the Pacific Northwest Cascade Mountains, USA. Ecological Applications 5(1), 87-96.

Active management of riparian zones can be economically as well as ecologically beneficial. Restoration of riparian forests is simulated with forest growth models. Logs were generated using the model to be of sufficient size to resist annual floods in salmon habitat streams on the west side of the Pacific Northwest Cascade Mountains. The economic feasibility is reported at real interest rates. Economic viability depends on initial volume removed, costs of regeneration and monitoring, volume of thinnings, and interest rate. Harvest operations allow for the restoration of forest structure and composition that is beneficial for salmonid habitat in areas where the primary forest has been replaced with early seral hardwood species and fiercely competitive shrubs. This silvicultural system restores natural functions of riparian forests of watersheds in the Pacific Northwest.

[ECONOMICS; FOREST MANAGEMENT; RIPARIAN HABITAT; RIPARIAN RESTORATION]

134. Bergstrom, $D$ (1985): Beavers: biologists "rediscover" a natural resource. p.1-5. In: Forestry Research West. October 1985. USDA Forest Service. 
In recent years, foresters have begun to utilize beavers as biological agents to restore degraded streambanks and riparian areas.

[BEAVER; RIPARIAN RESTORATION]

135. Berris, SN; Harr, RD (1987): Comparative snow accumulation and melt during rainfall in forested and clear-cut plots in the western Cascades of Oregon. Water Resources Research 23(1), 135-142.

Absence of forest vegetation affected both snow accumulation and amount of energy available for melt during rainfall in the transient snow zone of the western Cascade Range of Oregon. Intercepted snow melted in the forest canopy and reached the ground as melt-water, therefore, water equivalents were commonly 2-3 times greater in the clear-cut plots that in the forested plot. During a rain-on-snow event, water outflow in the clear-cut plot was 21 percent greater than in the forested plot. During the common period of melt, total energy available in the clear-cut plot was 40 percent than that in the forested plot. Greater wind speeds in the clear-cut plot caused the combined sensible and latent heat transfers there to be almost 3 times those in the forested plot. [LOGGING IMPACTS; PRECIPITATION; WATERSHED; WATER YIELD]

136. Beschta,RL (1997): Riparian shade and stream temperature: an alternative perspective. Rangelands 19(2), 25-28.

Increased levels of shading for water quality limited streams would greatly improve summertime stream temperatures in most situations. In many instances, it may even be possible to reduce maximum temperatures so that they no longer exceed state water quality standards. It is clear that achieving improved levels of riparian shade and decreased summertime temperatures will require landowners to change those management practices that have contributed to current conditions.

[RIPARIAN CONDITION; RIPARIAN HABITAT; STREAM TEMPERATURE]

\footnotetext{
137. Beschta,RL; Platts,WS (1986): Morphologic features of small streams: Significance and function. Water Resources Bulletin 22(3), 369-379.

Where channel morphology is modified or structural features added, stream dynamics and energy dissipation need to be considered. Unit stream power (the time-rate loss of potential energy per unit mass of water) can be reduced by adding stream obstructions, increasing channel sinuosity, or increasing flow resistance with large roughness
}

elements such as woody root systems, logs, boulders, or bedrock. Pools, which vary in size and shape and causative factors, are important rearing habitat for fish. Riffles represent storage locations for bed material and are generally utilized for spawning. Particle sizes and distributions of bed materials influence channel characteristics, bedload transport, food supplies for fish, spawning conditions, cover, and rearing habitat. Engineered structures for modifying habitat may alter stream characteristics but channel morphology must ultimately be matched to the hydraulic, geologic, and vegetative constraints of a particular location.

[CHANNEL MORPHOLOGY; RIPARIAN HABITAT]

138. Best,LB; Stauffer,DF; Geier,AR (1978): Evaluating the effects of habitat alteration on birds and small mammals occupying riparian communities. p.117-124. In: Proceedings of the National Symposium on strategies for protection and management of floodplain wetlands and other riparian ecosystems. 11-13 December 1978. Pine Mountain, GA.

Birds and small mammals were censused along stream segments that represented a range of habitats from open fields to closed-canopy woodlands. The reciprocal of Simpson's Index was used to express breadth of habitats selected and nest-site specificity. The general application of using an index of niche breadth in conjunction with conventional plant and animal sampling techniques to assess species' susceptibility to habitat alteration was discussed. [AVIAN ECOLOGY; RIPARIAN HABITAT; SMALL MAMMALS]

139. Bettinger,P; Sessions, J; Johnson, KN (1998): Ensuring the compatibility of aquatic habitat and commodity production goals in eastern Oregon with a Tabu search procedure. Forest Science 44(1), 96-112.

A land management scheduling model is presented for ensuring the compatibility of aquatic habitat quality and commodity production goals in forest management. This model uses Tabu search procedures to select feasible land management activities (timber harvesting and road system management) subject to an even-flow constraint and aquatic habitat goals, as represented by stream sediment and temperature indices. The model was not without certain limitations but it demonstrated that moderately complex aquatic habitat quality evaluation techniques, with spatial elements, can be nested inside a land management scheduling model. 
[AQUATIC ECOSYSTEMS; MODELING; RIPARIAN HABITAT]

140. Bettis III,EA; Thompson,DM (1985): Gully erosion. Rangelands 7(2), 70-72.

Former gullies and the erosion resulting from their growth have molded many landscapes. The process is active today and will continue to be far into the future. Our understanding of factors contributing to gully initiation is inconclusive. Somewhat better understood are the processes and factors involved in gully growth and degradation. Both subjects are urgent research needs. [CHANNEL MORPHOLOGY; EROSION; GULLY CONTROL]

141. Bevenger,GS; King,RM (1995): A pebble count procedure for assessing watershed cumulative effects. USDA Forest Service. Research paper RM-RP-319.17 p.

Land management activities can result in the delivery of fine sediment to streams. Over time, such delivery can lead to cumulative impacts to the aquatic ecosystem. Because numerous laws require Federal land managers to analyze watershed cumulative effects, field personnel need simple monitoring procedures that can be used directly and consistently. One approach to such monitoring is described. The approach involves sampling a longitudinal reach of stream channel several hundred feet long using a zigzag pebble count procedure that crosses all habitat features within a stream channel. The approach accommodates reference (nonimpacted) and study (impacted) reaches so that impact comparisons can be made. Case studies are described. [GEOMORPHOLOGY; MONITORING; PEBBLE COUNTS; WATERSHED]

142. Bezanson,CE; Hughes,LE (1989): A riparian zone - One story. Rangelands 11(2), 56-57.

A rest-rotation grazing system implemented in northern Arizona, which allows 6 months of grazing and 6 months of rest, has resulted in considerable improvement of the riparian zone. The system has also promoted the sprouting of young cottonwoods. [GRAZING IMPACTS; GRAZING TREATMENTS; RIPARIAN ENHANCEMENT; SOUTHWESTERN DESERT STREAMS]

143. Biddlecomb,ME (1994): Railroad Valley wetlands enhancement. p.105. In: Summit showcase displays and ecosystem case studies. USDI Bureau of Land Management Summit.
Incline Village, NV. April, 1994.

A cooperative venture between BLM, Ducks

Unlimited (DU), and Round Mountain Gold

Company (RMGC) to maintain and enhance a wetlands Wildlife Management Area (WMA) near Tonopah, Nevada, is described. Cooperative efforts like this one have the advantage of shared costs and expertise on projects that may otherwise not be affordable or logistically possible. Moreover, the opportunities for good public relations advance the relationship between the agency and the public it serves.

[COLLABORATION; RIPARIAN HABITAT; WETLANDS]

144. Bilby, RE (1981): Role of organic debris dams in regulating the export of dissolved and particulate matter from a forested watershed. Ecology 62(5), 1234-1243.

Organic debris dams accumulate organic material in a stream which obstructs water flow. Debris dams trap sediments in the pool formed upstream from them and the dam structure itself collects organic matter. In this study, a $175 \mathrm{~m}$ stretch of stream was cleaned of debris dams. Following dam removal, export of dissolved matter increased slightly due to an increase in the concentration of dissolved organic carbon in the stream water during periods of high discharge. Dam removal brought about a 6 percent increase in the export of dissolved matter and a 500 percent increase in the export of both fine particulate and coarse particulate matter. [NUTRIENT CYCLES; ORGANIC DEBRIS; STREAM ECOLOGY]

145. Bilby,RE (1984): Removal of woody debris may affect stream channel stability. Journal of Forestry, 82:609-613.

Although many states mandate the removal of logging debris from streams, accumulations of which may obstruct passage of anadromous fish, stream cleaning may have other deleterious effects.

Monitoring a Washington stream demonstrated large changes in channel structure during the first high flow after cleaning. Nearly 60 percent of woody debris moved downstream during the storm, channel cross sections were substantially altered, and the number, area, and volume of pools declined. Degrees of channel rearrangement were greater than in comparable undisturbed streams. Subsequent storms caused much less debris movement and channel change than the first storm.

[LARGE WOODY DEBRIS; LOGGING IMPACTS; RIPARIAN FOREST; RUNOFF] 
146. Bilby, RE (1987): Interaction of aquatic and terrestrial systems. In: Streamside management: Riparian, wildlife, and forestry interactions. An interdisciplinary symposium. 11-13 February 1987. University of Washington. Seattle, WA.

Interactions between terrestrial and aquatic ecosystems depend upon the size of the aquatic system. Properties of the riparian zone along smaller streams control nearly all the features of those waters. Woody debris input from the riparian zone, may be a major determinant of channel form and regulates transport of particulate material through the system. Shade from streamside vegetation moderates water temperature, and root systems help stabilize the banks. Shading of the water also limits aquatic plant growth. The primary energy source for small streams is provided by the input of terrestrial litter from riparian vegetation. Control of properties of the aquatic system by riparian areas decreases as stream size increases. While aquatic/terrestrial interactions are similar for all-sized streams, the relative influence of one system on the other changes appreciably with stream size.

[RIPARIAN HABITAT;

TERRESTRIAL/AQUATIC INTERACTIONS]

147. Bilby,RE; Likens, GE (1980): Importance of organic debris dams in the structure and function of stream ecosystems. Ecology 61(5), 1107-1113.

Removal of all organic debris from a $175-\mathrm{m}$ stretch of second order stream led to a dramatic increase in the export of organic carbon from the ecosystem. Coarse organic particulate organic matter $(<1 \mathrm{~mm})$ export increased by 138 percent; fine organic particulate carbon export increased 632 percent. Measurement of standing stock of coarse particulate organic matter revealed that debris dams were important for accumulating this material. Debris dams contain almost 75 percent of the standing stock of organic material in first order streams; 58 percent in second order streams, and 20 percent in third order streams. Organic debris dams are important components of the small stream ecosystem and allow it to be processed into finer size in headwater tributaries before being transported downstream. [LOGGING IMPACTS; ORGANIC DEBRIS; STREAM ECOLOGY]

148. Bilby,RE; Wasserman,LJ (1989): Forest practices and riparian management in Washington State: Data-based regulation requirement. p.87-94. In: Gresswell,RE; Barton,BA; Kershner,JL [eds.]. Practical approaches to riparian resource management. An educational workshop. 8-11 May 1989.

Billings, Montana.

Since 1986, separate regulations were devised for eastern and western Washington due to the differences in vegetation, climate, and timber management strategies. In western Washington, where clear-cutting is the predominant harvest method, regulations were based on existing data on large organic debris (LOD) loading in channels coupled with simulation models of stand dynamics. Data for eastern Washington were collected specifically for the purpose of developing new regulations. Uneven-aged management is the most common silvicultural technique practiced in this area. Regulations were designed to maintain LOD levels observed in unmanaged stands and were based on the relationship between stand density and LOD frequency.

[LOGGING IMPACTS; ORGANIC DEBRIS; RIPARIAN FOREST; RIPARIAN HABITAT; RIPARIAN MANAGEMENT ZONE]

149. Binns, NA (1979): Quantification of fluvial trout habitat in Wyoming. p.215-228. In: Transactions of the American Fisheries Society.108(3):213-226.

This paper describes the development of a Habitat Quality Index (HQI) to provide objective and quantitative evaluations of the trout fishery resource in non-monetary terms. HQI is based on trout standing crop and is derived from measurements of biologically relevant attributes.

[FISHERIES; MONITORING; RIPARIAN HABITAT]

150. Binns,NA (1986): Stabilizing eroding stream banks in Wyoming, a guide to controlling bank erosion in streams. Wyoming Game and Fish Department Bulletin. Cheyenne, WY. 42 p.

This guidebook summarizes some key principles of river mechanics and details bank stabilization methods used on Wyoming streams. The structures and techniques described in this publication have been used successfully to stabilize eroding banks and provide effective bank protection.

[RIPARIAN RESTORATION; STREAMBANK PROTECTION]

151. Binns,NA; Eiserman,FM (1979): Evaluation of fluvial trout habitat in Rocky Mountain streams. p.361-364. In: Swanson,GA [ed.]. The mitigation symposium: A national workshop on mitigating losses of fish and wildlife habitats. USDA Forest Service. General Technical Report 
RM-65.

A Habitat Quality Index (HQI) was developed to quantify fluvial trout habitat in Wyoming. As an aid to the mitigation process, the $\mathrm{HQI}$ has been used to document and quantify the deterioration of trout habitat and populations caused by man's activities. [FISHERIES; RIPARIAN HABITAT; TROUT]

152. Biswell,HH (1968): Water control by rangeland management. p.740-746. In: Water for peace: International conference. 23-31 May 1967.

Rangeland water can be regulated by controlling the intensity and season of grazing and prohibiting livestock on areas susceptible to compaction. In areas of deep soils and excess precipitation, water runoff can be increased by replacing deep-rooted species with shallow-rooted species (such as desirable grasses and forbs). This cannot occur in areas where precipitation is less than 18 inches annually. In areas of relatively high rainfall and erodible soils, runoff and erosion can be lessened by planting deep-rooted plants (such as shrubs and trees) to increase water storage capacity.

[FROSION; HYDROIOGY; RUNOFF; WATERSHED]

153. Bjornn,TC; Burns,DC; Collotzi,AW; Newhouse,HW; Platts,WS (1980): A method for predicting fish response to sediment yields. USDA Forest Service, Intermountain and Northern Regions. A working draft. $35 \mathrm{p}$.

The process defined in this report to evaluate the sediment effects on the fishery as an output from linear programs identifies sediment/fish interactions in one step but allows the user to take a multi-step process that may provide more accuracy. The process identifies sediment impacts as only one of the components that influence a fishery. The user must consider that other conditions that impact fish biomass such as temperature, nutrients, and water flows may be more important and must still be evaluated by the user based on individual concerns. It is possible that any one of these variables may have morc influence on the fish population than sediment. [CLASSIFICATION; FISHERIES; RIPARIAN HABITAT; SEDIMENTATION]

154. Black,S; Broadhurst,P; Hightower,J; Schauman,S (1985): The value of riparian habitat and wildlife to the residents of a rapidly urbanizing community. p.413-416. In: Johnson,RR; Ziebell,CD; Patton,DR; Ffolliott,PF; Hamre, RH [tech. coord.]. Riparian ecosystems and their management: Reconciling conflicting uses. 16-18 April 1985. Tucson, AZ. USDA Forest Service. General Technical Report RM-120.

Two surveys tested the values of residents. In the first, the community's knowledge and preference for riparian habitat and wildlife was established. The second survey established the position of the specific values among a broader range of human values. The results indicate that residents value natural habitat. This suggests important policy implications for the management of urban water systems.

[ECONOMICS; RIPARIAN HABITAT; URBAN IMPACTS]

155. Blakesley,JA; Reese,KP (1986): Avian habitat relationships in riparian zones of northern Utah. Completion Report to USDA Forest Service. Ogden, UT. 59 p.

[AVIFAUNA; RIPARIAN HABITAT]

156. Blakesley,JA; Reese,KR (1988): Avian use of campground and noncampground sites in riparian zones. Journal of Wildlife Management 52(3), 339-402.

Use of riparian habitat by 14 avian species was compared during the breeding season on campground and noncampground sites in northern Utah. Multivariate analysis indicated that 7 avian species were closely associated with campgrounds, whereas 6 of 7 species associated with noncampgrounds were ground- or shrub-nesting, or ground-foraging. Results may be explained by vegetative differences between the 2 habitats.

[AVIFAUNA; RECREATION IMPACTS; RIPARIAN HABITAT]

157. Blank,RR; Chambers, J; Linnerooth,A (1998): Influence of fall-prescribed burning on nutrient levels in riparian soils of central Nevada. p. 235-241. In: Potts,DF [ed.]. Rangeland management and water resources: Proceedings of the AWRA specialty conference. American Water Resources Association. 27-29 May 1998. Reno, NV.

Livestock overgrazing, fire suppression, and stream incision have fostered encroachment of sagebrush into riparian areas. Replacement of this sagebrush by meadow vegetation can increase stream flows, increase water storage, and reduce erosion. Prescribed burning shows promise for restoring dry meadows. In this study, prescribed burning increased extractable sulfate, potassium, and ammonium to a depth of $5 \mathrm{~cm}$. Burning decreased extractable nitrate and ortho-phosphate. Lack of spring and summer precipitation hindered establishment of seeds sown 
after the prescribed burn. The growth of sedges and rushes, however, was significantly greater in post-fire interspaces than in unburned shrub interspaces. Unless conditions are favorable for spring plant establishment, fall prescribed burning may result in leaching losses of soil nutrients, and the potential for soil erosion.

[FIRE IMPACTS; GRAZING IMPACTS; MEADOWS; NUTRIENT CYCLES; PRESCRIBED BURNING]

158. Blank,RR; Palmquist,DE; Young,JA (1992): Plant-soil relationships of greasewood, Torrey saltbush, and allenrolfea, that occur on coarse-textured mounds on playas. p.194-198. In: Clary,WP; McArthur,ED; Bedunah,D; Wambolt,CL [comp.]. Proceedings - Symposium on ecology and management of riparian shrub communities. USDA Forest Service. General Technical Report INT-289.

Plant-soil relationships at playa-sand veneer interfaces in the Lake Lahontan Basin of northwest Nevada were studied. The data demonstrated that the mounds were extremely saline, more saline than nonvegetated mound interspaces. Moreover, there were significant $(\mathrm{P}<0.05)$ differences in the soil-solution chemistry among the shrubs, which suggests that the shrubs have modified the soil solution through elemental cycling. Vegetative recruitment occurs during environmentally optimal periods.

[PLANT-SOIL RELATIONSHIPS; PLAYAS; RIPARIAN HABITAT; SALINITY]

159. Blank,RR; Trent,JD; Young,JA (1992):

Sagebrush communities on clayey soils of northeastern California. p.198-202. In: Clary,WP; McArthur,ED; Bedunah,D; Wambolt,CL [comp.|. Proceedings - Symposium on ecology and management of riparian shrub communities. USDA Forest Service. General Technical Report INT-289.

The presence of shrubs on clayey soils has, over time, increased the site potential by capturing aeolian dust. This veneer of coarse-textured materials is a better seedbed than the clayey substratum, supports an extensive cryptogamic community, and limits the natural churning of the high shrink-swell clays. Past overgrazing has, in some instances, caused the veneer of aeolian dust to erode, exposing the clay substratum. Those siles now support a near monoculture of medusahead (Taeniatherum caput-medusae). Where medusahead invades on high-condition sites, wildfires may occur, and consequently, wind erosion increases, the aeolian veneer is thinned, and a permanent loss in site potential may occur.

[MEDUSAHEAD; RIPARIAN HABITAT; SAGEBRUSH]

160. Bledsoe, $S$ (1987): Alternatives to riparian management regulations that would be incentives. In: Streamside management: Riparian wildlife and forestry interactions. An interdisciplinary symposium. 11-13 February 1987. University of Washington. Seattle, WA.

This paper describes a process known as the Timber, Fish, and Wildlife Project (TFW). This agreement is designed to lead to increased protection for fish and wildlife habitat, water quality and tribal cultural and archeological sites while ensuring a healthy timber industry in Washington state. [RIPARIAN FOREST; RIPARIAN HABITAT]

161. Bledsoe, $S$ (1987): An alternative approach to the regulation of riparian management. p.239244. In: Streamside management: Riparian wildlife and forestry interactions. University of Washington. Institute of Forest Resources., Seattle, WA.

A forest industry proponent, bureaucrat, regulator and legislator comments on regulatory approaches to riparian management after serving as an agency head on the Forest Practices Board. He comments on the shift from the judicial forum and policy-making activities of the legislature to the politicalization of the FPB. He concludes that regulations are best designed to support site-specific decision making processes and that monitoring is essential.

[POLICY; REGULATIONS; RIPARIAN HABITAT]

162. Blinn,CR; Dahlman,RA (1995): Riparian harvesting with a soft footprint. p.76-81. In: At the water's edge: The science of riparian forestry conference. 19-20 Junc 1995. Duluth, MN.

A variety of approaches are available to leave a soft footprint when harvesting within a riparian management zone (RMZ). A selection of planning considerations, harvesting strategies, equipment options, and alternatives for temporary crossings of streams and areas with weak or wet soils are discussed. The specific practices selected for operating in a particular RMZ needs to consider the operational capabilities and economic constraints that the logger faces.

[LOGGING IMPACTS; RIPARIAN HABITAT; 


\section{RIPARIAN MANAGEMENT ZONE]}

163. BLM (Bureau of Land Management)-USDI, Oregon State Office (1987): Oregon/Washington Riparian Enhancement Plan. 13 p.

Enhancement of riparian areas, which are key habitat for 80 percent of the wildlife species of eastern Oregon and Washington, will provide increased opportunities for bird watching, photography, and hunting upland game, waterfowl and big game. The improved vegetative diversity and productivity resulting from implementation of this plan will be instrumental in reaching prescribed condition and trend objectives.

[RIPARIAN ENHANCEMENT; RIPARIAN HABITAT]

164. Blosser,RO (1984): The effects of fine sediment on salmonid spawning gravel and juvenile rearing habitat - a literature review. Technical Bulletin No. 428.66 p. National Council of the Paper Industry for Air and Stream Improvement, Inc., 260 Madison Ave., New York, NY, 100016.

This is a review of literature on the effects of fine sediment on salmonid spawning gravel and juvenile rearing habitat. This review covers 67 references and includes a broad spectrum of subjects relating to salmon spawning gravels. It deals specifically with the biological implications of fine sediments to salmonid eggs and larvae. [BIBLIOGRAPHY; FISHERIES; FOREST MANAGEMENT; RIPARIAN HABITAT; SALMONIDS; SEDIMENTATION]

165. Bock,JH; Bock,CE (1985): Patterns of reproduction in Wright's sycamore. p. 493-94. In: Johnson,RR; Ziebell,CD; Patton,DR; Ffolliott,PF; Hamre, RH [tech. coord.]. Riparian ecosystems and their management: Reconciling conflicting uses. 16-18 April 1985. Tucson, AZ. USDA Forest Service. General Technical Report RM-120.

In southeast Arizona, Wright's sycamore produces large numbers of viable seeds that fall in a compact fruit shadow around parent individuals. Drought or flash-flooding usually causes sexual reproduction to fail. In one site with permanent water and little flooding, large numbers of seedlings and saplings grew. Young trees grew in clumps, usually of similar size individuals, away from mature tree canopy but always in the stream channel. [RIPARIAN FOREST; RIPARIAN HABITAT]

166. Boeer,WJ; Schmidly,DJ (1977): Terrestrial mammals of the riparian corridor in Big Bend National Park. p.212- 217. In: Johnson,RR; Jones, DA [tech. coord.]. Importance, preservation, and management of riparian habitats: A symposium. 9 July 1977 . Tucson, AZ. USDA Forest Service. General Technical Report RM-43.

Thirty species of terrestrial mammals inhabit the riparian habitats of the Park. Compared to other major plant communities in the Park, the rodent fauna of the riparian community has lower evenness, richness, and diversity indices. Human use and livestock grazing are the major impacts acting upon the riparian areas.

[RIPARIAN HABITAT; SMALL MAMMALS]

167. Bochne,P; House,R (1983): Stream ordering; a tool for land managers to classify western Oregon streams. USDI Burcau of Land Management, Oregon State Office. Tech. Note OR-3. 6 p.

Increasing width and depth and decreasing gradicnt with increasing stream order werc obscrved. Fish diversity increased with increasing stream order, with cutthroat trout inhabiting all orders and chinook salmon inhabiting fourth and fifth order streams. Fourth order strcams arc the most important for coho salmon and steelhead trout. Stream ordering can be a more useful tool than other stream classification systems for fisheries and habitat analysis in the Northwest. A 1:12,000 scale is suggested as optimal for fish and habitat analysis.

[CLASSIFICATION; RIPARIAN HABITAT; SPATIAL SCALE]

168. Boggs,K (1990): A site classification with management information for riparian and wetland sites in northwest Montana. In: Management of riparian and wetland forested ecosystems in Montana. Fourth annual Montana Riparian Association workshop. 5-7 September 1990. Whitefish, MT.

Riparian/wetland sites in northwest Montana support a complex array of plant communities. Using Daubenmire's methodology based on habitat types, a classification was developed that describes major seral plant communities that are stable for time frames relevant to land management decisions. The classification is useful as a management tool. Management considerations include what seral stage a site is in, timber productivity, and forage values. [CLASSIFICATION; PLANT COMMUNITIES; RIPARIAN HABITAT] 
169. Boggs,K; Hansen,P; Pfister,R; Joy,J (1990): Classification and management of riparian and wetland sites in northwestern Montana. Draft Version 1. Montana Riparian Association, Montana Forest and Conservation Experiment Station, University of Montana. Missoula, MT. $217 \mathrm{p}$.

This publication presents a key for identifying riparian site types, i.e., areas occupied or potentially occupied by a specific riparian association (plant community type representing the latest successional stage attainable on a specific hydrologic site). Community types which represent disclimax or seral communities that are stable for time frames relevant to land management decisions are described. Habitat types are described for specific communities. Soils, adjacent communities and management information are provided for each habitat type. This classification is useful both as a management tool and a scientific reference.

[CLASSIFICATION; PLANT COMMUNITIES; RIPARIAN HABITAT; RIPARIAN MANAGEMENT ZONE; SOILS]

170. Boggs,K; Weaver,T (1992): Response of riparian shrubs to declining water availability. p.48-51. In: Clary,WP; McArthur,ED; Bedunah,D; Wambolt,CL [comp.]. Proceedings Symposium on ecology and management of riparian shrub communities. USDA Forest Service. General Technical Report INT-289.

Community dominance, productivity, and grazing effects were recorded in a cottonwood sere along the Yellowstone River. The sere progressed from seedlings of Great Plains cottonwood and sandbar willow to cottonwood forests with a dense shrub understory, and finally, to grasslands.

[COTTONWOOD; GRAZING IMPACTS; RIPARIAN SHRUBS; SECONDARY SUCCESSION; WILLOW]

171. Bohn,CC (1983): The response of soils, streambanks and instream coliform bacteria levels to grazing management in a riparian area. MS Thesis, Oregon State University, Corvallis, OR. 85 p.

Mammals may transmit pathogenic organisms through water supplies. $E$. coli are commonly measured to indicate fecal contamination of water. In a second-order, wildland stream in northeast Oregon, coliform concentrations were cyclic. Generally, counts were highest on July 1 but some sites peaked as late as August 7. Counts declined through the summer, reached a low by end of August, and peaked again in late September, after fall rains and leaf-fall began. Some contamination counts resulted directly from cattle standing in or adjacent to the water. Coliform counts also related to hydrologic events on the watershed.

[COLIFORM BACTERIA; GRAZING IMPACTS; NON-POINT SOURCE POLLUTION; SOILS; WATER QUALITY]

172. Bohn, CC (1986): Biological importance of streambank stability. Rangelands 8(2), 55-56.

New interest in streambank stability originates from the influence streambanks have on a stream system and fish habitat. Streambank stability has traditionally been defined from an engineering perspective, but stability in terms of the biological function means the maintenance of the channel shapc suited to the native streambank vegetation and soils and the stream gradient. Streams naturally work slowly across a floodplain while the channel shape maintains regular patterns within a reach and sediment enters the water primarily when flows are big cnough to carry it. [RIPARIAN HABITAT; SEDIMENTATION; STREAMBANK STABILITY]

173. Bohn,CC (1989): Management of winter soil temperatures to control streambank erosion. p.69-71. In: Gresswell, RE; Barton, BA; Kershner, JL [eds.]. Riparian resource management. An educational workshop. USDI Bureau of Land Management. Billings, MT.

Winter soil temperatures were measured in streambanks under different vegetative cover conditions in northeastern Nevada. Grass provided significant streambank insulation at two different elevations and aspects compared to bare soils. It was postulated that the formation of soil ice weakens the internal structure of stream banks. Weakened banks are less able to resist disturbance from high-velocity runoff and ice floes. Temperature modifications resulting from vegetative cover appear to be sufficient to reduce damage.

[RIPARIAN HABITAT; SOIL TEMPERATURE; STREAMBANK STABILITY]

174. Bohn, CC; Buckhouse,JC (1981): Interpreting coliform counts in northeast Oregon rangeland streams. p.15-17. In: 1981 Research in rangeland management, Agricultural Experiment Station, Oregon State University Corvallis, OR. Special Report 620.

Grazed areas had the highest counts of coliform bacteria and controls had the lowest. Stream 
segments in pastures rested one month had counts similar to those rested one year. Season-long grazing had the greatest input. Drinking water required treatment even in ungrazed portions. [COLIFORM BACTERIA; NON-POINT SOURCE POLLUTION; WATER QUALITY]

175. Bohn,CC; Buckhouse,JC (1985): Coliform organisms as an indicator of water quality in wildland streams. Journal of Soil and Water Conservation 40(1), 95-97.

Coliform bacteria from watersheds and riparian zones originating from livestock can cause temporary and short-term declines in water quality. This result is not apparent on ungrazed watersheds or riparian pastures.

[COLIFORM BACTERIA; GRAZING IMPACTS; NON-POINT SOURCE POLLUTION; WATER QUALITY]

176. Bohn,CC; Buckhouse,JC (1985): Some responses of riparian soils to grazing management in northeastern Oregon. Journal of Range Management 38(4), 378-381.

Various parameters were measured over five years on control/treatment paired plots of several grazing strategies in a northeast Oregon riparian zone. These included infiltration, sediment production, penetrometer penetrability, and bulk density. The hydrologic parameters were favored by rest-rotation grazing. Deferred rotation and season-long grazing did little to enhance, and sometimes hindered, hydrologic expression. Late-season grazing in September demonstrated a positive hydrologic response but late season grazing in October was negative. This was attributed to onset of fall rains and higher soil moisture content.

[GRAZING IMPACTS; SOILS]

177. Bohn,CC; Buckhouse,JC (1986): Effects of grazing management on streambanks. p.265-271. In: Proceedings of the 51 st North American wildlife and natural resources conference. 21-26 March 1986. Reno, NV. The Wildlife Management Institute.

Despite limitations imposed by methodology, this study produced some insights into the complex relationship between bank dynamics and grazing management. Streambank retreat may increase as animal use increase, both in numbers and in years. There was more bank-edge retreat on grazed treatments with big game access than in ungrazed treatments. Numerically, there was more bank retreat on treatments that had big game access and higher livestock numbers. Ice related and runoff related bank disturbances occurred during the study and appeared to be linked to season-long grazing. Ice and animals, however, appear to exert very different forms of disturbance on channel walls and geometry. [GRAZING IMPACTS; GRAZING TREATMENTS; STREAMBANK STABILITY; WATER QUALITY]

178. Bohn,CC; Megahan,WF (1991): Changes in sediment storage in the South Fork Salmon River, Idaho. p. 12-23. In: Proceedings of the fifth federal intragency sedimentation conference. 18-21 March 1991. Las Vegas, NV.

A large volume of sediment was deposited in the upper 60 miles of the South Fork Salmon River in 1965. A survey of the sediment storage in 1989 demonstrated that large amounts of material, primarily sands, have been transported out of the study area in the ensuing 24 years. As much as 78 percent of the sand and gravel have moved out of the study area. The particle size distribution of the stream bed describes a shift toward larger particles. Results suggest that the sources of sediment have stabilized to some degree and that stream power has been sufficient to transport sediment out of the study area. [GFOMORPHOI.OGY; SFDIMENTATION; WATERSHED]

179. Boldt,CE; Uresk,DW; Sevenson,KE (1978): Riparian woodlands in jeopardy on northern Great Plains. p.184-189. In: Proceedings, National Symposium on strategies for protection and management of floodplain wetlands and other riparian ecosystems. Atlanta, $G A$.

Deciduous tree and shrub species occurring in woody draws are being threatened by multiple impacts, of which the most visible and detrimental is cattle damage. The solutions include combinations of fencing, resprouting, and under planting.

[GRAZING IMPACTS; RIPARIAN RESTORATION]

180. Bolen,EG; Smith,LM; Schramm,Jr.,HL. (1989): Playa lakes: Prairie wetlands of the southern High Plains. BioScience 39(9), 615-623.

Playas have received little study focused on their ecological structure and function as wetland ecosystems. Future investigations should emphasize primary production, energy flow, and nutrient budgets. Future quantifications of these processes will allow integration of playa ecosystems with other, more thoroughly investigated wetlands. Furthermore, better understanding of these processes will provide a foundation for uses and management of playas. 
[PLAYAS; RIPARIAN HABITAT; STREAM

FLOW; WATER RIGHTS; WETLANDS]

181. Bond,CE; Rexstad,E; Hughes,RM (1988):

Habitat use of twenty-five common species of Oregon freshwater fishes. Northwest Science 62(5), 223-231.

The purpose of this paper/study was twofold. The first objective was to determine the use of physical habitat by the 25 most common native freshwater fishes of Oregon, and the second was to evaluate the use of a large computer database of museum records in the determination. Habitat use identified by this study was generally consistent with the subjective evaluations of field ichthyologists, and the study revealed additional information for some species. A large computer database compiled from field notes of many collectors allowed useful generalizations concerning species habitat, even though methods of collecting and recording differed greatly. Small databases also permit greater quantification than is typical of species accounts and more robust habitat descriptions than those gleaned from a small number of site specific studies. [FISH DISPERSAL; FISH POPULATIONS; FISHERIES; RIPARIAN HABITAT]

182. Bonomo,T (1996): Public involvement and consensus building in the Verde River Watershed in central Arizona. p.230-236. In: Shaw,DW; Finch,DM [tech. coord.|. Desired future conditions for Southwestern riparian ecosystems: Bringing interests and concerns together. USDA Forest Service. General Technical Report RM-GTR-272.

The Verde Watershed Association is the central point for consensus building and public involvement in water issues in the Verde River Watershed. The association is an outgrowth of efforts toward the resolution of watershed issues without passing new laws, initiating regulations, or entering the win-lose arena of litigation. The association is premised on the idea that truly effective river management and protection strategies cannot succeed without local consensus and support. The establishment of the Verde Watershed Association and subsequent activities surrounding the association resulted in the national organization American Rivers removing the Verde River from its list of the 20 most endangered rivers in the United States.

[CONSENSUS; RIPARIAN HABITAT; RIVER ECOLOGY; WATER ISSUES; WATERSHED]

183. Booth,DT (1992): Bitterbrush dormancy - a discussion. p. 208-211. In: Clary,WP;
McArthur,ED; Bedunah,D; Wambolt,CL [comp.]. Proceedings - Symposium on ecology and management of riparian shrub communities. USDA Forest Service. General Technical Report INT-289.

Seed dormancy in bitterbrush may be due to: (1) direct interference with the cell metabolism (inhibitor theory), or (2) an oxygen deficient, non-dormant embryo (the hypoxic theory). Results to date indicate that bitterbrush seed-coat chemicals will inhibit glycolysis.

[BITTERBRUSH; RIPARIAN HABITAT; SEED PRODUCTION]

184. Boring,KK; Boring,L; Harris, T; Cubbage,F (1988): Section 404 Federal Wetlands Regulation: defining wetlands and Corps jurisdiction. TOPS. Spring 1988. $21 \mathrm{p}$.

A review of federal law that has evolved regarding the waters of the United States that fall under the 404 permit requirements administered by the COE (Corps of Engineers). Comparison of the scientific concept of wetlands with the current method of wetlands delineation employed by the COE.

[CLEAN WATER ACT; REGULATIONS; RIPARIAN HABITAT; WETLANDS]

185. Born,SM; Rumery,C (1989): Institutional aspects of lake management. Environmental Management 13(1), 1-13.

The major barriers to successful lake management are institutional but these aspects have received little attention. These institutional factors include: overlapping areal jurisdictions among governmental units, fragmented functional program responsibilities, ineffective coordination, limited authority, financial constraints, private sector roles, and inadequate public awareness and consensus. Because lake management programs with institutional shortcomings rarely realize their goals, it is critical to assimilate, evaluate, and apply this experience in order to effectively manage lake resources.

[LACUSTRINE ECOLOGY; RIPARIAN

HABITAT; WATER RESOURCE MANAGEMENT]

186. Bornette, G; Amoros, $C$; Lamouroux,N (1998): Aquatic plant diversity in riverine wetlands: The role of connectivity. Freshwater Biology 39, 267-283.

The study tested the hypothesis that intermediate connectivity to a river results in propagule inputs to 
wetlands, whereas excessive connectivity causes less competitive species to be eliminated, with no recruitment of new species. As a consequence, very low or very high nutrient levels should decrease species richness by selecting specialized species, whereas intermediate nutrient levels should favor the co-occurrence of species with contrasting nutrient requirements. In the study, the most frequently flooded channel showed the highest species richness and occurrence or rare and fugitive species, because of floods which compensate competition by scouring sediments and plants, and afford regeneration niches for propagules. In this case, conservation of biodiversity necessitates propagule sources at the level of the river landscape.

[BIODIVERSITY; CONNECTIVITY; ECOLOGICAL INTEGRITY; RIPARIAN HABITAT]

187. Borutski,D (1988): The Alberta streambank fencing program. p.133-137. In: Mutz,K; Cooper,D.J; Scott,ML; Miller,LK [eds.]. Restoration, creation, and management of wetlands and riparian ecosystems in the American West. A symposium of the Rocky Mountain Chapter of the Society of Wetland Scientists. 14-16 November 1988. Denver, CO.

The streambank fencing program in Alberta has experienced a high degree of public support because of dramatic increases in fish populations and angling use. Landowner concerns, however, continue to be problematical. Strategies to address these concerns include: financial and other forms of compensation for lost agricultural production in riparian areas, implementation of low-impact grazing systems, and land exchanges to acquire desirable riparian areas. [RIPARIAN ENHANCEMENT; RIPARIAN HABITAT]

188. Bottom,DL; Howell,PJ; Rodgers,JD (1985): The effects of stream alterations on salmon and trout habitat in Oregon. Oregon Dept. of Fish and Wildlife. Portland, OR. 70 p.

Many pollution problems are to some extent the products of natural processes. Erosion and mass soil movements have always occurred and will continue. Flooding in winter and spring and low water flows-warm water during the summer are normal cycles for many streams. Fish are adapted to the environment in which they have evolved and have survived many perturbations and changes in their habitats. Many natural processes are beneficial to fish production even though they may have negative short-term impacts. Runoff from the land contains nutrients that increase stream productivity. Bank cutting and landslides release spawning gravel and add structural elements to streams. Soil and water are both organs of a single landscape. Principal habitat problems affecting fisheries begin when land use practices greatly accelerate these processes. Salmonids are not able to tolerate many of the large scale changes brought about by land use practices. [FISHERIES; RIPARIAN RESTORATION; STREAM IMPROVEMENTS]

\section{Boughton,WC (1986): Evaluating partial} areas of watershed runoff. Journal of Irrigation and Drainage Engineering 113(3), 356-366.

Variations in surface storage capacity over a watershed produce partial areas of saturation overland flow, which vary from storm to storm. A method is described by which the proportions of the watershed that contributes overland flow in different storms and at different times during the same storm can be determined by analysis of rainfall and runoff records. The method was demonstrated on two catchments in Australia. The calculated amounts and proportions of surface storage capacity were incorporated into water balance models of watershed runoff to show the accuracy of runoff estimation. [HYDROLOGY; MODELING; RUNOFF; WATERSHFD]

190. Boule, ME (1988): Wetland creation and enhancement in the Pacific Northwest. p.130-135. In: Zelazny, J; Feierbend, JS [eds.|. Increasing our wetland resources. National Wildlife Federation Proceedings. Washington DC. Enhancement and creation of wetlands have become common components of suburban development activities in western Washington and elsewhere. Enhancement of storm water storage functions has often been a key goal of project design, but concern for water quality, fisheries and wildlife habitat, and aesthetic values is also important. Design of enhancement projects should be based on incorporation of these elements into overall project goals and objectives as defined by the project proponent and the regulatory agencies.

[CREATED WETLANDS; RIPARIAN RESTORATION; WETLANDS]

191. Bovee,KD (1982): A guide to stream habitat analysis using the instream flow incremental methodology. Instream Flow Information Paper No. 12. USDI Fish and Wildlife Service/OBS-82/26. $248 \mathrm{p}$. [FISHERIES; RIPARIAN HABITAT; STREAM 


\section{FLOW]}

192. Bowers, W; Hosford,B; Oakley,A; Bond,C (1979): Wildlife habitats in managed rangelands. The Great Basin of southeastern Oregon. Native trout. USDA Forest Service. General Technical Report PNW-84. 16 p.

All land management activities on managed rangelands will have some impacts on fish habitats; those in the riparian zone will have the greatest impacts. Native trout populations of the Great Basin exhibit predictable responses to alterations in their habitats; optimum production of native trout is therefore achievable through careful habitat management.

[FISHERIES; GRAZING IMPACTS; RIPARIAN HABITAT; TROUT]

193. Bowers, W; Hosford,W; Oakley,A; Bond,C (1979): Native trout hahitat in managed rangelands. In: Thomas,JW; Maser,C [ed.]. Wildlife habitats in managed rangelands -- the Great Basin of Southeastern Oregon. USDA Forest Service. General Technical Report PNW-80.

There were studies available that defined the habitat components necessary for good trout production, identified limiting factors, and described land-use conflicts. Data specific to southeastern Oregon and other locations were synthesized to provide rangeland managers with the information necessary to make the best possible decisions with respect to fish habitat management. The objectives of the authors were to present those data in ways that would assist managers in evaluating trade-offs while achieving short-term management goals and provide a tool that could be used in long-range land use planning.

[FISHERIES; RIPARIAN HABITAT; RIPARIAN MAN $\Lambda$ GEMENT ZONE; TROUT]

194. Braasch,S; Tanner,GW (1989): Riparian zone inventory. Rangelands 11(3), 103-106.

Riparian zones were characterized at 13 locations along Jim Creek in southern Colorado using the Pfankuch Channel Stability Rating, which considered the vegetative aspects along the stream bank. Within each zonc, various attributes were evaluated visually and then ranked numerically. Evaluations were influenced by both cattle and beaver impacts. [BEAVER; GRAZING IMP $\Lambda$ CTS; INVENTORY; PFANKUCH STREAM CHANNEL EVALUATION]
195. Braatne,JH; Hinckley,TM; Stettler,RF

(1992): Influence of soil water on the physiological and morphological components of plant water balance in Populus trichocarpa, Populus deltoides, and their F1 hybrids. Tree Physiology 11, 325-339.

Patterns of leaf growth and whole-plant water balance in Populus trichocarpa, P. deltoides, and their $\mathrm{F} 1$ hybrids were studied during a soil drying cycle. Survival was more strongly correlated with the hydraulic conductivity than with the dehydration tolerance of leaf tissues. Collectively, responses suggested that $F 1$ hybrids were more drought resistant than either parental species and highlight the importance of whole-plant studies of functional relationships between plant growth, water balance and hydraulic conductivity.

[RIPARIAN HABITAT; RIPARIAN FOREST; SOII -WATER CONDITIONS]

196. Bradford,JM; Farrell,DA; Larson,WE (1973): Mathematical evaluation of factors affecting gully stability. Soil Science Society of America Proceedings 37, 103-107.

A study of the factors influencing the stability of gully banks was conducted. A two-dimensional stability analysis was completed using the Simplified Bishop Method of Slices. Where the angle of internal friction was $=<35$ degrees, vertical, saturated, or near-saturated gully walls in loessial soils will fail if a ground water table exists at the base of the wall and if the cohesion for the saturated soil system is zero at a hydrostatic pressure of zero. The calculated stability for gully banks is relatively insensitive to slope height and soil bulk density. Tension cracks that open back from the gully face do not materially influence stability. The effect of infiltration rate into the soil on the stability of the gully wall depends upon the rate of water conductivity through the soil or the level of the ground water table. Increasing infiltration rate decreases stability.

[CHANNEL MORPHOLOGY; GULLY CONTROL; SEDIMENTATION; SOILS]

197. Bradford,JM; Piest,RF (1977): Gully wall stability in loess-derived alluvium. Soil Science Society of America Proceedings 41, 115-122.

An instrumented vertical slope was used to investigate triggering mechanisms that initiate gully wall failure in loess-derived alluvium. Relevance of hydrology, soil morphology, and soil mechanics to gully slumping was examined. Conventional limit equilibrium slope stability methods were of little value in predicting failure volumes or in understanding the failure mechanics. The geometry 
and time of failure are greatly influenced by the structural features of loess-derived alluvium and by the dependence of the shear strength on the pore water pressure within the soil. [CHANNEL MORPHOLOGY; GULLY CONTROL; SEDIMENTATION; STREAMBANK STABILITY]

198. Bradley,C (1993): A conservation and management strategy for riparian forests in southern Alberta. p.246. In: Tellman,B; Cortner,HJ; Wallace,MG; DeBano,LF; Hamre, RH [tech. coord.]. Riparian management: Common threads and shared interests. USDA Forest Service. General Technical Report RM-226.

The strategy document contains a statement of vision and mission, guiding principles, and recommended goals, objectives, and actions. [CONSERVATION; RIPARIAN FOREST; RIPARIAN HABITAT]

199. Bradshaw,S (1993): The river through the recreationist lens. p. 43-45. In: Tellman,B; Cortner,HJ; Wallace,MG; DeBano,LF; Hamre,RH [tech. coord.]. Riparian management: Common threads and shared interests. USDA Forest Service. General Technical Report RM-226.

The River Restoration Funds in Montana is a rewarding initiative that involves partnerships between sportsmen and landowners. Emphasis should be on similar programs on a larger scale. Approaches that are permanent and effective will only arise out of a sense of shared responsibility.

[PARTNERSHIPS; RECREATION IMPACTS; RIPARIAN HABITAT; RIPARIAN MANAGEMENT ZONE]

200. Brady,W; Patton,DR; Paxson,J (1985): The development of southwestern riparian gallery forests. p.39-43. In: Johnson,RR; Ziebell,CD; Patton,DR; Ffolliott,PF; Hamre,RH [tech. coord.]. Riparian ecosystems and their management: Reconciling conflicting uses. 16-18 April 1985. Tucson, AZ. USDA Forest Service. General Technical Report RM-120.

Riparian gallery forests along two southwestern rivers are described in a developmental continuum ranging from nursery bar to mature forest. Habitats suitable for tree production are recognizable by their position relative to the active water course. Sites are typically located in overflow channels and only receive flow during flooding. Floods and subsequent aggradation appear to be the major variables for the natural sequence of development within riparian stands.

[GALLERY FOREST; RIPARIAN HABITAT; RIPARIAN VEGETATION]

201. Braun, $R$ (1986): Livestock grazing in riparian zones: Ensuring fishery protection in federal rangeland management. Anadromous Fish Law Memo. Issue No. 37. October 1986. 18 p. Natural Resource Law Institute, Lewis and Clark College, Portland, OR.

This memo discusses: 1) the functions of riparian ecosystems and information about the benefits of riparian zone restoration; 2) the conflict between livestock grazing and restoration of riparian zones; 3 ) the evolution of range management policy from the enactment of the Taylor Grazing Act through recent judicial interpretation of the Public Rangeland Improvement Act of 1978, and (4) the role of the Clean Water Act in limiting BLM discretion to forestall or scale down riparian zone restoration, including the availability of citizen suits to enforce agency compliance with water quality laws. The memo concludes that the agencies involved must give a high priority to implementing a program for rehabilitation of streamside ecosystems.

[CLEAN WATER ACT; GRAZING IMPACTS; RIPARIAN HABITAT; RIPARIAN RESTORATION; WATER LAW]

202. Braun,RH (1986): Emerging limits on federal land management discretion: Livestock, riparian ecosystems, and Clean Water Law. Environmental Law 17(43), 43-79.

Historically, unregulated use of the public range by domestic livestock destroyed the health and benefits of vast quantities of riparian ecology. Although recent evidence demonstrates that riparian systems have remarkable restorative capacity, there is currently no national program to begin that restoration. The lack of such a program is largely due to the fact that federal land management law provides no judicially enforceable duties to restore damaged ecological systems. This article discusses the ecological role of riparian systems, the history of their destruction, and the failure of land management law to adequately address their restoration. The article concludes that agency discretion to ignore ecological restoration is substantially constrained by resource specific statutes such as the Clean Water Act.

[CLEAN WATER ACT; GRAZING IMPACTS; RIPARIAN HABITAT; RIPARIAN MANAGEMENT ZONE; WATER LAW] 
203. Bravo,M (1993): A view from the Hualapai tribe. In: Tellman,B; Cortner,HJ; Wallace,MG; DeBano,LF; Hamre, RH |tech. coord.|. Riparian management: Common threads and shared interests. USDA Forest Service. General Technical Report RM-226.

The Hualapai tribe owns lands which include 108 miles of frontage on the Colorado River within the Grand Canyon. At present, the tribe is involved in several cooperative projects regarding environmental issues with contractors and consultants. They are now seeking equity with federal and state agencies in dealing with concerns and problems related to riparian management.

[COLORADO RIVER; RIPARIAN HABITAT; RIPARIAN MANAGEMENT ZONE]

204. Brayton,D Scott (1984): The beaver and the stream. Journal of Soil and Water Conservation. March-April 1984, 108-109.

Riparian restoration using beavers instead of bulldozers is attracting wide attention. In Wyoming, beavers incorporated old truck tires provided by biologists into aspen log dams which now collect 10 $\mathrm{X}$ more sediment than normal log dams. Three years after beaver introduction, willows have returned in abundance, and the water table rose to encourage growth of aquatic vegetation. Marsh and wet meadow habitat were created and more wildlife are seen in the area.

[BEAVER; RIPARIAN RESTORATION]

205. Breeding,NA (1996): Management plan for the Rio Cebolla watershed, Sandoval County and Rio Arriba County, New Mexico. p.346-350. In: Shaw,DW; Finch,DM [tech. coord.]. Desired future conditions for Southwestern riparian ecosystems: Bringing interests and concerns together. USDA Forest Service. General Technical Report RM-GTR-272.

The upper 16.8 miles of the Rio Cebolla watershed were studied to identify water-related management concerns. Land ownership is divided between private, state, and federal. Recreation is the predominant activity, particularly fishing and camping. Other major land users are residents of the Seven Springs Community, cattle grazers, and fish hatchery employees. In 1994-95, a program to reintroduce now vanished Rio Grande cutthroat trout into the less accessible reaches of the river was undertaken. Water quality problems include eutrophication of Fenton Lake reservoir, riparian damage, and heavy sediment in the river. As a result, fish productivity is low, fishing is poor, and scenic enjoyment is spoiled. A watershed management plan is proposed to remedy these problems.

Implementation of the plan is cost-effective, as the benefit/cost ratio equals 2.5 . Benefits are derived from the value of an angler day. [FISH HABITAT; RIPARIAN HABITAT; WATER QUALITY; WATERSHED]

206. Bren,LJ (1993): Riparian zone, stream, and floodplain issues; A review. Journal of Hydrology, 150: 277-299.

The effects of forest management on streams, riparian zones, and floodplains has become a focal issue in recent years. There is general agreement that such areas should be managed in a state of "naturalness", although the definition of that term is subject to debate. A number of management standards have been recognized, however, and some quantified. Issues regarding upland catchments particularly relate to direct disturbance in the zone, changes in the flow of woody debris into the stream, or disturbance to the environment by occurrences upstream or downstream. For large rivers, the most common issue is the effect of river management on flooding forests. Most collected data and information tends to be at a local level, but the concept of "cumulative effects" has much potential value. [CUMULATIVE IMPACTS; LARGE WOODY DEBRIS; RIPARIAN ZONES; RIPARIAN FOREST]

\section{Brenner,FJ (1986): Evaluation and} mitigation of wetland habitats on mined lands. In: The 1986 national symposium on mining, hydrology, sedimentology, and reclamation. 8-12 December 1986. Lexington, KY.

Wetland evaluation and mitigation criteria based on ecological principles is proposed as a guide to both regulatory agencies and the mining industry. These criteria may include Habitat Evaluation Procedures (HEP) developed by USDI Fish and Wildlife Service and/or other operational variables concerned with the severity of impact and the costs and technical aspects of mitigation. Regional numerical indices should be developed for established wetlands that impacted wetlands can be compared with on a regional basis. Mitigated wetlands should be concerned not only with the principle species being impacted by mining but also with the ecology of the region.

[HYDROLOGY; MINING IMPACTS; RIPARIAN HABITAT; WETLANDS]

208. Bridgham,SD; Faulkner,SP; Richardson,CJ 
(1991): Steel rod oxidation as a hydraulic indicator in wetland soils. American Journal of the Soil Science Society 55, 856-862.

Depth of rusting on steel rods is proposed as an inexpensive means of determining depth to the water table. In laboratory microcosms, the steel rod rusting depth exactly matched water-table levels under both permanently flooded and drained conditions. Under a rapidly fluctuating hydrology, however, once heavy rust formed on the rods, it did not dissolve upon partial flooding.

[HYDROLOGY; SOILS; WATER TABLE EFFECTS]

209. Briggs, $M$ (1995): Evaluating degraded riparian ecosystems to determine the potential effectiveness of revegetation. p.63-67. In: Roundy,BA; McArthur,ED; Haley,JS; Mann,DK [comp.]. Proceedings: Wildland shrubs and arid land restoration symposium. 19-21 October 1993. Las Vegas, NV. USDA Forest Service. General Technical Report INT-GTR-315.

Revegetation is often limited in its ability to improve the condition of degraded riparian ecosystems. In some cases, revegetation has been implemented in riparian areas that were fully capable of coming back naturally. In other instances, plantings were made in riparian sites where they could not survive. To accomplish riparian revegetation most effectively, the causes of site decline and the current ecological condition of the site need to be understood. This can best be accomplished by evaluating the condition of the riparian ecosystem from a watershed perspective that takes into consideration how perturbations in surrounding ecosystems may be affecting site conditions.

[RIPARIAN RESTORATION; WATERSHED]

210. Briggs, MK (1996): Riparian ecosystem recovery in arid lands. 1st ed. University of Arizona Press, Tucson, A7. 159 p.

Ecosystem managers have an increased need to restore riparian ecosystems in the arid West that have been degraded by land and water management practices. The author emphasizes several concepts that should be fundamental to restoration projects but are often ignored. One of these is that the underlying causes of degradation need to be identified before restoration projects are undertaken. He also advocates considering multiple impacts, interactions between impacts, and site history when assessing causes of site degradation. Causes can be complex and difficult to assess and may include depletion of water availability by ground water pumping, alteration of flood water regimes, overgrazing by cattle, and increased soil salinity from upstream agricultural activities, and others. Another related concept is that riparian restoration is often best accomplished by restoring natural processes or conditions, then allowing these factors to restore the ecosystem naturally. Because of resiliency, most riparian ecosystems will undergo natural recovery over time.

[RIPARIAN ECOLOGY; RIPARIAN

RESTORATION]

211. Briggs,MK (1997): Riparian river restoration and conservation - Some lessons from the southwestern U.S. and northern Mexico. In: Proceedings of the Society of Wetland Scientists. 18 th annual meeting. Restoration and Management Notes 16(1):92.

Four factors play a critical role in stemming ecological decline and improving riparian site stability: 1) recovery strategies need to address the principal causes of ecological decline; 2) strategies need to be developed from a watershed perspective; 3 ) an awareness of current conditions such as stream flow, depth-to-groundwater, and soil chemistry is critical to an effective riparian recovery plan; and 4) working with local community peoples can provide crucial benefits to increase long-term effectiveness. [COLLABORATION; RIPARIAN RESTORATION; STREAM FLOW; WATERSHED]

\section{Brinson,MM (1980): Riparian and} floodplain ecosystems functions, values, and management. USDI Fish and Wildlife Service, Biological Services Program, Eastern Energy and Land Use Team. Kearneysville, WV. 7 p.

This is a preview summary of a future manuscript that would focus on the functions, values, and management of riparian and floodplain ecosystems. The purpose of that effort was to document and interpret the available information so that consequences of riparian/floodplain alteration and deterioration could be assessed at a national level. [FCONOMICS; FLOODPLAIN MANAGEMENT; RIPARIAN HABITAT; RIPARIAN MANAGEMFNT 7.ONE]

213. Brinson, $M M$ (1988): Strategies for assessing the cumulative effects of wetland alteration on water quality. Environmental Management 12(5), 655-662.

Three fundamental wetland categories should be 
recognized for the assessment of cumulative impacts on wetlands: basin, riverine, and fringe. Basin, or depressional, wetlands are located in headwater areas, and capture runoff from small areas. Riverine wetlands interface extensively with uplands. Fringe wetlands are very small in comparison with the large bodies of water that flush them. The relative proportion of these wetland types within a watershed and their reactive status to past impacts can be used to develop strategies for wetland protection. [CUMULATIVE IMPACTS; WATERSHED; WETLANDS]

214. Brinson,MM; Swift,BL; Plantico,RC; Barclay,JS (1981): Riparian ecosystems: Their ecology and status. USDI Fish and Wildlife Service, Biological Services Program. FWS/OBS-81/17.

This is a comprehensive manuscript that addresses the functions, values, and management of riparian and floodplain ecosystems. It documents and interprets available information on these ecosystems so that consequences of their alteration and degradation can be assessed on a national level. The document focuses on the issues of major concern that might impinge upon riparian and floodplain ecosystems. It also discusses the common properties of these ecosystems in order to simplify recommendations and decisions that affect their management and protection.

[CLASSIFICATION; FLOODPLAIN

MANAGEMENT; RIPARIAN ECOLOGY; RIPARIAN HABITAT]

215. Britton,CM; Cornely,JE; Sneva,FA (1980): Burning, haying, grazing, and non-use of flood meadow vegetation. p.7-9. 1980 Progress Report, Research in rangeland management, Agricultural Experiment Station, Oregon State University Corvallis, OR. Special Report 586.

This study evaluated vegetalive response to burning and grazing plots that had been in non-use for 3 years. Burning provided the greatest maximum height and yield of vegetation after non-use. Grazing, however, produced the most desirable overall response.

[FIRE IMPACTS; GRAZING IMPACTS; MEADOWS; VEGETATION MANIPULATION; WETLANDS]

216. Britton,CM; Sneva,FA (1979): Effects of haying and non-use on flood meadow vegetation. p. 5-7. In: Research in rangeland management. Oregon State University. Corvallis, OR. Special

\section{Report 549.}

Management of flood meadow vegetation appears to have dramatic effects on the ability of these areas to produce and the species composition of what is produced. This study compared an area that was hayed with an area that was not. The comparison was made through measurements of herbage yield and plant species composition. Non-use had a pronounced effect on meadow vegetation.

[MEADOWS; RIPARIAN HABITAT]

217. Brock,JH (1985): Physical characteristics and pedogenesis of soils in riparian habitats along the upper Gila River basin. p.49-53. In: Johnson,RR; Ziebell,CD; Patton;DR; Ffolliott,PF; Hamre, RH [tech.coord.|. Riparian ecosystems and their management: Reconciling conflicting uses. 16-18 April 1985. Tucson, AZ. USDA Forest Service. General Technical Report RM-120.

Knowledge of soils in Southwestern riparian habitats is minimal. Soil profiles in the riparian zone on the Gila and San Franscisco Rivers were studied. The soils that support trees can be classified as Torrifluvents or on the more stable sites as Haplustolls. Coarse textures and low water holding capacity are dominant characteristics.

[RIPARIAN HABITAT; SOILS]

218. Brode,JM; Bury,RB (1984): The importance of riparian systems to amphibians and reptiles. p.30-36, In: Warner,RE; Hendrix, KM [eds.]. Proceedings of the California riparian systems conference. 17-19 September 1981. Davis, CA. University of California. Berkeley, CA.

California has a rich herpetofauna which includes about 120 native species. Riparian systems provide habitat for 83 percent of the amphibian and 40 percent of the reptile species. Amphibians and reptiles utilize these systems to varying degrees and can be classified according to the type of use. Riparian systems provide corridors for dispersal and also allow certain species to use otherwise unsuitable environments. Timber harvesting and water diversions are detrimental to amphibians and reptiles in the zone of influence of such activities because their entire life histories occur in the riparian zone. [HERPETOFAUNA; LOGGING IMPACTS; RIPARIAN HABITAT]

219. Brothers, TS (1984): Historical vegetation change in the Owens River riparian woodland. p. 75-84. In: Warner,RE; Hendrix,KM |eds.| California riparian systems: Ecology, conservation and productive management. 17-19 
September 1981. Berkeley, CA.

Human-caused vegetation change in the Owens

River, California, is evaluated. Greatest changes have occurred below the intake of the Los Angeles

Aqueduct, where drying of the channel has

eliminated most native riparian cover and allowed invasion of salt cedar. Fire, water management, and other factors may have reduced tree cover above the aqueduct intake and encouraged proliferation of weedy native shrubs. Present scarcity of tree seedlings suggests that one or more of these factors continues to inhibit tree regeneration. [HISTORIC RECORDS; HUMAN IMPACTS; PHREATOPHYTES; RIPARIAN HABITAT]

220. Brouha,P; Chappell,W (1997): A watershed call to arms. Fisheries 22(5), 4.

Current understanding and knowledge of the effects of chemical, biological, and mechanical processes in North America's streams and rivers is often inadequate and not well applied. Public policies often aggravate watershed problems. Inadequate and misapplied policies are a major cause of continued deterioration of many of our watersheds. [RIPARIAN RESTORATION; WATERSHED]

221. Brown,AV; Lyttle,MM; Brown,KB (1998): Impact of gravel mining on gravel bed streams. Transactions of the American Fisheries Society 127: 979-994.

Gravel mining in Arkansas streams significantly altered the geomorphology, fine particle dynamics, turbidity, and biotic communities. Stream channel form was altered by increased bankfull widths, lengthened pools, and decreased riffles in affected reaches. Fine particulate organic matter transported from riffles to pools was decreased. Biofilm organic content was decreased on flats and increased on remaining riffles. Density and biomass of large invertebrates and density of small invertebrates were reduced by mined sites. Total densities of fish in pools and game fish in pools and riffles were reduced. Silt-sensitive species of fish were less numerous downstream from mines. Many attempts at restoration or mitigation prove to be ineffective. Mining gravel from streams results in irreconcilable conflicts.

[FISH HABITAT; MINING IMPACTS; RIVER ECOLOGY; WATER QUALITY]

222. Brown,BT; Trosset,MW (1989): Nesting habitat relationships of riparian birds along the Colorado River in Grand Canyon, AZ. The Southwestern Naturalist 34(2), 260-270.
Vegetation structure and the numbers of shrubs were measured at nest sites of 11 species of riparian birds in a tamarisk community to characterize breeding habitat by species. Riparian birds exhibited significant differences in their use of nesting habitat. Bell's vireo, yellow warbler, and yellow-breasted chat were relative generalists in their use of nesting habitat, while common yellow-throat and Bullock's oriole were relative specialists. Bell's vireo and American coot used the most dissimilar habitats. Willow flycatcher and yellow warbler consistently used habitat most similar to that used by other species. The tamarisk community created by the operation of the Glen's Ferry Dam represents the ecological equivalent of native habitat for some riparian birds, and its presence has enhanced breeding habitat for these 11 species of birds. [AVIAN ECOLOGY; CLASSIFICATION; RIPARIAN HABITAT; SALT-CEDAR]

223. Brown,CB; Murphy,WT (1955): Conservation begins on the watersheds. p.161-165. In: Water: The yearbook of agriculture. 84th Congress. House document No. 32.

At the time of writing, the concept of small watershed management was just beginning to be applied on the ground. National programs of assistance to landowners had not provided adequate aid in the resolution of interrelated community problems. Such problems included local agricultural and urban flood control, mutual irrigation developments, drainage improvements on creeks, local water supplies, pollution abatement on tributaries, wildlife habitat improvements, and stabilization of eroded and degraded lands. [FLOOD IMPACTS; PLANNING; RIPARIAN HABITAT; WATERSHED]

224. Brown,CR (1990): Avian use of native and exotic riparian habitats on the Snake River, Idaho. M.Sc. Thesis, Colorado State University, Ft. Collins, CO. 60 p.

Avian use in 5 riparian habitat types (willow, Russian olive, willow-Russian olive mix, river birch and hackberry) was inventoried during the winter and breeding seasons, 1989. Twenty-two species were observed during winter inventories and 36 species observed during the breeding season of which 21 species bred in the study area. Willow sites had higher species richness and density than the exotic Russian olive sites.

[AVIFAUNA; BIODIVERSITY; RIPARIAN HABITAT] 
225. Brown,DE (1981): Evolution and riparian dynamics. p.288-290. In: Warner,RE;

Hendrix,KM eds.|. Proceedings of the California riparian systems conference. 17-19 September 1981. Davis, CA.

Perennial streams and marshes in Arizona have been mapped and classified under a new wetland classification system. The latter is systematic, universal, and hierarchical, and recognizes evolutionary relationships. Biogeography was an important consideration.

[CLASSIFICATION; RIPARIAN HABITAT]

\section{Brown,DE; Carmony,NB; Turner,RM} (1977): Inventory of riparian habitats. p.10-13. In: Johnson, RR; Jones, DA [tech. coord.]. Importance, preservation, and management of riparian habitat: A symposium. USDA Forest Service, General Technical Report RM-43.

The paper presents a recently published map of Arizona's perennial streams and important wetlands. Perennial streams were illustrated rather than riparian vegetation because the streams were of more direct biotic significance and were more identifiable. [INVENTORY; RIPARIAN HABITAT]

227. Brown,DE; Lowe,CH; Hausler,JF (1977): Southwestern riparian communities: Their biotic importance and management in Arizona. p. 201-211. In: Johnson,RR; Jones,DA [tech. coord.]. Symposium on the importance, preservation and management of the riparian habitat. 9 July 1977. Tucson, AZ. USDA Forest Service. General Technical Report RM-43.

Various riparian communities occurring in Arizona and the southwest and their biotic importance are described. Recommendations are also made regarding management of streamside environments and watersheds. These include classification and inventory; determination of limiting factors; establishment of study areas; regulation and elimination of livestock grazing; water management projects; and watershed conservation. [CLASSIFICATION; RIPARIAN HABITAT; RIPARIAN MANAGEMENT ZONE]

228. Brown,DE; Lowe,CH; Pase,CP (1979): A digitized classification system for the biotic communities of North America, with community series and association examples for the Southwest. Journal of the Arizona-Nevada Academy of Science 14(1), 1-16. [CLASSIFICATION]
229. Brown,GW (1970): Predicting the effect of clear-cutting on stream temperatures. Journal of Soil and Water Conservation 25, 11-12.

Temperature changes that occur between two points on a stream are strictly proportional to the surface area of the stream and the heat load applied hetween those points. They are also inversely proportional to flow. Adequate estimates of the heat load can be made with solar radiation data if the stream is uniformly exposed to sunlight. This technique can be used by foresters to predict the effect of clear-cutting on stream temperatures. [LOGGING IMPACTS; SOLAR RADIATION; STREAM TEMPERATURE]

230. Brown,GW; Beschta,RL (1985): The art of managing water. Journal of Forestry. October, 1985, 604-615.

The forestry profession, sensitive to environmental problems, is in a good position to manage the nation's forest water resources but they face scientific, legal, social, and political issues. It is time to reinvest in water research for forestry, especially studies relating directly to intensive forest operations.

[WATER QUALITY; WATER RESOURCE MANAGEMENT]

231. Brown,GW; Krygier, JT (1971): Clear-cut logging and sediment production in the Oregon Coast Range. Water Resources Research 7(5), 1189-1198.

The impacts of clear-cutting, road construction, and slash burning were studied for 11 years. Sediment production was doubled after road construction but before logging in one watershed and tripled after burning and clear-cutting. Felling and yarding did not contribute significantly to sediment production. Conclusions were limited because of annual variation for each watershed, variation between watersheds, and variation with stage of the process.

[LOGGING IMPACTS; SEDIMFNTATION; WATERSHED]

232. Brown,J (1993): Play hard, play fair, nobody hurt. p.128-129. In: Tellman,B; Cortner,HJ; Wallace,MG; DeBano,LF; Hamre, RH [tech. coord.]. Riparian Management: Common threads and shared interests. USDA Forest Service. General Technical Report RM-226.

Strategies for river protection should include: 1) maintaining a regular presence at the statehouse and 
being available to legislators and agency personnel;

2) avoid using deceptive tactics, gross exaggerations or misleading half-truths; and 3 ) those playing the political game must be sensitive and respectful to the needs and limitations of others.

[POLITICAL ISSUES; RIPARIAN HABITAT; RIVER ECOLOGY]

233. Brown,JE (1994): Oregon's Forest Practices Act and riparian rules. p.51-59. In:

Fredericton,NB [ed.]. Proceedings of the symposium on riparian zone management. Canadian Forest Service (Maritimes Region). Natural Resources Canada.

Recent legislation amending Oregon's Forest Practices Act called for the Board of Forestry to review its classification of waters of the state and make appropriate changes to its riparian administrative rules. The Legislative Assembly did not provide any direction about the expected levels of protection for fish, wildlife, biodiversity, etc. To further complicate matters, the parties involved in negotiating the development of the Bill would not agree to a negotiated process to establish the levels of protection and develop the rules. Rather, they demanded that the Department of Forestry follow wherever "good science" might lead. Additionally, the Legislature constrained the project by establishing a deadline. The Department staff is currently working to redraft the administrative rules. [FOREST MANAGEMENT; POLICY; RIPARIAN HABITATT

234. Brown,JK (1989): Effects of fire on aquatic systems. p. 106-110. In: Proceedings of the wild trout IV symposium. Mammoth, WY. 18-19 September 1989.

Fire affects spawning areas and food habitat in streams by indirectly influencing water flow, nutrients, erosion, sedimentation, debris, and water temperature. The response of vegetation following fire is the most important factor affecting aquatic areas. Effects of fire on aquatic systems vary over time tending to be detrimental at first but often beneficial later.

[FIRE IMPACTS; RIPARIAN HABITAT; RIPARIAN MANAGEMENT ZONE]

235. Brown,MK; Parsons,GR (1979): Waterfowl production on beaver flowages in a part of northern New York. New York Fish and Game Journal 26(2), 142-153.

Waterfowl were observed on numerous occasions on selected beaver flowages in upstate
New York. These flowages were classified as new active, old active, or abandoned. New active flowages were used to a greater degree than the other classifications. The use by waterfowl of these flowages was concluded to be sufficient to warrant a beaver management program that would in turn benefit waterfowl.

[BEAVER; RIPARIAN HABITAT; WATERFOWL MANAGEMENT]

236. Brown,TC; Daniel,TC (1991): Landscape aesthetics of riparian environments: Relationship of flow quantity to scenic quality along a wild and scenic river. Water Resources Research 27(8), 1787-1795.

The relationship between flow quantity and scenic quality was measured for a "wild and scenic" river in Colorado. Respondents' scenic beauty judgements of video sequences depicting the river at flow rates of 120 to $2650 \mathrm{cfs}$ were scaled to an interval scale measure of perceived scenic beauty following psycho-physical procedures. Regressions of scenic beauty on variables describing flow increased up to about $1100-1500 \mathrm{cfs}$ and then fell as flow continued to increase. Optimum flows for scenic quality typically occur for two short periods each year, during the ascending and descending portions of the annual late spring runoff season.

[RIPARIAN HABITAT; SCENIC QUALITY; STREAM FLOW]

237. Brunsfeld,SJ; Johnson,FD (1985): Field guide to the willows of east-central Idaho. College of Forestry, Wildlife and Range Sciences, University of Idaho, Moscow, ID. Bulletin No. 39. 95 p.

An illustrated handbook for field identification of willow species growing in east-central Idaho. A key for species identification is included. [CLASSIFICATION; RIPARIAN PLANTS; RIPARIAN VEGETATION]

238. Brussock,PP; Brown,AV; Dixon,JC (1985): Channel form and stream ecosystem models. Water Resources Bulletin 21(5), 859-866.

The authors propose to classify running water habitats based on their channel form which can be considered in three different sedimentological settings: a cobble and boulder bed channel, a gravel bed channel, or a sand bed channel. The physical factors - relief, lithology, and runoff - were selected as state factors that control all other interacting parameters associated with channel form. Integrating these factors produced seven distinct stream regions 
each representing a succession of channel forms downstream. These applications refine the River Continuum Concept by recognizing the nonrandomness of the effects of geomorphology on stream ecosystems. This is a regional perspective of streams that enhances the geographical considerations affecting study areas.

[CHANNEL MORPHOLOGY; GEOMORPHOLOGY; SEDIMENTATION; STREAM ECOLOGY]

239. Bryan,RB; Campbell,IA (1982): Surface flow and erosional processes in semiarid mesoscale channels and drainage basins. p.123-133. In: Proceedings of the Exeter symposium: Recent developments in the explanation and prediction of erosion and sediment yield. July 1982. IAHS Publ. No. 137.

Detailed studies of surface flow and initiation of channels and drainage networks are facilitated in badlands where barren, rapidly eroded surfaces offer ideal sites for micro and meso-scale experiments. In the micro-scale application, the response of dessicated shales depends on the detailed interaction of raindrop impact, particle detachment, surface sealing and sub-surface flow, while indurated sandstones and pediments yield flow and sediment almost instantly, even under low rainfall. The water and sediment flows from a complex system and different response thresholds pose considerable problems for precise monitoring in meso-scale applications.

[CHANNEL MORPHOLOGY; DRAINAGES; GEOMORPHOLOGY; STREAMBANK PROTECTION]

240. Bryant,HT; Blaser,RE; Peterson,JR (1972). Effect of trampling by cattle on bluegrass yield and soil compaction of a Meadowville Loam. Agronomy Journal 64, 331-334.

This study evaluated the tolerance of loam soils and bluegrass to trampling by cattle. The trampling pressures, repeated four times a year, were 0,60 , and 120 trips per cow. As trampling pressure increased, maximum resistance to the penetrometer was encountered closer to the soil surface. The height of forage at trampling had no significant effect on either the force required to penetrate the soil or depth of soil at which maximum resistance to penetration was encountered. Increasing trampling pressure had a significantly adverse effect on forage yield for tramplings in June and September.

[GRAZING IMPACTS; LIVESTOCK EFFECTS; SOILS]
241. Bryant,LD (1982): Livestock response to riparian zone exclusion. Journal of Range Management 35(6), 780-785.

The best alternative for rapid restoration of streamside riparian zones is fencing. While excluding the major portion of the riparian zone by fencing, use by cows with calves and by yearlings was evaluated on the remaining portion. Both classes of livestock generally selected the riparian zone over the uplands throughout most of the summer grazing season. Both classes of livestock reversed their selection in favor of upland vegetation in the latter part of the season. Slopes less than 35 percent were preferred. Cows were more selective in use of certain plant communities than yearlings and, contrary to usual findings, distributed themselves over the range better than yearlings. Neither salt placement nor alternate water location away from the riparian zone influenced livestock distribution appreciably.

[EXCLOSURES; GRAZING IMPACTS; LIVESTOCK EFFECTS]

242. Bryant,LD (1985): Livestock management in the riparian ecosystem. p.285-289. In: Johnson,RR; Ziebell,CD; Patton,DR; Ffolliott,PF; Hamre, RH [tech. coord.]. Riparian ecosystems and their management: Reconciling conflicting uses. 16-18 April 1985. Tucson, AZ. USDA Forest Service. General Technical Report RM-120.

Intensive, long-term livestock grazing has occurred along most streams in the western United States. Although most livestock grazing on public lands is now under some form of management, many riparian areas are below "good" in ecological condition, with forage production considerably below normal. Eight years of research in northeast Oregon indicates that forage production was increased 1-4 X through timing and season of grazing. Grazing systems did not statistically affect plant composition but production of graminoids and forbs were increased dramatically.

[GRAZING IMPACTS; GRAZING TREATMENTS]

243. Bryant,LD; Skovlin,JM (1982): Effect of grazing strategies and rehabilitation on an eastern Oregon stream. p.27-30. In: Proceedings: Habitat disturbance and recovery. California Trout, Inc., San Francisco, CA.

Planting conifers adjacent to the riparian zone was not successful even where cattle did not graze. Since conifers within the riparian zone or adjacent flood plain can provide important shade and cover, however, a successful methodology should be 
pursued. Streambanks can be stabilized by planting native shrub cuttings, and growth can be accelerated if they are protected from grazing. Browsing of native shrubs, primarily mountain alder, averaged between 60-65 percent, where cattle, deer, and elk had unlimited access, regardless of grazing treatment. Big game apparently accounted for 25-30 percent of this use. This degree of browsing did not appear to be detrimental to established shrubs, it could have adverse effects on natural regeneration and stand recruitment.

[GRAZING IMPACTS; GRAZING TREATMENTS; RIPARIAN RESTORATION; RIPARIAN VEGETATION]

244. Bryant,MD (1983). The role and management of woody debris in west coast salmonid nursery streams. North American Journal of Fisheries Management. 3:322-330.

Management techniques for small streams in logged watersheds frequently include debris removal. Many stream cleaning techniques, however, overlook important habitat requirements of juvenile salmonids. Reviews of past management practices show little systematic evaluation or monitoring of biological or physical effects. This paper discusses: 1) past vs. current management of woody debris resulting from logging operations; 2) summarizes the role of woody debris and its effect on salmonid habitat; and 3) presents general guidelines for debris management in anadromous salmonid streams.

[FISH HABITAT; LARGE WOODY DEBRIS; LOGGING IMPACTS]

245. Bryant,MD (1985): Changes 30 years after logging in large woody debris, and its use by salmonids. p.329-334. In: Johnson,RR; Ziebell,CD; Patton,DR; Ffolliott,PF; Hamre,RH [tech. coord.]. Riparian ecosystems and their management: Reconciling conflicting uses. 16-18 April 1985. Tucson, AZ. USDA Forest Service. General Technical Report RM-120.

Changes in large woody debris in fourth- and fifth-order salmon streams with logged, unlogged, and partially logged riparian zones were documented over a 30-year period. Most changes in the amount of large woody debris occurred in the logged systems. During and immediately after logging large increases were noted. Amounts in the other categories remained relatively stable. Thirty years after logging, habitat formed as a result of large debris provided important rearing areas for juvenile salmonids. Results from this study emphasize the importance of managing riparian zones as a source of large organic debris.

[FISHERIES; LARGE WOODY DEBRIS; LOGGING IMPACTS; RIPARIAN HABITAT]

246. Bryant,MD; Everest, FH (1998): Management and condition of watersheds in southeast Alaska: The persistence of anadromous salmon. Northwest Science 72(4), 249-269.

Numerous intact or lightly disturbed watersheds are present throughout southeast Alaska that support abundant and diverse populations of anadromous salmonids. Significant human disturbance of the watersheds did not begin until the 1950's with the advent of commercial logging. The most intensive logging occurred in the first 20 years when there were few constraints. As a result, there is a legacy of streams with deteriorating habitat from that period. Escapement records on specific watersheds that were most affected by management are lacking. The present status of salmon stocks may be attributed to abundant intact watersheds, high marine survival, and escapement levels that fully seed most watersheds. Intact watersheds are the key to maintaining sustainable salmon stocks in this region. [ANADROMOUS FISH; FISH HABITAT; LOGGING IMPACTS; WATERSHED]

247. Buckhouse,JC (1980): Water quality and its relationship to range livestock. p.1-3. In:

Proceedings of the 1980 summer meeting of the American Society of Agricultural Engineers. 15-18 July, 1980. San Antonio, TX.

There have been many concerns in recent years over the compatibility of domestic livestock and other multiple uses. It appears that with appropriate managerial constraints, livestock can be compatible, and even an important managerial tool, in rangeland/riparian ecosystems.

[GRAZING IMPACTS; STREAMBANK STABILITY; WATER QUALITY]

248. Buckhouse,JC (1984): Riparian shrubby vegetation protection against herbivore browsing. Water Resources Research Institute, WRRI-94. Corvallis, OR. 8 p.

Plastic caps can be used to protect replanted shrubs from browsing by livestock. The caps provide adequate protection and divert the livestock to older shrubs.

[GRAZING IMPACTS; RIPARIAN

RESTORATION]

249. Buckhouse,JC (1984): Riparian shrubby vegetation protection against herbivore grazing. 
p.1-2. 1984 Progress report -- Research in rangeland management. Agricultural Experiment Station, Oregon State University Corvallis, OR. Special Report 715.

Plastic-mesh bud caps have been used inexpensively to protect replantings in forest clearcuts. Their application to riparian zone plantings needs feasibility testing to determine if quick, low-cost rejuvenation of overgrazed streambanks might be possible while continuing to permit livestock needed livestock browsing of mature riparian vegetation.

[GRAZING IMPACTS; RIPARIAN

RESTORATION; RIPARIAN VEGETATION]

250. Buckhouse,JC (1985): Water and people: Common denominators in riparian zones. p.369-370. In: Johnson,RR; Ziebell,CD;

Patton,DR; Ffolliott,PF; Hamre,RH [tech. coord.|. Riparian ecosystems and their management: Reconciling conflicting uses. 16-18 April 1985. Tucson, AZ. USDA Forest Service. General Technical Report RM-120.

There are many approaches to allocating water. People are much harder to manage since they work from diverse social, psychological, economic, and aesthetic backgrounds. Any approach that brings people together makes the most sense for multiple use management.

[COLLABORATION; HUMAN IMPACTS; RIPARIAN HABITAT; WATER ALLOCATION]

251. Buckhouse,JC (1986): Riparian responses to various grazing systems and to periodic ice flows. p. 79-86. In: Gudmundsson, 0 . [ed.]. Grazing research at northern latitudes workshop. 5-10 August 1986. Hvanneyri, Iceland, NATO Advanced Science Institutes Series: Series A. Life Sciences, Vol. 108.

The rest-rotation grazing system appeared to favor increased infiltration, while deferred rotation and season-long grazing did not enhance and probably hindered it. Infiltration responded positively to a short-duration, high-intensity deferred rotation scenario in September and negatively to the same application in October because of the onset of fall rains. No grazing and season-long grazing following long periods of rest (4 years) appeared to be associated with the least bank loss. Season-long grazing for five consecutive years was associated with the most bank sloughing. Winter processes are also powerful influences on bank erosion. Major ice floes caused bank erosion throughout the whole stream system without regard to previous grazing treatment.

[GRAZING IMPACTS; GRAZING TREATMENTS; LIVESTOCK EFFECTS; RIPARIAN VEGETATION; RIVER ECOLOGY]

252. Buckhouse,JC; Bohn,CC (1983): Response of coliform bacteria concentration to grazing management. p.1-7. In: 1983 Progress Report --Research in Rangeland Management. Agricultural Experiment Station, Oregon State University Corvallis, OR. Special Report 682.

T-tests were applied to determine if coliform counts changed significantly within grazing treatments/systems. Although large numerical differences were seen, differences between grazing systems were not statistically significant. The number of colonies and the range of the counts generally decreased the first year livestock were not present. These numbers, however, were not statistically significant. Interpretation of coliform data from non-point sources must be cautious and must recognize a large number of sources of variation. Recent literature suggests large indicator bacteria populations are present in the bottom sediments and may or may not track with pathogenic organisms. [COLIFORM BACTERIA; GRAZING IMPACTS; GRAZING TREATMENTS; NON-POINT SOURCE POLLUTION; RIPARIAN MANAGEMENT ZONE; WATER QUALITY]

253. Buckhouse,JC; Gaither,RE (1982): Potential sediment production within vegetative communities in Oregon's Blue Mountains. Journal of Soil and Water Conservation March-April, 1982, 120-122.

A Rocky Mountain infiltrometer that simulated convectional rainstorms of $10 \mathrm{~cm}$ in 28 minutes was utilized to generate potential sediment losses from 10 natural ecosystems in Oregon's Blue Mountains. The grassland ecosystem produced a potential sediment loss of $431 \mathrm{~km} / \mathrm{ha}$. Sagebrush and juniper ecosystems showed potential sediment losses exceeding the losses in all other ecosystems with rates of 1,284 and $1,572 \mathrm{~km} / \mathrm{ha}$, respectively. As ecological condition class and/or vegetative productivity class changed within ecosystems, statistically significant changes in potential sediment production occurred.

[HYDROLOGY; SEDIMENTATION; SOILS; WATERSHED]

254. Buckhouse,JC; Skovlin,JM (1979): Streambank erosion in a Blue Mountain stringer meadow in response to livestock and big game grazing management. p. 2-4. In: Progress report -- 
Research in rangeland management. Agricultural Experiment Station, Oregon State University, Corvallis, OR. Special Report No. 549.

Streambank erosional losses in response to several management schemes continue to be investigated on Meadow Creek in the Blue Mountains of Oregon. Evidence indicates that after two years of grazing treatment, no significant differences were apparent. It appeared that the over wintering processes of high water ice floes and channel physiognomy were at least as important in this stream system as the grazing management schemes under investigation.

[EROSION; GRAZING IMPACTS; RIPARIAN HABITAT; RIPARIAN MANAGEMENT ZONE; STREAMBANK PROTECTION]

\section{Buckhouse,JC; Skovlin,JM; Knight,RW} (1981): Streambank erosion and ungulate grazing relationships. Journal of Range Management 34(4), 339-340.

Erosional patterns of streambanks were studied for 3 years in the Blue Mountains of Oregon. Livestock grazing use at the rate of $3.2 \mathrm{ha} / \mathrm{AUM}$ ( 8 acres/AUM) had not accelerated streambank degradation. Most erosion occurred during wintering periods and this erosion has been independent of grazing season treatments. It appeared that high runoff and occasional ice flows were the most significant factors in bank cutting on this stream. [EROSION; GRAZING IMPACTS; RIVER ECOLOGY; STREAMBANK PROTECTION]

256. Buckhouse,J; Todd,R (1998): Making watershed management a community activity. p.291. In: Potts, DF [ed.]. Rangeland management and water resources: Proceedings of the AWRA specialty conference. American Water Resources Association. 27-29 May 1998. Reno, NV.

Watershed management education is predicated upon three principles: 1) ecological reality and sustainability, 2) economic stability, and 3) social acceptability. The process of providing solid ecological principles and facts to local communities, where grass roots development of local watershed plans take place is described.

[PLANNING; WATERSHED]

257. Buckner,DL; Wheeler,RL (1988):

Construction of cattail wetlands along the East Slope of the Front Range of Colorado. p.126-131. In: Mutz,K; Cooper,DJ; Scott,ML; Miller, LK [eds.]. Restoration, creation, and management of wetland and riparian ecosystems in the American
West. A symposium of the Rocky Mountain Chapter of the Society of Wetland Scientists. 14-16 November 1988. Denver, CO.

This paper describes the objectives, methods, and results of construction of 12 acres of cattail wetland at Boulder Reservoir and discusses recommended procedures and potential problems for similar projects along the east slope of the Front Range, Colorado. Use of live topsoiling was a feasible means of establishing wetland vegetation quickly, with a high diversity of species. Cattails were propagated by seed resulting in almost-mature stands in about four months. The creation of appropriate hydrological conditions was more critical than propagating wetland species.

[CREATED WETLANDS; RIPARIAN

RESTORATION; WETLANDS]

\section{Budd,WW; Cohen,PL; Saunders,PR;} Steiner,FR (1987): Stream corridor management in the Pacific Northwest: 1. Determination of stream corridor widths. Environmental Management 11(5), 587-597.

Growth in King County, Washington, has placed pressure on stream corridors. Past studies and existing literature were used to provide guidelines for determining optimal stream corridor widths.

[BUFFER ZONES; RIPARIAN ZONES; WATERSHED]

259. Bull,EL; Skovlin,JM (1982): Relationships between avifauna and streamside vegetation. p.496-506. In: Transactions of the forty-seventh North American wildlife conference.

The avifauna is influenced by the deciduous vegetation in riparian habitats. One group of birds, the deciduous users, is particularly dependent on shrubs and deciduous trees for nesting and feeding. By understanding the associations between birds and habitat, management activities can be implemented to provide appropriate habitat for desired species. Removal of vegetation that reduces structural diversity also reduces bird diversity. Management by limited entry or closure during the spring nesting season may restore habitat and, as a result, maintain bird populations.

[AVIAN ECOLOGY; RIPARIAN HABITAT]

260. Bunte,K (1996): Analysis of the temporal variation of coarse bedload transport and its grain size distribution: Squaw Creek, Montana, USA. USDA Forest Service. General Technical Report RM-GTR-288. 124 p.

A continuous record of coarse material bedload 
transport was obtained for an entire snowmelt at Squaw Creek, a gravel-bed mountain stream. The measuring principle, the Magnetic Tracer Technique, makes use of naturally magnetic rocks (andesites) which induce a voltage peak as they pass over a detector log installed across the channel bottom. Signal rates were counted for 1-hour and 5-minute intervals and yielded a 17-day and a 3-day time series. Bedload transport exhibits recurring wave patterns and disintegrates into fluctuating and pulsating transport features as the temporal resolution is increased. The wide scatter in the relationship between bedload transport and discharge indicates that other parameters than flow affect bedload transport as well.

[BEDLOAD; GEOMORPHOLOGY; SEDIMENTATION]

261. Burghduff,AE (1934): Stream improvement. California Fish and Game 18 (1932-34), 113-118.

Stream improvement is a phase of conservation that may be divided into two classes of endeavor: 1) retardation of stream flow by the construction of dams or weirs; and 2) storage of water near the source of streams to be released in a continuous quantity sufficient to maintain stream flow during that portion of the year when streams would normally be low or dry. Numerous examples of stream improvements in California are discussed. [RIPARIAN RESTORATION; STREAM IMPROVEMENTS]

262. Burgi,PH; Karaki,S (1971): Seepage effect on channel bank stability. Journal of Irrigation and Drainage Engineering 97(No. IR1), 59-72.

Seepage flow frequently occurs across boundaries of unlined channels but the effect on bank stability is not clearly understood. Due to a general opinion that seepage effects are small, they are generally neglected in channel design. The basic objective of this study was to develop an empirical relationship between the seepage forces acting on a side slope of a channel and the stability of the side slope with various flow conditions present in the channel. The relationship shown provides significant insight into the process of channel side slope erosion when ground water seepage is prevalent. [CHANNEL MORPHOLOGY; STREAMBANK STABILITY; SURFACE WATERGROUNDWATER INTERACTION]

263. Burke,IC; Reiners,WA; Schimel,DS (1989): Organic matter turnover in a sagebrush-steppe landscape. Biogeochemistry 7, 11-31.
Laboratory incubations of $\mathrm{N}$-amended soils from a sagebrush steppe in south-central Wyoming indicate that nutrient turnover and availability have complex patterns across the landscape. Total and available $\mathrm{N}$ and $\mathrm{P}$ and microbial $\mathrm{C}$ and $\mathrm{N}$ were highest in topographic depressions characterized by tall shrub communities.

[LANDSCAPE ECOLOGY; NUTRIENT CYCLES; RIPARIAN HABITAT; SOILS]

264. Burke,TD; Robinson,JW (1979): River structure modifications to provide habitat diversity. p.556-561. In: Swanson,GA [ed.]. The mitigation symposium: A national workshop for mitigating losses of fish and wildlife habitat. USDA Forest Service. General Technical Report RM-65.

A discussion of the beneficial and detrimental effects of the Missouri River Bank Stabilization and Navigation Project and descriptions of structure modifications used to improve fish and wildlife habitats, flood carrying capacity, and accretion control. Methods include notched, rootless, and low elevation structures.

[RIPARIAN HABITAT; RIPARIAN

RESTORATION]

265. Burkham,DE (1976): Hydraulic effects of changes in bottom-land vegetation on three major floods, Gila River in southeastern AZ. USDI Geological Survey. Professional Paper 655-J. 14 p. [CHANNEL DYNAMICS; CHANNEL MORPHOLOGY; FLOOD IMPACTS; RIPARIAN VEGETATION]

266. Burns,JW (1981): Public values and riparian systems. p. 226-227. In: Warner,RE; Hendrix,KM [eds.]. California riparian systems conference. 17-19 September 1981. University of California. Davis, CA. [ECONOMICS; RIPARIAN HABITAT]

267. Burns, RG; Huendo,LM; Neary,DG (1995): Low cost methods to control sedimentation from roads. p.121-127. In: Aguirre-Bravo,C; VillaSalas, AB [comp.|. Partnerships for sustainable forest ecosystem management: Fifth Mexico/U.S. biennial symposium. 17-20 October 1994 . Guadalajara, Jalisco, Mexico.

Throughout the world there are many $\mathrm{km}$ of roads or natural surface roads located along streams. Sediment reduces the water quality for human uses and aquatic ecosystem productivity. One objective of road management should be to protect adjacent 
resources, such as streams and riparian areas. Common practices presented in this paper can be built by hand or machines using resources that are commonly available in the area. These include: wing ditches, sediment traps, berms, weeps, outslopes, humps, and relief pipes. These practices are described and illustrated.

[ROAD IMPACTS; SEDIMENTATION; STREAM IMPROVEMENTS; WATER QUALITY]

268. Bury,RB (1987): Ecological relationships of riparian systems and associated uplands: Amphibians and reptiles. In: Streamside management: Riparian wildlife and forestry interactions. An interdisciplinary symposium. 11-13 February 1987. University of Washington. Seattle, WA.

This paper discusses the occurrence and abundance of amphibians and reptiles in aquatic and riparian zones in the Pacific Northwest. Most species of herpetofauna have distinct habitat preferences or associations. Stream size is an important determinant of the fauna as well as development of the riparian zone. Composition of herpetofauna varies across a gradient from headwaters through a transition to rivers. Many species use the riparian zone for cover and breeding habitat, but in the Pacific Northwest the riparian zone is relatively narrow and often bordered by extensive stands of conifers. This zone is functionally an extension of the aquatic habitat, which the author defines as an interdependent unit: the bank - aquatic- riparian Zone (BAR). [HERPETOFAUNA; RIPARIAN ECOLOGY; RIPARIAN HABITAT]

269. Busby,FE (1979): Riparian and stream ecosystems, livestock grazing, and multiple-use management. p.6-12. In: Cope,OB [ed.]. Forum -Grazing and riparian/stream ecosystems. 3-4 November 1978. Denver, CO. Trout Unlimited, Inc.

Unregulated livestock grazing in an area through which a trout stream flows can result in a retrogressive process, but it does not have to result in these impacts. This paper discusses: 1) trends of livestock grazing and other uses of western rangelands in which riparian/stream habitats occur; 2) implications of use trends to past and present ecological condition of riparian/stream habitat; and 3) range, livestock, and multiple-use management approaches that might help improve and maintain desirable riparian and stream ecosystem conditions. [GRAZING IMPACTS; LIVESTOCK EFFECTS; MULTIPLE USE; RIPARIAN ECOLOGYI
270. Busch,DE (1995): Effects of fire on southwestern riparian plant community structure. The Southwestern Naturalist 40(3), 259-267.

Studies of plant water- and salinity-relations suggest that halophytic riparian shrubs may recover from burning more efficiently than do mesophytic trees. A compilation of fire records from the lower Colorado River floodplain was used to assess the change in riparian community structure resulting from fire. Approximately 37 percent of the riparian vegetation in the study area burned during the 12-year period evaluated. Fire extent was associated with the area of salt-cedar burned, whereas fire affected disproportionately small areas formerly dominated by mesquite. Salt-cedar and arrow-weed were dominant in post-fire riparian communities. Arrow-weed replaced riparian trees in response to fire in habitats dominated by cottonwood/willow and mesquite. Species turnover was low over the post-fire periods evaluated, so the replacement of riparian forests by water- or salinity-stress tolerant shrubs can be considered long-lived.

[EXOTICS; FIRE IMPACTS; RIPARIAN FOREST; RIPARIAN HABITAT; RIPARIAN SHRUBS; SALT-CEDAR]

271. Busch,DE; Scott,ML (1995): Western riparian ecosystems. p.286-290. In: Our living resources: $A$ report to the nation on the distribution, abundance, and health of U.S. plants, animals, and ecosystems. USDI National Biological Survey. Washington, DC.

Health of natural riparian ecosystems is linked to the periodic occurrence of flood flows, associated channel dynamics, and the preservation of base flows capable of sustaining high floodplain water tables. Establishment of native riparian vegetation is diminished when the frequency and magnitude of peak river flows are reduced. Water uptake and water-use patterns indicate that native trees are replaced by non-native species in riparian ecosystems where streamflows are highly modified. Additional factors threaten riparian integrity including: groundwater pumping, grazing, timber harvest, and land-clearing. Studies underway will focus on the effects of global climate change on the encroachment of exotic plants into riparian ecosystems. [EXOTICS; RIPARIAN HABITAT; RIPARIAN VEGETATION]

272. Busch,DE; Smith,SD (1992): Fire in a riparian shrub community: post-burn water relations in the Tamarix-Salix association along the lower Colorado River. p.52-55. In: Clary,WP; 
McArthur,ED; Bedunah,D; Wambolt,CL [comp.|. Proceedings - Symposium on ecology and management of riparian shrub communitics. USDA Forest Service. General Technical Report INT-289.

Hydraulic efficiencies in willow and salt-cedar may contribute to differences in firc recovery. Higher water potentials in burned salt-cedar relative to unburned plants and the opposite response in willow provide evidence that post-fire water stress is reduced in the former but not the latter. Diurnal patterns of stomatal conductance are also consistent with the existence of more vigor in burned salt-cedar than burned willow.

[EXOTICS; FIRE IMPACTS; RIPARIAN HABITAT; RIPARIAN SHRUBS; SALT-CEDAR; WATER STRESS; WILLOW]

273. Butt,AZ; Ayers,MB; Swanson,S; Tueller,PT (1998): Relationship of stream channel morphology and remotely sensed riparian vegetation classification. p. 409-416. In: Potts,DF [ed.]. Range management and water resources: Proceedings of the AWRA specialty conference. American Water Resources Association. 27-29 May 1998. Reno, NV.

This study suggests that there may be greater utility in monitoring stream restoration and management by combining observations of remotely sensed and ground based data along the entire stream. The authors classified the reaches of two streams in the Lake Tahoe Basin according to the Rosgen system; and simultaneously used airborne multispectral videography to produce riparian vegetation maps. Combining these data allowed them to examine the relationships between the stream morphology and riparian vegetation over large areas. Significant differences among stream reach types were found in vegetation cover estimates. The current data, however, is still insufficient to derive strong inferences using multiple regression. [CHANNEL MORPHOLOGY; CLASSIFICATION; REMOTE SENSING; RIPARIAN RESTORATION; RIPARIAN VEGETATION]

274. Butterick,M (1993): A view from the federal government. In: Tellman,B; Cortner,HJ; Wallace,MG; Debano,LF; Hamre, RH |tech. coord.|. Riparian management: Common threads and shared interests. USDA Forest Service. General Technical Report RM - 226. 419 p.

The Watershed Protection Approach (WPA) continues to be an effective program for U.S. Environmental Protection Agency (EPA) by refocusing the existing programs of EPA and other state and federal agencies on pollution and habitat degradation problems. The basic components of this strategy are: 1) risk-based geographic targeting; 2) stakeholder involvement; and 3) integraled solutions. Lessons learned from this program will be applied to future watershed planning efforts.

[POLLUTION; RIPARIAN HABITAT; WATERSHED]

275. Caffrey,J; Rivers,J (1993): The Bluewater Creek story - rebuilding a land ethic. p.391-394. In: Tellman,B; Cortner,HJ; Wallace,MG; Debano,LF; Hamre, RH [tech. coord.]. Riparian management: Common threads and shared interests. USDA Forest Service. General Technical Report RM-226.

The Bluewater Creek watershed in the Zuni Mountains of northwest New Mexico has a long history of man-caused exploitation and land abuse. A rehabilitation program, beginning in 1986, utilized funding for reforestation, watershed structures, and recreation improvements to promote multi-resource management of the area. Large numbers of volunteers, partners, and cooperators contributed to the variety and success of the completed project. This project was remarkable for two primary reasons: short-term resource recovery and public involvement. [COLLABORATION; LAND USE; PLANTINGS; RIPARIAN RESTORATION]

\section{Cagney,J (1993): Riparian area} management: Green-line riparian-wetland monitoring. USDI Bureau of Land Management. Technical Reference 1737-8. 45 p.

The green-line monitoring method is a viable alternative for developing the vegetation portion of an Activity Plan. Green-line vegetative data are an ideal complement to data collected by wildlife and fishery biologists, soil scientists, and hydrologists, in order to evaluate the complex relationships found in riparian areas. The method is described and illustrated with photos and diagrams.

[GREEN-LINE METHOD; MONITORING; PLANT COMMUNITIES; RIPARIAN HABITAT; WETLANDS]

277. Calamusso,B; Rinne,JN (1996): Distribution of the Rio Grande cutthroat trout and its co-occurrence with the Rio Grande sucker and Rio Grande chub on the Carson and Santa Fe National Forests. p.157-167. In: Shaw,DW; Finch,DM |tech. coord.]. Desired future conditions for Southwestern riparian ecosystems: Bringing 
interests and concerns together. USDA Forest Service. General Technical Report RM-GTR-272.

Studies were initiated in June, 1994, by the USDA Forest Service to update knowledge on the distribution of the Rio Grande cutthroat trout and it's co-occurrence with two native cypriniforms, Rio Grande sucker and the Rio Grande chub. Rio Grande cutthroat trout has been reduced to 5-7 percent of its former range. The decline is continuing. Remaining populations of pure Rio Grande cutthroat need to be protected and management efforts to reintroduce the species into its former range need to continue. [FISH M $\Lambda$ NAGEMENT; FISHERIES; RIPARIAN HABITAT; TROUT]

278. Cale,WG; Henebry,GM; Yeakley,JA (1989): Inferring process from pattern in natural communities. Can we understand what we see? BioScience 39(9), 600-605.

The study of pattern, isolated from the biological processes that generate it, is not likely to advance ecosystem theory. That is because multiple process configurations can produce the same pattern, understanding and predictive capability. Pattern must evolve from analysis of fundamental ecological processes. A hypothetical system is presented as a model of two natural processes.

[CHANNEL MORPHOLOGY; ECOSYSTEM MANAGEMENT; LAND USE; LANDSCAPE ECOLOGY; MODELING]

279. Calhoun,J (1987): Riparian management practices of the Washington Department of Natural Resources. In: Streamside management: Riparian wildlife and forestry interactions. An interdisciplinary symposium. 11-13 February 1987. University of Washington. Seattle, WA.

The Washington State Department of Natural Resources has been practicing riparian protection practices on its 2.1 million acres of forest land for 20 years. Operational experience and technical knowledge of riparian systems have increased through time as public policy has developed. The Department's Forest Management Plan was adopted in 1984.

[RIPARIAN FOREST; RIPARIAN HABITAT]

\section{Callicott, JB (1991): Conservation ethics} and fishery management. Fisheries 16(2), 22-28.

All decisions and all actions are necessarily based on both facts and values. From a practically infinite variety of possibilities, we choose certain ends as well as the technical ends to achieve them. Ethics or morality - the science of value - is therefore inescapable. A bricf history and analysis of the several ethics governing the American conservation movement since its inception are provided. But, because Aldo Leopold's Land Ethic is firmly grounded in evolutionary and ecological biology, it ought to provide the moral anchor for conservation in the present and in years ahead. [CONSERVATION BIOLOGY; FISHERIES; LAND ETHICS]

281. Cameron,FW (1993): Malheur National Wildlife Refuge. p.364-368. In: Tellman,B; Cortner,HJ; Wallace,MG; DeBano,LF; Hamre; RH |tech. coord.|. Riparian management: Common threads and shared interests. USDA Forest Service. General Technical Report RM-226.

The land use pattern of Malheur National Wildlife Refuge has been dominated by livestock grazing for 140 years. Currently, grazing is still allowed but only in circumstances that benefit wildlife objectives. Consequently, there has been a transition in which 100,000 AUMs were reduced on the Refuge and only 15 percent of the available habitat is presently utilized by livestock. Other changes include the current encouragement of willow regrowth when previously they were considered counterproductive. Such changes in management direction require the involvement and participation of all affected interests.

[GRAZING IMPACTS; GRAZING TREATMENTS; HISTORIC RECORDS; RIPARIAN HABITAT; RIPARIAN RESTORATION]

282. Campbell,AG; Franklin,JF (1979): Riparian vegetation in Oregon's western Cascade Mountains: composition, biomass, and autumn phenology. Coniferous Forest Biome. Bulletin 14, p.90.

Sixteen understory plant communities in the riparian zones of small streams were identified and described. They ranged from pioneer communities on gravel and rock to well-developed shrub communities on flood plains and terraces. The Acer circinatum community had the widest distribution but the Rubus spectabilis/Ribes bracteosum community was more common. Biomass estimates were made for 3 stream segments. Abscission and fall senescence for 13 species were monitored. Leafy and herbaceous detrital input was timed. Rates of leaf fall and decadence were related to environmental factors. [RIPARIAN HABITAT; RIPARIAN VEGETATION] 
283. Campbell,CJ (1970): Ecological implications of riparian vegetation management. Journal of Soil and Water Conservation 25(2), 49-52.

Managing riparian vegetation in the Southwest to increase water yield may require selective clearcutting rather than complete removal of riparian plants to maintain a biological balance and prevent thermal pollution, channel erosion, and destruction of aquatic and wildlife habitats.

[HYDROLOGY; RIPARIAN MANAGFMENT ZONE; WATER YIELD]

284. Campsey,L (1991): Riparian management improves western rangeland. Rangelands 13(1), 26-27.

The efforts of rancher Bill Gibbs of Wells, Nevada were recognized for improving riparian conditions on his public lands allotment. Water developments, grazing systems, salting practices, and erosion control structures have contributed to streambank and riparian recovery.

[GRAZING IMPACTS; GRAZING TRE $\triangle T M E N T S$; RIPARIAN HABITAT]

285. Canterbury,RA; Smith,BH (1981): Energy development in the overthrust belt of southwestern Wyoming: Present problems and future potentials for aquatic resources on public lands. In: Proceedings of the 16th annual meeting. Colorado-Wyoming Chapter, American Fisheries Society. 25-26 February 1981. Laramie, WY. 7 p.

[MINING IMPACTS; OIL/GAS IMPACTS; RIPARIAN HABITAT]

286. Cantor,LF; Whitham,TG (1989): Importance of below ground herbivory: Pocket gophers may limit aspen to rock outcrop refugia. Ecology 70(4), 962-970.

Aspens may be limited to rock outcrops that are largely inaccessible to pocket gophers and act as refugia from below ground herbivory. The authors found that distributions of pocket gophers and aspen were nonoverlapping 93 percent of the time. Pocket gophers were almost always associated with the deep soils of mountain meadows while the centers of aspen clones were almost always associated with rock outcrops. Although tree ring analyses indicate that aspens grow best in the deep soils of meadows in the absence of pocket gophers, when pocket gophers encounter aspens, tree mortality can be high. [ASPEN; BELOW-GROUND HERBIVORY; MEADOWS; RIPARIAN HABITAT; SMALL MAMMALS]
287. Capen,DE; Low,JB (1980): Management considerations for nongame birds in Western wetlands. p.67-77. In: Proceedings, Management of western forests and grasslands for nongame birds. 11-14 February 1980. Salt Lake City, UT. USDA Forest Service. General Technical Report INT-86.

Management practices which may enhance habitat for birds include manipulating water levels; maintaining isolated stands of emergent vegetation; creating islands and furrows; altering the composition of emergent vegetation; and controlling livestock access. The practices benefit most wetland birds, game and nongame, but may be selectively employed to favor certain groups of nongame species if management practices dictate. Four types of wetlands which are distinguished by degree of water permanence, soil salinity, and composition of aquatic habitats are described.

[ $\Lambda$ VIFAUN $\Lambda$; RIP $\Lambda$ RIAN HABITAT; RIPARIAN MANAGEMENT ZONE; WETLANDS]

288. Carling,PA; Williams,JJ; Kelsey,A; Glaister,MS; Orr,HG (1998): Coarse bedload transport in a mountain river. Earth Surface Processes and Landforms 23, 141-157.

Coarse bedload transport dynamics were investigated utilizing hydrodynamic and sediment transport data obtained in an extensively instrumented study reach in Montana. Data show that initiation of bedload transport was accompanied by a reduction in bed roughness and by changes in bulk dynamic parameters. For larger discharges, coarser fractions of the bed material mobilized, and bedload transport rates and average hydraulic parameters stabilized. As discharge reduced, mobile coarse particles became less frequent and deposited fine particles were removed, resulting in an increase in bed roughness. Bedload pulses were aperiodic but spatially variable.

[BEDLOAD; HYDROLOGY; SEDIMENTATION; STREAM FLOW]

289. Carlson,JR (1991): Selection, production, and use of riparian plant materials for the western United States. p.55-67. In: Proceedings, Intermountain Forest Nursery Association. 12-16 August 1991. Park City, UT. USDA Forest Service. General Technical Report RM-211.

Riparian plantings are established to restore native plant communities, stabilize streambanks and shorelines, restore fish and wildlife habitat, improve surface and ground water quality, and control weedy phreatophytes. Native planting stock may be 
collected from local sources or provided by commercial nurseries. Source guidelines are based on relatively narrow target areas inferred from riparian site classifications and constrained by limited knowledge of the genetic structure of plants. Riparian plant cultivars are developed with specific structural attributes. Nurseries should emphasize production of large plant materials, such as stumps and poles. [PHREATOPHYTES; PLANT MATERIALS; PLANTINGS; RIPARIAN RESTORATION]

290. Carlson,JR; Conaway,GL; Gibbs,.IL; Hoag,JC (1992): Design criteria for revegetation in riparian zones of the Intermountain area. p.145-150. In: Clary,WP; McArthur,ED; Bedunah,D; Wambolt;CL [tech. coord.]. Proceedings - Symposium on ecology and management of riparian shrub communities. 2931 May 1991. Sun Valley, ID. USDA Forest Service. General Technical Report INT-289.

Design criteria for the USDA Soil Conservation Service channel vegetation practice for the Intermountain area consider watershed condition, geomorphology, stream types, community types, stream size, velocity, sinuosity, and bank slope, uniformity, and stratigraphy. Performance standards address benefits to soil stability, fish and wildlife habitat, water quality and esthetic and recreational value.

[RIPARIAN RESTORATION; RIPARIAN ZONES]

291. Carlson,JY; Andrus, CW; Froehlich,HA (1990): Woody debris, channel features, and macroinvertebrates of streams with logged and undisturbed riparian timber in northeastern Oregon, USA. Canadian Journal of Fish Aquatic Science 47(6), 1103-1111.

Macroinvertebrate communities and several aspects of fish habitat were examined for northeast Oregon stream segments. Amounts of woody debris in streams and pools formed by the debris were similar between undisturbed and logged siles. Pool volume was inversely related to stream gradient and directly related to the amount of woody debris in the stream. Stream surface substrate composition was not significantly different between streams in logged and undisturbed areas. Macroinvertebrate density was 20 to 113 percent greater at the logged sites and diversity was similar at undisturbed and logged sites. Macroinvertebrates were most abundant at lower elevation streams and at streams less shaded by surrounding vegetation. Timber harvesting does not appear to have damaged aquatic insect habitat and pool abundance was not altered, suggesting the habitat's carrying capacity for fish was not affected.

[FISHERIFS; IOGGING IMPACTS; MACROINVERTEBRATES; RIPARIAN HABITAT]

292. Carpenter,SR; Caraco,NF; Correll,DL; Howarth,RW; Sharpley,AN; Smith,VH (1998): Non-point pollution of surface waters with phosphorus and nitrogen. Ecological Applications 8(3), 559-568.

The major sources of phosphorous and nitrogen to aquatic ecosystems are agriculture urban activities. Non-point inputs of nutrients are difficult to measure because they derive from activities dispersed over wide areas of land and are variable in time. Based on a review of scientific literature, the authors conclude that: 1) eutrophication is a widespread problem in rivers, lakes, estuaries, and other water bodies; 2 ) non-point pollution results primarily from agricultural and urban activity; 3 ) inputs of $\mathrm{P}$ and $\mathrm{N}$ to agriculture in the form of fertilizers exceed outputs in produce; 1) nutrient flows to aquatic ecosystems are directly related to animal stocking densities; 5) excess fertilization causes a $P$ surplus to accumulate; and 6) excess fertilization and manure production on agricultural lands create surplus $\mathrm{N}$, which is mobile in many soils and often leaches to aquatic ccosystems.

[AGRICULTURAL IMPACTS; FERTILIZATION; NON-POINT SOURCE POLLUTION; NUTRIENT CYCLES; RUNOFF]

293. Carson,MA; Griffiths, GA (1987): Influence of channel width on bedload transport capacity. Hydraulic Engineer 113(12), 1489-1509.

Influence of channel width on bedload capacity in river reaches of given slope, water discharge, and channel-bed material is examined. The view that transport capacity is a decreasing function of width is shown to be dependent upon an invalid premise. The contrary view that transport capacity increases as channel width increases are also considered but are shown to be inconsistent with transport formulas. The existence of an optinum width that maximizes capacity is demonstrated.

[BEDLOAD; CHANNEL MORPHOLOGY; SEDIMENT TRANSPORT]

294. Carson, RG; Edgerton,PJ (1989): Creating riparian wildlife habitat along a Columbia River impoundment in north-central Washington. p.65-69. In: Clary,WP; McArthur,ED; Bedunah,D; Wambolt,CL [comp.]. Proceedings Symposium on shrub ecophysiology and 
biotechnology. USDA Forest Service. General Technical Report INT-256.

Irrigated riparian plantings totaling 37.5 ha were developed to compensate for habitats lost as the result of an increase in the operating level of Rufus Woods Lake. Twenty four species of shrubs and trees were planted to provide forage and cover for wildlife. Soil characteristics, deer browsing, grass competition, and individual species' moisture needs have influenced development of the plantings. [BROWSING EFFECTS; PLANTINGS; RIPARIAN HABITAT]

\section{Carson,RG; Peek,JM (1987): Mule deer habitat selection patterns in north-central Washington. Journal of Wildlife Management 51(1), 46-51.}

Habitat selection and movement patterns of mule deer (Odocoileus hemionus) were studied in northcentral Washington to evaluate the effect of habitat loss resulting from water impoundment. Deer preferred the conifer and riparian cover types and the Breaks Land Form during summer and winter. Big sagebrush and bitterbrush cover types were also preferred during winter. Orchard development in this area had eliminated large amounts of habitat. [BITTERBRUSH; MULE DEER; RIPARIAN HABITAT; SAGEBRUSH I]

296. Carter, $V$ (1986): An overview of the hydrologic concerns related to wetlands in the United States. Canadian Journal of Botany 64, 364-374.

There is a tremendous diversity in wetland types and wetland vegetation in the United States, caused primarily by regional, geologic, topographic, and climatic differences. Wetland hydrology, a primary driving force influencing wetland ecology, development, and persistence, is poorly understood. The interaction between groundwater and surface water and the discharge - recharge relationships in wetland affect water quality and nutrient budgets as well as vegetative composition. Hydrologic considerations necessary for an improved understanding of wetland ecology include detailed water budgets, water chemistry, water regime, and boundary conditions. These hydrologic functions include: flood storage and flood-peak desynchronization; recharge and discharge; base flow and estuarine water balance; and water quality regulation. Expanded research and data collection are needed.

[GROUNDWATER; HYDROLOGY; WETLANDS]
297. Caruso,BS; Ward,RC (1998): Assessment of non-point pollution from inactive mines using a watershed-based approach. Environmental Management 22(2), 225-243.

The watershed-based approach methodology was designed to use limited stream discharge and chemical data from synoptic surveys to derive key information required for targeting impaired water bodies and critical source areas for detailed investigation and remediation. It was presented in this article as steps in a framework including evaluation of existing data/information and identification of data gaps; definition of assessment information goals for targeting and monitoring data; data collection, management, and analysis; and information reporting and use for targeting. [ASSESSMENTS; MINING IMPACTS; NON-POINT SOURCE POLLUTION; WATER QUALITY; WATERSHED]

298. Case,RL; Kauffman,JB (1997): Wild ungulate influences on the recovery of willows, black cottonwood, and thin-leaf alder following cessation of cattle grazing in northeastern Oregon. Northwest Science 71(2), 115-125.

Restoration of degraded riparian ccosystems is of great importance to recovery of Columbia River salmonids and riparian-obligate wildlife species. Willows, thin-leaf alder, and black cottonwood are important features of regional riparian ecosystems and have multiple functional roles that influence biodiversity, water quality, water quantity, and aquatic/terrestrial food webs and habitats. Livestock removal and big game exclosures have been suggested as passive means to riparian restoration. On Meadow Creek, cattle were removed in 1991 and elk- and deer-proof exclosures were constructed. After two years, significant increases in height, crown area, crown volume, stem diameter, and biomass were measured both inside and outside the exclosures. Mean crown volume of willows increased 550 percent inside of wild ungulate exclosures and 195 percent outside. Black cottonwood increased 773 percent inside of exclosures and 808 percent outside. Thin-leaf alder increased 1,046 percent inside and 198 percent outside. Wild herbivores were found to have significant influences on the rate of growth for the parameters of height, crown ared, crown volume, and standing biomass. Riparian plants displayed an inherent resilience and adaptations to natural disturbance processes. Additionally, however, there was a rapid and positive response to cessation of land use activities, like cattle grazing, that had caused habitat degradation and prevented recovery. 
[EXCLOSURES; GRAZING IMPACTS; RIPARIAN SHRUBS; RIPARIAN VEGETATION; WILD UNGULATES]

299. Chadde,SW; Pfister,RD; Hansen,PL (1989): Management implications for riparian dominance types of Montana. p.83-85. In: Gresswell,RE; Barton,BA; Kershner,JL [eds.]. Practical approaches to riparian resource management. An educational workshop. 8-11 May 1989. Billings, MT.

A classification system of Montana's riparian plant communities, based on dominant species, was developed by the Montana Riparian Association. The dominance-type approach allows land managers to identify, inventory, and map riparian communities, plus it provides basic management information for each type. A weakness of this classification method is the broad and overlapping range of environments spanned by individual dominance types. [CLASSIFICATION; RIPARIAN HABITAT; RIPARIAN MANAGEMENT ZONE]

300. Chadde,SW; Shelly,JS; Bursik,RJ; Moseley,RK; Evenden,AG; Mantas,M; Rabe,F; Heidel,B (1998): Peatlands on National Forests of the Northern Rocky Mountains: Ecology and conservation. USDA Forest Service. General Technical Report RMRS-GTR-11.75 p.

Peatlands can be an important contributor to local and regional biological diversity. They may also have considerable scientific value as repositories of pollen and ash deposits, providing insight into post-glacial vegetation and climates. This report describes physical components, vegetation, vascular and nonvascular flora, and invertebrate fauna on peatlands. Detailed site descriptions of 58 northwestern peatlands are included.

[INVERTEBRATES; PEATLANDS; RIPARIAN VEGETATION; WETLANDS]

301. Chadwick,DH (1990): The biodiversity challenge. Defenders of Wildlife Magazine. Portland, OR. 14 p. Defenders Magazine Special Report.

The essay introduces concepts of island biogeography and applies these to wildlife survival on islands of natural habitat created by human conversion of landscapes. Wildlife conservation is discussed in terms of conservation of habitat types, the areal extent and continuity of habitats. The author believes that conservation is evolving again and that the challenge now is to conserve the nature of nature - the power to connect, to sustain, to heal, and to invent. This is the substance of biodiversity and landscape linkages.

[BIODIVERSITY; GAP ANALYSIS; RIPARIAN HABITAT]

302. Chainey,S; Yates,G; O'Leary,B (1993): Groundwater and surface flow models used to simulate impacts and benefits to riparian vegetation caused by flood control and water supply management projects. p.240. In: Tellman,B; Cortner,HJ; Wallace,MG; DeBano,LF; Hamre, RH [tech. coord.|. Riparian management: Common threads and shared interests. USDA Forest Service. General Technical Report RM-226.

San Simeon Creek, a central California coastal stream, supports a channel riparian forest that could potentially be affected by groundwater extraction for the nearby community of Cambria. A one-dimensional finite difference groundwater flow model was "embedded" in a conjunctive use operations and storage model to show the interrelation of surface flow in the creek, surface diversions, seasonal depth to water table, and evapotranspiration water use by riparian vegetation. [FLOOD IMP $\Lambda$ CTS; GROUNDW $\Lambda$ TER; HYDROLOGY; RIPARIAN VEGETATION; W $\Lambda$ TER SUPPLY]

303. Chalk,DE (1979): Predicting impacts of a proposed irrigation water conservation project on wildlife habitat. p.305-309. In: Swanson, GA [ed.]. The mitigation symposium: A national workshop on mitigating losses of fish and wildlife habitat. USDA Forest Service. General Technical Report RM-65.

Irrigation improvements on 84 percent of the treatable land in the Uintah Basin, Utah, could reduce water available to phreatophytes by 40 percent, resulting in the conversion of 19,800 acres of wetlands to upland habitat. Twenty-three percent of the water presently diverted for irrigation is consumed by phreatophytes.

[PHREATOPHYTES; RIPARIAN HABITAT; WETLANDS]

304. Chambers,JC; Blank,RR; Zamudio,DC; Tausch,RJ (1999): Central Nevada riparian areas: Physical and chemical properties of meadow soils. Journal of Range Management 52(1), 92-99.

There is little existing information on western riparian soils or the factors that influence them even though soil characteristics are important for classifying riparian ecosystem types and evaluating 
condition. This study examined the effects of drainage basin geology and water table depth on soil morphology and soil physical and chemical properties of meadow sites. High water table sites had organic matter, total nitrogen, cation exchange capacity, and extractable $\mathrm{K}$, but lower $\mathrm{pH}$ than low water table sites. Additionally, high water table sites had lower percentage sand, lower bulk densities, and higher soil moisture retention. Significant differences in $\mathrm{pH}$, extractable $\mathrm{K}$, and extractable $\mathrm{P}$ existed among drainages that were explainable largely from the parent materials. Drainages with chert, quartzite, and limestone had higher silt and clay, neutral $\mathrm{pH}$, and high levels of extractable P. Drainages formed in acidic volcanic tuffs, rhyolites, and breccia were characterized by coarser textured soils and low $\mathrm{pH}$ and extractable $P$. In riparian areas, soil table depth interacts with soil parent material to significantly affect soil morphology and soil physical and chemical properties. These factors vary over large and small spatial scales, therefore, must be carefully interpreted when classifying ecosystems or evaluating condition.

[CLASSIFICATION; MEADOWS; SOILS; WATER TABLE EFFECTS; WATERSHED]

305. Chambers,JC; Farleigh,K; Tausch,RJ; Miller,JR; Germanoski,D; Martin,D; Nowak,C (1998): Understanding long- and short-term changes in vegetation and geomorphic processes: The key to riparian restoration. p. 101-110. In: Potts,DF [ed.]. Rangeland management and water resources: Proceedings of the AWRA specialty conference. American Water Resources Association. 27-29 May 1998. Reno, NV.

This paper examined the linkages between past and present vegetation and geomorphic processes, natural and human-caused disturbance, and current stream and riparian ecosystem dynamics. Study watersheds were located in central Nevada and were characterized by high-gradient, low-flow streams. Vegetation and geomorphic processes during the past 11,500 years have tracked temperature and rainfall patterns. Dry and cool periods exhibited low species numbers and significant hillslope erosion, the creation of side-valley alluvial fans, and aggradation of valley floors. More recent and warmer/wetter periods resulted in higher species numbers, a decline in hillslope erosion and sediment supply to stream channels, and a tendency toward stream incision. Recent down-cutting occurred after about 290 YBP and has been accelerated by human activities such as roads and livestock grazing. At present, floods that are capable of entraining channel bed sediment are controlling down-cutting and riparian ecosystem dynamics.

[CLIMATE; GEOMORPHOLOGY; RIPARIAN

ECOLOGY; RIPARIAN RESTORATION; STREAM ECOLOGY]

306. Chambers,SM (1996): The riparian species recovery plan: A status report. p.277-280. In: Shaw,DW; Finch, DM [tech. coord.]. Desired future conditions for Southwestern riparian ecosystems: Bringing interests and concerns together. USDA Forest Service. General Technical Report RM-GTR-272.

Several state and federal agencies in Arizona and New Mexico are collaborating on the development of a strategy for the restoration of riparian systems. The strategy that is taking shape is a package of formats, methods, and information that can guide local groups in developing/implementing riparian restoration plans. The major elements of the preliminary strategy are described.

[COLLABORATION; RIPARIAN RESTORATION; SPECIES RECOVERY]

307. Chan,S (1994): Dynamics of planted conifers and hardwoods in the understory of hardwood dominated riparian zones. p.17-18. In: The ecology and management of Oregon Coast Range forests: A mid-term COPE symposium. 29-31 March 1994. Gleneden Beach, OR. Coastal Oregon Productivity Enhancement Program; Oregon State University. Corvallis, OR.

Successful regeneration of trees in hardwood shrub dominated riparian areas will likely require active management of the vegetation to promote the successful establishment and growth of trees. This may mean that short-term disturbances are necessary to achieve long-term riparian restoration goals. Elimination of hardwoods and shrubs is unlikely to occur through mechanical means, nor would it be ecologically desirable. However, substantial thinning of the hardwood and shrub complex may be necessary to create conditions favorable for the establishment of trees to provide vegetative complexity and woody structure. Growing conditions and vegetative development are not static. Active monitoring and evaluation are critical to determine if management/restoration objectives are being met. [RIPARIAN FOREST; RIPARIAN RESTORATION; RIPARIAN SHRUBS]

308. Chaney,E; Elmore,W; Platts,WS (1990): Livestock grazing on western riparian areas. US Environmental Protection Agency. 45 p. 
This is a glossy, semi-technical presentation intended for wide public distribution. It contains a series of color photographs which show successful riparian enhancement applications in various locations in the western U.S. It also addresses riparian functions, values, and issues, and documents best management practices in riparian zones. [GRAZING IMPACTS; RIPARIAN ENHANCEMENT; RIPARIAN MANAGEMENT ZONE]

309. Chaney,E; Elmore,W; Platts,WS (1993): Managing change: Livestock grazing on western riparian areas. U.S. Environmental Protection Agency. Denver, CO 80202.

This document is a topical sequel and companion piece to its predecessor "Livestock grazing on western riparian areas" (1990). Together the two publications are intended to provide an overview of the functions and values of western riparian areas, the causes and effects of degraded riparian areas and water quality, and case studies representative of problems and opportunities involving improved grazing practices on riparian areas. They are designed to foster broader understanding of how grazing management can enhance water quality and overall productivity of rangeland watersheds. [GRAZING IMPACTS; LIVESTOCK EFFECTS; RIPARIAN; WATER QUALITY]

310. Chang,HH (1985): Water and sediment routing through curved channels. Hydraulic Engineer 111(4), 644-658.

This paper describes a mathematical model for water and sediment routing through curved alluvial channels. The model applies to alluvial streams with nonerodible banks. In the simulation of the evolution in stream bed profile, the effect of transverse flow is tied in with the aggradation and degradation development. River flow through curved channels is characterized by the changing curvature, to which variations of flow pattern and bed topography are closely related. Simulation of these changing features is based upon the fluid dynamics governing the growth and decay of transverse circulation along the channel.

[CHANNEL MORPHOLOGY; MODELING; SEDIMENT TRANSPORT]

311. Chapman,DW (1962): Effects of logging upon fish resources of the West Coast. Journal of Forestry. August, 1962, 533-537.

[FISHERIES; LOGGING IMPACTS; RIPARIAN HABITAT]
312. Chapman,DW (1979): Summarization of sessions. p. 75-76. In: Cope, OB [ed.|. Forum -Grazing and riparian/stream ecosystems. 3-4 November 1978. Denver, CO. Trout Unlimited, Inc.

A synopsis of the professional and topical papers presented at this forum, along with suggestions on how all of the various viewpoints expressed at this forum can be integrated and reconciled.

[GRAZING IMPACTS; RIPARIAN ISSUES]

313. Charlton,FG (1982): River stabilization and training in gravel-bed rivers. p. 635-652. In: Gravel hed rivers. [Fds: Hey,RD; Bathurst,JC; Thorne,CR|. John Wiley and Sons Ltd., New York, NY.

Boundary characteristics of rivers with gravel beds vary widely. There is a great range in sizes and shapes of bed material in different rivers, while the sizes and grading of bank material often change with elevation and short distances along a bank and between banks of the same river. The composition of the bed and banks of some rivers is examined to establish how these variations might affect the choice of river training methods. This paper reviews the variety of methods used to control and train natural river channels. These range from the direct methods of protecting banks using revetments, through semi-direct methods based on training fences of different types to the indirect methods including spurs and sills to control the main current, and structures to control the bed levels and water levels. [CHANNEL MORPHOLOGY; STREAMBANK PROTECTION]

314. Chavez,L (1996): Above-bclow diversion study, p.145-150. In: National hydrology workshop proccedings. 27 April - 1 May 1992; Phoenix, AZ. USDA Forest Service. General Technical Report RM-GTR-279.

Stream channel conditions were studied above and below diversion sites on 20 streams in Colorado. Ninety-one percent of the channel reaches showed a decrease in a bankfull cross-sectional area, below diversions. Eighty-five percent sustained a decrease in bankfull width and 88 percent had decreased in mean depth at bankfull. D50 particle sizes of streambed material decreased in seventy-two percent of the reaches.

[CHANNEL DYNAMICS; DIVERSION SITES; GEOMORPHOLOGY]

315. Cheng,JD (1989): Streamflow changes after clear-cut logging of a pine beetle-infested 
watershed in southern British Columbia, Canada. Water Resources Research 25(3), 449-456.

In response to clear-cut logging over 30 percent of a watershed, annual and monthly water yields and annual peak flows increased, and annual peak flow and half flow volume occurrence dates arrived earlier than for pre-logging conditions and for a no-cut control watershed.

[LOGGING IMPACTS; RIPARIAN HABITAT; STREAM FLOW]

316. Childers,DL; Gosselink,JG (1990): Assessment of cumulative impacts to water quality in a forested wetland landscape. Journal of Environmental Quality 19, 455-464.

Improvement of the aquatic ccosystem can bc achieved in a number of ways, including the reestablishment of natural hydrologic flow wherever possible, the use of agricultural practices that reduce runoff, the protection of forested corridors along streams, and the mitigative creation of new buffering zones. In this conservation plan, site-by-site permitting occurs within the context of a comprehensive plan for managing the renewable resources of an entire Basin landscape; a plan based on the intensity of past cumulative impacts to the ecosystem.

[CUMULATIVE IMPACTS; ENVIRONMENTAL MANAGEMENT; WATER QUALITY; WETLANDS]

317. Chilman,KC; Foster,D; Everson,A (1985): Using visitor perceptions in river use planning, 1972-1984. p.393-97. In: Johnson, RR; Ziebell,CD; Patton,DR; Ffolliott,PF; Hamre,RH [tech. coord.]. Riparian ecosystems and their management: Reconciling conflicting uses. 16-18 April 1985. Tucson, AZ. USDA Forest Service. General Technical Report RM-120.

Determining recreational carrying capacity for large wildland areas is complex and controversial. At Ozark National Scenic Riverways in Arkansas, visitor perception information has been gathered periodically since 1972 . The data provides strong support for the carrying capacity rationale used for river use planning. Implications for other carrying capacity management decisions are discussed. [HUMAN IMPACTS; RECREATION IMPACTS; RIPARIAN HABITAT]

318. Chischilly,S (1993): The San Juan River. p.323-327. In: Tellman,B; Cortner,HJ; Wallace,MG; DeBano,LF; Hamre,RH [tech. coord.]. Riparian management: Common threads and shared interests. USDA Forest Service. General Technical Report RM-226.

The San Juan River, which previously flooded periodically, has been dammed and flow controlled since 1962. Environmental consequences after dam construction include: decrease of mean river temperature below the dam, mean decrease in volume ( $\mathrm{cfs}$ ), cessation of great flood stages, and riverbed geomorphology alteration. Physical alterations have caused dramatic changes in the biological components. Non-native fish species have increased because of thcir adaptation to warmer water temperatures and native species have declined. Without flood stages, cottonwood recruitment does not occur and that species has been replaced by tamarisk and Russian olive. Concentration of contaminants in irrigation settling ponds and oil and gas exploration sites is affecting the health of resident fish species. Further alteration of the river could have accelerated detrimental impacts on the associated ecosystem.

[COTTONWOOD; DAMS; FLOOD IMPACTS; RIPARIAN HABITAT; SALT-CEDAR]

319. Christensen, KM (1985): The linear interval method for determining habitat selection of riparian wildlife species. p.101-104. In: Clary,WP; McArthur,ED; Bedunah,D; Wambolt;CL [comp.]. Riparian ecosystems and their management: Reconciling conflicting uses. 16-18 April 1985. Tucson, AZ. USDA Forest Service. General Technical Report RM-120.

This technique can be used in highly heterogeneous habitats, incorporates both categorical and continuous data, yields a physiographic representation of habitat structure, and facilitates the use of multivariate statistics in data analysis. It is believed to be inherently superior to those techniques typically employed by wildlife ecologists in studies of habitat selection.

[MONITORING; MULTIVARIANCE ANALYSIS; RIPARIAN HABITAT]

320. Christman,C; Shaw,DW; Spann,CL; Luehring,P (1996): GIS applications in riparian management. p.327-328. In: Shaw, DW; Finch, DM [tech. coord.]. Desired future conditions for Southwestern riparian ecosystems: Bringing interests and concerns together. USDA Forest Service. General Technical Report RM-GTR-272.

GIS was used to prioritize watersheds for treatment needs across the USDA Forest Service Southwestern Region. Factors in this analysis included soil condition, riparian habitat, population 
centers and mining sites.

[GIS; RIPARIAN HABITAT; WATERSHED]

321. Chung-MacCoubrey,A (1996): Bat species using water sources in pinyon-juniper woodlands. p.166-168. In: Shaw,DW; Finch,DM [tech. coord.]. Desired future conditions for Southwestern riparian ecosystems: Bringing interests and concerns together. USDA Forest Service. General Technical Report RM-GTR-272.

There is much to be learned about the importance of bats in Southwestern ecosystems, their ecological requirements, and how habitats should be managed to sustain these important species. The primary objective of this study was to identify the bat species which use pinyon-juniper habitats of the middle Rio Grande Basin. Ten pinyon-juniper sites with permanent water on the Cibola National Forest were mist netted four times from May to September 1995. Sixteen bat species were captured from the 10 sites. The number of sites a species was captured at and frequency of capture varied according to species. [BAT SPECIES; RIO GRANDE; RIPARIAN HABITAT; WATER SOURCES]

322. Cicero,C (1997): Boggy meadows, livestock grazing, and interspecific interactions: Influences on the insular distribution of montane Lincoln's sparrows (Melospiza lincolnii alticola). Great Basin Naturalist 57(2), 104-115.

Lincoln's sparrows were counted in 34 California and Oregon meadows and habitat features that might influence their local occurrence were identified. This species was found at 72 percent of the sites. Counts of single males were low and not correlated with meadow sizc. Counts were highest in wet meadows with little damage by grazing. Singing males were concentratcd in floodcd or boggy areas near meadow edges, where pines provided elevated perches for singing and vigilance. Lincoln's sparrows breeding in montane meadows are potentially vulnerable to local extirpation because of their insular distribution, low population density, and fluctuating habitat conditions. Heavy damage from livestock grazing dramatically impacts local populations.

[AVIFAUNA; GRAZING IMPACTS; MEADOWS; RIPARIAN HABITAT]

323. Claire,EW; Storch,RL (1977): Streamside management and livestock grazing: An objective look at the situation. p.1-46. In: Proceedings of the fisheries workshop. American Fisheries Society. Reno, NV.

Good streamside management within the Blue
Mountains of eastern Oregon can be summarized with the following list: a) improved forage for livestock and wildlife; b) improved water quality and quantity in streams; c) reduced soil erosion; d) improved fish and wildlife habitat; e) improved recreational and visual opportunities; f) timber harvesting and roads will be compatible with sound watershed management objectives; and g) high quality water and water-related resources will be made available for downstream uses. The authors urge cooperation between agencies and sectors. [GRAZING IMPACTS; RIPARIAN MANAGEMENT ZONE; SMZ]

324. Clark,J (1993): The state role in riparian management. p.25 -26. In: Tellman,B;

Cortner,HJ; Wallace,MG; DeBano,LF;

Hamre, RH [tech. coord.]. Riparian management: Common threads and shared interests. USDA Forest Service. General Technical Report RM-226. 419 p.

Many states are beginning to look at riparian management as a part of larger scale planning strategies. Most states are also attentive to new management and protection criteria. The author suggests that the most promising approach is to employ a systems approach to comprehensive management and the accommodation of multiple partners.

[COLLABORATION; PARTNERSHIPS; RIPARIAN HABITAT; RIPARIAN MANAGEMENT ZONE]

325. Clark, M (1987): Institutional arrangements for resolving forestry/wildlife conflicts: $A$ comparison of regulations, taxes and subsidies, and markets in habitat rights. In: Streamside management: Riparian wildlife and forestry interactions. An interdisciplinary symposium. 11-13 February 1987. University of Washington. Seattle, WA.

This poster paper compares three policy alternatives/institutional systems for managing timber harvesting/habitat problems discusses the reward systems inherent in each application, and evaluates the relative efficiency of outcomes under the different institutional structures using a case study watershed and a mathematical model.

[MODELING; RIPARIAN FOREST; RIPARIAN HABITAT]

326. Clark,P; Seyfried,M; Neal,C; Harris,B (1998): Use of multispectral aerial videography for riparian condition assessment in 
sagebrush-steppe rangelands. p. 120. In: Potts,DF [ed.|. Rangeland management and water resources: Proceedings of the AWRA specialty conference. American Water Resources Association. 27-29 May 1998. Reno, NV.

Ground-based methods, satellite imagery, and large scale aerial photography have all been used for ecological condition assessments of rangelands, but all have significant shortcomings. Recent technological advances in multispectral videography provides high spatial and spectral resolution, inflight data evaluation, inexpensive data acquisition and storage, and automation of many post-flight processing procedures. Studies were conducted at Reynolds Creek Experimental Watershed near Boise, Idaho. Mature cottonwood overstories can be readily separated from overstories composed of juvenile cottonwood. Image classification accuracy for multilayered shrub and tree canopy and for herbaceous communities is being evaluated. [ASSESSMENTS; CLASSIFICATION; EVALUATION; RIPARIAN CONDITION; RIPARIAN VEGETATION; VIDEOGRAPHY]

327. Clark, R (1993): Riparian-wetland initiative for the 1990's. p.243. In: Tellman,R; Cortner,HJ; Wallace,MG; DeBano LF; Hamre,RH |tech. coord.|. Riparian management: Common threads and shared interests. USDA Forest Service. General Technical Report RM-226.

An updated plan for managing riparian areas and wetlands on federally managed public lands was released by the Department of the Interior's Bureau of Land Management in September 1991.

[RIPARIAN HABITAT; RIPARIAN-WETLAND INITIATIVE]

328. Clary,WP (1995): Vegetation and soil responses to grazing simulation on riparian mcadows. Journal of Range Management 48(1), 18-25.

Riparian areas have not responded consistently to grazing systems, suggesting that more knowledge is needed to explain how different areas respond to specific stresses. Studies were conducted to determine herbaceous plant response to simulated grazing on riparian areas, including: one low-elevation redtop site and two high-elevation sedge sites in Idaho. The most consistent plant response among areas was reduction in height growth and biomass production following compaction treatments. When both defoliation and compaction were considered, it appeared that spring, fall, or spring and fall grazing to a $5-\mathrm{cm}$ stubble height on the redtop site did not decrease riparian herbage production. In contrast, when defoliation, compaction, and nutrient return effects were considered in the mountain meadow sedge-dominated communities, grazing once annually during the growing season to a $5-\mathrm{cm}$ stubble height in the spring, or to a $10-\mathrm{cm}$ stubble height in late summer, or at a utilization rate exceeding 30 percent of the total annual biomass production reduced herbage production significantly. [DEFOLIATION; GRAZING IMPACTS; LIVESTOCK EFFECTS; SOILS; STUBBLE HEIGHT]

329. Clary,WP; Abt,S; Thornton,C (1993): Vegetation effects on retention of stream channel sediments. p.221. In: Tellman,B; Cortner,HJ; Wallace,MG; DeBano,LF; Hamre,RH [tech. coord.]. Riparian management: Common threads and shared interests. USDA Forest Service. General Technical Report RM-226.

Vegetation height and biomass within a stream channel system are known to enhance sediment deposition and to improve the retention of deposits. These features are dependant upon the management of grazing livestock. In this study, the ability of a typical riparian graminoid (Kentucky bluegrass) to entrap sediments was measured. The rate of deposition retention was also studied. [CHANNEL DYNAMICS; GRAZING IMPACTS; SEDIMENTATION; VEGETATION MANAGEMENT]

330. Clary,WP; Abt,SR; Thornton,CI (1993): Sediment entrapment by stream channel vegetation. p.335-342. In: Management and irrigation of drainage systems. Proceedings of the Irrigation and Drainage Division/American Society of Civil Engineers. 21-23 July 1993. Park City, UT.

Degraded headwater streams are common in the mountainous West. It is generally recognized that deposited sediments are required for the natural rebuilding of streambanks. This study evaluated the effects of vegetation lengths and other attributes in entrapping and retaining sediments on a simulated stream reach in the Hydraulics Lab at Colorado State University. Loading and flushing of sediments was a function of vegetation characteristics and stream discharge.

[CHANNEL DYNAMICS; RIPARIAN

RESTORATION; RIPARIAN VEGETATION; SEDIMENTATION] 
331. Clary,WP; Booth,GD (1993): Early riparian utilization of mountain meadow riparian pastures. Journal of Range Management 46(6), 493-497.

Observations suggest that spring grazing of riparian areas is a good management strategy because of a reduced tendency for cattle to concentrate along streams during that season. Cattle distribution was examined within 4 experimental pastures located along Stanley Creek, Idaho. Cattle were not disproportionately attracted to the streamside areas during the June period. As stocking rates increased from light to medium, cattle concentrated most of their additional use on the adjacent drier meadow. Utilization of riparian plant communities during the early summer period had no relationship to the amount of plant moisture content, but was negatively associated with surface soil moisture. [GRAZING IMPACTS; SOILS; STUBBLE HEIGHT; UTILIZATION]

332. Clary,WP; McArthur,ED; Bedunah,D; Wambolt,CL [comp.| (1992): Proceedings Symposium on ecology and management of riparian shrub communities. USDA Forest Service, Intermountain Research Station, Ogden, UT. 232 p.

The proceedings included 41 papers and accounts of field trips from a symposium focused on riparian shrub communities and their habitats. Papers discuss values, classification methods, conditions, and rehabilitation techniques for riparian areas, with one section devoted to similar topics for upland shrubs.

[CLASSIFICATION; FIRE IMPACTS; PLANT

YIELDS; RIPARIAN HABITAT; SEED

PRODUCTION; XERORIPARIAN]

333. Clary,WP; Medin,DE (1990): Differences in vegetation biomass and structure due to cattle grazing in a northern Nevada riparian ecosystem. USDA Forest Service. Research Paper INT-427. Ogden, UT. 8 p.

The study area is on the West Fork of Deer Creek in northcastern Nevada. Plots are located within an 11-year grazing exclosure and on the adjacent grazed riparian zone. Cattle grazing effects were concentrated in the riparian, not in adjacent uplands. Positioning of the exclosure fence across the narrow Deer Creek canyon probably reduced cattle access to the unfenced riparian, resulting in similar aspen stands upstream of the exclosure and within the exclosure. Below the exclosure, grazing had a major impact on aspen regeneration and stand structure. Greatest vegetation biomass differences between the grazed and fenced areas occurred among graminoid species. Willow stands were extremely variable, masking biomass differences. There were no significant differences between sites for biomass of small shrubs, but large shrubs other than willow had significantly greater biomass in the grazed areas. [EXCLOSURES; GRAZING IMPACTS; PLANT COMMUNITIES]

334. Clary,WP; Medin,DE (1992): Vegetation, breeding bird, and small mammal biomass in two high- elevation sagebrush habitats. p.100-110. In: Clary,WP; McArthur,ED; Bedunah,D; Wambolt,CL [comp.]. Proceedings - Symposium on ecology and management of riparian shrub communities. USDA Forest Service. General Technical Report INT-289.

Two riparian areas, one in Nevada and one in Idaho were compared. Except for geomorphology, the two study areas had many similar environmental characteristics. The biological communities, however, differed widely in many attributes. Total plant biomass differed by 25 -fold between the two areas. Differences were seen to be primarily due to geomorphic conditions, which far exceeded the variation introduced by the impact of livestock grazing.

[AVIFAUNA; GRAZING IMPACTS; RIPARIAN HABITAT; SAGEBRUSH; SMALL MAMMALS]

335. Clary,WP; Medin,DE (1993): Vegetation, nesting bird, and small mammal characteristics Wet Creek, ID. USDA Forest Service. General Technical Report INT-293. 11 p.

Most ground cover and herbaceous plant measures were similar among the riparian plant communities. Shrub cover was greatest in the Potentilla- and Salix-dominated communities while shrub height and biomass were greatest in the Salix community. Fourteen species of birds established nesting territories on the study reaches. Four bird foraging guilds were represented by the riparian nesters, while only one foraging guild was represented by the upland nesters. Nine species of small mammals were trapped on the study sites. [AVIAN ECOLOGY; RIPARIAN HABITAT; SMALL MAMMALS]

336. Clary,WP; Shaw,NL (1992): Grazing riparian issues: a Sawtooth National Recreation Area field trip. p.228-232. In: Clary,WP; MeArthur,ED; Bedunah,D; Wambolt,CL [comp.]. Proceedings - Symposium on ecology and management of riparian shrub communities. 


\section{USDA Forest Service. General Technical Report} INT-289.

Symposium attendees were offered a full-day field trip to the Sawtooth National Recreation Area. The particular focus of the tour was the relationship between livestock grazing and riparian stream conditions. Instructional demonstrations on the field identification of local willow species were also provided.

[GRAZING IMPACTS; RIPARIAN ISSUES; RIPARIAN SHRUBS]

337. Clary,WP; Shaw,NL; Dudley,JG; Saab,VA; Kinney,JW; Smithman,LC (1996): Response of a depleted sagebrush steppe riparian system to grazing control and woody plantings. USDA Forest Service. Research Paper INT-RP-492. 32 p.

Five management systems were applied to a depleted riparian system in sagebrush steppe for a period of 7 years. These treatments ranged from none to heavy grazing and, in some cases, planting of woody species. All treatments were too limited to significantly restore the damaged areas within the 7-year term of study. Although some improvements were made in woody plant densities, little meaningful change occurred in the frequencies of herbaceous wetland plants, densities of small wildlife, or stream channel morphology. Without increased revegetation efforts, they concluded that restoration would take many years, possibly decades.

[GRAZING IMPACTS; LIVESTOCK EFFECTS; PLANTINGS; RIPARIAN RFSTORATION; SAGEBRUSH]

338. Clary,WP; Thornton,CI; Abt,SR (1996): Riparian stubble height and recovery of degraded streambanks. Rangelands 18(4), 137-140.

In small stream systems, herbaceous vegetation enhances sediment deposition and the channel restoration process. Shorter length vegetation ( 0.5 to 6 inches) is most effective in improving sediment entrapment during the deposition phase. The longer length vegetation ( 8 to 12 inches) retains a larger portion of the deposited sediment during the flushing phase. Both deposition and retention of sediments are building blocks in the stream restoration process. The authors insist that it is imperative that an optimal vegetation length is determined for specific stream conditions to accommodate grazing while allowing stream restoration to occur. The frequency of sediment loading and flushing cycles as well as vegetation type play important roles in the determination of optimum stubble height. [GRAZING IMPACTS; RIPARIAN
RESTORATION; RIPARIAN VEGETATION; SEDIMENT TRANSPORT; STUBBLE HEIGHT]

339. Clary,WP; Webster,BF (1989): Managing grazing of riparian areas in the Intermountain Region. USDA Forest Service. General Technical Report INT-263. Ogden, UT. 11 p.

Concern about livestock grazing in riparian areas and its effect upon riparian-dependent resources has resulted in numerous controversies about the appropriate management approach. This document provides guidance for grazing of riparian areas in a manner that should reduce both non-point source pollution and potential grazing impacts on other riparian-dependent resources.

IGRAZING TREATMENTS; NON-POINT

SOURCE POLLUTION; STUBBLE HEIGHT; UTILIZATION]

340. Clary,WP; Webster,BF (1990): Riparian grazing guidelines for the Intermountain Region. Rangelands 12(4), 209-212.

Grazing practices which intend to reduce impacts on the herbaceous plant community, the woody plant community and streambank morphology are recommended. Criteria of minimum season-end stubble heights and an emphasis on early grazing are aimed at the maintenance of the woody plant community and streambank morphology. Herbaceous plants can also be expected to respond favorably to management. Many moist site forage species have strong vegetative reproductive capabilities and are favored by early season grazing.

[GRAZING IMPACTS; GRAZING TREATMENTS; RIPARIAN MANAGEMENT ZONE; STUBBLE HEIGHT]

341. Clary,WP; Wehster, BF (1990): Recommended riparian grazing practices. p.77-81. In: Erosion control: Technology in transition. Proceedings of Conference XXI of the International Erosion Control Association. 14-17 February 1990. Washington, D. C.

Management practices in any grazing system must provide for regrowth of riparian plants after use or should leave sufficient vegetation at the time of grazing for maintenance of plant vigor and streambank protection. Minimum herbage stubble height must be present on all streamside areas at the end of the growing season, or at the end of the grazing season if grazing occurs after frost in the fall. Residual stubble/regrowth should average at least 4 to 6 inches in height to provide sufficient herbaceous biomass. Spring grazing should be emphasized and 
the use level limited to about 65 percent. If summer grazing is conducted, the suggested use level is 40 to 50 percent, and if fall grazing is conducted, the suggested use level is about 30 to 40 percent. The key point is to end the grazing season with the 4 to 6 inches of streamside herbaceous stubble height. These riparian grazing management practice recommendations were developed as an aid to reduce non-point pollution in western streams and for application in Best Management Practices. [BEST MANAGEMENT PRACTICES; GRAZING IMPACTS; LIVESTOCK EFFECTS; STUBBLE HEIGHT]

342. Clayton,S (1996): Factors influencing Black Cottonwood (Populus trichocarpa) recruitment on the Upper Clark River, Western Montana. M.S.

Thesis, Montana State University; Bozeman, MT.

Treatments to create bare substrate - manual and herbicidal - had no significant effect on cottonwood seedling establishment or survival. The depth to water table, however, (measured with piezometers) at the time of seed release was highly correlated with seed establishment. More than 1,200 seedlings $/ \mathrm{m} 2$ established in some plots but few survived the summer. Highest seedling survival occurred on those plots where the water table was within $20 \mathrm{~cm}$ of the ground surface during the time of seed release (early July) and when the water table dropped to less than $50 \mathrm{~cm}$ by early September. More seedlings survived on gravel than on sand substrate. Average lifespan of the cottonwood appeared to be about 100-150 years. Only 5 percent of the study area, however, was currently occupied with stands less than 10 years old. [COTTONWOOD; RIPARIAN FOREST; WATER TABLE EFFECTS]

343. Clayton,SR; Moynahan,BJ; Parker,TG; Weisenburger,TR; Thompson,WH; Hansen,PL (1998): The response of streambank stabilization treatments to ice and a major flood event on the Upper Clark River, western Montana. p. 85-95. In: Potts,DF [ed.]. Rangeland management and water resources: Proceedings of the AWRA specialty conference. American Water Resources Association. 27-29 May 1998. Reno, NV.

In 1996, a study to evaluate 12 bank treatments was initiated emphasizing the use of native plant materials and other bioengineering materials. It is still too early to determine long-term effectiveness of individual treatments. However, first year survival was high for mature transplants, containerized seedlings, and vertically-planted willow cuttings. Treatments which best withstood flooding were on resloped banks and included coir fabric and toe protection. Installation costs varied from $\$ 5.58-\$ 82.29 / \mathrm{ft}$. In general, treatments requiring heavy equipment were less expensive than treatments that were labor-intensive.

[BIOENGINEERING; RIPARIAN RESTORATION; RIPARIAN VEGETATION; STREAMBANK PROTECTION]

\section{Clements, $C$ (1991): Beavers and riparian ecosystems. Rangelands 13(6), 277-279.}

Habitat changes resulting from beaver activities can have dramatic influences on the quality of a riparian system in both positive and negative ways. In western Nevada, beavers can eliminate black cottonwood from the riparian zone, but leave mountain alder. This, in turn, leads to changes in tree density, height, forest structure, cavity availability, and other physical aspects. Unlimited beaver populations can be harmful to beaver habitats and ultimately to the beavers themselves. Complete removal will eliminate a natural feature of the environment that is important to many other organisms. Beaver management is an important aspect of natural resource stewardship.

[BEAVER; RIPARIAN HABITAT; RIPARIAN MANAGEMENT ZONE]

345. Clemmer,P (1994): Riparian area management. The use of aerial photography to manage riparian-wetland areas. USDI Bureau of Land Management. Technical Reference 1737-10. $64 \mathrm{p}$.

This report provides basic information, concepts, and procedures associated with using aerial photography to establish baseline data for effective management of riparian-wetland areas. Suggestions for the use of various scales of photography, guidance for acquiring aerial photography, and general procedures for conducting a vegetation inventory are included.

[AERIAL PHOTO; MONITORING; REMOTE SENSING; RIPARIAN HABITAT; WETLANDS]

346. Clifton, $C$ (1989): Effects of vegetation and land use on channel morphology. p.121-129. In: Gresswell,RE; Barton,BA; Kershner,JL [eds.]. Practical approaches to riparian resource management. An educational workshop. 8-11 May 1989. Billings, MT.

Spatial and temporal morphologic variability in mountain streams may be attributed to local prevailing conditions. In the Blue Mountains of central Oregon, morphologically distinct reaches 
result from differences in the composition and structure of streamside vegetation, physiography, and land use. Comparisons of grazed and ungrazed meadow reaches and a forested reach loaded with large organic debris reveal special differences related to the local environmental setting. Overall, width, depth, and cross-section area do not increase systematically downstream.

[CHANNEL MORPHOLOGY; LAND USE; VEGETATION MANAGEMENT]

347. Clifton,C; Thomas, AE (1988): A bibliography of riparian and related topics with emphasis on the Intermountain West. USDI Bureau of Land Management. Idaho State Office. Boise, ID. Technical Bulletin 88-2. 69 p.

This bibliography lists relevant publications on the topic of riparian management in the western U.S., with emphasis on the Intermountain Region. The bulletin contains 322 referenced publications dealing with riparian subjects. Copies are available in both hard copy and diskette from Idaho State Office, BLM.

[RIBIIOGRAPHY; BI.M; RIPARIAN HABITAT; RIPARIAN MANAGEMENT ZONE]

348. Clifton,CF (1987): Effects of land use and vegetation on the channel morphology of Wickiup Creek, Blue Mountains, Oregon. MS Thesis, University of Wisconsin, Madison.

Over a 50-year period without grazing, there was a 94 percent reduction in the channel cross section area. Grazed and ungrazed meadow reaches and forested reaches with large woody debris revealed specific differences related to the local environmental setting. Width, depth, and cross-section area did not increase systematically downstream. Greatest widths were found in the forested reach. Greatest depths were in the ungrazed meadow reach.

[CHANNEL MORPHOLOGY; GRAZING IMPACTS; ORGANIC DEBRIS; RIPARIAN VEGET $\Lambda$ TION]

349. Cline,LD; Short,RA; Ward,JV (1979): The inertia and resiliency of a mountain stream to construction impact. p. 617-620. In: Swanson,GA [ed.|. The mitigation symposium: A national workshop on mitigating losses of fish and wildlife habitat. USDA Forest Service. General Technical Report RM-65.

Predictive indices of inertia (ability to resist disturbance) and resiliency (ability to recover from disturbance) were applied to a mountain stream in Colorado subjected to highway construction activities. Expected inertia values were exceeded as demonstrated by physical, chemical, and biological parameters. Application of ecological principles elucidates the discrepancy between predicted and observed responses.

[INERTIA VALUES; RESILIENCY; RIPARIAN

RESTORATION]

350. Cline,LD; Short,RA; Ward,JV; Carlson,CA; Gray,HL (1983): Effects of highway construction on water quality and biota in an adjacent Colorado mountain stream. USDA Forest Service. Rocky Mountain Forest and Range Experiment Station. Research Note RM-429. 11 p. [ROAD IMPACTS; STREAM ECOLOGY; WATER QUALITY]

351. Cline,SP; Phillips,CA (1983): Coarse woody debris and debris-dependent wildlife in logged and natural riparian zone forests - a western Oregon example. USDA Forest Service. General Technical Report RM-99. [LOGGING IMPACTS; ORGANIC DEBRIS; RIPARIAN HABITAT]

352. Coats,RN; Leonard,RL; Goldman,CR (1976): Nitrogen uptake and release in a forested watershed, Lake Tahoe Basin, CA. Ecology 57:995-1004.

The supply of nitrogen is an important factor limiting primary productivity in Lake Tahoe, California/Nevada. Factors controlling nitrification were studied using a soil perfusion technique. Output of inorganic nitrogen from the watershed to the lake is 10 to 33 percent of the precipitation input. Inorganic nitrogen is removed from snowmelt water almost completely by well developed conifer stands. Alder stands release NO3 - N to soil water especially in fall and early winter. Nitrification does occur in some coniferous forest soils in the watershed and is closely associated with NO3 release. The occurrence of significant nitrification in the watershed is related more to the $\mathrm{C}: \mathrm{N}$ ratio and stand basal area than to either $\mathrm{pH}$ or release of toxic substances by decaying litter. [NUTRIENT CYCLES; WATER QUALITY; WATERSHED]

353. Coats, R; Swanson,M; Williams,P (1989): Hydrologic analysis for coastal wetland restoration. Environmental Management 13(6), 715-727.

Increasing recognition of the values of tidal wetlands has led to interest in how to restore and 
enhance areas that have been modified by human activity. The policy of recognizing restoration or enhancement as mitigation for destruction of other wetlands is controversial. One key element of the design of a successful project is quantitative hydraulic and hydrologic analysis of alternatives. Restoration projects at two sites in California used a combination of empirical geomorphic relationships, numeric modeling, and verification with field observations. Experience with wetland restoration projects indicates the importance of post-project monitoring, inspection, and maintenance. [HYDROLOGY; RIPARIAN HABITAT; WETLANDS]

354. Cockman,JS; Pieper,R; Clason,D (1996): Arroyo-riparian shrub diversity along a transition zone between the Sacramento Mountains and Tulorosa Basin, NM. p.230-236. In: Proceedings: Shrubland ccosystem dynamics in a changing environment. 23-25 May 1995. Las Cruces, NM. USDA Forest Service. Intermountain Research Station. General Technical Report INT-GTR-338. 275 p.

Arroyos in the Sacramento Mountains of New Mexico were examined to determine the type differences and to describe the vegetation diversity of the main channel relative to the surrounding watershed. Each arroyo was selected to represent foothills and a sub-mesa which characterized a shrub, half-shrub, grass, and forb functional group. Groups responded differently depending on the response variable (cover, density, diversity). Interactions were masked by the fact that these response variables were comprised of different species, depending on the location of the arroyo.

[ARROYOS; RIPARIAN SHRUBS; RIPARIAN VEGETATION]

355. Colby,BG (1990): Enhancing instream flow benefits in an era of water marketing. Water Resources Research 26(6), 1113-1120.

This article examines current instream flow policies in the western states and outlines the economic values generated by stream flows. The author argues that instream values are high enough to compete in the market for water rights with offstream uses when important recreation sites and wildlife species are involved. The paper suggests how western state policies might be altered to accommodate instream flow protection within the context of water marketing, with the objective of improving the efficiency of water allocation among instream and consumptive uses.
[HYDROLOGY; STREAM FLOW; WATER RIGHTS]

356. Coleman, NI (1986): Effects of suspended sediment on the open-channel velocity distribution. Water Resources Research 22(10), 1377-1384.

Experiments were performed in which suspended sediment concentration in open-channel bounded shear flow was varied systematically while flow depth, slope, and discharge were held essentially constant. The effect of variation in suspended sediment concentration on velocity profile characteristics was investigated. The experiments used both the Karman coefficient and the Coles wake strength coefficient to detect changes. The thickness of the logarithmic part of the velocity profile decreased as sediment concentration increased. The logarithmic parts of velocity profiles in sediment-suspending flow were shifted downward relative to control profiles in comparable clear flows. [CHANNEL DYNAMICS; CIIANNEL MORPHOLOGY; SEDIMENTATION]

\section{Colman,EA (1953): Vegetation and watershed management. The Ronald Press Co., New York, NY. 412 p. \\ The key relationship investigated in this book is that of vegetation management water control and supply. Plant life influences the rate at which rain and snow can enter the soil and groundwater reservoirs and slows the runoff of water and inhibits erosion of soils. Vegetation can be used to manage the timing, quality, and quantity of water harvest from watersheds. Riparian and phreatophytic vegetation also play important roles in the utilization of surface waters from streams and rivers and from the groundwater table. \\ [PHREATOPHYTES; RIPARIAN HABITAT; RIPARIAN VEGETATION; WATERSHED]}

358. Comanor,K (1998): The inefficacy of using a solute transport model to assess the impact of grazing on a small intermontane stream. p. 442. In: Potts,DF [ed.]. Rangeland management and water resources: Proceedings of the AWRA specialty conference. American Water Resources Association. 27-29 May 1998. Reno, NV.

Continuous loading solute experiments were conducted in a area of the Sierra Nevadas in two land use areas - one grazed, the other not. Shallow wells were installed near the stream in both areas using the Bencala method (1983). No significant responses were measured in each of three separate experiments; 
nor were there any significant differences in the timing of well responses. The connectivity of the stream water to shallow ground water does not appear to be affected by the land use of the grazing. [GRAZING IMPACTS; NUTRIENT CYCLES; WATER QUALITY]

359. Compton,BB; Mackie,RJ; Desek,GL (1988): Factors influencing distribution of white-tailed deer in riparian habitats. Journal of Wildlife Management 52(3), 544-548.

Factors influencing distribution of white-tailed deer (Odocoileus virginianus) along the lower Yellowstone River in eastern Montana were evaluated during winter, summer and fall, 1985. The amount of riparian forest and shrubland cover was the most important factor influencing deer distribution and accounted for 70 percent of the variation observed in relative deer abundance among sections of the river bottom. Cattle distribution and amount of island area also influenced the distribution of deer.

[GRAZING IMPACTS; RIPARIAN HABITAT; WHITE-TAILED DEER]

360. Conners, ME; Naiman, RJ (1984): Particulate allochthonous inputs: relationships with stream size in an undisturbed watershed. Canadian Journal of Fish Aquatic Science 41(10), 1473-1484.

Four streams of a pristine boreal watershed in eastern Qucbec werc examined to assess the composition, seasonal pattern and ash-free dry mass (AFDM) of particulate allochthonous input. Study sites on streams ranging from 1 st - 6 th order exhibited significant differences in the types and magnitude of litter input. Composition of litter fall varied according to vegetation and physical structure of the riparian zone. Although the forest in the watershed is dominated by conifers, deciduous leaves dominated annual budgets and seasonal input patterns. A watershed budget calculated from results estimated that a total input of $729 \mathrm{t}$ (ton) $\mathrm{yr}-1$ to streams of this $673 \mathrm{~km} 2$ watershed. When particulate allochthonous input is compared with primary production measurements in these streams, 81-95 percent of the organic $C$ supplied to the Ist- and 2nd-order streams is allochthonous but 85-95 percent of the supply to the 5th- and 6th-order streams is autochthonous. The importance of local effects illustrates the need for a more mechanistic approach in allochthonous input research. [NUTRIENT CYCLES; ORGANIC DEBRIS; RIPARIAN HABITAT; RIPARIAN VEGETATION]
361. Connin,S (1991): Characteristics of successful riparian restoration projects in the Pacific Northwest. US Environmental Protection Agency, Region 10, Water Division. 53 p.

This report summarizes and evaluates thirteen successful riparian enhancements in the region. These projects represent a wide range of geographic locations, disturbance histories, restoration techniques (Best Management Practices), and restoration participants. Processes related to successful BMP design, implementation, and monitoring were evaluated for effectiveness and contribution to final project results. Analyses were conducted through questionaire surveys, personal interviews, and site visits. The evaluation identified various process-oriented characteristics which contributed to project success. Some of these were common to several or all projects. These attributes appear to be "key" components of success and should be acknowledged as operational standards for riparian restoration. These characteristics and recommendations are summarized.

[BEST MANAGEMENT PRACTICES; MONITORING; RIPARIAN MANAGEMENT ZONE; RIPARIAN RESTORATION]

362. Conroy,SD; Svejcar,TJ (1991): Willow planting success as influenced by site factors and cattle grazing in northeastern California. Journal of Range Management 44(1), 59-63.

This study evaluated the influence of grazing and selected site factors on survival and leader growth of planted Geyer willow cuttings. Three grazing treatments (early summer, late summer, and non-use) were evaluated on each of 3 streams in broad, low-gradient meadows with silt loam soils in the northern Sierra Nevada. There was no significant effect on grazing treatment on either willow survival or growth despite 3.5 to 5 times more defoliation use of the willow cuttings in the grazed pastures. Stream channel location (proximity) did significantly affect willow survival but not individual plant leader length. There was a clear relationship between water table depth, soil moisturc, and willow planting survival but not between moisture measurements and leader length. Once the water table has declined to the point that Artemisia spp. can survive on a site, the chances of successfully replanting willows are minimal. However, even during drought years, a survival rate of 60 percent or greater was achieved by planting into Carex nebraskensis communities or bare ground in the channel.

[GRAZING IMPACTS; SAGEBRUSH; SOILS; WATER TABLE EFFECTS; WILLOW] 
363. Contor,CR; Platts,WS (1991): Assessment of COWFISH for predicting trout populations in grazed watersheds of the Intermountain West. USDA Forest Service. General Technical Report INT-278. $28 \mathrm{p}$.

The COWFISH model, developed and applied in selected Montana streams, was tested on 14 streams in Idaho, Nevada, and Utah, where it proved to have little value for predicting numbers of trout in watersheds grazed by livestock. The model holds promise for estimating the health of stream channels and riparian complexes.

[COWFISH; FISHERIES; GRAZING IMPACTS; LIVESTOCK EFFECTS; MODELING]

364. Cook,CW (1966): Factors affecting utilization of mountain slopes by cattle. Journal of Range Management 19, 200-204.

Many factors affect the utilization of mountain terrain by cattle and these factors are interrelated and exert their influence in a complicated manner. Actual use obtained under good management is the most accurate method of determining the utilization obtainable on a particular mountain slope. [GRAZING IMPACTS; UTILIZATION]

365. Cooper,DJ (1988): Mountain wetland vegetation dynamics. p.23-25. In: Mutz,K; Cooper,DJ; Scott,ML; Miller,LK [eds.]. Restoration, creation, and management of wetland and riparian ecosystems in the American West. A symposium of the Rocky Mountain Chapter of the Society of Wetland Scientists. 14-16 November 1988.

Many wetland plants reproduce largely by very vigorous rhizomes. This can be used to the advantage of those trying to revegetate disturbed wetlands that do not have hydrologic problems. Many of the most common wetland species have very broad niches and can occur in a wide variety of situations. They can be propagated by stem cuttings, sprigging, soil banking and respreading, plugs and many other means. [PLANT COMMUNITIES; PLANT PROP $\Lambda$ G TION; RIPARIAN RESTORATION; WETLANDS]

366. Cooper,DJ (1988): Colorado's wetlands. The Green Thumb 45(2), 38-45.

In dry regions, where water is at a premium, wetlands are cxtremely valuable ecosystems. The diversity of habitat is important both to wildlife and people. In addition, many wetlands provide other important functions including water quality control that is vital to downstream users. Wetlands should be preserved and protected wherever possible. Many of the plants occurring in these sites occur nowhere else. [RIPARIAN HABITAT; WATER QUALITY; WETLANDS]

367. Cooper,DJ (1990): Ecology of wetlands in Big Meadows, Rocky Mountain National Park, Colorado. USDI Fish and Wildlife Service. Biological Report 90(15). Washington, DC. 45 p. This paper describes in detail the results of studies of hydrology, water chemistry, soils, and vegetation at a wetland complex in the Rocky Mountain National Park in north-central Colorado. Five water sources affect the complex and each water source somewhat differently structures the hydrological character, vegetation, and water chemistry of various portions of the complex. Twelve plant communities that make up the complex are described and characterized relative to measurements taken throughout the complex. The water table is highest in March and lowest in fall and early winter. The growing season usually lasts only three months and water tables fluctuate drastically among years depending on the depth of the snow pack. Soil saturation during July is seemingly the critical variable for peat formation in the study area. Sites with a water table within $20-30 \mathrm{~cm}$ of the surface in July usually support peat soils. Oxidation - reduction potential measurements indicate that for any soil depth, the soils stay reduced for up to 3 weeks after a water table drop below that depth.

[HYDROIOGY; REDOX POTFNTIAI; WATFR

TABLE EFFECTS; WETLANDS]

368. Cooper,DJ; Merritt,DM; Chimner,R; Anderson,DC (1997): Establishment and survival of Fremont Cottonwood and Tamarisk on regulated and unregulated rivers: The Green and Yampa Rivers. In: Proceedings of the Society of Wetland Scientists. 18th annual meeting. Restoration and Management Notes 16:1:92.

Cottonwood and tamarisk seedlings along a regulated river and an unregulated river were compared. Cottonwood seedlings could not establish near older cottonwoods due to competition for water. Shade was not as important as available soil water in all areas. The Yampa River in Colorado (unregulated) experienced multiple establishments of both species, while the Green River (regulated) had only sporadic establishment of tamarisk due to sporadic summer flows.

[EXOTICS; RIPARIAN FOREST; RIPARIAN

SHRUBS; SALT-CEDAR; SOIL-WATER

CONDITIONS; STREAM FLOW] 
369. Cooper,JL (1978): A technique for evaluating and predicting the impact of grazing on small stream channels. In: Transactions, Bonneville Chapter, American Fisheries Society. 3-4 February 1978. Salt Lake City, UT. 17 p. A modification of a widely used USDA Forest Service technique for evaluating impacts of increased water yields on streambank channel substrate stability was employed to predict impacts of grazing on bank-channel stability. The technique consisted of adding a parameter ( percent ungulate damage) and correlating present and potential bank-channel stability. Bank features (slope, log debris, vegetation, rock content, shade, and vegetation palatability) interact to influence impact of grazing on bank-channel stability. [EVALUATION; GRAZING IMPACTS; MONITORING]

370. Cooper,SD; DiehI,S; Kratz,K; Sarnelle,O (1998): Implications of scale for patterns and processes in stream ecology. Australian Journal of Ecology 23, 27-40.

Current knowledge of scale effects by freshwater ecologists is rudimentary and non-quantitative. The authors review issues of spatial and temporal scale in this paper to highlight conceptual problems relating to scale and some potential solutions. They recommend that freshwater ecologists undertake more multi-scale sampling and experimentation to examine patterns and processes at multiple scales. [RIPARIAN HABITAT; SPATIAL SCALE; SIREAM ECOLOGY]

371. Cooperrider,AY (1990): Conservation of biological diversity on western rangelands. In: Transactions of the North American wildlife and natural resources conference. 16-21 March 1990. Denver, $\mathrm{CO}$. Wild life Management Institute. Washington, DC.

Biological diversity at the community/habitat, species, and genetic levels is threatened by our activities on the western rangelands. Sustainable ecosystems are required for sustainable economies. Conservation of biological diversity will require awareness of the relationship between biological diversity and sustainability. It will require awareness by all involved parties.

[BIODIVERSITY; ECOSYSIEM MANAGEMENT; RIPARIAN HABITAT; SUSTAINABILITY]

372. Cooperrider,AY; Boyd,RJ; Stuart,HR (1986): Inventory and monitoring of wildlife habitat. USDI Bureau of Land Management,
Denver Service Center. Denver, CO. 858 p.

A book intended to guide field biologists and managers in planning, organizing, and administering wildlife inventory and monitoring projects. Primarily designed for professional wildlife biologists working for USDI Bureau of Land Management, much of the material is relevant for those working in other agencies or institutions.

LAQUATIC ECOSYSTEMS; INVENTORY; MONITORING; RANGELAND ECOSYSTEMS; RIPARIAN HABITAT; STREAM ECOLOGY; WETLANDS]

373. Cope,OB [ed. | (1979): Proceedings of the Forum -- Grazing and riparian/stream ecosystems. 3-4 November 1979. Denver, CO. Trout Unlimited, Inc. 94 p.

A forum organized by Trout Unlimited, Inc. to bring together all interested agencies and organizations to present a balanced and current spectrum of issues as well as scientific state-of-the-art knowledge on grazing and riparian/stream management in order to derive the best possible management guidelines. The published proceedings consolidate the 30 professional and topical presentations under one cover.

[GRAZING IMPACTS; RIPARIAN ECOLOGY; STREAM ECOLOGY]

374. Corbett,ES; Lynch,JA (1985): Management of streamside zones on municipal watersheds.

p.187-190. In: Johnson,RR; Ziebell,CD;

Patton,DR; Ffolliott,PF; Hamre,RH [tech.coord.]. Riparian ecosystems and their management: Reconciling conflicting uses. 16-18 April 1985. Tucson, AZ. USDA Forest Service. General Technical Report RM-120.

Riparian zones are important in water quality management. Water supply considerations and maintenance of streamside zones from the municipal watershed managers' perspective are discussed. Management impacts affecting water quality and quantity on forested municipal watersheds are discussed in relation to the structure of the riparian zone.

[HUMAN IMPACTS; RIPARIAN MANAGEMENT ZONE; WATER QUALITY]

375. Corn,PS; Bury,RB (1987): The effects of timber harvest on aquatic amphibians. In: Streamside management: Riparian wildlife and forestry interactions. An interdisciplinary symposium. 11-13 February 1987. University of Washington. Seattle, WA. 
Species diversity of amphibians was much lower in logged streams than in controls. Eleven control streams contained all four inventoried species. Only two controls had as few as two species present. Of the logged streams, 11 had one or no species present, and only one contained all four. Densities of all species were significantly greater (by 2-10 X) in control vs logged streams.

[AMPHIBIANS; LOGGING IMPACTS: RIPARIAN HABITAT]

376 Corn,PS; Bury,RB (1989): Logging in western Oregon: Responses of headwater habitats and stream amphibians. Forest Ecology and Management 29, 39-57.

This paper compared the occurrence and abundance of amphibians between streams flowing through uncut forests and streams in logged stands where second growth has reestablished the canopy. Pacific giant salamanders (Dicampton ensatus), Olympic salamanders (Rhyacotriton olympicus), Dunn's salamanders (Plethodon dunni), tailed frogs (Ascaphus truei) were inventoried. Eleven streams in logged stands had one or no species present. Density and biomass of all four species were significantly greater in uncut forests.

[AMPHIBIANS; BIODIVERSITY; RIPARIAN FOREST; RIPARIAN HABITAT]

377. Corner,RA; Bassman,JH (1993): Contribution of legal buffer zones to non-point source pollution abatement following timber harvesting in northeast Washington. p.245. In: Tellman,B; Cortner,HJ; Wallace,MG; DeBano,LF; Hamre,LF [tech. coord.]. Riparian management: Common threads and shared interests. USDA Forest Service. General Technical Report RM-226.

Sedimentation of streams resulting from forest management practices is among the greatest non-point source pollution concerns. This study concluded that although riparian buffer zones can be instrumental in protecting against non-point source pollution, their effectiveness is directly related to physical properties and the nature of management on the upland area. Therefore, a legal buffer zone width should be calculated as a function of physical parameters (e.g. slope, soil permeability, soil erodibility) and intensity of management practices rather than as a designated fixed distance. [BUFFER ZONES; LOGGING IMPACTS; NON-POINT SOURCE POLLUTION; RIPARIAN HABITAT]
378. Cornwell,J (1990): Developing grazing management plans for riparian areas. USDA Soil Conservation Service, Boise, ID. Idaho Range News. April 1990.

This article provides a topical background for preparing, implementing, and sustaining a management plan for riparian grazing. It is useful for providing a step-by-step outline for developing and using a grazing management plan.

[GRAZING IMPACTS; GRAZING

TREATMENTS]

379. Corradini,C; Singh,VP (1985): Effect of spatial variability of effective rainfall on direct runoff by a geomorphologic approach. Journal of Hydrology 81(1985), 27-43.

The importance of spatial variability of effective rainfall input to a direct runoff model was analyzed by the geomorphologic approach based on the use of different paths determined according to the Horton-Strahler ordering scheme. Actual effective rainfall distributions, derived from observed rainfall were employed. The authors argue that it is unreasonable to use the geomorphologic approach in computing basin response for spatially variable effective rainfall as model input. Analysis of the distribution throughout the basin revealed that the averaging scheme of the channel network, following the Horton-Strahler ordering scheme, was not appropriate.

[GEOMORPHOLOGY; HYDROLOGY; MODELING; SPATIAL SCALE]

380. Coulson,RN; Folse,LJ; Loh,DK (1987): Artificial intelligence and natural resource management. Science 237(July), 262-267.

Use of artificial intelligence (AI) in natural resource management began with the development of expert systems for problem-solving and decision-making. The use of expert systems in turn led to the development of other procedures. These include: integrated expert systems, which link management models with natural resource models; intelligent geographic information systems, which permit interpretation of relations within and among landscape data themes; and, modeling of animal behavior and interaction with the environment. [ARTIFICIAL INTELLIGENCE; GIS; MONITORING; RIPARIAN HABITAT]

381. Covich,AP; Palmer,MA; Crowl,TA (1999): The role of benthic invertebrate species in freshwater ecosystems. BioScience 49(2), 119-126. Benthic invertebrates in freshwater sediments are 
diverse and abundant but are often patchily distributed and relatively difficult to sample, particularly when they live in deep subsurface sediments. Species richness and functional importance of freshwater invertebrates generally go unnoticed until something unexpected occurs in ecosystems. Such changes may be caused by floods, drought, disease, fish kills, etc. Physical, chemical, and biological processes create significant horizontal and vertical heterogeneities in the substrata that provide a template for distinct niches. Some species have a disproportionately large impact on food-web dynamics and provide essential ecosystem services. These functions include mixing, nutrient cycling, and energy flow through food webs. Adequate models, however, for ecosystem services is lacking. Public understanding of these mechanisms is also poor. Much of flowing water eventually passes through subsurface zones where rich faunal diversities contribute to a multiplicity of services. Benthic biota mediate biogeochemical transformations and act directly to prevent buildup of carbon in the sediments and deoxygenation of bottom waters. They also sequester and move contaminants and excess nutrients from groundwaters and sediments and influence the flux of greenhouse gases.

[FOOD WEBS; INVERTEBRATES; MACROINVERTEBRATES; NUTRIENT CYCLES; SPECIES RICHNESS; WATER QUALITY]

382. Cowan,WL (1956): Estimating hydraulic roughness coefficients. Agricultural Engineering 37, 473-475.

[CHANNEL DYNAMICS; HYDROLOGY]

383. Cowardin,LM; Carter,V; Golet,FC; LaRoe,ET (1979): Classification of wetlands and deep water habitats of the United States. USDI Fish and Wildlife Service. Biological Services Program. FWS/OBS-79/31. 103 p.

The classification was intended to describe ecological taxa, arrange them into a useful system, furnish units for mapping, and provide uniformity of terms and concepts. Wetlands are defined by plants (hydrophytes), soils (hydric soils), and frequency of flooding. Deep water habitats are also included in the classification. The wetlands classification has been in general use by the USDA Forest Service since its publication. [CLASSIFICATION; RIPARIAN HABITAT; WETLANDS]

384. Cowell,DW (1984): The Canadian Beaver,
(Castor canadensis), as a geomorphic agent in karst terrain. Canadian Field-Naturalist 98(2), 227-230.

The karst-drainage of a beaver-occupied lake and a sinkhole pond resulted in dam and canal building by Canadian beavers. The beavers were unsuccessful in maintaining their habitat. Their activities probably enhanced karsification.

[BEAVER; GEOMORPHOLOGY]

385. Cowley,ER (1992): Protocols for classifying, monitoring, and evaluating stream/riparian vegetation on Idaho rangeland streams. Idaho Dept. of Health and Welfare. Division of Environmental Quality. 37 p.

The document defines appropriate parameters and outlines specific monitoring protocols and procedures for evaluating vegetation and streambank stability for Idaho's small (usually less than 30 feet) rangeland streams. It also provides protocols for monitoring stream canopy cover, streambank stability, solar input, and establishing permanent photo points associated with livestock grazing and other activities that affect streamside (riparian) vegetation and beneficial uses of water. These protocols are directed at three of the important pollutant sources affecting the biological integrity of streams and lakes that may result from livestock grazing: streambank erosion, water temperature, and vegetation.

[GRAZING IMPACTS; MONITORING; PROTOCOLS; RANGELAND STREAMS; STREAMBANK STABILITY]

386. Cox,JR; Morton,HL (1985): Above-ground biomass quantities and livestock production in big sacaton riparian areas in southeastern Arizona. p.305-309. In: Johnson, RR; Ziebell,CD; Patton,DR, Ffolliott,PF; Hamre,RH [tech. coord.]. Riparian ecosystems and their management: Reconciling conflicting uses. 16-18 April 1985. Tucson, AZ. USDA Forest Service. General Technical Report RM-120.

In southeastern Arizona, two big sacaton riparian sites were studied and compared. At one, the standing biomass was measured for 3 years. At the other, the standing crop was burned or mowed in February before grazing. Dead standing biomass accumulated in the fall and disappeared following precipitation in fall, winter, or summer. Both burning or mowing reduced biomass production. Stocking rates on mowed or burned sites were only one-third as high as on untreated. Total gains per pasture were 512 and $235 \mathrm{~kg}$ on the untreated and treated, respectively. 
[FIRE IMPACIS; GRAZING IMPACTS; LIVESTOCK EFFECTS; MOWING]

387. Crance,JH (1988): Relationships between palustrine wetlands of forested riparian floodplains and fishery resources: $A$ review. USDI Fish and Wildlife Service. Biological Report 88(32), 27.

This literature review focuses on management approaches and research for the identification and mitigation of wetland impacts and on the importance of wetlands to fisheries. Productivity, species diversity and structure, and nutrient cycling respond to hydrologic regimes. Deterioration of hydrologic regimes of wetlands is likely to reduce habitat quality or quantity and may block fish access. Fishery resources should be given high priority when regulated stream flow, channelization, diking, and watershed practices are being evaluated.

[FISHERIES; HYDROLOGY; RIPARIAN

FOREST; RIPARIAN HABITAT]

388. Crandall,KB; Colby,BG; Rait,KA (1992): Valuing riparian areas: $A$ southwestern case study. Rivers 3(2), 88-98.

Instream flows typically have been neglected in the competitive distribution of water in the West, because many of the benefits they provide have public goods characteristics and tend not to be legally recognized as beneficial uses of water. Economists have developed several techniques to value amenity resources, including the Travel Cost Method, the Contingent Valuation Method, and local economic impact analyses. This paper provides a brief review of these techniques and their application to sites with instream flows and riparian ecosystems. It provides economic data to facilitate more informed decisions regarding protection of streamflows, land use alternatives, and riparian habitat preservation. [ECONOMICS; RIPARIAN HABITAT]

389. Crawford,CS; Ellis,LM; Molles,MC; Valett,HM (1996): The potential for implementing partial restoration of the Middle Rio Grande ecosystem. p.93-99. In: Shaw,DW; Finch,DM [tech. coord.]. Desired future conditions for Southwestern riparian ecosystems: Bringing interests and concerns together. USDA Forest Service. General Technical Report RM-GTR-272.

The Rio Grande currently inundates only a small portion of its riparian forests during late spring runoff. Such flood events were once responsible for the germination of cottonwoods and willows along the river, for a mosaic of wetlands mixed with different aged stands of forest, and for enhancement of decomposition and nutrient cycling. River regulation in this century has decoupled the linkage between the floodplain and the river and has led to senescence without replacement of the once dominant native cottonwoods in the Middle Rio Grande (MRG) valley. The authors propose that partial restoration can be accomplished by re-establishing a regime of seasonal wetting of riparian soils at select sites, most likely in the MRG's southern reach. Research at Bosque del Apache National Wildlife Refuge suggests that this practice would: 1) accelerate decomposition and nutrient cycling within existing stands; and 2) promote cottonwood-willow germination on banks and other cleared areas. It could also expedite the creation of wetlands.

[COTTONWOOD; NUTRIENT CYCLES; RIO GRANDE; RIPARIAN RESTORATION; WETLANDS; WILLOW]

390. Creamer,WH,IV; Wamboldt,CL; Rossi,RJ (1992): Comparison of three groups of variables for predicting big sagebrush forage production. p.217-221. In: Clary,WP; McArthur,ED; Bedunah,D; Wambolt,CL [tech. coord.]. Proceedings - Symposium on ecology and management of riparian shrub communities. USDA Forest Service. General Technical Keport INT-289.

This paper reports modeling procedures used to develop regression equations to predict forage production available in the winter from three subspecies of big sagebrush of high- and low-use form classes.

[FORAGE PRODUCTION; GRAZING IMPACTS; MODELING]

391. Crisco,W (1990): Riparian vegetation analysis with low altitude aerial photography. A case study report, USDI Bureau of Land Management. Vale District, $O R$.

Infrared aerial photographs of 11 riparian sites were obtained during two periods, 1981-1982 and in 1987, at scales from 1:1,790 to 1:3,570. Vegetation and channel characteristics were characterized and acreages of each category determined. Significant vegetation changes were observed. [AERIAL PHOTO; BLM; MONITORING; RIPARIAN HABITAT]

392. Croft,AR; Hoover,MD (1951): The relation of forests to our water supply. Journal of Forestry 49(4), 245-249. 
A usable water supply can be sustained only if the forestry profession assumes responsibility for water management as well as timber management. For that to occur, these things must happen: 1) the forestry profession must clearly recognize and assume responsibility for management of water from forested lands; 2) the job of managing water supply from forested lands must be integrated with forest management; and 3) forestry schools must give adequate instruction in the hydrology of forested lands to prepare managers for doing their job. [HYDROLOGY; LOGGING IMPACTS; WATER RESOURCE MANAGEMENT]

393. Cronemiller,FP (1955): Making new trout streams in the Sierra Nevada. p.583-586. In: Water: The yearbook of agriculture. 84th Congress. House document No. 32 .

Small, intermittent streams have been improved to accommodate trout spawning and summer-long habitat by the construction of small,

"flow-maintenance" dams. Such dams, developed through cooperative efforts with sportsmen groups, assure the release of stored water through the summer to create permanent streams with excellent fishing. These installations become natural "trout factories" which have very low maintenance costs. [FISHERIES; RIPARIAN RESTORATION; TROUT]

394. Cross,SP (1985): Responses of small mammals to forest riparian perturbations. p.269-275. In: Johnson,RR; Ziebell,CD; Patton,DR; Ffolliott,PF; Hamre,RH [tech. coord.]. Riparian ecosystems and their management: Reconciling conflicting uses. 16-18 April 1985. Tucson, AZ. USDA Forest Service. General Technical Report RM-120.

In southwest Oregon, trapping studies at several mixed conifer forest sites demonstrated a differentially high use of riparian habitat by small mammals. Harsh perturbations of this habitat radically affect the presence and abundance of many species. Riparian leave-strips were found to support small mammal communities comparable to undisturbed sites.

[BUFFER STRIPS; LOGGING IMPACTS; RIPARIAN HABITAT; SMALL MAMMALS]

395. Cross,SP (1987): Small mammals and bats in riparian studies. In: Streamside management: Riparian wildlife and forestry interactions. 11-13 February 1987. University of Washington. Seattle, WA.
Small mammals, primarily insectivores and rodents, are well suited for studies that provide information regarding wildlife utilization of relatively small or irregularly shaped habitat areas such as streamside riparian zones. Natural history observations and quantitative comparative habitat studies indicate that the forest streamside riparian zone supports a greater abundance and diversity of small mammals than the neighboring upland zone. Habitat utilization patterns differ from species to species, showing various degrees of affinity for the riparian zone. Some species are almost restricted to that zone. Others may enter upland areas but occupy riparian zones as their primary habitat. Still others are primarily upland forest species but use the riparian zone as secondary habitat. In mature forests, the riparian habitat supports virtually all small mammal species that are also present in neighboring habitats. [RIPARIAN HABITAT; SMALL MAMMALS]

396. Crouch, GL (1978): Effects of protection from livestock grazing on a bottomland wildlife habitat in northeastern Colorado. p.118-125. In: Proceedings of the lowland river and stream habitat in Colorado symposium. 4-5 October 1978. Greeley, CO.

Vegetation on a bottomland wildlife habitat protected from grazing for 7 and 25 years was compared to an adjacent grazed tract along the South Platte River in northeast Colorado. Overall cover and height of the understory was about twice as great on the ungrazed area for each evaluation, but did not change appreciably over the 18 -year interval. A significant decrease in the number of cottonwood trees occurred on both areas, particularly the grazed area.

[GRAZING IMPACTS; LIVESTOCK EFFECTS; PLATTE RIVER; RIPARIAN HABITAT]

397. Crouch,GL (1979): Long-term changes in cottonwoods on a grazed and ungrazed plains bottomland in northeastern Colorado. USDA Forest Service. Research Note RM-370. 4 p.

Numbers of cottonwood trees declined between 1961 and 1978 on a grazed and an ungrazed bottomland in northeast Colorado. Cottonwoods were larger in diameter in 1978 but basal area stocking was unchanged. Trees were taller in 1978 on the ungrazed area, and the amounts of canopy deadwood were greater on both areas. Water management, grazing by livestock and deer, plant competition on the ungrazed area, and beaver-felling of young trees all contributed to a lack of regeneration that appears responsible for the general decline in overstory 
vegetation.

[COTTONWOOD; GRAZING IMPACTS; LIVESTOCK EFFECTS; RIPARIAN FOREST]

398. Crouch,GL (1984): Wildlife habitat on the lower South Platte River in Colorado. p.1-3. In: Proceedings of the Symposium on wooded draws. South Dakota School of Mines and Technology. 12-13 June 1984. Rapid City, SD.

Wooded riparian habitats present today along the South Platte River appear to be of recent origin. Early explorers found few trees and a river that tlooded in the spring and was dry in late summer each year. The bottomlands could be drastically changed if management practices are not modified to favor the present environment.

[HISTORIC RECORDS; PLATTE RIVER; RIPARIAN HABITAT; RIPARIAN VEGETATION]

399. Crouse,MR; Kindschy,RR (1981): A method for predicting riparian vegetation potential of semiarid rangelands. p.110-116. In: Symposium on acquisition and utilization of aquatic habitat inventory information. 28-30 October 1981. Portland, OR.

Predicting potential of riparian areas to recover after protection from livestock is difficult because examples of pristine riparian communities have generally destroyed by excessive grazing. A method for predicting riparian site potential is described for semiarid climates. This method is based on physical characteristics of stream and reservoir riparian zones, such as extent of water level fluctuation, persistence of flow, scouring, and soil type. Such factors have been organized into a key for predicting potential recovery.

[CLASSIFICATION; MONITORING; RIPARIAN HABITAT; RIPARIAN VEGETATION]

400. Crumpacker,DW (1985): The Boulder Creek Corridor projects: Riparian ecosystem management in an urban setting. p.389-92. In: Johnson,RR; Ziebell,CD; Patton,DR; Ffolliott,PF; Hamre,RH [tech coord.|. Riparian ecosystems and their management: Reconciling conflicting uses. 16-18 April 1985. Tucson, AZ. USDA Forest Service. General Technical Report RM-120.

Protection of the Boulder Creek riparian corridor is a major priority of the citizens of Boulder, Colorado. Policies for protection and management for the benefit of the community are described. [HUMAN IMPACTS; RIPARIAN HABITAT; URBAN IMPACTS]

401. Crymes,GD; Stringham,TK; Buckhouse,JC
(1998): Methodology for measurement of riparian woody vegetation for the purpose of determining their contribution to shade on the water surface. p.98. In: Potts, DF [ed.]. Rangeland management and water resources: Proceedings of the $A W R A$ specialty conference. American Water Resources Association. 27-29 May 1998. Reno, NV.

Belt transects were employed that measured height, width, overhang, distance from the stream and compass orientation of the stream. A minimum of 6 diverse reaches were adopted per stream in order to establish statistical veracity. Belt transects were run parallel to the stream edge on both sides of the stream. Directional starting points were randomized. All measurements were collected during the low flow periods of late summer, the period in which eastern Oregon streams are most susceptible to temperature increases.

[MONITORING; RIPARIAN VEGETATION; SHADING]

402. Culler,RC (1970): Water conservation by removal of phreatophytes. American Geophysical Union Transactions 51(10), 684-689.

Removal of phreatophytes from the Gila River floodplain in southeastern Arizona produces a significant reduction in evapotranspiration. Long-term benefits from phreatophyte removal depends on the successful establishment of vegetation with low consumptive use of water. [HYDROLOGY; PHREATOPHYTES; RIPARIAN HABITAT; WATER RESOURCE MANAGEMENT]

403. Cummins,KW; Wilzbach,MA; Gates,DM; Perry,JB; Taliaferro,WB (1989): Shredders and riparian vegetation. BioScience 39(1), 24-30.

Stream invertebrates that feed on leaf litter (called shredders) are intimately tied to litter input. The major role of shredders in stream ecosystems is the conversion of large organic plant substrates (coarse), such as leaf litter, into smaller particles. A model is described that would operate on a broad spatial scale. The shredder-litter association represents the closest and most direct link between the dominant plant community and the biota of the receiving stream channel network. The model can provide a tool to evaluate watersheds that have been modified by various processes.

[LITTER FALL; INVERTEBRATES; MODELING: ORGANIC DEBRIS; RIPARIAN ECOLOGY; RIPARIAN HABITAT; SPATIAL SCALE]

404. Cuplin,P (1978): Remote sensing streams. 
BLM/ASP workshop on practical applications and use of color infrared and color imagery. 30 January -1 February 1978. Denver, CO. 3 p.

A method of stream habitat inventory using photo interpretation of large scale color infrared photography is described. The supporting methods of ground truth, targeting for aerial photo identification and photo scale, film format exposure for water penetration of clear water, lens filters, and description of acceptable weather and sunlight conditions for optimum film exposure are identified. [INVENTORY; MONITORING; RIPARIAN HABITAT]

405. Cuplin, $P$ (1981): The use of large scale color infrared photography for stream habitat and riparian vegetation inventory. USDI Bureau of Land Management Tech. Note 325. 7 p.

The interpretation of large scale color photogrammetry is a useful tool for identifying riparian habitat types and for monitoring the condition of these locations.

[AERIAL PHOTO; INVENTORY; RIPARIAN HABITAT]

406. Cuplin, $P$ (1987): A selected annotated bibliography of riparian area management. USDI Bureau of Land Management. Technical Reference 1737-1. 68 pp.

This bibliography contains 135 references, with abstracts and keywords, which the Riparian Area Task Force considered the most significant contributions to the state-of-the-art. Those references were chosen from more than 1,200 reviewed. [BIBLIOGRAPHY; RIPARIAN HABITAT; RIPARIAN MANAGEMENT ZONE]

407. Cuplin,P; Batson,F (1985): Stream/riparian area inventory and monitoring using large scale color infrared airphotos. p.356-361. In:

Proceedings of the (Pecora) Symposium for remote sensing in forest and range resource management. 20-22 August 1985. Colorado State University. Ft. Collins, CO.

There is an increasing level of interest in inventory and monitoring of critical stream/riparian environments. The BLM has investigated the use of remote sensing procedures to increase the efficiency of traditional ground-based methodologies. Ground data collection combined with photo interpretation of large scale airphotos provide inventory and monitoring capability for riparian areas. Variables that can be photo interpreted from large scale color infrared airphotos and used to detect change in riparian areas are stream width, flood plain width, stream channel stability, stream shade, ground cover of trees, shrubs, herbaceous vegetation, bare soil, riparian area and width, density and structure of large trees and shrubs.

[AERIAL PHOTO; MONITORING; REMOTE SENSING; RIPARIAN HABITAT]

408. Cuplin,P; Platts,WS; Casey,O; Masinton,R (1985): A comparison of riparian area ground data with large scale airphoto interpretation. p.67-68. In: Johnson,RR; Ziebell,CD; Patton,DR; Ffolliott,PF; Hamre, RH [tech. coord.]. Riparian ecosystems and their management: Reconciling conflicting uses. 16-18 April 1985. Tucson, AZ. USDA Forest Service. General Technical Report RM-120.

A study site in northeast Nevada was rnonitored 1979-1985. Aerial photos of the study site were acquired in large-scale, infrared, $9 \times 9$ in. format. Ground data and airphoto interpretation are compared.

[AERIAL PHOTO; MONITORING; RIPARIAN HABITAT]

409. Dahl,TE; Johnson,CE; Frayer,WE (1991): Wetlands: Status and trends in the conterminous United States mid-1970's to mid-1980's. USDI Fish and Wildlife Service. Washington, DC. 28 p.

Increased awareness regarding the ecological, social, and economic values of wetlands has resulted in the development of wetlands protection legislation and programs. Since 1983, the USDI Fish and Wildlife Service has been monitoring the rate and magnitude of wetlands conversions. Since the mid-1980's, indications are that wetland losses are slowing. Programs to restore wetlands under the $U S$ Food Security Act have added about 90,000 acres to the nations wetlands inventory during 1987-1990. [MONITORING; WETLANDS]

410. Dahlem,EA (1979): The Mahogany Creek watershed -- with and without grazing. p.31-34. In: Cope, OB [ed.]. Forum -- Grazing and riparian/stream ecosystems. 3-4 November 1978. Denver, CO. Trout Unlimited, Inc.

Based on photographic evidence and available data, reduction in livestock grazing but continued annual use had little or no beneficial effect on riparian habitat along Mahogany Creek. Only after complete removal of livestock use by fencing was significant riparian habitat improvement accomplished. [GRAZING IMPACTS; LIVESTOCK EFFECTS] 
411. Dale,HM; Garton,CE (1984): The aquatic macrophyte vegetation of an isolated island lake adjacent to Lake Nipigon, Ontario: A comparative study after a fifty-six year interval. Canadian Field Naturalist 98(3), 444-450.

The authors had a unique opportunity to compare the present vegetation of an isolated island lake with the records of vegetation that were made 53 years before. Since the impacts of man have been minimal because of rare visitations, predictions of change made in 1926 could be assessed.

Additionally, comparisons were made between a small island lake and a larger encompassing lake. Decrease in some species was attributed to the increase in water level. Opportunistic species flourished. Differences in the flora of the small isolated lake and the larger encompassing one were attributed to differences in the temperature of the water, alkalinity, and wave action. Lack of suitable invading disseminules may have prevented the establishment of certain species in the smaller lake. The reasons for the absence of other species are unclear.

[AQUATIC PLANTS; BEAVER; RIPARIAN

HABITAT; SECONDARY SUCCESSION]

412. Dalton,RS; Bastian,BT; Jacobs,JJ;

Wesche,TA (1998): Estimating the economic value of improved trout fishing on Wyoming streams. North American Journal of Fisheries Management. 18:786-797.

The objective of this study was to generate estimates of economic benefits of improvements on Wyoming fishing streams that could be used to evaluate different improvement projects. A mail survey was conducted to determine angler (both resident and tourist) preferences and to estimate economic benefits. Consumer surplus estimates for the complete sample were US\$101/day for increased trout populations and US\$132/day for doubling the chances of catching a large trout. These results may be used within a framework of net present value to evaluate potential projects.

[ECONOMICS; FISHERIES; RIPARIAN

RESTORATION; 'TROU'I']

413. Darling,LA; Coltharp,GB (1973): Effects of livestock grazing on the water quality of mountain streams. p. 1-8. In: Mayland, HF [ed.]. Proceeding: Water-animal relations. Kimberly, ID. University of Idaho. Moscow, ID.

This study was designed to determine the type and extent of livestock grazing effects on the water quality of streams passing through grazing compartments. Emphasis was placed on the effect of livestock grazing on the bacteriological and indicator groups of total coliform, fecal coliform, and fecal streptococci, with less attention given to selected physical and chemical parameters. The study was conducted on three mountain streams in the Bear River Range of northern Utah. Significant increases in the bacterial counts were noted during the grazing of cattle and sheep at stream locations at immediately downstream from the grazing activity. Bacterial counts in streams draining grazed watersheds reached seasonal maximum values during the grazing season, while counts from the ungrazed watershed remained relatively low and constant. The chemical and physical water quality parameters showed no clear-cut effect from livestock grazing.

[COLIFORM BACIERIA; GRAZING IMPACTS; NON-POINT SOURCE POLLUTION; WATER QUALITY]

414. Darveau, M; Beauchesne,P; Belanger,L; Huot,J; Larue,P (1995): Riparian forest strips as habitat for breeding birds in boreal forest. Journal of Wildlife Management 59(1), 67-78.

Riparian forest strips are usually protected from logging for their buffer effect on aquatic habitats. However, their value to terrestrial wildlife is generally unknown. From 1989-1992, the authors compared bird abundance and species composition in 5 experimental riparian forest strips $(20-\mathrm{m}, 40-\mathrm{m}$, $60-\mathrm{m}$, and control $[>300 \mathrm{~m}$ wide $]$, intact strips, and 20- $\mathrm{m}$ wide thinned strips), in boreal balsann fir stands, for three years following clear-cutting. Bird densities increased $30-70$ percent in all strips the year after clear-cutting and decreased thereafter to approximately pretreatment levels. The 20 - and 40-m wide riparian strips had the highest mean bird densities, but also the fastest decreases thereafter. The removal of 33 percent of the trees in some of the 20 -m strips resulted in a $<20$ percent decline of bird densities. There was evidence that 60 -m strips are required for forest-dwelling birds. Bird populations may continue to decline in strips before regeneration of adjacent clear-cuts provides suitable habitat for forest-dwelling species.

[AVIAN ECOLOGY; BOREAL FOREST; RIPARIAN FOREST; RIPARIAN HABITAT]

415. Davidson,AS; Knight,RL (1997): Effects of cottonwood forest patch characteristics on predation and parasitism of songbird nest in northwestern Colorado. p.77. In: Abstracts. 1997 Annual meeting of the Ecological Society of America jointly with The Nature Conservancy. 
Changing ecosystems: Natural and human influences. 10-14 August 1997. Albuquerque, NM.

The size and shape of cottonwood forest patches along the Yampa River in northwest Colorado have dramatically changed because of agriculture and development. This study monitored rates of predation and parasitism for two seasons. Predation of both artificial and natural nests depended on patch shape for some size classes. Evidence was produced that even in naturally fragmented cottonwood riparian habitat, the size and shape of forest patches can affect avian nesting grounds. Restoration efforts should promote larger and more circular patches.

[AVIAN ECOLOGY; COTTONWOOD; PARASITISM; PREDATION; RIPARIAN FOREST]

416. Davies,BR; Walker, KF (1986): The ecology of river systems. Monographiae Biologicae.

Volume 60. Dr. W. Junk Publishers. Boston, MA. 792 p.

A compendium of articles relating to thirteen major rivers of the world: six in Africa, two in North America, three in South America, one in Asia, and one in Australia. Several recurrent issues emerge as important: floodplain - river interactions, biogeographical affinities, and modifications caused by development, especially dams.

[CLIMATE; DAMS; GEOMORPHOLOGY; HYDROLOGY; RIVER ECOLOGY]

417. Davis, EA (1987): Chaparral conversion and streamflow: Nitrate increase unbalanced mainly by a decrease in bicarbonate. Water Resources Research 23(1), 215-224.

Chaparral watershed conversion to grass by controlling the brush with herbicides increases water yield as substrate runoff to streams. Increased stream discharge is accompanied by several hundredfold increases in the filtrate concentration of the stream water. Nitrate concentrations remained 46 to $69 \mathrm{X}$ above normal for 11 years or more. Nitrate concentration increases were balanced mainly by bicarbonate ion concentration decreases. One mechanism suggested to explain the latter was the reaction producing carbon dioxide and water. [SOILS; VEGEIIATION MANAGEMENT; WATER QUALITY]

418. Davis,EA; DeBano,LF (1986): Nitrate increases in soil water following conversion of chaparral to grass. Biogeochemistry 2, 53-65.

A watershed in Arizona converted from chaparral to grassland released high concentrations of nitrate to stream water. The nitrate originated from the rooting zone of the decomposing shrubs. High nitrate concentrations were found in soil solutions from all measured depths on the converted watershed as compared with low nitrate concentrations found in an adjacent undisturbed area.

[SOILS; VEGETATION MANAGEMENT; WATER QUALITY; WATERSHED]

419. Davis,EM; Rucker,A (1993): Lessons learned from large-scale riparian restoration projects. p.186-188. Tellman,B; Cortner,HJ; Wallace, MG; DeBano,LF; Hamre,RH |tech. coord.|. Riparian management: Common threads and shared interests. USDA Forest Service.

General Technical Report RM-226.

Large-scale restoration projects should have the following components: 1) clearly define restoration goals; 2) identify physical requirements of target riparian habitat; 3 ) address multipurpose needs; 4) evaluate potential obstacles and use effective establishment techniques; and 5) plan ahead for appropriate timing of implementation.

[RESTORATION PROJECTS; RIPARIAN RESTORATION]

420. Davis, GA (1977): Management alternatives for the riparian habitat in the Southwest. p.59-67. In: Johnson,RR; Jones,DA [tech. coord.]. Symposium on the importance, preservation and management of the riparian habitat. 9 July 1977. Tucson, AZ. USDA Forest Service. General Technical Report RM-43.

Southwestern riparian habitat has been significantly altered by exploitation from man. For decades, the primary or dominant use of riparian habitat has been water management; other values were not considered. Management alternatives and objectives are evaluated for environmentall consequences.

[PLANNING; RIPARIAN HABITAT; RIPARIAN MANAGEMENT ZONE]

421. Davis,GJ; Brinson,MM (1980): Responses of submersed vascular plant communities to environmental change: Summary. USDI Fish and Wildlife Service. Biological Services Program: FWS/OBS-80/42. 15 p.

This report is a condensation of a more comprehensive, technical publication by the same authors entitled RESPONSES OF SUBMERSED VASCULAR PLANT COMMUNITIES TO ENVIRONMENTAL CHANGE, FWS/OBS-79/33. Environmental parameters include: light 
transmission, fluctuating water levels, wave action, sedimentation, nutrients, and seasonal effects.

Potential impacts of various developmental activities are discussed briefly. The uncondensed version contains several tables and figures that either summarize data or illustrate phenomena of submerged vascular plants.

[AQUATIC PLANTS; BIBLIOGRAPHY; RIPARIAN HABITAT; WATER QUALITY]

422. Davis,HS (1934): The purpose and value of stream improvement. p.63-67. In: The Proceedings of the American Fisheries Society.

The aims of stream improvement include: 1) to provide sufficient cover and shelter for the needs of the fish, 2) to prevent, as far as possible, extreme and rapid fluctuations in the volume of flow; 3 ) to prevent or control soil erosion and its consequent evils; 4) to ensure the production of fish food; 5) to ensure favorable temperatures for the species of fish to which the stream in question is best adapted; and 6) to provide favorable conditions for natural propagation. Methods to achieve these objectives are discussed.

[FISHERIES; RIPARIAN RESTORATION; STREAM IMPROVEMENTS]

423. Davis,JW (1981): Livestock vs. riparian habitat management - there are solutions. In: Proceedings of the symposium on wildlife-livestock relationships. University of Idaho. 20-22 April 1981. Coeur d'Alene, ID.

The riparian habitat of the Southwest, once in great abundance along every stream, is now greatly reduced. Many factors account for this destruction but one of the most destructive forces is the long-term impact of livestock. Many techniques are being used to solve the problem including protective fencing and rest-rotation grazing. The most encouraging development is the adaptation of the rest-rotation system being tested on the Santa Rita Experimental Range.

[GRAZING IMPACTS; LIVESTOCK EFFECTS; RIPARIAN HABITAT]

424. Davis,JW (1982): Livestock and riparian habitat management -- why not? In: Western proceedings, $62 \mathrm{nd}$ annual conference of the Western Association of Fish and Wildlife Agencies. 19-22 July 1982. Las Vegas, NV.

Since the introduction of livestock into the western ecosystems, the once abundant riparian habitat and herbaceous forage have continued to deteriorate. After one hundred years, livestock mismanagement still appears to be the rule rather than the exception. On many grazing allotments, it continues to be a livestock and livestock mismanagement or a livestock and riparian mismanagement choice with riparian habitat and its associated wildlife species the losers. There are solutions to the problem that may permit resource managers the opportunity to add the option of livestock and riparian habitat management. [GRAZING IMPACTS; RIPARIAN HABITAT; RIPARIAN MANAGEMENT ZONE]

425. Davis,JW (1986): Options for managing livestock and riparian habitats. In: Proceedings of the 51 st North American wildlife and natural resources conference. 21-26 March 1986. Reno, NV. The Wildlife Management Institute. 20 p.

The adverse effects of livestock mismanagement on the once abundant riparian habitats and herbaceous forage have been recognized for over one hundred years. Even with problem recognition and the increased emphasis on riparian habitat awareness, the problem still persists. On many grazing allotments, the management choice continues to be livestock mismanagement. There are management choices available to mitigate or resolve the problem. [GRAZING IMPACTS; RIPARIAN MANAGEMENT ZONE]

426. Davis,RK (1989): The benefits of riparian development. A report to TGS Technology, Inc., on procedures for the economic evaluation of riparian protection projects of the USDI Bureau of Land Management.

This study was implemented to document methods used to evaluate riparian improvement projects and provide examples of economic benefits of properly managed riparian areas. It reviews individual benefits that have been analyzed, monitored, and administered. It recommends quantification and modeling techniques and identifies obstacles to greater acceptance.

[ECONOMICS; RIPARIAN MANAGEMENT ZONF]

427. Dawson,KJ; Sutter,GE (1985): Research issues in riparian landscape planning. p. 408-412. In: Johnson RR; Ziebell.CD; Patton,DR; Ffolliott,PF; Hamre,RH [tech. coord.]. Riparian ecosystems and their management: Reconciling conflicting uses. 16-18 April 1985. Tucson, AZ. USDA Forest Service. General Technical Report RM-120.

The 80-acre Putah Creek Reserve on the 
University of California (Davis) campus offers the opportunity to research issues related to the leveed floodways that flow through California's agricultural landscape. The integration of issues related to research, education, conservation, recreation, and flood control is explored.

[AGRICULTURAL IMPACTS; FLOOD IMPACTS; RIPARIAN HABITAT; URBAN IMPACTS]

428. Day,RT; Keddy,PA; McNeill,J; Carleton,T (1988): Fertility and disturbance gradients: $A$ summary model for riverine marsh vegetation. Ecology 69(4), 1044-1054.

Freshwater shorelines occupy extensive areas of the temperate zone but there are still few conceptual models for pattern and process in shoreline vegetation. This study used multivariate analysis of vegetation data to describe vegetation-environment relationships in a set of riverine wetlands. Ordination showed that four vegetation types were arranged along two major axes: a standing crop and litter gradient, and a water depth gradient. The three main factors controlling vegetation composition were water depth, the effects of spring flooding in removing litter, and the fertility gradient produced by waves and flowing water.

[NUTRIENT CYCLES; SHORELINES; WETLANDS]

429. Dean,R (1993): Water quality tools for national and western non-point source control. p.102-106. In: Tellman,B; Cortner,HJ; Wallace,MG; DeBano,LF; Hamre,RH [tech. coord.]. Riparian management: Common threads and shared interests. USDA Forest Service. General Technical Report RM-226.

This paper reviews the various programs in which Environmental Protection Agency (EPA) is involved independently, or as an active partner with other agencies or entities. It also reviews EPA funding for various research and monitoring programs. The author also encourages agencies and organizations to become involved in the Coordinated Resource Management Plan (CRMP) process. [CRMP; NON-POINT SOURCE POLLUTION; RIPARIAN HABITAT; WATER QUALITY]

430. Dean, $R$ (1996): Section 319 Clean Water Act funds: Opportunities for cooperative non-point pollution projects. p.141-145. In: Evans, KE [comp.]. Sharing common ground on western rangelands: Proceedings of a livestock/big game symposium. 26-28 Feb 1996. Sparks, NV. USDA Forest Service. General Technical Report
INT-GTR-343. 164 p.

This presentation outlines various opportunities for collaboration by utilizing Section 319 of the Clean Water Act. Non-point source pollution program funds are available for implementation of cooperative management practices on both public and private lands.

[ASSESSMENTS; CLEAN WATER ACT; NON-POINT SOURCE POLLUTION; WATER QUALITY]

431. Dearden,M; Roundy,B; Wollstenhulme,L (1998): Patterns of vegetation dynamics in the created Jordenelle wetlands. p. 346. In: Potts,DF [ed.]. Range management and water resources: Proceedings of the AWRA specialty conference. American Water Resources Association. 27-29 May 1998. Reno, NV.

In order to mitigate for 92 acres of wetland lost by construction of the Jordenelle Reservoir in Utah, the Bureau of Reclamation created a series of 34 wet meadows. After four years, vegetation and species patterns varied with respect to topographic position and hydrologic regime. Species diversity decreased as ground became more saturated with water.

Frequency of wetland indicator species increased with water availability. More species of plants were found in the created wet meadows compared to neighboring natural wetlands. A strong relationship was found between the position of individual species on the landscape and hydrologic conditions.

[BIODIVERSITY; CREATED WETLANDS; HYDROLOGY; MEADOWS; WATER TABLE EFFECTS]

432. Deardorff,D; Wadsorth,K (1996): Cooperative management of riparian forest habitats to maintain biological quality and ecosystem integrity. p.227-229. In: Shaw,DW; Finch,DM [tech. coord.]. Desired future conditions of Southwestern riparian ecosystems: Bringing interests and concerns together. USDA Forest Service. General Technical Report RM-GTR-272.

The New Mexico State Land Office has initiated a rare plant survey of state trust land, an inventory and assessment of riparian areas on the trust land, and the development of a biological resources data base and information management system. Some riparian sites that still belong to the trust have been negatively impacted by livestock such that biological quality and ecological integrity have been reduced. Some sites on state trust land may have high potential for the development or restoration of riparian forests 
which could serve as essential habitats for neotropical migratory birds. The New Mexico State Land Office is currently studying ways to manage trust land and restore riparian sites.

[ECOLOGICAL INTEGRITY; GRAZING IMPACTS; NEOTROPICAL BIRDS; RIPARIAN RESTORATION]

433. DeBano,LF; Brejda,JJ; Brock,JH (1984): Enhancement of riparian vegetation following shrub control in Arizona chaparral. Journal of Soil and Water Conservation 39(5), 317-320.

Effect of upstream shrub control on the establishment of riparian vegetation was evaluated on a chaparral watershed in central Arizona. After 20 years of increased streamflow and longer duration streamflow, a riparian zone below the watershed treated for shrub control had 7 riparian plants per 100 $\mathrm{m} 2$ compared with a nearby, untreated watershed that had 2.3 plants per $100 \mathrm{~m} 2$. The increase in riparian vegetation has implications for water quality, wildlife, and water use.

[RIPARIAN RESTORATION; RIPARIAN SHRUBS; RIPARIAN VEGETATION; VEGETATION MANIPULATION]

434. DeBano,LF; Ffolliott,PF; Brooks, KN (1996): Flow of water and sediments through Southwestern riparian systems. p.128-134. In: Shaw,DW; Finch,DM [tech. coord.]. Desired future conditions for Southwestern riparian ecosystems: Bringing interests and concerns together. USDA Forest Service. General Technical Report RM-GTR-272.

The paper describes streamflow, sediment movement, and vegetative interactions within riparian systems of the Southwestern United States. Riparian systems are found in a wide range of vegetation types, ranging from lower elevation desert environments to high elevation conifer forests. The climatic, vegetative, and hydrologic processes operating in the southwestern environments provide a unique setting for discussing riparian ecosystem interactions with both water and sediment. Most streamflow at lower elevations is intermittent, and riparian vegetation frequently occupies channels that are dry at least part of the year. As a result, water table fluctuations in relation to streamflow and their subsequent effects on the establishment and maintenance of healthy riparian vegetation are key processes. At higher elevations, streamflow from snowmelt and rainfall is sufficient to sustain perennial streamflow and thereby provides a more consistent source of water for riparian vegetation. At all elevations, precipitation fluctuates widely, with many high-intensity, localized, convection storms occurring during the summer. As a result of this highly variable precipitation-runoff regime, erosion in the southwestern United States is an unsteady or discontinuous process that transports sediments from source areas through a channel system with intermittent periods of storage. This episodic transport process is characteristic of drylands in the southwestern United States where big storms are the prime movers of sediment. Intermittent streamflow coupled with the discontinuous storage and subsequent movement of sediment through channel systems in response to fire and other disturbances is extremely complex, and can be difficult to interpret when assessing responses of southwestern riparian systems to management.

[EROSION; HYDROLOGY; RIPARIAN

ECOLOGY; RIPARIAN HABITAT; SEDIMENTATION; STREAM FLOW; WATER TABLE EFFECTS]

435. DeBano,LF; Hansen,WR (1989): Rehabilitating depleted riparian areas using channel structures. p.141-148. In: Gresswell,RE; Barton,BA; Kershner,JL [eds.]. Riparian resource management. An educational workshop. USDI Bureau of Land Management. Billings, MT. Abusive land use activities have deteriorated valuable riparian areas in the southwest U.S. Loss of protective vegetative cover causes erosion which reduces soil moisture and channel stability necessary for riparian maintenance. A review of three rehabilitation projects in New Mexico and Colorado suggest that channel structures store sediment, stabilize channels, raise water tables, and enhance riparian plant communities. Rehabilitation planning should consider quantifiable treatment goals as well the need for specific treatments.

[CHANNEL DYNAMICS; RIPARIAN

ENHANCEMENT; RIPARIAN RESTORATION]

\section{DeBano,LF; Heede,BH (1987):}

Enhancement of riparian ecosystems with channel structures. Water Resources Bulletin 23(3), 463-470.

Manmade and natural structures can be used for enhancing riparian zone development. Natural structures include: cienegas, beaver dams, and log steps. These affect streamflow hydraulics and sedimentation and can create a more favorable environment for riparian zone establishment. Used improperly, however, they can be destructive to existing riparian zones. Since stream processes are 
generally slow, long-time spans may pass before the effects of management action become visible. Also, the effects of large dam installations may appear a long distance downstream from the dam. Investigations must therefore be of a wide scope. Interactions between riparian site, channel, and streamflow may be so complex that an interdisciplinary approach is required. [GEOMORPHOLOGY; INSTREAM STRUCTURES; RIPARIAN RESTORATION]

437. DeBano,LF; Rinne,JN; Medina,AL (1996): Understanding and managing southwestern riparian-stream ecosystems: National Forest Systems and Forest Service partnerships. p.96-102. In: National hydrology workshop proceedings. 27 April - 1 May 1992; Phoenix, AZ. USDA Forest Service. General Technical Report RM-GTR-279.

Partnerships between research scientists and land managers can facilitate the application of research findings. Successful partnerships developed between scientists and field staff have been involved in addressing riparian-stream interactions. These successful partnerships involve several interpersonal and organizational considerations. Examples and keys to successful partnerships are described. [PARTNERSHIPS; RIPARIAN HABITAT; RIPARIAN MANAGEMENT ZONE]

438. DeBano,LF; Schmidt,L (1989): Interrelationship between watershed condition and health of riparian areas in southwestern United States. p.45-52. In: Gresswell,RE; Barton,BA; Kershner,JL [eds.]. Riparian resource management. An educational workshop. USDI Bureau of Land Management. Billings, MT.

There are sensitive hydrologic interrelationships between watershed conditions and the health of associated riparian areas in the southwestern U.S. $\Lambda$ key factor in improving deteriorated riparian areas is to understand the balance that existed between watershed condition and riparian health in near pristine conditions. This paper discusses the interdependency between hydrologic processes operating on the upland slopes of a watershed and the channel processes affecting downstream riparian stability.

[LIVESTOCK EFFECTS; RIPARIAN

ENHANCEMENT; RIPARIAN MANAGEMENT

ZONE; RIPARIAN RESTORATION; WATERSHED]

439. DeBano,LF; Schmidt,LJ (1989): Improving southwestern riparian areas through watershed management. USDA Forest Service. General Technical Report RM-182. Ft. Collins, CO. 33 p.

This paper reviews opportunities and watershed restoration techniques available for rehabilitating and enhancing riparian ecosystems in southwestern environments. It was intended to serve as a state-of-the-art report on riparian hydrology and improvement in both naturally occurring and man-made riparian areas throughout the Southwest. [CHANNEL DYNAMICS; EROSION; RIPARIAN RESTORATION; STREAMBANK PROTECTION; WATERSHED]

440. DeBoer,DH (1992): Constraints on spatial transference of rainfall-runoff relationships in semiarid basins drained by ephemeral streams. Hydrological Sciences 37, 491-504.

Field data on drainage basin response have a characteristic scale which is determined by the size of the basin investigated, and this scale can be extrapolated over a limited range only. This paper identifies the nature of constraints on spatial scale transference. Spatial scale transference between systems of differing scale was restricted by morphological and functional constraints. Morphological constraints are caused by morphological elements present in large scale systems but absent in small ones. Functional constraints arise solely from the characteristics of the matter and energy flows in the systems of interest. Limits imposed upon spatial scale transferences by morphological and functional constraints are fuzzy rather than sharp in character.

[DRAINAGES; EPHEMERAL STREAMS; HYDROLOGY; RUNOFF; SPATIAL SCALE]

441. deBuys, $W$ (1993): Moving from diverse viewpoints to results. p.255-260. In: Tellman, $B$; Cortner,HJ; Wallace,MG; DeBano,LF; Hamre, RH [tech. coord.]. Riparian management: Common threads and shared interests. USDA Forest Service. General Technical Report RM-226.

The author describes the efforts of the Rio Grande Bosque Conservation Committee to develop comprehensive management strategies for the middle Rio Grande and bosque. I Iistorically, the public has demanded three components of river management: flood control, drainage, and irrigation. The committee learned that the middle Rio Grande had received more than 70 years of biological management but that nearly all that management had been inadvertent and virtually all of it had a negative 
effect on native ecosystems. The river is managed by several agencies with overlapping, conflicting, and frequently ambiguous jurisdictions. The management structure of the middle Rio Grande requires a greater responsiveness to public concerns and inputs. The value of the resource is clearly greater than the sum of its individual uses and benefits.

[BOSQUE; RIO GRANDE; RIPARIAN HABITAT; RIPARIAN MANAGEMENT ZONE]

442. DeGraff,RM; Tilghman, NC [tech. coord.] (1980): Workshop proceedings: Management of western forests and grasslands for nongame birds. 11-14 February 1980. Salt Lake City, UT. USDA Forest Service. General Technical Report INT-86. 535 p.

This document contains the proceedings of the fourth and last regional workshop by the Nongame Bird Steering Committee. The workshop presented information on management of western forests and grasslands for nongame birds. Several of the papers relate directly to riparian habitat issues. [AVIFAUNA; RIPARIAN HABITAT]

\section{Delaune,RD; Patrick,WH; Pezeshki,SR} (1987): Foreseeable flooding and death of coastal wetland forests. Environmental Conservation 14(2), 129-133.

Relationships between sedimentation, submergence, and deterioration, of a Mississippi River deltaic-plain coastal wetland forest were investigated. The combined effects of rapid subsidence, eustatic sea-level rise, and accompanying salt-water intrusion, resulting from atmospheric $\mathrm{CO} 2$ accumulation and global warming, could destroy much of these swamp forests and cause major habitat changes.

[GEOMORPHOLOGY; GLOBAL WARMING; GREENHOUSE EFFECT; WETLANDS]

444. Dellapenna,JW (1994): The regulated riparian version of the ASCE model ware code: The third way to allocate water. Water Resources Bulletin 30(2), 197-204.

Lawyers, engineers, and hydrologists are accustomed to thinking of water law as falling into one of two incompatible models: riparian rights (under which water is allocated by courts according to the relative reasonableness of the competing uses) and appropriative rights (under which water is allocated according to the temporal priority of the competing uses, largely by the action of the water users themselves but perfected by the issuance of an administrative permit). Usually unnoticed is the existence of a third approach, called "regulated riparianism". Under this concept, water is allocated by water permits issued after an administrative determination of the reasonableness of the proposed use before the use is commenced. This practice is widely used in the eastern United States. [HYDROLOGY; RIPARIAN RIGHTS; WATER PERMITS; WATER RIGHTS]

445. Delmas,R; Swanson,S (1993): The Modoc-Washoe Experimental Stewardship Process. p.290-293. In: Tellman,B; Cortner,HJ; Wallace,MG; DeBano,LF; Hamre,RH |tech. coord.]. Riparian management: Common threads and shared interests. USDA Forest Service. General Technical Report RM-226.

The foundation for the success of this program has been its willingness to incorporate all interested publics into the resource management process. Consensus is a necessary component of this process. "It is critical that land use goals and resource issues be translated into realistic, measurable objectives from which management action, monitoring, and evaluation parameters can be derived". [COLLABORATION; CONSENSUS; INTERESTED PUBLICS; PLANNING; RIPARIAN RESTORATION; STEWARDSHIP]

446. Delong,MD; Brusven,MA (1998): Macroinvertebrate community structure along the longitudinal gradient of an agriculturally impacted stream. Environmental Management 22(3), 445-457.

Lapwai Creek in northern Idaho was sampled to determine if macro-invertebrate community composition changed along the longitudinal gradient and if changes followed predictions of the river continuum. Analysis suggested there was no longitudinal gradient for either number of individuals or functional feeding group composition. All locations, excluding a site receiving outflow from a small reservoir, had a similar community structure. Results suggest that agricultural changes have influenced community structure of the creek leading to a relatively homogeneous assemblage of macroinvertebrates capable of tolerating agricultural nonpoint source pollution.

[AGRICULTURAL IMPACTS; CLASSIFICATION; MACROINVERTEBRATES; NON-POINT SOURCE POLLUTION]

447. DeMeo,TE; Loggy,WD (1989): Development of wetlands mapping procedures for forest planning in southeast Alaska. p.57-72. In: 
Alexander,EB [ed.]. Proceedings of Watershed 89: A conference of the stewardship of soil, air, and water resources. USDA Forest Service. Alaska Region. Juneau, AK. 215 p.

Wetlands were defined using a 3-parameter approach employed by US Army Corps of Engineers. Plant species were ranked as to wetland status. Average areal cover of each species in each status category was determined. A weighted comparison was used to determine if each plant association was wetland or non-wetland. Plant associations were related to hydric soils. Soils were related to existing map units. Wetland boundaries were generated from existing soil maps in a geographic information system (GIS).

[CLASSIFICATION; GIS; RIPARIAN HABITAT]

448. Denwars,CMT; Tranvik,LJ (1998): Effects of solar radiation on aquatic macrophyte litter decomposition. Oikos 82, 51-58.

In the littoral zone of many lakes, macrophytes contribute a large proportion of the primary production. In this study, more dissolved organic material (DOM) was leached from exposed detritus vs. shaded matter and there was a higher loss of particulate organic matter (POM) in the shade. Experiments showed that solar radiation promotes the leaching of DOM from littoral detritus and photosynthetically active radiation (PAR) is also active in this process.

[DECOMPOSER FOOD CHAIN; DETRITUS; LITTORAL ZONE; ORGANIC DEBRIS; UV RADIATION]

449. DeRoo,APJ; Hazelhoff,L; Burrough,PA (1989): Soil erosion modeling using 'ANSWERS' and geographical information systems. Earth Surface Processes and Landforms 14, 517-532.

A model that simulates surface runoff and erosion was linked to a Geographical Information System. Model output is very sensitive to small changes of several input variables, such as infiltration, antecedent soil moisture, and soil roughness. Detailed information about rainfall intensities during an event is needed. Sensitivity and insufficient input data make the validation of answers difficult.

[EROSION; MODELING; GIS; HYDROLOGY; SOILS]

450. Deusen, MS; Adams,PW (1989): Riparian areas: Fish and wildlife havens. Woodland Fish and Wildlife Project, June 1989. Woodland Fish and Wildlife Center. World Forestry Center. June
1989. Portland, OR. 7 p.

This publication tells how riparian areas provide essential fish and wildlife habitat, how land use can affect this habitat, and briefly describes management practices that protect or enhance the habitat. The publication is aimed to serve as a practical guide to woodland owners for managing riparian areas on private land.

[RIPARIAN ECOLOGY; RIPARIAN FOREST; RIPARIAN HABITAT]

451. Deuser, CE (1993): Tamarisk control methods and water table relations at Sacatone Spring. p.203. In: Tellman,B; Cortner,HJ; Wallace,MG; DeBano,LF; Hamre,RH [tech. coord.|. Riparian management: Common threads and shared interests. USDA Forest Service. General Technical Report RM-226.

Springs and streambeds within the Lake Mead National Recreation Area in Arizona have been heavily invaded by the alien tree, tamarisk. Removal using a combination of methods including mechanical, herbicides, and prescribed fire is underway.

[EXOTICS; RIPARIAN HABITAT; RIPARIAN MANAGEMENT ZONE; SALT-CEDAR; WATER TABLE EFFECTS]

452. DeVelice,RL (1990): Potential effects of global climate change on riparian forests. p.7. In: Management of riparian and wetland forested ecosystems in Montana. 4th Annual Montana Riparian Association Workshop. 5-7 September 1990. Whitefish, MT.

Global climate change is likely to affect fire management policies and budgets, insect and disease programs, wildlife prescriptions, natural area management, forest tree planting and harvest guidelines, and other aspects of management in riparian forests. Current management does not consider the potential effects of climatic change. [GLOBAL WARMING; RIPARIAN FOREST; RIPARIAN HABITAT]

453. Dewberry,C; Burns,P; Hood,L (1998): After the flood: The effects of the storms of 1996 on a creek restoration project in Oregon. Restoration \& Management Notes 16(2), 174-181.

Deposition of large woody debris in the stream course of Knowles Creek in southern Oregon results in complex dynamics of water, wood, and sediment. These forces are exaggerated by a high-relief terrain and a climate that produces torrential rainfalls. These combined factors have shaped the waterway and 
profoundly affected the area ecology. Since settlement, clearing of hillsides has drastically altered these dynamics. The restoration strategy there was designed to minimize the ecologically destructive results of floods and maximize their beneficial effects, by restoring the natural dynamics of sediment and organic matter to what as believed to be the pre-contact condition. In the future, the valley floor forest must recover the capacity to stop the debris torrents and dam break floods. These events, in the past, have destroyed large amounts of salmon habitat. [FISH HABITAT; FLOOD IMPACTS; LARGE WOODY DEBRIS; RIPARIAN RESTORATION; STREAM FLOW]

454. DeYoung, T; Ridgeley,GC (1993): Instream flow protection: legal constraints and opportunities. p.76-84. In: Tellman,B; Cortner,HJ; Wallace,MG; DeBano,LF; Hamre, RH [tech. coord.]. Riparian management: Common threads and shared interests. USDA Forest Service. General Technical Report RM-226.

The legal context for instream flow protection is constituted by an array of federal, state, and local laws and regulations, along with a large body of case law. This doctrine was designed to remove water from stream and river channels; therefore, it has inhibited efforts to protect stream flows and their riparian habitat. The authors advocate solutions achieved by cooperation instead of litigation. [RIPARIAN HABITAT; STREAM FLOW; WATER LAW; WATER RIGHTS]

455. Dick-Peddie,WA; Hubbard,JP (1977): Classification of riparian vegetation. p.85-90. In: Johnson,RR; Jones,DA [tech. coord.]. Symposium on the importance, preservation and management of the riparian habitat. 9 July 1977. Tucson, AZ. USDA Forest Service. General Technical Report RM-43.

Historically, little attention has been paid to vegetation associated with water courses. The reasons for this neglect are reviewed. Today there is considerable interest in riparian classification which could have great value. A classification system for riparian vegetation in New Mexico is proposed. [CLASSIFICATION; RIPARIAN HABITAT]

456. Dickson,JG (1989): Streamside zones and wildlife in southern U.S. forests. p.131-133. In: Gresswell,RE; Barton,BA; Kershner,JL [eds.]. Practical approaches to riparian resource management. An educational workshop. 8-11 May
1989. USDI Bureau of Land Management. Billings, MT.

Strips of mature trees, retained along intermittent streams when streams were harvested and replanted to pine, reduce effects of non-point pollution and enhance wildlife habitat. Relative abundance of vertebrates was related to the width of those strips. Virtually no squirrels were found in narrow streamside zones. Amphibians and reptiles were abundant in medium and wide streamside zones characterized by canopied overstory, shaded understory, and leaf litter. Amphibians and reptiles were low in abundance in dense brushy narrow zones with logging slash, but this habitat supported the highest abundance of small mammals.

[INVERTEBRATES; NON-POINT SOURCE POLLUTION; RIPARIAN HABITAT; WATER QUALITY]

457. Dickson,JG; Howard,J (1989): Small mammals in streamside management zones in pine plantations. p.375-378. In: Management of amphibians, reptiles, and small mammals in North America. Proceedings of the symposium. 19-21 July 1988. Flagstaff, AZ. USDA Forest Service. General Technical Report RM-166.

The study quantified captures of small mammals in mature hardwood or pine-hardwood strips along streams that flow through pine plantations in Texas. More small mammals were captured in the narrow streamside management zones (tree canopy absent and dense brushy vegetation) than in medium or wide zones.

[RIPARIAN FOREST; RIPARIAN HABITAT; SMALL MAMMALS; SMZ]

458. Dickson,JG; Williamson,JH (1988): Small mammals in streamside management zones in pine plantations. p.375-378. In: Proceedings of the symposium: Management of amphibians, reptiles, and small mammals in North America. USDA Forest Service. General Technical Report RM-166.

Small mammals were captured in live traps in 6 mature-forested zones of 3 widths: narrow $(<25 \mathrm{~m})$, medium (30-40 m), and wide (50-90 m), which traversed young, bushy pine plantations. More small mammals were captured in the narrow zones than in the other two, respectively or together.

[FOREST MANAGEMENT; RIPARIAN

HABITAT; SMALL MAMMALS]

459. Dieter,CD (1991): Water turbidity in tilled and untilled prairie wetlands. Journal of 
Freshwater Ecology 6(2), 185-189.

Water turbidity was compared between tilled prairie pothole wetlands, partially tilled wetlands, and untilled wetlands in South Dakota. Specific differences in sedimentation as measured by humidity were indicated. Turbidity was significantly higher in tilled than in untilled wetlands. Average turbidity was 24 times greater in tilled than in untilled wetlands. There was no significant difference in turbidity between tilled and untilled wetlands. Turbidity measurement may be a useful tool for estimating relative sedimentation rates.

[SEDIMENTATION; WATER QUALITY; WATER TURBIDITY; WETLANDS]

460. Dieter,CD; McCabe,TR (1989): Habitat use by beaver along the Big Sioux River in eastern South Dakota. p.135-140. In: Gresswell,RE; Barton,BA; Kershner,JL [eds.]. Practical approaches to riparian resource management. An educational workshop. 8-11 May 1989. USDI

Bureau of Land Management. Billings,MT.

Habitat use by beavers was investigated in grazed and ungrazed areas. Forty-eight percent of the trees in ungrazed areas were small $(<7.5 \mathrm{~cm})$, but a majority of trees ( 58 percent) in grazed areas were large $(>30 \mathrm{~cm})$. A greater proportion of trees were cut by beavers in ungrazed than grazed areas. Beaver did not select trees for cutting according to availability. Trees cut by beaver were significantly smaller in diameter than uncut trees. Mean distance from water for cut trees was less than for uncut trees. Over one-half of the trees damaged by beavers either resprouted or remained alive after cutting. [BEAVER; GRAZING IMPACTS; RIPARIAN FOREST; RIPARIAN HABITAT]

461. Dileanis,PD; Branson,FA; Sorenson,SK (1985): Methods for determining effects of controlled dewatering of small aquifers on desert phreatophytes in Owens Valley, California. p.197-200. In: Johnson,RR; Ziebell,CD; Patton,DR; Ffolliott,PF; Hamre, RH [tech. coord.]. Riparian ecosystems and their management: Reconciling conflicting uses. 16-18 April 1985. Tucson, AZ. USDA Forest Service. General Technical Report RM-120.

Ability of phreatophytic plants to tolerate and survive dewatering of shallow aquifers was being tested. On sites that had been equipped with pumping wells, soil moisture and plant physiological responses were being monitored as water levels declined. [DEWATERING; PHREATOPHYTES; RIPARIAN HABITAT]
462. Dinan, KF (1988): Wetland protection in the Rainwater Basin of Nebraska. p.65-72. In: Stuber,PJ [tech. coord.|. Proceedings of the national symposium on the protection of wetlands from agricultural impacts. 25-29 April 1988. Ft. Collins, CO. USDI Fish and Wildlife Service. Biological Report 88(16).

The Rainwater Basin covers parts of 17 counties in central Nebraska south of the Platte River. Historically, 4,000 wetlands totaling 94,000 acres occurred in the Basin. Today, less than 400 of these wetlands remain, totaling about 20,000 acres. Many of the Rainwater Basin wetlands have been dramatically altered or destroyed, primarily due to agricultural practices designed to gain additional cropland and eliminate wetlands that interfere with center-pivot systems. One step being taken by federal and state agencies to protect the Rainwater Basin is application of the Advanced Identification of Disposal Sites Process within the Clean Water Act, more commonly called the 230.80 Process. [AGRICULTURAL IMPACTS; PLATTE RIVER; POLLUTION; RIPARIAN HABITAT; WETLANDS]

463. Dinius,SH (1987): Design of an index of water quality. Water Resources Bulletin 23(5), 463-470.

The formulation of an Index of Water Quality to evaluate the level of pollution in the water is described. A Four-Round Delphi Equation, using a panel of 7 nationally recognized water scientists, was performed to ascertain the pollutants to be included in the index, the relationship between the quantity of these pollutants in the water and the resulting quality of the importance of each pollution variable to each water use as well as to overall pollution. A multiplicative index was used to bring the pollutants together into one system.

[POLLUTION; WATER QUALITY]

464. Dixon,MD; Johnson,WC (1999): Riparian vegetation along the Middle Snake River, Idaho: Zonation, geographical trends, and historical changes. Great Basin Naturalist 59(1), 18-34.

This research project on the Middle Snake River had two components: 1) characterization and inventory of existing riparian flora, vegetation, and environment; and 2) mapping historic changes by means of historic photos and GIS. At least 185 species of vascular plants were identified; of these, 63 species were exotics. Vegetation was structured vertically into habitat types: emergent, riparian shrub-forb, tree, transitional grass-shrub, and upland. 
Riverbank seepage blurred this zonation at some sites. Coverage of riparian woodland, island riparian, and total riparian vegetation, and area of islands, have increased since the 1930's, with the biggest changes occurring in the 1969-1987 period. [EXOTICS; GIS; RIPARIAN VEGETATION; SNAKE RIVER]

465. Dmowski,K; Kozakiewicz,M (1990): Influence of a shrub corridor on movements of passerine birds to a lake littoral zone. Landscape Ecology 4(2/3), 99-108.

A pine forest was separated from a lake littoral zone by a meadow on one area (discontinuous), while these habitats were separated by a shrub strip in another area. This shrub strip acted as an ecological corridor enhancing the movement of birds between the forest and the littoral reed zone. Movements of birds were concentrated along the edge of the shrub strip. The spatial configuration of the landscape facilitated access by some forest birds to the littoral habitat.

[AVIFAUNA; LANDSCAPE ECOLOGY; RIPARIAN HABITAT]

466. Dobyns,HF (1989): Historical perspective. p.1-23. In: Gresswell,RE; Barton,BA; Kershner,JL |eds.|. Practical approaches to riparian resource management: An educational workshop. 8-11 May 1989. USDI Bureau of Land Management. Billings, MT.

A history of use of riparian resources in North America from paleo-Indian times $(8000 \mathrm{BC})$ to present. The author's thesis is that riparian "management" by human communities occurs only within the priorities for selective riparian resource use as defined by the social structure. Human beings selectively exploit resources according to their economic systems and technologies. [HISTORIC RECORDS; RIPARIAN HABITAT; RIPARIAN MANAGEMENT ZONE]

467. Dodd,JL (1992): Viewpoint: an appeal for riparian zone standards to be based on real world models. Rangelands 14(6), 332.

Riparian systems tolerate spatially and temporally scattered disturbances by domestic and indigenous ungulates. Managers need to recognize that local disturbances are a natural part of large ungulate herbivory that these systems evolved with. Local perturbations may well contribute to the long term good of the system. These are naturally occurring disturbances, whether caused by wild or domestic ungulates.
[GRAZING IMPACTS; HERBIVORY; RIPARIAN]

468. Dodd,JL; Smith,MA; Rodgers,JD; Siekert and,RE; Skinner,QD (1987): Influence of grazing on above ground biomass and shrub density associated with an ephemeral stream in Wyoming. Abstracts. 40th annual meeting, Society for Range Management.

[GRAZING IMPACTS; RIPARIAN

VEGETATION]

469. Dolloff,A (1996): Ecological role of large woody debris in forest streams. p.54-57. In: National hydrology workshop proceedings. 27 April - 1 May 1992. Phoenix, AZ. USDA Forest Service. General Technical Report RM-GTR-279.

This paper summarizes the key role of large woody debris (LWD) in mountain streams and its importance to fish habitat. Management strategies are described which can promote sources of LWD and maturation of riparian vegetation.

[FISH HABITAT; LARGE WOODY DEBRIS; RIPARIAN HABITAT; RIPARIAN VEGETATION]

470. Dombeck,MP; Williams,JE; Wood,CA (1997): Watershed restoration: Social and scientific changes for fish biologists. Fisheries 22(5), 26-27.

Profound changes are impacting natural resource management as evidenced by the profusion of watershed-based community coalitions. The implications of these changes are substantial. First, proliferation of local coalitions provides a new framework for fish biologists to work with a broad spectrum of public interests. Second, these coalitions are vehicles to tackle fish and aquatic health problems at the geographic scale most conducive of long-term solutions. Third, because many of the issues that initially catalyze watershed conditions are related to fish/water quality, fish biologists can provide a leadership role in these groups. [FISHERIES; WATER QUALITY; WATERSHED]

471. Donnelly,DD (1987): State-of-the-art methods of assessing wildlife values, benefits, and costs. In: Streamside management: riparian wildlife and forestry interactions. An interdisciplinary symposium. 11-13 February 1987. University of Washington. Seattle, WA.

Assessment, or estimation, of values, benefits, and costs implies several steps that precede the actual valuation effort. Most attention in this paper is given to defining the product in terms of inputs and production functions. A second portion offers a 
framework for suggesting appropriate valuation analysis techniques considering the product, its economic characteristics, and the markets. Finally, the particular techniques available --- market analysis, travel cost and contingent valuation methods, and hedonic methods --- are briefly reviewed.

[ASSESSMENTS; ECONOMICS; RIPARIAN HABITAT]

472. Doppelt,B; Scurlock,M; Frissell,C; Karr,J (1993): Entering the watershed: A new approach to save America's river ecosystems. Island Press. Covelo, CA. 504 p.

The authors recommend a nationwide, strategic community- and ecosystem-based watershed restoration initiative founded upon the principles of watershed dynamics, ecosystem function, and conservation biology.

[RIPARIAN ECOLOGY; RIPARIAN HABITAT; WATERSHED]

473. Dortignac,EJ (1965): Forest water yield management opportunities. p.579-592. In: International symposium on forest hydrology. National Science Foundation advanced science seminar proceedings. 29 Aug-10 Sept 1965. University Park, PA. Pergamon Press. NY,NY.

Strategies are described for enhancing the quantity, quality, and timing of water yield from forested and untilled watersheds. The author regards as overly optimistic the estimate that $1 / 4$ of the water now used by phreatophytes could be saved by management or control techniques. The removal of trees from stream borders and waterways may raise the water temperatures beyond the acceptable limits for game fish. Streamside/lakeside trees are also important for wildlife, recreation, and aesthetic values. In general, tree removal is not sound management and is unlikely to gain public acceptance. Reduction of vegetation mass might be more acceptable and still meet essential goals. [FISHERIES; RIPARIAN FOREST; RIPARIAN HABITAT; W $\triangle$ TER RESOURCE MANAGEMENT]

474. Dose,JJ (1998): Major changes needed for restoration to succecd. Restoration: Newsletter for the Oregon Sea Grant. Winter, 6-7.

The author believes that the current native salmon and trout restoration activities in the Pacific Northwest treat only the symptoms of habitat degradation. The notion that destructive land-use practices can be mitigated through increased spending on restoration elsewhere is misguided. The more productive approach, he believes, is an approach that protects and restores ecosystem processes at the watershed scale. A watershed-based conservation plan regards changes in agricultural and forestry practices, urban/industrial development, and water use as paramount. Although some federal mandates exist, their implementation is often inadequate.

[ECOSYSTEM MANAGEMENT; FISH HABITAT; RIPARIAN RESTORATION; WATERSHED]

475. Dosskey,MG (1998): Viewpoint: Applying riparian buffers to Great Plains rangelands. Journal of Range Management 51(4), 428-431.

Efforts have recently intensified to achieve better management of riparian areas, but serious concerns remain. Widespread acceptance and application of recommended riparian practices will be required to achieve mandated conservation goals. Success in the Great Plains will require recognition of the differences between the interests of public agencies and those of private landowners, and the development of an approach to riparian management that can accommodate both.

[GRAZING IMPACTS; PARTNERSHIPS; RIPARIAN MANAGEMENT ZONE; WATER QUAIITY]

476. Dougherty,S (1988): Wetlands mitigation banking: a policy worth pursuing in Colorado. p.49-54. In: Mutz,K; Cooper,D.J; Scott,ML; Miller,LK [eds.]. Restoration, creation, and management of wetland and riparian ecosystems in the American West. A symposium of the Rocky Mountain Chapter of the Society of Wetland Scientists. 14-16 November 1988. Denver, CO.

Mitigation banking is a concept in which a developer or group of developers would undertake measures to create, restore, enhance, or restore environments similar to those that will be impacted. The adoption and implementation of wetlands mitigation banking can produce win-win solutions to many of the present Section 404 (FWPCA) difficulties experienced by agencies and applicants. [RIPARIAN RESTORATION; WETLAND MITIGATION BANKING]

477. Douglas, AJ (1989): Annotated bibliography of economic literature on wetlands. USDI Fish and Wildlife Service Biological Report 89(19), 67 p.

This bibliography focuses on valuation problems that arise from wetlands allocations, issues, and conflicts. It deals, almost exclusively with research 
and policy analysis that looks at wetlands economics. A brief discussion of natural resource economics precedes the bibliography in an effort to facilitate the recognition of unity of approaches and concepts employed in the references.

[BIBLIOGRAPHY; ECONOMICS; RIPARIAN HABITAT; WETLANDS]

478. Dovel,RL (1996): Cutting height effects on wetland meadow forage yield and quality. Journal of Range Management 49(2), 151-156.

Research was conducted to determine the effect of clipping height on forage yield and quality of 3 wetland meadow plant associations.

Bluegrass-clover, grass-sedge, and sedge associations were cut to stubble heights of 5,10 , or $15 \mathrm{~cm}$ in 1988 , 1989, and 1990. Forage yield, herbage residuc, crude protein (CP), and acid detergent fiber (ADF) were determined for forage harvested in June, July, and August. Highest forage yield, regrowth following clipping, and overall forage quality were obtaincd at the $5 \mathrm{~cm}$ clipping height in all associations. The $5 \mathrm{~cm}$ grazing height did not appear to reduce stand vigor or persistence as indicated by high forage yields in the third year of the study. Animal performance in a short duration grazing system would also be expected to be highest at the $5 \mathrm{~cm}$ clipping height since forage production was greatest at this defoliation intensity without decreasing forage quality or availability. Acid detergent fiber of the sedge association was lower than the 2 grass dominated associations, and sedge crude protein content was slightly lower than the other 2 associations.

[FORAGE PRODUCTION; GRAZING IMPACTS; STUBBLE HEIGHT; WETLANDS]

479. Downes,BJ; Lake,PS; Schreiber,ESG; Glaister,A (1998): Habitat structure and regulation of local species diversity in a stony, upland stream. Ecological Monographs 68(2), 237-257.

Species diversity at local scales may be regulated by habitat structure and complex habitats may normally be associated with greater species richness. In this study, habitat structure altered faunal diversity and abundances, with the majority of common species reaching higher abundances on creviced or rough surfaces. The latter were also associated with shifts in overall faunal composition and markedly smaller body sizes. Each separate element of habitat structure (large crevices, roughness, and macroalgae) promoted both increased species richness and individual density. Habitat structure also affected the epithelion, suggesting that sources of habitat complexity and heterogeneity were interwoven in this system.

[FISH HABITAT; MACROINVERTEBRATES; SPECIES RICHNESS]

480. Doyle,JE (1998): Watershed restoration: Challenges and obstacles. Fisheries 23(3), 16-17.

The author identifies six obstacles to large-scale watershed restoration: 1) lack of will to form interdisciplinary teams; 2 ) many restoration efforts lack an effective protection component; 3 ) the realization that agencies cannot carry out restoration at the watershed- or river-basin-scale alone; 4) the difficulty in gaining consensus; 5) the commitment to monitoring, cvaluation, and documentation; and 6) the leadership vacuum in many restoration programs. [MONITORING; RIPARIAN RESTORATION; WATERSHED]

481. Draper,SE; Rao,SG (1986): Runoff prediction using remote sensing imagery. Water Resources Bulletin 22(6), 463-470.

Percent imperviousness is an important parameter in modeling the urban rainfall-runoff process and is usually determined using manual methods such as random sampling or conventional accounting records. In this study, two computerized methods -the Laser Image Processing Scanner and the Video-Tape Camera system - were used for estimating the imperviousness of urban watersheds. The percent imperviousness computed by utilizing remote sensing imagery was used with the conceptual models of rainfall-runoff models. "Imperviousness" determined by using remote sensing imagery was as accurate as that obtained by the manual methods with significantly less time or money.

[HYDROLOGY; MODELING; REMOTE SENSING; RUNOFF]

\section{Dudley,SJ; Bonham,CD; Abt,SR;} Fishenich,JC (1998): Comparison of methods for measuring woody riparian vegetation density. Journal of Arid Environments 38, 77-86.

Flow resistance caused by vegetative drag depends on vegetation densily, the area of vegetation projected onto a plane perpendicular to the flow direction per unit volume of flow. However, research concerning the accuracy and efficiency of field measurements of vegetation density is limited. Measurements were conducted at two willow stands with different vegetation densities using the horizontal point frame, board, and camera methods. Results obtained with the point frame method were accurate and were used as a standard in other tests. 
Results of the other methods were varied. [MONITORING; RIPARIAN HABITAT; RIPARIAN VEGETATION]

483. Duff,D (1996): Conservation assessment for inland cutthroat trout status and distribution. USDA Forest Service. Intermountain Region. 120 p.

This report focuses on the current status, distribution and range for five subspecies of cutthroat trout (Oncorhynchus clarki), which are found largely on the national forest system lands and ecosystems in the Rocky Mountain and Intermountain West within the United States. All five subspecies are designated species of special concern or sensitive. All are presently restricted to a fragment of their former range, and they primarily occupy small, high-elevation streams in remote headwaters. Human activities have reduced their ranges more than natural occurrences. The plans, agreements, and strategies discussed in this report focus on the restoration of aquatic habitats and maintenance of existing populations.

[AQUATIC ECOSYSTEMS; CUTTHROAT TROUT; FISH HABITAT]

484. Duff,DA (1978): Livestock grazing effects on aquatic habitat in Big Creek, UT. USDI Bureau of Land Management. Technical Bulletin. Salt Lake City, UT

In 1970, BLM constructed a large exclosure fencing off $3,300 \mathrm{ft}$ of Big Creek in Utah from livestock grazing. Recovery of riparian habitat from the grazing impacts was monitored. Numerous instream improvement structures were placed inside and outside the exclosed area. By 1973, fish sampling showed 3.6 times more trout inside than outside the exclosure. Habitat inside the exclosures responded significantly to rest, while areas outside the exclosure continued to decline.

[EXCLOSURES; FENCING; GRAZING IMPAC'IS; RIPARIAN HABITAT]

485. Duff,DA (1979): Riparian habitat recovery on Big Creek, Rich County, Utah -- a summary of eight years of study. In: Cope,OB [ed.]. Forum -Grazing and riparian/stream ecosystems. 3-4 November 1978. Denver, CO. Trout Unlimited Inc.

The author believes that streamside riparian zones, whether fenced for protection or for recovery and later use, should become and be thought of as separate pastures within allotments. Since riparian/aquatic habitats are the most diverse and important in flora and fauna use as well as recreation and livestock uses, it would be advantageous to establish riparian zone pastures, with off-site water developments so that recovery, protection, or rest could be provided. This would allow utilization of the pasture for a specified time or season with certain numbers of livestock until a prescribed level of utilization is reached on specific woody vegetation used as indicator species.

[EXCLOSURES; GRAZING IMPACTS; GRAZING TREATMENTS; RIPARIAN RESTORATION]

486. Duff,DA; Cooper,JL (1976): Techniques for conducting stream habitat survey of national resource lands. USDI Bureau of Land

Management Tech. Note T/N 283. 72 p.

The basic procedures in this report were previously developed for use in stream habitat surveys by the USDA Forest Service. The procedures proposed contain these existing methodologies, developed by USFS personnel in Regions 1, 4, and 3, plus revisions added by the authors. The technical note provides guidance and standards for conducting certain types of aquatic surveys on national resource lands. Objectives were to provide adequate procedures designed to evaluate most of the common environmental conditions that limit aquatic habitat and fish production.

[FISHERIES; INVENTORY; RIPARIAN

HABITAT; STREAM ECOLOGY]

487. Duff,DA; Gnehm,M; Shrader,T; Howard,L (1986): Indexed bibliography on stream habitat improvement. USDA Forest Service. Intermountain Region. Ogden, UT. 97 p.

This bibliography contains 1106 entries of published and unpublished references on or related to stream habitat improvement. Entries are categorized into 20 subject areas relating to both instream and streambank-riparian structural and non-structural improvement. References relate to resident and anadromous salmonid and cold water fish species as well as warm water fish species. The manuscript contains most of the important references to stream habitat from 1933 to 1985.

[BIBLIOGRAPHY; FISHERIES; HABITAT

MANAGEMENI; RIPARIAN HABITAT]

488. Duff,DA; Wydoski,RS (1982): Indexed bibliography on stream habitat improvement. USDA Forest Service. Intermountain Region. Ogden, UT. 98 p.

An updated and revised bibliography containing 828 references. References are arranged into one or 
more of 20 subject indices. The document is designed to serve as a basis for evaluation of past practices and stimulate future studies that will allow the establishment of effective priorities and procedures for the improvement and management of stream habitats.

[BIBLIOGRAPHY; FISHERIES; RIPARIAN HABITAT; STREAM IMPROVEMENTS]

489. Duncan,KW; Schemnitz,SD; Suzuki,M; Homesley,Z; Cardenas,M (1993): Evaluation of salt-cedar control - Pecos River, New Mexico. p.207-210. In: Tellman,B; Cortncr,HJ; Wallace,MG; DeBano,LF; Hamre,RH [tech. coord.|. Riparian management: Common threads and shared interests. USDA Forest Service. Gencral Technical Report RM-226.

Every stream or river system in New Mexico is infested or has the potential to be infested with saltcedar. Protection of native riparian habitat has become a management priority. In the past, salt-cedar manipulation has been cost-prohibitive. The development of imazapyr and imazapyr + glyphosate tank mixes, however, may cost as little as $\$ 60 /$ ac and result in a 90-99 percent control.

[HERBICIDES; RIPARIAN HABITAT; RIPARIAN RESTORATION; SALT-CEDAR]

490. Duncan,SH; Bilby,RE; Ward,JW; Heffner,JT (1987): Transport of road-surface sediment through ephemeral stream channels. Water Resources Bulletin 23(1), 113-119.

The majority of road drainage points in western Oregon-Washington enter small, often ephemeral streams, rather than large, fish-bearing waters. Therefore, impact of road-surface sediment on biota in permanent streams depends to a large extent, on transport through these small watercourses. Small streams were found to store large quantities of sediment washed from road surface. In no instance, did streams transport more than 45 percent of the added material to their mouths. Larger-sized sediment particles were delivered at a lower rate than finer material. There were significant differences in the transport of sediment in size categories between different streams, due to a much greater amount of woody debris in one stream. This trapped and held sediment as did a slightly longer and less steep channel.

[HYDROLOGY; LOGGING IMPACTS; ORGANIC DEBRIS; ROAD IMPACTS; SEDIMENTATION; SEDIMENT TRANSPORT]

\section{Duncan,SL (1984): Leaving it to beaver.}

Environment 26(3), 41-45.

Much of the recent attention to beavers has emphasized the negative aspects of bcaver activity: dams that need to be blasted to release water, culverts that are continually dammed, and trees that are lost. However, beaver are also seen as a keystone species in the structure and dynamics of aquatic ecosystems. In habitats where they remain, they are important regulators of stream dynamics and morphology, with pervasive effects far beyond their food and space requirements.

[BEAVER; RIPARIAN HABITAT]

\section{Dunne,T; Leopold,LB (1978): Water in} Environmental Planning. W.H. Freeman and Co., San Francisco, CA. 795 p.

This book is divided into three main parts. Part I: Introduction contains six field examples. Part II: I Iydrology discusses precipitation, interception, water loss, vegetative water use, soil water, groundwater, water balance, runoff processes, flood hazards, human impacts, water supply and use, and snow hydrology. Part III: Geomorphology addresses drainage basins, hillslope processes, river channels, and sediment production/transport.

[GEOMORPHOLOGY; HYDROLOGY; WATER RESOURCE MANAGEMENT]

493. Durkin,P; Muldavin,E; Bradley,M; Carr,S (1996): A preliminary riparian/wetland vegetation community classification of the Upper and Middle Rio Grande watersheds in New Mexico. p.44-57. In: Shaw,DW; Finch,DM [tech. coord.]. Desired future conditions for Southwestern riparian ecosystems: Bringing interests and concerns together. USDA Forest Service. General Technical Report RM-GTR-272.

The riparian/wetland vegetation communities of the upper and middle Rio Grande watersheds in New Mexico were surveyed in 1992 through 1994. The communities are hierarchically classified in terms of species composition and vegetation structure. The resulting community types are related to soil conditions, hydrological regime, and temporal dynamics. The classification is part of a comprehensive effort to develop a systematic understanding across the state of riparian/wetland communities and how they are influenced by specific hydrologic, edaphic and climatic environments. An overview of the classification is presented with an emphasis on the middle Rio Grande watershed. The floristic composition, structure, environmental relationships, and successional trends of example communities are briefly described. 
[CLASSIFICATION; INVENTORY; PLANT COMMUNITIES; RIPARIAN HABITAT]

494. Durkin,PM; Bradley,M; Muldavin,E (1997): Riparian plant species diversity of the Rio Grande and Gila, San Francisco, and Mimbres Rivers in New Mexico. p. 81. In: Abstracts. 1997 annual meeting of the Ecological Society of America jointly with The Nature Conservancy. 10-14 August 1997. Albuquerque, NM.

The study involved an inventory/comparison between the Rio Grande watershed and the adjacent Gila, San Francisco, and Mimbres watersheds in New Mexico. Flows along the Rio Grande are highly regulated whereas the latter are unregulated. Diversity differences were found to be dramatically disparate between the two types of basins. The majority of permanent species introductions occur in the highly regulated middle segments of the Rio Grande. Nearly one-half of the trees occurring in the regulated floodplain are exotic. In the unregulated basins, only 16 percent of the woody species were exotic. The frequency of herbaceous exotics is similar for both conditions except for those from the grass family, Poaceae. In the Rio Grande basin 35 percent of the herbaceous exotics are grasses, while only 7 percent of the grasses in the unregulated basins are exotic.

[EXOTICS; FLOOD IMPACTS; RIPARIAN VEGETATION; STREAM FLOW]

495. Durst,JD (1987): Predicting riparian vegetation changes downstream of a large hydroelectric development. In: Streamside management: Riparian wild life and forestry interactions. An interdisciplinary symposium. 11-13 February 1987. University of Washington. Seattle, WA.

Hydrologic modeling was used to predict flow and ice regimes during construction and operation of a 3-phase, 2-dam system. Stereoscopic examination of aerial photos in conjunction with surveyed river cross sections yielded empirical values for river discharges associated with the lower limits of vegetation and mature riparian communities. These discharges were then related to predictable hydrologic events which had been modeled previously.

[CLASSIFICATION; HYDROELECTRIC IMPACTS; MODELING; RIPARIAN HABITAT]

496. Dusek,GL (1990): Use of riparian areas in Montana by white-tailed deer. In: Management of riparian and wetland forested ecosystems in
Montana. Fourth annual Montana Riparian Association workshop. 5-7 September 1990. Whitefish, MT.

A relationship between density and distribution of white-tailed deer and abundance of wooded riparian communities has been documented along the lower Yellowstone River in eastern Montana. Spatial coverage of riparian forest and shrublands explained about 70 percent of the variation in relative abundance of deer. Livestock use and amount of island area also influenced relative deer abundance. [GRAZING IMPACTS; RIPARIAN HABITAT; WHITE-TAILED DEER]

497. Dworsky,RF (1998): Range management and control at the crossroads. p.281-290. In: Potts,DF [ed.|. Range management and water resources: Proceedings of the AWRA specialty conference. American Water Resources Association. 27-29 May 1998. Reno, NV.

The outcome of management/leadership in the range management/watershed interface will depend in large part of the effectiveness of competing management and control systems. These systems: Management by Direction, Management by Planning, or Management by Influence can each provide strong control systems within an organization. The three methods of leadership are explained and evaluated within the context of contemporary range management and water resource leadership. [MANAGEMENT PLANS; RANGE MANAGEMENT; WATERSHED]

498. Eastern Energy and Land Use Team (1980): Summaries of riparian and stream alteration studies completed by the Eastern Energy and Land Use Team. National Water Resources Analysis Group. USDI Fish and Wildlife Service. Kearneyville, WV. 38 p.

A compilation of abstracts relating to stream alterations and riparian studies. Most of the studies, however, occurred in the eastern and mid-western US and were collected as a service to USFWS personnel in response to growing demands for a quick reference and overview of agency projects.

[RIPARIAN HABITAT; STREAM ECOLOGY; STREAM FLOW]

499. Eastern Washington University (1986): Symposium on monitoring aquatic and riparian natural areas. Cheney, WA. Eastern Washington University 5 p.

Abstracts of papers regarding monitoring methodologies for aquatic/riparian sites. 
[MONITORING; RIPARIAN ECOLOGY; RIPARIAN HABITAT]

500. Ebersole,JL; Liss,WJ; Frissell,CA (1997): Restoration of stream habitats in the western United States: Restoration as a re-expression of habitat capacity. Environmental Management 21, 1-14.

A new method of evaluating stream biota dynamics is proposed that accounts for temporal behaviors that alter biotic interactions throughout the year. Restoration of stream systems is defined as a process that allows these systems to re-express their former traits. Key tasks are: 1) identification of historic patterns in habitat development; 2) identification of constraints on those developments; 3) relief of those constraints; 4) classification of sensitive habitats; and, 5) protection of the diversity that remains.

[BIODIVERSITY; HISTORIC RECORDS; RIPARIAN HABITAT; RIPARIAN RESTORATION]

501. Eckert,Jr.,RE (1974): Improvement of mountain meadows in Nevada. USDI Bureau of Land Management Research Report. Reno, NV. $45 \mathrm{p}$.

This research report describes five methods in use for improving mountain meadows for livestock, wildlife, and site stability. These five methods include iris control studies, fertilization studies, tree and shrub transplants, and hydrologic evaluations. [MEADOWS; RIPARIAN RESTORATION; STREAM IMPROVEMENTS]

502. Eckert,Jr.,RE (1983): Methods for improving mountain meadow communities. Proceedings of symposia: Managing intermountain rangelands - improvement of range and wildlife habitats. 15-17 September 1981; Twin Falls, ID. 22-24 June 1982. Elko, NV. USDA Forest Service. General Technical Report INT-157.

Mountain meadows in poor condition were improved rapidly through seeding. A summer fallow gave excellent control of competitive vegetation. Mountain meadows in fair condition, but with dense stands of Rocky Mountain iris were improved through use of 2,4,-D. Small meadows improved by seeding or iris control may justifiably be fenced to meet wildlife habitat requirements. Response of native grass, grass-like, and forb species to nitrogen fertilization depended on climatic conditions, plant vigor, and rates of $\mathrm{N}$. Routine use of $\mathrm{N}$ fertilizer is not recommended. Fertilization of small stringer meadows in sage grouse habitat is not recommended. Trees and shrub species were successfully introduced into the mountain meadow ecosystem with best results from spring planting of container grown stock. Peak water flow from spring runoff was greatest during the wettest year. Water table height maintained will influence the productivity of native and introduced species.

[CHECK DAMS; LIVESTOCK EFFECTS; RIPARIAN RESTORATION; VEGETATION MANAGEMENT]

503. Ecklov,AG; Greenberg,LA; Bronmark,C; Larson,P; Berglund,O (1999): Influence of water quality, habitat, and species richness on brown trout populations. Journal of Fish Biology 54, 33-43.

Discriminant analysis of data collected on 216 stream sites showed that occurrence of trout at a locality was largely determined by oxygen conditions and medium-sized substrata. At localities where trout occurred, the density of young trout was highest in narrow streams with high oxygen concentrations. For older trout, stream size and temperature were negatively related to density. Intraspecific competition appeared to be important, as length of young trout was inversely related to density. Trout density was also related to abundance of predators and co-existing species.

[FISH HABITAT; SPECIES RICHNESS; TROUT; WATER QUALITY]

504. Eddleman,LE; Miller,PM (1992): Potential impacts of western juniper on the hydrologic cycle. p.176-180. In: Clary,WP; McArthur,ED; Bedunah,D; Wambolt,CL [comp.]. Proceedings Symposium on ecology and management of riparian shrub communities. USDA Forest Service. General Technical Report INT-289.

Precipitation, through-fall, stem flow, and interception of western juniper were examined in central Oregon. Ranges were correlated with tree size, and type of vegetation. Stem flow ranged from $1.0-3.2$ percent, through-fall from $33.0-52.3$ percent, and interception from $44.4-65.9$ percent. Transpiration occurred year-long and reached 3.03 $1 / \mathrm{kg}$ in summer months. Dense western juniper woodlands may reduce winter soil moisture recharge by over 50 percent.

[HYDROLOGY; SOILS; WESTERN JUNIPER]

505. Edmonds, RL [Ed.] (1982): Analysis of coniferous forest ecosystems in the western United 
States. Hutchinson Ross Publishing Co., Stroudsburg, PA.

Results from the Coniferous Forest Biome program have provided further insight into the changing nature of western coniferous forests and the impact of man. The program established the use of ecosystem analysis as a means of studying coniferous forests. The approach is now firmly established and it should help in the development of sensible land-use decisions.

[FOREST MANAGEMENT; GEOMORPHOLOGY; HYDROLOGY; ORGANIC DEBRIS; RIPARIAN VEGETATION; SOILS]

506. Ehlers, R (1956): An evaluation of stream improvement devices constructed eighteen years ago. California Fish and Game 42, 203-217.

An evaluation of stream improvement devices on the Kaweah River found ten of the total of 41 improvements still in place after 18 years. Only log structures were still intact while rock, masonry, earth and crib dams were all washed out. Fifteen pools have resulted from the original 41 improvements. From all indications, the failures resulted from the end-cutting and undercutting action of water on the loose bottom and bank materials.

[RIPARIAN RESTORATION; RIPARIAN STRUCTURES]

507. Ehrhart,B; Hansen,PL (1998): Riparian grazing management: Strategies and techniques. p.191-201. In: Potts,DF [ed.]. Rangeland management and water resources: Proceedings of the AWRA specialty conference. American Water Resources Association. 27-29 May 1998. Reno, NV.

Livestock grazing in riparian zones may be ecologically feasible during a variety of seasons of use, lengths of grazing periods, and different vegetation community types, according to the evaluations of 71 ecologically functioning streams in Montana. The study suggests that there are numerous management techniques which may reduce the amount of time animals spend in the riparian area itself while in a given pasture. These may be more important than either the particular season or the length of the grazing period in the pasture. The consistently common denominators of good management were high degrees of operator involvement and alternative water sources. Grazing in riparian areas requires a much more intensive management to be ecologically sound.

[GRAZING IMPACTS; LIVESTOCK EFFECTS; RIPARIAN; RIPARIAN VEGETATION]
508. Ehrhart,RC; Hansen,PL (1997): Effective cattle management in riparian zones: A field survey and literature review. Montana BLM Riparian Technical Bulletin No. 3. USDI Bureau of Land Management. Montana State Office. 92 p.

There is no single or simple solution on how to graze livestock in riparian areas in ecologically and economically feasible ways. Each situation requires a carefully considered prescription drawn up to address the conditions at a specific site. This approach is referred to as prescription grazing. There are numerous techniques available but the only required ingredients are a serious commitment and personal involvement on the part of managers and operators. This bulletin draws upon a number of previous compilations to summarize successful grazing applications and the variety of factors that contribute to them.

[BIBLIOGRAPHY; GRAZING IMPACTS; RIPARIAN MANAGEMENT ZONE]

509. Ehrhart,RC; Hansen,PL (1998): Successful strategies for grazing cattle in riparian zones. Montana BLM Riparian Technical Bulletin No. 4. USDI Bureau of Land Management. Billings, MT. $48 \mathrm{p}$.

One of the most extensive human-caused influences on riparian zones in the western US has been livestock grazing. It is well-known that improper grazing practices can adversely affect riparian areas. What is less obvious is what grazing management techniques are compatible with maintaining or improving these areas and under what conditions. This document discusses both general and specific principles for grazing cattle in riparian areas and employed techniques to avoid sacrificing the ecological or financial condition of their land. This bulletin is based on the substantial body of literature on the subject and on observations/evaluations of operations on more than 70 ranches in Montana.

[GRAZING IMPACTS; RIPARIAN MANAGEMENT ZONE]

510. Eicher,AL (1988): Soil-plant correlations in wetlands and adjacent uplands of the San Francisco Bay estuary, California. USDI Fish and Wildlife Service. Biological Report 88(21), 35.

As part of a national study, a vegetation association with known hydric and nonhydric soils was sampled in California. Data on hydrolic conditions of each soil was also collected. Weighted average and index average were calculated (presence/absence values were calculated for each soil). Five of the six hydric soils examined were 
designated wetlands by these analyses. All of the upland soils supported a preponderance of upland vegetation.

[CLASSIFICATION; PLANT COMMUNITIES; RIPARIAN HABITAT; SOILS]

511. Elder,RG; Moore,RC (1985): Impacts of oil and gas development on riparian zones in the overthrust belt: The role of industrial siting. p.379-383. In: Johnson,RR; Ziebell,CD;

Patton,DR; Ffolliott,PF; Hamre,RH [tech. coord.|. Riparian ecosystems and their management: Reconciling conflicting uses. 16-18 April 1985. Tucson, AZ. USDA Forest Service. General Technical Report RM-120.

Oil and gas development in the Overthrust Belt of Wyoming is expanding. Concurrently, the need to minimize impacts to riparian systems becomes more important. Regulatory control is frequently ineffective. Due to broad powers, the Industrial Siting Process can play a key role in mitigating environmental impacts that are otherwise unregulated.

[IMPACT MITIGATION; OIL/GAS IMPACTS; RIPARIAN HABITAT]

512. Ellis,LM; Crawford,CS; Molles,Jr.,MC (1998): Comparison of litter dynamics in native and exotic riparian vegetation along the middle Rio Grande of central New Mexico, USA. Journal of Arid Environments 38, 283-296.

Exotic plants and river regulation have changed riparian ecosystems throughout the southwestern U.S. Litter dynamics were compared at sites dominated by native cottonwoods or exotic saltcedar. Litter production was greater at cottonwood sites and may have increased after accidental flooding for both. Decomposition was similar for both types of leaves and increased with experimental flooding for both. Forest floor litter was greater at cottonwood sites; litter storage decreased after flooding at the salt-cedar site but not at the cottonwood site. Flooding may help reduce the impact of fires by increasing decomposition and reducing the standing stock of forest floor organic matter.

[EXOTICS; FLOOD IMPACTS; LITTER FALL; NUTRIENT CYCLES; RIO GRANDE; RIPARIAN HABITAT]

513. Ellis,S; Danley,L (1993): Prescription for a troubled stream. Rangelands 15(5), 233-235.

The management prescription for a degraded stream in south-central Idaho included these components: 1) a deferred rotation grazing system;2) maintaining sufficient habitat for big game and upland game birds; 3 ) a goal of maintaining 80 percent of the allotment in native vegetation; and 4) a goal of brush control on private land. In addition, several beavers were released in the riparian system. The effort required the intensive cooperation of federal and private landowners.

[BEAVER; GRAZING TREATMENTS; RIPARIAN HABITAT; RIPARIAN RESTORATION]

514. Elmore,W (1987): Riparian management: back to basics. Paper presented at the Natural Resources Law Center, University of Colorado School of Law. 8-10 June 1987. Boulder, CO.

The primary management focus for riparian ecosystems should be restoring streamside vegetation. In contrast to structures, riparian vegetation can maintain itself in perpetuity as new plants continually replace those that die. Riparian vegetation allows streams to function in ways that artificial structures cannot replicate. The resiliency of these plants enable riparian systems to withstand a variety of environmental conditions. To accomplish what is needed, a dialogue between managers, ranchers, and other public sectors is imperative. [RIPARIAN ECOLOGY; RIPARIAN MANAGEMENT ZONE; RIPARIAN RESTORATION]

515. Elmore,W; Beschta,R (1987): Riparian areas: Perceptions in management. Rangelands 9(6), 260-265.

This topical article was intended to: 1) promote awareness and discussion of riparian issues by and among livestock owners, environmentalists, biologists, and the general public; 2) identify the characteristics and benefits of productive riparian systems; and 3) encourage managers of public and private land to reconsider the effects of traditional grazing practices and of recent attempts to control channels structurally.

[GRAZING IMPACTS; INSTREAM

STRUCTURES; RIPARIAN MANAGEMENT ZONE]

516. Elmore,W; Cuplin, $P$ (1984): Use of color infrared photography in stream habitat inventories. p.6-12. In: Bedell,TE [ed.|. Proceedings of 1984 Pacific Northwest range management short course: Range watersheds, riparian zones and economics: Interrelationships in management and use. 25-27 January 1984. Pendleton, OR. 
[AERIAL PHO'TO; INVENTORY; MONITORING; RIPARIAN HABITAT]

517. Elmore,W; Kauffman,B (1994): Riparian

and watershed systems: Degradation and

restoration. In: Ecological implications of livestock herbivory in the West. First Edition.

[Eds]: Vavra,M; Laycock,WA; Pieper,RD. Society

for Kange Management. Denver, CO.297 p.

The authors maintain that livestock grazing can be present in some riparian areas during periods of recovery. Grazing strategies that link the uplands, the riparian areas and the stream channels must be used to accomplish effective and self-sustaining restoration. Various grazing strategies are described and evaluated. Major short-comings of grazing strategies that fail to result in the restoration of degraded riparian zones are as follows: 1) they are applied with a cookbook approach with little analysis of riparian effects or recognition of the complex and heterogenous nature of riparian zones; 2) the grazing strategies utilized were developed for uplands and/or for herbaceous recovery with little consideration of woody vegetation, streambank integrity, or riparian function; and 3) they were developed for increased livestock production with similar short-comings in considerations of riparian values. Successful management strategies must consider the following: a) the linkages and processes that are associated with full floodplain function; b) the extreme complexity of riparian zones; c) headwater streams have not received necessary levels of management attention to achieve landscape-level goals; d) restoration within the stream channel and riparian zone should reestablish natural ecological processes and communities; and e) manage to maintain connectivity across landscapes and minimize ecosystem fragmentation.

[GRAZING IMPACTS; GRAZING TREATMENTS; RIPARIAN RESTORATION]

518. Emerick,JC (1988): The restoration potential for wetlands impacted by acid mine drainage in the Colorado Rocky Mountains. p.109-111. In: Restoration, creation, and management of wetland and riparian ecosystems in the American West.

Restoration possibilities for wetland systems that are presently impacted by mine drainage include: 1) removing the source of metals (by rechanneling drainages or removing tailings); 2) reducing the toxicological effects of some metals by judicious application of $\mathrm{Ca}$ and $\mathrm{P}$ to stimulate plant production; and 3) removing some of the soil and replacing it with a layer of organic mulch, then planting plugs of healthy vegetation on 2- or 3-foot centers.

[ACID MINE WASTES; MINING IMPACTS; RIPARIAN RESTORATION; WETLANDS]

519. Emmerich,WE (1998): Estimating prescribed burn impacts on surface runoff and water quality in southeastern Arizona. p.149-158. In: Potts, DF [ed.]. Rangeland management and water resources: Proceedings of the AWRA specialty conference. American Water Resources Association. 27-29 May 1998. Reno, NV.

Burning effects on surface runoff, sediment yield, and nutrient dynamics were evaluated with a large rainfall simulator following spring and fall burns at two different soil/vegetation types. The study was replicated in a second year and results were compared with unburned areas. Surface runoff, sediment yield, and nutrient loss were controlled primarily by the soils and the soils interacting with the vegetation. Significant season and year effects were found for runoff, sediment yield, and nutrient loss irrespective of the burn treatment. The burning effects were much greater than the season or year effects one year after the first burn. The nutrient dynamics showed the magnitude of the pools to be soil $\gg>$ biomass $\gg \gg>$ surface runoff losses, which implied that there could be many burns before a significant amount of nutrients would be depleted from the soil and the ecosystem changed. [FIRE IMPACTS; NUTRIENT CYCLES; PRESCRIBED BURNING; WATERSHED]

520. Emmett,WW (1975): The channels and waters of the upper Salmon River area, ID. USDI Geological Survey Professional Paper 870-A. 96 p.

The upper 1,800 square miles of the Salmon

River drainage basin in south-central Idaho is an area of great scenic beauty and little-disturbed natural habitat. Proper use and development of this land and its natural resources are contingent on a multifaceted and detailed environmental study. This report emphasizes the complex interaction of hydrological, biological, geological, and chemical parameters. The report concentrates on the hydraulics and geometry of streamflow and the composition of stream water. [GEOMORPHOLOGY; HYDRAULICS; HYDROLOGY; SALMON RIVER]

521. Emmington,WH; Maas,KG; Tucker,GF (1994): Survival and growth of conifers under planted or released in alder dominated riparian zones. p.19-22. In: The ecology and management of Oregon Coast Range forests: A mid-term 
COPE symposium. 29-31 March 1994. Gleneden

Beach, OR. Coastal Oregon Productivity

Enhancement Program; Oregon State University

Release or planting of conifers in small clearings or partially cut riparian zone alder stands appeared to be viable options for enhancing conifer survival and growth, thereby contributing to stream rehabilitation. Where planting is practiced, control of understory competition has short term beneticial effects. Killing (i.e. thinning) of 50 percent of the alder appeared to be a good option for restoration in the short run, but length of treatment effect should be determined. Duration of beneficial effect of thinning would depend on age and density of residual alder, and site conditions. Shade-tolerant species performed better, but Douglas fir did survive and grow when released and under planted with modest initial success.

[RIPARIAN FOREST; RIPARIAN

RESTORATION]

522. Ensign,WE; Leftwich,KN; Angermeier,PL; Dolloff,CA (1997): Factors influencing stream fish recovery following a large-scale disturbance. Transactions of the American Fisheries Society 126, 895-907.

Following a massive fish kill, fish distribution and abundance were examined. Combining results across scales and estimator types showed that distributions and abundances of 5 of 11 species in the reach affected by the kill were similar to those observed in unaffected upstream and downstream reaches 8-11 months following the perturbation. Indications were that 4 of 11 species had not recovered in the same time period. The authors attribute differences in recovery rates to differences in parental investment in offspring. Species exhibiting rapid recovery either engage in extensive spawning site preparation or guard the spawning site following egg deposition and fertilization. [FISHERIES; RIPARIAN RESTORATION]

523. Erman,NA (1981): The use of riparian systems by aquatic insects. p.177-182. In: Warner,RE; Hendrix,KM [eds.]. Proceedings of the California riparian systems conference. 17-19 September 1981. Davis, CA.

Nearly all aquatic insects spend some portion of their lives in riparian zones. Many examples are given of terrestrial stages and activities of aquatic insects. The examples are divided into the areas of feeding, pupation, emergence, and egg laying. Special emphasis is given to recent studies on caddisflies (Trichoptera) in riparian systems of the Sierra Nevada. Knowledge of life cycles is essential for predicting the effect of disturbance in riparian areas on populations of aquatic insects.

[AQUATIC ECOSYSTEMS; INVERTEBRATES; RIPARIAN ECOLOGY; RIPARIAN HABITAT]

524. Erwin, KL (1990): Wetland evaluation for restoration and creation. p.429-458. In: Wetland creation and restoration. [Eds.: JA Kusler; ME Kentula.|. Island Press. Washington, DC.

A rapidly accessible, easily understood, and cost effective database on wetland creation and restoration projects is needed to support environmental regulatory agency review, decision making, and action on specific projects. Any comprehensive wetland evaluation effort must be preceded by the establishment of criteria which the investigator and regulator believe to be fundamental to the existence, functions, and contributions of the wetlands system and its surrounding landscape. Failure to address the wetland system's surrounding landscape leads to an inaccurate characterization of the wetland. Additional research is needed to establish the inter-relationships between wetlands, transitional areas, and adjacent uplands.

[RIPARIAN RESTORATION; WETLANDS]

\section{Estes,CC; Orsborn,JF (1986): Review and} analysis of methods for quantifying instream flow requirements. Water Resources Bulletin 22(3), 389-398.

Present guidelines for selecting a method to determine instream flow requirements and evaluating the validity of the results from a particular method are insufficient. A review of current methods for instream flow determinations is supplemented by a summary of four independent analyses. Results of these analyses indicate that each method can be used independently or collectively to generate instream flow recommendations, if calibrated to the area or site studied.

[FISHERIES; HYDROLOGY; RIPARIAN

HABITAT; STREAM FLOW]

526. Evans,B; Babcock,H (1987): Why riparian management regulations are not disincentives. In: Streamside management: Riparian wildlife and forestry interactions. An interdisciplinary symposium. 11-13 February 1987. University of Washington. Seattle, WA.

There are strong incentives to press for timber harvesting elimination or restriction of harvest activities in riparian zones, ranging from increased water quality and better fisheries to more assured supplies of water and better recreation opportunities. 
From the standpoint of the timber owner or operator, riparian management regulations may seem to be disincentives to conduct timber operations in general but careful adherence to such regulations results in more favorable environmental and therefore social impact and eases the pressure for potentially unwise restrictive regulations elsewhere.

[ECONOMICS; LOGGING IMPACTS; POLICY; RIPARIAN HABITAT; RIPARIAN

MANAGEMENT ZONE]

527. Evans,JM (1991): Propagation of riparian species in southern California. p.87-90. In: Proceedings, Intermountain Forest Nursery Association, 12-16 August 1991. Park City, Utah. USDA Forest Service. General Technical Report RM-211.

Riparian corridors in southern California are typically vegetated with a tree cover, an understory shrub layer of woody plants, and a sub-shrub cover of herbaceous plants. As mitigation for Least Bell's Vireo, an endangered species, habitat is being restored using nursery produced container and bare root plants. Propagation and production techniques are described.

[AVIFAUNA; PLANT MATERIALS; PLANT PROPAGATION; RIPARIAN HABITAT; RIPARIAN RESTORATION]

528. Everest,FH (1978): Anadromous fish habitat and forest management --economic considerations. p.153-171. In: Proceedings of the Western Association of Fish and Wildlife Agencies/Western Division. American Fisheries Society.

[FISHERIES; LOGGING IMPACTS; RIPARIAN HABITAT]

529. Everest,FH; Meehan,WR (1981): Forest management and anadromous fish habitat productivity. p.521-530. In: Transactions of the 46th North American wildlife and natural resources conference. Wildlife Management Institute. Washington, DC. [ANADROMOUS FISH; FISHERIES; LOGGING IMPACTS; RIPARIAN HABITAT]

530. Everett,RL; Meeuwig,RO; Robertson,JH (1978): Propagation of Nevada shrubs by stem cuttings. Journal of Range Management 31(6), 426-429.

Stem cuttings of 54 Nevada shrub species varied in rooting capacity. Semi-hardwood cuttings were superior to either softwood or hardwood cuttings in rooting success. Differences in rooting potential among cuttings of the same species taken from different sites were also apparent.

[RIPARIAN RESTORATION; RIPARIAN SHRUBS]

531. Fannin,TE; Parker,M; Maret,TJ (1985): Multiple regression analysis for evaluating non-point source contributions to water quality in the Green River, Wyoming. p.201-205. In: Johnson,RR; Ziebell, CD; Patton,DR; Ffolliott,PF; Hamre,RH [tech. coord.]. Riparian ecosystems and their management: Reconciling conflicting uses. 16-18 April 1985. Tucson, AZ. USDA Forest Service. General Technical Report RM-120.

The Green River Basin of western

Wyoming/northern Utah incorporates a diverse spectrum of geology, topography, soils, and climate. Land use is predominantly range and forest but an increasing number of industries are locating in the southern half of the drainage. The application of a multiple regression model was used to associate various riparian and nonriparian attributes with previous measurements of $\mathrm{P}, \mathrm{N}$, and dissolved solids in the Green River system. Possible reasons for significant water quality/basin attribute associations are proposed. Some of the advantages and disadvantages of using such a technique to explore those associations are explained.

[HYDROLOGY; NON-POINT SOURCE

POLLUTION; WATER QUALITY]

532. Fatooh,J; Halford,A; Pollini,J (1994): Fish slough: From ancient wetland to community stewardship. p.83-88. In: Summit showcase displays and ecosystem case studies. USDI Bureau of Land Management Summit. Incline Village, NV. April, 1994.

At Fish Slough Area of Critical Environmental Concern, north of Bishop, California, interagency collaboration, along with public involvement, has produced a managed landscape that exemplifies broad-based stewardship of public land. [COLLABORATION; RIPARIAN HABITAT; STEWARDSHIP; WETLANDS]

533. Fenner,P; Brady,WW; Patton,DR (1985): Effects of regulated water flows on regeneration of Fremont cottonwood. Journal of Range Management 38(2), 135-138.

The reduction in extent of riparian forests in the southwestern United States has been a topic of recent concern. The effect of dams on downstream river 
flow and the consequent modification of the riparian habitat was studied along the lower Salt River in central Arizona. Dams were found to change the magnitude of river flows and change the timing of flows in such a way that the habitat appeared less adapted for regeneration of Fremont cottonwood. Modification of river flow patterns, therefore, appears likely to have been a significant factor causing change in vegetation along the Salt River. [COTTONWOOD; DAMS; RIPARIAN HABITAT; STREAM FLOW]

\section{Ferguson,BK (1987): Environmental patterns of water management. Journal of Environmental Systems 16(3), 161-178.}

This article attempts to provide a framework for understanding what a range of water management steps are trying to do and the approaches available for doing it. The framework is built upon previously suggested concepts of "landscape ecology, which sees the hydrologic landscape as a combination of surface, soil, groundwater, atmospheric and cultural "mantles" in which different types of hydrologic processes occur. Major aspects of the framework are the types of functions that management steps perform and the types of environments in which they are practiced. Uses of water demand that water have specific characteristics of quality, time, quantity, and place.

[HYDROLOGY; WATER RESOURCE MANAGEMENT]

535. Ferren,Jr.,WR; Fiedler,PL; Leidy,RA (1996): Wetlands of California, Part 1: History of wetland habitat classification. Madrono 43(1), 105-124.

This review of the history of vegetation classification in California reveals a serious underestimation of the diversity, extent, and functions of the state's wetlands and a misrepresentation of the perceived paucity of wctlands in the arid West. The classification systems of California's wetlands is reviewed beginning with early cfforts in vegetation typing by the USDA Forest Service. A comprehensive methodology for classifying and describing wetlands is required before they can be adequately protected and managed. [CLASSIFICATION; RIPARIAN HABITAT; WETLANDS]

536. Ferren,Jr.,WR; Fiedler,PL; Leidy,RA; Lafferty,KD; Mertes,LAK (1996): Wetlands of California, Part II: Classification and description of wetlands of the central and southern California coast and costal watersheds. Madrono 43(1), 125-182.

The modified Cowardin et al. (1979) classification is described which provides a methodology to identify all wetlands along the central and southern California coast and in the adjacent coastal watersheds. Use of classification tables in association with concepts of ecosystem context. site scale, and classification goals was intended to result in the development of a code (wetlands type number) that include information on the: 1) system, subsystem, class, and subclass; 2) water regime and water chemistry; 3 ) hydrogeomorphic unit; and substrate, dominance, or characteristic type of the wetland in question. [CLASSIFICATION; RIPARIAN HABITAT; WATERSHED; WETLANDS]

537. Field,DR; Lee,ME; Martinson,K (1985):

Human behavior and recreation habitats:

Conceptual issues. p.227-231. In: Johnson, RR;

Ziebell,CD; Patton DR; Ffolliott,PF; Hamre,RH [tech. coord.]. Riparian ecosystems and their management: Reconciling conflicting uses. 16-18 April 1985. Tucson, AZ. USDA Forest Service. General Technical Report RM-120.

Individual recreation behavior and recreation experience are more often than not determined by three sets of factors: the social group within which an individual participates, including the mix of social groups occupying a specific recreation place; the biological or physical characteristics of that place; and the management prescriptions applied there. Human ecological principles, along with concepts used to classify recreation habitats according to the recreation opportunities they provide, form the conceptual framework for this paper.

[HUMAN IMPACTS; RECREATION IMPACTS; RIPARIAN HABITAT]

538. Filip,GM; Bryant,LD; Parks,CA (1989): Mass movement of river ice causes severe tree wounds along the Grande Ronde River in northeastern Oregon. Northwest Science 63(5), 211-213.

Lateral movement of river ice across the floodplain caused large wounds on tree stems (mountain alder) and direct mortality of shrubs or indirect mortality through wounding and subsequent infection by canker fungi. The ages of wounds indicated a 20 to 30 year period between river-ice events.

[HYDROLOGY; RIPARIAN FOREST; RIVER ECOLOGY; STREAMBANK STABILITY] 
539. Finch,D; Marshall,RM (1993): Bird use of riparian habitats in north-central Arizona during fall migration - results and recommendations. p.212-218. In: Tellman,B; Cortner,HJ; Wallace,MG; DeBano,LF; Hamre,RH [tech. coord.]. Riparian management: Common threads and shared interests. USDA Forest Service. General Technical Report RM-226.

The two most important factors governing capture rate of birds were seasonal timing and net placement within the study site. Migration periods for neotropical birds varies annually as a result of the length and timing of the breeding season and weather patterns during the fall. The authors recommend that fall migration studies be started in early August and run through the end of September.

[AVIAN ECOLOGY; NEOTROPICAL BIRDS; RIPARIAN HABITAT]

540. Finch,DM (1985): A weighted-means ordination of riparian birds in southeastern Wyoming. p.495-498. In: Johnson, RR; Ziebell,CD; Patton,DR; Ffolliott,PF; Hamre,RH [tech. coord.]. Riparian ecosystems and their management: Reconciling conflicting uses. 16-18 April 1985. Tucson, AZ. USDA Forest Service. General Technical Report RM-120.

Variation among habitat associations of 31 riparian bird species in southeastern Wyoming was analyzed using a weighted-means ordination. Three principal components explained 86.7 percent of the variation among habitat associations of bird species. Components showed high positive loadings for variables associated with canopy, shrub size, and vegetation height.

[AVIFAUNA; RIPARIAN HABITAT]

541. Finch,DM (1986): Similarities in riparian bird communities among elevational zones in southeastern Wyoming. p.105-109. In:

Proceedings of the 1986 Wyoming water and streamside zone conference. 28-30 April 1986. Casper, WY.

At elevations of $6740-9800 \mathrm{ft}$ in southeast Wyoming, bird species diversity ranged from a low of 3 bird species and 29 pairs in subalpine shrub willow habitat to a maximum of 21 species and 101 pairs in lowland cottonwood habitat. Higher elevations had less diverse bird communities probably because of increased environmental severity and reduced vegetational complexity. Despite loss of tree overstory, bird species composition on mid-elevation shrub sites was more similar to lowland cottonwood habitats than to subalpine shrub areas. Similarity in bird species composition was greatest within elevational zones. Management recommendations are offered.

[AVIAN ECOLOGY; RIPARIAN HABITAT]

542. Finch,DM (1988): Bird-habitat relationships in subalpine riparian shrublands of the central Rocky Mountains. p.167-172. In: Management of subalpine forests: Building on 50 years of research. Troendle,CA. Kaufmann,MR, Hamre, RH [tech. coords.]. USDA Forest Service. General Technical Report RM-149.

The author examined associations between bird abundance, habitat structure measured at random sites, and habitat measured at bird locations in subalpine riparian shrublands. The subalpine riparian avifauna were depauperate with only four abundant species-- song sparrow, white-crowned sparrow, Lincoln's sparrow and Wilson's warbler. Habitat requirements overlapped among these species but differed significantly from randomly-sampled habitat in the same areas. Results indicated that species preferred densely-foliated ground and shrub layers, and higher effective vegetation height.

[AVIFAUNA; BIODIVERSITY; RIPARIAN HABITAT]

543. Finch,DM (1989): Habitat use and habitat overlap of riparian birds in three elevational zones. Ecology 70(4), 866-880.

The low elevation riparian habitat provides a broader more complex resource base than higher elevation riparian habitats. Over all sites, zone-independent bird species were generalists and zone-dependent species were more often habitat specialists. On a site-by-site basis, however, some high elevation specialists were generalists for their sites, and some zone generalists were in fact specialists within a particular site. Avifauna diversity in western and Rocky Mountains riparian sites is not saturated, indicating that the Great Plains region still offers a barrier to western dispersal.

[AVIFAUNA; BIODIVERSITY; RIPARIAN ECOLOGY; RIPARIAN HABITAT]

\section{Finch,DM (1996): Research and} management of soil, plant, animal, and human resources in the Middle Rio Grande Basin. p.69-76. In: Shaw,DW; Finch,DM [tech. coord.]. Desired future condition for Southwestern riparian ecosystems: Bringing interests and concerns together. USDA Forest Service. General Technical Report RM-GTR-272.

The Rocky Mountain Forest and Range 
Experiment Station initiated a research program in 1994 that is funded by an Ecosystem Management grant from USDA Forest Service Research. Its mission focuses on the development and application of new knowledge to sustain ecological systems and human populations in the Middle Rio Grande Basin. Research studies emphasize upland ecology and management, linkages between watersheds and riparian zones, sensitive fish and wildlife populations and species of concern, and past and present cultural resources.

[RFSFARCH; RIO GRANDF; RIPARIAN HABITAT; RIPARIAN MANAGEMENT ZONE; SUSTAINABILITY]

545. Findley,J (1984): Riparian monitoring using large scale infra-red aerial photography in southeastern Oregon. p.13-17. In: Bedell,TE [ed.]. Proceedings of 1984 Pacific Northwest range management short course; Range watersheds, riparian zones and economics: Interrelationships in management and use. 25-27 January 1984. Pendleton, OR. Oregon State University.

Large scale color infra-red aerial photography is being used by the BLM in Vale, Oregon to monitor effects of management on selected riparian habitat. Approximately 130 miles of stream have been photographed at a scale of 1:2000, with repeat photography to be acquired on a five or ten year cycle. Measurements were made to determine existing cover of perennial woody and herbaceous cover in the riparian zone. Changes in cover over time will determine subsequent management actions. Other measurements including bank and stream channel stability/instability may also be made. [AERIAL PHOTO; MONITORING; RIPARIAN HABITAT]

546. Fisher,HM; Thomas,AE (1990): Riparian communities: An annotated bibliography of ecosystem and management topies with emphasis on the Intermountain Region. Idaho BLM Technical Bulletin 90-7. USDI Bureau of Land Management. Boise, ID.

This bulletin updates two previous bibliographies (1986 and 1988) published by Idaho BLM. It contains 234 publications appearing in the years 1990 and earlier. Each cited article/paper/technical note is accompanied by a brief abstract of the citation, the authors, the publication source, and key words or phrases.

[BIBLIOGRAPHY; RIPARIAN HABITAT]

\section{Fisher,SG; Grimm,NB; Marti,E; Gomez,R}

(1998): Hierarchy, spatial configuration, and nutrient cycling in a desert stream. Australian Journal of Ecology 23, 41-52.

Recent studies of nutrient cycling in Arizona suggest that a thorough understanding requires a spatially explicit, hierarchical approach. Physical configurations determine the path that water follows as it moves downstream. Water follows flow paths through surface stream components, the hyporheic zone beneath the surface stream and the parafluvial (sand bar) zone. Characteristic biogeochemical processes in these subsystems alter $\mathrm{N}$ species in transport, in part as a function of available concentration of $\mathrm{N}$ species. At several hierarchical levels, substrate materials are an important determinant of nitrogen dynamics in desert streams. [HYDROLOGY; NUTRIENT CYCLES; RIPARIAN HABITAT]

548. Flanagan,LB; Ehleringer,JR; Dawson, TE (1992): Water sources of plants growing in woodland, desert, and riparian communities: Evidence from stable isotope analysis. p.43-47. In: Clary,WP; McArthur,ED; Bedunah,D; Wambolt,CL [comp.|. Proceedings - Symposium on ecology and management of riparian shrub communities. USDA Forest Service. General Technical Report INT-289.

Analysis of the ratio of deuterium to hydrogen in stem xylcm water can be used to determine the water sources used by individual plants. Because the potential water sources for plants often have different isotopic compositions, the composition of stem water reflects the composition of watcr taken up by the roots. In riparian communities, small trees used either stream water or summer precipitation, depending on location. Large trees used subsurface groundwater exclusively, regardless of location relative to stream. [CLASSIFICATION; ISOTOPE ANALYSIS; RIPARIAN HABITAT; WATER SOURCES]

549. Fleming,CM; Kunkle,SH; Flora,MD (1996): Riparian wetlands and visitor use management in Big Bend National Park, Texas. p.212-215. In: Shaw,DW; Finch,DM [tech. coord.]. Desired future conditions for Southwestern riparian ecosystems: Bringing interests and concerns together. USDA Forest Service. General Technical Report RM-GTR-272.

Wetlands and riparian habitats constitute a small but nonetheless vital component in the Chihuahuan Desert. Big Bend National Park encompasses 801,000 acres, of which 27,000 acres is wetland. The Park has riparian or wetland habitat distributed 
around 315 water sources, some perennial streams, and along 118 miles of the Rio Grande Corridor. These areas contain unique vegetation components, which provide habitats for wildlife, including resident and migratory birds. The same habitats have become increasingly popular as overnight campsites for rafters and boaters on the Rio Grande, or serve as water stops and destination points for back country hikers/campers. The paper summarizes these impacts and appropriate park management responses/actions. [PARK MANAGEMENT; RECREATION IMPACTS; RIPARIAN HABITAT; RIPARIAN MANAGEMENT ZONE]

550. Fleming,G; Kadhimi,AA (1982): Sediment modeling and data sources a compromise in assessment. p.251-259. In: Proceedings of the Exeter symposium, July 1982. Recent developments in the explanation and prediction of erosion and sediment yield. IAHS Publication No. 137.

The major problem in modeling sediment erosion, transport and deposition for the assessment of sediment yield is the shortage of reliable data with which to develop and test the desired model. This limitation of data source restricts the modeler in selecting the appropriate theory to describe a model structure that accounts for the correct interaction between processes contributing to the sediment yield of drainage basins. It also restricts the application of developed models in their practical design application. Compromises must always be made before models can be usefully employed in sediment yield assessment for water resource system design.

[GEOMORPHOLOGY; MODELING; SEDIMENT TRANSPORT; SOILS]

551. Flessncr,TR; Davis,DC; Lambert,SM (1992): Seed source evaluation of four native riparian shrubs for streambank rehabilitation in the Pacific Northwest. p.155-162. In: Clary,WP; McArthur,ED; Bedunah,D; Wambolt,CL [comp.]. Proceedings - Symposium on ecology and management of riparian shrub communities. USDA Forest Service. General Technical Report INT-289.

Forty-six to 72 populations of the four deciduous shrubs: Sitka alder, Pacific serviceberry, oceanspray, and vine maple are being evaluated at the Corvallis, Oregon plant materials center. Morphological traits of each population, such as growth rate, fruit/flower abundance, vigor, foliage appearance, phenology, and form are being tested. Successful clones or seed sources will be released as cultivars.
[PLANT MATERIALS; RIPARIAN

RESTORATION; RIPARIAN SHRUBS]

552. Fletcher,HC; Rich,LR (1955): Classifying southwestern watersheds by their water yields. Journal of Forestry 53(3), 196-202.

Annual water yield from southwestern watersheds are more affected by elevation, soil, temperature, and prevailing precipitation than from other areas. Topography and vegetation are other factors affecting water yield which may be primary in classification of these watersheds.

Evapotranspiration by vegetative cover may also be effective in classifying those areas.

[CLASSIFICATION; HYDROLOGY; WATER

YIELD; WATERSHED]

553. Fletcher,SW (1986): Planning and evaluation techniques for replacement of complex stream and wetland drainage systems. p. 195-200. In: Proceedings of the 1986 national meeting of the American Society for Surface Mining and Reclamation. 17-20 March 1986. Jackson, MS.

Restoration of some lands to pre-mining conditions is becoming a required action. A methodology for determining environmental and ecological parameters is described. Existing systems are characterized and hydrological/soil/vegetational profiles are developed for each community type and stream reach. Post-mining requirements and attributes are matched to pre-mining conditions to develop the conceptual plan. The reclaimed complex is then designed in a series of iterative steps to allow reestablishment of each profile until optimal configuration is reached. Unit boundary and stable channel dimensions are defined. Flow barriers, contouring, etc., are designed. Backwater analysis and other standard methods may be used to evaluate hyperperiod conditions for various flow regimes, to provide balanced systems without further subsidies or manipulation.

[HYDROLOGY; MINING IMPACTS; RIPARIAN RESTORATION]

554. Floyd,D; Ogden,P; Roundy,B; Ruyle,G; Stewart,D (1988): Improving riparian habitats. Rangelands 10(3), 132-134.

The article briefly describes two Arizona grazing allotments where the authors claim that rotational grazing and sensitivity to the riparian habitat values have resulted in greatly enhanced riparian habitats. [GRAZING IMPACTS; RIPARIAN ENHANCEMENT; RIPARIAN HABITAT; SOUTHWESTERN DESERT STREAMS] 
555. Fogel,MN; Ffolliott,PF (1985): Evaluating effects of management on riparian ecosystems. p.384-388. In: Johnson,RR; Ziebell,CD; Patton,DR; Ffolliott,PF; Hamre, RH |tech. coord.|. Riparian ecosystems and their management: Reconciling conflicting uses. 16-18 April 1985. Tucson, AZ. USDA Forest Service. General Technical Report RM-120.

Computer simulation of the hydrologic processes and biomass production was used to assess the effects of management to determine whether such actions were a deterrent to desertification of riparian ecosystems. This approach allowed the evaluation to be made prior to implementation of these actions. [MODELING; RIPARIAN HABITAT; RIPARIAN MANAGEMENT ZONE]

556. Fonseca,J (1993): A county government perspective. p.22-24. In: Tellman,B; Cortner,HJ; Wallace,MG; DeBano,LF; Hamre,RH [tech. coord.|. Riparian management: Common threads and shared interests. USDA Forest Service. General Technical Report RM-226.

The Federal Government would have difficulty imposing riparian habitat protection measures on an unwilling local community. Moreover, many federal laws are at cross-purposes. In Pima County, Arizona, a "wonderful" riparian habitat has been created by the discharge of municipal effluent into the Santa Cruz River. Besides sustaining bird habitat and vegetation, the effluent has also helped to clog the channel, causing protests from downstream floodplain farmers. Local communities can accomplish riparian objectives even without consensus or federal program support.

[EFFLUENTS; FLOODPLAIN MANAGEMENT; REGULATIONS; RIPARIAN HABITAT]

557. Foote,AL (1988): Effects of wave energy on plant establishment in shallow lacustrine wetlands. p.115-119. In: Mutz,KM; Cooper,DJ; Scott,ML; Miller,LK [eds.]. Restoration, creation, and management of wetland and riparian ecosystems in the American West. Symposium. 14-16 November 1988. Denver, CO. Rocky Mountain Chapter of the Society of Wetland Scientists. 293 p.

Studies address effects of wave action on sediment resuspension, seed bank redistribution and survival of tubers in shallow wave-washed wetlands. [EMERGENT VEGETATION; LACUSTRINE ECOLOGY; RIPARIAN HABITAT; SEED BANK]

558. Forchhammer,NC (1999): Production potential of aquatic plants in systems mixing floating and submerged macrophytes. Freshwater Biology 41:183-191.

Floating and submerged plants were grown together to investigate whether the areal production of aquatic plant systems can be increased. Maximum production was not enhanced by this strategy. [AQUATIC ECOSYSTEMS; AQUATIC PLANTS]

559. Forster,DL; Bardos, CP; Southgate, DD (1987): Soil erosion and water treatment costs. Journal of Soil and Water Conservation 42(5), 349-352.

The relationship between communities' water treatment costs and soil erosion is estimated. Independent variables, other than soil erosion, used in the analysis included treatment plant size, storage time of untreated water, and turbidity improvement due to water treatment. Results indicate that a 10 percent reduction in annual gross soil erosion results in a 4 percent reduction in annual water treatment costs. For the test communities, reduced annual water treatment costs would total $\$ 2.7$ million, with a 25 percent reduction in soil erosion.

[EROSION; WATER QUALITY; WATER TREATMENT; WATERSHED]

560. Fort,DD (1993): The protection of riparian areas: New approaches for new times? p.70-75. In: Tellman,B; Cortner,HJ; Wallace,MG; DeBano,LF; Hamre, RH [tech. coord.]. Riparian management: Common threads and shared interests. USDA Forest Service. General Technical Report RM-226.

This paper contains an appraisal of the opportunities for and barriers to riparian protection and restoration, especially relating to current and future public policy. State, federal, and tribal entities require assistance for the improvement of management of riparian areas. New partnerships and management models have enormous potential for intensificd riparian protection.

[POLICY; RIPARIAN HABITAT; RIPARIAN MANAGEMENT ZONE; WATER RESOURCE MANAGEMENT]

561. Fouty,S (1998): Stream channel morphological response to reductions in grazing pressures. p.97. In: Potts,DF [ed.]. Rangeland management and water resources: Proceedings of the AWRA specialty conference. American Water Resources Association. 27-29 May 1998. Reno, NV.

Reductions in elk and livestock grazing 
pressures were studied in the White Mountains in Arizona to determine short-term rates, magnitudes, locations, and directions of change in stream channel morphology. Results indicate that there is an adjustment period during which a channel may continue to widen even after all grazing pressure is eliminated. Thus, livestock grazing strategies which rest riparian pastures for less than three years do not provide adequate time for channel narrowing and pool development to occur.

[CHANNEL DYNAMICS; ELK GRAZING; EXCLOSURES; GRAZING IMPACTS; LIVESTOCK EFFECTS]

562. Fowler,R (1990): Grazing management heads Colorado range in right direction.

Rangelands 12(6), 308-312.

The Cathedral Bluffs Allotment in western Colorado has shown excellent improvement since 1978. Constant monitoring of use and moving of livestock has been critical to proper use of riparian and upland ranges on the unit.

[GRAZING IMPACTS; GRAZING TREATMENTS; MONITORING]

563. Fox,JD (1989): Simulating vegetation-water yield relations in interior Alaska. p.179-189. In: Alexander, FB [ed.]. Proceedings of Watershed '89: A conference on the stewardship of soil, air, water resources. USDA Forest Service. Juneau, AK.

The paper introduces a model for predicting spring runoff in cold climates. The model incorporates interactions among snowmelt and soil infiltration capacity. The former is affected by all factors influencing the snow pack energy balance and the latter is affected by soil texture, autumn soil moisture, snow pack depth and air temperature, all of which determine soil freezing and thawing. The study hypothesized that runoff will increase after timber harvest, not only due to increased snowmelt rates and decreased transpiration, but also due to fall soil moisture and subsequent formation of concrete frost.

[HYDROLOGY; MODELING; WATERSHED]

564. Fox,K (1977): Importance of riparian ecosystems: economic considerations. p.19-22. In: Johnson,RR; Jones,DA [tech. coord.]. Importance, preservation, and management of riparian habitat: A symposium. 9 July 1977. Tucson, AZ. USDA Forest Servicc. General Technical Report RM-43.

The initiative to prescrve riparian habitat must consider man's growing demands to put this area to other uses. Economic pressures which are at conflict with the environmental concerns, pose an inevitable problem to vegetation and wildlife. Compromises in the balance of preservation and development must be maintained.

[RIPARIAN HABITAT]

565. Fraas,WW; Wambolt,CL; Frisina,MR (1992): Prescribed fire effects on a bitterbrush mountain big sagebrush - bluebunch wheatgrass community. p.212-216. In: Clary,WP;

McArthur,ED; Bedunah,D; Wambolt,CL [comp.]. Proceedings - Symposium on ecology and management of riparian shrub communities. USDA Forest Service. General Technical Report INT-289.

Eight years after burning, effects on bitterbrush, mountain big sagebrush, and bluebunch wheatgrass were measured. Bitterbrush density did not differ between burned and unburned sites, while bitterbrush canopy cover, flower production, and seed production were less on the burned sites. Big sagebrush canopy cover and density were less on the burned sites. Total herbaceous cover did not differ between sites.

[BITTERBRUSH; FIRE IMPACTS; PLANT COMMUNITIES; RIPARIAN HABITAT; SAGEBRUSH]

566. France, RL (1997): Potential for soil erosion from decreased litter fall due to riparian clearcutting: Implications for boreal forestry and warm- and cool-water fishes. Journal of Soil and Water Conservation 52(6), 452-455.

Riparian stands around 10 Ontario lakes, clearcut 4 to 10 years previously, were found to produce only 60 percent of the litter fall of nearby uncut riparian forests. As a result of this decrease in protective ground cover, the retention of organic duff within deployed mesh-bags was significantly reduced in clear-cut riparian zones. A rainfall simulation experiment further suggested that the erosion of sandy loam can be twice as great under litter fall conditions representative of clear-cut, compared to forested shorelines. A return to a policy that prevents timber harvesting around lakes that contain percid and esosid sport fish is recommended.

[FISHERIES; LOGGING IMPACTS; RIPARIAN HABITAT; SOILS]

567. France,RL; Peters, RH (1995): Predictive model of the effects of lake metabolism of decreased airborne litter fall through riparian 
deforestation. Conservation Biology 9(6), 1578-1586.

The importance of airborne allochthonous litter to the carbon and nutrient budgets of lakes has been seldom studied. These studies suggest that terrestrial litter can contribute up to 15 percent of the total carbon supply to oligotrophic lakes and up to 10 percent of the total phosphorous supply to lakes with a large surface area relative to that of their drainage basin. Results were incorporated into a simple model that predicts that removal of shoreline trees could increase the ratio of plankton production to respiration in oligotrophic lakes situated within small drainage basins. Such lakes may therefore shift from allotrophy to autotrophy following riparian deforestation.

[MODELING; NUTRIENT CYCLES; RIPARIAN FOREST; RIPARIAN HABITAT]

568. Franz,C; Rodgers,JD; Dodd,JL; Smith,MA; Siekert,RE; Skinner,DQ (1987): Influence of grazing on root biomass and soil texture associated with an ephemeral stream in Wyoming. Abstracts. 40th annual meeting, Society for Range Management.

[GRAZING IMPACTS; RIPARIAN VEGETATION; SOILS]

569. Frasier,G; Kidwell,MR; Weltz,MA; Yakowitz,DS; Fox,HD (1998): Assessing rangeland health with a multi-attribute decision support system. p.99. In: Potts,DF [ed.]. Rangeland management and water resources: Proceedings of the AWRA specialty conference. 27-29 May 1998. Reno, NV.

A structure is presented for determining rangeland health. The methodology was applied to six small watersheds within the Santa Rita Experimental Range in southern Arizona. Rangeland health is the product of summing the results from three functional categories: watershed function and soil stability, distribution of nutrient cycling and energy flow, and recovery dynamics. There were seventeen individual altributes, allocated to one or more of these categories. A simple algorithm based on linear and dynamic programming principles implemented in a computer spreadsheet allows one to quickly compute the possible range of overall site ratings from high to low. There is a hierarchical arrangement of the individual attributes. This decision tool is useful for examining land areas from numerous, often conflicting, decision making viewpoints or by multiple decision makers. [ASSESSMENTS; DECISION SUPPORT
SYSTEMS; EVALUATION; RANGE MANAGEMENT; RANGELAND HEALTH]

570. Frasier,GW; Trlica,MJ; Leininger,WC; Pearce,RA; Fernald,A (1998): Runoff from simulated rainfall in two montane riparian communities. Journal of Range Management 51(3), 315-322.

Riparian ecosystems are the final terrestrial zone before runoff enters a stream. They provide the last opportunity to decrease non-point pollution delivery to streams by removing sediments from overland water flow from uplands and roads. In simulated rainfall trials, several runoff parameters had characteristics of runoff from water repellent soils. The organic layer on the soil surface exhibited signs of water repellency that reduced the water infiltration rate during the initial stages of a rainfall simulation. These results suggest that runoff and infiltration processes in the surface organic horizon of riparian zones may not respond in the classical manner. This characteristic has important implications if criteria developed in areas with less organic matter on the soil surface are used to manage overland flow. No differences in time to runoff initiation could be attributed to vegetation height. [GRAZING IMPACTS; RUNOFF; SEDIMENTATION]

571. Frasier,GW; Weltz,M; Weltz,L (1998): Rainfall simulator runoff hydrograph analysis. Journal of Range Management 51(5), 531-535.

For more than 50 years, rainfall simulators have been used to evaluate hydrologic parameters. Complexity and interaction of site factors on runoff and infiltration processes have made it difficult to isolate and identify single components of the hydrograph that accurately characterize the entire runoff event. This technical note describes a tcchnique that was developed to separate the runoff hydrograph into segments representative of different portions of the flow event. Segment groupings are analyzed for treatment and/or site factor differences or influences on the runoff. This has allowed a more detailed interpretation of the runoff and infiltration processes and makes it possible to quantitatively assess differences in rainfall simulator runoff results and provide insight into hydrograph inconsistencies. [HYDROLOGY; INFILTRATION; MODELING: RUNOFF]

572. Friedman,J; Osterkamp,WR; Scott,ML; Auble,GT (1997): Regional pattern in response of riparian forest to water management in the Great 
Plains. In: Proceedings of the Society of Wetland Scientists. 18th annual meeting. Restoration and Management Notes 16(1):92.

Artificial water management has caused proliferation of cottonwood, salt-cedar, and willow populations in the southern and western plains, while reproduction in the northern and eastern plains has been reduced. Differences in the channels found in these areas react oppositely to controlled water regimes. Shallow channels of the southern and western plains consist of coarse-grained sediment. Reduced flows result in greater buildups of silt, which allows these species to establish. In the northern and eastern plains, streams are slower and more meandering and are not as prone to establishment by woody plants because of reduced flow rates and subsequent erosion.

[CHANNEL MORPHOLOGY; RIPARIAN FOREST; RIPARIAN SHRUBS; STREAM FLOW; WATER REGIMES]

573. Friedman,JM; Auble,GT; Scott,ML (1994): Geomorphic requirements for establishment and maintenance of cottonwood forest. p.80-88. In: Proceedings of the 46th annual meeting of the Forestry Committee, Great Plains Agricultural Council. 20-23 June 1994. Manhattan, KS.

The relation between streamflow and establishment of bottomland trees is conditioned by the dominant fluvial process(es) acting along a stream. Plains cottonwood requires bare, moist surfaces protected from disturbance for successful establishment. Channel narrowing, channel meandering, and flood deposition promote different spatial and temporal patterns of establishment. Floods, sediment deposition, and channel change are essential for establishment of disturbance-dependent species like plains cottonwood. Managers need to be aware that they cannot have both a channelized, regulated stream and a naturally reproducing stand of plains cottonwood.

[COTTONWOOD; GEOMORPHOLOGY; RIPARIAN FOREST; STREAM FLOW]

574. Frissell,CA; Liss, WJ; Warren,CE; Hurley,MD (1986): A hierarchical framework for stream habitat classification: Viewing streams in a watershed context. Environmental Management 10(2), 199-214.

This article presents a framework for a hierarchical classification system, entailing an organized view of spatial and temporal variation among and within stream systems. Stream habitat systems, defined and classified on several spatiotemporal scales, are associated with watershed geomorphic features and events. Variables selected for classification define relative long-term capacities of systems, not simply short-term states. Streams and their watershed environments are classified within the context of a regional biogeoclimatic landscape classification. The framework is a perspective that should allow more systematic interpretation and description of watershed-stream relationships. [CLASSIFICATION; GFOMORPHOLOGY; RIPARIAN HABITAT; SPATIAL SCALE; WATERSHED]

575. Frissell,CA; Nawa,RK (1992): Incidence and causes of physical failure of artificial habitat structures in streams of western Oregon and Washington. Journal of Fisheries Management 12, 182-197.

Increasing shares of fishery management resources have been committed in recent years to alteration of fish habitat with artificial stream structures. The authors evaluated rates and causes of physical impairment or failure for 161 fish habitat structures following a flood of a magnitude that recurs every 2-10 years. The median failure rate was 18 percent and the median impairment rate was 60 percent. Results suggest that commonly prescribed structural modifications are often inappropriate and counterproductive in streams with high or elevated high peak flows, or highly erodible bank materials. Large-scale restoration will require reestablishment of natural watershed and riparian processes. [FISHERIES; RIPARIAN HABITAT; RIPARIAN RESTORATION; WATERSHED]

576. Fukushima,L; Lesh,EW (1998): Adult and juvenile anadromous salmonid migration timing in California streams. California Fish and Game 84(3), 133-145.

The peak spawning migration for most species of salmonids is in fall and winter. Most chinook salmon smolts outmigrate in spring and summer. Coho salmon smolts outmigrate from March to July and usually peak between mid-April and mid-May. Probably the most important environmental factor affecting the timing for both returning adult salmon migration and smolt outmigration is the condition of the river mouth and the amount of runoff from rainfall. Many small coastal streams are entirely closed by sandbars that build across the mouths during periods of low rainfall and mild summer ocean conditions. In studies, first major upstream migrations coincide with large increases in stream flow. Heavy rainfall and subsequent runoff removes 
the bar and provides an opening for migrating fish. Runoff may also provide olfactory clues to attract adult salmon into the stream. Heavy runoff also serves to flush smolts through an estuary into the ocean.

[MIGRATION; RUNOFF; SALMONIDS; SPAWNING HABITAT]

577. Funk,R (1993): Rio Grande Valley State Park. p.159-161. In: Tellman,B; Cortner,HJ; Wallace,MG; DeBano,LF; Hamre, H [tech. coord.|. Riparian management: Common threads and shared values. USDA Forest Service. General Technical Report RM-226.

The Rio Grande Valley State Park in New Mexico was created in 1983 to preserve and improve the natural character of the river and bosque, while allowing low impact recreation. The Open Space program of the City of Albuquerque was designated as the operating party. As a first step, clean up and motor vehicle closure resulted in an immediate reduction in dumping and other illegal activities. At the same time, recreational activities increased. Fire and exotic species invasion continue to be problems in combination with lack of cottonwood reproduction. Many opportunities exist for improving the Park, as it continues to be a refuge for people and wildlife.

[BOSQUE; RECREATION IMPACTS; RIO

GRANDE; RIPARIAN HABITAT; STATE PARKS]

578. Galbraith,WA; Anderson,EW (1971): Grazing history of the northwest. Journal of Range Management 24(1), 6-12.

This is a historical account of grazing history in the Pacific Northwest from grazing by Indian horses beginning around 1,700 to the introduction of Spanish cattle in 1789 to modern times. In this region, it continues to be one of the major uses of the resource.

[GRAZING IMPACTS; HISTORIC RECORDS]

579. Ganskopp,DC (1978): Plant communities and habitat types of the Meadow Creek Experimental Watershed. MS Thesis, Oregon State University, Corvallis, OR. 162 p.

Objectives of this study were: 1) identify and map an experimental area of Meadow Creek watershed by existing vegetation; and 2) to identify and map the experimental area of Meadow Creek watershed by habitat types. Forty-four riparian communities were delineated by reconnaissance methods. Seventeen plant communities were detected and mapped on upland sites.
[CLASSIFICATION; MICROHABITATS; RIPARIAN HABITAT; WATERSHED]

580. Garbrecht,J; Starks,PJ (1998):

Characterization and implications of inter-annual precipitation variability for central Oklahoma grazing lands. p.385-394. In: Potts,DF [ed.] Rangeland management and water resources: Proceedings of the AWRA specialty conference. American Water Resources Association. 27-29 May 1998. Reno, NV.

The authors suggest that the trends and anomalies of general precipitation can be forecasted with some accuracy up to one year in advance. The benefits to grazing lands management of these general forecasts can be increased by complementary precipitation characteristics at monthly and daily time scales. The existence and possible quantification of systematic trends and distinguishing characteristics in precipitation at smaller time scales is demonstrated in this study for central Oklahoma.

[CLIMATE; PRECIPITATION; RANGE MANAGEMENT]

581. Garcia,B; Williams,RL (1992): The Strawberry Valley Project: A history and initial experiences. p.68-70. In: Proceedings, Intermountain Forest Nursery Association. 12-16 August 1991. Park City, UT.

At this location in central Utah, rehabilitation projects are ongoing since the lands were transferred to the USDA Forest Service and subsequent changes in grazing management were made. The rehabilitation projects included streambank stabilization, installation of gully plugs, and willow plantings.

[GRAZING IMPACTS; RIPARIAN

MANAGEMENT 7ONE; RIPARIAN RESTORATION]

582. Garcia,JC (1985): A method for assessing the value of stream corridors to fish and wildlife resources. p.335-338. In: Johnson,RR; Ziebell,CD; Patton,DR; Ffolliott,PF; Hamre,RH [tech, coord.]. Riparian ecosystems and their management: Reconciling conflicting uses. 16-18 April 1985. Tucson, AZ. USDA Forest Service. General Technical Report RM-120.

Stream Corridor Inventory and Evaluation System (SCIES) provides a method for managers to measure the habitat value of stream corridors and to quantify in explicit terms many complex values and factors. The procedure was developed to have broad applications, to be flexible, to be capable of 
incorporating existing methods and knowledge, and to be comprehensive, easy to use, and verifiable. [FISHERIES; MODELING; RIPARIAN HABITAT]

583. Gay,LW (1985): Evapotranspiration from salt-cedar along the lower Colorado River. p.171-174. In: Johnson,RR; Ziebell,CD; Patton,DR; Ffolliott,PF; Hamre,RH [tech. coord.]. Riparian ecosystems and their management: Reconciling conflicting uses. 16-18 April 1985. Tucson, AZ. USDA Forest Service. General Technical Report RM-120.

During two growing seasons, Bowen ratio evapotranspiration (ET) was measured periodically in a stand of salt-cedar on the lower Colorado River. Annual total ET at this site was estimated to be 1727 mm.

[EVAPOTRANSPIRATION; RIPARIAN HABITAT; SALT-CEDAR; WATER LOSS]

584. Gebhardt,K; Vinson,M; Platts,WS; Jackson,W (1989): Using expert systems in riparian management. p. 187. In: Gresswell,RE; Barton,BA; Kershner,JL [eds.]. Practical approaches to riparian resource management: An educational workshop. 8-11 May 1989. USDI Bureau of Land Management. Billings, MT.

BLM in Idaho has begun a project to develop knowledge based expert systems for riparian management. Project objectives are to provide a means for the riparian expert to store knowledge of management outcomes, to help others to apply the knowledge to other areas, and to help in selecting appropriate monitoring techniques. One expert system is designed to capture knowledge on the causes and effects from management actions. The second is to link the management options to riparian types defined by classification. The third is designed to help users select monitoring techniques. [CLASSIFICATION; MONITORING; RIPARIAN HABITAT; RIPARIAN MANAGEMENT ZONE]

585. Gebhardt,KA (1982): Development of a monitoring program for natural resource management. USDI Bureau of Land Management. Idaho BLM Manual Supplement (4421-Planning the Monitoring Studies).

Monitoring concepts are basic and well-established. Monitoring is a necessary tool for making sound management decisions. The process requires time, thought, and discussion to develop a good monitoring program but dollars saved in the long run are worth the effort. Once the work has been planned, the plan must be implemented.
[HYDROLOGY; MONITORING; WATER RESOURCE MANAGEMENT]

586. Gebhardt,KA (1986): Determining hydrologic properties of soils. USDI Bureau of Land Management Tech. Note 371. Idaho State Office, Boise, ID. 34 p.

[HYDROLOGY; SOILS; TECHNIQUES]

587. Gebhardt,KA; Bohn,C; Jensen,S; Platts,WS (1989): Use of hydrology in riparian classification. p.53-59. In: Gresswell,RE; Barton,BA; Kershner,JL [eds.]. Riparian resource management: An educational workshop. 8-11 May 1989. USDI Bureau of Land Management. Billings, MT.

A general classification scheme for riparian zones is presented based on hydrologic and geomorphic features. Recognizing the dynamic nature of the riparian, a concept of 'state' is introduced as a unit of classification to indicate the responses of a site type to physical impacts. Physical processes that affect soil water regime and erosion resistance can effect 'state' changes. The relative vulnerability and resilience of riparian vegetation may be described in terms of the 'state' of the riparian and the physical processes occurring within. [CLASSIFICATION; HYDROLOGY]

588. Gebhardt,KA; Gebhardt,J; Koonce,G; O'Brien,B; Sweet,S; Tiedmann,RB (1988): Creating wildlife and wetland amenities in an urban environment. p.157-161. In: Mutz,KM; Cooper,DJ; Scott,ML; Miller,LK [eds.]. Restoration, creation, and management of wetland and riparian ecosystems in the American West. Proceedings of the symposium. 14-16 November 1988. Denver, CO. Rocky Mountain Chapter of the Society of Wetland Scientists.

Spring Meadow is a major housing development adjacent to the Boise River on the eastern edge of the city of Boise, Idaho. Spring Meadow was the first subdivision to implement the 1985 river plan guidance. Inventories and Environmental Assessments (EAs) were conducted on the site prior to development. Mitigation and enhancement plans included projects for wetland and stream creation and wildlife habitat creation and enhancement. [CREATED WETLANDS; MITIGATION; RIPARIAN HABITAT; URBAN IMPACTS]

589. Geist,DR; Dauble,DD (1998): Redd site selection and spawning habitat use by fall chinook salmon: The importance of geomorphic features 
in large rivers. Environmental Management 22(5), 655-669.

A conceptual spawning habitat model for fall chinook salmon is presented that describes how geomorphic features of river channels create hydraulic processes, including hyporheic flows, that influence where salmon spawn in unconstrained reaches of large mainstream alluvial rivers. This conceptual model can be combined with traditional models to predict the limits of suitable fall chinook spawning habitat.

[FISHERIES; FISH HABITAT; GEOMORPHOLOGY; MODELING]

590. Genter,DL (1990): The role of riparian habitat in maintaining rare and endangered species. In: Management of riparian and wetland forested ecosystems in Montana. Fourth annual Montana Riparian Association workshop. 5-7 September 1990. Whitefish, MT.

The State of Montana, reflective of a varied topography, climate, geology, and glacial history, has a considerable diversity of habitats. Within the state, there are over 350 major terrestrial plant communities and 105 identified riparian/aquatic communities. Among these vegetative types can be found over 600 species of vertebrate animals. [BIODIVERSITY; RIPARIAN HABITAT]

591. George,H; DeLasaux,M; Mainwaring, $P$ (1998): Monitoring riparian areas with a camera. p.131. Potts,DF [ed.]. In: Rangeland management and water resources: Proceedings of the AWRA specialty conference. American Water Resources Association. 27-29 May 1998. Reno, NV.

A manual and accompanying videos have been developed to enable ranchers to establish their own photo monitoring systems. Riparian photographs are intended to provide a representative view of the actual stream channel, bank, and back vegetation. Photos are taken in several directions to document conditions. This provides a simple methodology that can be readily implemented by ranchers and others.

[GRAZING IMPACTS; MONITORING; RIPARIAN CONDITION; RIPARIAN VEGETATION]

592. George,M; Harper,J; Larson,S; Weitkamp,B; George,H; Jolley,L (1998): Implementing California's rangeland water quality management plan. p. 299-303. In: Potts,DF [ed.]. Rangeland management and water resources: Proceedings of the AWRS specialty conference. American Water Resources
Association. 2729 May 1998. Reno, NV.

The University of California Extension Service and the USDA Natural Resources Service are jointly conducting the Ranch Water Quality Management Planning Short Courses where landowners learn about non-point source pollution, self assessments, develop a water quality plan, and complete a letter of interest.

[EDUCATION; NON-POINT SOURCE

POLLUTION; RANGE MANAGEMENT; WATER QUALITY]

593. Gholz,HL; Hawk,GM; Campbell,A; Brown,AT (1985): Early vegetation recovery and element cycles on a clear-cut watershed in western Oregon USA. Canadian Journal of Forest

Resources 15(2), 400-409.

Aboveground biomass and leaf area, net primary productivity and nutrient cycling through vegetation were studied for 3 years after clear-cutting of a 0.24 ha watershed in the Oregon Cascade Mountains. No correlation was found between plant uptake and nutrient loss in streamflow. Uptake of all elements exceeded return through leaching and litter fall by 16 percent, except that of $\mathrm{Mg}$, which exceeded return by 44 percent. Because of early dominance by annual species, the proportion of elements redistributed internally by vegetation was generally low. The amount of nutrients of flux through vegetation, atmosphere and stream was small in comparison to the amount lost in the removal of tree stems.

[LOGGING IMPACTS; NUTRIENT CYCLES; PRIMARY PRODUCTION; RIPARIAN HABITAT; WATERSHED]

594. Gibbons,DR (1985): The fish habitat management unit concept for streams on national forests in Alaska. p.320-323. In: Johnson, RR; Ziebell,CD; Patton,DR; Ffolliott,PF; Hamre.RH [tech. coord.]. Riparian ecosystems and their management: Reconciling conflicting uses. 16-18 April 1985. Tucson, AZ. USDA Forest Service. General Technical Report RM-120.

The occurrence of alternatives invariably exists between the management of timber and fisheries resources. The concept of Fish Habitat Management Units has been developed on National Forest lands to describe the specific streamside requirements for maintenance and improvement of aquatic resources. Development and management applications are discussed.

[LOGGING IMPACTS; RIPARIAN HABITAT]

595. Gibbons,DR; Salo,EO (1973): An annotated 
bibliography of the effects of logging on fish of the western United States and Canada. USDA Forest Service. General Technical Report PNW-10. 145

p.

This bibliography compiles scientific and topical literature published in the western U.S. and Canada on the effects of logging on fish and aquatic habitat. Included are 278 annotations and 317 total references. Subjects include: erosion and sedimentation, water quality, related influences upon salmonids, multiple logging effects, alteration of stream flow, stream protection, multiple-use management, streamside vegetation, stream improvement, and descriptions of studies on effects of logging.

[BIBLIOGRAPHY; FISHERIES; LOGGING IMPACTS; RIPARIAN HABITAT; RIPARIAN VEGETATION]

596. Gillen,RL; Krueger,WC; Miller,RF (1985): Cattle use of riparian meadows in the Blue Mountains of northeastern Oregon. Journal of Range Management 38(3), 205-209.

Intensity and pattern of cattle use of small riparian meadows were studied by periodically sampling vegetative standing crop and by continuously monitoring meadows with time-lapse photography. Temperature and relative humidity were also measured in riparian and upland plant communities. Herbage standing crop at the end of the grazing season was similar under continuous grazing and the early and late grazing periods of a two pasture deferred-rotation grazing system. Early grazing tended to decrease the cattle occupation and the frequency of cattle occupation of riparian meadows when compared to continuous grazing. Late grazing tended to increase the frequency of cattle occupation but did not change the total cattle occupation of riparian meadows when compared to continuous grazing. Cattle were present on a given meadow site on about 60 percent of all days but for only 3-10 percent of the total daylight period. Cattle occupation of riparian meadows was greater during the afternoon hours.

[GRAZING IMPACTS; GRAZING TREATMENTS; MEADOWS]

\section{Gillilan,DM; Brown,TC (1997): Instream} flow protection. Island Press. Covelo, CA. 427 p.

A comprehensive overview of western water use and the issues that surround it, this book explains instream flow and its historical, political, and legal context. It also describes instream flow laws and policies and present methods of protecting instream flow.

[HYDROLOGY; STREAM FLOW; WATER LAW; WATER RIGHTS]

598. Gilliland,MW; Baxter-Potter,W (1987): A geographic information system to predict non-point source pollution potential. Water Resources Bulletin 23(2), 281-291.

A Geographic Information System (GIS), which utilizes a roster of grid-cell format, was developed to include algorithms associated with non-point pollution. The system accepts digitally mapped information on soil type, topography, and land use. It calculates characteristics such as slope and slope length, and relates these characteristics to soils and land use parameters in order to produce three dimensional maps of runoff potential, and bacterial pollution potential. It has the advantages of retaining the geographic character of pollution potential information and of conveying in graphical terms the effects of topography, soil type, land use, and land management practices.

[GIS; NON-POINT SOURCE POLLUTION; WATER QUALITY]

599. Girard,MM (1985): Native woodland ecology and habitat type classification of southwestern North Dakota. Ph.D. Thesis, North Dakota State University. 331 p.

Native woodlands are a component of the vegetation mosaic of the mixed grass prairie of southwestern North Dakota. Due to a semi-arid climate, these woodlands are restricted to areas of increased moisture: drainage ways, streams, springs, floodplains, north-facing slopes, and "scoria" buttes. A habitat type classification system for these woodlands was developed to provide a framework for future management. The Daubenmire habitat type method was used. A key was developed to identify each type in the field. The characteristics of each habitat and community type are described. [CLASSIFICATION; RIPARIAN HABITAT; RIPARIAN VEGETATION]

600. Glascow,C (1993): Six Rivers National

Forest watershed management and road restoration. p.195-197. In: Tellman,B;

Cortner,HJ; Wallace,MG; DeBano,LF;

Hamre, RH [tech. coord.]. Riparian management:

Common threads and shared values. USDA Forest

Service. General Technical Report RM-226.

Forest roads can dramatically alter natural drainage networks and related physical processes. The primary goal of road restoration is to minimize 
future erosion and mass wasting through removing culverts and outsloping unstable portions of the road. Excavating fill from stream crossings and removing culverts is one of the cost-effective treatments available for reducing sediment input into streams. [RIPARIAN RESTORATION; ROAD IMPACTS; WATERSHED]

601. Glass,S; Thullen,J; Sartoris,J; Roline,R (1996): Albuquerque constructed wetlands pilot project: Summary and status of City of Albuquerque project, September 1995. p.243-252. In: Shaw,DW; Finch,DM [tech. coord.]. Desired future conditions for Southwestern riparian ecosystems: Bringing interests and concerns together. USDA Forest Service. General Technical Report RM-GTR-272.

After imposition of stricter water quality standards, it became necessary to pursue methods to enhance the purity of treated municipal wastewater effluent produced at the Southside Water Reclamation Plant (SWRP). Design has begun for additional facilities to support biochemical processes that effectively reduce nitrogen during wastewater treatment. The present permit contains potential limitations for substances including arsenic, silver, aluminum, and cyanide. The permit also requires that water quality evaluations be completed within three years to provide a foundation for future decisions about the river.

[BIOCHEMICAL PROCESSES; EFFLUENTS; RIO GRANDE; WASTEWATER; WATER QUALITY]

602. Gleick,PH (1998): Water in crisis: Paths to sustainable water use. Ecological Applications 8(3), 571-579.

Crises relating to use and management of freshwater resources are increasing. Some of these are: destruction of aquatic ecosystems and extinction of species, deaths from water-related illnesses and growing conflicts over scarce, shared water supplies. Seven "sustainability criteria" are discussed here as part of an effort to reshape long-term water planning and management.

[AQUATIC ECOSYSTEMS; POLICY;

SUSTAINABILITY; WATER QUALITY]

603. Glimp,HA; Swanson,SR (1994): Sheep grazing and riparian and watershed management. Sheep Research Journal, Special Edition:1994, 65-71.

A critical measure of grazing management success is the functional capacity of rangeland watersheds and riparian ecosystems. It is clear that overgrazing and poorly timed grazing by any livestock species can be detrimental to riparian and watershed resources. However, the literature generally suggests that low to moderate sheep grazing levels at optimum times for the vegetation community are not detrimental. Based on reviews of research and anecdotal experiences, recommended management practices for various sheep grazing systems are suggested.

[GRAZING IMPACTS; GRAZING TREATMENTS]

604. Glinski,RL (1977): Regeneration and distribution of sycamore and cottonwood trees along Sonoita Creek, Santa Cruz County, Arizona. p.116-123. In: Johnson,RR; Jones,DA [tech. coord.]. Symposium on the importance, preservation and management of the riparian habitat. 9 July 1977. Tucson, AZ. USDA Forest Service. General Technical Report RM-43.

The effects of livestock grazing and streambed erosion on the regeneration and distribution of sycamores and cottonwoods were studied. Sycamores reproduced from root and trunk sprouts but cottonwood reproduction was nearly absent in areas grazed by cattle. Cottonwoods were confined entirely to the narrow erosion channel. If this regeneration pattern continues, the future maximum width of the cottonwood forest will decrease by nearly 60 percent. [RIPARIAN HABITAT; RIPARIAN VEGETATION; TREE DISTRIBUTION]

605. Gold,AJ; Jacinthe,PA; Groffman,PM; Wright,WR; Puffer,RH (1998): Patchiness in groundwater nitrate removal in a riparian forest. Journal of Environmental Quality 27, 146-155.

The ability to identify and manage riparian sites for groundwater nitrate removal is limited by uncertainty surrounding the relative importance of plant uptake vs. microbially mediated removal processes. Microcosm studies often demonstrate negligible transformation rates in the subsoil of riparian forests, even in situations where groundwater well networks showed substantial groundwater removal and nitrate removal during the winter and a decline in dissolved oxygen in ambient groundwater moving through the site. The authors hypothesize that microcosm studies may miss groundwater transformations that occur within micro-sites, that is "hotspots" of riparian subsoils. [GROUNDWATER; HYDROLOGY; NUTRIENT CYCLES; RIPARIAN FOREST]

606. Goldman-Carter,JL (1988): Implementing 
Swampbuster: Plowing new ground at USDA. p.106-112. In: Stuber,PJ [tech. coord.]. Proceedings of the national symposium on the protection of wetlands from agricultural impacts. 25-29 April 1988. Ft. Collins, CO. USDI Fish and Wildlife Service. Biological Report 88(16).

During the two years since Swampbuster was passed, the law has not been implemented and has contributed little to wetland conservation. Future implementation will depend upon how strictly Swampbuster is implemented at the local level beyond the 1988 growing season. Congressional oversight, expeditious wetland delineation, strengthening amendments, and adequate agency resources will improve Swampbuster implementation.

[AGRICULTURAL IMPACTS; RIPARIAN HABITAT; WETLANDS]

607. Goldner,BH (1981): Riparian restoration efforts associated with structurally modified flood control channels. p.445-451. In: Warner, E; Hendrix,KM [eds.]. Proceedings of the California riparian systems conference: Ecology, conservation and productive management. University of California. 17-19 September 1981. Berkeley, CA.

The Santa Clara Valley Water District has revegetated flood control channels to benefit wildlife and provide aesthetic improvement. Drought-tolerant ornamental and native riparian species have been planted along channel banks and levees with mixed results. Successful establishment depends mostly on a fixed irrigation system and a well-managed weed abatement program. Densely planted, linear-size rooted cuttings irrigated by overhead sprinklers can reduce both installation and maintenance costs.

[INSTREAM STRUCTURES; RIPARIAN

RESTORATION; VEGETATION

MANAGEMENT]

608. Goldsmith,E; Hildyard, N (1984): The social and environmental impacts of large dams. Sierra Club Books. San Francisco, CA. 404 p.

The authors argue that large scale dams should not be built. They provide a checklist of social and environmental considerations, particularly in regard to major irrigation projects.

[DAMS; IRRIGATION IMPACTS; WATER

RESOURCE MANAGEMENT; WATER

QUALITY]

609. Goldstein,JH (1991): The road to no-net-loss of wetlands. p.73-77. In: Proceedings of the Forum for applied research and public policy. Spring, 1991.

Wetlands have multiple environmental functions, and they have them in varying proportions. If acreage is used as the sole unit of measurement, a loss would be recorded when wetland is degraded. Although conducting the accounting in functional terms has an intellectual basis, implementing the concept has difficulties. Wetland science is not precise and there is no universally accepted method of quantifying wetland functions. The definition of no-net-loss has implications for the manner in which the goal is achieved, the nature of mitigation, and the character of the environment.

[MITIGATION; RIPARIAN RESTORATION; WETLANDS]

610. Gomez,DM; Anthony,RG (1996):

Amphibian and reptile abundance in riparian and upslope areas of five forest types in western

Oregon. Northwest Science 70(2), 109-119.

This paper compares species composition and relative abundance of herpetofauna between riparian and upslope habitats among 5 forest types (shrub, open sapling-pole, large saw timber and old-growth conifer forests, and deciduous forests) in western Oregon. Riparian and upslope associated species were identified based on capture frequencies from pitfall trapping. Species richness was similar among forest types but slightly greater in the shrub stands. The abundances of 3 species differed among forest types. Total captures was highest in deciduous forests, intermediate in mature conifer forests, and lowest in the 2 young coniferous forests. Species richness was between stream and upslope habitats; however, captures were higher in riparian than upslope habitat. The authors suggest that riparian management zones should be at least $75-100 \mathrm{~m}$ on each side of the stream and that management for upslope and/or old forest associates may be equally as important as for riparian species.

[AMPHIBIANS; HERPETOFAUNA; REPTILES; RIPARIAN HABITAT]

611. Gomez,DM; Anthony, RG (1998): Small mammal abundance in riparian and upland areas of five seral stages in western Oregon. Northwest Science 72(4), 293-302.

Species composition and relative abundance of small mammals between riparian and upland habitats among five seral stages in the Coast Range of Oregon were compared to determine the significance of these areas to different species. Riparian and upland associated species were identified based on capture 
frequencies from pitfall trapping. Species richness was similar between stream and upland habitats and among the five seral stages. However, there were significant changes in the abundances of nine small mammal species among seral stages. Total captures were highest in deciduous stands and progressively lower from shrub to old growth coniferous forests. Results indicate that small (second, third, and fourth order) riparian systems and adjacent upland areas provide important habitat for small mammals on the Oregon Coast Ranges.

[RIPARIAN HABITAT; SMALL MAMMALS; UPLAND VEGETATION]

612. Gonzales,P; Gonzales,J (1998): Local communities and partnerships develop common ground in range management and water quality. p.341. In: Potts,DF |ed.|. Range management and water resources: Proceedings of the AWRS specialty conference. American Water Resources Association. 27-29 May 1998. Reno, NV.

Several partnerships in Wyoming to demonstrate that common goals can be achieved in range management and water quality led to the development of the Interpretive Sign Project. These signs were placed along scenic byways to inform visitors and others of the importance of partnerships to the landscape.

[PARTNERSHIPS; RANGE MANAGEMENT; WATER QUALITY]

613. Gonzalez,MA; Sanford,Jr.,RD (1997). Geomorphic perspectives on cottonwood (Populus deltoides) recruitment, regeneration, and decline in the Little Missouri Badlands of North Dakota. p. 95. In: Abstracts. 1997 annual meeting of the Ecological Society of America jointly with The Nature Conservancy. 10-14 August 1997.

Albuquerque, NM.

Recent work in seven small, unregulated, intermittent basins in southwest North Dakota suggests that short-term geomorphological processes provide important controls on cottonwood regeneration. Natural fluvial cycles of channel incision, lateral channel migration, and stream aggradation dictate when and where cottonwoods can regenerate.

[COTTONWOOD; RIPARIAN FOREST; RIPARIAN RESTORATION]

614. Goodell,BC (1965): Watershed treatment effects on evapotranspiration. p.477-482. In: International symposium on forest hydrology. National Science Foundation. Advanced science seminar proceedings. 29 Aug - 10 Sept 1965. Pergamon Press. NY, NY.

Spatial and temporal confluence of water and thermal energy at watershed surfaces controls evapotranspiration. Radiant energy provides the heat source for evapotranspiration (ET). In any vegetation mass on any land area, ET is maximized when plant substance is most uniformly distributed. Canopy interception of precipitation and radiation and transport of soil water to transpiring surfaces are maximized in those circumstances. Any kind of forest manipulation can cause heterogeneity in canopy and root distribution, resulting in a tendency to minimize ET. Persistent discontinuities in the canopy must be produced in order to reduce ET. [HYDROLOGY; WATER RESOURCE MANAGEMENT; WATERSHED]

615. Goodloe,S (1994): Watershed restoration through integrated resource management on public and private rangelands. p.136-140. In: Shaw,DW; Finch,DM [tech. coord.]. Desired future conditions for Pinyon-juniper ecosystems: Proceedings of the symposium. 8-12 August 1994. Flagstaff, AZ. USDA Forest Service. General Technical Report RM-258.

Until recently, much of the rangeland in the western United States was in a serious downward trend. Water quantity and quality were declining as the result of the continuous livestock grazing practices employed at the turn of the century followed by 80 years of fire suppression. Thirty-five years of integrated/holistic resource management at the Carrizo Valley ranch site has reversed this trend. In addition to restoration of rangeland productivity, the riparian area of the ranch has been restored, wildlife populations enhanced, and perennial streamflow restored. The practical experience gained at the ranch should be useful to private landowners, public land managers, and water quality agencies throughout the brittle ecosystems of the southwestern United States.

[GRAZING IMPACTS; RIPARIAN HABITAT; STREAM FLOW; WATER QUALITY; WATERSHED]

616. Goodman,T; Donart,GB; Kiesling,HE; Holochek,JL; Neel,JP; Manzanares,D; Severson,KE (1989): Cattle behavior with emphasis on time and activity allocations between upland and riparian habitats. p.95-102. In: Gresswell,RE; Barton,BA; Kershner,JL [eds.]. Practical approaches to riparian resource management. An educational workshop. 8-11 May 
1989. Billings, MT.

Cattle distribution and behavior were studied in riparian and upland habitats at Fort Bayard in southwest New Mexico. A three-pasture seasonal rotation grazing scheme with a moderate stocking rate was employed after 47 years of no grazing. Habitat use shifted from heavy use on riparian areas during the growing season to virtually no grazing use during the dormant season. Riparian use was also influenced by pasture changes. Riparian observations increased significantly $(\mathrm{P}<0.05)$ during the first data collections in a new pasture. During the dormant season, open-upland and browse-upland were selected. Time spent grazing and distance traveled were greatest during the summer months and least during the winter months.

[GRAZING IMPACTS; GRAZING TREATMENTS]

617. Goodrich,S (1991): Field key to Salix of Utah based on vegetative features. p.71-73. In: Proceedings, Intermountain Forest Nursery Association. 12-16 August 1991. Park City, Utah. USDA Forest Service. General Technical Report RM-211.

A field key to Salix (willows) of Utah based on vegetative features is presented. Thirty species are described.

[FIELD KEY; PLANT IDENTIFICATION; RIPARIAN HABITAT; WILLOW]

618. Goodrich,S (1992): Summary flora of riparian shrub communities of the Intermountain Region with emphasis on willows. p.62-67. In: Clary,WP; McArthur,ED; Bedunah,D; Wambolt,CL [comp.]. Proceedings - Symposium on ecology and management of riparian shrub communities. USDA Forest Service. General Technical Report INT-289.

Management of riparian communities depends on an understanding of the dominant species in different riparian communities. Common plants of riparian communities are discussed briefly. Habitat, distribution, and other descriptors are presented for 24 species of willow.

[RIPARIAN HABITAT; RIPARIAN

VEGETATION; WILLOW]

619. Goodwin,CN; Hawkins,CP; Kershner,JL (1997): Riparian restoration in the western United States: Overview and perspective. Restoration Ecology 5(4), 4-14.

This paper is a historical and conceptual overview of riparian ecosystem restoration. It discusses how riparian ecosystems have been defined, describes the hydrologic, geomorphic, and biotic processes that create and maintain riparian ecosystems of the western U.S., identifies the main types of anthropogenic disturbances occurring in these ecosystems, and provides an overview of restoration methods for each disturbance type. The authors suggest that riparian ecosystems consist of two zones: Zone 1 occupies the active floodplain and is frequently inundated and Zone II extends from the active floodplain to the valley wall.

[ECOSYSTEM MANAGEMENT; RIPARIAN RESTORATION]

620. Gore,JA; Johnson,LS (1979): Biotic recovery of a reclaimed river channel after coal strip mining. p.239-244. In: Swanson, GA [ed.]. The mitigation symposium: A National workshop on mitigating losses of fish and wildlife habitats. USDA Forest Service. General Technical Report RM-65.

A newly constructed channel of the Tongue River, Wyoming, reclaimed with layers of gravel and medium cobble, pine snags, bouldered rip-rap, and rubble piles, was rapidly recolonized with stream invertebrates (70 days). Fish were found only in "snag" areas. Colonization curves predict attainment of a resident fish population in one to two years after channel opening.

[CHANNEL DYNAMICS; FISH HABITAT; RIPARIAN RESTORATION]

\section{Gore,JA; Shields,Jr.,FD (1995): Can large} rivers be restored? BioScience 45(3), 142-151.

Large rivers have a remarkable resiliency in their ability to recover from physical and chemical disturbances. When the disturbance occurs as a pulse (instantaneous alteration), recovery to the original condition of the ecosystem frequently occurs. When the disturbance is sustained (press disturbance) and causes a complete loss of critical habitat elements, ecological integrity cannot be maintained. The stability and sustained function of large river ecosystems is dependant upon maintenance of watershed and floodplain integrity. The process of restoration is an attempt to direct biological, geological, and hydrological processes toward an end point at or near predisturbance conditions. Although this is not practical in most cases, rehabilitation or partial restoration of riverine habitats and ecosystems - has considerable potential. Systems that have not achieved true restoration will continue to require constant management. [BIOLOGICAL INTEGRITY; FLOODPLAIN 
MANAGEMENT; RIPARIAN RESTORA'IION; RIVER ECOLOGY]

622. Gorman,OT; Karr; JR (1978): Habitat structure and stream fish communities. Ecology 59(3), 507-515.

Stream habitat complexity was correlated with fish species diversity in selected streams. Habitat diversity was measured along three dimensions important to a wide range of fish groups: stream depth, bottom type, and current. Increasing community and habitat diversity followed stream order gradients. Natural streams supported fish communities of high species diversity which were seasonally more stable than lower diversity communities of modified streams. Seasonal changes in stream quality were high. 'Therefore, the stability of the fish community was lower in modified than in natural streams. The general correlation between habitat characteristics and presence and absence of fish species suggested that most fishes of small streams are habitat specialists. [AQUATIC ECOSYSTEMS; BIODIVERSITY; FISHERIES; FISH HABITAT]

623. Goss, DW (1973): Relation of physical and mineralogical properties to streambank stability. Water Resources Bulletin 9(1), 140-144.

Alluvial streambank properties from nine unstable and six stable reaches showed little variation in physical and mineralogical properties. The bulk density of the samples was so similar that they could be considered from the same population. Particle size distributions showed that the many fractions were slightly, but significantly, higher for the stable reaches. The sand-sized grains of the stable areas were less rounded than those of unstable areas. This somewhat angular shape of the grains may have produced an interlocking between grains that added stability to the bank material. Clay coatings on the sand-sized grains may also have strengthened the material by causing cementation.

[EROSION; GEOMORPHOLOGY; SEDIMENTATION; STREAMBANK STABILITY]

624. Gosselink,JG; Shaffer,GP; Lee,LC; Burdick,DM; Childers,DL; Leibowitz,NC; Hamilton,SC; Boumans, R; Cushman,D; Fields,S; Koch,M; Visser,JM (1990): Landscape conservation in a forested wetland watershed. BioScience 40(8), 588-600.

General issues in environmental planning are addressed in this article, relating to the cumulative impacts of human activities on these ecosystems.
Specific focus is directed on wetlands. The legal and administrative framework for wetland regulation is introduced, as well as the use of ecological principles in environmental planning. The cumulative impacts of human impacts in a case study are assessed and the assessment is used to show how they can be used for planning purposes.

[CUMULATIVE IMPACTS; HUMAN IMPACTS; PLANNING; RIPARIAN FOREST; WETLANDS]

625. Gottfried,GJ; Ffolliott,PF (1992): Effects of moderate timber harvesting in an old-growth Arizona mixed conifer watershed. p.184-194. In: Old growth forests in the Southwest and Rocky Mountain Regions. USDA Forest Service. General Technical Report RM-213.

There is growing interest in the development of silvicultural prescriptions that will maintain old-growth characteristics while allowing some degree of commercial utilization. A silvicultural prescription based on small patch-clearcut and group-selection openings and single-tree selection in most remaining areas was evaluated in a watershed supporting an old-growth mixed conifer stand. The treatment resulted in increased residual tree growth and relatively constant stand growth. The stand retained its uneven-aged structure and relative species composition. The watershed has retained many of the desired old-growth attributes although many of the largest trees were harvested. The increased growth rates indicate that the basal area in larger trees should recover relatively rapidly. Tree regeneration also has been satisfactory. In addition, the treatment resulted in significant increases in water yields and in herbaceous plants for livestock and wildlife use. Nongame birds were generally unaffected by the treatment.

[LOGGING IMPACTS; OLD-GROWTH FOREST; WATER QUALITY; WATERSHED]

626. Gottfried,GJ; Ffolliot,PF (1995): Stand dynamics on upper elevation pinyon-juniper watersheds at Beaver Creek, AZ. p.38-45. In: Shaw,DW; Finch,DM [tech. coord.]. Desired future conditions for pinyon-juniper ecosystems:

Proceedings of the symposium; 8-12 August 1994; Flagstaff, AZ. USDA Forest Service. General Technical Report 258.

There is a lack of information about stand dynamics, especially volume growth, in the pinyon-juniper woodlands of the southwestern United States. Such information is vital for managing woodlands on a sustainable basis for tree products. Harvesting in excess of growth will diminish the 
resource. Growth information is also needed to understand ecosystem dynamics and to ascertain stand changes that affect other resources, such as wildlife habitat. Two overstory inventories, spanning a 24-year period, were conducted on permanent points on two untreated watersheds in central Arizona. Alligator juniper is the dominant species on the watersheds, which are representative of woodlands at the upper elevations of the Mogollon Rim. Although inventory techniques have changed since the first inventory in 1964 , repeated measurements using the original techniques can produce valuable information about stand changes in the interim. Mean annual growth for trees present in 1964 and 1988 was 18.5 cubic feet per acre and net periodic annual growth was 20.3 cubic feet per acre. [EVALUATION; PINYON-JUNIPER; RIPARIAN FOREST; RIPARIAN HABITAT; TREE PRODUCIS; WATERSHED]

627. Gough,G; George,MR; McDougald,N; Jolley,L (1998): Developing California's rangeland water quality management plan: Range livestock industry responds to clean water issues. p.187-190. In: Potts,DF [ed.]. Rangeland management and water resources: Proceedings of the AWRA specialty conference. American Water Resources Association. 27-29 May 1998. Reno, NV.

The California livestock industry, in 1989 , embarked on a pro-active program of information and education that resulted in the development of the California Rangeland Water Quality Management Plan (CRRWQMP). The plan is being implemented by voluntary development or through workshops and conservation planning.

[BEST MANAGEMENT PRACTICES; GRAZING IMPACTS; LIVESTOCK EFFECTS; NON-POINT SOURCE POLLUTION]

628. Gough,S (1994): Riparian trees and stream channel management. p.66-72. In: Proceedings of the 46th annual meeting of the forestry committee, Great Plains Agricultural Council. 20-23 June 1994. Manhattan, KS.

Management of streamside trees is poorly understood, even though trees greatly influence the form and process in many river systems. In order to manage riparian areas, we must first understand fluvial process and be able to separate systemic forces, such as large-scale watershed change, from local influences, such as vegetation clearing. We must also better understand the history of river systems and acknowledge past fluvial change. In
Missouri, photographic analysis revealed that cattle exclusion was more effective than rip-rap in stabilizing streambanks. Vegetation is the only manageable component in most wildland stream reaches.

[GRAZING IMPACTS; RIPARIAN FOREST; RIPARIAN VEGETATION]

629. Gourley,C (1997): Instream flows and the restoration of river and riparian ecosystems. In: Proceedings of the Society of Wetland Scientists. 18th annual meeting. Restoration and Management Notes 16(1);92.

Altered streamflow patterns and stunted cottonwood replenishment from damming and irrigation along the Truckee River in Nevada lasted for most of the 20th century. Placement of the cui-ui sucker on the Endangered Species list caused biologists to increase late spring flow to enhance the suckers' spawning survival. Increased flow also created ideal conditions for cottonwood seed dispersal. This circumstance had a double benefit and illustrates that river and riparian habitats frequently have common needs.

[COTTONWOOD; RIPARIAN FOREST; RIPARIAN RESTORATION; SPAWNING HABITAT; STREAM FLOW]

630. Gourley,C; Lillquist,N (1993): A demonstration of biogeomorphic techniques to restore a segment of the East Fork of the Sevier River, Garland County, Utah. p.180-185. In: Tellman,B; Cortner,HJ; Wallace,MG; DeBano,LF; Hamre, RH [tech. coord.] Riparian management: Common threads and shared interests. USDA Forest Service. General Technical Report RM-226.

The purpose of this project was to demonstrate the use of biogeomorphic techniques to restore a privately owned $2 \mathrm{~km}$ stream segment. Management of livestock adjacent to the stream channel has had a positive effect on the demonstration area. Willow and aquatic grasses are encroaching into the channel causing it to become narrower and deeper. Vertical stream banks are now sloped and naturally revegetated. Biogeomorphic techniques were successfully employed to restore a single meandering channel.

[BIOGEOMORPHIC TECHNIQUES; CHANNEL DYNAMICS; MONITORING; RIPARIAN RESIORATION]

631. Graf,WL (1979): The development of montane arroyos and gullies. Earth Surface 
Processes 4, 1-14.

Field investigations in Colorado confirm that the spatial distribution of vegetation in watersheds exerts strong control on the entrenchment of streams in the montane zone. When tractive forces in channels exceeds threshold values of resistance on the valley floors, cutting of arroyos begins, producing forms that change allometrically. Thresholds exist in the montane erosion system for gradient, mean biomass in the basin, biomass on the valley floor, channel roughness, and channel width. Each threshold value, however, depends on the interrelationships among other variables in the system. Manipulation of the vegetative cover is the primary human impact on the montane channels, and management of the distribution of vegetation offers the most efficient method of maintaining the stability of channels. [CHANNEL DYNAMICS; GEOMORPHOLOGY; GULLY CONTROL; RIPARIAN VEGETATION]

\section{Graf,WL(1979): Mining and channel} response. Annals of the Association of the American Geographer 69(2), 262-275.

Gold/silver mining in central Colorado has caused severe disruption of the landscape. Arroyos and gullies developed on many valley floors as responses to increases in channel tractive force from 1 dyne before settlement to 8 dynes during the mining period. The spatial distribution of energy and force has been substantially altered by human activities. Threshold values of erosive force were surpassed in response to changes in general basin vegetation cover, channel slope, width, and roughness. Landscape stability, which depends on the relationship of the distribution of energy to the material landscape, has been reestablished in some locations but others may require several decades for recovery.

[CHANNEL DYNAMICS; EROSION; GEOMORPHOLOGY; MINING IMPACTS; PHOTO PLOTS]

633. Graf,WL (1980): Riparian management: A flood control perspective. Journal of Soil and Water Conservation 35(4), 158-161.

Review of riparian change in the Southwest, examination of the relationship between channel vegetation and water resources, and a preliminary evaluation of alternative methods of phreatophyte control suggest the following conclusions: First, some sort of channel clearing and maintenance is unavoidable. Second, mechanical removal and control of phreatophytes is possible, with regrowth controlled by chemicals or by mowing and grazing.
Third, for the long-term restoration of riparian habitats without dense phreatophyte growth by groundwater control should be investigated further. [FLOOD IMPACTS; PHREATOPHYTES; RIPARIAN MANAGEMENT ZONE]

634. Graf,WL (1985): Geomorphic measurements from ground-based photographs. p.211-235. In: Geomorphology: Themes and trends. [Ed: Pitte,A.]. Barnes and Noble Books; Totowa, NJ.

Characterization and explanation of earth surface properties as they vary over time and space are the major objectives of geomorphologic inquiries. The analysis of changing dimensions of land forms is a useful approach. Methods of measuring heights and horizontal lengths from photos are described. In remote field locations accessible only by foot, the photogrammetric approach is a cost-effective substitute for more expensive techniques. Moreover, ground-based photographs may have a significant historical dimension. Exact relocation of the original camera position and duplication of historic photos can provide striking evidence of the progress of geomorphological processes. [GEOMORPHOLOGY; MONITORING; PHOTO PLOTS]

635. Graham,WG (1993): The Idaho protected rivers program. p.352-355. In: Tellman, $B$; Cortner,HJ, Wallace,MG; DeBano,LF; Hamre, RH [tech. coord.]. Riparian management: Common threads and shared interests. USDA Forest Service. General Technical Report RM-226.

At the time of this paper, 960 miles of Idaho rivers were protected under the state program, in addition to the 550 miles protected under the federal Wild and Scenic Rivers Act. Comprehensive state water plans had been completed for four river basins and one river reach. Three other plans were in preparatory stages of the planning process. The first coordinated planning effort was underway in the South Fork of the Snake River, involving the Bureau of Land Management. Forest Service, and Idaho Water Resource Board. Recommended actions could include a mix of state and federal protection mechanisms.

[PLANNING; PROTECTED RIVERS; RIPARIAN HABITAT; WILD AND SCENIC RIVERS]

636. Grant,G (1986): Assessing effects of peak flow increases on stream channels: $A$ rational approach. p.142-149. In: Proceedings of the 
California watershed management conference. 18-20 November 1986. West Sacramento, CA.

This paper criticizes employment of arbitrary limits to the basin drainage area affected by forestry activities. It recommends a procedure using the magnitude of flow increases that can be accommodated by downstream channels before channel instability occurs to determine the upper limit for basin area compaction. It also discusses the physical factors which affect channel stability and ways to determine this component of the cumulative watershed effects of forest practices. Streams with different channel geometries and bed materials have different intrinsic sensitivities to peak flow increases.

[CUMULATIVE IMPACTS; HYDROLOGY; STREAM FLOW; WATERSHED]

637. Grant,G (1988): The RAPID technique: a new method for evaluating downstream effects of forest practices on riparian zones. USDA Forest Service. General Technical Report PNW-GTR-220. Portland, OR. 36 p.

The RAPID technique (riparian aerial photographic inventory of disturbance), uses aerial photographs to evaluate changes in channel conditions through time and links such changes with their possible stream causes.

[AERIAL PHOTO; CHANNEL MORPHOLOGY; INVENTORY; LOGGING IMPACTS]

638. Grant,JWA; Englert,J; Bietz,BF (1986): Application of a method for assessing the impact of watershed practices: Effects of logging on salmonid standing crops. North American Journal of Fisheries Management 6(1), 24-31.

Preliminary studies on 3 control streams (unaffected by logging) indicated that there were no significant intrastream differences in the total biomass of Atlantic salmon, brown trout, and brook trout between discrete areas or similar habitat. Therefore, total salmonid biomass should be a good indicator of stream habitat quality for salmonids and useful in assessing the impacts of watershed practices. Salmonid biomass decreased significantly downstream of two stream crossings, probably because of increased siltation, while seven clear-cuts and one bank modification along the other eight streams had no significant effect on salmonid biomass. Removal of the canopy cover was associated with increases in the fork length or weight at age, or both, of Atlantic salmon but had no consistent effect on the size at age of brook trout. [FISHERIES; LOGGING IMPACTS; RIPARIAN

\section{HABITAT; WATERSHED]}

639. Grasse,JE; Putnam,EF (1950): Beaver management and ecology in Wyoming. Federal Aid in Wildlife Restoration Project Bulletin No. 6, Wyoming Game and Fish Commission, Cheyenne, WY. 75 p.

This comprehensive study was an early effort to confront the conflict between the damage by beavers to man-made installations and the value of indirect benefits by beavers to public land. The document consolidates all that was known about beaver ecology at the time of publication. Management practices are described including techniques for live-trapping and transplanting.

[BEAVER; RIPARIAN HABITAT]

640. Great Plains Riparian Forest Management Task Force. (1993): Riparian forest management in the Great Plains. p.32-45. In: Riparian area management: Proceedings of the 46th annual meeting, Forestry Committee, Great Plains Agricultural Council. 20-23 June 1994.

Manhattan, KS.

On the Great Plains, specialized woodlands known as riparian forests, grow along streams and rivers. These important but sensitive ecosystems are extremely productive and play a crucial role in the plains environment. Two of their more vital functions include protecting water quality and increasing biodiversity. At this time, however, the current amount or condition of riparian forests in any state cannot be substantiated. The decline of this vital ecosystem has attracted the attention of the Great Plains Agricultural Council (GPAC), which considers the management of riparian forests as extremely important. The Great Plains Riparian torest Management Task Force was assembled to find solutions to reverse this trend of destruction. The key objective of the task force was to identify the issues and problems confronting riparian forests, and to develop recommendations to address the situation. This white paper captures the recommendations of the task force for suggested actions. [BIODIVERSITY; RIPARIAN FOREST; RIPARIAN HABITAT; RIPARIAN MANAGEMEN'I' ZONE]

641. Green,DM (1998): Recreational impacts on erosion and runoff in a central Arizona riparian area. Journal of Soil and Water Conservation 53(1), 38-42.

The areas bordering lakes and streams are often focal points for recreation which can be negatively 
impacted by many forms of recreation. In this study, the impact of soil compaction, runoff, erosion, rates, and vegetation along an Arizona stream was assessed. The dominant recreational use of the study area was camping and access by automobile. Total runoff (under simulated conditions), was significantly higher when compared to light- and moderate-use areas. Amounts of plant materials were higher in light and moderate use than in the high-use area. Higher degrees of soil compaction and larger area of exposed soil surface probably contributed to runoff.

[HUMAN IMPACTS; RECREATION IMPACTS; RIPARIAN HABITAT; SOILS]

642. Green,DM; Kauffman,JB (1989): Nutrient cycling at the land-water interface: The importance of the riparian zone. p.61-68. In: Gresswell,RE; Barton,BA; Kershner,JL [eds.]. Riparian resource management; An educational workshop. USDI Bureau of Land Management. Billings, MT.

Riparian ecosystems are sites of important biogeochemical processes that affect the composition and structure of the streamside biota as well as aquatic systems. Microbial activity, coupled with the slow diffusion of oxygen in waterlogged soils, causes anaerobic conditions and reduction in reduction-oxidation (redox) potential. Redox potentials provide a useful measurement as to the intensity of anaerobic conditions and the degree of chemical transformation. Grazing and other anthropogenic disturbances can alter biogeochemical cycles resulting in drastic alterations in riparian vegetation. The effect of land use activities on biogeochemical cycles of riparian-stream ecosystems should receive full consideration.

[GRAZING IMPACTS; NUTRIENT CYCLES; REDOX POTENTIAL; RIPARIAN ECOLOGY]

643. Green,DM; Kauffman,JB (1995): Succession and livestock grazing in a northwestern Oregon riparian ecosystem. Journal of Range Management 48(4), 307-313.

Comparisons of vegetation dynamics of riparian communities under livestock use and exclusions over a 10-year period were quantified in a northwestern Orcgon riparian zone. Species frequency, richness, diversity, evenness, and livestock utilization were measurcd. Livestock grazed the study area from late August until mid-September at a rate of 1.3 to 1.8 ha/AUM. Utilization varied from $>70$ percent in dry meadows to $<3$ percent in cheatgrass dominated stands. Ungrazed dry and moist meadow communities had significantly lower $(\mathrm{P}<0.1)$ species richness and diversity when compared to grazed counterparts. In the most heavily grazed communities, competitive species were favored by grazing disturbance. In exclosures of the same communities, competitive or competitive stress tolerant species were favored. Both height and density of woody riparian species were significantly greater in ungrazed gravel bar communities. Results indicated that influences of herbivory on species diversity and richness varies from one community to another. Management recommendations based on only one component ignores the complexity of riparian ecosystems.

[BIODIVERSITY; GRAZING IMPACTS; RIPARIAN MANAGEMENT ZONE; SUCCESSION]

644. Greenway,SH (1990): Aspen regeneration: A range management problem. Rangelands 12(1), 21-23.

Management of browsing pressures upon aspen regeneration is necessary. In live standing aspen, regeneration will be limited due to apical dominance. Around disturbances, from fire, clear-cutting, or around beaver ponds, aspen shoots should be abundant. If they are not, over-browsing should be suspected. Reduced or removed livestock from local areas for $5-10$ years after disturbance, plus wildlife control should result in successful aspen regeneration.

[ASPEN; GRAZING IMPACTS; LIVESTOCK EFFECTS]

645. Gregg,R (1979): A method for analyzing livestock impacts on stream and riparian habitats. p.92-94. In: Cope, OB [ed.]. Forum -- Grazing and riparian/stream ecosystems. 3-4 November 1978. Denver, CO. . Trout Unlimited, Inc.

This paper presents a method for quantifying the effects of livestock use on stream and riparian habitats, using a combination of techniques taken from range management, wildlife biology and fishery biology.

[GRAZING IMPACTS; MONITORING; TECHNIQUES]

646. Gregory,KJ; Gurnell,AM; Hill,CT (1985): The permanence of debris dams related to river channel processes. Journal of Hydrological Science 30(3), 371-381.

Vegetation debris dams occur on the average of every $27 \mathrm{~m}$ of channel in a drainage basin in England. Within less than 12 months, 36 percent had 
changed position or were destroyed and 36 percent had changed character. These dams significantly affect the timing of flood peaks as they are routed through the channel network. This significance has been demonstrated by a preliminary analysis of hydrograph travel times by measurements before and after dam clearance. The difference in travel times was 100 minutes (with and without dams) for a discharge of $0.1 \mathrm{cub} . \mathrm{m} / .01 \mathrm{sec}$ and 10 minutes for a discharge of $1.0 \mathrm{cub} . \mathrm{m} / .01 \mathrm{sec}$.

[FLOOD IMPACTS; GEOMORPHOLOGY; HYDROLOGY; ORGANIC DEBRIS]

647. Gregory,KJ; Madew,JR (1982): Land use change, flood frequency, and channel adjustments. p. 757 - 781. In: Gravel bed rivers. [Eds:] Hey,RD; Bathurst,JC; Thorne,CR. John Wiley and Sons, Ltd.

Land use changes on areas adjacent to the river channel and over large parts of the river channel can induce changes in water and sediment discharge which may instigate a whole range of river channel adjustments. Based on previous studies, flood frequency analysis was often dependent upon the annual maximum series. In areas with a flashy hydrological regime, estimates from the annual maximum series may be as low as 50 percent of the values derived from an annual exceedance series. Type of series used should always be specified. [CHANNEL DYNAMICS; FLOOD IMPACTS; GEOMORPHOLOGY; LAND USE]

648. Gregory,SV; Swanson,FJ; McKee,WA; Cummins, KW (1991): An ecosystem perspective of riparian zones. BioScience 41(8), 540-551.

Riparian zones contain valuable water resources, plant communities, fisheries, and wildlife.

Perspectives of riparian zones based on isolated components of the terrestrial-aquatic interface are ecologically incomplete and have limited application to understanding of ecosystems. The structure and processes of lotic ecosystems are determined by their interface with adjacent ecosystems and are extremely dynamic, having frequent disturbance events. They are important routes for the dispersal of plants and animals, as well as avenues for the transfer of water, nutrients, sediments, and organic matter. The ecosystem perspective provides a rigorous ecological basis for identifying riparian management objectives, cvaluating current land-use practices, and developing future resource alternatives.

[CLASSIFIC $\Lambda T I O N ;$ RIPARIAN HABITAT;

RIPARIAN MANAGEMENT ZONE]
649. Gresswell,RE; Barton,BA; Kershner,JL (1989): Practical approaches to riparian resource management. An educational workshop. (USDI Bureau of Land Management. Billings, MT. 193 p.

This workshop was sponsored by a coalition of professional societies and federal agencies and addressed major topics relating to riparian management. There were 24 presented papers and 29 extended abstracts collected in the proceedings. [GRAZING IMPACTS; HYDROLOGY; RIPARIAN MANAGEMENT ZONE]

650. Grette, T (1990): Successful range management in the McCoy Gulch Riparian Demonstration Area. Rangelands 12(6), 305-307.

Woody riparian vegetation can improve with livestock grazing, even heavy use on grass species (62 to 80 percent), as long as the use on willows is regulated. The objective in this demonstration was to have willow leaders browsed just once to remove four to five inches of foliage.

[GRAZING IMPACTS; LIVESTOCK EFFECTS; WILLOW]

651. Greytak,D (1991): A technique for producing riparian plants for Nevada. p. 91-93. In: Proceedings, Intermountain Forest Nursery Association. 12-16 August 1991. Park City, UT.

A brief overview of riparian planting as it occurs in Nevada. Paper then describes a method the nursery is using to produce plants for use in constructed wetland creation.

[CREATED WETLANDS; RIPARIAN HABITAT; RIPARIAN PI.ANTS; RIPARIAN RFSTORATION]

652. Griffiths,D (1902): Forage conditions on the northern border of the Great Basin, being a report on investigations made during July and August, 1901, in the region between Winnemucca, NV and Ontario, OR. USDA Bureau of Plant Industry Bulletin No. 15.

One of the earliest reports on range conditions in the West to report the degradation of open ranges in the Great Basin, and, by implication, all of the West. In part, it states that " as the better land has been taken up by settlers - the cattle and sheep ranges have become more restricted, and stock are now forced back from the fertile river bottoms and other lands so situated as to make irrigation possible, and the inevitable result has been overstocking of those poorer and restricted ranges, with all the attendant evils".

[GRAZING IMPACTS; HISTORIC RECORDS; RANGELAND HEALTH] 
653. Griggs,J (1990): Trout in small woodland areas. Woodland Fish and Wildlife Project, August 1990. World Forestry Center. Portland, OR.

Growth of trout depends on the geographic area, water temperature, water fertility, and a variety of lesser factors. All species are opportunistic feeders taking everything from aquatic insects to other fish, and much of their diet depends on what happens to be available at the particular time of year. This leaflet was intended to provide basic information on trout production to private woodland owners and managers.

[FISHERIES; RIPARIAN HABITAT; SALMONIDS; TROUT]

654. Grissinger,EH (1982): Bank erosion of cohesive material. p. 273-287. In: Gravel bed rivers. [Eds:] Hey,RD; Bathurst,JC; Thorne,CR. John Wiley and Sons, Ltd.

Resistance of cohesive materials to erosion by discrete particle scour is very complex. Soil properties and their interactions determine the magnitude of the inter-particle forces of cohesion that resist detachment. Soil properties also influence the physical configuration of particles at the bank material surface. The bank surface, in turn, interacts with the hydraulics of flow near the surface. Bank failure results not only from hydraulic forces but also from gravity forces, depending on the properties of the bank system. Drainage systems with high, steep banks are susceptible to mass failure because gravity forces are more significant than hydraulic forces. 'The mechanism of bank failure is uniquely related to the properties of the individual valley-fill stratigraphic units that make up a bank.

[CHANNEL DYNAMICS; CHANNEL MORPHOLOGY; SEDIMENTATION ; STREAMBANK PROTECTION]

655. Grissinger,EH; Little,WC; Murphey,JB (1981): Erodibility of streambank materials of low cohesion. p.624-630. In: Transactions of the American Society of Agricultural Engineers.

A portable flume was used to determine erosion rates of channel bank materials. Two primary erosive forces were identified. Samples that were relatively dry before testing eroded excessively, probably the result of the detaching effect of sample wetting. Samples wet before testing did not display this excessive erosion and were entirely dependent upon bed shear stresses. Clay content of the samples correlated significantly with shear stress-dependent erosion rates. Significance of sample morphology was sample dependent, varying in size of the test sample in relation to the size of the morphological components.

[CHANNEL MORPHOLOGY; SOILS; S'IREAMBANK PROTECTION]

656. Grizzel,JD; Wolff,N (1998): Occurrence of windthrow in forest buffer strips and its effect on small streams in northwest Washington.

Northwest Science 72(3),214-223.

During timber harvest operations, retaining streamside buffer strips has become a common way of protecting streams. Trees in these buffers, however, are frequently subjected to increased levels of windthrow. In an assessment of 40 forest buffers bordering small streams, windthrow affected 33 percent of the buffer trees and ranged from 2 to 92 percent across the sites. Windthrow increased total instream large woody debris by 52 percent. At most sites, the volume of sediment input to streams was small relative to the amount stored behind obstructions.

[BUFFER STRIPS; LARGE WOODY DEBRIS; SEDIMENTATION; WINDTHROW]

657. Groeneveld,DP; Griepentrog,TE (1985): Interdependence of groundwater, riparian vegetation, and streambank stability: $A$ case study. p.44-48. In: Johnson,RR; Ziebell,CD; Patton,DR; Ffolliott,PF; Hamre,RH [tech. coord.]. Riparian ecosystems and their management: Reconciling conflicting uses. 16-18 April 1985. Tucson, AZ. USDA Forest Service. General Technical Report RM-120.

Groundwater is closely coupled with streamflow to maintain water supply to riparian vegetation, especially where precipitation is seasonal. In this case study, Mediterranean climate and groundwater extraction are linked with the decline of riparian vegetation and subsequent severe erosion on the Carmel River in California.

[GROUNDWATER; RIPARIAN HABITAT; RIPARIAN VEGEIIATION; STREAMBANK STABILITY]

658. Grossman,GD; Ratajczak,Jr.,RE; Crawford,M; Freeman,MC (1998): Assemblage organization in stream fishes: Effects of environmental variation and interspecific interactions. Ecological Monographs 68(3), 395-420.

The study assessed the relative importance of environmental variation, interspecific competition for space, and predator abundance on assemblage 
structure and microhabitat use in a stream fish assemblage. Results demonstrated that variability in both mean and peak flows had a much stronger effect on the structure and use of spatial resources within this assemblage than either interspecific competition for space or predation. These suggested that the patterns in both assemblage structure and resource use arose from the interaction between environmental variation and species-specific evolutionary constraints on behavior, morphology, and physiology.

[FLOOD IMPACTS; PREDATION; STREAM FLOW]

659. Groves,JR (1989): A practical soil moisture profile model. Water Resources Bulletin 25(4), 875-880.

A computationally simple, physically based model capable of generating reliable estimates of volumetric soil moisture content is described. The model requires only rainfall, pan evaporation, and soil column description by texture groups as inputs, and predicts soil moisture values within as many as three user-defined soil horizons. The micrometer based model is intended for practical engineering and agricultural applications.

[HYDROLOGY; MODELING; SOILS]

660. Grue,CE; Tome,MW; Swanson,GA; Borthwick,SM; DeWeese,LR (1988): Agricultural chemicals and the quality of prairie-pothole wetlands for adult and juvenile waterfowl - what are the concerns? p.55-64. In: Stuber,PJ [tech. coord. . Proceedings of the national symposium on the protection of wetlands from agricultural impacts. 25-29 April 1988. Ft. Collins, CO. USDI Fish and Wildlife Service. Biological Report 88(16).

A review of the literature and results of ongoing studies indicates that the potential for agricultural chemicals, particularly aerially-applied insecticides, to enter prairie potholes and reduce the quality of these wetlands for waterfowl is great, and that a coordinated effort by farmers, wildlife managers, and regulatory agencies is needed to minimize and mitigate these impacts.

[AGRICULTURAL IMPACTS; POLLUTION; RIPARIAN HABITAT; WATERFOWL MANAGEMENT; WETLANDS]

661. Gruell,GE (1980): Fire's influence on wildlife habitat on the Bridger-Teton National Forest, Wyoming. Volume 1 -- Photographic record and analysis. USDA Forest Service
Research Paper INT-235. 207 p.

The body of this report is comprised by 85 matched photos arranged in three geographic sections with elevational ranges of 5,800 to 12,165 feet - cold desert to alpine. Captions describe vegetational changes and their significance, with emphasis on wildlife habitat. The role of fire receives special emphasis. Vegetational changes are summarized at the end of each section.

[FIRE IMPACTS; RIPARIAN HABITAT]

662. Guertin,DP; Mokhothn,MN; Weltz,MA; Stone,J (1998): Evaluating the effect of vegetation variability on modeling runoff and erosion processes on a grassland watershed in southeastern Arizona. p. 395. In: Potts,DF [ed.]. Rangeland management and water resources: Proceedings of the AWRA specialty conference. American Water Resources Association. 27-29 May 1998. Reno, NV.

It is well-known that vegetation is very important for regulating the runoff and erosion processes on rangeland watersheds. The degree to which vegetation must be characterized for understanding and predicting its influence on runoff and erosion, however, is still unclear. The Water Erosion Prediction Model (WEPP) was used to simulate runoff, peak discharge, and sediment yield for an experimental watershed near Tombsone, Arizona. The model performed poorly when the watershed was represented by a single hillside element. Model performance improved with increasing hillside elements up to an eight hillside element configuration. No significant improvement was realized with the ten hillside element configuration.

[EROSION; MODELING; RUNOFF; SEDIMENTATION]

663. Guertin,DP; Womack,JD; MacArthur,R; Ruyle,GB (1998): Geographic information system based tool for integrated allotment and watershed management. p.35-44. In: Potts,DF [ed.]. Rangeland management and water resources: Proceedings of the AWRA specialty conference. American Water Resources Association. 27-29 May 1998. Reno, NV.

The spatial relationship between grazing patterns and watershed characteristics must be understood to evaluate the impact of livestock grazing on watershed values. Forage is utilized across an allotment at different rates and intensities as a function of topography, fencing, water locations, and vegetation characteristics. Soil types and erosion rates also 
contribute to the complex surface. Estimating an optimal grazing capacity requires the integration of these and other factors. A GIS-based tool has been developed from grazing-allotment decision making to address both resource production and conservation, using the Environmental Systems Research Institute's ARCVIEW GIS 3.0. This tool can estimate forage production using range site guides, utilization rates, pasture stocking rates, and erosion potential. It can also be used to determine the effects of various management strategies.

[ARCVIEW; GIS; GRAZING IMPACTS; LIVESTOCK EFFECTS; MONITORING; UTILIZATION]

664. Gunderson,DR (1968): Floodplain use related to stream morphology and fish populations. Journal of Wildlife Management 32(3), 507-514.

In two contiguous sections of a Montana stream, the agricultural use of the floodplain was related to cover, stream morphology, and fish populations. In one section, the vegetation of the floodplain had been reduced by clearing and intensive livestock grazing; in the other, which had received light use by livestock, vegetation was relatively unchanged. The ungrazed section had 76 percent more cover (undercut banks, debris, overhanging brush, etc.) per acre of stream than the grazed section. Brown trout ( +6 inches) were estimated to be 27 percent more numerous and to weigh 44 percent more per acre in the ungrazed section of the stream, although rate of growth was similar in both of the sections. [AGRICULTURAL IMPACTS; FISHERIES; GRAZING IMPACTS; RIPARIAN HABITAT; STREAM ECOLOGY]

665. Gurnell,AM; Gregory,KJ (1981): The influence of vegetation on stream channel processes. p.515-535. In: Catchment experiments in fluvial geomorphology. |Eds: Burt,TP; Walling,DE]. Geo Books, Norwich, UK.

Results from small catchment experiments have often led to inferences about the significance of vegetation, it is only by use of a hierarchical investigation encompassing several complimentary scales that the significance of vegetation may be identified. It is clear that just as vegetation can be an indicator of runoff production at the subcatchment and hillslope scale, it can provide an influence upon the flow and sediment routing and storage at the catchment scale and an influence upon channel morphology, particularly where stream channel adjustment is taking place.
[CHANNEL MORPHOLOGY; GEOMORPHOLOGY]

666. Gutzwiller,KJ (1985): Riparian habitat use by breeding cavity-nesting birds in southeastern Wyoming. Ph.D. Thesis, University of Wyoming, Laramie, WY. 125 p.

The differences and similarities among species' nest sites and random sites and among species nest substrates and random substrates can be used by wildlife managers to specify habitat conditions acceptable to the various birds at their nests. The models relating bird parameters to habitat-island characteristics can be used to help manage habitats on a broader scale.

[AVIAN ECOLOGY; RIPARIAN HABITAT]

667. Gutzwiller,KJ; Anderson,SH (1987): Multiscale associations between cavity-nesting birds and features of Wyoming streamside woodlands. The Condor 89, 534-548.

Riparian habitat use by cavity-nesting birds was studied at 3 scales: 1) nest trees; 2) nest sites (vegetation surrounding nest trees); and 3 ) disjunct fragments ( 0.1 to $32.3 \mathrm{ha}$ ) of floodplain forest. Features of Wyoming streamside woodlands on all three spatial scales influence habitat use and are important in structuring communities of cavity-nesting birds. Some patterns of habitat use on the scales of nest trees and habitat fragments were not predictable from habitat associations observed elsewhere for the same species. Bird-habitat relations on one scale were (or were not) predictable from relations on other scales, depending on the species. [AVIFAUNA; RIPARIAN HABITAT; SPATIAL SCALE]

668. Hachmoeller,B; Matthews, RA; Brakke,DF (1991): Effects of riparian community structure, sediment size, and water quality on the macroinvertebrate communities in a small, suburban stream. Northwest Science 65(3), 125-132.

The paper examined the relationships between benthic macroinvertebrates, water quality, sediment characteristics, and riparian community structures in Washington to look for patterns in the macroinvertebrate community structure between upstream and downstream sites. The effects of channelization, deforestation, and pollution resulted in major changes in the structure of macroinvertebrate communities at downstream sites, suggesting that such riparian alterations imitate similar urbanization effects of higher-order rivers. 
[MACROINVERTEBRATES; RIPARIAN

HABITAT; WATER QUALITY]

669. Haeber,RA; Michener,WK; Swanson,FJ (1997): Managed and natural floods: Implications

for management, policy, and research. p.14. 1997 annual meeting of the Ecological Society of America jointly with The Nature Conservancy. 10-14 August 1997. Albuquerque, NM.

Natural flood responses by ecosystems are affected by disturbance magnitude, geomorphology, stage of succession, and human resource modification. Flood "pulses" can initiate a process of riparian reorganization via physical mechanisms (erosion, landslides, ice scour, etc.). Comparing and contrasting natural and managed flood events yields valuable insights. Managed flooding may be useful for restoring ecosystem structure and function. Understanding ecosystem responses to natural floods may be useful for defining restoration targets and placing floods within broader ecological and socioeconomic contexts.

[FLOOD IMPACTS; RIPARIAN ECOLOGY]

670. Hagan,JM; Grove,SL (1999): Coarse woody debris. Journal of Forestry 97(1), 6-11.

Coarse woody debris in a forest can take the form of standing snags, fallen logs, or broken branches and tops. Most often, these accumulate, decompose, and slowly dissolve back into the forest floor. In the meantime, direct and indirect use by an infinite number of species is critically important. Woody debris also plays roles in nutrient cycling, slope/soil stability, and stream morphology. This article recommends that: 1) snags be left standing; 2) tops and branches be left in the woods; 3 ) boles with rotten centers be left in the woods; 4) create short snags by cutting 2 to $5 \mathrm{~m}$ above the ground; 5 ) delimbed branches from the landing should be hauled back into the woods; 6 ) downed material in streams and riparian areas should not be moved; 7) leave trees of little commercial value standing on site; 8) create snags through poison, girdling, or topping; 9) do not run over large downed logs; 10) distribute woody debris over harvest site instead of piling; 11) leave clumps of snags; 12) if used, herbicides can be targeted to kill mature trees and create snags; 13) leave big snags and big logs; 14) leave an array of size classes and species; and 15) experiment with your own ideas.

[BIODIVERSITY; LARGE WOODY DEBRIS; LOGGING IMPACTS]

671. Haines, FD [Ed.] (1971): The Snake Country expedition. University of Oklahoma Press, Norman, OK. 172 p.

[HISTORIC RECORDS; RIPARIAN HABITAT]

672. Hair,JD; Hepp,GT; Luckett,LM; Reese,KP; Woodward,DK (1978): Beaver pond ecosystems and their relationships to multi-use natural resource management. p.80-92. In: Proceedings of the symposium, Strategies for protection and management of floodplain wetlands and other riparian ecosystems. 11-13 December, 1978. Callaway Gardens, GA. USDA Forest Service. General Technical Report WO-12.

Impoundments by beavers have resulted in significant economic losses to agribusiness and forest production. However, beaver impoundments are valuable components of many regional riparian ecosystems and provide numerous opportunities for multi-use management programs. Beaver populations can be regulated through an annual sustained harvest. Beaver impoundments are important wetland habitats and have higher avian diversity values than adjacent upland areas. They can be effectively managed for waterfowl hunting and with the increased importance of non-consumptive utilization of wildlife resources, provide many opportunities for development of natural resource education programs.

[BEAVER; RIPARIAN HABITAT]

673. Hall,DA; Amy,PS (1990): Microbiology and water chemistry of two natural springs impacted in south central Nevada. Great Basin Naturalist 50(3), 289-294.

Bacterial levels were influenced by water temperatures, with higher counts correlating with warmer water. Bacterial levels also reflected precipitation and cattle presence because of the influx of nutrients necessary for growth of microorganisms. Influence of cattle could be seen months after their physical presence when precipitation allowed an influx of nitrogen and phosphorous.

[GRAZING IMPACTS; LIVESTOCK EFFECTS; NUTRIENT CYCLES]

674. Hall,FC (1985): Management practices and options. In: Thomas,JW; Maser,C [eds.]. Wildlife habitats in managed rangelands-- the Great Basin of southeastern Oregon. USDA Forest Service.

General Technical Report PNW-189.

This section deals primarily with livestock management in relationship to wildlife and wildlife habitat. Included are discussions of ecological status (range condition), livestock management, multiple-use options for each species (trout, sage 
grouse, pronghorn, mule deer, and bighorn sheep), and diversity.

[GRAZING IMPACTS; RIPARIAN HABITAT]

675. Hall,FC; Bryant,L (1995):Herbaceous stubble height as a warning of impending cattle grazing damage to riparian areas. USDA Forest Service. General Technical Report PNW-GTR$362.9 \mathrm{p}$.

Cattle grazing of riparian areas must be monitored closely to prevent damage. A technique is proposed in which various stubble heights of the most palatable species are used as predictive observations of when heavy use or trampling is about to occur. Three guidelines are presented to determine the appropriate time to move cattle: 1) stubble height approaches 3 inches; 2) stubble height changes from 3 inches to $3 / 4$ inch; and 3 ) the most palatable vegetation starts drying out, regardless of stubble height.

[GRAZING IMPACTS; RIPARIAN

MANAGEMENT ZONE; STUBBLE HEIGHT; UTILIZATION]

676. Halwasser,H; Cantu,R (1993): Eventually all things merge into one and a river runs through it. p.3-7. In: Tellman,B; Cortner,HJ;

Wallace,MG; DeBano,LF; Hamre,RH |tech, coord.]. Riparian management: Common threads and shared interests. USDA Forest Service. General Technical Report RM-226.

A topical article that examines rivers as allegories of life, the land ethic, and the shared uses and politics of rivers. In summary, they state that "rivers run through our lands and our lives. They reflect our values, our sense of self, and our concern for fellow beings. They tell us and others what we stand for and what we think about our grandchildren."

[LAND ETHICS; RIPARIAN HABITAT; SOCIAL VALUES; STEWARDSHIP]

677. Hamilton,JB (1989): Response of juvenile steelhead to instream deflectors in a high gradient stream. p.149-158. In: Gresswell,RE; Barton,BA; Kershner,JL [eds.]. Practical approaches to riparian resource management. An educational workshop. 8-11 May 1989. USDI Bureau of Land Management. Billings, MT.

Stream channel characteristics and juvenile steelhead populations were estimated before and after placement of boulder/rock triangular wing deflectors in 10 sections of a northern California stream in an effort to improve rearing habitat. After winter flows, only 14 percent of the structures were functionally intact. Reviews of similar projects indicated that habitat improvements that actually increase steelhead populations have usually been sited on lower gradient (mean $=1$ percent) stream reaches.

[FISH HABITAT; HABITAT MANAGEMENT; STREAM IMPROVEMENTS]

678. Hancock,JL (1989): Selling a successful riparian management program: A public land manager's point of view. p.1-3. In: Gresswell,RE; Barton,BA; Kershner,JL [eds.]. Practical approaches to riparian resource management. An educational workshop. 8-11 May 1989. USDI

Bureau of Land Management. Billings, MT.

The major challenge for public land managers is selling an effective riparian management program to public land users, interest groups, and private landowners whose holdings are intermingled with public lands throughout the west. A successful program developed in central Oregon in the preceding 10 years was based upon six major steps: 1) identifying benefits derived from proper riparian management; 2) having access to a recovered riparian area accomplished through grazing management; 3 ) bringing key players together to agree on goals, alternatives, and a plan of action; 4) closely monitoring progress in reaching goals, 5) keeping all parties involved and communicating; and 6) remaining flexible to changes needed to make the program work.

[RIPARIAN HABITAT; RIPARIAN MANAGEMENT ZONE]

679. Hansen, PL (1990): Alternative approaches for inventory and mapping of riparian and wetland areas. In: Management of riparian and wetland forested ecosystems in Montana. Fourth annual Montana Riparian Association workshop. 5-7 September 1990. Whitefish, MT.

Vegetation mapping projects require careful planning and administration to ensure success. Map unit design, accuracy testing, extrapolation methods, and final report are examples of mapping project components that should not be ignored. A list of mapping project components to be examined before mapping begins is included.

[INVENTORY; MAPPING; RIPARIAN HABITAT]

680. Hansen,PL (1990): The development of a site classification with management information for riparian and wetland areas - its applicability and use. In: Management of riparian and wetland forested ecosystems in Montana. Fourth annual 
Montana Riparian Association workshop. 5-7

September 1990. Whitefish, MT.

This paper summarizes the classification scheme developed for riparian and wetland areas in Montana by the Montana Riparian Association. It also suggests ways in which the habitat-type classification can be applied (as described by Boggs et al. (1990) and Hansen et al. (1989) who developed complete riparian and wetland classification schemes with habitat types defined for Montana.

[CLASSIFICATION; RIPARIAN HABITAT]

681. Hansen,PL (1992): Classification and management of riparian-wetland shrub sites in Montana. p.68-78. In: Clary,WP; McArthur,ED; Bedunah,D; Wambolt,CL [comp.]. Proceedings Symposium on ecology and management of riparian shrub communities. General Technical Report INT-289.

The author has developed a classification system for riparian-wetland sites in Montana that is consistent with terms and concepts proposed by Daubenmire and in wide usage in numerous vegetation studies. Thirty-two riparian-wetland shrub communities are described, of which 16 each represent habitat types or community types, respectively. Management information and implications are also discussed.

[CLASSIFICATION; RIPARIAN HABITAT]

682. Hansen,PL (1993): Developing a successful riparian-wetland grazing management plan for the upper Ruby River cattle and horse allotment in southwestern Montana. p.328-335. In: Tellman,B; Cortner,HJ; Wallace,MG; DeBano,LF; Hamre, RH [tech. coord.|. Riparian management: Common threads and shared interests. USDA Forest Service. General Technical Report RM-226.

Livestock grazing is a compatible use in riparian-wetland areas when the functions of the riparian system (sediment filtering, streambank building, water storage, aquifer recharge, energy dissipation during storm events, etc.) are stable and not degrading. The potential of the site and the needs of the riparian vegetation should guide the development of the grazing management strategy. [GRAZING IMPACTS; LIVESTOCK EFFECTS; WETLANDS]

683. Hansen,PL; Chadde,SW; Pfister,RD (1987): Riverine wetlands of southwestern Montana. Montana Riparian Association. University of Montana. Missoula, MT. 39 p.
This study describes dominant plant species and major riparian dominance types occurring along major rivers of southwestern and west central Montana. The primary objective of the study was to describe the major riparian types occurring along the rivers.

[INVENTORY; PLANT COMMUNITIES; RIPARIAN HABITAT]

684. Hansen,PL; Chadde,SW; Pfister,RD (1987): Riparian dominance types of Montana. Review Draft. Montana Riparian Assoc., School of Forestry, University of Montana. Missoula, MT. $358 \mathrm{p}$.

This handbook was developed to provide dominance type classifications, habitat type classifications, and management information. This information was based on data collected from riparian communities throughout the state of Montana by the authors, cooperators, and other sources. All plant species included in the handbook either dominate or are codominant in one or more riparian communities. The text offers both illustrations with prominent plant characteristics and ecological descriptions and management implications for each dominance type.

[CLASSIFICATION; RIPARIAN HABITAT; RIPARIAN PLANTS; RIPARIAN VEGETATION]

685. Hansen,PL; Miles,SL; Hinckley,D (1998): Developing an inventory and mapping methodology for riparian and wetland sites in Montana, North Dakota, and South Dakota. Unreferenced 58, 47-59.

An inventory and mapping procedure was developed for riparian and wetland areas throughout Montana and western North Dakota and western South Dakota. The ecosystems occurring within this 3-state region include the Northern Rocky Mountain Ecosystem of northwest Montana, the Middle Rocky Mountain Ecosystem of southern Montana and the Black Hills of South Dakota, the Pacific Northwest Temperate Rainforest Ecosystem of northern Montana, the Aspen Groveland Ecosystem of the eastern Rocky Mountain Front in north-central Montana, the Great Basin Ecosystem of south-central Montana, and the Northern Great Plains Ecosystem of eastern Montana and western North and South Dakota. The inventory and mapping methodologies have been evolving since 1988. Currently, over 2,250 miles of rivers and lakes throughout the region have been inventoried and mapped using the procedure.

[INVENTORY; MAPPING; RIPARIAN

ECOLOGY; RIPARIAN IIABITAT] 
686. Hansen,PL; Pfister,RD; Boggs,K; Cook,BJ; Joy,JW; Hinckley,DK (1995): Classification and management of Montana's riparian and wetland sites. Montana Forest and Conservation Experiment Station, School of Forestry, the University of Montana. Missoula, Montana. Miscellaneous Publication No. 54.

In the West, riparian and wetland areas are important in the overall landscape mosaic, even though they represent a very small fraction of the total area. Having greater than normal soil moisture, they are more productive than the surrounding upland areas, add to the overall diversity of the landscape, and attract livestock and wildlife for the forage, thermal and other cover, nesting habitat, water, and browse species they afford. Because of this, riparian and wetland areas are focal points for livestock, timber, and wildlife management. Management strategies that recognize all resource values must be designed to maintain or restore the integrity of riparian and wetland communities. Proper stewardship of riparian and wetlands areas presents multiple opportunities for the land manager. Proper management of riparian and wetland areas means decreased streambank erosion and floodplain losses, increased forage production for livestock, increases in wildlife and fisheries resources, and an increase in water quality and quantity, and recreational opportunities.

[CLASSIFICATION; INVENTORY; MONITORING; RIPARIAN HABITAT; RIPARIAN MANAGEMENT ZONE; WETLANDS]

687. Hansen,P; Pfister,R; Joy,J; Svoboda,D; Boggs,K; Myers,L; Chadde,S; Pierce,J (1989): Classification and management of riparian sites in southwestern Montana, Draft version 2. Montana Riparian Association. University of Montana. Missoula, MT.

This draft document provides a key for identifying riparian site types, i.e., areas occupied or potentially occupied by a specific riparian association (plant community type representing the latest successional stage attainable on a specific hydrologic site). Community types which represent disclimax or seral communities that are stable for time frames relevant to land management decisions are described. Habitat types are described for specific communities. The classification system was developed from 1071 riparian sample plots. Soils, adjacent communities and management information are provided for each habitat type.

[CLASSIFICATION; PLANT COMMUNITIES; RIPARIAN HABITAT; RIPARIAN

\section{MANAGEMENT ZONE; SOILS]}

688. Hansen,WF (1996): Watershed rehabilitation and monitoring. p.187-200. In: National hydrology workshop proceedings. 27 April - 1 May 1992; Phoenix, AZ. USDA Forest Service. General Technical Report RM-GTR-279.

An overview of watershed rehabilitation is discussed. Examples of project successes and failures are included. Primary emphasis is placed on USDA Forest Service opportunities and programs to rehabilitate severe natural or man-induced conditions that can dominate water quality and beneficial uses. The information provided may prove useful to increase management or specialist awareness of rehabilitation opportunities and benefits as well as encourage the use of public participation and involvement to provide support to agency land and resource stewardship efforts.

[MONITORING; RIPARIAN RESTORATION; STEWARDSHIP; WATERSHED]

689. Hanson,JS; Malanson,GP; Armstrong,MP (1990): Landscape fragmentation and dispersal in a model of riparian forest dynamics. Ecological Modeling 49, 277-296.

A computer simulation model, SEEDFLO, is described, which models tree species dispersal based on empirical evidence. The analyses test the hypothesis that a model with seed dispersal differs in its projections from a model that assumes ubiquitous dispersal. The effects of considering landscape fragmentation and dispersal are amplified when environmental stress, in this case flooding, is increased. The results conform to theoretical expectations and indicate that seed dispersal should be incorporated in landscape simulation models. [MODELING; RIPARIAN FOREST; RIPARIAN HABITAT; SEED PRODUCTION]

690. Hanson, ML (1989): The Oregon Watershed Improvement Coalition's approach to riparian management. p.5-6. In: Gresswell,RE; Barton,BA; Kershner,JL [eds.]. Practical approaches to riparian resource management. An educational workshop. 8-11 May 1989. USDI Bureau of Land Management. Billings, MT.

A unique coalition of ranchers, environmentalists, and range specialists, the Oregon Watershed Improvement Coalition is dedicated to improving communications between its member groups and improving riparian ecological conditions in Oregon's rangeland environment. Formed in 1986, the OWIC has developed, through the consensus 
process, specific objectives to meet it's goal of insuring the long term benefits of riparian areas and their associated uplands.

[COLLABORATION; RIPARIAN HABITAT; RIPARIAN MANAGEMENT ZONE]

691. Hardin, TS (1986): Use of hydraulic simulation to evaluate habitat improvement structures. p.111-119. In: Proceedings of the Western Association of Fish and Wildlife Agencies and the Western Division of the American Fisheries Society. Portland, OR. [HABITAT MANAGEMENT; MODELING; RIPARIAN HABITAT]

692. Hare,SR; Mantua,NJ; Francis,RC (1999): Inverse production regimes: Alaska and west coast Pacific salmon. Fisheries 24(1), 6 p.

Pacific salmon catches in Alaska have varied inversely with catches from the west coast during the last 70 years, according to a principal component analysis. If variations in catch reflect variations in salmon production, the analysis suggests that the spatial and temporal characteristics of this catch/production pattern are related to climate forcing associated with the Pacific Decadal Oscillation, a recurring pattern of atmosphere-ocean variability. During the period 1977 to the early 1990 's, ocean conditions have favored Alaska stocks and disfavored West Coast stocks. Recovery of at-risk (threatened and endangered) stocks may need to await the next reversal of the Pacific Decadal Oscillation.

[CLIMATE; SALMON RECOVERY]

693. Harenberg, WA (1980): Using channel geometry to estimate flood flows at ungaged sites in Idaho. USDI Geological Survey. Water Resources Investigations 80-32.

During this study, measurements at bankfull stage were made at 136 sites to determine whether predictions of flood discharges using channel-geometry characteristics were as good as or better than predictions using basin characteristics. Variables measured at those sites were bankfull width, area, depth, and velocity. Variables were combined with basin characteristics for each site, and multiple-regression techniques were used to select the best variables to estimate flooding. In general, discharge estimates obtained from equations using channel characteristics have smaller standard errors than those using basin characteristics. Equations using both basin and channel characteristics had the lowest standard errors.
[CHANNEL MORPHOLOGY; FLOOD IMPACTS; HYDROLOGY]

694. Harig,AL; Bain,MB (1998): Defining and restoring biological integrity in wilderness lakes. Ecological Applications 8(1), 71-87.

Restoring ecosystems to some previous "natural" state is often impeded by the lack of information on what goal is to be attained. A target for restorations of lake ecosystems can be established by developing a multimetric tool for the assessment of biological integrity. This study identified a set of recurring responses to disturbance that indicate impaired biological integrity in lakes. These responses were then tested. Six indicators of biological integrity were sensitive to disturbance in wilderness lakes including: dominance of native fish, relative abundance of Daphnia, dominant phytoplankton taxa, number of zooplankton species, dominance of large-bodied zooplankton, and zooplankton biomass. [ECOLOGICAL INTEGRITY; RIPARIAN HABITAT; RIPARIAN RESTORATION]

695. Harmon,KW (1979): Mitigating losses of private wetlands: The North Dakota situation. $p$. 157-163. In: Swanson,GA [ed.]. The mitigation symposium: A national workshop on mitigating losses of fish and wildlife habitat. USDA Forest Service. General Technical Report RM-65.

No legal means presently exist for mitigation of private drainage of wetlands. In order to reduce losses, the USDI Fish and Wildlife Service (USFWS) purchases fee or easement interests in North Dakota wetlands. Concern for reaching its 1,000,000-acre goal caused the USFWS to make concessions in a watershed project that left 30,000 acres of wetlands subject to drainage. As opposition to the wetlands program increased, the USFWS abolished key positions that provided the only public relations effort for countering the opposition. After six years, this situation remained unchanged.

[DRAINAGES; RIPARIAN RESTORATION; WATERSHED; WETLANDS]

696. Harper,KT; Sanderson,SC; McArthur,ED (1992): Riparian ecology in Zion National Park. p.32-42. In: Clary,WP; McArthur,ED; Bedunah,D; Wambolt,CL [comp.|. Proceedings Symposium on ecology and management of riparian shrub communities. USDA Forest Service. General Technical Report INT-289.

Approximately $40 \mathrm{~km}$ (24.9 mi) of perennial streams occur in Zion National Park in Utah. This report resulted from a large-scale survey of all 
vegetational types within the Park. Dominant trees and shrubs are identified. Woody species of early-seral and late-seral riparian successions are listed.

[CLASSIFICATION; PLANT COMMUNITIES; RIPARIAN HABITAT]

697. Harr,RD; McCorison,FM (1979): Initial effects of clear-cut logging on size and timing of peak flows in a small watershed in western Oregon. Water Resources Research 15(1), 90-94.

Annual peak flow size in a small watershed in Oregon was reduced 32 percent, and average delay of all peak flows was nearly 9 hours following clear-cut logging. Size of annual peak flows caused by rain with snowmelt was reduced 36 percent, and peak flows resulting from rain with snowmelt were delayed an average of nearly 12 hours following logging. Changes are attributed mainly to differences in short-term accumulation and melting of snow. No significant changes were detected in size or timing of peak flows that resulted from rainfall alone.

[HYDROLOGY; LOGGING IMPACTS; STREAM FLOW; WATERSHED]

698. Harr,RD; Nichols, RA (1993): Stabilizing forest roads to help restore fish habitats: $A$ northwest Washington example. Fisheries 18(4), 18-22.

As part of a total watershed rehabilitation to improve fish habitats and reduce flood hazards, 30 to 40-year old, unused, largely impassable roads and landings within the Nooksack River watershed were decommissioned by stabilizing fills, removing stream crossings, recontouring slopes, and reestablishing drainage patterns to reduce the landslide hazards. The average cost for decommissioning a road was $\$ 3500$ per kilometer (earthmoving) where considerable amounts of alder brush were cleared and side-cast material was pulled back upslope. Lower costs were associated with lesser earthmoving jobs; the highest costs resulted when fills at stream crossings or landings had to be removed. In contrast to unused roads not treated, decommissioned roads and landings were largely undamaged by rain-on-snow runoff that produced a 50-year flood in 1989 and sustained little damage during rain-on-snow runoff in 1990 that severely damaged main haul roads in the region.

[FLOOD IMPACTS; RIPARIAN HABITAT; RIPARIAN RESTORATION; ROAD IMPACTS; WATERSHED]

699. Harrelson,CC; Rawlins,CL; Potyondy,JP
(1994): Stream channel reference sites: An illustrated guide to field techniques. USDA Forest Service. General Technical Report RM-245. 61 p.

This document is a guide to establishing permanent reference sites for gathering data about the physical characteristics of streams and rivers. The minimum procedure consists of the following: 1) select a site; 2) map the site and location; 3) measure the channel cross-section; 4) survey a longitudinal profile of the channel; 5) measure stream flow; 6) measure bed material; and 7) permanently file the information with the Vigil network. The document includes basic surveying techniques, provides guidelines for identifying bankfull indicators and measuring other important stream characteristics. The object is to establish the baseline of existing physical conditions for the stream channel. With this information, changes in the character of streams can be quantified for monitoring purposes or to support other management decisions.

[CHANNEL DYNAMICS; CHANNEL MORPHOLOGY; MONITORING; REFERENCE SITES]

700. Harris,DD; Hubbard,LE (1983): Magnitude and frequency of floods in eastern Oregon. USDI Geological Survey. Water Resource Investigation Rep. 82-4078. 39 p.

A method for estimating the magnitude and frequency of floods at ungaged sites is presented for unregulated streams in eastern Oregon. Equations relating flood magnitude to basin characteristics were developed for exceedance probabilities of 0.5 to 0.01 . Also presented are values of maximum discharges, of flood discharges for selected exceedance probabilities, and of basin characteristics for all gaging stations used in the analysis.

[FLOOD IMPACTS; HYDROLOGY; STREAM FLOW]

701. Harris, LD (1988). The nature of cumulative impacts on biotic diversity of wetland vertebrates. Environmental Management 12(5), 675-693.

There is no doubt that cumulative impacts have important effects on wetland vertebrates. Interactions of species diversity and community structure produce complex patterns in which environmental impacts can play a highly significant role. Habitat fragmentation can have severe effects at all levels, reducing the usable range of the larger habitat generalists while threatening the genetic integrity of small, isolated populations. The complexity of trophic interactions - of which we have incomplete knowledge - makes using food chain support for 
predicting environmental impacts very questionable. At present, it is nearly impossible to predict the result of three or more different kinds of perturbations, although long range effects can be observed. Multiplicative effects of similar actions, effects with long time lags, diffuse processes in the landscape that may have concentrated effects on a component subsystem, and a variety of other interactions have an accumulation of impacts on vertebrates. More information is needed at all levels and impacts must be assessed on a regional or landscape scale to produce informed management decisions.

[BIODIVERSITY; CUMULATIVE IMPACTS; ECOSYSTEM MANAGEMENT; WETLANDS]

702. Harris,NR; Borman,MM; George,MR; Johnson,DE (1998): Monitoring changes in channel morphology with multi-scale aerial photography. p. 132. In: Potts,DF [ed.]. Rangeland management and water resources: Proceedings of the AWRA specialty conference. American Water Resources Association. 27-29 May 1998. Reno, NV.

High resolution aerial photography is being used to quantify changes in stream/riparian systems.

Changes are monitored by geopositioning equipment serial photography taken annually or every few years. Photographs are scanned into electronic format and corrected for lens or topographic distortions. Streams with little canopy coverage and little topographic relief are the easiest to correct. Photographs with scales of $1: 1,000$ to $1: 3,000$ can document lateral movement of streams greater than $25 \mathrm{~cm}$.

[AERIAL PHOTO; MONITORING; RIPARIAN ZONES]

703. Harris,NR; George,MR; Johnson,DE; McDougald,NK (1998): Supplement induced changes of cattle distribution on California foothill rangeland. p.217. In: Potts, DF [ed.]. Rangeland management and water resources: Proceedings of the AWRA specialty conference. American Water Resources Association. 27-29 May 1998. Reno, NV.

Landscape use patterns of cattle reflect the configuration and quality of forage and water resources available. Riparian zones often receive heavy use because they provide water, shade, thermal cover, and high quality forage. Off-site water and supplement have been used to reduce time spent in or near streams. This study employed global positioning systems, geographic information systems, and geostatics to analyze how spatial and temporal livestock use patterns change. Preliminary results reconfirm that distribution of livestock can be controlled with supplemental feed. Patterns of livestock use shifted dramatically toward supplement sites. Small riparian patches along the edge of the pasture used before and after supplement was made available were not used during supplementation. [GRAZING IMPACTS; LIVESTOCK EFFECTS]

704. Harris,RR (1984): Relationships between vegetation and fluvial geomorphology at Cottonwood Creek. CA. Ph.D. Thesis, University of California, Berkeley,CA. 337 p.

Floodplain topography and surface soil texture were correlated with each other and with simulated flood frequency and magnitude when elevation above the stream was used as a measure of flooding. Elevation alone, however, did not adequately explain environmental conditions. Flooding affects land surface formation and environmental conditions in the active floodplain and plants are responsive to that interactive process. Changes in flooding behavior caused by water resource development will cause changes in vegetation. Locations where vegetation development is arrested by flooding effects may experience increased plant growth. Areas which are benefitted by occasional flooding may experience long-term losses in vegetation or changes in species composition.

[GEOMORPHOLOGY; RIPARIAN MANAGEMENT ZONE; RIPARIAN VEGETATION]

705. Harris,RR; Fox,CA; Risser, R (1987): Impacts of hydroelectric development on riparian vegetation in the Sierra Nevada Region, California, USA. Environmental Management 11(4), 519-527.

Fourteen streams in the Sierra Nevada were sampled to determine whether diversions of streamflow for hydroelectric development had caused significant changes in riparian vegetation. Several streams showed significant differences in vegetation cover, community composition, or community structure between pairs of diverted and undiverted areas. On some streams, environmental conditions rather than streamflow diversions may have been responsible for vegetation differences. Streams in the Sierra Nevada respond individually to diversions. Prediction of vegetation responses must take into consideration environmental characteristics of specific stream reaches.

[HYDROELECTRIC IMPACTS; RIPARIAN HABITAT; RIPARIAN RESTORATION; RIPARIAN VEGETATION] 
706. Harris,RR; Olson,C (1997): Two-stage system for prioritizing riparian restoration at the stream reach and community scales. Restoration Ecology 45(5), 34-42.

A two-stage system for prioritizing stream reaches and riparian communities along a given river for protection or restoration is proposed. The system uses associations between geomorphology and riparian vegetation at stream reach and community scales as a basis for defining reference conditions. First-stage reach classification involves collecting and analyzing data from topographic maps and aerial photographs. Second-stage field sampling is conducted on the reaches needing further analysis to determine the riparian communities present, the associations between communities and floodplain landforms, and reference community conditions. Cluster analysis or a comparable technique is used to classify plant communities associated with floodplain landforms and identify reference conditions for each landform.

[GEOMORPHOLOGY; HYDROLOGY; MONITORING; RIPARIAN RESTORATION; SPATIAL SCALE]

707. Harris,RR; Risser,RJ; Fox,CA (1985): A method for evaluating streamflow discharge -plant species occurrence patterns on headwater streams. p.87-90. In: Johnson,RR; Ziebell,CD; Patton,DR; Ffolliott,PF; Hamre,RH [tech. coord.]. Riparian ecosystems and their management: Reconciling conflicting uses. 16-18 April 1985. Tucson, AZ. USDA Forest Service. General Technical Report RM-120.

Hydrologic simulation modeling (Instream Flow Incremental Method) can be used in conjunction with vegetation sampling to assist in the evaluation of instream flow requirements for riparian plant species. These have proven applications on headwater streams proposed or developed for hydroelectric projects. Field studies have been undertaken to test the methodology.

[HYDROELECTRIC IMPACTS; HYDROLOGY; MODELING]

708. Harrison,AE (1974): Re-occupying unmarked camera stations for geological observations. Geology 2, 469-471.

This paper describes a method for finding the site of unmarked camera stations. The method is based on repeated trials until a transparent plastic overlay of landmarks in the original picture is fitted to the scene to be repeated. Distances between five landmarks, as measured on the old and new photographs with respect to an arbitrary axis, are needed to determine ratios of distances independent of scale. Correctness of the trial location can be derived from the ratios. Distances can usually be measured within 1 percent accuracy. [GEOMORPHOLOGY; MONITORING; PHOTO PLOTS]

709. Harrison,B; Kellogg,G (1987): Mapping riparian/wetland habitats on the Nez Perce National Forest - a cooperative approach. USDA Forest Service and USDI Fish and Wildlife Service. 9 p.

This report describes the efforts of the Nez Perce National Forest to implement an inventory of all riparian areas on the Forest in order to facilitate management of forest activities potentially impacting riparian and wetland resources. The classification system used was hierarchical and based primarily on hydrologic conditions, soils, and vegetation. [AERIAL PHOTO; INVENTORY; MONITORING; RIPARIAN HABITAT]

710. Harvey,BC (1986). Effects of suction gold dredging on fish and invertebrates in two California streams. North American Journal of Fisheries Management. 5:401-409.

The effects of dredges in two California streams were monitored to compare macroinvertebrate abundances before, after, and during dredging. Dredging significantly affected some insect taxa when substrate was altered. A recolonization experiment indicated that rapid recovery of insects at dredged sites occurred. Censuses/observations of tagged fish suggested that major changes in available habitat caused local decreases in fish density. Dredging affected riffle sculpins more severely than rainbow trout, probably because of differences in microhabitat requirements. Increase in turbidity below dredging did not appear to affect fish or invertebrates.

[DREDGING; FISH HABITAT; MACROINVERTEBRATES; MINING IMPACTS]

711. Harvey,BC; Lisle, TE (1998): Effects of suction dredging on streams: $A$ review and an evaluation strategy. Fisheries 23(8), 8-.

Suction dredging for gold in the western US is common in many streams. It is a small-scale mining practice whereby streambed material is sucked up a pipe or hose, passed over a sluice box to sort out the gold, the discarded as tailings over another area of bed. Frequently, these streams contain populations of sensitive species. The activity is subject to both state 
and federal regulations and has sometimes been the basis for litigation. Effects can vary widely from stream to stream and between reaches. Managers should be especially concerned when dredging coincides with the incubation of embryos in stream gravels or precedes spawning runs followed by high flows. Analyses by managers should include a strategy to: 1) evaluate interactions between suction dredging and other activities; 2 ) use information thus obtained to regulate dredging and mining; 3 ) monitor implementation of regulations; and 4) adapt management strategies to new information. [DREDGING; MINING IMPACTS; RIPARIAN MANAGEMENT ZONE]

712. Harvey,MD; Watson,CC (1986): Fluvial processes and morphological thresholds in incised channel restoration. Water Resources Bulletin 22(3), 359-368.

Incised channels are those in which an imbalance between sediment transport capacity and sediment supply has led to degradation of their beds. This is a frequent response to stream channelization, changes in land use, or lowering of base level. If the degradation causes a critical bank height threshold to be exceeded, which is dependent on the geotechnical properties of the bank materials, then bank failure and channel widening follow. Interdependent adjustments of channel slope and cross-sectional area occur until a new state of dynamic equilibrium with the imposed discharge and sediment loss is attained. These geomorphic adjustments can be described and quantified by using location-for-time substitution and a model of channel evolution can be formulated. Three approaches to rehabilitation of the degraded channels are possible; geomorphic, engineering, and rational. The rational approach is based on the channel evolution model and generally involves control of discharge or control of grade, or both. [CHANNEL DYNAMICS; GEOMORPHOLOGY]

713. Harvey,MD; Watson,CC; Schumm,SA (1985): Gully erosion. USDI Bureau of Land Management. Tech. Note 366. Denver Federal Center, Denver, CO. (1985-578-193/25153). 181 p. [CHANNEL DYNAMICS; GEOMORPHOLOGY; GULLY CONTROL]

714. Hashisaki,S (1996): Functional wetland restoration: An ecosystem approach. Northwest Science 70(4), 348-351.

The hydrogeomorphic wetland classification system (HGM) evaluates a broad suite of wetland functions such that specific goals can be established.
In planning functional restoration projects, it is important to consider the interactions between upland and wetland areas, and to work within the bounds of functional units such as floodplains or riparian zones, rather than restrict actions only to jurisdictionally recognized areas.

[RIPARIAN RESTORATION; WETLANDS]

715. Hatfield,D; Hatfield,C (1991): The Trout Creek Working Group. Rangelands 13(3), 112-115.

This article tells a story of building trust and understanding among people who view the same area from vastly different perspectives. A widely publicized example of what can occur when that trust and understanding is cultivated is described.

[COLLABORATION; GRAZING IMPACTS; GRAZING TREATMENTS; PARTNERSHIPS; RIPARIAN ZONES]

716. Hatfield,D; Hatfield,C (1993): Solutions for the land and the people. p.147-153. In: Tellman,B; Cortner,HJ; Wallace,MG; DeBano,LF;

Hamre, RH [tech. coord.]. Riparian management: Common threads and shared interests. USDA Forest Service. General Technical Report RM-226.

This paper describes the personal efforts of the authors to build bridges between urban environmentalists and long-term ranchers who live and depend on the land - i.e. people who view the same area from a vastly different perspective. The Trout Creek Mountain Working Group was composed of a wide variety of representatives from different land-use advocacy groups. The process of developing trust, respect, and understanding took time and commitment by all parties but resulted in a positive coalition. People-to-people alliances where landowners, environmentalists, and federal agency personnel can have dramatically constructive results. [CONSENSUS; PARTNERSHIPS; RIPARIAN HABITAT; TROUT]

717. Haugen, G [Chairman]; Duff,D [Chairman] (1982): The best management practices for the management and protection of western riparian stream ecosystems. American Fisheries Society. 45 p.

Best Management Practices (BMPs) means a practice or combination of practices that is determined by a state or agency after program assessment, examination of alternative practices, and appropriate public participation to be the most effective, practicable sources to a level means of 
preventing or reducing the amount of pollution generated by non-point sources to a level compatible with water quality and related aquatic-riparian goals. BMPs also refer to a broader process of identifying practices and techniques that may be used to reduce impacts on resources. The latter concept is used in summarizing state-of-the-art impacts on resources. The major emphasis in identifying BMPs was on technical adequacy of practices to reduce impacts on aquatic-riparian habitat. Limited emphasis is placed on economic and institutional acceptability. This paper addresses the primary impacts on riparian resources: grazing, mining, water development, roads, agriculture and urbanization, and timber harvest.

[BEST MANAGEMENT PRACTICES; RIPARIAN HABITAT; RIPARIAN RESTORATION]

718. Haugen,GN (1983): Riparian best management practices. Fisheries 8(1), 2-9. [BEST MANAGEMENT PRACTICES; RIPARIAN HABITAT; RIPARIAN MANAGEMENT ZONE]

719. Haugen,GN (1985): American Fisheries Society position statement: Strategies for riparian area management. p.21-22. In: Johnson,RR; Ziebell,CD; Patton,DR; Ffolliott,PF; Hamre,RH [tech. coord.]. Riparian ecosystems and their management: Reconciling conflicting uses. 16-18 April 1985. Tucson, AZ. USDA Forest Service. General Technical Report RM-120.

A draft of the American Fisheries Society's position statement is presented. [RIPARIAN HABITAT; RIPARIAN MANAGEMENT ZONE]

720. Haugen,GN (1985): Strategies for riparian area management. Fisheries 10(4), 20-21.

In 1982 the Western Division of the American Fisheries Society published a Guide (Best Management Practices for the Management and Protection of Western Riparian Ecosystems) to aid managers of riparian areas in making decisions in making decisions and developing management strategies to benefit riparian-dependent resources. [BEST MANAGEMENT PRACTICES; FISHERIES; RIPARIAN HABIIAT; RIPARIAN MANAGEMENT ZONE]

721. Haukos,DA; Smith,LM (1997). Common flora of playa lakes. Texas Tech University Press. Lubbock, TX. 196 p.

This book is a research-based examination of plants common to playa lakes. The authors provide:
1) a photographic guide to the plant species commonly found in playa wetlands; 2) a comprehensive list of plant species found in playas; and 3) a baseline dataset that researchers can use to evaluate future changes in playa plant communities. [PLANT COMMUNITIES; PLAYAS; RIPARIAN VEGETATION]

722. Hawkins,CP; Bartz,KL; Neale,CMU (1997): Vulnerability of riparian vegetation to catastrophic flooding: implications for riparian restoration. Restoration Ecology 45(5), 75-84.

This study examined the site-specific effects of a large episodic flood on the riparian vegetation within the floodplain of the San Luis Rey River floodplain in southern California. Cover of riparian vegetation was quantified using multispectral airborne videography. The amount of vegetation destroyed by the flood from each section varied from nearly zero to almost 40 percent of pre-flood coverage. The magnitude of loss in riparian vegetation was most strongly related to the amount of riparian vegetation initially present in the floodplain and the amount of urban surfaces in the nearby watershed. It was inferred by the results that sites near existing large areas of intact riparian vegetation and away from urban development would have the highest potential for successful long-term restoration.

[FLOOD IMPAC'IS; RIPARIAN RESTORATION; RIPARIAN VEGETATION; VIDEOGRAPHY]

723. Hawkins,CP; Kershner,JL; Bisson,PA; Bryant,MD; Decker,LM; Gregory,SV;

McCullough,DA; Overton,CK; Reeves,GH; Steedman,RJ; Young,MK (1993): A hierarchical approach to classifying stream habitat features. Fisheries 18(6), 3-11.

The paper proposes a hierarchical system of classifying stream habitats based on three increasingly fine descriptions of the morphological and hydraulic properties of channel geomorphic units. Channel geomorphic units are defined as areas of relatively homogeneous depth and flow that are bounded by sharp gradients in both depth and flow. Differences among these units provide a natural basis for habitat classification that is independent of spatial scale. At the most general level of resolution, they divide channel units into fast- and slow-water categories that approximately correspond to the commonly used terms "riffle" and "pool". Within the fast-water category, they identify two subcategories of habitat, those that are highly turbulent (falls, cascades, chutes, rapids, and riffles) and those with low turbulence (sheets and runs). Slow-water habitats 
include pools formed by channel scour (eddy pools, trench pools, channel pools, convergence pools, lateral scour pools, and plunge pools) and those formed behind dams. Dammed pools include those obstructed by debris dams, beaver dams, landslides, and abandoned channels. Backwaters are a kind of dammed pool. Fishes and other stream organisms distinguish among these habitats at one or more levels of the hierarchy. Habitats defined in this way represent an important habitat template on which patterns of biological diversity and production form. [CLASSIFICATION; FISHERIES; RIPARIAN HABITAT]

724. Hawkins, RH; Ward,TJ (1998): Site and cover effects on event runoff, Jornada Experimental Range, New Mexico. p.361-370. In: Potts,DF [ed.]. Rangeland management and water resources: Proceedings of the AWRS specialty conference. American Water Resources Association. 27-29 May 1998. Reno, NV.

At various locations on the Jornada Long-Term Ecological Research Site in southern New Mexico, measurements were made including: event rainfall depth, runoff depth, and periodic cover density. Results showed differences within groups, between groups, and with cover. Findings affirm customary but seldom confirmed expectations - that the most hydrologic improvement per unit of cover would be on the better sites and that vegetation management for hydrologic benefits on the harsher sites is futile. [HYDROLOGY; RUNOFF; VEGETATION MANAGEMEN'I]

725. Heatwole,CD; Bottcher,AB; Baldwin,LB (1986): Basin scale model for evaluating best management practice implementation programs. Transactions of the American Society of Agricultural Engineers 29(2), 439-444.

The Basin model provides field scale simulation of over 50,000 five-acre grid cells and contains a methodology for combining these cell results to predict basin-wide reduction in $\mathrm{N}$ and $\mathrm{P}$ loading. This enables basin-wide analysis of various implementation scenarios in which management alternatives are applied are applied selectively to each cell. Analysis of 15 different scenarios shows fencing of beef and dairy cattle from streams and wetlands to be the single most effective management practice in Florida.

[BEST MANAGEMENT PRACTICES; DRAINAGES; GRAZING IMPACTS; MODELING; WATER RESOURCE MANAGEMENT]
726. Heede,B (1976): Gully development and control: The status of our knowledge. USDA Forest Service, Research Paper RM-169. 42 p.

Gully formation is discussed in terms of mechanics, processes, morphology, and growth models. Design of gully controls should draw on our understanding of these aspects. Establishment of an effective vegetation cover is the long-term objective. Structures are often required. The least expensive, simply built structures are loose rock check dams, usually constructed with single- or double-wire fences. Prefabricated concrete dams are also effective. Functional relationships between dams, sediment catch, and costs, as well as a critical review of construction procedures, are also discussed. [CHECK DAMS; GEOMORPHOLOGY; GULLY CONTROL; RIPARIAN RESTORATION]

727. Heede,B (1977): Case study of a watershed rehabilitation project: Alkali Creek, CO. USDA Forest Service, Research Paper RM-189. 18 p.

The Alkali Creek project described herein may have been unique because of the availability of intensive background data. All gullies had been thoroughly surveyed and eight precipitation gages had been installed. Objectives were to: 1) rehabilitate the depleted watershed by vegetative and engineering measures; 2) test their combined effectiveness on restoration; and 3) develop new treatment approaches where required.

[CHECK DAMS; EROSION CONTROL; VEGETATION MANAGEMENT; WATERSHED]

728. Heede,B (1985): Interactions between streamside vegetation and stream dynamics. p.54-58. In: Johnson,RR; Ziebell,CD; Patton,DR; Ffolliott,PF; Hamre,RH [tech. coord.]. Riparian ecosystems and their management: Reconciling conflicting uses. 16-18 April 1985. Tucson, AZ. USDA Forest Service. General Technical Report RM-120.

Before managers attempt to alter natural riparian systems, they need to consider the interrelationships between vegetation and natural processes. Logs that fall across channels from streamside forests dissipate flow energy, maintain channel stability, decrease bedload movement, and enhance water quality. [CHANNEL MORPHOLOGY; RIPARIAN VEGETATION; STREAM ECOLOGY; WOODY DEBRIS]

729. Heede,BH (1966): Design, construction and cost of rock check dams. USDA Forest Service Research Paper RM-20. 20 p. 
During construction of the check dams in 1965 , detailed records were kept on time and materials expended for each work phase and structure. Costs were based on 1965 values and should be converted into present day values/prices. Indices of these values give an insight into the intricate relationships between costs of different types of check dams and between costs of dams and channel characteristics. These indices will hold true for other watersheds. [CHECK DAMS; EROSION CONTROL; RIPARIAN RESTORATION]

730. Heede,BH (1971): Characteristics and processes of soil piping in gullies. USDA Forest Service Research Paper RM-68. 15 p.

Soil piping was observed on a study area for more than 4 consecutive years. During this time a complete topographic survey of a soil pipe, pictures of its interior, and analyses of soil and sediment samples from the interior and from flows through the pipe were made. Observations indicated that piping may not only lead to a karst-like topography along gullies, but may indeed help induce reclamation of the soils. A second study was initiated to investigate the latter premise.

[GEOMORPHOLOGY; GULLY CONTROL; SOILS]

731. Heede,BH (1976): Equilibrium condition and sediment transport in an ephemeral mountain stream. p.97-102. In: Volume 6 of Hydrology and water resources in Arizona and the Southwest. Proceedings of the 1976 meeting of the Arizona Section of the American Water Resources Association and Hydrology Section. Arizona Academy of Science. Tucson, AZ.

Flow frequency curves supported the hypothesis that channel-forming flows are exceptional events in ephemeral mountain streams. This was substantiated by the lack of a relationship between sediment production and sediment yield. Numerous bed nickpoints indicated channel instability, despite gravel bars and log steps that are a part of the slope adjustment processes. Due to differences in structural density between bars and steps, size distribution of the sediment deposits above them differs. Although only qualitative guidelines are presented the watershed or wildlife manager should be in a position to utilize the formation of gravel bars and log sleps for his management goals.

[CHANNEL DYNAMICS; GEOMORPHOLOGY; HYDRAULICS; RIPARIAN ECOLOGY]

\section{Heede, BH (1977): Rehabilitation of}

disturbed watersheds through vegetation treatment and physical structures. Research Note. USDA Forest Service. Rocky Mountain Forest and Range Experiment Station. 7 p.

Watersheds can be successfully rehabilitated by combining physical structures with vegetation management. This combination of treatments in the southern Rocky Mountains reduced suspended sediment by 95 percent in 11 years, reduced erosion rate in waterways by 80 percent after 12 years, and produced perennial streamtlow in a formerly ephemeral gully system 7 years after treatment. Results indicate that stabilization could be achieved by placing physical structures only in the mainstream gully, the larger tributary gullies and the head-cuts of discontinuous gullies. Placing physical structures only at strategic locations could have reduced treatment costs 30 percent. This study demonstrated the need for basing watershed rehabilitation treatments on basic geomorphic processes. [EROSION CONTROL; RIPARIAN RESTORATION; WATERSHED]

733. Heede, $\mathrm{BH}$ (1978): Designing gully control systems for eroding watersheds. Environmental Management 2(6), 509-522.

Effective design of gully control systems must consider the gully network as a whole and be based on geomorphological indicators such as type of network, stream order, and stage of development. Consideration of geomorphological characteristics allows a ranking of gully treatment priorities that, in turn, promises the highest return for expenditures. Relationships between sediment catch, channel gradient, treatment cost, and height of check dams in a treatment system are presented. Return is considered within a physical rather than economic framework. Future soil savings are the main focus. [CHECK DAMS; GEOMORPHOLOGY; GULLY CONTROL; VEGETATION MANAGEMENT]

734. Heede,BH (1979): Deteriorated watersheds can be restored: A case study. Environmental Management 3(3), 271-281.

In this study, check dam systems, aided by improved vegetative cover through reduced cattle grazing and plantings, stabilized not only the structurally treated gullies, but also gullies within the network that were not structurally treated. Check dams decreased gully depth by accumulating sediment deposits. In turn, gully bank stabilization was hastened and alluvial aquifer volumes increased. Peremnial stream flow was renewed after seven treatment years. Within 11 years, check dam systems 
and improved vegetation reduced sediment loads in the flows by more than 90 percent. Only part of a gully network requires structural treatment. The mainstream gully, and those tributaries controlling the local base levels of others, are the critical segments that should be structurally treated. [GULLY CONTROL; SOILS; WATERSHED]

735. Heede,BH (1980): Stream dynamics: An overview for land managers. USDA Forest Service. General Technical Report RM-72. 26 p.

Concepts of stream dynamics were demonstrated through discussion of processes and process indicators; theory is included only where helpful to explain concepts. Present knowledge allows only qualitative prediction of stream behavior. However, such predictions show how management actions will affect the stream and the environment.

[CLASSIFICATION; HYDROLOGY; RIPARIAN MANAGEMENT ZONE]

736. Heede,BH (1981): Dynamics of selected mountain streams in the western USA. Zeit. fur Geomorph. N.F. 25(1), 17-32.

In high mountain regions, channel slope adjustments are required to offset steep potential gradients that otherwise would cause excessive erosion, resulting in deeply incised channels and over steepened valley slope sides. The process study demonstrates adjustment within six streams, located in Arizona and Colorado, not only progressed by the formation of gravel bars transverse to the flow, but also by the incorporation of downed timber into the streambed. Thus, streamside forests became an important part of the hydraulic geometry. The concept of dynamic equilibrium was applied to evaluate stream stability conditions. There was a significant negative correlation between gravel bars, log steps, and channel gradient in the equilibrium streams, but not in the non-equilibrium streams. The evaluation was based on morphologic and hydraulic indicators. This indicated that knowledge of the longitudinal profile and the yearly runoff characteristics only are required to determine the dynamic equilibrium condition. Dynamic equilibrium existed if the profile was concave and streamflow perennial, and it did not exist if the profile was convex and streamflow ephemeral. [CHANNEL DYNAMICS; CHANNEL, MORPHOLOGY; GEOMORPHOLOGY]

737. Heede,BH (1982): Gully control: Determining treatment priorities for gullies in a network. Environmental Management 6(5),
441-451.

This report addresses a newly developed procedure for setting priorities in gully control. It explains basic gully systems and developments as influenced by geomorphologic processes on which the proposed procedure is based. These processes consist of two types: one, representing interactions between the individual gullies of a network; the other, mechanisms initiated within a given gully by localized instability conditions. Classifying gullies into continuous and discontinuous types not only allows determination of network types but also points to critical locations that must be considered by the designer.

[CHECK DAMS; EROSION CONTROL; GEOMORPHOLOGY; GULLY CONTROL]

738. Heede,BH (1986): Balance and adjustment processes in stream and riparian systems. p.3-7. In Proceedings of the 1986 Wyoming water and streamside zone conference. 28-30 April 1986. Casper, WY.

All natural systems are dynamic and are changing regardless of man's or other influences. Natural processes within and between systems will eventually restore dynamic equilibrium after disturbances, but control measures may be desirable to speed the processes after serious disruptions. Control measures must work with, rather than against, ongoing natural adjustment processes. [CHANNEL DYNAMICS; GEOMORPHOLOGY; RIPARIAN ECOLOGY]

739. Heede,BH (1986): Designing for dynamic equilibrium in streams. Water Resources Bulletin 22(3), 351-357.

Streams are dynamic systems, so steady state does not exist for any appreciable period of time. Streams in dynamic equilibrium respond quickly to change, regaining a new equilibrium. From the response system it follows that there is a causative reason why a stream meanders, degrades, or aggrades. The actions represent adjustment processes. Local base level change represents one of the most influential channel changes, especially the lowering of this level. Loss of base level may cause degradation throughout a stream network, because the main stem is the base level for all its tributaries. Often, degradation causes bank instability and lowering of streamside water tables that, in turn, endanger the riparian ecosystem. Preventing local base level changes of a stream network, therefore, is a cost-effective measure.

[CHANNEL DYNAMICS; CHECK DAMS; 


\section{GEOMORPHOLOGY]}

740. Heede,BH (1987): Opportunities and limits of erosion control in stream and gully systems. In: Proceedings of the 18th International Erosion Control Association conference: You're gambling without it. Reno, NV.

The selection of erosion control projects should be based on expected returns from the project. Returns are influenced by the ongoing physical processes and the advance of the system toward a new dynamic equilibrium. If the ongoing adjustment processes can attain equilibrium within an acceptable time period, human interference will not be required. Interactions between gullying and soil piping processes in sodic soil are an example. Other examples demonstrate the intricate processes in streams and gullies, and stress the interactions between different natural systems. Thus, gully erosion may be caused by a degrading river system a great distance from the gully. Or a river may aggrade its bed because a riparian community upstream was destroyed. Cause and effect must be determined for effective control, which often is difficult due to separation in time and space.

[CHANNEL DYNAMICS; GULLY CONTROL; RIPARIAN RESTORATION; SOILS]

741. Heede,BH; DeBano,LF (1984): Gully rehabilitation - a three-stage process in a sodic soil. Soil Science of America Society Journal 48, 1416-1422.

The geomorphic, edaphic, and vegetation changes occurring in sodic soils were studied during a gully rehabilitation project in western Colorado. Data analysis showed that gully rehabilitation occurred in three stages: nonvegetated sodium banks disintegrated; the colluvial material from these eroded banks was weathered and leached; and, finally, when enough sodium had been leached from the eroded material, it was stabilized and vegetated as older colluvial material at the base of high sodium gully banks or as channel alluvium deposited behind gully structures. These changes led to an overall stabilization of the gullies and reduced suspended sediment and peak flows.

[EROSION CONTROL; GULLY CONTROL; RIPARIAN RESTORATION]

742. Heede,BH; Harvey,MD; Laird,JR (1988): Sediment delivery linkages in a chaparral watershed following a wildfire. Environmental Management 12(3), 349-358.

A study of sediment delivery and redistribution following chaparral wildfire, Arizona, US. Channel processes were interpreted from sequential aerial photographs, field measurements of sediment delivery, and overland flow from ten microwatersheds (erosion pavement-no vegetation, erosion pavement with vegetation buffer strips, open chaparral cover). Before the fire, the bulk of the sediment was stored in colluvial deposits.

Immediately following the fire, sediment eroded from hillslopes into the channels. Sediment was still not exported from the basin 33 years later. Relatively rapid vegetation recovery led to the reestablishment of chaparral buffer strips on most channel banks.

[CHANNEL MORPHOLOGY; EROSION; SEDIMENT TRANSPORT; WATERSHED; WILDFIRE]

743. Heede,BH; Rinne,JN (1990): Hydrodynamic and tluvial morphologic processes: Implications for fisheries management and research. North American Journal of Fisheries Management 10(3), 249-268.

Streamflow, sediment transport, and channel morphology have been used in the past to describe the interactions between physical and biological processes. Interaction of the hydraulic and morphological factors creates either equilibrium or disequilibrium. Indicators are given for the type of equilibrium condition. Characteristics of fish habitat must be modified with great care, only if: 1) the causes for undesirable condition are known; and 2) the measures will be compatible with future stream development.

[FISH HABITAT; FISH MANAGEMENT; HYDROLOGY]

744. Heifetz,J; Murphy,ML; Koski,KV (1986): Effects of logging on winter habitat of juvenile salmonids in Alaskan streams. North American Journal of Fisheries Management 6(1), 52-58.

Effects of logging on preferred winter habitat of juvenile salmonids were assessed by comparing the area of preferred habitat in 54 reaches. Most wintering coho salmon, Dolly Varden, and steelhead occupied deep pools with cover (i.e. uplurned tree roots, accumulations of logs, and cobble substrate). Seventy-three percent of all pools had significantly less area of pool habitat than old-growth reaches. Buffer strips protected winter habitat of juvenile salmonids by maintaining pool area and cover within pools. In some cases, blow-down from buffer strips added large organic debris to the stream and increased the cover within pools. [BUFFER STRIPS; FISHERIES; LOGGING 
seepage from the wetlands. Difference in seepage rate was attributed to two factors: 1) hydraulic conductivity of sand and gravel versus till; and 2) wetlands over till were flow-through ponds and wetlands over sand and gravel were primarily groundwater recharge areas.

[CREATED WETLANDS; GROUNDWATER; HYDROLOGY]

752. Henszey,RJ; Skinner,QD; Wesche,TA (1998): Estimating root depths from diurnal water table fluctuations along the Platte River in Nebraska. p.119. Potts,DF [ed.]. In: Rangeland management and water resources: Proceedings of the AWRA specialty conference. American Water Resources Association. 27-29 May 1998. Reno, NV.

An accurate and potentially inexpensive method for describing root zones could use the diurnal water table fluctuations caused by evapotranspiration to estimate root depth. The technique was tested in wet meadows along the Platte River in central Nebraska. Relationships at five sites were developed by converting the diurnal water table fluctuations to daily evapotranspiration amounts, with adjustments for seasonal variations. A best-fit curve was used to identify the depth where evapotranspiration no longer affected the water table. Estimated maximum root depths for sedge (Carex spp.) meadows was 85-90 $\mathrm{cm}$. Estimated root depth for meadows with big bluestem (Andropogon gerardii) and Indian grass (Sorgastrum nutans) was $165-170 \mathrm{~cm}$. Preliminary observations suggest that roots occur to at least 75 percent of the estimated maximum root depth. [BELOW-GROUND BIOMASS; PLATTE RIVER; ROOT DEPTH; WATER TABLE EFFECTS]

753. Henszey,RJ; Wolff,SW; Wesche,TA; Skinner,QD; Hubert,WA (1988): Assessment of a flow enhancement project as a riparian and fishery habitat mitigation effort. p.88-93. In: Mutz,RE; Cooper,DJ; Scott,ML; Miller,LK [eds.] Restoration, creation, and management of wetland and riparian ecosystems in the American West.

As part of mitigation procedures for impacts caused by a water development project in the Little Snake River Drainage, Wyoming, the flow in a previously ephemeral watercourse on the east slope of the Laramie Range is being enhanced to create a perennial stream. Water used to enhance this flow is obtained by transbasin diversion. The mitigation is being done in hopes of enhancing the riparian and fishery habitat. This paper describes the study to assess the results of this action and the feasibility of applying this strategy to other watersheds. [FISHERIES; RIPARIAN HABITAT; STREAM ECOLOGY; STREAM FLOW]

754. Hewitt,III,MJ (1990): Synoptic inventory of riparian ecosystems: The utility of Landsat Thematic Mapper data. Forest Ecology and Management 33/34, 605-620.

It is estimated that 66 percent of the naturally occurring vegetation of the U.S. has been eradicated since 1776. Even though riparian zones are critical to the maintenance of wildlife populations, no adequate methods exist for the synoptic inventory and assessment of this resource. Results of a feasibility study in central Washington are presented. The map accuracy assessment in this study was only 80 percent but recommendations for improving accuracy are discussed. High resolution satellite systems potentially provide the means to synoptically inventory riparian habitat.

[INVENTORY; REMOTE SENSING; RIPARIAN HABITAT]

755. Hey,RD (1982): Gravel-bed rivers: Form and processes. p. 5-13. In: Gravel bed rivers. [Eds: Hey,RD; Bathurst,JC; Thorne,CR|. John Wiley and Sons, Ltd. New York, NY.

The methods available for predicting the threedimensional morphology of gravel-bed rivers is presented. Empirical models can only be used to predict the dimensions of stable channels under certain conditions. Process-response models, in contrast, are universally applicable provided they are based on general equations defining the operation of channel processes. These models are demonstrated to explain how rivers modify their overall shape and dimensions, predict regime conditions and simulate the dynamic adjustments of a river system to erosional and depositional activity. [CHANNEL MORPHOLOGY; MODELING]

756. Hey,RD (1986): River mechanics. Journal of the Institute of Water Engineers and Scientists 40(2), 139-158.

This paper reviews recent research on river mechanics and considers the application of those principles for river engineering. Design methods, flood alleviation, and land drainage schemes could benefit from research findings.

[CHANNEL DYNAMICS; CHANNEL MORPHOLOGY; SEDIMENT TRANSPORT]

757. Hibbs,D; Giordano,P (1994): Structure, composition, and dynamics of riparian buffer 
IMPACTS; RIPARIAN HABI'TA'I]

745. Heimlich, RE (1988): The swampbuster provision: Implementation and impact. p.87-94. In: Stuber,PJ [tech. coord.|. Proceedings of the national symposium on protecting wetlands from agricultural impacts. 25-29 April 1988. Ft. Collins, CO. USDI Fish and Wildlife Service. Biological Report 88(16).

The location and conversion probability of wetlands were analyzed in relation to direct government payments for U.S. counties.

Swampbuster provisions will likely retard conversion on only about one-third of convertible wetlands. The author suggests that preservation of our wetland heritage, because federal programs fall short, may now be up to state and local efforts.

[AGRICULTURAL IMPACTS; RIPARIAN HABITAT; WETLANDS]

746. Heinze,DH (1991): Willows of Montana. Riparian Technical Bulletin No. 2. USDI Bureau of Land Management. Billings, MT. 69 p.

This bulletin is a technical guide to assist field people in the identification of 34 species of Salix. [RIPARIAN HABITAT; RIPARIAN SHRUBS; WILLOW]

747. Helm,WT (1985): Glossary of stream habitat terms. American Fisheries Society, Western Division. 34 p.

Realizing the need for standardization of nomenclature, the American Fisheries Society undertook the effort to generate the compilation of this glossary. It was developed to encourage consistent use of those terms by multi-disciplinary workers involved in the inventory and analysis of stream habitat.

[CLASSIFICATION; DEFINITIONS; GLOSSARY; RIPARIAN HABITAT]

748. Hemond, HF; Benoit, J (1988): Cumulative impacts on water quality functions of wetlands. Environmental Management 12(5), 639-653.

The total effect of cumulative impacts on the water quality functions of wetlands cannot be predicted from the sum of the effects each individual impact might have. Wetland water quality functions result from the operation of many individual, distinct, and quite dissimilar mechanisms. It is, therefore, necessary to consider the nature of each individual process. Consideration of these processes suggests that many common wetland alterations probably do entail cumulative impacts.
[CUMULATIVE IMPACTS; WATER QUALITY; WETLANDS]

749. Hemstrom,MA (1989): Integration of riparian data in a Geographic Information System. p.17-22. In: Gresswell,RE; Barton,BA;

Kershner,JL [eds.]. Riparian resource management: An educational workshop. 8-11 May 1989. USDI Bureau of Land Management. Billings, MT.

A geographic information system (GIS) offers the opportunity to integrate stream resource information at the watershed scale. A case study is presented that uses several layers of information and their uses in developing a stream enhancement model. The GIS map and information bases for Cummins Creek, Oregon Coast Range, included geomorphic stream reaches, stand conditions, plant associations, large woody debris survey, and the stream network. Integration of these data bases allows analysis of the distribution of large woody debris, potential input of woody debris from riparian stands, and the location of areas most suitable for silvicultural treatment to increase the representation of decay-resistant wood in riparian stands. [GIS; RIPARIAN HABITAT; STREAM ECOLOGY]

750. Henke,RJ (1994): Using geographic information systems to manage wetlands and riparian areas. p.101-103. In: Issues and technology in the management of impacted wildlife: Proceedings of the 6th symposium. 6-8 April 1994. Boulder, CO.

GIS is a common computer tool for projects involving natural resources and is designed to manage, analyze, and display spatial data. The ARC/INFO GIS software package can be used to facilitate the identification, delineation, monitoring, and impact assessment of wetlands and riparian areas. This tool enables planners and scientists to analyze large remote sites quickly and economically. [GIS; MONITORING; RIPARIAN HABITAT; WETLANDS]

751. Hensel,BR; Miller,MV (1991): Effects of wetlands creation on groundwater flow. Journal of Hydrology 126, 293-314.

Changes in groundwater flow near Experimental Wetland Areas were observed during monthly monitoring of groundwater elevation in nested piezometers and shallow observation wells before and after the wetlands were filled with water. Increase in groundwater levels was a result of 
strips. p.14-16. In: The ecology and management of Oregon Coast Range forests: A mid-term COPE symposium. 29-31 March 1994. Gleneden Beach, OR. Coastal Oregon Productivity Enhancement Program; Oregon State University

Geomorphology was important to riparian vegetation structure. Vegetation on terraces adjacent to streams differed from vegetation on slopes. Overstory cover and basal area were higher on terraces than slopes. Comparing slopes within buffer strips with slopes within intact riparian forest showed increased shrub cover and lowered overstory basal area cover in buffers. Alder-dominated buffer strips were found to be quite biologically stable leading to concerns about the long-term supply of conifers. [BUFFER STRIPS; GEOMORPHOLOGY; RIPARIAN FOREST; RIPARIAN HABITAT]

758. Hibbs,DE; Giordano,PA (1996): Vegetation characteristics of alder-dominated riparian buffer strips in the Oregon Coast Range. Northwest Science 70(3), 213-222.

The authors examined the effects of harvesting adjacent trees on tree regeneration, understory development, and overstory dynamics in riparian buffer strips and compared them with undisturbed riparian communities. Through a chronosequence of buffers aged 0 to 32 years, little change in overstory composition or cover was observed. Tree regeneration was scarce. The alder-dominated community appeared largely resistant to environmental changes associated with becoming buffer strips. Future tree regeneration may be limited after alder senescence.

[RIPARIAN FOREST; RIPARIAN HABITAT; RIPARIAN SHRUBS]

759. Hickin,EJ (1983): River channel changes: Retrospect and prospect. International Association of Sedimentologists 6 (Spec. Publ), 61-83.

This paper reviews some of the major developments in the study of channel changes during this century and offers comments on the direction of future research. Topics addressed include the relation of channel equilibrium to time-scale, the process relations of the formal theory of equilibrium channel-morphology, regime theory and hydraulic geometry, complex channel response, human-induced channel adjustments, and channel changes of the Holocene and Pleistocene. [CHANNEL DYNAMICS; CHANNEL MORPHOLOGY; GEOMORPHOLOGY; HYDRAULICS]
760. Hickin,EJ (1984): Vegetation and river channel dynamics. Canadian Geographer 28(2), 111-126.

The physical science of fluvial geomorphology is flawed because it ignores processes that are not easily quantifiable and statistically or physically manipulable. Vegetation may exert significant control over fluvial processes and morphology through five mechanisms: flow resistance, bank strength, bar sedimentation, formation of log-jams, and concave-bank bench deposition. Examples of these are presented and the research implications of each are discussed.

[CHANNEL MORPHOLOGY; GEOMORPHOLOGY; RIPARIAN VEGETATION]

761. Hicks,L; Warren,A (1996): Loco Creek watershed project. p.139-140. In: Evans,KE [comp.]. Sharing common ground on western rangelands: Proceedings of a livestock/big game symposium. 26-28 Feb 1996. Sparks, NV. USDA Forest Service. General Technical Report IN'T-GTR-343. 164 p.

Concerns about high stocking rates within riparian areas on the Morgan-Boyer grazing allotment in south-central Wyoming preceded a collaborative alliance of ranchers and agency representatives. The project employed drift fencing, upland water development, prescribed burning, vegetative plantings, and installation of instream structures. Stocking rates and season of use were not changed. After 4 years, better function of the watershed and riparian areas were noted; stream channel morphology and hydrology improved; and, riparian vegetative communities expanded in both cover and height - facilitating the introduction of trout into Loco Creek.

[GRAZING IMPACTS; INSTREAM

STRUCTURES; RIPARIAN; RIPARIAN MANAGEMENT ZONE]

762. Hicks,L; Warren,A; Hicks,C (1996): Upper Muddy Creek coordinated resource management. p.125-128. In: Evans, KE [comp.]. Sharing common ground on western rangelands: Proceedings of a livestock/big game symposium. 26-28 Feb 1996. Sparks, NV. USDA Forest Service. General Technical Report IN'T-GTR-343. $164 \mathrm{p}$.

On the Muddy Creek CRM, numerous people of diverse backgrounds came together to develop a common goal and conservation ethic on land management. The ecosystem management concept assured that all users and impacts of the area were 
addressed.

[COLLABORATION; ECOSYSTEM

MANAGEMENT; RIPARIAN MANAGEMENT

ZONE; WATERSHED]

763. Higgins,DA; Maloney,SB; Tiedemann,AR; Quigley,TM (1989): Storm runoff characteristics of grazed watersheds in eastern Oregon. Water Resources Bulletin 25, 87-100.

Rainfall and runoff data from 485 storms during the summers of 1979-84 were evaluated to characterize storm runoff and peak flows for 13 small watersheds in the Blue Mountains of eastern Oregon and to determine differences between grazing intensities and vegetation types. Four levels of grazing intensity had no effect on storm runoff. [GRAZING IMPACTS; HYDROLOGY; RUNOFF; WATERSHED]

764. Higgins,DA; Tiedemann,AR; Quigley,TM; Marx,DB (1989): Streamflow characteristics of small watersheds in the Blue Mountains of Oregon. Water Resources Bulletin 25(6), 1131-1149.

Many studies on storm runoff and grazing have two basic limitations. Most have determined infiltrations and runoff from small plots; relatively few have evaluated responses of entire watersheds. In this study, 7 years of streamflow data were evaluated for 13 small watersheds, with different grazing intensities and vegetation types. Four levels of grazing intensity had no effect on storm runoff. [GRAZING IMPACTS; HYDROLOGY; RUNOFF; WATERSHED]

765. Hilderbrand,RH; Lemly,AD; Dolloff,AC; Harpster,KL (1997): Effects of large woody debris placement on stream channels and benthic macroinvertebrates. Canadian Journal of Fish Aquatic Science 54, 931-939.

As an experimental stream restoration technique, large woody debris (LWD) was added to two streams in Virginia. Random and systematic log placements were compared in low-and high-gradient streams. Pool area increased 146 percent in the systematic placement and 32 percent in the random placement sections of the low-gradient stream. The high-gradient stream, however, changed very little after LWD placements. Logs oriented as dams were responsible for all pools created by additions regardless of method or placement. Greater numbers of pools were created by single log placement. Total benthic macroinvertebrate abundance did not change as a result of LWD additions in either stream.
[CHANNEL DYNAMICS; LARGE WOODY DEBRIS; MACROINVERTEBRATES; RIPARIAN RESTORATION]

766. Hill,AR (1996): Nitrate removal in stream riparian zones. Journal of Environmental Quality 25(4), 743-755.

The current consensus is that most riparian zones effectively remove NO3 from subsurface water. However, research has not focused on the relationship between hydrology and chemistry within the context of the riparian zone hydrogeologic setting. Most riparian zones that remove NO3 occur in landscapes with impermeable layers near the ground surface. Limited research suggests that riparian zones have less effect on NO3 transport in hydrogeologic settings where groundwater has little interaction with vegetation and sediments because flow occurs mainly across the surface, or at depth beneath the riparian zone before discharging to the stream. An interdisciplinary approach is needed to provide a better understanding of $\mathrm{NO} 3$ regulation in riparian zones.

[GROUNDWATER; HYDROLOGY; NUTRIENT CYCLES; POLLUTION]

767. Hill,DP (1985): The site signature method of land suitability planning in river corridors. p.398-402. In: Johnson,RR; Ziebell,CD; Patton,DR; Ffolliott,PF; Hamre,RH [tech. coord.]. Riparian ecosystems and their management: Reconciling conflicting uses. 16-18 April 1985. Tucson, AZ. USDA Forest Service. General Technical Report RM-120.

A performance-based methodology was developed for location and construction of a variety of land use applications in fragile environments. Landscape synthesis and land uses were represented by graphic "signatures". Through synthesis, a land suitability plan was created. Site specific performance criteria assure environmental protection while allowing developers locational flexibility. [HUMAN IMPACTS; PLANNING; RIPARIAN HABITAT]

768. Hill,MT; Platts,WS (1998): Ecosystem restoration: $A$ case study in the Owens River Gorge, CA. Fisheries 23(11), 18-27.

The Owens River Gorge Project aims at returning the river channel, dewatered for more than 50 years, to a functional riverine-riparian ecosystem. The passive, or natural, restoration approach focused on the development of riparian habitat and channel complexity using incremental increases in pulse and 
base flows. Increasing pulse and base flows resulted in establishment and rapid growth of riparian vegetation on all land forms, and the formation of good quality micohabitat features (pools, runs, depth, and wetted width). An extremely complex and productive habitat now occupies these bottomlands. A healthy fishery in good condition has quickly developed in response to habitat improvement. [FISHERIES; PASSIVE RESTORATION; RIPARIAN RESTORATION]

769. Hill,WR; Knight, AW (1987): Experimental analysis of the grazing interaction between a mayfly and stream algae. Ecology 68(6), 19551965.

Interaction between the grazing mayfly and periphyton in a small, northern California stream was examined by manipulating the density of the mayfly . The mayfly significantly depressed the periphyton standing crop. It also influenced two structural attributes of periphyton, increasing the amount of Chlorophyll A per unit biomass and decreasing the relative contribution of the loose, upper layer to total periphyton biomass.

[ALGAE; INVERTEBRATES; STREAM ECOLOGY]

770. Hinchman,VH; Birkeland,KW (1995): Age prediction based on stem size for riparian cottonwood stands. The Southwestern Naturalist 40(4), 406-409.

Accurate estimations of tree age based on size are useful for hydrologic and geomorphic studies of riparian environments. The use of stem size to predict age for Fremont cottonwood is assessed based on increment bores and stem diameter measurements along two rivers of the southwestern United States. Predictive models for tree age were established for creeks in Utah and Arizona and were compared to previously published regression equations. Results indicated that good age-size relationships exist within short reaches with uniform geomorphic site conditions. However, these correlations may not hold for entire drainage basins, or larger geographic areas. [COTTONWOOD; RIPARIAN FOREST; RIPARIAN HABITAT; TREE SIZE]

771. Hindley,E (1996): Observing physical and biological change through historical photographs. USDI Bureau of Land Management. Technical Report 1737-13.

This publication provides an approach for using historical photos to analyze vegetation and stream channel conditions and trends for riparian-wetland areas. Historic photographs can portray the character of landscapes as they were many years ago. Retaking photos from the same location can provide comparisons from which vegetation and stream channel changes can be objectively described. Visual comparisons can also be useful in depicting the dynamic nature and resiliency of ecosystems, and dispelling some of the myths that exist regarding historic conditions and their causes.

[AERIAL PHOTO; CHANNEL DYNAMICS; HISIORIC RECORDS; PLANT COMMUNITIES; RIPARIAN MANAGEMENT ZONE]

772. Hines,C; Bradshaw,GA (1997): Landscape analysis of black cottonwood community dynamics, Grande Ronde River, Oregon, USA: Assessing restoration potential and long-term viability. p.109. In: Abstracts. 1997 Annual meeting of the Ecological Society of America jointly with The Nature Conservancy. 10-14 August 1997. Albuquerque, NM.

Black cottonwood communities in the West have been severely degraded by intensive grazing, irrigation, and mining activities in the last century. In this study, historic and current populations were examined to evaluate restoration capacity given present day geomorphic conditions and land use patterns. There is discussion relative to the feasibility of restoration plans seeking reestablishment of viable riparian plant communities.

[COTTONWOOD; RIPARIAN FOREST; RIPARIAN RESTORATION]

773. Hixson,S; Herman,D (1998): A practical approach for documenting cattle effects on water and soils resources. p.209-216. In: Potts,DF [ed.]. Rangeland management and water resources: Proceedings of the AWRA specialty conference. American Water Resources Association. 27-29 May 1998. Reno, NV.

USDA Forest Service field interdisciplinary teams evaluated both upland and riparian cattle use to determine compliance to Best Management Practices (BMPs) and forest plans.

[BEST MANAGEMENT PRACTICES; GRAZING IMPACTS]

774. Hoag,JC (1992): Planting techniques from the Aberdeen, ID, plant materials center for vegetating shorelines and riparian areas. p.163-166. In: Clary,WP; McArthur,ED; Bedunah,D; Wambolt,CL [comp.]. Proceedings Symposium on ecology and management of riparian shrub communities. USDA Forest 
Service. General Technical Report INT-289.

The following woody riparian species were effective in shoreline protection and revegetation of eroded stream channels: coyote willow, dwarf blue Artic willow, laurel willow, prairie willow, "Siouxland" eastern cottonwood, "Imperial" Carolina poplar, and robust poplar. Hormones, fungicides, and fertilizer did not consistently enhance survival or establishment.

[PLANT MATERIALS; RIPARIAN RESTORATION; RIPARIAN SHRUBS]

775. Hoar,AR; Erwin,MJ (1985): Relationships between the expansion of agriculture and the reduction of natural riparian habitat in the Missouri River floodplain of northeast Montana, 1938 - 1982. p. 250-256. In: Johnson,RR; Ziebell,CD; Patton,DR; Ffolliott,PF; Hamre,RH [tech. coord.]. Riparian ecosystems and their management: Reconciling conflicting uses. 16-18 April 1985. Tucson, AZ. USDA Forest Service. General Technical Report. RM-120.

Over a 45-year period, the floodplain composition of the Missouri River at four points in time is described. Broad changes in the area, density, and percent of the floodplain represented by agriculture and other developed land and three general riparian cover types are documented. Evidence is provided of the patterns and rates at which riparian cover types were lost or gained, including the conversion of agricultural and other developed land.

[AGRICULTURAL IMPACTS; FLOODPLAIN MANAGEMENT; RIPARIAN HABITAT; RIPARIAN VEGETATION]

776. Hockberger,Jr.JJ. (1986): Indiscrete regulation of indiscrete sources: The Idaho water quality standards and control of sediment impacts on salmon and steelhead spawning and rearing habitat. Idaho Law Review 22, $469 \mathrm{p}$.

Crucial streams in Idaho capable of supporting anadromous salmonid populations flow through the Idaho batholith, a geologic area characterized by steep slopes and fragile granitic soils. Logging, grazing, mining, and other extractive resource uses, have historically been responsible for tremendous erosion in the batholith. Denuded land areas increase erosion leading to increased turbidity and sediment in streams, which are detrimental to salmonid populations. Anadromous populations are especially vulnerable to habitat degradation since if 4 or 5 successive annual classes of spawners returning from the sea are unable to reproduce, the run will become extinct. Much of the Idaho batholith and other salmonid habitat is overlain by land administered by the USDA Forest Service. Such lands have come under increasing scrutiny from those interested in protecting sensitive habitat. This article gives an in-depth history of the Idaho water quality standards for non-point source pollution and an analysis of these standards along with some comparable regulations from other Pacific Northwest states. [CLEAN WATER ACT; FISHERIES; NON-POINT SOURCE POLLUTION; WATER LAW; WATER QUALITY]

777. Hoffman,GR; Stanley,LD (1978): Effects of cattle grazing on shore vegetation of fluctuating water level reservoirs. Journal of Range Management 31(6), 412-416.

Shore vegetation of reservoirs develops between periods of high water; thus annual fluctuations in water levels, along with cattle grazing as limiting factors, keep shore vegetation in an early seral stage. Minimizing both water fluctuation levels and cattle grazing for a reservoir in a given year, or years, permits considerably more shoreline vegetation development.

[GRAZING IMPACTS; LIVESTOCK EFFECTS; SHORELINES]

778. Hogan,DL (1989): Channel response to mass wasting in the Queen Charlotte Islands, British Columbia: Temporal and spatial changes in stream morphology. p.125-142. In: Alexander,EB [ed.]. Proceedings of Watershed '89: A Conference on the stewardship of soil, air, and water resources. USDA Forest Service. Juneau, AK.

A paired watershed study was used to compare stream channels with various ages of mass wasting disturbance with similar channels in undisturbed basins. Morphological parameters of relevance to fish habitats were the focus of the field surveys. Debris torrent inputs to stream channels establishes sediment wedges associated with debris jams.

Sedimentological, morphological, and hydraulic changes occur upstream and downstream of the jams. Sediment wedges are of two basic types, vertical and lateral. The location, size, and function of each type of jam controls morphology and their distribution along the water course influences the spatial adjustment of the channel. Results indicate that severe morphological alterations persist during the first decade following debris torrenting, but the channel begins to develop more normal characteristics during the second and third decades. After 30 years, the morphological nature of stream 
channels begins to resemble undisturbed channels. [CHANNEL DYNAMICS; CHANNEL MORPHOLOGY; LARGE WOODY DEBRIS; RIPARIAN FOREST]

779. Hogg,ID; Williams,DD (1996): Response of stream invertebrates to a global warming thermal regime: An ecosystem level manipulation. Ecology 77(2), 395-407.

The thermal regime of a first-order permanent stream near Ontario, Canada was manipulated in accordance with global warming predictions. The effects of a 2.0 - 3.5 degree $C$ water temperature increase on densities, biomass, species composition, and life histories of resident stream invertebrates were examined. The stream was divided longitudinally at the source into two channels, one control and onc experimental. Following commencement of the manipulation, these changes were observed: 1) decreased total animal densities, particularly Chironomidae (Diptera); 2) earlier onset of adult insect emergence; 3 ) increased growth rates and precocious breeding in Amphipoda; 4) smaller size at maturity for Plecoptera; and 5) altered sex ratios for Lepidostoma vernale (Trichoptera). Results partially corroborated previous laboratory and field studies but variation of the responses of individual target species was unexpected and may have been influenced by the genetic structure of local populations.

[GLOBAL WARMING; INVERTEBRATES; RIPARIAN HABITAT; STREAM TEMPERATURE]

780. Holechek,JL; Berry, TJ; Vavra,M (1987): Grazing system influences on cattle performance on mountain range. Journal of Range

Management 40(1), 55-59.

The influences of rest-rotation, deferred rotation, and season-long grazing systems on cattle diet botanical composition and quality and weight gains were studied over 5 years in northeastern Oregon. There were no significant differences in weight gains among the three systems. Crude protein, in vitro organic matter digestibility, and acid detergent fiber percentages did not differ among systems. Key forages wcre Idaho fescue, bluebunch wheatgrass, and common snowberry. Cattle diet botanical composition under the 3 grazing systems did not differ.

[GRAZING IMPACTS; GRAZING TREATMENTS; MEADOWS]

781. Holechek,JL; Vavra,M; Skovlin,J (1982):
Cattle diet and daily gains on a mountain riparian meadow in northeastern Oregon. Journal of Range Management 35(6), 745-747.

The authors evaluated cattle weight gains, diet botanical composition, and diet quality on riparian meadow range in eastern Idaho. Pregnant yearling heifers were used to evaluate livestock performance. Esophohageally fistulated cows were used to evaluate diet quality and diet botanical composition. Cattle diets showed little difference in botanical composition between periods or years. Grasses comprised an average of 80 percent of the diet during the 3-year study period. Kentucky bluegrass was the most important grass in cattle diets and had the highest percent cover on the study pastures. Daily gains were erratic between and within years averaging $.41 \mathrm{~kg} /$ day for 3 years. Average daily gains on the meadow were better than or equal to those reported in other studies. Separate fencing and deferred grazing of mountain meadows could improve cattle performance and aid ranchers in gathering cattle at the end of the grazing season. Deferred grazing should result in pasture improvement and provide better habitat for nesting birds but cost of fencing would be a primary disadvantage.

[ECONOMICS; GRAZING IMPACTS; GRAZING TREATMENTS; LIVESTOCK EFFECTS]

782. Holl,RG (1982): Grazing non-point source control strategy. Prepared under an interagency agreement between the US Environmental Protection Agency, Region 8, Denver CO, and the USDI Bureau of Land Management. 24 p.

The Clean Water Act (PL95-217, 1977), Section $208(\mathrm{~b})(2)(\mathrm{F})$, requires that various non-point sources of pollution, including runoff from land managed for livestock production, be identified, and to the extent possible, controlled. The strategy contained in this document provides guidance for the prevention and control of non-point source water quality degradation resulting from livestock use of public land. It describes procedures for identifying problem areas and those remedial measures to maintain water quality or reduce water pollution.

[CLEAN WATER ACT; GRAZING IMPACTS; NON-POINT SOURCE POLLUTION; WATER QUALITY]

783. Hollands, GG (1990): Regional analysis of the creation and restoration of kettle and pothole wetlands. p.281-296. In: Wetland creation and restoration. The status of the science. Island Press. Washington, DC. 
Kettles are topographic basins created by a variety of glacial processes and occur randomly throughout glaciated regions. They are associated with both permeable and impermeable deposits. They may have complex hydrology but are divided into two general hydrologic types: those associated with surface streams and those without inlets or outlets. Water hydrology depends on whether kettles are associated with permeable or low permeable deposits. A primary concern with creating kettle wetlands is establishment of the proper hydrology. There is little research available specific to kettle and pothole creation and restoration.

[HYDROLOGY; POTHOLES; RIPARIAN RESTORATION; WETLANDS]

784. Honey,WD; Seidler,RJ; Klingeman,PC (1984): Riparian zone systems, uses and management. USDI Geological Survey, Water Resources Division. Reston, VA. Report No. USGS/G-864-22. 78 p.

This paper is a comprehensive review of the status of knowledge regarding riparian zone systems, uses, and management. Part I describes natural features and processes found in riparian zones. Part II describes major types of human uses and the management methods that have evolved to sustain those uses.

[GEOMORPHOLOGY; RIPARIAN ECOLOGY; RIPARIAN VEGETATION]

785. Hooke,JM (1979): An analysis of the processes of river bank erosion. Journal of Hydrology 42, 39-62.

Field observations were shown to aid considerably in understanding the processes of removal during river bank erosion. Two main methods of river bank removal were identified, corrosion and slumping, and these appear to be associated with the influence of river flow levels and antecedent precipitation conditions, respectively. Antecedent precipitation index emerged as the variable that provided the highest explanation of the erosion characteristics, but the diversity of results from different sites illustrates the complex combinations of conditions related to erosion events. [GEOMORPHOLOGY; HYDROLOGY; STREAMBANK PROTECTION]

786. Hoover,SL; King,DA; Matter,WJ (1985): A wilderness riparian environment: Visitor satisfaction, perceptions, reality, and management. p.223-226. In: Johnson,RR; Ziebell,CD; Patton,DR; Ffolliott,PF; Hamre,RH [tech. coord.]. Riparian ecosystems and their management: Reconciling conflicting uses. 16-18 April 1985. Tucson, AZ. USDA Forest Service. General Technical Report RM-120.

Visitors to the Mt. Baldy Wilderness Area in northeast Arizona, though generally satisfied with their recreation experience, cited distraction from cattle, fishermen, and other people. Perceptions closely matched real-world values. Attributes given the highest desirability ratings were mostly features that prevail in healthy riparian systems. Management that maintains or enhances the ecological integrity of an area may also contribute to its potential recreation value.

[ECONOMIC VALUES; RECREATION IMPACTS; RIPARIAN HABITAT; SOCIAL VALUES]

787. Horak,GC (1979): The status and success of fish and wildlife mitigation in western water resource projects, 1949-1979. p. 391-395. In: Swanson,GA [ed.]. The mitigation symposium: A national workshop on mitigating losses of fish and wildlife habitat. USDA Forest Service. General Technical Report RM-65.

This paper summarizes six research projects analyzing the formulation, acceptance, and implementation of 600 fish and wildlife recommendations as well as the effectiveness of these measures to preserve of improve populations and habitats in twenty states west of the Mississippi River. Recommendations are offered to improve the effectiveness of fish and wildlife measures. [RIPARIAN HABITAT; WATER RESOURCE MANAGEMENT]

788. Horak, GC (1989): Integrated riparian planning in the urban setting. p.41-44. In: Gresswell,RE; Barton,BA; Kershner,JL [eds.]. Practical approaches to riparian resource management. An educational workshop. 8-11 May 1989. USDI Bureau of Land Management. Billings, MT.

The city of Ft. Collins, Colorado has implemented an innovative approach to riparian area creation and preservation. The solid foundation provided by previous planning products (open space, basin master, urban fishery, wildlife, and national recreation plans) are contributing to sensible decisions concerning riparian areas. Environmental advantages are complemented by functional values such as flood control and recreational benefits. [PI ANNING; RIPARIAN MANAGFMENT ZONE; RIPARIAN RESTORATION] 
789. Horton,JE (1973): Evapotranspiration and water research as related to riparian and phreatophyte management - An abstract bibliography. USDA Forest Service. Miscellaneous Publication No. 1234. 192 p.

This bibliography, containing 713 entries, emphasizes moist-site vegetation, both phreatophyte and riparian, but watershed and plot studies were included where they were helpful in determining the effect of vegetation management on water yield. Methods of estimating or measuring water losses were given full coverage.

[BIBLIOGRAPHY; HYDROLOGY; RIPARIAN

MANAGEMENT ZONE; VEGETATION

MANAGEMENT; WATER RESOURCE MANAGEMENT]

790. Horton,JS (1966): Problems of land management in the various phreatophyte zones. p.1-6. In: Vegetation management on flood plains and riparian lands. Phreatophyte symposium. 30 August 1966. Albuquerque, NM.

Water shortages in the Southwest began to become apparent about the same time that tamarisk (an introduced ornamental) began to aggressively spread along major flood plains. In mountainous areas streams and rivers have a wide variety of vegetation types which depend on amounts of flowing water, elevation, and amount and character of alluvial deposits. Removing shade along these streams will increase water temperature, which will create greater evaporation losses.

[PHREATOPHYTES; RIPARIAN HABITAT; RIPARIAN VEGETATION]

791. Horton,JS (1977): The development and perpetuation of the permanent tamarisk type in the phreatophyte zone of the Southwest. p.124-127. In: Johnson,RR; Jones,DA [tech. coord.]. Importance, preservation, and management of the permanent tamarisk type in the phreatophyte zone of the Southwest: A symposium. 9 July 1977. Tucson, AZ. USDA Forest Service. General Technical Report RM-43.

Several species of tamarisk (salt-cedar) introduced to this country as ornamentals have become naturalized and have become a dominant shrub along Southwestern rivers. Its aggressive characteristics suit it to be a permanent dominant in much of the phreatophyte vegetation of this region. Successful management of this vegetation must carefully consider its ecological characteristics. [PHREATOPHYTES; RIPARIAN FOREST; RIPARIAN HABITAT; SALT-CEDAR]
792. Horton,JS; Campbell,CJ (1974): Management of phreatophyte and riparian vegetation for maximum multiple use values. USDA Forest Service. Research Paper RM-117. 23 p.

This paper reviews the status of our knowledge about environmental relations of vegetation along water courses in the southwestern U.S. and the impacts of vegetation management to reduce evapotranspiration on other resource values. Measurement and evaluation of water losses from moist-site vegetation, ecological relationships, other resource uses of phreatophyte and riparian areas, and control methods are described. Management approaches of moist-site areas by zones are described based primarily on water table depth, elevation, and tree species.

[MULTIPLE USE; PHREATOPHYTES; RIPARIAN HABITAT; RIPARIAN VEGETATION]

793. Horton,JS; Robinson,TW; McDonald,HR (1964): Guide for surveying phreatophyte vegetation. USDA Agricultural Handbook 266. 37 p.

The extent and nature of vegetation cover is essential information for planning treatments of the vegetation and estimating potential water savings or other events. Vegetative surveys require an economical sampling scheme that can be repeated and will yield data that are precise enough to be reliable.

[PHREATOPHYTES; RIPARIAN HABITAT; RIPARIAN VEGETATION]

794. Hostetler,SW (1991): Analysis and modeling of long-term stream temperatures on the Steamboat Creek Basin, OR; Implications for land use and management. Water Resources Bulletin 27(4), 637-647.

Steamboat Creek Basin is an important source of timber but also is crucial habitat for steelhead trout. Stream temperatures have gradually decreased since major logging operations ceased in 1969, but most tributaries are still at the upper limit of tolerance for survival of juvenile steelhead. Changes in forest management practices have somewhat lessened the logging effects on stream temperatures, but there is little margin for increases in temperature stemming from land-use in the watershed or natural causes. [FISHERIES; LOGGING IMPACTS; RIPARIAN HABITAT; STREAM TEMPERATURE]

795. House,RA; Boehne,PL (1985): Evaluation of instream enhancement structures for salmonid 
spawning and rearing in a coastal Oregon stream. North American Journal of Fisheries

Management 5(2B), 283-295.

The authors present the example of a stream in Oregon that lost much of its productivity as an andromonous salmonid stream following logging activities, intensive stream cleaning, and flooding. The stream was almost totally devoid of instream structures, resulting in a nearly total lack of spawning gravel and rearing habitat. Stream enhancement structures were successful and functional after two winters. Structures greatly increased the diversity of the stream bed, trapped gravel, and created shallow gravel bars and deep, covered pools. Number, size, and quality of pools increased in areas with structures. Coho salmon and steelhead spawning and numbers increased substantially. The study shows that similar degraded streams can be rehabilitated by properly designed enhancement programs.

[FISHERIES; RIPARIAN RESTORATION; STREAM IMPROVEMENTS]

796. House,RA; Crispin,V (1990): Economic analyses of the value of large debris as salmonid habitat in coastal Oregon streams. USDI Bureau of Land Management. Oregon State Office. Technical Note OR-7-6512. Portland OR. 11 p.

Management scenarios which involved stream rehabilitation with large woody debris additions and rehabilitation combined with conifer harvest from the riparian zone showed greater short-term fishery benefits than leaving a stream under a low debris loading level. However, the best long-term economic alternative to maintain salmonid productivity in coastal streams is through maintenance of mature coniferous riparian zones under continuous high debris loading.

[INSTREAM STRUCTURES; LARGE WOODY DEBRIS; RIPARIAN FOREST; RIPARIAN RESTORATION; SALMONIDS]

797. Howard,RJ; Larson,JF (1985): A stream habitat classification for beaver. Journal of Wildlife Management 49(1), 19-25.

Beaver habitat use over a 28-year period permitted development and testing of two models for predicting density of active beaver colonies on streams. Principal components regression, a technique that reduced the confounding effects of closely correlated ecological variables found in earlier studies of this type, and discriminant analysis were used for model development. In mixed coniferous-deciduous forest habitat, the percentage of hardwood vegetation, watershed size, and stream width had significant positive effects on active colony density. Increasing stream gradient and progressively well-drained soils had negative effects. [BEAVER; HABITAT MANAGEMENT; MODELING; RIPARIAN HABITAT]

798. Howard-Williams,C; Pickmere,S; Davies,J (1986): Nutrient retention and processing in New Zealand streams: The influence of riparian vegetation. New Zealand Agricultural Science 20(2), 11-114.

[NON-POINT SOURCE POLLUTION; NUTRIENT CYCLES; RIPARIAN HABITAT]

799. Howe,WH; Knopf,FL (1991): On the imminent decline of Rio Grande cottonwoods in central New Mexico. The Southwestern Naturalist 36(2), 218-224.

Increment cores from 144 Fremont cottonwoods were taken at three riparian woodland sites along the Rio Grande in New Mexico. Trees at two study sites averaged 38.8 and 43.2 years old. All trees fewer than 26 years old at those sites were root suckers from older trees whose primary trunks had decayed. The third site, one of a few known locations where young trees were present, had 75 percent of the trees between 5 and 25 years old. Cottonwood recruitment generally, but not always, could be associated with years of overbank flooding. The combination of a paucity of cottonwood regeneration over the last 30 years, the rapid colonization during this century of Russian-olive and salt-cedar into the valley, and current river channel management practices suggest that the Rio Grande riparian woodland will become dominated by the exotic shrubs over the next 50 to 100 years. To assure the continued survival of the cottonwood riparian community along the Rio Grande, resource managers need to implement strategies to enhance cottonwood regeneration and survival and to control the spread of exotics. [COTTONWOOD; RIO GRANDE; RIPARIAN FOREST; RIPARIAN RESTORATION]

800. Hruby, T (1999): Assessments of wetland functions: What they are and what they are not. Environmental Management 23(1), 75-85.

In this assessment, methods for generating information about wetlands were analyzed to understand their similarities, differences, and the type of information they provide. Rapid assessment methods based on mechanistic models do not assess the rates or dynamics of ecological processes in wetlands. This is a limitation that is frequently misunderstood. Advantages and limitations of these 
approaches are discussed.

[ASSESSMENTS; MODELING; WETLANDS]

801. Hubbard,JP (1977): Importance of riparian ecosystems: Biotic considerations. p.14-18. In: Johnson,RR; Jones,DA [tech. coord.]. Proceedings of the Symposium on the importance, preservation, and management of the riparian habitat. 9 July 1977 . Tucson AZ.

The southwest states of New Mexico and Arizona are among the richest of any in the USA as far as biotic diversity and richness. They also display significant and important area-to-area differences in the composition of biota occupying similar situations. Riparian ecosystems are described in terms of their importance in perpetuating these varied resources. [BIODIVERSITY; RIPARIAN ECOLOGY; RIPARIAN HABITAT]

802. Hubbs,C; Miller,RR; Edwards,RJ; Thompson,KW; Marsh,E; Garrett,GP; Powell,GL; Morris,DJ; Zerr,RW; Johnson,RR; Jones,DA (1977): Fishes inhabiting the Rio Grande, Texas and Mexico, between EI Paso and the Pecos confluence. p.91-99. In: Johnson,RR; Jones, DA [tech. coord.]. Importance, preservation, and management of riparian habitats: A symposium. 9 July 1977. Tucson, AZ. USDA Forest Service. General Technical Report RM-43.

The fishes of the middle part of the Rio Grande can be divided into three faunal assemblages: the saline Rio Grande fauna (made up of widely distributed and salt tolerant species) upstream from the Conchos confluence, the Rio Conchos-Rio Grande fauna (mostly south Texas and Mexican species) in the Rio Grande between the Conchos and Pecos, and the tributary creek fauna (Chihuahuan species plus some derivatives) that depend on tributary creeks for all or part of their life history stages.

[FISHERIES; RIO GRANDE; RIPARIAN HABITAT]

803. Hubert,WA; Lanka,RP; Wesche,TA; Stabler,F (1985): Grazing management influences on two brook trout streams in Wyoming.

p.290-294. In: Johnson,RR; Ziebell,CD;

Patton,DR; Ffolliott,PF; Hamre,RH [tech. coord.]. Riparian ecosystems and their management: Reconciling conflicting uses. 16-18 April 1985.

Tucson, AZ. USDA Forest Service. General Technical Report RM-120.

The abundance of brook trout and instream habitat characteristics were evaluated in two rangeland streams. Heavily grazed and lightly grazed reaches of two streams with different grazing measurements were compared. Relationships between stream morphology, riparian zone characteristics, and trout abundance were observed. [FISHERIES; GRAZING IMPACTS; STREAM ECOLOGY; TROUT]

804. Hudak,HG; Ketcheson,GL (1992): Willow community types as influenced by valley bottom and stream types. p.16-17. In: Clary,WP; McArthur,ED; Bedunah,B; Wambolt,CL [comp.]. Proceedings - Symposium on ccology and management of riparian shrub communities.

USDA Forest Service. General Technical Report INT-289.

An interdisciplinary team conducted inventories of willow community types in the Sawtooth National Forest of south central Idaho. Stands dominated by one or several willow species were related to elevation, parent material, substrate, stream gradient, and configuration of the valley floor.

[CLASSIFICATION; RIPARIAN HABITAT; WILLOW]

805. Huerta,YC; Medina,AL; Sanchez,XM; Reyes,TS (1995): A preliminary classification of the riparian vegetation of El Carrizal in Tapalpa, Jalisco, Mexico. p. 128-133. In Partnerships for sustainable forest ecosystem management: Fifth Mexico/U.S. biennial symposium. 17-20 October 1994; Guadalajara, Jalisco, Mexico. USDA Forest Service. General Technical Report RM-GTR-266.

The primary objective of this study was to identify a classification for the riparian vegetation of "El Carrizal" watershed in Tapalpa, Jalisco, Mexico. The classification was proposed for application to: 1) better understand the structure and composition of the riparian vegetation; 2) provide a point of reference for other riparian studies where comparisons of types, species, etc. could be made; 3 ) provide hasic, essential information for the development of watershed management plans; 4) provide a basis for defining critical wildlife habitat; and 5) provide a model for assessing the condition of other watersheds in the region.

[CLASSIFICATION; RIPARIAN HABITAT; RIPARIAN VEGETATION]

806. Hughes,D (1996): Restoring native riparian vegetation. p.262-264. In: Shaw,DW; Finch,DM [tech. coord.]. Desired future conditions for Southwestern riparian ecosystems: Bringing 
interests and concerns together. USDA Forest Service. General Technical Report RM-GTR-272.

In the lower Pecos Rasin, an unusual coalition of conservationists, agriculture producers, business owners, and state agencies have joined together to save what is left of the once naturally diverse Pecos River ecosystem. This organization is going to show a state-of-the-art, economical, effective, efficient and environmentally safe method to control salt-cedar and reestablish native riparian vegetation. The objectives of the project were to realize native wetlands and wildlife habitat improvement through salt-cedar management and to monitor possible hydrologic effects.

[PARTNERSHIPS; PECOS RIVER; RIPARIAN HABITAT; RIPARIAN RESTORATION]

807. Hughes, RM (1985): Use of watershed characteristics to select control streams for estimating effects of metal mining wastes on cxtensively disturbed streams. Environmental Management 9(3), 253-262.

Impacts of sediments and heavy metals on the biota of streams in copper-mined areas of southuest Montana were examined by comparing aquatic communities of impacted streams with those of control streams. Control streams were chosen through the use of a technique that identifies sim lar streams based on commonalities in their watershed characteristics. Significant differences between impacted and control sites existed for surface substrate, riparian vegetation, and the number of macroinvertebrate taxa. Results led to the conclusions that: 1) chemical and physical habitats at the impacted sites were disrupled; 2) the presence of trout was an inadequate measure of ecological integrity; and 3) watershed classification based on a combination of mapped terrestrial characteristics provided a reasonable method to select control sites. [MACROINVERTEBRATES; MINING IMPACTS; RIPARIAN HABITAT; SEDIMENTATION; STREAM ECOLOGY]

808. Huisman,J; Weissing,FJ (1994): Lightlimited growth and competition for light in well mixed aquatic environments: An elementary model. Ecology 75(2), 507-520.

A model is investigated for light-limited growth and competition among phytoplankton species in a mixed water column. Some of the conclusions were: 1) outcome of competition for light may depend on the light supply; 2) the compensation point is not a good predictor for the outcome of competition; 3 the resource ratio hypothesis does not apply when species compete for both nutrients and light. The outcome of competition for nutrients and light may depend on the nutrient and light supply, the mixing depths, and the background turbidity due to inanimate substances.

[AQUATIC ECOSYSTEMS; LIGHT ABSORPTION; NUTRIENT CYCLES]

809. Hunt,PG; Stone,KC; Humenik,FJ; Matheny,TA; Johnson,MH (1999): In-stream wetland mitigation of nitrogen contamination in a USA coastal plain stream. Journal of Environmental Quality 28, 249-256.

Non-point source $\mathrm{N}$ from riverine origin is a major water quality problcm. In this study, nitrogen removal from a contaminated stream was evaluated using an in-stream wetland (ISW). Total annual N removal for the ISW was approximately 37 percent of the inflow N. ISW's appear to be a very good landscape feature for mitigating excess non-point source $\mathrm{N}$ in coastal plains. They are also a complement to other best management practices to improve water quality.

[BEST MANAGEMENT PRACTICES; CONTAMINATION; NON-POINT SOURCE POLLUTION; WATER QUALITY]

810. Hunter,BA; Johnson,MS; Thompson,DJ (1989): Ecotoxicology of copper and cadmium in a contaminated grassland ecosystem. IV. Tissue distribution and age accumulation in small mammals. Journal of Applied Ecology 26, 89-99.

In order to assess the potential toxicological significance of accumulated metals in wild small mammals, both the tissue distribution and dynamics of age accumulation of metals in populations of animals from contaminated environments were established. This paper examines both these issues in small mammals inhabiling grasslands contaminated by metal refinery emissions. Species examined: common shrew (Sorex araneus L.), field vole (Microtus agrestis L.), wood mouse (Apodemus sysvaticus L.).

[CONTAMINATION; RIPARIAN HABITAT; SMALL MAMMALS; TOXICOLOGY]

811. Hunter,WC; Anderson,BW; Ohmart,RD (1985): Summer avian community composition of tamarix habitats in three southwestern desert riparian systems. p.128-134. In: Johnson,RR; Ziebell,CD; Patton,DR; Ffolliott,PF; Hamre,RH [tech. coord.]. Riparian ecosystems and their management: Reconciling conflicting uses. 16-18 April 1985. Tucson, AZ. USDA Forest Service. 
General Technical Report RM-120.

Avian response to salt-cedar was assessed using data from three southwestern river systems. Spedies were grouped by breeding biology and groups responded differently in their occurrence in salt-gedar among the valleys. Differences may be explaine by biogeographical and climatic factors. [AVIFAUNA; RIPARIAN HABITAT; SALT-CEDAR]

812. Huntoon,VG (1979): Public input in decision-making. p.65-67. In: Cope,OB [ed.]. Forum: Grazing and riparian/stream ecosystems. 3-4 November 1978. Denver, CO. Trout Unlimited, Inc.

This paper describes ways to involve the public in agency decision-making and emphasizes the importance of public participation. Appropriate, timely public involvement reduces criticism and facilitates the execution of goals and policies. [GRAZING IMPACTS; PUBLIC COMMENT; RIPARIAN ISSUES]

813. Hurd,EG; Goodrich,S; Shaw,NL (1994); Field guide to Intermountain rushes. USDA Forest Service. General Technical Report INT-306. 56 p.

This guide provides technical descriptions of 23 Intermountain rushes (Juncus spp.), including th common and several less abundant species. Line drawings and color or black and white photos illustrate diagnostic characteristics of each species. An illustrated morphology and a glossary acquaiht the lay person with terminology used to classify rushes. The guide is intended as a tool to aid in classification; it is not inclusive.

[CLASSIFICATION; GRAMINOIDS; RIPARIAN RESTORATION; RIPARIAN HABITAT; RUSH IES; WETLANDS]

814. Hurd,EG; Shaw,NL (1991): Seed technology of Carex and Juncus species of the Intermounfain Region. p.74-83. In: Proceedings, Intermount in Forest Nursery Association. 12-16 August 1991. USDA Forest Service. General Technical Report RM-211.

Seed technology is being developed for common sedges and common rushes of the Intermountain Region to evaluate the feasibility of propagating container stock from seed as well as from vegetafive material. Germination requirements vary among species. Pre-treatments are being developed to enhance germination.

[PLANT MATERIALS; RIPARIAN RESTORATION; SEED PRODUCTION]
815. Hurd,EG; Shaw,NL (1993): Influence of dry storage on seed viability and germination of eight intermountain rushes. p.220. In: Tellman, $B$; Cortner,HJ; Wallace,MG; DeBano,LF; Hamre, RH [tech.coord.]. Riparian management: Common threads and shared interests. USDA Forest Service. General Technical Report RM-226.

Results to date indicate that seeds of these rush species can be maintained in dry storage for at least two years. Successful propagation of rushes from seed will require further study of germination requirements for individual species and populations. [RIPARIAN RESTORATION; RUSHES; SEED PRODUCTION]

816. Hurd,EG; Shaw,NL; Mastrogiuseppe,J; Linda,LC; Goodrich,S (1998): Field guide to intermountain sedges. USDA Forest Service. Rocky Mountain Research Station General Technical Report RMRS-GTR-10.

The field guide provides descriptions of morphological characteristics, habitat, and geographic distributions for 114 sedges (Carex spp.). The text includes a dichotomous key, color photographs, line drawings, discussions highlighting differences, an illustrated morphology, glossary, and an index of common names.

[GRAMINOIDS; RIPARIAN VEGETATION; SEDGES]

817. Huryn,AD; Wallace,JB (1987): Local geomorphology as a determinant of macrofaunal production in a mountain stream. Ecology 68(6), 1932-1942.

The authors compared the distributions of functional group production among different habitats in an Appalachian mountain stream. Local geomorphology determined the diversity and spatial distribution of bedrock-outcrops, riffles, and pools in the study stream. The functional structure of the macrofauna, however, when viewed holistically, was the result of the integration of the relative contributions of each habitat type of total stream area. The distribution of habitat-weighted production among functional groups was: collector-gatherers (39 percent), followed by shredders (22 percent), scrapers ( 13 percent), and collecter-filterers ( 8 percent). The functional structure agreed favorably with other conceptual models of headwater streams draining forested catchments.

[GEOMORPHOLOGY; MACROFAUNA; STREAM ECOLOGY] 
818. Huser,VC (1985): The use of third-party interveners in negotiated settlements: Lessons from the past ten years. p.439-42. In:

Johnson,RR; Ziebell,CD; Patton,DR; Ffolliott,PF; Hamre, RH [tech. coord.]. Riparian ecosystems and their management: Reconciling conflicting uses. 16-18 April 1985. Tucson, AZ. USDA Forest Service. General Technical Report RM-120.

A decade of experience in the use of third-party interveners to settle riparian ecosystem management conflicts allowed the author to suggest a number of lessons for addressing conflict, for designing forums to enable disputing parties to negotiate, and for reaching meaningful, realistic implementable decisions.

[COLLABORATION; CONFLICT RESOLUTION; RIPARIAN HABITAT]

819. Hussey,MR; Skinner,QD; Adams,JC; Harvey,AJ (1985): Denitrification and bacterial numbers in riparian soils of a Wyoming mountain watershed. Journal of Range Management 38(6), 492-496.

Presence and activity of denitrifying bacteria and bacteria capable of reducing sulfate were studied on both upland and riparian soils in Wyoming. Bacteria were enumerated from soil samples collected during summer along transects placed perpendicular to stream flow. Higher counts of total heterotrophic aerobic bacteria, sulfate-reducing bacteria, denitrifying bacteria, and denitrification potential existed in the upper 5 to $15 \mathrm{~cm}$ of soil than at $30 \mathrm{~cm}$. Soils located next to the stream edge tended to have more bacterial activity than those further from the stream, indicating that these soils may be important areas for nitrate and sulfate reduction. Soil organic matter and water content decreased with depth in all plant communities, and those closer to the stream contained more organic matter and water than those farther from the stream.

[MICROBIOLOGY; NUTRIENT CYCLES; RIPARIAN HABIT $\Lambda$ T]

820. Hyatt,JM; Cole,EC; Newton,M (1991): The effects of animal damage upon the growth of western hemlock seedlings in riparian zones of the Oregon Coast Range. In: Abstracts of the sixty-fourth annual meeting of the Northwest Scientific Association. 20-22 March 1991. Boise State University. Boise, ID.

Effects of deer and lagomorph damage on western hemlock and its subsequent growth were examined for four years after planting. Growth of seedlings exhibiting similar lcvels of damage was compared when growing under different levels of competition. As vegetative competition increased, seedling growth decreased. The occurrence of deer damage decreased as cover increased, whereas lagomorph damage increased as cover increased. [DEER BROWSING; LAGOMORPHS]

821. Ice,GG (1996): Approaches to solving nonpoint source issues. p.74-79. In: National hydrology workshop proceedings. 27 April - 1 May 1992. Phoenix, AZ. USDA Forest Service. General Technical Report RM-GTR-279.

Numerous difficult non-point source issues are currently being addressed by western state agencies using innovative approaches. Issues include managing for cumulative effects, how to cooperatively manage in mixed-ownership watersheds, development and monitoring of load allocations for non-point sources, revisions to nonpoint source control programs, assessing BMP effectiveness, and application of antidegradation water quality standards. Many of these issues present almost intractable technical or social difficulties. A number of special approaches are being followed by states to address these concerns. These include: panels of experts, detailed decision strategies, adaptive management, interdisciplinary team assessments, cooperative watershed planning, and focused forest practice regulations. [BEST MANAGEMENT PRACTICES; NON-POINT SOURCE POLLUTION; WATER QUALITY; WATERSHED]

822. Idaho Cattle Association (1985): Epidemic strikes --ripariopsychorrhea. The Line Rider. 2(8), 1,8 .

RIPARIOPSYCHORRHEA refers to a person that talks about stream banks in an endless flow of words that do not reflect a natural evolution that is a constant factor in all streams. People afflicted will present a normal appearance until they approach a stream bank, at which time moaning, trembling, and teeth gnashing occur.

[GRAZING IMPACTS; RIPARIAN ISSUES]

823. Idaho Department of Health and Welfare (1987): Riparian areas: What are they and what do they do. In: Clean Water, the newsletter of the Idaho Water Quality Bureau, 450 W. State St., Boise, ID. 83720.

Riparian areas are those adjacent green zones along the banks of rivers and streams. The term is used in a broader sense to refer to similar areas around springs, lakes, ponds, and reservoirs. Riparian 
areas are sometimes classified as "wetlands', a broader term referring to areas subjected to periodic saturation with water and having soil and vegetative characteristics that separate it from surrounding land. Unlike riparian areas, wetlands can encompass larger areas of land such as bogs and swamps.

[RIPARIAN HABITAT; WATER QUALITY]

824. Idaho Department of Health and Welfare. (1988): Idaho water quality status report and nonpoint source assessment 1988 . Division of Environmental Quality. Water Quality Bureau. State of Idaho. $138 \mathrm{p}$.

The purpose of this report was to provide an assessment of the water quality of rivers, lakes, and groundwater in the state of Idaho, that were being impacted by non-point, point, and toxic pollutants. The report was also intended to satisfy the requirements of Sections 319, 305b, 304, and 314 of the federal Water Quality Act. It also serves as a management tool for targeting priority waters and implementing pollution control strategies. [NON-POINT SOURCE POLLUTION; WATER QUALITY]

825. Idaho Partners in Flight (1998): Riparian riches: Habitat management for birds in Idaho. 18 p.

No habitat type is more important to more bird species than riparian habitat. The Idaho Partners in Flight is a coalition of federal and state agencies, private citizens, non-governmental groups, and the forest products industry, formed as part of a hemispheric effort to save bird populations. The recommendations contained in this pamphlet have a single purpose - to maintain or restore structurally diverse, healthy native plant communities for the benefit of birds and other wildlife.

[AVIFAUNA; CONSENSUS; RIPARIAN HABITAT]

826. Ingebo,PA (1971): Suppression of channel-side chaparral cover increases streamflow. Journal of Soil and Water Conservation 26(2), 79-81.

Shrubs and trees in an experimental watershed in central Arizona were chemically suppressed. Both duration and volume of streamflow increased in the two years following treatment. Intermittent streamflow became continuous.

[HYDROLOGY; RIPARIAN MANAGEMENT ZONE; STREAM FLOW]

827. Interagency Wetlands Coordinating Body.
(1989): Wise use and protection of federally managed wetlands: The federal land management agency role. Proceedings of the workshop, 18-20

October 1989. Harpers Ferry, WV.

At the invitation of US EPA, staff from nine federal agencies participated as speakers and audience in a 3-day workshop on policy, coordination, and cooperation on wetland land management issues. The workshop focused on further enhancing wise use and protection of wetlands on federal lands by: 1) understanding what a wetland is; 2) understanding key points of agencies' missions and programs; 3) understanding constraints and opportunities; and 4) developing a list of common issues and concerns.

[POLICY; RIPARIAN HABITAT; WETLANDS]

828. Irizarry, RA (1969): The effects of stream alteration in Idaho. Idaho Fish and Game Dept., Federal Aid in Fish and Wildlife Restoration Job Completion Report F55-R-2, Boise, ID. 26 p.

Approximately 300 miles of streams were studied in Idaho, of which 29.8 percent had undergone alteration. About one alteration per stream mile was found, with the average length of a channel alteration being 1,617 feet. Of the channel changes, encroachment was responsible for 59 percent of the alterations, 22 percent was due to channel relocation, 15 percent to mining, 8 percent railroad construction, 5 percent flood control, and 4 percent agricultural practices. Almost seven times more catchable trout and over $60 \mathrm{X}$ as many whitefish were censused in unaltered (natural) sections.

[FISHERIES; RIPARIAN HABITAT; WATER RESOURCE MANAGEMENT]

829. Irvine,JR; West, NE (1979): Riparian tree species distribution and succession along the lower Escalante River, Utah. The Southwestern Naturalist 24(2), 331-346.

The Escalante River is one of the few Southwestern rivers that have escaped impoundment. Livestock grazing and wood cutting have also been minimal because of the rugged canyon topography. Therefore, it was possible to relate distribution of trees and successional status of the geologic strata, river bank morphology, and river flow. Populus fremontii was found only on the broad flood terraces in wide sections of the upper part of the study area. Major populations of Tamarix pentandra was found in the section of the canyon where large boulders provided protection from the full force of flooding water. Salix exigua occurred throughout the study area, but was least dense in the narrower, steeper 
stretches of the canyon where tamarisk occurred. Recolonization of lower terraces occurs from higher terraces after each major flooding event. Tamari $\mathrm{k}$ seems to increase in density if river flow is diminished by impoundments.

[FLOOD IMPACTS; RIPARIAN HABITAT; RIPARIAN SHRUBS; SIREAM ECOLOGY]

830. Isabelle,PS; Fooks,LJ; Keddy,PA (1987): Effects of roadside snowmelt on wetland vegetation: An experimental study. Journal of Environmental Management 25, 57-60.

Mixtures of wetland plant seeds were sown and supplied with roadside snowmelt, diluted snowmelt and tap water to test the hypothesis that water produced by melting roadside snow can affect wetland plant community structure. After one month of growth, community biomass, species diversity, evenness, and richness all decreased significantly with increasing snowmelt concentration. Roadside snowmelt may have profound effects on wetland plant community structure. [RIPARIAN HABITAT; SNOW MELT; WATER QUALITY; WETLANDS]

831. Ischinger,LS; Schneller-McDonald,K (1988): Wetland restoration and creation in the west: what do we really know? p.29-42. In: Mutz,KM; Cooper,DJ; Scott,ML; Miller;LK [eds.]. Restoration, creation, and management of wetland and riparian ecosystems in the American West. Proceedings of the symposium. 14-16 November 1988. Denver, CO. Rocky Mountaih Chapter of the Society of Wetland Scientists. This is an analysis of articles collected and documented in the USDI Fish and Wildlife Service wetland creation/restoration data base. Of 1,000 records in the data base, 79 deal with non-coastal freshwater wetlands in the West. Of the 79 records, 30 are concerned with the restoration of riparian areas, and 34 cite the creation or restoration of fish or wildlife habitat as a major objective. The availab lity of quality data from baseline studies, qualitative or quantitative measurements of wetland functions, and monitoring efforts are discussed. Research needs are addressed.

[BIBLIOGRAPHY; CREATED WETLANDS; I.ACUSTRINE ECOLOGY; RESEARCH; RIPARIAN RESTORATION]

832. Ives, RL (1942): The beaver-meadow complex. Journal of Geomorphology 5, 191-203.

Beaver work, in conjunction with sedimentation and plant growth, is an important factor in the creation and continued existence of large, wet meadows in the mountainous parts of Colorado. Interrelations of beaver work, sedimentation, and plant growth are described, and the apparent relations of this beaver-meadow complex to other valley features are briefly discussed. [BEAVER; GEOMORPHOLOGY; RIPARIAN HABITAT]

833. Jackson,AJ; Grimm,NB; Marti,E; Fisher,SG (1997): Denitrification within algal mats along a nitrate gradient in a Sonoran Desert stream. p.116. Abstracts. 1997 Annual meeting of the Ecological Society of America jointly with The Nature Conservancy. 10-14 August 1997.

Albuquerque, NM.

This study examined factors controlling denitrification within algal mats and measured the contribution of the process to nitrate loss. Denitrification rates decreased downstream concomitantly with nitrate concentration, suggesting nitrate limitation of denitrification. Ammonium, dissolved organic nitrogen, and dissolved organic carbon concentrations did not exhibit any longitudinal pattern. Denitrification rates were higher during the day than at night. Denitrification in the algal mat could account for up to 35 percent of the decrease in nitrate concentration along the stream reach.

[NUTRIENT CYCLES; RIPARIAN ECOLOGY]

834. Jackson,SG; Kadlec,JA (1988): Recent flooding of wetlands around Great Salt Lake, Utah. p. 120-125. In: Mutz,KM; Cooper,DJ; Scott,MI; Miller,LK; [eds.]. Restoration, creation, and management of wetland and riparian ecosystems in the American West. Proceedings of the symposium. 14-16 November 1988. Denver, CO. Rocky Mountain Chapter of the Society of Wetland Scientists.

Within the past 25 years, the Great Salt Lake level has ranged from $4191.6 \mathrm{ft}$ in 1963 to 4211.85 in 1987. This represents a change in the surface area of almost threefold. Since that high level the lake level has been dropping steadily. Thousands of acres of former emergent marsh has been exposed and is already regenerating. Researchers are optimistic that the marshes will recover fully as the lake level drops. [LACUSTRINE ECOLOGY; RIPARIAN RESTORATION; SALT MARSHES; WATER LEVELS]

835. Jackson,TJ (1986): Soil water modeling and remote sensing. IEEE Transactions on Geoscience 
and Remote Sensing 24(1), 37-46.

Soil modeling research was reviewed along with other relevant studies. Research was categorized as follows: review of models, development of simulation models, integrating remotely sensed data and models, surface versus profile soil moisture, and estimating soil water properties. This review and evaluation found that some of the major objectives of the program were satisfied and that several of the results represent significant contributions to the science.

[HYDROLOGY; MODELING; REMOTE SENSING; SOILS]

836. Jackson,W; Martinez, $T$; Cuplin,P; Minckley,WL; Shelby,B; Summers,P; McGlothlin,D; VanHaveren,B (1988): Assessnent of water conditions and management opportunities in support of riparian values: B.M San Pedro River Properties, Arizona. Project Completion Report 88/004+7200. USDI Bureau of Land Management. Denver, CO. $180 \mathrm{p}$.

This report presents information on the condition of water resources and the riparian vegetation in the San Pedro River Management Area. It also justif|es the quantification of instream-dependent uses identified in the area and examines and recommends strategies for protecting or enhancing the water-related values. [BLM; GEOMORPHOLOGY; GROUNDWATAR; RIPARIAN HABITAT; WATER RIGHTS]

837. Jackson,WL; Beschta,RL (1984): Influences of increased sand delivery on the morphology of sand and gravel channels. Water Resources Bulletin 20(4), 527-533.

Increased sand concentrations in transport can enable lower stream discharges to transport riffle gravel materials. The net response of a channel to increased sand delivery will be to fill pools, increase width, and decrease depth. If increases in sand delivery are great enough, gravel features will be increasingly smothered by deposited sands even though sediment transport rates will have increased. The increased hydraulic efficiency of the channe could encourage channel straightening and, therefore, steepening of slope. This could also affect additipnal adjustments in channel cross-sections.

[CHANNEL DYNAMICS; CHANNEL MORPHOLOGY; SEDIMENT TRANSPORT]

838. Jackson,WL; Hudson,S; Gebhardt,K (1985): Considerations in rangeland watershed monitoring. USDI Bureau of Land Managem $\notin n t$
Technical Note. BLM/YA/DT/85-006-4341. BLM

Service Center. Denver, CO. 25 p.

This paper describes the components of a rangeland watershed monitoring plan, distinguishes between direct monitoring strategies (sampling) and indirect monitoring strategies (modeling), describes common watershed monitoring techniques, and discusses statistical considerations in sampling designs and data analysis. It also describes some monitoring principles and concepts but does not prescribe applications since these will always need to be tailored to meet particular issues, objectives, and conditions.

[GRAZING IMPACTS; MONITORING; SAMPLING; WATERSHED]

\section{Jackson,WL; VanHaveren,BP (1984):}

Design for a stable channel in coarse alluvium for riparian zone restoration. Water Resources

Bulletin 20(5), 695-703.

In designing a stable stream channel for a degraded segment of Badger Creek, Colorado, and its associated riparian and meadow complexes, geomorphic, hydraulic, and hydrological principles were applied. An objective was to shorten the period of time required for a channel in coarse alluvium to recover from an impacted morphological state to a regime condition representative of current watershed conditions. Channel geometry measurements describe the stream channel and the normal bankfull stage in relatively stable reaches. Critical shear stress equations were used to design a stable channel in noncohesive materials with dimensions which approximate those of less disturbed reaches. Gabion controls, spaced at approximately $300 \mathrm{~m}$ intervals were recommended to help reduce the chance of lateral migration of the newly constructed channel. The floodplain was designed to dissipate flood flow energy and discourage multiple flood channels. Above considerations gave the channel approximately a 90 percent chance of remaining stable the first two years following construction, which is the time estimated for increased stability to occur.

[CHANNEL DYNAMICS; RIPARIAN RESTORATION; STREAM ECOLOGY]

840. Jackson,WL [ed.] (1986): Engineering considerations in small stream management. American Water Resources Association Monograph Series \#5, reprinted from the Water Resources Bulletin 22(3):351-415.

The seven papers in this collection were invited for a special session of the American Water 
Resources Association. The purpose was to present important concepts, issues and constraints pertaining to the design of engineered solutions to small stream and riparian problems from a multidisciplinary perspective.

[RIPARIAN RESTORATION; STREAM ECOLOGY]

841. Jacobs,DF (1993): The public trust doctrine and river conservation. p.85-91. In: Tellman, $B$; Cortner,HJ; Wallace,MG; DeBano,LF; Hamre, RH [tech. coord.]. Riparian management: Common threads and shared interests. USDA Forest Service. General Technical Report RM-226.

Under the public trust doctrine, which governs the management and use of tidal and navigable waterways, the people have inalienable rights to use and enjoy public waterways. The doctrine can be an important legal mechanism for river conservation. If the states, as trustees, fail to meet their obligations, the public can enforce doctrine principles. Cooperative planning between entities can eliminate much conflict.

[PUBLIC TRUST DOCTRINE; RIPARIAN HABITAT; RIVER ECOLOGY]

842. Jacobs, TC; Gilliam,IW (1985): Riparian losses of nitrate from agricultural drainage waters. Journal of Environmental Quality 14(4), 472-478.

Increased nutrient levels in surface streams and eutrophication of Coastal waters has led to inquiries about both amount and control of nitrate losses from agricultural fields. Where fields were bordered by forested buffers, evidence of this study strongly indicated that a substantial part of the nitrate in the drainage water was denitrified in the buffer strip and that assimilation by vegetation was insignificant. The extensive floodplain of the natural stream had a high capacity to reduce large quantities of $\mathrm{N}$ but the low total loss from the watershed is largely a result of low input to the drainage water from non-point sources. [BUFFER ZONES; EUTROPHICATION; NONPOINT SOURCE POLLUTION; NUTRIENT CYCLES]

843. Jahn,LR (1978): Value of riparian habitats to natural ecosystems. p.157-160. In: Proceedings of the National Symposium on Strategies for protection and management of floodplain wetlands and other riparian ecosystems. 11-13 December 1978. Callaway Gardens, GA. USDA Forest Servicc. General Technical Report
GTR-WO-12.

Riparian vegetation stabilizes soils and supplies organic matter that sustains aquatic communities. Nutrient-rich silt deposited periodically in these habitats by floodwaters enriches soils that support bottomland hardwood forests, forage for wildlife and livestock, and outdoor recreation. Broader applications of management guidelines are required to adjust human-related activities in riparian zones. [POLICY; RIPARIAN ECOLOGY; RIPARIAN HABITAT]

844. Jahn,LR (1988): Strengthening procedures for maintaining wetlands. p.1-8. In: Stuber,PJ [tech. coord.]. Proceedings of the national symposium on the protection of wetlands from agricultural impacts. 25-29 April 1988. Ft. Collins, CO. USDI Fish and Wildlife Service. Biological Report 88(16).

Legal authorities, implementation procedures, and management techniques to maintain and enhance our wetlands must be strengthened to perpetuate their wide array of public values and services. The pressing need is for federal, state, and local governments to recognize all values associated with wetlands and to work actively and cooperatively to advance comprehensive wetland maintenance programs through the public trust doctrine of law. [PUBLIC TRUST DOCTRINE; RIPARIAN HABITAT; WETLANDS]

845. Jakle,MD; Gatz,TA (1985): Herpetofaunal use of four habitats of the Middle Gila River Drainage, Arizona. p.355-358. In: Johnson, RR; Ziebell,CD; Patton,DR; Ffolliott,PF; Hamre,RH [tech. coord.].Riparian ecosystems and their management; Reconciling conflicting uses. 16-18 April 1985. Tucson, AZ. USDA Forest Service. General Technical Report RM-120.

Pit-fall traps and observations were used along the Gila River, Arizona, to gather data on reptiles and amphibians. Four habitat types were sampled: saltcedar, mesquite bosque, desert wash, and desert upland. Twelve species and 104 individuals were trapped and another 7 species were observed. Species diversity was greatest in the desert wash and lowest in the salt-cedar thicket. Reptiles/amphibians showed little use of the salt-cedar community which may reflect the lack of structural diversity in the herbaceous layers and reduced light penetration because of the dense canopy. [HERPETOFAUNA; RIPARIAN HABITAT; SALTCEDAR] 
846. Jalbert,LM; Heim,M (1993): Rehabilitation of sites along the Colorado River through Grand Canyon National Park. p.192. In: Tellman,B; Cortner,HJ; Wallace,MG; DeBano,LF; Hamre, RH |tech. coord.|. Riparian management: Common threads and shared interests. USDA Forest Service. General Technical Report RM-226.

An integrated monitoring program assesses impacts resulting from recreational use. When the Limits of Acceptable Change prescribed in the management plan are exceeded, remediation projects are planned. Such work includes multiple trail eradication, trail delineation/relocation and maintenance, recreation site stabilization and revegetation. The latter function emphasizes the use of native seed.

[MONITORING; RIPARIAN RESTORATION]

847. Jankiewicz,CJ (1984): Cottonwood sprout protection. Southwest Habitater 5(6).

Mature cottonwoods are the most important component of riparian area foliar diversity from the wildlife point of view on southwestern habitat. There have been many proposed solutions to protecting and regenerating woody riparian species. In this article, livestock exclusion and use of simple exclosures to prevent browsing are recommended.

[COTTONWOOD; EXCLOSURES; LIVESTOCK EFFECTS; RIPARIAN HABITAT]

848. Jankovsky-Jones,M; Rust,SK; Moseley,RK (1999): Riparian reference areas in Idaho: $A$ catalog of plant associations and conservation sites. USDA Forest Service. Rocky Mountain Research Station. General Technical Report RMRS-GTR-20. 141 p.

Ecological reference areas are remnants of the natural landscape preserved as ecological baselines. Such sites are fundamental to land management where monitoring and the effects of management strategies are to be compared or measured. Since 1984, the Idaho Conservation Data Center, Boise, Idaho, has compiled information in a series of interrelated databases on the distribution and condition of plant associations in high quality reference sites. This report summarizes association-specific and reference area-specific information from databases and presents a standardized classification of Idaho riparian and wetland plant associations. Summary information includes location, management responsibility, site description, and a list of all riparian and wetland associations that occur in the area.
[CLASSIFICATION; REFERENCE SITES; RIPARIAN; WETLANDS]

849. Jatnieks-Straumanis,SA; Foote,LE (1988): Wetland mitigation banking: How it works in Minnesota. Rangelands 10, 120-123.

The banking mitigation process insures that decisions made within banking guidelines follow a consistent, standardized approach to impact assessment/mitigation between various agencies. Mutual agreement among all agencies is needed for a project to successfully go through the bank.

[WETLAND MITIGATION BANKING; WETLANDS]

850. Java,BJ; Everett,RL (1992): Rooting hardwood cuttings of Sitka and thinleaf alder. p.138-141. In: Clary,WP; McArthur,ED; Bedunah,D; Wambolt,CL [comp.|. Proceedings Symposium on ecology and management of riparian shrub communities. USDA Forest Service. General Technical Report INT-289.

Rooting abilities of woody cuttings were evaluated after cold storage and growth regulator treatments. No cuttings of Sitka alder rooted in response to either treatment. When thin-leaf alder cuttings were treated with a solution of $2000 \mathrm{ppm}$ indolebutryic acid (NAA) and placed in cold storage at $1-3$ degrees $\mathrm{C}$ for one month, 76 percent rooted, compared to 11 percent rooting success for untreated thin-leaf cuttings.

[ALDER; CUTTINGS; RIPARIAN

RESTORATION]

851. Jayne,JAB (1985): Effects of dryland farming on Navajo riparian lands. p.479-481. In: Johnson,RR; Ziebell,CD; Patton,DR; Ffolliott,PF; Hamre, RH [tech. coord.]. Riparian ecosystems and their management: Reconciling conflicting uses. 16-18 April 1985. Tucson, AZ. USDA Forest Service. General Technical Report RM-120.

Dryland farming has been recognized by the Navajo people as a major cause of accelerated erosion, depletion of vegetation, and water shortages in their riparian zones. Water and land conservation development policies are currently being implemented to protect agricultural lands. [ $\Lambda$ GRICULTURAL IMPACTS; EROSION CONTROL; RIPARIAN HABITAT]

852. Jemmison, RL (1993): Associations between riparian ecosystem parameters in Happy Valley, Arizona. p.233-239. In: Tellman,B; Cortner,HJ; Wallace,MG; DeBano,LF; Hamre,RH [tech. 
coord.]. Riparian management: Common threads and shared interests. USDA Forest Service.

General Technical Report RM-226.

The study reported in this paper addressed the relationships and associations between hydrologic inputs, vegetation, and soils in a low mountain $(1,000$ to $2,000 \mathrm{~m}$ ) riparian ecosystem. Specific observed parameters included precipitation, streamflow, water table level, vegetation, soils, location relative to stream channel, and date of abservation.

[HYDROLOGY; RIPARIAN ECOLOGY; WATER TABLE EFFECTS]

853. Jemmison, $R$ (1996): Riparian areas, watersheds, and water quality: A panel discussion. In: Tellman,B; Finch,DM; Edminster,C; and Hamre, $R$ [eds.]. 1998. The future of arid grasslands: Identifying issues, seeking solutions, Proceedings. RMRS-P-3. Tucson, AZ. USDA Forest Service. 392 p.

Location and extent of riparian ecosystems depends upon excess water in surrounding ecosystems. We also need to know the quantity, quality, and source of that water. Reference, or exemplary, ecosystems should always be noted during investigations to serve as barometcrs against which other sites can be compared. Monitoring of environmental parameters such as water quality and quantity or the health and abundance of dependent species can serve as indications of unbalanced ecosystems.

[HYDROLOGY; MONITORING; RIPARIAN ECOLOGY; WATER QUALITY; WATERSHED]

854. Jenkins,KJ; Wright,RG (1987): Simulating succession of riparian spruce forests and white-tailed deer carrying capacity in northwestern Montana. Western Journal of Applied Forestry 2(3),80-83.

Successional modeling demonstrated the effects of two timber harvesting strategies on white-tailed deer populations. Simulated populations declined following two timber harvesting schedules, but recovered after cessation of harvest. Gradual but continuing deer population decline was predicted for activities that increase runoff and erosion.

[MODELING; POPULATION DYNAMICS; RIPARIAN HABITAT; RIPARIAN FOREST; WHITE-TAILED DEER]

855. Jensen,SE; Platts,WS (1990): Restoration of degraded riverine/riparian habitat in the Great Basin and Snake River Regions. p.367-403. In: Wetland creation and restoration. The status of the science. Island Press. Washington, DC.

Riverine/riparian habitat (RRH) includes interdependent aquatic (riverine) and streamside (riparian) resources that are valuable for fish and wildlife habitat, flood storage, and

desynchronization, nutrient cycling and water quality, recreation, and heritage values. $\mathrm{RRH}$ includes resources both wetter and drier than stipulated for wetlands. Whereas, the "natural or achievable state" of a riparian habitat may be wetland, the "existing state" may be non-wetland because of natural or anthropogenically induced changes in the hydrologic character of RRH. [FISHERIES; RIPARIAN HABITAT; RIPARIAN RESTORATION]

856. Johannesson,KH; Lyons,WB; Graham,EY; Welch,KA; Bonzongo,JC; Jones, T; Doyle,GA (1998): The biogeochemical controls of oxyanionic metals in arid vs. humid rivers. p.441. In: Potts,DF [ed.]. Range management and water resources: Proceedings of the AWRA specialty conference. American Water Resources Association. 27-29 May 1998. Reno, NV.

This study analyzed the following oxyanionic metals: AS, SE, Sb, Mo, Va, and in some cases, W and $U$ from rivers draining the eastern slope of the Sicrra Nevada and the Mobile, Alabama River system. In general, the arid rivers were more alkaline and had higher concentrations of the metals. In part, this was due to evapoconcentration of the river along its flow path. Differences in watershed lithology also played an important role. Metal distribution in rivers depends on $\mathrm{pH}$, watershed lithology, and biologically induced redox changes.

[HEAVY METALS; REDOX POTENTIAL; WATER QUALITY]

857. Johnejack,KR; Megahan,WF (1991): Sediment transport in headwater channels in Idaho. p.4-155 to 4-161. In: Proceedings of the fifth federal interagency sedimentation conference. [Eds. Tan,SS; Kuo, YH]. Subcommittee on Sedimentation of the Interagency Advisory Committee on Water Data.

Prediction of sediment transport in steep, headwater channels is complicated by step-pool profiles and large-scale roughness from boulders, $\operatorname{logs}$, and brush. This study evaluated four common sediment transport equations. Although agreement between predicted and measured transport rates was encouraging, appropriate modeling of the physical processes was not necessarily indicated.

[GEOMORPHOLOGY; HYDROLOGY; 


\section{SEDIMENT TRANSPORT]}

858. Johnson,BL; Richardson,WB; Naimo,TJ (1995): Past, present, and future concepts in large river ecology. BioScience 45(3), 134-141.

Neither the river-continuum concept nor the flood-pulse concept explains system function in all large rivers. Within a single river, both concepts may apply, depending upon the geomorphology of the system and the temporal and spatial scale of analysis. Multidisciplinary studies, involving hydrologists, geomorphologists, and aquatic and terrestrial biologists, are needed to elucidate the relations between and among physical and biological components. There is a current challenge to develop partnerships among researchers, managers, governmental agencies, and the private sector necessary to plan and conduct these large-scale studies.

[GEOMORPHOLOGY; MULTIDISCIPLINARY STUDIES; PARTNERSHIPS; RIVER ECOLOGY]

859. Johnson,CW; Engleman,RL; Smith,JP; Hanson, CL (1977): Helley-Smith bed load samplers. Journal of Hydrology 103(10), 1217-1221.

Users of Helley-Smith bed load samplers, under conditions of high organic and sediment transport, should recognize the possible sampling error caused by clogging of sampler bags and instead use either larger bags or bags with a mesh larger than $0.2 \mathrm{~mm}$. Helley-Smith samplers are inexpensive and easily used at some bridge sites but additional calibration is needed to improve the accuracy of sediment transport computations from bed load sample data.

[HYDROLOGY; SEDIMENT TRANSPORT; STREAM FLOW; TECHNIQUES]

860. Johnson,CW; Gordon,ND (1984): Streamflow measurement and analysis for northwest rangelands. p.469-473. In: Proceedings of the water for resource development conference, Soil and Water Division, American Society of Civil Engineers. 14-17 August 1984. Coeur d'Alene, ID.

This paper reports precipitation, runoff, and streamflow data from three source watersheds administered by the Northwest Watershed Research Center near Boise, Idaho. Grazing intensity and duration were shown to have a profound influence on the quality and quantity of streamflow measured from those watersheds on sagcbrush rangelands. Accounts of field-testing of the drop-box weir and other devices for streamflow measurcment are described.

[HYDROLOGY; TECHNIQUES; WATERSHED]

861. Johnson,CW; Smith,JP (1978): Sediment characteristics and transport from Northwest rangeland watersheds. p.1157-1163. In: Transactions of the American Society of Agriculture Engineers, Soil and Water Division. Paper 77-2509.

Rangeland hydrology and sedimentation studies on a main stem and three source watersheds within the Reynolds Creek Experimental Watershed, show a wide range in precipitation, runoff, sediment transport and particle-size characteristics from year to year and from station to station. Results are useful in rangeland erosion and sediment models.

[GEOMORPHOLOGY; MODELING; SEDIMENTATION; SEDIMENT TRANSPORT]

862. Johnson,JE (1976): A proposed change in livestock grazing on national resource lands and its effects on aquatic and riparian communities. In: Proceedings of the Colorado-Wyoming chapter of the American Fisheries Society. 3-4 March 1976.

The fundamental problem between stream bottoms and grazing is the attraction they hold for livestock. Some examples are: 1) after watering at the stream it is natural for the cattle to begin feeding there; 2) riparian vegetation turns greener earlier in the spring and later in the fall than the more xeric upland plants, cattle seek the cooler, shady riparian areas for relief from summer heat and insects, and it is generally uphill out of stream valleys and cattle prefer to avoid exertion whenever possible. Implementation of rest-rotation grazing systems, together with general reduction in livestock numbers, would provide longer rest periods and potentially result in better riparian conditions.

[GRAZING IMPACTS; GRAZING TREATMENTS; UTILIZATION]

863. Johnson,KL; Mosley,C; Mosley,JC; O'Laughlin,J (1990): BLM riparian policy in Idaho: Analysis of public comment on a proposed policy statement. Idaho Forest, Wildlife, and Range Policy Analysis Group. Report No. 2. Moscow, ID. 28 p.

The Policy Analysis Group gathered and analyzed two separate sets of information: 1) public concerns about riparian use and management were identified during eight workshops using a standard nominal group process technique; and 2) comments on the proposed BLM riparian policy statement were 
obtained by mailing a request for comments to 225 organizations believed to be interested in riparian policy.

[POLICY; PUBLIC COMMENT; RIPARIAN HABITAT]

864. Johnson, RR (1982): Riparian habitats and recreation: Interrelationships and impacts in the Southwest and Rocky Mountain region.

Eisenhower Consortium Bulletin No. 12. Eisenhower Consortium for Western

Environmental Forestry Research. 31 p. [RECREATION IMPACTS; RIPARIAN HABITAT; RIPARIAN VEGETATION]

865. Johnson,RR; Carothers,SW; Simpson,JM (1981): A riparian classification system. p.374-382. In: Warner,RE; Hendrix,KM [eds.]. Proceedings of the California riparian conference. 17-19 September 1981. Davis CA.

Riparian ecology, as one of the newest scientific disciplines, is developing a conceptual framework which includes new supportive terminology and classification schemes. This branch of ecology has developed largely in the arid western U.S. as an offshoot of wetlands ecology. This paper discusses concepts, classifications, and interrelationships between riparian ecology and other disciplines. Applications are important to floodplain zoning and management, natural resource management, and recreation management.

[CLASSIFICATION; RIPARIAN ECOLOGY; RIPARIAN HABITAT]

866. Johnson,RR; Haight,LT (1985): Avian use of xcroriparian ccosystems in the North American warm deserts. p.156-160. In: Johnson,RR; Ziebell,CD; Patton,DR; Ffolliott,PF; Hamre,RH [tech. coord.]. Riparian ecosystems and their management: Reconciling conflicting uses. 16-18 April 1985. Tucson, AZ. USDA Forest Service. General Technical Report RM-120.

Xeroriparian avian censuses were compared with paired desert upland censuses for various subdivisions of the Sonoran Desert. With few exceptions, xeroriparian habitat supports 5 to 10 times the population densities and species diversities of surrounding desert uplands.

[AVIAN ECOLOGY; RIPARIAN HABITAT; RIPARIAN VEGETATION]

867. Johnson,RR; Haight,LT; Simpson,JM (1977): Endangered species vs. endangered habitats. p.68-79. In: Johnson,RR; Jones,DA [tech.coord.]. Importance, preservation, and management of riparian habitats. 9 July 1977. Tucson, AZ. USDA Forest Service. General Technical Report RM-43.

Riparian habitats are important for both their diversity and their productivity. The highest densities of nesting birds for North America have been reported for southwestern cottonwood riparian forests. Complete loss of riverine habitat in the Southwest lowlands could result in the extirpation of 47 percent of the 166 species of birds known to nest in this region.

[AVIFAUNA; COTTONWOOD; RIPARIAN FOREST; RIPARIAN HABITAT]

868. Johnson,RR; Jones, DA [tech.coord.] (1977): Importance, preservation and managennent of riparian habitat: A symposium. 9.July 1977. Tucson, AZ. USDA Forest Service. General Technical Report RM-43. $217 \mathrm{p}$.

Twelve presented and 15 contributed papers highlight what is known about riparian habitat: characteristics, classification systems, associated fauna, use conflicts, management alternatives, and research needs. Presenters stressed the continuity and interrelationships of riparian ecosystems, their wildlife and vegetation, historic and current uses. [RIPARIAN HABITAT; RIPARIAN MANAGEMENT ZONE]

869. Johnson,RR; Lowe, CW (1985): On the development of riparian ecology. p. 112-116. In: Johnson,RR; Ziebell,CD; Patton,DR; Ffolliott,PF; Hamre, RH [tech. coord.]. Riparian ecosystems and their management: Reconciling conflicting uses. 16-18 April 1985. Tucson, AZ. USDA Forest Service. General Technical Report RM-120.

The historical development of riparian ecology is discussed. Gradients in riparian systems are described with regard to transriparian and intrariparian continua, including xeroriparian communities, consistent with the fact that riparian lands are technically wetlands. Aquatic, riparian, and terrestrial systems harbor peculiarly obligate species structured into distinctive biotic communities throughout North America.

[RIPARIAN ECOLOGY; RIPARIAN HABITAT; XERORIPARIAN]

870. Johnson,RR; McCormick,JF (1978):

Strategies for protection and management of floodplain Wetlands and other riparian ecosystems. In: Proceedings. 11-13 December 1978. Callaway Gardens, GA. USDA Forest 
Service. General Technical Report GTR-WO-12. $410 \mathrm{p}$.

[MANAGEMENT PLANS; RIPARIAN HABITAT; WETLANDS]

871. Johnson,SR (1990): Protecting riparian values during timber harvest and related activities: Kootenai National Forest experience. In: Management of riparian and wetland forested ecosystems in Montana. Fourth annual Montana Riparian Association workshop. 5-7 September 1990. Whitefish, MT.

In the Kootenai National Forest, northwestern Montana, large woody debris is a particularly important factor in determining the physical and biological characteristics of small and intermediate sized streams. A task force effort to address inadequacies in the national forest plan regarding timber harvests in forested riparian zones is discussed. The paper includes stream classification and management recommendations for streamside management zones (SMZ).

[LARGE WOODY DEBRIS; RIPARIAN FOREST; RIPARIAN HABITAT; SMZ]

872. Johnson,SR; Gary,HL; Ponce,SL (1978): Range cattle impacts on stream water quality in the Colorado Front Range. USDA Forest Service, Rocky Mountain Forest and Range Experiment Station. Research Note RM-359. 8 p.

Studies on two adjacent pastures along Trout Creek in central Colorado indicated only minor effect of cattle grazing on water quality. Bacterial contamination of the water, however, significantly increased. Following removal of livestock, bacterial counts dropped to levels similar to those in the ungrazed pasture.

[GRAZING IMPACTS; NON-POINT SOURCE POLLUTION; WATER QUALITY]

873. Johnston,CA; Naiman,RJ (1990): The use of a geographic information system to analyze long-term landscape alteration by beaver.

Landscape Ecology 4(1), 5-19.

A Geographic Information System (GIS) was used to analyze how beaver had altered hydrology and vegetation in Minnesota over a 46-year period. Total area impounded increased from 1 percent to 13 percent of the landscape between 1940 and 1986 as the beaver population increased from near extirpation to a density of 1 colony $/ \mathrm{km} 2$. Most of the impoundment area increase occurred during the first two decades, when 77 percent of cumulative impoundment area was flooded. Once impounded,
$>60$ percent of the area maintained the same water depth or vegetation during any decade. GIS procedures were combined with field data to show that available nitrogen stocks nearly tripled between 1940 and 1986 as a result of beaver impoundment. [BEAVER; FISHERIES; GIS; RIPARIAN HABITAT]

874. Johnston,CA; Naiman,RJ (1990): Aquatic patch creation in relation to beaver population trends. Ecology 71(4), 1617-1621.

The creation of aquatic patches by beaver in the boreal forest of northern Minnesota was studied to determine how the population dynamics of a disturbance-causing animal are linked to the rates of patch formation and growth over a period of population and expansion. Earlier ponds tended to be larger. Even though rate of pond creation paralleled the increase in number of beaver colonies between 1961 and 1986, the rate of new pond creation prior to 1961 greatly exceeded the increase in number of beaver colonies. The authors conclude that the rate of patch formation after the first two decades of beaver colonization was constrained by geomorphology, which limited the availability of sites at which a beaver dam could impound a large area of water. [BEAVER; GIS; RIPARIAN HABITAT]

875. Johnston,CA; Naiman,RJ (1990): Browse selection by beaver: Fffects on riparian forest composition. Canadian Journal of Forest Research 20, 1036-1043.

Beaver herbivory has both immediate and long-term effects on biomass, structure, and composition of riparian forests. Intense beaver foraging of aspen decreased tree density and basal area by as much as 43 percent within 1-ha forage zones surrounding two beaver ponds in Minnesota. Maximum diameter of trees cut was $43.5 \mathrm{~cm}$; average aspen stem diameter cut was $13.9 \mathrm{~cm}$ and $10.2 \mathrm{~cm}$, respectively. Woody biomass harvested per beaver averaged $1.4 \mathrm{mg} / \mathrm{ha} /$ year over a 6 -year foraging period. Most wood was left on site or used in dam construction. Selective foraging by beaver decreased the relative importance of preferred species (e.g. aspen) and increased the relative importance of avoided species (e.g. alder), with long-term implications to forest succession and dynamics. [BEAVER; RIPARIAN FOREST; RIPARIAN HABITAT]

876. Jolly,JP (1982): A proposed method for accurately calculating sediment yields from reservoir deposition. p.153-161. In: Proceedings of 
the Exeter symposium: Recent developments in the explanation and prediction of erosion and sediment yield. July 1982. IAHS Publ. No. 137.

This paper proposes a means of developing a relation between sediment yield and the hydrological, geological, and climatic characteristics of the upstream drainage basin. The relation can be used to estimate sediment loads at potential reservoir sites. The method is applied using the data from many rivers and is suggested to be both economical and accurate.

[FROSION; GEOMORPHOI OGY; MODFIJING; SEDIMENT TRANSPORT]

877. Jones,AR; Sharpe,FP; Strauss,P; Deason,WO (1978): Interaction of water management and riparian ecosystems: Altitudes, practices, and effects. p.284-288. In: Proceedings of the symposium on strategies for protection and management of floodplain wetlands and other riparian ecosystems. 11-13 December 1978. Callaway Gardens, GA.

Under the broad mission of planning, developing, and managing water and related land resource projects which supply water for agriculture, domestic, and industrial use in the 17 western states, the USDI Bureau of Reclamation also fulfills the mission of preserving or mitigating riparian habitat. [RIPARIAN ECOLOGY; RIPARIAN HABITAT; WATER RESOURCE MANAGEMENT]

878. Jones,JA; Grant,GE (1996): Peak flow discharges to clear-cutting and roads in small and large basins, western Cascades, Oregon. Water Resources Research 32(4), 959-974.

This study examined long-term changes in streamflows associated with clear-cutting and road construction and explored alternative hydrologic mechanisms to explain stream hydrochanges in the Cascades Range, western Oregon. They determined differences in paired peak discharges for 150 to 375 storm events for five basin pairs, using 34-year records from two pairs of 60- to 101-ha experimental basins in the H.J. Andrews Experimental Forest, and 50- to 55-year records from three pairs of adjacent basins ranging from 60 to $600 \mathrm{~km} 2$. Forest harvesting has increased peak discharges by as much as 50 percent in small basins and 100 percent in large basins over the last 50 years. These increases are attributable to changes both in flow routing due to roads and in water balance due to treatment effects and vegetation succession.

[HYDROLOGY; LOGGING IMPACTS; STREAM FLOW; WATER BALANCE]
879. Jones, KB (1988): Comparison of herpetofaunas of a natural and altered riparian ecosystem. p.222-227. In: Management of amphibians, reptiles, and small mammals in North America. Proceedings of the symposium. 19-21 July 1988. Flagstaff, AZ.

Reptile abundance and diversity were greater on an unaltered riparian ecosystem than on an altered site. Two streams; one having no major water impoundments and the sampling site located in a mature gallery-type stand of cottonwood and willow (unaltered), the other river having major impoundments, regulated flow, reduced flooding and the sample site located in a poorly developed tree gallery with no evidence of tree reproduction (altered). The distribution and abundance of certain microhabitats appear to account for differences in reptile abundance and diversity on the two sites. In conserving riparian ecosystems, attention needs to be given to protecting more habitat components, including microhabitats such as surface litter found important to herpetofauna.

[AMPHIBIANS; BIODIVERSITY; HERPETOFAUNA; REPTILES; RIPARIAN HABITAT]

880. Jones,KB; Glinski,PC (1985): Microhabitats of lizards in a southwestern riparian community. p.342-346. In: Johnson,RR; Ziebell,CD;

Patton,DR; Ffolliott,PF; Hamre,RH [tech. coord.]. Riparian ecosystems and their management: Reconciling conflicting uses. 16-18 April 1985. Tucson, AZ. USDA Forest Service. General Technical Report RM-120.

In a southwestern riparian community, relationships between lizard abundance and distribution, and certain selected microhabitats were studied. The distribution of lizards appears to reflect availability of preferred habitat; certain lizards and microhabitats were widespread while others were limited to small portions of the study area. Patterns of lizard distribution are discussed.

[HERPETOFAUNA; RIPARIAN HABITAT]

881. Jones,LA (1988): Swampbuster in North Dakota. p.103-105. In: Stuber, PJ [tech. coord.]. Proceedings of the national symposium on the protection of wetlands from agricultural impacts. 25-29 April 1988. Ft. Collins, CO. USDI Fish and Wildlife Service. Biological Report 88(16).

The Swampbuster provision has had a very controversial beginning in North Dakota. Landowner opposition due to the lack of information, severe penalties, loss of managerial rights, and a desire to be 
compensated for preserving wetlands have all led to a thrust for changes. As a consequence, the state's Congressional delegation has been active in pursuing changes to Swampbuster. The effectiveness of Swampbuster to protect prairie wetlands will be determined by the outcome of legislative efforts to weaken or modify the current regulations. [AGRICULTURAL IMPACTS; RIPARIAN HABITAT; WETLANDS]

882. Jorgenson,SE (1989): Changes of redox potential in aquatic ecosystems. p. 341-355. In: Ecological engineering: An introduction to ecotechnology. [Eds: Mitsch,WJ; Jorgenson,SE]. John Wiley \& Sons, New York, NY.

Some model exercises have shown that the minor phosphorus input during a period of heavy rain due to discharge of overflow water from the watershed is not insignificant for eutrophication. This point is often overlooked, but the modeling concept always takes the total nutrient balance into consideration. Case studies on shallow lakes confirm these observations. Destratification has certain disadvantages caused by the elevation of the hypolimnetic temperature, but positive effects on hydrogen sulfide, phosphorus, and oxygen were observed, though the effect on primary production seemed minimal.

[EUTROPHICATION; HYDROLOGY; PRIMARY PRODUCTION; REDOX POTENTIAL]

883. Julien,PY; Frenette,M (1987): Macroscale analysis of upland erosion. Journal of Hydrologic Sciences 32(3), 347-357.

Scale effects in computing sheet and rill erosion losses from large basins have been studied for grid sizes ranging from 0.03 to $4 \mathrm{~km} 2$ over drainage areas up to $3000 \mathrm{~km} 2$. $\Lambda \mathrm{fter}$ analysis of a basin in Quebec, Canada, the mean characteristics of the basin could be used to estimate the mean annual upland erosion losses after a correction factor for the influence of grid size was introduced into the calculation. The use of fine-meshed grids can be justified when information on the areal distribution of soil crosion is desired.

[DRAINAGES; IIYDROLOGY; SOILS; WATERSHED]

884. Jurmu,MC; Andrle,R (1997): Morphology of a wetland stream. Environmental Management 21(6), 921-941.

In the recently expanding field of wetland reconstruction, stream design has been primarily based on stream morphologies typical of non-wetland alluvial environments. In this investigation, several significant differences between the morphology of the stream and the typical morphology of nonwetland alluvial streams were revealed. Six morphological features of the study reach were examined: bankfull flow, meanders, pools and riffles, thalweg location, straight reaches, and cross-sectional shape. It was found that bankfull flow definitions originating from streams in non-wetland environments did not apply. Unusual features observed in the wetland reach include tight bends and a large axial wavelength to width ratio. A lengthy straight reach exists that exceeds what is typically found in non-wetland alluvial streams. The lack of convex bank point bars, a greater channel width at riffle locations, and small form ratios deep and narrow channel, were also differences identified. [GEOMORPHOLOGY; STRFAM FCOI.OGY; WETLANDS]

885. Kaczynski,VW; Moos,DW (1979): Strategies for Mid-Columbia fish production. p.289-295. In: Swanson,GA [ed.]. The mitigation symposium: $A$ national workshop on mitigating losses of fish and wildlife habitats. USDA Forest Service. General Technical Report RM-65.

Putting the area-wide fisheries mitigation requirements into one package dramatically increases ways to meet the requirements. Treating salmonid fisheries mitigation for several individual projects in the mid-Columbia on a combined basis has many apparent advantages.

[COLUMBIA RIVER; FISHERIES; RIPARIAN HABITAT]

886. Kaniuka, $R$ (1987): Underground channels mapped by radar. Agricultural Research 35(1), 14-15.

Radar is being used by USDA scientists to: 1 ) identify the locations/depths of perched and main aquifers; 2) determine lateral flows of water; 3) select the best locations for observation wells and sampling sites; and 4) measure the volume of lakes and ponds. [HYDROLOGY; MONITORING; SURF $\Lambda$ CE WATER-GROUNDWATER INTERACTION; TECHNIQUES]

887. Kantrud,HA (1986): Effect of vegetative manipulation on breeding waterfowl in prairie wetlands - A literature review. USDI Fish and Wildlife Service. Washington, DC. Report No .3.

A compilation of technical and scientific articles and publications dealing with artificial manipulation of vegetation for the purpose of improving, restoring, 
or enhancing prairie wetland habitat for breeding waterfowl.

[BIBLIOGRAPHY; RIPARIAN HABITAT; VEGETATION MANAGEMENT; WATERFOWL MANAGEMENT]

888. Kantrud,HA; Krapu,GL; Swanson,GA (1989): Prairie basin wetlands of the Dakotas: $A$ community profile. USDI Fish and Wildlife Service. Biological Report 85(7.28). Washington, DC. $89 \mathrm{p}$.

The shallow basin wetlands of the Dakotas form the bulk of the portion of the Prairie Pothole Region lying within the United States. This region produces a large proportion of North American waterfowl and other prairie dwelling marsh and aquatic hirds. Wetlands in the region are frequently drained for crop production. These wetlands vary greatly in their ability to maintain surface water and their water chemistry, which varies from fresh to polysaline. In addition, these wetlands are affected by a variety of agricultural land uses and practices, including pasture, cultivation, mechanical forage removal, idle conditions, and burning. It is important to understand how these factors operate in prairie basin wetlands, since they profoundly affect flora and fauna. [MARSHES; RIPARIAN HABITAT; WETLANDS]

889. Karr,JR; Chu,EW (1998): Restoring life in running waters: Better biological monitoring. 1st ed. Island Press. Covelo, CA. 200 p.

The book addresses freshwater ecosystems in the US and biology's role in understanding them. A methodology for using multimetric indices to integrate measurements of many attributes is presented, for assessing and communicating environmental health. It provides practical tools for understanding the impact of human activities on natural systems and the appropriate actions to remedy those impacts.

[ASSESSMENTS; MONITORING; RIPARIAN RESTORATION]

890. Karr,JR; Yant,PR; Fausch,KD (1987): Spatial and temporal variability of the index of biotic integrity in three midwestern streams. Transactions of the American Fisheries Society 116(1), 1-11.

The index of biotic integrity (IBI) has been used to assess the biological quality of flowing water systems in all areas of the US. Biotic integrity, however, has rarely been related to independent measures of water or habitat quality. In two watersheds where conditions were relatively stable,
IBI ranked sites similarly. Rankings among sites conformed to prior assessments of site quality based on habitat and water quality. Sampling should be conducted during summer to reduce variation due to seasonal fish migration and fall recruitment of young-of-the-year fish. Generally, the IBI reflects known habitat and water quality of both natural and anthropogenic origin. Little or no improvement in biotic quality was detected following implementation of numerous soil and water conservation practices. [FISH POPULATIONS; FISHERIES; RIPARIAN HABITAT; WATER QUALITY]

891. Kauffman,JB (1987): The status of riparian habitats in Pacific Northwest forests. In: Streamside management: Riparian, wildlife, and forestry interactions. 11-13 February 1987. University of Washington. Seattle, WA.

The typical characterization of undisturbed riparian ecosystems is that of a high spatial heterogeneity of plant communities of varying age classes and seral stages. Each seral stage is utilized by different species of wildlife; however, the greatest use has been described for those late successional arboreal riparian communities dominated by a mix of coniferous and deciduous species. In intensively managed forests with short rotation schedules, these communities may never develop, and the biotic potential for the riparian ecosystem is never attained. If these productive riparian communities are the desired status of a given ecosystem, then alterations in land use, such as establishment of buffer zones and extended rotation schedules, may be necessary. [BIOTIC POTENTIAL; RIPARIAN FOREST; RIPARIAN HABITAT]

892. Kauffman,JB; Beschta,RL; Otting,N; Lytjen,D (1997): An ccological perspective of riparian and stream restoration in the western United States. Fisheries 22(5), 12-24.

There is an unprecedented need to preserve and restore aquatic and riparian biological diversity before extinction eliminates the opportunity. "Ecological restoration" is the re-cstablishment of processes, functions, and related biological, chemical, and physical linkages between the aquatic and associated riparian ecosystems; it is the reparation of damages caused by human activities. The first and most critical step in ecological restoration is "passive restoration", the cessation of anthropogenic activities that are causing degradation or preventing recovery. Given the capacity of riparian ecosystems to naturally recover, this is often all that is needed to achieve successful restoration. A 
period of time sufficient for natural recovery is recommended prior to the beginning of active and physical restoration approaches. Restoration should be undertaken at the watershed or landscape scale. Riparian/ stream ecosystems cannot be restored by manipulations within the channel only.

[BIODIVERSITY; PASSIVE RESTORATION; RIPARIAN RESTORATION; STREAM IMPROVEMENTS]

\section{Kauffman,JB; Krueger,WC (1984):}

Livestock impacts on riparian ecosystems and streamside management implications -- a review. Journal of Range Management 37(5), 430-437.

This review summarizes the available literature to date regarding livestock impacts and management implications on riparian ecosystems. Public grazing lands should be evaluated on a true multiple use basis that recognizes and evaluates the biological potential of each ecological zone in relation to the present and future needs of our society. Management strategies that recognize all resource values must be designed to maintain or restore the integrity of riparian communities.

[GRAZING IMPACTS; RIPARIAN MANAGEMENT ZONE; RIPARIAN VEGETATION]

894. Kauffman,JB; Krueger,WC; Vavra,M (1983): Effects of late season cattle grazing on riparian plant communities. Journal of Range Management 36(6), 685-690.

The impacts of livestock on riparian community composition, structure, and productivity were evaluated over 3 years. Between fall grazed and enclosed areas, 4 out of 10 plant communities displayed significant species composition and productivity changes. Two meadow types and the Douglas hawthorne type had significant changes in standing phytomass. These types were also utilized more heavily than the other communities. Shrub use was generally light except on willow-dominated gravel bars. Succession appeared to be retarded by livestock grazing on gravel bars. [GRAZING IMPACTS; GRAZING TREATMENTS; RIPARIAN VEGETATION]

895. Kauffman,JB; Krueger,WC; Vavra,M (1983): Impacts of cattle on streambanks in northeastern Oregon. Journal of Range Management 36(6), 683-685.

Impacts of a late season livestock grazing strategy on streambank erosion, morphology, and undercutting were studied for 2 years. Streambank loss, disturbance, and undercutting were compared between grazing treatments, vegetation type, and stream-meander position. No significant differences were found among vegetation types or stream meander location. Significantly greater streambank erosion and disturbance occurred in grazed areas than in enclosed areas during grazing periods. Over-winter erosion was not significantly different among treatments. Annual streambank losses were greater in grazed than in ungrazed areas.

[GRAZING IMPACTS; LIVESTOCK EFFECTS; STREAMBANK PROTECTION]

896. Kauffman,JB; Krueger,WC; Vavra,M (1985): Ecology and plant communities of the riparian area associated with Catherine Creek in northeastern Oregon. Technical Bull. No. 147. Agricultural Experiment Station, Oregon State University, Corvallis, OR. 33 p.

A multitude of biotic/abiotic factors interacted to form an extremely complex ecosystem along Catherine Creek in the Wallowa mountains. A total of 258 stands of vegetation representing 60 plant communities were identified. At least 20 species of mammals and 81 species of birds utilize the area May-October. The diversity of riparian communities was attributed to factors such as: soil characteristics, streamflow dynamics, climate, plant community interactions, animal effects, and man's effects. Analysis of the nine most common community types indicated their composition and structure were significantly affected by those factors. [RIPARIAN ECOLOGY; RIPARIAN HABITAT]

897. Kaufman,H (1997): Riparian management: The future is in our hands. Rangelands 19(6), 18-19.

This paper was a winner in the High School Youth Forum of the Society for Range Management Annual Meeting. The author advocates a greater awareness of riparian issues and better cooperation to deal with riparian zones on active ranches.

[GRAZING IMPACTS; RIPARIAN

MANAGEMENT ZONE]

898. Kay,CE (1995): Browsing by native ungulates: Effects on shrub and seed production in the Greater Yellowstone Ecosystem. p.310-320. In: Proceedings: Wildland shrub and arid land restoration symposium; 19-21 October 1993; Las Vegas, NV. USDA Forest Service. General Technical Report INT-GTR-315.

Long-term grazing exclosures were used to compare browsed vs unbrowsed shrubs in the Greater 
Yellowstone Ecosystem. Deciduous shrubs protected by wild ungulates exhibited greater canopy cover, height, size, and volume than unprotected plants. Browsed shrub populations were dominated by significantly smaller plants than were unbrowsed populations. Protected shrubs increased in canopy coverage and size while browsed plants remained static or declined. Ungulate browsing in recent times has virtually eliminated shrub seed production in areas frequented by wintering elk. This elimination of shrub seed production over much of the ecosystem suggests that ungulates are not in equilibrium with their food resources, as required under the "natural regulation" paradigm.

[GRAZING IMPACTS; RIPARIAN HABITAT; RIPARIAN SHRIJBS]

899. Kay,CE; Chadde,S (1992): Reduction of willow seed production by ungulate browsing in Yellowstone National Park. p. 92-99. In: Clary,WP; McArthur,ED, Bedunah,D; Wambolt,CL [comp.]. Proceedings - Symposium on ecology and management of riparian shrub communities. USDA Forest Service. General Technical Report INT-289.

Long-term grazing exclosures were used to compare seed production in unbrowsed vs. browsed communities. Inside exclosures, the number of seeds per $s q \mathrm{~m}$ of female canopy coverage ranged from 109,000 to 583,000 . Outside exclosures, no male or female aments (catkins) or willow seeds were produced. Willow stems above the browse height $(2.5 \mathrm{~m})$ produced an abundance of male or female aments.

[BROWSING EFFECTS; GRAZING IMPACTS; SEED PRODUCTION; WILLOW]

900. Keddy,PA (1989): Effects from competition from shrubs on herbaceous wetland plants: a 4-year field experiment. Canadian Journal of Botany 67, 708-716.

While competition is known to occur among some species in some plant communities, it is still not possible to predict in which environments, or among which species, competitive interactions will be most intense. On this study site between shrubs and herbaceous lakeshore plants, shrubs were removed from treatment plots paired with controls. On shores with frequent disturbance and low fertility there was no evidence for competitive release. There were highly significant increases in cover, richness, and diversity in the removal plots, but less than one-quarter of the individual species responded significantly.
[LACUSTRINE ECOLOGY; RIPARIAN HABITAT; RIPARIAN SHRUBS; WETLANDS]

901. Keeley,JE (1999): Photosynthetic pathway diversity in a seasonal pool community. Functional Ecology 13, 106-118.

Diversity of photosynthetic pathway was evaluated for dominant species in a seasonally aquatic community in the southwestern United States. Pulse-chase techniques were used in this evaluation. Under submerged conditions, only about half the species were clearly $\mathrm{C} 3$, three of the 15 dominants were CAM, one species was $\mathrm{C} 4$, and three of the species potentially assimilated carbon with both $\mathrm{C} 3$ and $\mathrm{C} 4$ fixation. During the brief terrestrial stage in the life history of these amphibious plants, both the CAM and the $\mathrm{C} 3+\mathrm{C} 4$ species switched to $\mathrm{C} 3$, whereas the $\mathrm{C} 4$ species did not switch. Species with $\mathrm{C} 4$ or $\mathrm{CAM} \mathrm{CO} 4$ concentrating mechanisms lacked the capacity for bicarbonate uptake, an alternative $\mathrm{CO} 2$ concentrating mechanism found in certain $\mathrm{C} 3$ plants in this community.

[BIODIVERSITY; NUTRIENT CYCLES; PHOTOSYNTHESIS; SEASONAL POOLS]

902. Keigley, RB (1988): Developing methods of restoring vegetation communities while preserving genetic integrity. In: Proceedings of the high altitude revegetation workshop No. 8. Colorado State University. Ft. Collins, CO. Information Series No. 59.

There is a good chance that restoration can meet established standards but this process at high elevations may requirc a longer period of timc. This is because: 1) restoration methods are in a state of development; and 2) successional processes will take much longer than reseeding to achieve a stabilizing ground cover. Sufficient quantitics of plant materials will require a developed propagation program.

[RIPARIAN RESTORATION]

\section{Keith,RM; Bjornn,TC; Meehan,WR;} Hetrick,NJ; Brusven,MA (1998): Response of juvenile salmonids to riparian and instream cover modifications in small streams flowing through second-growth forests of southeast Alaska. Transactions of the American Fisheries Society 127:889-907.

Canopy of second-growth red alder and instream cover was manipulated to assess the effects on abundance of juvenile salmonids in small streams. Sections of red alder canopy were removed to compare responses of salmonids to open and closed canopy sections. Alder brush bundles were then 
placed in $1 / 2$ of the pools to test the response of juvenile salmonids to additions in instream cover. Abundance of age- 0 coho salmon decreased in both open and closed canopy sections, but abundance decreased at a higher rate in closed canopy sections. More age-0 Dolly Varden trout were in open canopy sections than in closed canopy sections. Numbers of age-1 coho salmon and Dolly Varden were relatively constant. Abundance of age- 0 coho salmon decreased in pools with and without additional instream cover. Abundance of age- 1 and older coho salmon and age0 Dolly Varden did not differ significantly in pools with added instream cover than in pools without cover. Abundance of age- 1 and older Dolly Varden was higher in pools with added cover than in pools without cover. Age- 0 coho salmon decreased in abundance throughout the summer. Emigration accounted for most of the decreases in abundance. [AQUATIC ECOSYSTEMS; CANOPY; FISH HABITAT; SALMONIDS]

904. Keller,CR; Anderson,L; Tappel,P (1979): Fish habitat changes in Summit Creek, Idaho, after fencing the riparian area. p.46-52. In: Cope,OB [ed.]. Forum: Grazing and riparian/stream ecosystems. 3-4 November 1978. Denver, CO. Trout Unlimited, Inc.

At Summit Creek, Idaho, the fish habitat protection provided by streambank fencing has negated the need for artificial structures intended to enhance trout production in this stream. The authors recommend that previously installed trash catchers and digger logs should be removed. Removal of instream structures will allow the affected portions of the creek to re-establish a stable, more productive stream environment. It also appeared that annual supplemental stocking would be unnecessary, judging from the abundance of wild trout.

[FISHERIES; RIPARIAN HABITAT; RIPARIAN RESTORATION]

905. Keller,CR; Burnham,KP (1982): Riparian fencing, grazing, and trout habitat preference on Summit Creek, Idaho. North American Journal of Fisheries Management 2(1), 53-59.

Livestuck were excluded from $3.2 \mathrm{~km}$ of riparian area by fencing on public lands. Four years later, 6 stream sections were electrofished to determine differences in trout abundance, size, and growth between grazed and ungrazed segments. Sampling stations were paired by habitat type. More trout were found in ungrazed sections in all three habitat types. Generally, there were more catchable rainbow and brook trout in ungrazed sections. There was evidence that fish size was reduced in grazed sections. The study supported the conclusion that trout prefer stream areas in ungrazed habitat over grazed habitat. [EXCLOSURES; FISHERIES; GRAZING IMPACTS; TROUT]

906. Keller,EA; Tally,T (1979): Effects of large organic material on channel form and fluvial processes. Earth Surface Processes and Landforms 4, 361-380.

Large organic debris in streams flowing through old-growth redwood forests in California significantly influence channel form and fluvial processes in small to intermediate size streams. Approximately 60 percent of the total drop in elevation over a several hundred meter reach was associated with large organic debris. Debris also provides numerous sites for sediment storage. The influence of large organic debris on channel forms and process in low gradient stream reaches is less than in steeper channels. However, the debris still may affect development of pools and may help stabilize channel banks.

[CHANNEL MORPHOLOGY; GEOMORPHOLOGY; ORGANIC DEBRIS]

907. Keller,EA; Tally,T (1979): Effects of large organic debris on channel form and fluvial processes in a coastal redwood environment. p.169-197. In: Adjustments of the fluvial system. Proceedings of the 10th annual geomorphic symposium series. Binghampton, NY. [Rhodes,D; Williams, GP : eds.|.

The role of large organic debris is especially important in controlling the development of the long profile and in producing a diversity of channel morphologies and sediment storage sites. Large organic debris in steep mountain streams may produce a stepped-bench profile where a large portion of the stream's potential energy loss is expended over short falls or cascades produced by the debris. The influence of large organic debris on channel form and process in low gradient streams is less than in steeper channels. However, the debris may still affect development of pools and may help stabilize the channel banks. Root mats may armor banks and provide important fish habitats in the form of undercut banks. The stream channel of some low gradient streams may be stable. Managers should use natural stream processes to regulate channel conditions rather than attempt absolute control by artificial means.

[CHANNEL MORPHOLOGY; GEOMORPHOLOGY; ORGANIC DEBRIS] 
908. Kelly,T (1985): Strategic riparian resource management in a metropolitan setting. p.403-407. In: Johnson,RR; Ziebell,CD; Patton,DR; FfolliottPF; Hamre,RH [tech.coord.]. Riparian ecosystems and their management: Reconciling conflicting uses. 16-18 April 1985. Tucson, AZ. USDA Forest Service. General Technical Report RM-120.

Riparian systems within metropolitan areas can come under extreme pressure to accommodate conflicting uses. Strategic management planning provides a method for mediating conflicts and developing realistic objectives. A discussion of the strategic management effort for the Minnesota Valley National Wildlife Refuge follows. [HUMAN IMPACTS; RIPARIAN HABITAT; URBAN IMPACTS]

909. Kelsay,LE (1964): List of cartographic records of the General Land Office. U.S. National Archive and Record Service, General Services Administration. Washington, DC.

Maps and survey documents preceding 1964 are available in the Map Rooms of BLM and other government agencies and in the National Archives. [HISTORIC RECORDS; HYDROLOGY; MAPPING]

910. Kenna,J; Devaurs,W; Troutman,D; King,G; Street,W; Cannon,B; Simontacchi,D; Modrell,D (1990): Warner Wetlands Area of Critical Environmental Concern (ACEC) management plan. USDI Bureau of Land Management. Lakeview, OR. BLM-OR-PT-90-28-1792.

A BLM management plan for Warner Wetlands $A C E C$, in eastern Oregon is presented. [BLM; GRAZING IMPACTS; LACUSTRINE ECOLOGY]

911. Kennedy,CE (1977): Wildlife conflicts in riparian management: water. p.52-58. In: Johnson, RR; Jones, DA [tech. coord.]. Symposium on the importance, preservation and management of the riparian habitat. $9 \mathrm{July} 1977$. Tucson, AZ.

This paper summarizes observations on the need for better understanding of the interactions of stream, riparian, vegetation, energy, nutrients, water production, aquatic life, and terrestrial life. These interactions have previously had little attention in Arizona and New Mexico.

[RIPARIAN HABITAT; RIPARIAN

MANAGEMENT ZONE; WATERSHED]

912. Kentula,M (1997): A step toward a landscape approach in riparian restoration.

Restoration Ecology 45(5), 2-3.

One potential solution to the problem of siting restoration projects was to provide resource managers and practitioners with a mechanism to place the individual restoration decisions in a larger context. This tool would also provide a way to identify the areas most important ecologically and could be used proactively in a watershed management strategy to balance land use and ecological values.

[LANDSCAPE ECOLOGY; RIPARIAN RESTORATION]

913. Kentula,ME (1989): Wetland creation and restoration: EPA's research program and investigation of an extensive sampling approach to comparing created and natural wetlands. In: Proceedings of the first annual meeting of the Society for Ecological Restoration. Oakland, CA.

Research by EPA is underway to: 1) synthesize knowledge on wetland creation and restoration; 2) describe trends and patterns in Section 404 permitting,; and 3) compare created and naturally occurring wetlands.

[RESEARCH; RIPARIAN RESTORATION; WETLANDS]

914. Kentula,ME (1997): A comparison of approaches to prioritizing sites for riparian restoration. Restoration Ecology 45(5), 69-74.

This paper compares previously cited studies by Olson and Harris (1997) and Russell et al. (1997) in their work to prioritize sites for riparian restoration in the San Luis Rey River watershed in southern California. For seven of the twelve management units delineated along the mainstream, the two studies agreed on a strategy of restoration or protection. They differed on two. No comparison could be made of the three units for which Olson and Harris used project review, a unique category. Agreement of the results is due to the similarity of criteria used to identify and rank sites for protection and restoration; disagreement is due primarily to the level of resolution of the data. Both approaches have potential for use in watershed-level planning. The predictive power of the two approaches may be maximized when they are used in a complementary fashion.

[HYDROLOGY; PLANNING; RIPARIAN RESTORATION]

915. Kershner,JL (1997): Setting riparian/aquatic restoration objectives within a watershed context. Restoration Ecology 5(5), 


\section{5-24.}

Declining native plant and animal communities have prompted new interest in restoration of aquatic and riparian ecosystems. Past activities have been typically site-specific, with little thought to processes operating at larger scales. A watershed analysis process developed in the Pacific Northwest identifies four operating scales useful in developing priorities: region, basin, watershed, and specific site. Watershed analysis provides a template for restoration biologists to use in prioritizing restoration activities. This template provides seven key steps necessary to understand and develop restoration priorities: 1) characterization; 2 ) identification of key issues and questions; 3 ) documentation of current conditions; 4) description of reference conditions; 5) identification of objectives; 6) summary of conditions and determination of causes; and 7) recommendations. [RIPARIAN RESTORATION; SPATIAL SCALE; WATERSHED]

916. Kershner,JL; Snider,WM; Turner,DM; Moyle,PB (1992): Distribution and sequencing of mesohabitats: Are there differences at the reach scale? Rivers 3(3), 179-190.

Stream classification techniques may provide useful information about the function of stream habitat. Relationships between habitat characteristics at the mesohabitat scale and how these characteristics are influenced by other scales, such as watershed and reach, is poorly understood. Results of studies in the Sierra Nevada Mountains indicated that even though differences in mesohabitat do occur between distinct stream reaches, the mesohabitat composition is highly variable. Use of representative reaches to describe stream habitats should be viewed with caution, given the dynamic nature of stream habitats and the biotic and abiotic factors that influence them. [CHANNEL DYNAMICS; CLASSIFICATION; RIPARIAN HABITAT; SPATIAL SCALE; STREAM FLOW]

\section{Ketcheson,GL (1986): Sediment rating} equations: An cvaluation for streams in the Idaho batholith. USDA Forest Service. General Technical Report INT-213. 12 p.

Sediment data from streams in the Idaho batholith were used to develop suspended, bedload, and total sediment rating equations. These equations were discussed in terms of statistical significance and their usefulness for documenting management impacts. Sediment yields were estimated using the rating equations and streamflow data. These yields were compared with those estimated from a time-integration method. For streams in the Silver Creek research area, sediment yields from rating equations and time-integration techniques were compared with estimates from sediment dams. Rating equation and time-integration estimates were statistically different. Time-integration estimates more closely matched those from the sediment dams. [BEDLOAD; HYDROLOGY; SEDIMENT TRANSPORT; STREAM FLOW]

918. Ketcheson,GL; Megahan,WF (1991): Sediment tracing in step-pool granitic streams in Idaho. p.4-147 to 4-153. In: Proceedings of the fifth federal interagency sedimentation conference. [eds. Tan,SS;Kuo,YH]. Subcommittee on Sedimentation of the Interagency Advisory Commission on Water Data.

Sediment tracer studies were conducted on four channels in the Silver Creek Study Area in south-central Idaho. A single dose of tracer particles was placed at the head of each reach just prior to snowmelt. After runoff, samples of bed material were collected from all discrete deposits within the test reaches. About two-thirds of the tracer material remaining in the reaches was deposited behind natural organic debris in the channel, while one-third was evenly divided among deposition in point bars, pools, and random bed and bank locations. Transport of tracer through the reaches was directly proportional to channel gradient and flow rate. [HYDROLOGY; SEDIMENTATION; STREAM FLOW]

919. Keys,J (1993): The Bureau of Reclamation's policies. p.130-133. In: Tellman,B; Cortner,HJ; Wallace,MG; DeBano,LF; Hamre,RH [tech.coord.]. Riparian management: Common threads and shared interests. USDA Forest Service. General Technical Report RM-226.

This paper focuses on USDI Bureau of Reclamation efforts for salmon recovery. Current activities include cooperation in over 20 salmon measures such as: coordination of Columbia River water and power operations, water supply forecasting, water quality issues, flood control strategies, water acquisition, and lower Snake River dam operations.

[ENDANGERED SPECIES ACT; RIPARIAN HABITAT; SALMON RECOVERY]

920. Kimbal,J; Savage,F (1977): Diamond Fork aquatic and range habitat improvement. USDA Forest Service, Intermountain Region, Uinta National Forest. 19 p. 
This paper concluded that aquatic systems are dependent upon the condition of the adjacent terrestrial environment. Unrestricted livestock grazing was found to be detrimental to the riparian zone of grazed streams through trampling and overuse of the plant community. Riparian zones require the same grazing management as other areas to maintain, reproduce, and remain stable. Intensive livestock management can restore or maintain aquatic ecosystems at a lower cost than the installation of artificial stream improvement structures.

[GRAZING IMPACTS; HABITAT

MANAGEMENT; RIPARIAN HABITAT]

921. Kinch,G (1989): Riparian area management: Grazing management in riparian areas. USDI Bureau of Land Management.

Technical Reference 1737-4. $44 \mathrm{p}$.

In general, riparian areas are among the most resilient ecosystems on public lands and usually respond more quickly to changes in management. This paper assembles information from various authors, land managers, and researchers that can be used to guide grazing management in riparian areas using their unique responsiveness to accomplish management objectives. The paper addresses the implications of grazing in riparian areas, establishing management, and grazing principles and concepts. Grazing management practices that have worked elsewhere are described.

[BEST MANAGEMENT PRACTICES; GRAZING IMPACTS; RIPARIAN]

922. Kindschy,RR (1984): A line-intercept method for monitoring riparian vegetation trend. p.25-30. In: Bedell,TE |ed.|. Proceedings of 1984 Pacific Northwest range management short course: Range watersheds, riparian zones and economics: Interrelationships in management and use. 25-27 January 1984. Pendleton, OR. Oregon State University

A procedure is described that utilizes a modified line intercept transect can provide quantitative and qualitative data for documenting vegetative changes in riparian communities. Data analysis will be useful to managers for determining achicvement of ecological trend objectives.

[MONITORING; RIPARIAN HABITAT; TECHNIQUES]

923. Kindschy,RR (1985): Response of red willow to beaver use in southeastern Oregon. Journal of Wildlife Management 49(1), 26-28.

Natural and prolonged heavy utilization of red willow by beaver did not appear to be responsible for the deterioration, reduction, and loss of this riparian species. Additional factors, including the continual cropping of willow regrowth by cattle during the growing season were involved in limiting red willow stands in many of the riparian communities of southeast Oregon. [BEAVER; GRAZING IMPACTS; RIPARIAN RESTORATION]

924. Kindschy,RR (1987): Riparian

reminiscences. Rangelands 9(2), 71-74.

The demonstrated resiliency of wetland habitats/riparian areas is such that recovery can be rapid. Successional progression likely follows a predictable sequence, dependent upon site potential and the control of dominant factors limiting such progression. Rangeland managers may be able to design management systems to optimize multiple use returns from this important natural resource. [RIPARIAN; RIPARIAN RESTORATION; SUCCESSION]

925. Kindschy, RR (1989): Regrowth of willow following simulated beaver cutting. Wildlife Society Bulletin 17, 290-294.

The author measured the responses of willows to cutting treatments that simulated beaver herbivory during different seasons. Red willow (Salix lasiandra) is the most susceptible to cutting during hot summer conditions.

[BEAVER; RIPARIAN HABITAT; RIPARIAN SHRUBS; WILLOW]

926. King,JG (1989): Streamflow responses to road building and harvesting: A comparison with the equivalent clear-cut area procedure. USDA Forest Service Research Paper INT-401. 13 p. Increases in annual streamflow and peak streamflows were determined on four small watersheds following timber harvesting and road building. The measured hydrologic changes are compared to those predicted by a methodology commonly used in the USDA Forest Service's Northern Region, the equivalent clear-cut area procedure. Increases in peak streamflows are discussed with respect to their potential to modify the channel system.

[HYDROLOGY; LOGGING IMPACTS; STREAM FLOW]

927. King,W; Thompson,F (1994): Fish Creek Restoration Project. p.81-82. In: Summit showcase displays and ecosystem case studies. 
USDI Bureau of Land Management Summit.

Incline Village, NV. April, 1994.

The fire that burned 70 acres in Fish Creek Basin south of Battle Mountain, Nevada in 1991 provided a collaborative opportunity for the local BLM office and community organizations. Participants in the restoration project included a local Boy Scout troop, the Lander County Rod and Gun Club, a grazing permittee, community volunteers, the Nevada Division of Forestry, and various BLM employees. This effort provided a restored watershed, improved wildlife habitat, and a re-established forage base. [COLLABORATION; RESEEDING; RIPARIAN RESTORATION]

928. Kingery,H (1991): Riparian value to birds. p.715. In: Roth,D; Bridges, C; Zimmerman,C [eds.]. What does riparian mean to me? Proceedings of the third annual convention. Colorado Riparian Association. 6-8 November 1991. Pueblo, CO.

The riparian systems in Colorado have an influence on bird life far beyond their dimensions. They have greater diversity and greater density of avifauna than any other forest or grassland habitat. If each layer of the riparian system is undisturbed, the system will support a higher population of birds. [AVIFAUNA; RIPARIAN HABITAT]

929. Kingsley,K (1985): The pecan orchard as a riparian ecosystem. p.245-249. In: Johnson, $R R$; Ziebell,CD; Patton,DR; Ffolliott,PF; Hamre,RH [tech. coord.]. Riparian ecosystems and their management: Reconciling conflicting uses. 16-18 April 1985. Tucson,AZ. USDA Forest Service. Gencral Technical Report RM-120.

The world's largest irrigated pecan orchard near Tucson, Arizona, is, at maturity, a dense woodland of deciduous trees, with abundant weeds as understory and surfacc water generally available. Native animals, including invertebrates, amphibians, reptiles, birds, and mammals, have invaded the orchard and adapted to it.

[AGRICULTURAL IMPACTS; RIPARIAN HABITAT]

930. Kinney,JW; Clary,WP (1994): A photographic utilization guide for key riparian graminoids. USDA Forest Service. General Technical Report INT-GTR-308. 13 p.

Photographic guides are presented to help estimate grazing utilization of important riparian grasses and grasslike plants. Graphs showing the percent of a plant's weight that has been consumed based on the percent of it's height left after grazing allow utilization estimates to be refined further. [GRAZING IMPACTS; GRAZING TREATMENTS; UTILIZATION]

931. Kirby,RE; Lewis,SJ; Sexson,TN (1988): Fire in North American wetland ecosystems and fire-wildlife relations: An annotated bibliography. USDI Fish and Wildlife Service. Biological Report 88(1), 146.

This report compiles an annotated bibliography dealing with the relationship between fire and wetlands. A total of 319 papers and articles are abstracted and presented.

[BIBLIOGRAPHY; FIRE IMPACTS; RIPARIAN HABITAT; WETLANDS]

932. Klebenow,DA; Oakleaf,RJ (1984):

Historical avifaunal changes in the riparian zone of the Truckee River, Nevada. p.203-209. In: Mutz,KM; Cooper,DJ; Scott,ML; Miller,LK [tech. coord.]. Proceedings of the California riparian systems conference. 17-19 September 1981. Davis, CA. University of California Press. Berkeley, CA.

A comparison of populations in the present avifauna with observations made during 1868 along the lower Truckee River showed species changes in abundance. The most noticeable changes in the avifauna involved species that require the dense understory of woody riparian vegetation, wet meadow, and marsh. Numerous species have declined in abundance. The apparent population declines can be related to the compounding of effects of farmland development, river channeling operations, and overgrazing.

[AGRICULTURAL IMPACTS; AVIFAUNA; GRAZING IMPACTS; RIPARIAN HABITAT]

933. Klock,GO (1985): Modeling the cumulative effects of forest practices on downstream aquatic ecosystems. Journal of Soil and Water Conservation, March-April 1985, 237-241.

A Watershed Cumulative Effects Analysis (WCEA) was developed to determine a watershed's hydrologic condition. It uses key watershed parameters affecting stream water quality and quantity. The model may be used to cvaluate the potential downstream impact of all forest practice options within a watershed and to schedule/coordinate forest practices within it. [AQUATIC ECOSYSTEMS; CUMULATIVE IMPACTS; FOREST MANAGEMENT; MODELING; RIPARIAN HABIT $\Lambda$ T] 
934. Klopatek,JM (1988): Some thoughts on using a landscape framework to address cumulative impacts on wetland food chain support. Environmental Management 12(5), 703711.

Primary production may not be the metric that best evaluates food chain support. Habitat variables appear to yield more information on life support functions. A landscape oriented approach was derived to hierarchically separate wetlands into ecological regions and landscape elements. This classification allows for predetermination of environmental constraints and possible natural limits of food chain support. Models derived from the spatial location theory can be used to determine the movement of animals from wetland patches experiencing impacts on food chain support. These models incorporate patch size, distance between patches, habitat quality, and environmental constraints.

[CUMULATIVE IMPACTS; FOOD CHAINS; MODELING; SPATIAL SCALE; WETLANDS]

935. Knapp,RA; Matthews, KR (1996): Livestock grazing, golden trout, and streams in the Golden Trout Wilderness, California: Impacts and management implications. North American Journal of Fisheries Management 16, 805-820.

Impacts of livestock grazing on golden trout (Oncorhynchus mykiss aguabonita) and their habitat were studied inside and outside of livestock exclosures in the Golden Trout Wilderness, California. In two consecutive years, the majority of stream physical characteristics showed large differences between grazed and ungrazed areas, and the directions of these differences were consistent with the recovery of exclosed streams and riparian areas from impacts caused by livestock grazing. Results suggest that current levels of livestock grazing are degrading the stream and riparian components of the area to the detriment of golden trout populations.

[FISHERIES; GRAZING IMPACTS; LIVESTOCK EFFECTS]

936. Knapp,RA; Vredenburg,VT; MatthewsKR (1998): Effects of stream channel morphology on golden trout spawning habitat and recruitment. Ecological Applications 8(4), 1104-1117.

This study was designed to determine whether stream channel morphology affects the availability of spawning habitat for California golden trout and whether spawning habitat availability influences the production of age- 0 trout and recruitment into the adult population. Wide stream reaches contained significantly more spawning habitat and higher density of nests and age- 0 trout than narrow reaches. Mortality of age- 0 trout was largely density dependent. In this study, the golden trout population was limited by spawning habitat. Grazing by livestock has widened the study streams which explained why these stream sections had more spawning habitat and higher golden trout densities than ungrazed sections. Individual growth rates of golden trout are apparently negatively density dependent.

[CHANNEL MORPHOLOGY; FISH HABITAT; GRAZING IMPACTS; RECRUITMENT; SALMONIDS]

937. Knight,AW; Bottorff,RL (1981): The importance of riparian vegetation to stream ecosystems. p.160-167. In: Warner,RE; Hendrix,KM [eds.|.California riparian systems conference.17-19 September 1981. Davis, CA.

Riparian vegetation is important in determining the structure and function of stream ecosystems. Most aquatic organisms, both invertebrates and fish, are directly or indirectly dependent on inputs of terrestrial detritus to the stream for their food. Natural changes in riparian vegetation and the biotic processing of detritus, as well as other factors, determine the kinds and abundance of aquatic invertebrates living in streams, from headwaters to large rivers. Removal of riparian vegetation will significantly affect stream organisms by: 1 ) decreasing detritus inputs; 2 ) increasing the potential for primary production in aquatic plants, 3 ) increasing the summer water temperatures; 4 ) changing water quality and quantity; and 5) decreasing terrestrial habitat for adult insects. [FISIIERIES; INVERTEBRATES; RIPARIAN HABITAT; RIPARIAN VEGETATION]

938. Knight,RW (1977): Streamside erosional response to animal grazing practices on Meadow Creek in northeastern Oregon. MS Thesis, Oregon State University. Corvallis, OR. 59 p.

A study to determine possible impacts of cattle and big game grazing on streamside erosional responses was initiated in 1975 . Objectives were to: 1) establish the study and collect baseline measurements; 2) determine the impact of animal grazing on soil bulk density and erosional potential; 3) determine characteristics of streambanks as influenced by animal trampling; and 4) determine infiltration rates and sediment production as they relate to soil structure. Very few differences were 
detectable in the short term of this study. Seasonal and natural variability were sufficiently large to mask a single year of grazing management at the seasons and intensities of stocking.

[EROSION; GRAZING IMPACTS; GRAZING TREATMENTS]

939. Knopf,FL (1985): Significance of riparian vegetation to breeding birds across an altitudinal cline. p.105-111. In: Tellman,B; Cortner,HJ; Wallace,MG; DeBano,LF; Hamre,RH [tech, coord.]. Riparian ecosystems and their management: Reconciling conflicting uses. 16-18 April 1985. Tucson, AZ. USDA Forest Service. General Technical Report RM-120.

This study documented the relative significance of riparian zones to breeding birds at six elevations between 1,200 and 2,750 $\mathrm{m}$ in the Platte River drainage of the Colorado Front Range. Bird communities were inventoried during 1,440 surveys at points in riparian and upland vegetation. Totals of 124 and 111 species were observed in each of two years; 82 percent of all species were observed in riparian sites. Species richness was higher in riparian sites than in uplands. Riparian bird communities were simplistically structured at high elevations and more complex at lower elevations. Upland communities were more complex at higher elevations. Riparian sites at the lowest and highest elevations were found via diversity analyses to be most significant to regional avifauna. Management actions to enhance avian communities in western states should place primary emphasis on riparian zones at low elevations, secondary emphasis on highest elevations, and de-emphasize efforts at intermediate elevations. [AVIFAUNA; PLATTE RIVER; RIPARIAN HABITAT; RIPARIAN VEGETATION]

940. Knopf,FL (1986): Changing landscapes and the cosmopolitanism of the eastern Colorado avifauna. Wildlife Society Bulletin 14, 132-142.

The development of a riparian forest on the Great Plains has provided a corridor for the movement of forest birds across those grasslands that have historically served as an ecological barrier to dispersal. The corridor has resulted in sccondary contact of many congeneric species which currently hybridize on the Great Plains; the hybridization may be interpreted either as reversing 10,000 years of speciation, or alternatively as promoting hybrid vigor within populations. Natural resource management agencies need to develop formal positions on the issues of cosmopolitanism and hybridization of wildlife species which occur with broad changes in native landscapes.

[AVIFAUNA; BIODIVERSITY; FLOODPLAIN

MANAGEMENT; RIPARIAN HABITAT]

941. Knopf,FL (1987): Ecological patterning of riparian avifaunas. In: Streamside management: Riparian wildlife and forestry interactions. An interdisciplinary symposium. 11-13 February 1987. University of Washington. Seattle, WA.

Riparian vegetation provides habitats for more species of birds than other vegetative communities in western states. Whereas less than 1 percent of the western landscape contains riparian habitat, these ecosystems provide habitat for up to 82 percent of the bird species of a region. The significance of a specific tract of riparian vegetation as avian habitats, however, varies with the scale from which a tract is evaluated. Avian communities within riparian ecosystems can be viewed as ecologically patterned along four distinct dimensions. These dimensions correspond to the hierarchical levels of calculating species diversity.

[AVIAN ECOLOGY; RIPARIAN ECOLOGY; RIPARIAN HABITAT]

942. Knopf,FL (1988): Riparian wildlife habitats: more, worth less, and under invasion. p.20-22. In: Mutz,K; Cooper,DJ; Scott,ML; Miller, LK [eds.]. Restoration, creation, and management of wetland and riparian ecosystems in the American West. A symposium of the Rocky Mountain Chapter of the Society of Wetland Scientists. 14-16 November 1988. Denver, $\mathrm{CO}$.

Displacement of native woody species will produce dramatic physiognomic transformation of native communities from multi-layered, multi-species assemblages to simpler, uniform "scrub" landscapes. This displacement will be accompanied by a 30 percent loss in the number of migratory bird species breeding in lowland areas. The author projects that Rocky Mountain and western Great Plains vegetation below $1,500 \mathrm{~m}$ elevation will include 50 percent canopy coverage of Russian olive within the next 50 years and 90 percent canopy coverage of Russian olive in 90 years.

[AVIFAUNA; EXOTICS; RIP $\Lambda$ RIAN HABITAT; RIPARIAN SHRUBS; RIPARIAN VEGETATION]

943. Knopf,FL; Johnson,RR; Rich,T;

Samson,FB; Szaro,RC (1988): Conservation of riparian ecosystems in the United States. Wilson Bulletin 100(2), 272-284.

Avian diversity is jeopardized on the continental scale by the decline of riparian ecosystems. The 
authors recommend coordinated management of geographic regions and habitat corridors for dispersal of avian species.

[AVIFAUNA; BIODIVERSITY; POLICY; RIPARIAN HABITAT]

944. Knopf,FL; Scott,ML (1990): Altered flows and created landscapes in the Platte River Headwaters, 1840-1990. p.47-69. In: Management of dynamic ecosystems. [Ed: Sweeney,JM] The Wildlife Society, West LaFayette, IN.

The North and South Platte Rivers played a major role in development of the West. Historical flow dynamics have been altered dramatically with annual runoff peaks and total discharge severely reduced in the North Platte drainage. In contrast, the South Platte continues to exhibit natural peak and annual flows. Impoundments in the North Platte and drought during the 1930's in both drainages have contributed to extensive vegetation development in the respective floodplains of the Great Plains. The deciduous vegetation provides local habitats for more wildlife species than currently occur elsewhere in the headwaters. Secondary successional vegetation is colonizing rapidly up the North Platte floodplain, but more slowly in the South Platte floodplain. Exotic plant species are spreading rapidly in both drainages. Extensive colonization by riparian vegetation has led to the development of rich vertebrate assemblages along both floodplains. The authors conclude that: 1) the South Platte is a unique river in the arid West because of historical peak flows and mean annual channel flows; 2) enhanced low flows have had the highest single ecological impact upon the Platte River headwaters, and 3) floodplain vegetation dynamics, historically regulated by pulsed flows, are now primarily driven by ecological processes. Conservation of biotic associations along the North and South Platte Rivers is clouded by the complexity of autonomous government authorities with jurisdiction in the headwaters.

[EXOTICS; RIPARIAN ECOLOGY; RIPARIAN HABITAT; RIPARIAN VEGETATION]

\section{Knopf,FL; Sedgwick,JA; Cannon,RW} (1988): Guild structure of a riparian avifauna relative to seasonal cattle grazing. Journal of Wildlife Management 52(2), 280-290.

The study evaluates the response of summer birds to grazing of a shrub-willow vegetation, Arapaho National Wildlife Refuge. Three response guilds were delineated: habitat generalists, habitat specialists, and intermediate habitat specialists. Authors hypothesized that the response-guild structure primarily reflects the impact of cattle upon the horizontal patterning of the vegetative community.

[AVIFAUNA; BIODIVERSITY; GRAZING IMPACTS; RIPARIAN HABITAT; RIPARIAN SHRUBS]

946. Kochman, $E$ (1979): Channelization in Colorado - past, present, and future. p.586-589. In: Swanson,GA [ed.]. The mitigation symposium: A national workshop for mitigating losses of fish and wildlife habitat. USDA Forest Service. General Technical Report RM-65.

Recognizing the need for control of stream channelization, the Colorado legislature passed the Stream Protection Act, 33-5-101, C.R.S., 1973. The law gave control over state agencies who proposed channelization or other projects that would modify aquatic habitat within streams or rivers. The Division of Wildlife has developed specific organizational guidelines/ procedures to carry out the intent of the law including mitigation measures.

[CHANNEL DYNAMICS; FISHERIES; RIPARIAN HABITAT]

947. Kondolf,GM (1995): Five elements for effective evaluation of stream restoration. Restoration Ecology 3(2), 133-142.

River and stream restoration projects are increasingly numerous but rarely subjected to systematic post-project evaluation. The few such evaluation studies conducted have indicated a high percentage of failures. Thus, post-project evaluation (and dissemination of results) is essential if the field of river restoration is to advance. Effective evaluation of project success should include: 1) clear objectives, to provide a framework for evaluation; 2) baseline data, for an objective basis for evaluating change; 3) good study design, to demonstrate restoration effects; 4) commitment to long-term monitoring; and 5) willingness to acknowledge failure, so that failures can contribute to the learning process.

[EVALUATION; MONITORING; RIPARIAN RESTORATION]

948. Kondolf,GM (1996): A cross section of stream channel restoration. Journal of Soil and Water Conservation 51(2), 119-125.

Professional/public interest in the restoration of traditional values to degraded stream channels has grown enormously in recent years. Interest in developing flood control strategies that retain ecological values has grown concurrently. "Stream 
restoration" has been frequently used to encompass all efforts at ecologically sound river management, even though some of these involve attempts to minimize negative environmental effects of flood management or channel relocation works. This paper presents case studies illustrating various goals and techniques in stream restoration projects and discusses the need for systematic studies to evaluate success of restoration projects.

[CHANNEL DYNAMICS; FLOOD IMPACTS; RIPARIAN RESTORATION]

949. Kondolf,GM; Micheli,ER (1995):

Evaluating stream restoration projects. Environmental Management 19(1), 1-15.

River and stream restoration projects are increasingly numerous but rarely subjected to systematic post-project evaluation. Post-project evaluation must be incorporated into the initial design of each project, with the choice of evaluation technique based directly upon the specific project goals against which performance will be evaluated. The authors emphasize measurement of geomorphic characteristics, as these constitute the physical framework supporting riparian and aquatic ecosystem. Techniques for evaluating other components are discussed, particularly where they relate to geomorphic variables.

[GEOMORPHOLOGY; RIPARIAN RESTORATION; STREAM IMPROVEMENTS]

950. Kondlof,GM; Webb,JW; Sale,MJ; Felando,T (1987): Basic hydrologic studies for assessing impacts of flow diversions on riparian diversions on riparian vegetation: Examples from streams of the eastern Sierra Nevada, California, USA. Environmental Management 11(6), 757-769.

There is increased interest in predicting the impacts of flow diversions on riparian vegetation as a consequence of proposals to use diversions of streamflow for power generation. Site-specific gcomorphic and hydrologic information is needed. This article describes the available methods for collecting relevant hydrologic data, including: 1) preparing geomorphic maps from aerial photographs; 2) using well level records to evaluatc the influence of streamflow on the riparian water table; 3) taking synoptic flow measurements to identify gaining and losing reaches; 4 ) analyzing flow records from an upstream-downstream pair of gages to document seasonal variations in downstream flow losses. [HYDROELECTRIC IMPACTS; HYDROLOGY; RIPARIAN VEGETATION; STREAM FLOW]
951. Konynenbelt,RD (1993): A stream restoration project along the north Raven River. p.294-304. In: Tellman, B; Cortner,HJ; Wallace,MG; DeBano,LF; Hamre, RH |tech. coord.|. Riparian management: Common threads and shared interests. USDA Forest Service. General Technical Report RM-226.

The long range management goal for this river is to maintain a high quality, naturally reproducing trout fishery for public benefit. Fence maintenance, beaver management, and active liaison with participating landowners are important features of the program.

[BEAVER; RIPARIAN RESTORATION; TROUT]

952. Korte,N; Kearl,P; Koehler,D (1993): Strategies to define and implement large-scale watershed restoration project policy on the Navajo Nation. p.198-202. In: Tellman,B; Cortner,H.J; Wallace,MG; DeBano,LF; Hamre, RH [tech. coord.]. Riparian management: Common threads and shared interests. USDA Forest Service. General Technical Report RM-226.

The condition of riparian areas on the Navajo Reservation has seriously deteriorated over the last century as a consequence of overgrazing, a circumstance that continues unabated. Large-scale riparian restoration of degraded areas has significant implications for the reservation because of the consequence of such actions on water balance, water quality, livestock production, and reservoir operation. Such actions, however, require a political and socioeconomic commitment that does not presently exist.

[LIVESTOCK EFFECTS; RIPARIAN MANAGEMENT ZONE; RIPARIAN RESTORATION]

953. Koski,KV; Heifetz,J; Johnson,S; Murphy,M; Thedinga,J (1984): Evaluation of buffer strips for protection of salmonid rearing habitat and implications for enhancement.

p.138-155. In: Hassler, TJ [ed.]. Pacific Northwest stream habitat management workshop. Humboldt State University 10-12 October 1984. Arcata, CA.

The effectiveness of buffer strips in protecting rearing habitat of juvenile salmonids from the effects of logging was evaluated by comparing habitat and fish population density in old-growth, buffered, and clear-cut reaches of streams. In summer, buffered and clear-cut reaches had more algae, benthos, and more salmonid fry than old-growth reaches. Densities of parr $($ age $>$ or $=1)$ in summer were higher in the 
buffered reaches than in either the clear-cut or old-growth reaches. In winter, old-growth and buffered reaches contained the most critical habitat and had the highest densities of parr. Clear-cut reaches had the least amount of debris, pool habitat, and fewer parr than either buffered or old-growth reaches. Buffer strips in logging operations appear to enhance fish production by increasing fry recruitment in summer while sustaining survival of parr in winter. [BUFFER STRIPS; FISHERIES; LOGGING IMPACTS; RIPARIAN HABITAT]

954. Kovalchik,BL (1987): Riparian zone associations: Descutes, Ochoco, Fremont, and Winema Forests. USDA Forest Service. Pacific Norhtwest Region. R6 ECOL Technical Paper-279-87. 171 p.

This technical paper addresses the classification, inventory, and delineation of riparian ecosystems for purposes of land management planning. The area covered by this classification extends along the Cascade Crest from Mount Jefferson in the north to the California border in the south, and eastward through the Deschutes, Winema, Ochoco, and Fremont National Forests. The paper describes the structural, compositional, and functional components of specific riparian zones.

[CLASSIFICATION; INVENTORY; RIPARIAN ECOLOGY; RIPARIAN HABITAT]

955. Kovalchik,BL (1992): Growth and yield of willows in central Oregon compared to reports in world literature. p. 83-88. In: Clary,WP; McArthur,ED; Bedunah,D; Wambolt,CL [comp.]. Proceedings -Symposium on ecology and management of riparian shrub communities. USDA Forest Service. General Technical Report INT-289.

Species of willows come in various shapes and sizes. Rates of growth and biomass accumulation are responsive to factors such as senescence, temperature, frost, flooding, soil nutrients, mineral toxicity, and fertilization. Height growth of willows at this location averages less than 1.5 feet per year and decreases with age. Accumulated biomass may range from 4,000 to 60,000 pounds per acre dry weight on bogs and well-drained sites.

[BIOMASS; GROWTH RATES; RIPARIAN HABITAT; WILLOW]

956. Kovalchik,BL; Chitwood,LA (1990): Use of geomorphology in the classification of riparian plant associations in mountainous landscapes of central Oregon, USA. Forest Ecology and
Management 33/34, 405-418.

Resource managers are increasingly interested in the importance, unique values, classification, and management of riparian zones. Understanding the ecology of the riparian zone is complicated by the extreme variation in geology, climate, terrain, hydrology, and disturbances by humans. Consequently, it is often difficult to determine the vegetation potential of riparian sites and develop management options. This study used geomorphology in addition to floristic classification to identify vegetation potential in riparian zones. A 4-level geomorphic/floristic classification is proposed. Geomorphology is especially useful on riparian sites where the natural vegetation composition, soils, and/or water regimes have been altered by past disturbance, either natural or human-induced.

[CLASSIFICATION; GEOMORPHOLOGY; RIPARIAN PLANTS; RIPARIAN VEGETATION]

957. Kozel,SJ; Hubert, WA; Parsons,MG (1989): Habitat features and trout abundance relative to gradient in some Wyoming streams. Northwest Science 63(4), 175-182.

Low-gradient reaches (0.1-1.4 percent) have deeper near-shore water depths, more undercut banks, and more trench pools than moderate-gradient reaches (1.5-4.0 percent), while moderate-gradient reaches have more cobble substrate, dammed pools formed by woody debris, and plunge pools. Habitat features that correlated with trout standing stock differed between gradient classes.

[CHANNEL DYNAMICS; CHANNEL MORPHOLOGY; LARGE WOODY DEBRIS; RIPARIAN HABITAT]

958. Kramer,NE; Steinman,AD (1993):

Responses of riparian vegetation and groundwater to activities along the Tijuana Corridor. p.241. In: Clary,WP; McArthur,ED; Bedunah,D; Wambolt,CL [comp.]. Riparian management: Common threads and shared interests. USDA Forest Scrvice. General Technical Report RM-226.

The potential effects of groundwater extraction and river diversion on riparian vegetation in southern San Diego County, California were monitored. Water potential data were collected on five riparian shrub spccies for two irrigated sites, two non-irrigated sites, and one reference site. Declines in water potential occurred in all monitored species at the non-irrigated sites during the sampling period.

[GROUNDWATER; HYDROLOGY; RIPARIAN 
VEGETATION; WATER POTENTIAL]

959. Kramer,PJ (1952): Plant and soil water relations on the watershed. Journal of Forestry 50(2), 92-95.

Forest and other vegetation affect soil moisture directly by transpiration, and indirectly by interception, evaporation, and infiltration. Transpiration can remove water from field capacity to permanent wilting point. Leaf structure is not a reliable indicator of transpiration rates. There are large seasonal variations in the rates and volumes of transpiration. Shallow-rooted trees and plants generally remove less water than deep-rooted species and are therefore preferable on watersheds where scarcities may occur.

[HYDROLOGY; SOIL-WATER CONDITIONS; WATFR REI .ATIONS]

960. Krasny,ME; Vogt,KA; Zasada,JC (1988): Establishment of four Salicaceae species on river bars in interior Alaska. Holaretic Ecology 11, 210-219.

In general, seed germination was not useful in explaining the patterns of plant distribution on river bar sites. Vegetative reproduction can be important in both initial establishment and survival on river bar sites. Seed reproduction was important on mesic sites and vegetative reproduction was important on sites favorable to seed germination. Once established on mesic sites, however, expansion does not take place by root sprouting.

[PLANT COMMUNITIES; RECRUITMENT; RIPARIAN RESTORATION; WILLOW]

961. Krausman,PR; Rautenstrauch,KR; Leopold,BD (1985): Xeroriparian systems used by desert mule deer in Texas and Arizona. p.144-149. In: Johnson,RR; Ziebell,CD; Patton,DR; DeBano,LF; Ilamre, RH [tech. coord.]. Riparian ecosystems and their management: Reconciling conflicting uses. 16-18 April 1985. Tucson, AZ. USDA Forest Service. General Technical Report RM-120.

This study examined desert mule deer occurrence in xeroriparian systems in Arizona and Texas. Most deer in Arizona were found in washes. Most deer in Texas were found between washes. Xeroriparian areas are important habitat components for desert mule deer when they provide forage, thermal cover, and travel lanes.

[MULE DEER; RIPARIAN HABITAT; XERORIPARIAN]
962. Krueger,HO (1985): Avian response to mountainous shrub-willow riparian systems in southeastern Wyoming. Ph.D. Dissertation, University of Wyoming. Laramie, WY. 101 p.

Census data within shrub-willow and upland habitats indicated that obligate avian species in each of the study sites. In study sites with high variation in shrub density, numerous bird species selected density values significantly different from random samples $(\mathrm{P}<0.05)$. Higher bird densities were found on the site associated with high beaver activity. Beaver impact bird communities by building dams which impound water and trap nutrients and sediment, both of which are factors which increase the productivity of the aquatic system and food availability. Cattle were found to alter shrub density and structure, both factors that affect bird communities.

[AVIAN ECOLOGY; BEAVER; GRAZING IMPACTS; RIPARIAN SHRUBS]

963. Krueger,HO; Anderson,SH (1985): The use of cattle as a management tool for wildlife in shrub-willow riparian systems. p.300-304. In: Johnson,RR; Ziebell,CD; Patton,DR; Ffolliott,PF; Hamre, RH [tech, coord.]. Riparian ecosystems and their management: Reconciling conflicting uses. 16-18 April 1985. Tucson, AZ. USDA Forest Service. General Technical Report. RM-120.

Cattle can have a beneficial effect on wildlife in high altitude shrub-willow riparian systems by creating tunnels through the habitat. Mean tunnel heights for two study areas were 0.75 and $0.95 \mathrm{~m}$ with 41 percent of the shrubs sampled forming tunnels in each study area. The tunnels benefit birds and mammals by opening up willows which in turn increases the grassland habitat and structural diversity of vegetation.

[GRAZING IMPACTS; RIPARIAN HABITAT; RIPARIAN MANAGEMENT ZONE]

964. Krueger,WC (1993): Managing areas in mixed ownership. p.307-310. In: Tellman,B; Cortner,HJ; Wallace,MG; DeBano,LF; Hamre, RH [tech. coord.]. Riparian management: Common threads and shared interests. USDA Forest Service. General Technical Report RM-226.

Coordinated resource management, which originated in Oregon in 1949, has proven to be an effective process to incorporate various interests into operational plans. As time has passed, CRM has been used to widen the scope of involved interests and include a greater variety of interests. This process encourages discussion, debate, and suggestions for 
solutions. Though most frequently used to solve resource problems, it has also been effective in preventing problems from developing. [CRMP; PLANNING; RIPARIAN HABITAT]

965. Krueger,WC (1994): Managing ungulates to allow recovery of riparian vegetation. p.160-164. In: Proceedings of a symposium on: Sustaining rangeland ecosystems. 29-31 August 1994. La Grande, OR.

Most of the literature on grazing evaluations of large ungulates and sustainability of riparian systems is based on observation and case history. The site specificity of management influences on riparian vegetation and the utility of using cattle to sustain riparian systems are clarified by this literature. Grazing strategies for livestock/big game can be most effective when they integrate knowledge of animal behavior, forage palatability, plant responses, plant community responses, hydrology, and practicality. Grazing strategies based on the above principles can be integrated into social and ecological needs to accomplish ecosystem management. The author describes a protocol to meet all legal obligations for public and private land in a coordinated resource management framework.

[ECOSYSTEM MANAGEMENT; GRAZING IMPACTS; LIVESTOCK EFFECTS; RIPARIAN MANAGEMENT ZONE]

966. Krueper,DJ (1992): Effects of land use practices on western riparian ecosystems. $p$. 321-330. In: Finch,DM; Stangell,PW [eds.]. Status and management of neotropical migratory birds. 21-25 September 1992. Estes Park, CO. USDA Forest Service. General Technical Report RM-229.

Riparian ecosystems are among the rarest and most sensitive habitat types in the western United States. Riparian habitat is critical for up to 80 percent of terrestrial vertebrate species, and is especially important in the arid West. Estimates have placed riparian habitat loss at greater than 95 percent in most western states. Impacts of riparian areas are reviewed along with mitigation and conservation recommendations for resource managers.

[LAND USE; RIPARIAN HABITAT; RIPARIAN MANAGEMENT ZONC]

967. Krueper,DJ (1996): Effects of livestock management on Southwestern riparian ecosystems. p.281-301. In: Shaw,DW; Finch,DM |tech. coord.|. Desired future conditions for Southwestern riparian ecosystems. USDA Forest
Service. General Technical Report RM-GTR-272.

Riparian habitats historically constituted 1 percent of the land mass in western North America. Within the past 100 years, an estimated 95 percent of this habitat has been altered, degraded or destroyed due to a wide variety of land use practices such as river channelization, clearing for agriculture, livestock grazing, water impoundments, and urbanization. Many authors now concur that the single most important land management practice impacting western riparian ecosystems has been unmanaged domestic livestock grazing. Over 70 percent of the western United States is currently being grazed by livestock in habitats ranging from sea level to alpine meadows. Unwise grazing practices have been shown to negatively affect Southwestern riparian vegetation composition, ecosystem function, and ecosystem structure. This has resulted in negative impacts on native wildlife populations including insects, fish, reptiles, amphibians, birds, and mammals. Negative impacts due largely from over a century of heavy domestic livestock utilization in riparian areas has resulted in the decline of many wildlife populations. Studies have shown that up to 70 percent of avian species in the desert Southwest depend upon riparian habitat for survival at some stage of their life. Over forty percent of Arizona's state-listed bird species are considered to be riparian obligate species. Ninety percent of Arizona's native fish species are now extinct, extirpated, or Federally or state listed. Many other vertebrate species have declined in recent years due to alteration of riparian habitats, and may soon be considered for Federal listing. To prevent future listings and to reverse population declines of sensitive wildlife species, land management agencies need to implement appropriate practices within riparian ecosystems.

[AVIAN ECOLOGY; GRAZING IMPACTS; LAND USE; LIVESTOCK EFFECTS; RIPARIAN HABITAT]

968. Kruse,CG; Hubert,WA; Rahel,FJ (1997): Geomorphic influences on the distribution of Yellowstone cutthroat trout in the Absaroka Mountains, Wyoming. Transactions of the American Fisheries Society 126, 418-427. Influcnces of large-scale geomorphic characteristics on distributions of cutthroat trout (Onchorhychus clarki bouveri) are poorly understood. In this study, channel slope, elevation, stream size, and barriers to upstream movement significantly influenced the presence and absence of Yellowstone cutthroat trout. Wild populations of 
cutthroat trout were not found upstream of barriers to fish migration, at sites with channel slopes of 10 percent or greater, or at elevations above 3,182 m. Logistic regression models correctly classified presence or absence of fish. Large-scale geomorphic variables influence Yellowstone cutthroat trout populations, and logistic functions can predict these distributions with a high degree of accuracy. [FISHERIES; GEOMORPHOLOGY; MODELING; TROUT]

969. Kruse,WH; Baker,Jr.,MB (1998): Twenty years of watershed response to strip-cutting Ponderosa Pine in central Arizona. p.179-185. In: Potts,DF [ed.]. Rangeland management and water resources: Proceedings of the AWRA specialty conference. American Water Resources Association. 27-29 May 1998. Reno, NV.

Water yield and understory biomass production were determined on a Ponderosa Pine watershed following a strip-cut treatment of the forest overstory. Water yield increased approximately 15 percent during the first six years after timber harvest. Understory biomass increased from an initial measurement of $132 \mathrm{~kg} / \mathrm{ha}$ to about $400 \mathrm{~kg} / \mathrm{ha}$ after seven years, then decreased after twenty years to less than $200 \mathrm{~kg} / \mathrm{ha}$.

[FORAGF. PRODUCTION; LOGGING IMPACTS; WATER YIELD; WATERSHED]

970. Kulla,A (1990): Transitional forest grazing and compatible grazing systems for forested riparian and wetland sites in western Montana. In: Management of riparian and wetland forested ecosystems in Montana. Fourth annual Montana Riparian Association workshop. 5-7 September 1990. University of Montana. Whitefish, MT.

All riparian compatible systems proposed to date have in common the prescription of less total grazing in the riparian area 'either through rest, season adjustment, number adjustment, livestock management, or structural improvement'. Whether the allotment can handle the same or increased stocking will depend on the availability and condition of the non-riparian upland areas.

[GRAZING IMPACTS; RIPARIAN FOREST]

971. Kus,BE (1998): Use of restored riparian habitat by the endangered Least Bell's Vireo (Vireo bellii pusillus). Restoration Ecology 6(1), 75-82.

$\Lambda$ primary objective of riparian restoration in California is the creation of habitat for endangered spccies. Four restoration sites in southern California were monitored and evaluated. Vireos visited restoration sites to forage as early as the first growing season, but did not establish territories or nest there until at least part of the site supported suitable habitat. Placement of territories and nests coincided with patches of dense vegetation characteristic of natural nesting areas. Occupation of restored sites was accelerated by the presence of adjacent mature riparian habitat, which afforded birds nests sites and/or foraging habitat. Vireos nesting in restored habitat achieved success comparable to that of vireos nesting in surrounding natural habitat. Findings suggest that the critical components of vireo nesting habitat have been captured in both the design and quantitative assessment of restoration sites. [AVIFAUNA; RIPARIAN HABITAT; RIPARIAN RESTORATION]

972. Kusler,J (1992): Wetlands delineation: An issue of science or politics? Environment 34(2), 7-37.

A 1991 USDI study indicates that only an estimated 103.3 million acres of wetland remain intact in the lower 48 states out of an original 221 million acres. Losses are continuing at an estimated rate of 200,000 to 300,000 acres each year. The author believes that the debate over appropriate federal regulatory definition of wetlands has become so politicized that delineation criteria could be adopted that will be scientifically unsound. This factor could not only reduce protection for wetlands but would be costly to developers and landowners as well. Setting national wetland policy should involve both politics and science. National debate is necessary to produce effective wetland management policies and guidelines.

[POLICY; RIPARIAN HABITAT; WETLANDS]

973. Kusler,JA (1985): A call for action: protection of riparian habitat in the arid and semi-arid West. p.6-8. In: Johnson,RR; Ziebell,CD; Patton,DR; Ffolliot,PF; Hamre,RH [tech. coord.]. Riparian ecosystems and their management: Reconciling conflicting uses. 16-18 April 1985. Tucson, AZ. USDA Forest Service. General Technical Report RM-120.

The scientific base documenting the wildlife, flood control, water pollution, erosion control, fisheries, and recreational values of riparian habitats has been strengthened in the past several years, yet there are no systematic protection policies or procedures at any level of government: federal, state, or local. The time is ripe for a coordinated riparian habitat protection program. 
[POLICY; RIPARIAN HABITAT; RIPARIAN RESTORATION]

974. Kusler,JA (1993): Floodplain management and the protection of riparian habitat: Status of efforts and possible future decisions. p.112-115. In: Tellman,B; Cortner,HJ; Wallace,MG; DeBano,LF; Hamre, RH [tech. coord.]. Riparian management: Common threads and shared interests. USDA Forest Service. General Technical Report RM-226.

Floodplain management regulations and other wetland and riparian habitat regulations and nonregulatory initiatives provide only limited protection for riparian areas in the West. These areas continue to be threatened by vegetative defoliation, grazing, water projects, urban development, and other activities. These circumstances, however, offer new opportunities for riparian protection because of the strong public support for such protection, growing interest in federal, state, and local agencies, and a rapidly growing science base with regard to stream management, riparian habitat restoration, and watershed management.

[FLOODPLAIN MANAGEMENT; RIPARIAN HABITAT; RIPARIAN RESTORATION; WATERSHED]

975. Kyle,HM; Schmidt,MG; Lertzman,KP (1996): A spatially dynamic riparian buffer model: Conservation on the edge. p.341-346. Proceedings of the ninth annual symposium on geographic information systems. Ft. Collins, $\mathrm{CO}$.

The procedural simplicity of constant width buffering in geographic information systems has compelled many resource managers to apply an unecologically sound conservation tool. This paper describes a spatially dynamic riparian buffer model with an edge mitigation component. This model more efficiently targets the zone of interest than traditional static width buffers, reduces the opportunity cost of losing land to "no-touch" areas, while maintaining a strong conservation agenda.

[EDGE EFFECT; GIS; RIPARIAN HABITAT; RIPARIAN ZONES]

976. LaBaugh,JW (1986): Wetland ecosystem studies from a hydrologic perspective. Water Resources Bulletin 22(1), 1-9.

Selected studies from the literature were reviewed to determine the extent of knowledge about the relationship between hydrology and wetland ecosystem studies. Very few studies have attempted to measure all the components of a wetlands water balance. Generally, measure components were calculated as the difference between measured inputs and outputs. Ground water was frequently overlooked. Few studies included direct measurement of biogeochemical processes within wetlands. The importance of uncertainties in chemical budgets to hydrologic budgets has been addressed in very few wetland investigations. Many studies have emphasized the importance of hydrology to wetland ecosystem research but few have documented this. [CHEMICAL BUDGETS; HYDROLOGY; WATER BALANCE; WETLANDS]

977. Lachowski,H; Fisk,H; Brohman,R (1998): Riparian area management - the role of remote sensing and geographic information systems. p. 45-54. In: Potts, DF [ed.]. Rangeland management and water resources: Proceedings of the AWRA specialty conference. American Water Resources Association. 27-29 May 1998. Reno, NV.

In the arid western states, riparian areas are the most sensitive components of our landscape. "Proper functioning condition", as defined by the agencies, includes all the elements of riparian areas, particularly vegetation, land forms, stream characteristics, and the presence of large woody debris. Proper management requires a 2-level approach: 1) a landscape view that shows riparian areas in relation to a watershed or management unit, e.g. a grazing allotment; and 2) a more detailed, close-up view. Remote sensing is vital to this approach. An application from Montana used imagery from the Landsat satellite at the landscape level, and a combination of imagery from a digital camera and other layers from a geospatial database at the detailed view.

[GIS; PROPER FUNCTIONING CONDITION; REMOTE SENSING; RIPARIAN MANAGEMENT ZONE]

978. Laenen,A; Dunnette,DA (1997): River quality: Dynamics and restoration. Lewis Publishers. $480 \mathrm{p}$.

River restoration is addressed through a series of case studies and articles written by various contributors. Part 1 covers physical, chemical, and biological features of a riverine system. Part 2 describes monitoring programs and remedial and restoration measures. [IIYDROLOGY; MONITORING; RIPARIAN RESTORATION]

979. LaFayette,RA; DeBano,LF (1990):

Watershed condition and riparian health: 
Linkages. p.473-484. In: Watershed planning and analysis in action. The symposium proceedings of IR conference on watershed management. 9-11 July 1990. Durango, CO.

The present focus on riparian areas could ignore the relationship of the riparian area to its contributing watershed. Failure to recognize the influence of the surrounding watershed may lead to unnecessary failures of many riparian projects. This paper presents 3 concepts to assist in the understanding the relationship between watershed condition and watershed health. The first addresses the commonality of possible combinations of the two factors. The second presents the acceptability of these combinations to managers and their publics. The third concept integrates the previous two in a way to: 1) aid understanding in assessment of existing conditions; 2) help in setting improvement goals; and 3) assist in formulating ways to achieve these goals. [RIPARIAN HABITAT; RIPARIAN HEALTH; WATERSHED]

980. LaFayette,RA; Paweleck,DW (1990): New revetment design controls streambank erosion. USDA Forest Service, Engineering Field Notes. 22(July-August):23-31.

Watershed condition analysis of the Bluewater Creek watershed near Grants, New Mexico, showed that although most of the uplands were in at least satisfactory condition, stream channel meander cutting continued to provide excessive sediments to the fluvial system. An innovative revetment system solved the problem.

[RIPARIAN RESTORATION; STREAMBANK PROTECTION]

981. LaFayette,RA; Pruitt,JR; Zeedyk,WD (1996): Riparian area enhancement through road design and maintenance. p.85-95. In: National hydrology workshop proceedings. 27 April - 1 May 1992; Phoenix, AZ. USDA Forest Service. General Technical Report RM-GTR-279.

Traditional road location, design, construction, and maintenance have generally had adverse effects on riparian areas. Road locations, drainage methods, and maintenance practices have resulted in a net loss of both acreage and related values in riparian areas, particularly in the arid and scmi-arid regions of the West. Results of these activities include drainage of riparian ecosystems, reduced site productivity, loss of fish and wildlife habitat, reduced base flows with increased peak flows, gully development, and accelerated downstream sedimentation. Recent changes in management philosophy and activities are reversing this trend by using road design and maintenance to rehabilitate riparian areas and restore their productivity. Methods being used to accomplish these goals include road obliteration, modified culvert designs, raised culvert inlets, modified bridge and ford design, flow dispersal, stilling basins, and more frequent and effective ditch management. Results have been dramatic, with more than 405 ha of degraded riparian areas improved or improving in the southwest Region of the USFS. [RIPARIAN RESTORATION; ROAD IMPACTS]

982. LaFayette,RA; Rinne,JN (1991): Riparian structures and watershed treatments in the Southwest: History, status, and management implications - a preliminary report. p.133-138. In: Proceedings 36th annual New Mexico water conference. New Mexico Water Resources Research Institute.

A summary of conclusions and recommendations based on site visits and data gathering efforts at riparian projects in southwest Region, USDA Forest Service. Information contained in the final report will be used to begin implementing changes aimed at increasing the success of riparian improvement projects.

[RIPARIAN RESTORATION; RIPARIAN STRUCTURES; WATERSHED]

983. LaGrange,TG; Dinsmore,JJ (1989): Plant and animal community responses to restored Iowa wetlands. Prairie Naturalist 21(1), 39-48.

The plant and animal communities of four formerly-drained wetland basins were inventoried several years after the basins had reflooded. The inventory recorded 45 plants, 18 invertebrates, and 11 birds. The study indicates that a high-quality wetland very similar to unaltered wetlands can be restored by removing or blocking the lines.

[CREATED WETLANDS; RIPARIAN RESTORATION; WETLANDS]

984. Lammert,M; Allan,JD (1999): Assessing biotic integrity of streams: Effects of scale in measuring the influence of land use/cover and habitat structure on fish and macroinvertebrates. Environmental Management 23(2), 257-270.

The study assessed fish and macroinvertebrate composition, instream habitat features and surrounding land use in agriculturally developed watershed. There was considerable variability in fish assemblages mcasured with an index of biotic integrity, macroinvertebrate assemblages characterized with several diversity indexes, and both 
quantitative and qualitative measurements of instream habitat structure. Land use immediate to the tributaries predicted biotic condition better than regional land use, but was less important than local habitat variables in explaining the variability observed in fish and macroinvertebrate assemblages. Differences in outcomes suggests that the scale of investigation influences the strength of predictive variables.

[BIOLOGICAL INTEGRITY; FISHERIES; MACROINVERTEBRATES; RIPARIAN HABITAT; SPATIAL SCALE]

985. Lancaster,DL; Vance,L; Tate,KW; Lile,D (1998): The Cedar Creek Restoration Project and the limits of cross-section monitoring as an indicator of change. p.136. In: Potts,DF led.]. Range management and water resources: Proceedings of the AWRA specialty conference. American Water Resources Association. 27-29 May 1998. Reno, NV.

The restoration plan for this site in northeastern California called for sagebrush and juniper burning, willow planting, and exclusion of livestock grazing. After 10 years, however, the cross-sections showed very little change, though visual assessment of the riparian area showed a marked improving trend. The authors concluded that cross-section monitoring does not always reflect accurately the degree of change. [CHANNFI, MORPHOIOGY; FXCI,OSURFS; MONITORING; RIPARIAN RESTORATION]

986. Landers,DH (1997): Riparian restoration: Current status and the reach to the future. Restoration Ecology 45(5), 113-121.

The nine technical articles in the December 1997 volume of Restoration Ecology were critically reviewed. The most common indicators in these papers is riparian vegetation. Several additional elements could provide vital information and advance our understanding of riparian restoration: developing interdisciplinary approaches more fully; defining endpoints and reference conditions; implementing multiple scale approaches; viewing restorations as experimental ecosystem manipulations; developing a philosophy regarding exotic species; incorporating GIS more often; and integrating science, society, and politics. [POLICY; RESEARCH; RIPARIAN RESTORATION]

987. Lane, EW (1953): Design of stable channels. Transactions of the American Society of Civil Engineers, 1234-1260. (Paper No. 2776).
A method of designing stable channels is presented based on securing a distribution of the tractive force along the sides and bottoms of channels such that the magnitude of this force at all points will be sufficiently large to prevent sediment deposits in questionable quantities, and at the same time will be small enough to prevent objectionable scour. Limiting values for the tractive force are offered for the various conditions under which a canal may be constructed. The effects of bends, side slope, and transported material on the design are reviewed. [CHANNEL DYNAMICS; HYDROLOGY; STREAMBANK STABILITY]

988. Lane,LJ (1982): Development of a procedure to estimate runoff and sediment transport in ephemeral streams. p.272-282. In: Proceedings of the Exeter symposium:

Developments in the explanation and prediction of erosion and sediment yield. July 1982. IAHS Publ. No. 137.

This paper describes a hydrological model for application with semi-arid watersheds. The model incorporates simplified routing schemes to include the influence of transmission losses on runoff. The procedure is used to estimate runoff rates and amounts together with sediment yields from semiarid watersheds. This procedure requires a minimum of observed data for calibration and is designed for practical applications.

[GEOMORPHOLOGY; MODELING; SEDIMENT TRANSPORT]

989. Lane,I.I; Diskin,MH; Wallace,DE; Dixon,RM (1978): Partial area response on small semi-arid watersheds. Water Resources Bulletin 14(5), 1143-1158.

If a watershed is assumed to contribute runoff uniformly over the entire area, significant errors in estimating surface runoff and erosion rates are possible if only a portion of the entire area may be contributing. Overland flow generation was measured by: 1) an average loss rate procedure; 2) a lumped-linear model; and 3) a distributed-nonlinear model. Those methods suggested that, on the average, 45,60 , and 50 percents were contributing runoff at the watershed outlet. Low infiltration zones are the runoff source areas.

[INFILTRATION; RUNOFF; SEDIMENT TRANSPORT; WATERSHED]

990. Lane,LJ; Nicks,AD; Laflen,JM; Weltz,MA; Rawls,WJ; Page,DI (1989): The water erosion prediction project: Model overview. p.487-494. In: 
Proceedings of national water conference, IR and WR Divisions of the American Society of Civil Engineers. 17-20 July 1989. Newark, DE.

A new generation of water erosion prediction technology is being developed by the USDA Water Erosion Prediction Project (WEPP). The models are based on fundamentals of stochastic weather generation, infiltration theory, hydrology, soil physics, plant science, hydraulics, and erosion mechanics. This new technology is expected to replace the Soil Loss Equation as the primary erosion prediction tool used by action agencies. [EROSION; HYDROLOGY; MODELING; SOILS]

991. Lanka,RP; Hubert,WA; Wesche, TA (1987): Relations of geomorphology to stream habitat and trout standing stock in small Rocky Mountain streams. Transactions of the American Fisheries Society 116, 21-28.

This paper presents evidence that drainage basin morphology and trout standing stock are related through a functional link between geomorphic features and stream habitat quality. Numerous significant univariate correlations were found between geomorphic variables, stream habitat variables, and trout standing stock in both high-elevation forest and low-elevation rangeland streams. When geomorphic variables alone were incorporated into regression models they predicted trout standing stock as accurately as did stream habitat variables.

[FISHERIES; GEOMORPHOLOGY; RIPARIAN HABITAT]

992. Larsen,RE; George,MR; McDougald,NK; Tate, KW; Fulgham, KO (1998): Evaluation of different seasons and intensities of grazing on erosion along intermittent stream channels at the San Joaquin Experimental Range. p.203. In: Potts, DF[ed.]. Rangeland management and water resources. Proceedings of the AWRA specialty conference. American Water Resources Association. 27-29 May 1998. Reno, NV.

This study was designed to evaluate the effect of intensity and season of grazing along intermittent streams in the central California foothills. There were no significant changes in cross-section areas for 5 grazing treatments. Erosion and deposition resulting from heavy rainfall and stream flow may have masked treatment.

[EROSION; GRAZING IMPACTS; RIPARIAN VEGETATION]

993. Larsen,RE; Krueger,WC; George,MR;
Barrington,MR; Buckhouse,JC; Johnson,DE (1998): Viewpoint: Livestock influences on riparian zones and fish habitat: Literature classification. Journal of Range Management 51(6), 661-664.

Articles about livestock influences on riparian zones and fish habitat were classified by a key into three classes: 1 ) papers that contained original data; 2) those that were commentary; and 3) reports about methodology such as classification systems, policies, and monitoring criteria. Some 428 of the total articles were directly related to grazing impacts on riparian zones and fish habitat. Of these, only 89 were classified as experimental, where treatments were replicated and results were statistically valid. Several limitations of riparian grazing studies were revealed: a) inadequate description of grazing management practices or treatments; b) weak study designs; and c) lack of pre-treatment data. More long-term, replicated treatment studies are needed in the future. [EXPERIMENTAL DESIGN; FISH HABITAT; GRAZING IMPACTS; LIVESTOCK EFFECTS; RIPARIAN]

994. Larson,JS (1988): Wetland creation and restoration: An outline of the scientific perspective. p.73-79. In: Zelazny,J; Feierbend,JS [eds.]. Increasing our wetland resources. Proceedings of the National Wildlife Federation. October 1987. Washington DC.

Data requirements for wetland creation and restoration projects with respect to hydrology, soils, and vegetation have been recommended by scientists. The appropriate scientific standard for assessing the success of artificial or restored wetlands should be functional performance.

[CREATED WETLANDS; HYDROLOGY; RIPARIAN RESTORATION]

995. Larson,LL; Larson,SL (1996): Riparian shade and stream temperature: A perspective. Rangelands 18(4), 149-152.

Woody vegetation is only one component in a riparian ecosystem. Its relative importance depends upon site conditions. Watershed attributes such as air mass characteristics, elevation gradient, adiabatic rate, channel width and depth, water velocity, surrounding landscape, and interflow inputs all influence water temperature and can be of greater importance to stream temperature than shade. Many stream management strategies were intended to meet a recognized land management need. A current emphasis involves controlling stream temperature with vegetation shade. Management strategies that do 
not account for the dynamics of riparian systems can lead to failure as well as success. Management decisions need to be site specific. Shade alone does not control stream temperature.

[RIPARIAN HABITAT; SHADING; STREAM TEMPERATURE; WATERSHED]

996. Larson,LL; Larson,SL (1997): The natural heating and cooling of water. Rangelands 19(6), 6-8.

After investigation into factors that must be considered to determine the natural temperature fluctuations for water bodies, the following observations were made: 1) climates produce weather systems that determine the patterns of heating and cooling within a watershed environment; 2) water temperatures are influenced by the thermal reservoir that surrounds the water body; 3 ) a portion of stream temperature change can be associated with the thermal environment and rates of adiabatic temperature change; 4 ) the difference between the air temperature and the water temperature influences the rate at which water will warm or cool; 5) the rate of flow of a stream must be determined to understand the entire process of how a stream heats and cools; and 6) two measurements are required at a minimum to estimate the thermal evolution of a stream: a) the flow rate; and b) the gradient between the air and water temperatures.

[HYDROLOGY; STANDARDS AND GUIDELINES; WATER TEMPERATURES]

997. Laycock,WA (1969): Exclosures and natural areas on rangelands in Utah. USDA Forest Service Research Paper INT-62. 44 p.

This paper presents a listing of 529 arcas in Utah that have received little or no use by domestic livestock. Areas are indexed by county, elevation, date established, vegetation type, and type of animal excluded. Locations are further described by section, township, range, and vegetational information.

[EXCLOSURES; GRAZING IMPACTS; NATURAL AREAS]

998. Laymon,SA (1981): Photo-documentation of vegetation and landform change on a riparian site, 1880-1980: Dog Island, Red Bluff, CA. p.150-158. In: Mutz,KM; Cooper,DJ; Scott,ML; Miller,LK [eds.]. Proceedings of the California riparian systems conference. 17-19 September 1981. Davis, co.

The author used ground and aerial photos taken over a 100-year period to track the development of present riparian vegetation. These photos show changes in the Sacramento River channel which have led to the present configuration of the area. The photos show: 1) the dynamic nature of the riparian system showing rapid and dramatic changes at this site; 2) the rapidity with which riparian vegetation develops; and 3) the use of historic and present day photography to document changes in riparian environment.

[AERIAL PHOTO; MONITORING; RIPARIAN HABITAT; RIPARIAN VEGETATION]

999. Lea,GD (1979): BLM management and policy for riparian/stream ecosystems. p.13-15. In: Cope,OB [ed.]. Forum: Grazing and riparian/stream ecosystems. 3-4 November 1978. Denver, CO. Trout Unlimited, Inc.

Riparian-aquatic habitat protection and enhancement on the public lands is required in good multiple-use management and in legislative and administrative intent. The agency concern for these important values will be reflected in positive programs. This represents the only applicable approach to riparian-aquatic habitats on public lands. But, it may take years to accomplish all of the necessary changes and adjustments. The recent passage of the Public Rangelands Improvement Act of 1978 will facilitate management efforts.

[GRAZING IMPACTS; RIPARIAN ECOLOGY; RIPARIAN MANAGEMENT ZONE]

1000. Leal,DA; Meyer,RA; Thompson,BC (1996): Avian community composition and habitat importance in the Rio Grande Corridor of New Mexico. p.62-68. In: Shaw,DW; Finch,DM [tech, coord.]. Desired future conditions for Southwestern riparian ccosystems: Bringing interests and concerns together. USDA Forest Service. General Technical Report RM-GTR-272.

Avian species abundance and richness were investigated within vegetation communitics of the Rio Grande Corridor during 1992-1993. A subset of 64 transects, for which all bird and vegetation variables were available, representing 16 composite community types, were subjected to canonical correlation analysis to investigate relative habitat importance. Generally, the higher ranking community types had cottonwood and other native woody species as dominants and the lower ranking communities were those types that are highly manipulated and/or monotypic, such as mowed river edge, pecan orchards, and relatively pure stands of salt-cedar. Bird occurrence and distribution in the Rio Grande Corridor is not so neatly related to composition of native vegetation as is sometimes 
characterized. Exotic plant species such as salt-cedar and Russian olive are utilized to varying degrees by the existing avian community. Ranking of avian use by habitat types may help direct restoration efforts towards situations where more significant gains in avian use can be made.

[AVIAN ECOLOGY; EXOTICS; PLANT COMMUNITIES; RIO GRANDE; RIPARIAN HABITAT; SPECIES RICHNESS]

1001. Leathery,S (1998): Restoring watersheds

for fisheries. Fisheries 4(1), 27-30.

There is widespread institutional and organizational support for enhancing water quality through holistic approaches to watershed management. In recent years, virtually all federal resource management agencies have incorporated some level of watershed restoration goals into management activities. The long-term efforts of state and federal agencies, combined with broad public support, have been instrumental in successful watershed case studies such as continued water quality and fisheries improvement at some locations. [FISHERIES; WATER QUALITY; WATERSHED]

1002. Legates,DR; Nixon,KR; Stockdale,TD; Quelch,GE (1998): Use of the WSR-88D weather radars in rangeland management. p.55-64. In: Potts,DF [ed.]. Rangeland management and water resources: Proceedings of the AWRA specialty conference. American Water Resources Association. 27-29 May 1998. Reno, NV.

Precipitation variability usually occurs on spatial and temporal scales that cannot be resolved adequately by traditional rain gage networks, thereby presenting a problem for range management. The National Weather Service's network of WSR-88D weather radar, however, provide a much finer spatial (4 $\mathrm{km} \mathrm{X} 4 \mathrm{~km}$ ) and temporal (about 6 minutes) resolutions. Any tool that provided real-time estimates of precipitation in a decision support package would greatly enhance the management of water resources in range management and other applications. The Radar Precipitation Interface for Hydrological Models (RPI) coupled with the Water Resource Decision Support System is such a real-time hydrological tool.

[GIS; HYDROLOGY; PRECIPITATION; WATER RESOURCE MANAGEMENT]

1003. Legge,TA; Herman,DJ; Zamora,B (1981): Effects of cattle grazing on mountain meadows in Idaho. Journal of Range Management 34(4), 324-328.
Vegetation changes were documented during 12 years of grazing exclusion. Plant composition changed for all treatments. Herbage production was significantly less on the grazed than ungrazed areas at two sites. On average, the percentages of bare ground and moss-covered areas were greater on grazed than ungrazed sites. Litter accumulation was greater, on average, on the ungrazed sites.

[GRAZING IMPACTS; LITTER FALL; PLANT COMMUNITIES; PLANT PRODUCTION]

1004. Lehman,S (1997): The national watershed assessment program. Fisheries 22(5), 25.

The Environmental Protection Agency (EPA), working with tribes, states, federal agencies, and other partners, initiated the National Watershed Assessment Program (NWAP) in 1996. NWAP is designed to collect, organize, and evaluate multiple sources of environmental information at the watershed level. Objectives of this program are to: 1) characterize the condition and vulnerability to pollution of 2,150 watersheds of the U.S., 2) empower citizens to learn more about their watersheds and work to protect them, 3) provide the basis of dialogue among water quality managers, and 4) measure progress toward the goal that all watersheds will be healthy places. [MONITORING; RIPARIAN HABITAT; WATERSHED]

1005. Leidholt-Bruner,K; Hibbs,DE; McComb,WC (1992): Beaver dam locations and their effects on distribution and abundance of Coho salmon fry in two coastal Oregon streams. Northwest Science 66(4), 218-223.

Beaver dams and coho salmon fry were examined for their relationships in two coastal Oregon streams in 1987. The initial spring survey of $19 \mathrm{~km}$ of stream found only one beaver dam intact after winter. By autumn, the number of dams had increased to 1.1 and 1.2 per $\mathrm{km}$ on the two streams. Beaver dams increased summer pool habitat 7 to 14 percent over unmodified conditions. Although density of coho was similar among pool types, beaver ponds were larger and contained more coho fry than non-beaver pools; thus, beaver increased rearing habitat for coho during the summer low flow. Beaver present a low-cost tool deserving more consideration for stream rehabilitation projects.

[BEAVER; RIPARIAN HABITAT; STREAM IMPROVEMENTS]

1006. Leinard,RE; Wyman,SK; Noggles,RS; Volk,WP (1998): A holistic approach to 
classification of riparian ecosystems. p.13-21. In: Potts,DF [ed.]. Rangeland management and water resources: Proceedings of the AWRA specialty conference. American Water Resources Association. 27-29 May 1998. Reno, NV.

Most classification systems for riparian ecosystems focus primarily on the vegetative community. The authors argue that soils, climate, landform, and fluvial geomorphology need to be included for classification reliability. When the physical aspects of the riparian ecosystem, including stream geomorphology, are known, potential vegetation can be predicted with reasonable accuracy. Riparian ecological site classifications were tested for one season along the Arkansas River in Colorado. Undisturbed reference reaches were selected for comparison. This approach suggested a broader, more practical utility for riparian utility for riparian classification based on soils, climate, landform, hydrology, and fluvial geomorphology. [CLASSIFICATION; ECOLOGICAL SITE; GEOMORPHOLOGY; RIPARIAN MANAGEMENT ZONE]

1007. Leininger,WC (1988): Non-chemical alternatives for managing selected plant species in the western United States. USDI Fish and Wildlife Service and University Cooperative Extension, Colorado State University. Ft. Collins, CO. 48 p.

A summary of technical literature on non-chemical plant control for 14 plant species, arranged by species specifically for land managers. The species include wild oats (Avena fatua), diffuse knapweed (Centaurea diffusa), spotted knapweed (Centaurea maculosa), Russian knapweed (Centaurea repens), musk thistle (Carduus nutans), Canada thistle (Cirsium arvense), field bindweed (Convolvulus arvensis), leafy spurge (Euphorbia esula), St. Johnswort (Hypericum perforatum), tall whitetop (Lepidium latifolium), giant foxtail (Setaria faberi), yellow foxtail (Setaria glauca), green foxtail (Setaria viridis), common cattail (Typha latifolia). [EXOTICS; GRAZING IMPACTS; RANGE MANAGEMENT]

1008. Leininger,WC; Stednick,JD (1982):

Rangeland Management. p.384-403. In: Introduction to forest science. Chapter 18. John Wiley and Sons, Inc., New York, NY.

Rangelands are areas of the world that, by reasons of physical limitations - low and erratic precipitation, rough topography, poor drainage, and cold temperatures - are unsuitable for cultivation. They remain a source of forage for free-ranging native and domestic animals, as well as a source of wood products, water, and wildlife. Approximately 47 percent of the earth's land surface is classified as rangeland, and of the estimated 385 million hectares of rangeland in the United States, a little over one-third is forested range.

[GRAZING IMPACTS; RANGELAND

ECOSYSTEMS; WATER RESOURCE MANAGEMENT]

1009. Leininger,WC; Trlica,MJ (1986):

Successional and hydrological changes following protection from long-term heavy grazing in a northern Colorado riparian zone. p.214. Abstracts of the IV International Congress of Ecology. Syracuse, NY. [GRAZING IMPACTS; LIVESTOCK EFFECTS; RIPARIAN ECOLOGY]

1010. Leitch,JA; Grosz,KL (1988): Wetlands and agriculture in transition: $A$ look at wetlands protection in North Dakota. p.95-98. In: Stuber,PJ [tech. coord.]. Proceedings of the national symposium on protection of wetlands from agricultural impacts. 25-29 April 1988. Ft. Collins, CO. USDI Fish and Wildlife Service. Biological Report 88(16).

North Dakota has been the center of controversy regarding drainage of of prairie potholes since the 1960 's. Landowners have typically treated wetlands as private property and as obstacles to farming. With federal "Swampbuster" sanctions and the state's "no net loss" law, landowners will need to more seriously evaluate plans to drain wetlands, even though some drainage may be economically feasible. The effect of Swampbuster may be negated by rises in land market prices.

[RIPARIAN HABITAT; WATERFOWL MANAGEMENT; WETLANDS]

1011. Leonard,S; Kinch,G; Elsbernd,V; Borman,M; Swanson,S (1997): Riparian area management: Grazing management for riparian-wetland areas. USDI Burcau of Land Management. Technical Reference 1737-14. Denver, CO. $80 \mathrm{p}$.

The document presents information from various land managers and researchers to guide livestock management in riparian areas using their unique responsiveness to accomplish management objectives. An ecosystem approach is used, in which riparian areas are considered a part of a larger landscape. Development of site-specific grazing prescriptions based on the function, capability, and 
potential of the site is discussed, and examples of grazing treatments are provided.

[GRAZING IMPACTS; RIPARIAN

MANAGEMENT ZONE]

1012. Leonard,S; Staidl,G; Fogg,J; Gebhardt,K; Hagenbuck, W; Prichard,D (1992): Riparian area management: Procedures for ecological site inventory - with special reference to riparian-wetland sites. USDI Bureau of Land Management. Technical Reference 1737-7. 135 p.

This report details field procedures for describing and documenting ecological site information as it applies to the interaction between soils, climate, hydrology, and vegetation for riparian-wetland resources as well as for uplands. Possible uses of this information in BLM's planning process, resource evaluations, and other applications are discussed. Maintenance and permanence of baseline data are also incorporated. This document is intended for use with related manuals, and handbooks documented in the work.

[CLIMATE; HYDROLOGY; RIPARIAN; SOILS; WFTI.ANDS]

1013. Leonard,SG; Staidl,G.J; Gebhardt,KA; Prichard,DE (1992): Viewpoint: Range site/ecological site information requirements for classification of riverine riparian ecosystems. Journal of Range Management 45(5), 431-435.

Few ecological sites have been described sufficiently to interpret the specific functions and processes unique to riverine riparian areas. The utility of using ecological site concepts for riparian classification has also been debated due to the dynamic nature of the systems and the paucity of unaltered vegetation. Riparian sites associated with streams or rivers in 9 western states were evaluated to determine the feasibility of using ecological site concepts in describing and assessing riverine riparian ecosystems. Associated water features must be described in riparian site characterizations to establish relationships and understand "process pathways." $A$ concept of "site progression" is proposed to differentiate between secondary succession associated with vegetation changes within a given physical environment and physical "state" changes that lead to a "new" or different potential plant community (i.e., a change in ecological site and sccondary succession sequences). The authors conclude that ecological site classification and inventory utilized on uplands can be used on riparian areas with some enhancements to maintain consistency in evaluations at a "management unit" level.

[CLASSIFICATION; RIPARIAN HABITAT; RIPARIAN RESTORATION; WATER FEATURES]

1014. Leopold,L (1990): Ethos, equity and the water resource. The Abel Wolman Distinguished Lecture, presented to the National Research Council. 15 February, 1990. National Academy of Sciences Auditorium. 14 p.

This paper discusses an ethos, or an unwritten guiding belief, in the maintenance of the hydrologic continuum (i.e., the effective operation of forces in the drainage basin that maintain a balance among processes of weathering, soil formation, water and sediment delivery to stream channels and the exit of water and sediment from the basin) in the administration of water resources. Evidence of how management fails to follow such an ethos and the effects of catastrophic change to the hydrologic continuum were explored. The author also addresses equity in administration -- a dedication to fairness, to consideration of various interests and treatment of all with some measure of equality.

[HYDROLOGY; POLICY; WATER RESOURCE MANAGFMENT]

1015. Leopold,LB; Langbein,WB (1966): River meanders. Scientific American 214:60-70.

The continuous changes that occur in rivers are primarily wrought by the erosion and deposition of sedimentary material. Rivers tend to avoid concentrating these processes in any one place. Any irregularity in the slope of a river is temporary on a geological time scale; the hydraulic forces at work in the river tend to eliminate such concentrations of change. The meandering curves of a river are the most probable result of the processes that tend to eliminate concentrations of energy loss but also tend to reduce the total energy loss to a minimum rate. The sine-generated curvature assumed by the meanders achieves these ends more satisfactorily than any other shape. The longitudinal concavity of the river's profile also minimizes work in the system as a whole. The typical meander shape is assumed because, in the absence of any other constraints, the sine-generated curve is the most probable path of a fixed length between two points.

[CHANNEL DYNAMICS; GEOMORPHOLOGY; RIVER MEANDERS]

1016. Leopold,LB; Maddock,T (1953): The hydraulic geometry of stream channels and some physiographic implications. USDI Geological 
Survey. Professional Paper 252.

Some hydraulic characteristics of stream channels - depth, width, velocity, and suspended load - are measured quantitatively and vary with discharge as simple power functions at a given river cross section. Similar variations in relation to discharge exist among the cross sections along the length of the river under the condition that discharge at all points is equal in frequency of occurrence. In the data studied, it appeared that when discharges are of equal frequency at different points along the river, the velocity as well as the width and depth of flow, increases with discharge downstream. This increase of velocity downstream results from the fact that the increase in depth overcompensates for the decrease in slope. An empiric quantitative relation among the average measurements of width, depth, velocity, discharge, and suspended sediment load is derived from data on natural rivers and shows that depth and width, as well as velocity, are functions of the load transported in the channel. The empiric relation between hydraulic characteristics of the channel and suspended load provides a logical explanation of the observed channel shape. The average river channel-system tends to develop in a way to produce an approximate equilibrium between the channel and the water/sediment it must transport. This state appears to exist even in headward ungraded tributaries and in given cross sections for all discharges.

[CHANNEL DYNAMICS; CHANNEL MORPHOLOGY; HYDRAULICS]

1017. Leopold,LB; Wolman,MG; Miller,JP (1964): Fluvial processes in geomorphology. W.H.Freeman and Co., San Francisco, CA. 522 p.

This book deals primarily with landform development under processes associated with running water and a comprehensive review of geomorphic processes. It provides a logical framework within which students and other readers can integrate material.

[CHANNEL MORPHOLOGY; GEOMORPHOLOGY; HYDRAULICS]

1018. Leopold,LH; Rosgen,DC (1991): Movement of bed material clasts in mountain streams. p.4-183 - 4-188. In: Proceedings of the fifth federal interagency sedimentation conference. [Eds. Tan,SS;Kuo,YH]. Subcommittee on Sedimentation of the Interagency Advisory Commission on Water Data.

The growth in observational data shows that it generally is true in gravel streams that the material on the immediate surface is coarser than that which lies below. Unfortunately, this has led to the use of the words armored or paved. The use of those words has given the impression to those who do not work directly with gravel bed streams that the bed material of the stream does not move with ordinary discharges. In this study, about 65 percent of the total rocks placed in stream channels moved during the season, even though discharges in none of the streams reached the bankfull stage. The distance the rocks moved was relatively small during one movement, generally less than a few meters. Some individual rocks moved more than once, and a few moved as many as four times during the season. These observations represent one type of evidence that material of the bed surface moves at discharges equal to or less than bankfull, even though the movement is for a short distance and the resultant transport rate is small.

[GEOMORPHOLOGY; HYDROLOGY; STREAM ECOLOGY; STREAM FLOW]

1019. Lew,L (1993): Floodplain management opportunities and constraints in reconciling an environmental mission with flood control. p.116-123. In: Tellman,B; Cortner,HJ; Wallace,MG; DeBano,LF; Hamre, RH |tech. coord.]. Riparian management: Common threads and shared interests. USDA Forest Service. General Technical Report RM-226.

In the five years preceding this paper, the U.S. Army Corps of Engineers had been developing an environmental mission. This resulted in the Corps considering restoration of the environment as a mission equal to flood control and navigation. The major constraints impeding this initiative are: environmental costs, mitigation efforts, and the need for good public relations; all of which contribute to economic feasibility. The Corps is committed to a balanced approach to integrating the three missions flood control, navigation, and environment - to preserve and enhance riparian sites.

[FLOOD IMPACTS; FLOODPLAIN MANAGEMENT; RIPARIAN RESTORATION]

1020. Lewis,GL; Bockelman,RJ (1988): Wetlands impacts of large scale center-pivot irrigation in Nebraska's Sandhills: Hydrologic and habitat issues. p.30-37. In: Stuber,PJ [tech. coord.|. Proceedings of the national symposium on protection of wetlands from agricultural impacts. 25-27 April 1988. Ft. Collins, CO. USDI Fish and Wildlife Service. Biological Report 88(16).

Wetlands impacts from irrigation were 
investigated at an intensive center-pivot irrigation operation in Nebraska's Sandhills region. Ground water levels have recently risen, creating record wet conditions and necessitating drainage of farmland. At issue in mitigation and restoration planning were whether climate or farming promoted high water tables and what effects ditching and wetland modification had on available breeding habitat for waterfowl. Hydrologic investigations indicated that area geology substantiated the existence of an aquitard below the property. Examination of well data and precipitation records did not support the hypotheses that excessive irrigation or pcrching due to the aquitard were causing the rises. Instead, there was strong temporal correlation between water level changes and corresponding precipitation amounts, since area precipitation was averaging 120 percent of normal for the previous six years. Blue-winged teal habitat units at two major ditches declined by $57-72$ percent in these same years. These declines occurred because the ditched areas had become so wet that the upland nesting habitat rather than wetland habitat was limiting production.

[AGRICULTURAL IMPACTS; RIPARIAN

HABITAT; WETLANDS]

1021. Lewis, II I,RR (1990): Wetlands restoration/creation/enhancement terminology: Suggestions for standardization. In: Wetland creation and restoration: The status of the science. [Eds: Kusler,JA; Kentula,ME]. Island Press, Washington, DC. p.417-422.

This chapter contains a glossary that was prepared after review by all authors contributing to this book. The specific definitions in the glossary represent an attempt to bring some order to the terminology applied to the topic of wetland creation and restoration.

[CREATED WETLANDS; RIPARIAN

RESTORATION; WETLANDS]

1022. Lichatowich,J; Mobrand,L; Lestelle,L; Vogel,T (1995): An approach to the diagnosis and treatment of depleted Pacific salmon populations in Pacific Northwest watersheds. Fisheries 20(1), 10-18.

The authors propose an approach to the development of restoration programs for Pacific anadromous salmon that recognizes the importance of an ecosystem perspective. Important concepts such as habitat complexity and self-organizing capacity of the stock are reviewed. A planning process comprised of six steps is described. The approach includes a comparison of historic and current habitat complexity and connectivity and intrapopulation life history diversity. Uncertainties are incorporated into the planning process through assumptions that are clearly identified. Risk of project failure is determined through a quantitative or qualitative weighing of the critical uncertainties. They emphasize the concept that restoration planning is an iterative process that must be continued after implementation.

[ANADROMOUS FISH; FISHERIES; PLANNING; RIPARIAN RESTORATION; RIVER ECOLOGY]

1023. Lienkaemper,GW; Swanson,FJ (1987): Dynamics of large woody debris in streams in old-growth Douglas-fir forests. Canadian Journal of Forest Research 17, 150-156.

This study reports the dynamics of woody debris in streams, based on 7 to 9 years of observations in five stream reaches in old-growth Douglas-fir forests. Addition of woody debris is widely scattered in time and space and comes mainly from single trees rooted away from the streambank. Wind appears to be the major agent of wood entry into streams. Downstream movement is strongly related to length of individual pieces; most pieces that moved were shorter than bankfull width.

[LARGE WOODY DEBRIS; RIPARIAN FOREST; RIPARIAN RESTORATION]

1024. Ligon,FK; Dietrich,WE; Trush,WJ (1995): Downstream ecological effects of dams. BioScience 45(3), 183-191.

Most resources committed to identifying the downstream effects of dams on riverine ecosystems are expended on biological studies. The authors suggest that geomorphic studies directed at ecologically significant features of river morphology and hydraulics may sometimes be more valuable in short-term evaluations associated with environmental assessments or relicensing procedures.

Geomorphological changes are usually the key to understanding the long-term consequences of dams and other disturbances. While geomorphological changes to rivers may be more subtle below dams, they are equally important and may have profound impacts on the ecosystem.

[DAMS; ECOLOGICAL IMPACTS; GEOMORPHOLOGY; RIVER ECOLOGY]

1025. Likens,GE; Bormann, FH (1974): Linkages between terrestrial and aquatic ecosystems.

BioScience 24(8), 447-456.

This paper considers some of the interactions and linkages that occur between aquatic and 
terrestrial ecosystems within the broader context of the watershed (drainage basin) or landscape. Mature ecosystems are resilient and have a variety of pathways for maintaining basic functions in spite of external pressures. The "assimilation capacity" of the environment reflects the ability of the system to hide or avoid short term effects. Long-term changes are more difficult to assess because of the long time lags inherent in food webs of ecosystems. Once overt changes appear, a very long time may be required for the ecosystem to recover after remediation.

Knowledge of land-water interactions is needed for intelligent management of these resources.

[AQUATIC ECOSYSTEMS; FOOD WEBS; NUTRIENT CYCLES; TERRESTRIAL ECOSYSTEMS]

1026. Liming,B; Mohr,R (1985): Bear Valley Creek fisheries habitat enhancement project Surface water hydrology analysis. Technical Memorandum No. 6. James M. Montgomery, Consulting Engineers, Inc. 30 p.

This technical memo provides an analysis of the surface water hydrology for the Bear Valley Creek study area based upon computer simulation modeling. Physical watershed characteristics directly measured or estimated were presented along with technical assumptions. Results indicate that the maximum snowmelt runoff event can be expected to generate an estimated peak flow of approximately $616 \mathrm{cfs}$, based on the record 1974 snow pack water content. This snowmelt runoff flow was compared with estimated peak flows resulting from the 100-year, 24-hour general storm event, and $48 \mathrm{cfs}$ from the 100-year, 1-hour thunderstorm event for the study area drainage basin.

[FISHERIES; HYDROLOGY; MODELING]

1027. Lindquist,D (1993): Rivers from a utility's perspective. p. 39-42. In: Tellman,B; Cortner,HJ; Wallace,MG; DeBano,LF; Hamre,RH [tech. coord.]. Riparian management: Common threads and shared interests. USDA Forest Service. General Technical Report RM-226.

The public's demand for hydroelectric power is in response to urban growth and other factors.

Concurrently, public concerns regarding environmental issues is also accelerating. Water is a valuable commodity that requires cooperative management to minimize pressures of competition. Fragmented approaches commonly fail. All stakeholders must be involved in the planning and implementation process to be successful.

[CRMP; HYDROELECTRIC IMPACTS;

\section{RIPARIAN HABITAT]}

1028. Linnerooth,AR; Chambers,JC; Mebine,PS (1998): Assessing the restoration potential of dry meadows using threshold and alternative states concepts. p.111-118. In: Potts,DF [ed.]. Rangeland management and water resources: Proceedings of the AWRA specialty conference. American Water Resources Association. 27-29 May 1998. Reno, NV.

Riparian ecosystems in central Nevada have been degraded by livestock grazing, fire suppression, and stream incision, resulting in basin big sagebrush (Artemisia tridentata ssp. tridentata) encroachment and dominance. In this area, dry meadows dominated by graminoids and basin big sagebrush/basin wildrye (Leymus cinereus) are two environmentally similar riparian ecosystem types that appear to represent alternative stable states. In this study, differences in understory vegetation and sagebrush abundance were examined on sagebrush dominated sites with low, intermediate, and high water tables to how water table and vegetation affect dry meadow restoration potential. High and intermediate water table sites had higher understory percent cover and were more similar to the high meadow ecosystem type. These sites were dominated by perennial graminoids and forbs. Lower understory cover values and the abundance of sagebrush may indicate that sites with lower water tables have crossed a threshold and cannot be restored to dry meadow types.

[MEADOWS; RIPARIAN ECOLOGY; RIPARIAN RESTORATION; SAGEBRUSH; WATER TABLE EFFECTS]

1029. Lipton,DW; Strand,IV (1997): Economic effects of pollution in fish habitats. Transactions of the American Fisheries Society 126, 514-518.

Pollution in fish habitats can have economic effects on three groups: 1) commercial users and consumers; 2) recreationists; and 3 ) nonusers. In commercial fisheries, the economic costs of pollution in the fishery habitats derive from lower production, or consumer perception of reduced fish quality, or both. Recreational losses due to pollution are manifest in the catch rates of recreational fishers. Some individuals may be willing to pay something to avoid pollution even though they do not intend to fish or consume fish. "Non-use" values are best measured through direct questioning rather than by observing market behavior.

[ECONOMICS; FISHERIES; POLLUTION; RIPARIAN HABITAT] 
1030. Lisle, TE (1982): Effects of aggradation and degradation on riffle-pool morphology in natural gravel channels, northwestern California. Water Resources Research 18(6), 1643-1651.

After a large flood in 1964, gaging stations in northern California widened as much as 100 percent and aggraded as much as $4 \mathrm{~m}$; then degraded to stable levels during a period of five years or more. As channels aggraded, bed material became finer, and low to moderate flow became shallower, faster, and steeper. Comparisons of longitudinal profiles also showed the diminishment of pools as well as a decrease in bar relief accompanying the excessive sediment load.

[CHANNEL DYNAMICS; CHANNEL MORPHOLOGY; SEDIMENT TRANSPORT]

1031. Lisle,TE (1986): Stabilization of a gravel channel by large stream obstructions and bedrock bends, Jacoby Creek, northwestern California. Geological Society of America Bulletin 97, 999-1011.

A general model is proposed that large obstructions and non-alluvial bends stabilize the form and location of gravel bars. Bars are stabilized by two related mechanisms: 1) large obstructions and bends cause intense, quasi-steady, secondary circulation in scour holes that terminate upstream bars at fixed locations; 2) bars are deposited upstream of large obstructions and sharp bends because of backwater reductions in stream power. The formation of bars and pools inherent in many gravel channels can, thus, be enhanced and fixed in position by flow structures set up around large obstructions and bends formed of resistant materials.

[CHANNEL DYNAMICS; CHANNEL MORPHOLOGY; HYDROLOGY; STREAMBANK PROTECTION]

1032. Lisle,TE (1989): Sediment transport and resulting deposition in spawning gravels, north central California. Water Resources Research 25(6), 1303-1319.

Ten storm flow events were measured in three streams of northern California to relate sedimentation of spawning beds to sediment transport, infiltration of fine sediment into clean gravel beds, bed material size distributions, scourfill depths. Sand trapped in the interstices of the top several centimeters formed a seal that impeded deeper deposition of very fine sand and finer material. This seal was responsible in part for a decrease in the rate of fine sediment accumulation with increasing cumulative bed load transport. Areas of the streambed commonly scoured or filled $0.1 \mathrm{~m}$ or more during storm flows. Scour and fill commonly created a sandy layer at least as thick as the seal formed by sediment infiltration. Such scour could erode eggs laid in the bed and expose deeper layers of the bed to infiltration by fine sediment. At the same time, however, it could be winnowed away. Individual storms could pose a threat to eggs in many but not all areas selected by fish for spawning. [FISH HABITAT; SEDIMENTATION; SPAWNING HABITAT]

1033. Lisle,TE; Lehre,AK; Martinson,HA; Meyer,DF; Nolan,KM; Smith,RD (1983): Stream channel adjustments after the 1980 Mt. St. Helens eruptions. p.31-72. In: Erosion control in volcanic areas: Proceedings of the symposium. 6-9 July 1982. Seattle and Vancouver, WA. Public Works Research Institute 1908.

Stream channels that received only air fall deposits from the 1980 Mount St. Helens eruption have shown no significant sedimentation following that event. In drainage channels that received both blast and air fall deposits, localized channel modifications have been observed. However, since the blast/air fall deposits are predominantly sand-sized, they have been quickly removed from the steep low-order channels surrounding the mountain. Some subsequent channel modification has resulted in lowered gradient reaches downstream as sediment eroded from upstream hillslopes has been redeposited in these reaches. Long-term effects in blast/air fall affected streams appears to be limited to channels subjected to debris torrents resulting from shallow seated landsliding and breakup of inchannel debris jams.

[CHANNEL MORPHOLOGY; GEOMORPHOLOGY; SEDIMENTATION; SEDIMENT TRANSPORT]

1034. Livingston,MF; Schemnitz,SD (1996): Summer bird/vegetation associations in tamarisk and native habitat along the Pecos River, southeastern New Mexico. p.171-180. In: Shaw,DW; Finch,DM [tech. coord.]. Desired future conditions for southwestern riparian ecosystems: Bringing interests and concerns together. USDA Forest Service. General Technical Report RM-GTR-272.

The Pecos River lies in the short-grass prairie ecotype and lacked a substantial woodland community prior to tamarisk invasion. Floodplain grassland areas on the middle Pecos River were low in bird abundance and species richness when 
compared to tamarisk habitat. Those areas, however, were important to grassland birds including Cassin's and lark sparrows, and eastern and western meadowlarks. Removing tamarisk from the Pecos River will provide those species with additional habitat. In contrast, they believe that the vegetational structure provided by tamarisk benefits certain species. Yellow-billed cuckoo, yellow-breasted chat, and rufous-sided towhee will lose essential habitat when tamarisk is removed. In order to prevent populations declines for these species on the middle Pecos River, the structure provided by tamarisk must be replaced. Establishment of native cottonwood/willow groves should be encouraged where conditions are favorable. Preferably, tamarisk removal will proceed at a rate that will leave sufficient structure for populations to persist. [AVIAN ECOLOGY; AVIFAUNA; PECOS RIVER; RIPARIAN HABITAT; SALT-CEDAR]

\section{Lloyd,J (1985): Cowfish: Habitat} capability model. USDA Forest Service. Northern Region. Missoula, MT'. 32 p.

The model described is the first in a series of aquatic models quantifying tisheries habitat capability. The model and its relationships were developed to reflect the characteristics and productivity levels of drainages found in the eastern half of Montana. The model is a hypothesis of fish habitat relationships and is not intended to be a definitive statement of cause and effect relationships. [COWFISH; FISHERIES; GRAZING IMPACTS; MODELING]

1036. Lloyd,JR (1988): A guide for estimating the effects current livestock management has on stream fish production. Unreferenced, 2-11. [FISH HABITAT; GRAZING IMPACTS; LIVESTOCK EFFECTS]

1037. Lock,PA; Naiman,RJ (1991): Old growth riparian birds of the Olympic Peninsula: Effects of stream size on community structure.

Proceedings of the sixty-fourth annual meeting of the Northwest Science Association. 20-22 March 1991. Boise, ID.

Spring breeding bird communities of large and small rivers on the Olympic Plateau were censused and compared. The objectives of this study were to: 1) provide a baseline description of old growth riparian bird communities; 2) determine whether there is a difference between bird communities along large and small rivers; and 3) define what aspects of the fluvial corridor are most important in determining bird abundance and community structure. [AVIAN ECOLOGY; RIPARIAN HABITAT]

1038. Loeks, CD (1985): Thinking laterally: Strategies for strengthening institutional capacity for integrated management of riparian resources. p.13-20. In: Johnson,RR; Ziebell,CD; Patton,DR; Ffolliott;PF; Hamre,RH [tech. coord.|. Riparian ecosystems and their management: Reconciling conflicting uses. 16-18 April 1985. Tucson, AZ. USDA Forest Service. General Technical Report RM-120.

A primary goal of environmental management is to maintain the capacity of the environment to meet human needs. This is best achieved when management is both integrated and differentiated. Differentiated resources such as riparian ecosystems are most manageable when integrated with the management of larger environments which subsume the relevant factors that affect the differential resource. Strategies to achieve integrated management are discussed.

[ENVIRONMENTAL MANAGEMENT; RIPARIAN HABITAT; RIPARIAN MANAGEMENT ZONE]

1039. Logan,RS (1994): Riparian forest stewardship. Montana State University. Extension Service. EB0118.

Damage to the riparian forest can destroy the sponge effect that controls water flow, ruin the filter that traps sediment, erode banks, and result in the deterioration of water quality. Other consequences are increased filtering costs for drinking water, damaged irrigation systems, increased flood potentials, reduced wildlife habitat, and property loss. [RIPARIAN HABITAT; RIPARIAN RESTORATION; STEWARDSHIP]

1040. Logan,RS (1997): Riparian forest wildlife: Guidelines for landowners and loggers. Montana State University. Extension Service. EB146.

The riparian forest, located along streams, rivers, and lakes, is an attraction for countless wildlife species. Many species like trout, beaver, dipper and tailed frog must have riparian forests to survive. Others, like white-tailed deer, grizzly bear, yellow warbler and garter snake use this place seasonally. Species like fox, chickadee, flying squirrel, and brown creeper use the riparian forest but also thrive in upland forests. Deer, elk, and bear are as dependent on the riparian forest as aquatic insects and fish. The attraction for all these animals is the diversity of plants found in the riparian forest, how 
these plants are arranged and the many food sources they provide. The working riparian forest requires large growing trees, logs falling into streams and a never ending supply of decomposing plants. [NUTRIENT CYCLES; RIPARIAN FOREST; RIPARIAN HABITAT]

1041. Lohrey, MH (1981): Planning gully control and restoration. Unpublished Report. Prepared for: USDA Forest Service; Fremont National Forest. 21 p.

This manuscript describes a step-by-step procedure leading to gully restoration that has becn used successfully on the Fremont National Forest. The process represents a consolidation of concepts and techniques applied elsewhere but collectively implemented at the above location.

[CHECK DAMS; GULLY CONTROL; RIPARIAN RESTORATION]

1042. Lopez,CF; Gradek,P; Saslaw,L (1993): Improvement of a Sierra Nevada riparian zone during the recent drought period. p.211. In: Tellman,B; Cortner,HJ; Wallace,MG; DeBano,LF; Hamre, RH [tech. coord.]. Riparian Management: Common threads and shared interests. USDA Forest Service. General Technical Report RM-226.

A demonstration project on sections of Long Valley Creek showed increases in the percent canopy cover and improvement of the riparian plant community. Change from a "hot" summer to fall/winter grazing system and the installation of check dams resulted in a positive channel response during the recent prolonged California drought. [CHECK DAMS; GRAZING IMPACTS; RIPARIAN MANAGEMENT ZONE]

1043. Lotspeich,FB; Platts, WS (1981): An integrated land-aquatic classification. p.103-109. In: Proceedings of the symposium on acquisition and utilization of aquatic habitat inventory. 28-30 October 1981. Portland, OR.

This paper develops a simple classification system based on causes of differences between classes of lands and integrates the riverine system into the land classification. The classification system integrates various resource components, with climate and geology as controlling, independent variables. Because of their homogeneity and simplicity, first order watersheds are used as the basic unit cell in the classification. Soils and vegetation are used to delineate individual classification units, which are then integrated into higher levels of classification.
[CLASSIFICATION; RIP $\Lambda$ RIAN HABITAT; RIVER ECOLOGY; WATERSHED]

1044. Lotspeich,FB; Platts,WS (1982): An integrated land-aquatic classification system. North American Journal of Fisheries Management 2(2), 138-149.

A simple classification system is proposed that is based on the causes of differences between classes of lands and integrates the riverine system into the land classification. Although the system integrates various resource components, climate and geology are the controlling variables. Because of their homogeneity and simplicity, first order watersheds are the basic cell unit.

[CLASSIFICATION; MODELING; RIPARIAN IIABITAT; RIVER ECOLOGY]

1045. Loucks, OL (1990): Restoration of the pulse control function of wetlands and its relationship to water quality objectives. p.467-477. In: Wetland creation and restoration: The status of the science. [Eds: Kusler,JA; Kentula,ME]. Island Press, Washington, DC.

Many wetlands and wetland restoration opportunities occur in the poorly drained headwaters of streams, along the stream floodplains, and at discharge points to larger water bodies. All of these were greatly changed by upland development that accelerates flows and increases the runoff pulse from headwater areas. In turn, the runoff increases scouring and transport of sediments, and subsequent deposition in or erosion of downstream wetland types. Successful restoration must consider how the hydrologic pulse may have been changed and whether pulse control measures can bring stream flows within a range consistent with historical development of downstream wetlands.

[HYDROLOGY; STREAM FLOW; WETLANDS]

1046. Lowdermilk, WC $(1953,1975)$ : Conquest of the land through 7000 years. USDA Soil Conservation Service. Agricultural Information Bulletin No. 99.30 p.

Soil erosion, deforestation, overgrazing, neglect, and conflicts between cultivators and herdsmen have served to topple empires and destroy entire civilizations. Careful stewardship of the land and the earth's resources, through terracing, crop rotation, and other soil conservation measures, has enabled other societies to flourish for centuries. [HISTORIC RECORDS; LAND USE; RIPARIAN HABITAI] 
1047. Lowe, $\mathrm{CH}$ (1985): Amphibians and reptiles in southwest riparian ecosystems. p.339-341. In: Johnson,RR;Ziebell,CD;Patton,DC;Ffolliott;PF;H amre, $\mathrm{RH}$ [tech. coord.]. Riparian ecosystems and their management: Reconciling conflicting uses. 16-18 April 1985. Tucson, AZ. USDA Forest Service. General Technical Report RM-120. Obligate riparian amphibians and reptiles in Arizona and Sonora, Mexico, are discussed. Some local populations have reached extinction. Special status and designation for riparian species is proposed.

[HERPETOFAUNA; RIPARIAN HABITAT]

1048. Lowe,CH; Johnson,RR; Bennett,PS (1986): Riparian lands are wetlands: The problem of applying eastern American concepts and criteria to environments in the North American southwest. p.119-122. In: Hydrology and water resources in Arizona and the Southwest. Proceedings of the American Water Resources Association (Arizona Section), Arizona-Nevada Academy of Science, the Arizona Hydrological Society, the American Water Resources Association (Arizona Section), the Arizona-Nevada Academy of Science, and the Arizona Hydrological Society. 19 April 1986. Glendale, AZ.

The paper argues that riparian lands are wetlands relative to the surrounding uplands. By this definition, the driest wetlands are ephemerally watered riparian scrub systems supported by infrequent water and sometimes by flow of surface water only once or less during a year's time. Periodic wetlands support riparian systems that are also watered by subsurface flow or sheet flow from higher areas.

[CI.ASSIFICATION; HYDROLOGY; RIPARIAN HABITAT; SOUTHWESTERN DESERT STREAMS]

1049. Lowrance, $R$ (1992): Groundwater nitrate and denitrification in a coastal plain riparian forest. Journal of Environmental Quality 21:401405.

Mechanisms of nitrate (NO3) removal from groundwater in riparian forests are poorly understood. In this study, both $\mathrm{NO} 3$ and $\mathrm{NO} 3 / \mathrm{Cl}$ ratios in the groundwater was decreased by a factor of 7 to 9 in the first $10 \mathrm{~m}$ of forest. Denitrification potential was more than two orders of magnitude higher in the top $10 \mathrm{~cm}$ of soil than in the top $10 \mathrm{~cm}$ of soil of the shallow aquifer. Denitrification potential was consistently highest in surface soil nearest the stream and was limited by NO3 availability in all surface soil samples. Denitrification potential was highest in August and October. High denitrification potential in surface soils, especially near the field/forest interface, may contribute to NO3 disappearance from shallow groundwater. Some of the processes associated with intact riparian vegetation appeared to have a role in $\mathrm{N}$ removal. [NUTRIENT CYCLES; RIPARIAN FOREST]

1050. Lowrance,R; Leonard,R; Sheridan,J (1985): Managing riparian ecosystems to control non-point pollution. Journal of Soil and Water Conservation 40(1), 87-91.

Many areas of riparian habitat, especially in the West, have been lost to impoundments or overwhelmed by the invasion of exotic species. Future management policies for riparian ecosystems should recognize inherent and man-made regional differences. In the West, restoration of riparian ecosystems may be a cost-effective means of controlling non-point pollution. Projects that link riparian ecosystem management with upland conservation practices should be considered in watershed management programs.

[NON-POINT SOURCE POIIIUTION; RIPARIAN HABITAT; RIPARIAN MANAGEMENT ZONE; WATER QUALITY]

1051. Lowrance,R; Sharpe,JK; Sheridan,JM (1984): Long term sediment deposition in the riparian zone of an agricultural watershed. Georgia Institute of Technology. Atlanta, GA. Environ-Resources Center. ERC-03-84, in cooperation with Georgia University, Athens Institute of Ecology, and Agricultural Research Service. Southeast Watershed Research Center. Tifton, GA. 92 p.

Sediment deposition over the last 100 years was measured on a coastal plain agricultural watershed. Three approaches were used to estimate long term sediment deposition: 1) determine the changes in depth to argillic horizon along transects from fields to streams; 2) estimate 10 year upland erosion with the Universal Soil Loss Equation and use a sediment delivery ratio to calculate mass of deposition; and 3 ) use radiometric dating techniques to estimate the age of deposited materials. Data suggest that riparian ecosystems are important sinks for agricultural chemicals (nutrients and pesticides). [AGRICULTURAL IMPACTS; CHEMICAL SINKS; RIPARIAN ECOLOGY; SEDIMENT TRANSPORT; WATER QUALITY]

1052. Lowrance,R; Shirmohammadi,A (1985): 
REM: A model for riparian ecosystem management in agricultural watersheds. p.237-240. In: Johnson,RR; Ziebell,CD; Patton,DR; Ffolliott,PF; Hamre,RH [tech. coord.]. Riparian ecosystems and their management: Reconciling conflicting uses. 16-18 April 1985. Tucson, AZ. USDA Forest Service. General Technical Report RM-120.

REM, a model for Riparian Ecosystem Management, is driven by daily hydrologic input and is designed to predict water quality changes in riparian ecosystems of agricultural watersheds. The model predicts water and nutrient inputs from uplands to the riparian ecosystem. Predictions of changes in nutrient levels due to interactions of water with soil, leaf litter, and vegetation were presented in four submodels.

[AGRICULTURAL IMPACTS; HYDROLOGY; MODELING]

1053. Lowry,MM (1993): Groundwater elevations and temperature adjacent to a beaver pond in central Oregon. p.219. In: Tellman,B; Cortner,HJ; Wallace;MG; DeBano,LF; Hamre, RH [tech. coord.]. Riparian management: Common threads and shared interests. USDA Forest Service. General Technical Report RM-226.

Studies were conducted within the Painted Hills National Monument to observe spatial and temporal dynamics of groundwater levels and temperatures adjacent to a beaver pond. Results indicate that stream temperatures can influence groundwater temperature, and that groundwater recharge is highest near the pond.

[BEAVER; GROUNDWATER; RIPARIAN HABITAT; WATER TEMPERATURES]

1054. MacDonald,LH (1991): Monitoring guidelines to evaluate effects of forestry activities on streams in the Pacific Northwest and Alaska. US Environmental Protection Agency. EPA 910/9-91-001).

The purpose of these guidelines is to expedite the development of water quality monitoring plans. The underlying rationale of the document is that nonpoint sources of pollution more commonly limit the designated uses of water in forested areas than point sources. Effective monitoring projects are essential to determine trends, evaluate control efforts, and assess the impact of management activities on the designated use of water. [HYDROLOGY; LOGGING IMPACTS; MONITORING; RIPARIAN FOREST; WATER
QUALITY]

1055. MacDonnel,LJ (1988): Wetlands protection and water rights. p.8-9. In: Mutz,K; Cooper,DJ; Scott,ML; Miller,LK [eds.]. Restoration, creation, and management of wetland and riparian ecosystems in the American West. A symposium of the Rocky Mountain Chapter of the Society of Wetland Scientists. 14-16 November 1988. Denver, CO.

Establishing a water right for wetlands likely will involve four legal issues: 1) the physical diversions requirement; 2 ) the exclusive enjoyment requirement; 3) the beneficial purpose requirement; and 4) the efficient and beneficial use requirement. Meeting all four requirements will pose significant difficulties in most states. However, there are options in most states by which water for wetlands can be given a legally protected status.

[WATER QUALITY; WATER RIGHTS]

1056. Magney,DL (1993): Faults with growing season determinations using the federal wetlands delineation manual. p.222-227. In: Tellman,B; Cortner,HJ; Wallace;MG; DeBano,LF;

Hamre, RH [tech. coord.]. Riparian management: Common threads and shared interests. USDA Forest Service. General Technical Report RM-226.

The federal wetlands delineation manual should be modified to allow for more flexibility in determining the growing season as determined by climate, not the frost-free period designed for agricultural crops. Modifying the manual would allow more accurate wetland delineations to be performed in the arid Southwest.

[CLIMATE; GROWING SEASONS; RIPARIAN HABITAT; WETLANDS]

1057. Magoulick,DD; Wilzbach,MA (1998): Effect of temperatures and macrohabitat on interspecific aggression, foraging success, and growth of brook trout and rainbow pairs in laboratory streams. Transactions of the American Fisheries Society 127, 708-717.

Abiotic conditions may influence interactions among salmonids in general and brook trout and rainbow trout in particular. Brook trout may have an advantage at lower temperatures and slower, deeper habitats. These assumptions were tested in artificial stream channels. Brook trout were significantly more aggressive, captured significantly more prey, and had significantly greater growth rates at both 13 degrees $\mathrm{C}$ and 18 degrees $\mathrm{C}$. The differential effects of 
temperature on aggressive interactions between the species was significant and a greater difference was found at the lower temperature, but brook trout dominated rainbow trout at both temperatures. Macrohabitat did not significantly affect aggressive interactions or foraging success, but growth rate was greater in riffles than in pools for both species. The differential effects of temperature and macrohabitat, however, did not sufficiently explain observed brook and rainbow trout distributions in streams. [FISH HABITAT; MACROHABITAT; STREAM TEMPERATURE; TROUT]

1058. Mahoney,DL; Erman,DC (1981): The role of streamside buffer strips in the ecology of aquatic biota. p.168-176. In: Warner,RE; Hendrix,KM |eds.|. Proceedings of the California riparian systems conference. 17-19 September 1981. Davis, CA.

Riparian vegetation is important as a source of food to stream organisms, as shade over small-order streams, and as a bank-stabilizing force to prevent excessive sedimentation and intercept pollutants. Logging may significantly affect each of these factors unless proper protective measures are employed. Light intensity and chlorophyll concentrations are also major factors related to logging activity and affect instream primary production. Transportable sediment was found to be significantly higher in logged and narrow buffered streams than in controls 7 to 10 years after logging. [BUFFER STRIPS; LOGGING IMPACTS; POLLUTION; RIPARIAN HABITAT; RIPARIAN VEGETATION; SEDIMENTATION]

1059. Mahoney,JM; Rood,SB (1993): A model for assessing the effects of altered stream flows on the recruitment of riparian cottonwoods. p.228-232. In: Tellman,B; Cortner,HJ; Wallace,MG; DeBano,LF; Hamre, RH [tech. coord.]. Riparian management: Common threads and shared interests. USDA Forest Service. General Technical Report RM-226.

The paper presents a model that provides a framework for assessing the effects of existing or proposed flow regimes on seeding recruitment of riparian cottonwoods. Recorded or projected flow patterns for a particular river reach can be evaluated for the critical period of seed release to determine whether river stages and rate of decline fall within the range necessary for seedling establishment. [COTTONWOOD; RECRUITMENT; RIPARIAN RESTORATION; SEED PRODUCTION; STREAM FLOW]
1060. Majors,AK (1998): Assessing climate's influence on vegetation. p.371-374. In: Potts,DF [ed.]. Range management and water resources: Proceedings of the AWRA specialty conference. American Water Resources Association. 27-29

May 1998. Reno, NV.

Vegetation regions with arid and semi-arid ecosystems have low precipitation averages and tend to have extreme variations in climate. These variations in temperature and moisture result in vegetation production and trend changes that are often unrecognized and not attributed to climate by many of the public. Seasonal precipitation has varied over 300 percent from year to year frequently resulting in drastic vegetation aspect changes. Calendar year moisture records are often not indicative of vegetation growth characteristics in a given year. Photographic records substantiate that historical plant composition and production trends resulted from timing and amount of available moisture during the growing season.

[CLIMATE; PHOTO PLOTS; PRECIPITATION; RANGE MANAGEMENT]

1061. Majors,JE (1989): Opportunities to protect instream flows and wetland uses of water in California. USDI Fish and Wildlife Service. Biological Report 89(10), 76.

This publication is one of a series of similar documents that provides a survey of State prerogatives and programs that may be used to protect the instream uses of water. Most of the opportunities for protecting instream flows are related to fish and wildlife habitat, although other uses are considered, including hydroelectric power, navigation, recreation, downstream delivery, and waste load assimilation. Articles and papers are included that illustrate methods to protect instream uses.

[RIPARIAN HABITAT; STREAM FLOW; WATER RIGHTS; WETLANDS]

1062. Malanson,GP (1996): Riparian landscapes. 1st ed. Cambridge University Press, New York, NY. 306 p.

This book examines the ecological systems of streamside and floodplain areas from the perspective of landscape ecology. The author describes the specific spatial pattern of riparian vegetation as a result of, and a control on, the ecological, geomorphological, and hydrological processes that operate along rivers. He also discusses the role of the riparian zone in controlling species distribution and abundance and highlights the intelligent management 
of these valuable ecological resources. Finally, he explores the potential for linking hydrological, geomorphological, ecological simulation models. [LANDSCAPE ECOLOGY; RIPARIAN HABITAT; RIPARIAN MANAGEMENT ZONE]

1063. Malanson,GP; Butler,DR (1990): Woody debris, sediment, and riparian vegetation of a subalpine river, Montana, USA. Artic and Alpine Research 22(2), 183-194.

The relationships among woody debris, composition of vegetation, topography, and sediment on ten gravel bars along a Montana river are examined in order to test a hypothesis of positive feedback leading to reduced rates of sediment transport. Plant species diversity is related to the area, sediment, and woody debris of bars. Several variables were significantly correlated and significant regressions of vegetative composition on sediment, topography, and debris resulted. The amount of wood debris, however, is not a statistically significant function of topography, sediment, or vegetation. Analyses of systems of linear equations representing hypothetical pathways of causality regarding vegetation, woody debris, topography, and sediment were not statistically significant.

[HYDROLOGY; RIPARIAN PLANTS; SEDIMENTATION; WOODY DEBRIS]

1064. Malde,HE (1973): Geological bench marks by terrestrial photography. Journal of Research of the USDI Geological Survey 1(2), 193-206.

A photograph made with a level camera, if taken at a known height above a permanent mark on the ground, can later be repeated with exactness for measurement of changes in terrain. Such a photograph is one of several means for establishing a geologic bench mark and is useful for monitoring the changes of landscape that are otherwise difficult to map or describe.

[GEOMORPHOLOGY; MONITORING; PHOTO PLOTS; TECHNIQUES]

1065. Manci,KM (1989): Riparian ecosystem creation and restoration: A literature summary. U.S. Fish Wildlife Service Biological Report 89(20), 59.

Compared to other wetland types (e.g. coastal wetlands), projects and techniques involving creation or restoration of riparian ecosystems are not well documented. To provide a source of currently available literature, 92 sources were collected to provide a literature summary. The summary provides an overview of the status of riparian ecosystems in the U.S., a discussion of riparian functions, and a review of some techniques used for planning, implementing, monitoring, and measuring project success of creation/restoration efforts. Case studies are used to demonstrate these techniques and report their results.

[BIBLIOGRAPHY; CREATED WETLANDS; RIPARIAN ECOLOGY; RIPARIAN

RESTORATION]

1066. Manning,ME; Padgett,WG (1992):

Distribution of willows on forest lands of Nevada and eastern California. p.11-15. In: Clary,WP; Zicbell,CD; Patton,DR; Ffolliott,PF; Hamre,RII [tech.coord.]. Proceedings - Symposium on ecology and management of riparian shrub communities. USDA Forest Service. General Technical Report INT-289.

Distributions and habitat characteristics of 14 common willows are described for the Toiyabe and Humboldt National Forests of Nevada and eastern California. Some species have restricted geographic distribution while others occur throughout the study area. Locally, species segregate by elevation and site characteristics.

[RIPARIAN HABITAT; SPECIES

DISTRIBUTION; WILLOW]

1067. Manning,ME; Padgett,WG (1995):

Riparian community type classification for Humboldt and Toiyabe National Forests, Nevada and eastern California. USDA Forest Service. General Technical Report INT-GTR-322. 142 pp.

A community type classification is presented for riparian plant communities on USDA Forest Service lands of Nevada and eastern California. The taxonomic classification is hierarchical and based on the reconnaissance of over 800 sample stands on the Humboldt and Toiyabe National Forests. A total of 7 overstory dominance groups and 93 community types are defined and described in detail. A diagnostic key to cover community types is provided for field identification.

[CLASSIFICATION; PLANT COMMUNITIES; RIPARIAN HABITAT]

1068. Manning,RE (1979): Impacts of recreation on riparian soils and vegetation. Water Resources Bulletin 15(1), 30-43.

[RECREATION IMPACTS; RIPARIAN HABITAT; RIPARIAN VEGETATION]

1069. Mantell,M; Metzger,P; Reid,C (1985): Improving riparian protection by linking state 
programs. p.421-425. In: Johnson, RR; Ziebell,CD; Patton,DR; Ffolliott,PF; Hamre,RH [tech. coord.]. Riparian ecosystems and their management: Reconciling conflicting uses. 16-18 April 1985. Tucson, AZ. USDA Forest Service. General Technical Report RM-120.

All elements of the riparian setting, including: river flow, flora, and fauna, are essential to maintaining healthy riparian ecosystems. But, the few state legal and institutional regimes to protect riparian habitats and streamflows are fragmented. Protection programs must be made more effective, better coordinated, and informed by more complete data.

[RIPARIAN HABITAT; WATER LAW]

1070. Marcuson,PE (1977): The effect of cattle grazing on brown trout in Rock Creek, Montana. Montana Department of Fish and Game Special Report No. F-20-R-21, II-a.

Studies of a natural, free flowing stream section with densely vegetated banks showed better fish population structure than a contiguous section flowing through a heavily grazed area. The natural area supported 4,645 brown trout $/ \mathrm{ha}$ at $238.8 \mathrm{~kg} / \mathrm{ha}$ compared to 1,732 browns at $71.0 \mathrm{~kg} / \mathrm{ha}$ in the overgrazed area. The biomass of brown trout was 3.4 $\mathrm{X}$ greater in the natural area. Species other than brown trout were 20 percent more numerous in the grazed area. Large numbers of juvenile mountain whitefish accounted for the difference. The natural area possessed fewer numbers of other fish, but they exceeded the biomass of the grazed area by 87 percent. The ungrazed section had 82 percent more cover per ha than the grazed section. Marked differences in floristic composition and density of herbaceous vegetation was evident between the two areas.

[FISHERIES; GRAZING IMPACTS; MONITORING; RIPARIAN VEGETATION]

1071. Maret,TR; Robinson,CT; Minshall,GW (1997): Fish assemblages and environmental correlates in least-disturbed streams of the Upper Snake River Basin. Transactions of the American Fisheries Society 126, 200-216.

Fish assemblages and environmental variables were evaluated from 37 least-disturbed, first through sixth order streams and springs in the Upper Snake River Basin. Geographically, the basin comprises four ecoregions. Environmental variables constituting various spatial scales, from watershed characteristics to instream habitat measures, were used to examine distribution patterns in fish assemblages. Major environmental factors determining species distributions in the basin were stream gradient, watershed size, conductivity, and percentage of watershed covered by forest. The data suggest that the evolutionary consequences of geographic features and fish species introductions transcend the importance of ecoregion boundaries on fish distributions in the Upper Snake River Basin. [ENVIRONMENTAL MANAGEMENT; FISHERIES; RIPARIAN HABITAT; SNAKE RIVER]

1072. Marks,JS; Saab-Marks,V (1988): Winter habitat use by Columbian sharp tailed grouse in western Idaho. Journal of Wildlife Management 52(4), 743-746.

Habitat use by Columbian sharp-tailed grouse (Tympanuchus phasianellus columbianus) was studied during three winters. Grouse were closely associated with mountain shrub and riparian cover types which provided food and escape cover regardless of snow depth. Fruits of Douglas hawthorn (Crataegus douglassi) and buds of Saskatoon serviceberry (Amelanchier alnifolia) and common chokecherry (Prunus virginiana) were important food sources.

[RIPARIAN HABITAT; SHARP-TAILED GROUSE]

1073. Marlow,CB (1988): Mitigating livestock impacts to streambanks within northern Rocky Mountain foothills riparian zones. p.147-150. In: Issues and technology in the management of impacted wildlife, Proceedings III. 2-4 November 1987. Colorado Springs, CO. Thorne Ecological Institute. Boulder, CO.

The most common mitigation action for livestock impacts is to reduce the number of animals using a particular riparian site. Recent research suggests that stocking rate reductions only delay the eventual deterioration of the riparian areas. Three management alternatives: deferred riparian, time control, and livestock exclusion, were chosen because of their potential for controlling cattle use of streambanks. After two years, there was no significant difference between the alternatives in regard to stream channel deformation. This suggests that grazing plans which prescribe specific grazing periods and limit the length of the grazing period may be successful in reducing stream damage. [GRAZING IMPACTS; GRAZING TREATMENTS; STREAMBANK PROTECTION]

1074. Marlow,CB; Olson-Rutz,K; Atchley,J 
(1989): Response of a southwest Montana riparian system to four grazing management alternatives. p.111-116. In: Gresswell,RE; Barton,BA; Kershner,JL [eds.]. Practical approaches to riparian resource management. An educational workshop. 8-11 May 1989. USDI Bureau of Land Management. Billings, MT.

The effects of deferred rotation, Savory Grazing Method (SGM), season-long, and livestock exclusion has been monitored for 3 years. A decline in trout habitat condition appeared to be more a function of stream discharge and channel aggradation than grazing management. Studies also suggest that it is the interaction between grazing and stream discharge events that dictate the magnitude of streambank alteration. Downward shifts in cattle numbers will probably not limit streambank degradation and loss of trout habitat. Decreasing the length of access time that cattle have to riparian zones and adjusting the grazing period to coincide with low streambank moisture levels are two devices that show promise for improving riparian zone protection.

[GRAZING IMPACTS; GRAZING TREATMENTS; RIPARIAN MANAGEMENT ZONE]

1075. Marlow,CB; Pogacnik,TM (1985): Time of grazing and cattle-induced damage to streambanks. p.279-284. In: Johnson,RR; Ziebell,CD; Patton,DR; Ffolliott,PF; Hamre,RH [tech. coord.]. Riparian ecosystems and thcir management: Reconciling conflicting uses. 16-18 April 1985. Tucson, AZ. USDA Forest Service. General Technical Report RM-120.

Grazing and trampling are the processes by which cattle impact riparian areas. Implementation of rest-rotation grazing and limiting cattle use of riparian vegetation to 20 percent of the standing crop will reduce impact. Rest rotation and light grazing may also improve plant vigor. A 3-year grazing study in southwestern Montana indicales that the level of cattle use has little bearing on streambank damage. Soil moisture content directly affects the streambank susceptibility to trampling. Postponing or deferring grazing until streambanks have dried protects the riparian zone from damage.

[GRAZING IMPACTS; GRAZING TREATMENTS; RIPARIAN MANAGEMENT ZONE; STREAMBANK STABILITY]

1076. Marlow,CB; Pogacnik,TM (1986): Cattle feeding and resting patterns in a foothills riparian zone. Journal of Range Management 39(3), 212-217.

The impacts of cattle on riparian areas depends on both their behavior and utilization of streamside vegetation. Results of a 2-year study indicated that seasonal trends in cattle use of uplands and riparian areas exist. Cattle spent significant amounts of their feeding time in upland areas in late June and early July. Significant levels of feeding activity occurred in the riparian zone from late August through September. Resting patterns differed only during the early part of the grazing season when cattle spent significantly more time resting in upland areas. Significant differences in resting time the rest of the season occurred only when adverse weather conditions caused cattle to seek shelter in the riparian zone. Cattle spend a disproportionate amount of their feeding time in the riparian zone during late summer and fall. Therefore, impacts could be limited by basing stocking rates for this period only on forage available in the riparian zone.

[GRAZING IMPACTS; LIVESTOCK EFFECTS; RIPARIAN VEGETATION]

1077. Marlow,CB; Pogacnik,TM; Murphy,DH (1983): Cattle behavior in a foothills riparian zone. In: Proceedings of the annual meeting of the Society for Range Management. 14-16 February 1983. Albuquerque, NM.

Cattle seek cooler, moister riparian zones during the summer grazing season. [LIVESTOCK EFFECTS]

1078. Marlow,CB; Pogacnik,TM; Quinsey,SD (1987): Strcambank stability and cattle grazing in southwestern Montana. Journal of Soil and Water Conservation. July-August 1987, 291-296.

Cattle impact riparian communities by grazing and trampling. Re-evaluation of management practices indicated that implementing rest-rotation grazing management and limiting cattle use of riparian vegetation will reduce cattle impacts. In southwest Montana, both streamflow and cattle use were highly correlated with the degree of change in stream channel profile. Streambank alteration may result from a combination of high soil moisture levels, high streamflow, and cattle use. Cattle use alone did not explain the degree of change in channel profile.

[GRAZING IMPACTS; LIVESTOCK EFFECTS; STREAMBANK STABILITY]

1079. Marron, DC (1989): Physical and chemical characteristics of a metal contaminated overbank deposit, west-central South Dakota, U.S.A. Earth Surface Processes and Landforms 14, 419-432.

Overbank deposition of arsenic and other 
mine-tailing metals is discussed in relation to sediment transport. Carbonate materials in the deposit limit the desorption of arsenic by preventing acid formation. Arsenic concentrations provide a measure of the dilution of mine tailings by uncontaminated sediment. [HEAVY METALS; RIPARIAN HABITAT; SEDIMENT TRANSPORT; WATER QUALITY]

1080. Marston,RA (1982): The geomorphic significance of $\log$ steps in forest streams. Annals of the Association of the American Geographer. 72, 99-108.

A functional account of log steps in forest streams is provided by field surveys of $163 \mathrm{~km}$ of streams in the Oregon Coast Range. Natural tree fall, rather than silvicultural activities, accounts for the majority of log steps. During low flow conditions, dissipation of potential stream energy by log steps amounts to 6 percent, approximately equal to that by falls. Depriving some streams of log steps by clean-out or repeated harvest of stream adjacent trees may initiate an episode of progressive erosion by not dissipating stream energy in excess of that needed to transport imposed sediment supplies. Addition of log stcps to streams with energy already insufficient to balance sediment inputs and outputs may only serve to accentuate progressive deposition.

[CHANNEL MORPHOLOGY; GEOMORPIIOLOGY; ORGANIC DEBRIS]

1081. Martens,E; Young,JA (1992): Seed germination data for yellow willow at a Nevada riparian site. p.142-144. In: Clary,WP; McArthur,ED; Bedunah,D; Wambolt,CL [comp,]. Proceedings -Symposium on ecology and management of riparian shrub communities. USDA Forest Service. General Technical Report INT-289.

Seeds of yellow willow (Salix lutea [Bebb] Jeps.) were collected from the riparian areas along the east side of the Sierra Nevada. Freshly collected seeds were germinable at a range of incubation temperatures from 5 through 30 degrees $\mathrm{C}$. Seeds remained viable at room temperatures for 7 weeks. [RIPARIAN HABITAT; SEED PRODUCTION; WILLOW]

1082. Marti,E; Schade,JD; Fisher,SG; Grimm,NB (1997): Episodic hydrologic and nutrient linkages in a desert stream-riparian ecosystem. p.139. Abstracts. 1997 annual meeting of the Ecological Society of America jointly with The Nature Conservancy. 10-14 August 1997.

\section{Albuquerque, NM.}

Hydrologic linkages between the riparian zone and the surface stream and the effect of those linkages were examined. Temporal variation of water chemistry in the riparian zone was compared to surface and subsurface water in the active channel. The most significant differences were found for inorganic nitrogen. Between floods, reduced $\mathrm{N}$ species predominated in the riparian zone, whereas subsurface water of the active channel was characterized by oxidized forms of $\mathrm{N}$. After flooding, concentrations of major ions and nutrients in the riparian zone increased significantly. Nitrate, particularly, was elevated in riparian surface water to concentrations similar to flood waters. Results suggest that surface-subsurface hydrologic linkages are episodic in desert-riparian ecosystems. [FLOOD IMPACTS; HYDROLOGY; NUTRIENT CYCLES; RIPARIAN ZONES]

1083. Martin,DJ (1985): Production of cutthroat trout (Salmo clarki) in relation to riparian vegetation in Bear Creek, Washington. Ph.D. Thesis, University of Washington, Seattle, WA. $166 \mathrm{p}$.

Removal of vegetation can alter salmonid production in streams. More than 70 percent of the food biomass consumed by all age groups of cutthroat trout was composed of aquatic insects, despitc the greater abundance of insect fallout. Only during the summer low flow period when aquatic production was low, did insect fallout become more important than aquatic insects in the trout diet. Changes in prey utilization were associated with temporal differences in prey availability. Following canopy removal, mean weights of each age group of trout increased only in the lower treatment zone, but not always. Densities of age I and II trout increased only in the upper treatment zone. Differences were attributed to differences in temperature and food supply between the upper and lower treatment zones. [FISH POPULATIONS; FISHERIES; LOGGING IMPACTS; RIPARIAN HABITAT; RIPARIAN VEGETATION]

1084. Martin,DJ; Wasserman,LJ; Dale,VH (1986): Influence of riparian vegetation on posteruption survival of coho salmon fingerlings on the west-side streams of Mount St. Helens, Washington. North American Journal of Fisheries Management 6(1), 1-8.

The 1980 eruption of Mount St. Helens impacled salmon streams on the west side of the mountain primarily by debris and mud deposits; depositions of 
ash and large wood were relatively minor occurrences. Correlations exist between the survival of anadromous fish, instream vegetative debris cover, and water temperature. Recovery of riparian vegetation would reduce stream temperatures and cause debris to be retained. However, it will be 50-75 years before the trees are large enough to create organic debris. Management activities that promote large organic debris will enhance fish survival. [FISHERIES; ORGANIC DEBRIS; RIPARIAN RESTORATION; RIPARIAN VEGETATION]

1085. Martin,DW; Chambers,JC (1998): Rooting and soil moisture responses to potential restoration treatments in central Nevada riparian meadows. p.435. In: Potts, DF [ed.]. Range management and water resources: Proceedings of the AWRA specialty conference. American Water Resources Association. 27-29 May 1998. Reno, NV.

This study was designed to increase understanding of how riparian meadows function and to evaluate specific restoration treatments. The effects of aeration, nitrogen addition, revegetation, and herbage removal on below ground processes and soil moisture were examined at several sites in central Nevada. Results indicated that there were significant differences between sites that could be related to differences in soil moisture. No discernible trends were evident in rooting depth. Rooting activity also appeared to be lower in plots receiving the nitrogen addition treatment. Soil moisture differed between sites, but not treatment plots. Results indicate that water table, $\mathrm{N}$ availability, and site differences may play significant roles in meadow below ground processes.

[BELOW-GROUND BIOMASS; MEADOWS; RIPARIAN RESTOR $\Lambda$ TION]

1086. Martin,SC (1978): Grazing systems - What can they accomplish? Rangeman's Journal 5(1), 14-16.

Dramatic improvement in range condition usually results from a combination of good range management and favorable growing conditions. Marked improvement in range condition may not be evident until a grazing system has been in effect for 6-12 years and has gone through several cycles.

[GRAZING IMPACTS; GRAZING TREATMENTS]

1087. Martin,SC (1979): Evaluating the impacts of cattle grazing on riparian habitats in the national forests of Arizona and New Mexico. p.35-38. In: Cope,OB [ed.]. Forum -- Grazing and riparian/stream ecosystems. 3-4 November 1979.

Denver, CO. Trout Unlimited, Inc.

Cattle spend very little time in the creek bottom of the study area because forage production is negligible. The study suggested that tree sprouts became more attractive to cattle after they leafed out. Browsing damage can therefore be reduced by removing animals before or soon after palatable species put on leaves. Of the five species of trees observed, willows and velvet ash were the most palatable, followed by Arizona alder and net-leaf hackberry, with Arizona sycamore less preferred. [GRAZING IMPACTS; LIVESTOCK EFFECTS; RIPARIAN HABITAT]

1088. Martinez, $D$ (1993): River restoration: financing opportunities and constraints. p.92-97. In: Tellman.B; Cortner,HJ; Wallace,MG; DeBano,LF; Hamre, RH [tech, coord.]. Riparian management: Common threads and shared values. ISDA Forest Service. General Technical Report RM-226.

It is imperative to integrate landowners, agribusiness, developers, and other non-traditional partners in conservation projects. Communications between sectors that have long-standing adversarial relationships will not only resolve specific problems but will discourage the creation of new ones. [PARTNERSHIPS; RIPARIAN RESTORATION]

1089. Martinsen,GD; Driebe,EM; Whitham,TG (1998): Indirect interactions mediated by changing plant chemistry: Beaver browsing benefits beetles. Ecology 79(1), 192-200.

An indirect interaction between beavers and leaf beetles was documented. Resprout growth arising from the stumps and roots of beaver-cut trees contained twice the level of defensive chemicals as normal juvenile growth. However, rather than be repelled by these defenses, leaf beetles were attracted to resprout growth, resulting in a strong positive association between beavers and beetles. Why? Cottonwoods contain phenolic glycosides, chemicals that are defensive against mammalian herbivores, but are sequestered and used by the beetles for their own defense.

[BEAVER; COTTONWOOD; INVERTEBRATES; RIPARIAN HABITAT]

1090. Martinsen,GD; Floate,KD; Whitham,TG; Keim,P (1997): The biogeographic conscquences of hybridization and introgression in Populus. p.140. Abstracts. 1997 annual mecting of the 
Ecological Society of America jointly with The Nature Conservancy. 10-14 August 1997. Albuquerque, NM.

Wherever two or more species of cottonwood are sympatric, hybridization occurs. Hybrid zones are often centers of abundance for diverse organisms. Using 50 RFLP markers, the researchers demonstrated that in older hybrid zones, introgression extends into the "pure" species zone. Younger hybrid zones, by contrast, may contain only F1 hybrids and no introgression. Introgression can extend over $100 \mathrm{~km}$ into native stands, a fact that has important implications for conservation. [BIODIVERSITY; COTTONWOOD; RIPARIAN FOREST]

1091. Marzolf,GR (1978): The potential effects of clearing and snagging on stream ecosystems. USDI Fish and Wildlife Service. Biological Services Program: FWS/OBS-78/14. 32 p.

The removal of obstructions from streams (clearing and snagging) to increase the channel water conveying capacity, is conducted to drain floodplains for agriculture, to reduce flooding, and to maintain navigable waterways. The process is also purported to decrease fish populations and be detrimental to stream ecosystems in other ways. Depression of fish populations potentially occurs in two ways: 1) alteration of the nature and abundance of the organisms utilized as food; and 2) by direct effects on fish behavior and reproduction. This paper also describes the parameters that could be measured for quantitatively evaluating the ecological effects of specific projects.

[BIBLIOGRAPHY; RIPARIAN HABITAT; RIPARIAN RESTORATION; WOODY DEBRIS]

1092. Maser,C (1990): On the "naturalness" of natural areas: $A$ perspective for the future. Natural Areas Journal 10(3), 129-133.

The key to and value of both restoration ecology and ecological restoration is the thought process the terms imply. Part of this process is setting aside an ecologically adequate system of natural areas - an unconditional gift of potential knowledge for the future. In doing so, present and future generations have a repository not only of species, which more often then not are region-specific, but also of processes, which more often than not are worldwide in principle and application.

[BIODIVERSITY; ECOLOGICAL INTEGRITY; RIPARIAN RESTORATION]

1093. Masters,L; Swanson,S; Burkhardt,W
(1996): Riparian grazing management that worked: I. Introduction and winter grazing. Rangelands 18(5), 192-195.

Various sites in Nevada represented a spectrum of elevations, vegetation communities, precipitation patterns, and historical uses. These factors all contributed to recent differences in watcrshed condition. On one allotment, long term winter use maintained healthy conditions along most of two streams. On another, winter grazing proved successful for restoring streamside vegetation and building new stream channels. These treatments followed scason-long and year-round grazing, which in combination with other use impacts, had created more unstable conditions.

[GRAZING IMPACTS; LIVESTOCK EFFECTS; RIPARIAN MANAGEMENT ZONE]

1094. Masters,L; Swanson,S; Burkhardt,W (1996): Riparian grazing that worked: II. Rotation with and without rest and riparian pastures. Rangelands 18(5), 196-200.

Rest-rotation grazing strategies can be specifically designed for the unique conditions of an allotment or watershed. The three-pasture rest-rotation systems can succeed with seasons of use matched to climate, moderate stocking rates, and maintenance (rather than improvement) of herbaceous and woody vegetation. More complex systems may be appropriate when streambanks require more protection and the additional pastures allow for shorter grazing seasons and greater flexibility. Season of grazing use should be determined by site elevation, mean annual precipitation and seasonal occurrence, and aspect. Higher elevation, cool, mesic sites may respond well to summer grazing. Low elevation, hot, dry sites, however, may respond better to early or late applications within the rotation schedule. Grazing use on critical riparian areas should be kept moderate to low. Utilization standards can guarantee conservative use if they focus on the right plants in the right places at the right levels. All such efforts require the full cooperation of both the managing agency and the permittees.

[GRAZING IMPACTS; GRAZING TREATMENTS; REST ROTATION; RIPARIAN MANAGEMENT ZONE; UTILIZATION]

1095. Masters,LS; Burkhardt,JW; Tausch,R (1991): The geomorphic process: Effects of base level lowering on riparian management. Rangelands 13(6), 280-284.

Drying of Pleistocene Lakes has resulted in 
widespread down-cutting and headward erosion that is continuing in Great Basin watersheds. Channel erosion and deposition in response to base level changes is a natural geomorphic process. Land managers should consider this when confronted by stream entrenchment and head cuts. Land use is not always the driving force behind stream dynamics. [CHANNEL DYNAMICS; EROSION; GEOMORPHOLOGY; RIPARIAN MANAGEMENT ZONE]

1096. Mathias,ME; Moyle, $P$ (1992): Wetlands and aquatic habitats. Agriculture, Ecosystems, and Environment 42, 165-176.

Riparian wetland areas often represent critical corridors for animal and plant dispersion in wildland watersheds and downstream river systems. It is essential that integrated management of riparian wetland areas be developed to reverse the loss of biological integrity. Agricultural and urban uses, and related water developments, have led to a marked decline of streamside wetland habitats. Six major ways are discussed in which conventional agriculture alters wetlands and aquatic habitats: wetland drainage, water diversions. stream channelizations, bank stabilization, grazing, and the release of agricultural pollutants. This paper also discusses ways that biological diversity can be protected or enhanced.

[BIODIVERSITY; RIPARIAN HABITAT; WETLANDS]

1097. Maxwell,JR; Soloman,RM (1983): Threshold limits of hydrologic function in arid and semiarid landscapes. Unpublished report. USDA Forest Service. Albuquerque, NM. 25 p.

A method is presented for determining threshold limits between satisfactory and unsatisfactory hydrologic function. The threshold limits reflect unacceptable risks of accelerated gully erosion caused by decreased ground cover. They define the minimum percent ground cover needed to maintain the hydrologic stability of watersheds and their land units. The method is especially useful for arid and semiarid landscapes where ground cover is strongly influenced by land management and lluvial processes are dominated by intense rainstorms, surface runoff, and gully erosion.

[GULLY CONTROL; HYDROLOGY; TECHNIQUES]

1098. May,BE; Davis,B (1982): Practices for livestock grazing and aquatic habitat protection on western rangelands. In: Proceedings of the symposium on wildlife-livestock relationships. 20-22 April 1981. Coeur d'Alene,ID. University of Idaho, Moscow, ID.

Recommendations for livestock management in riparian zones which contain important fisheries are presented. All recommendations are based on review of the literature, experience, and consultation with others. Management practices were considered in relation to stream size, gradient, and riparian vegetation.

[FISHERIES; GRAZING IMPACTS; RIPARIAN HABITAT]

1099. May,BE; Guest,JE (1984): The riparian pasture: Opportunity for coordinated management. Proceedings of the Bonneville Chapter of the American Fisheries Society. 8-9 February 1984. Utah State University; Logan, UT. $11 \mathrm{p}$.

The riparian pasture concept may afford the rangeland manager a positive approach in resolving conflicts between wildlife, fish and livestock in many western allotments. Results of the approach have proven beneficial in restoring aquatic/riparian habitats for fish and wildlife while minimizing detrimental influences upon livestock operations. Riparian pastures afford the needed administrative control in utilizing forage resources, while effectively providing for fish and wildlife habitat.

[GRAZING IMPACTS; RIPARIAN HABITAT; RIPARIAN VEGETATION]

1100. Mazzoni,J ;Barber,M; Critchlow,R; Miller,W; Studenski,G; Menke,JW (1977): Livestock and Waterfowl. p.87-94. In: Procecdings of the workshop on livestock and wildlife; Fisheries relationships in the Great Basin. 3 May 1977. Sparks, NV. University of California. Berkeley, CA. [GRAZING IMPACTS; LIVESTOCK EFFECTS; RIPARIAN HABITAT; WATERFOWL MANAGEMENT]

1101. McAdoo,JK; Back,GN; Barrington,MR; Klebenow,DA (1986): Wildlife use of lowlands meadows in the Great Basin. p.310-319. In: Transactions of the North American wildlife and natural resources conference. Wildlife Management Institute. Washington, DC.

Lowland meadows in the Great Basin comprise only a small portion of the total land area, but they provide critical wildlife habitat for many species. Lowland meadows maintain high species diversities of both plants and animals. Numerous other species 
use these areas for short periods when lush vegetation and water are not available in other habitats.

Meadows also produce high populations of prey species important to a variety of avian and mammalian predators.

[AVIFAUNA; MEADOWS; RIPARIAN HABITAT; SMALL MAMMALS]

1102. McArthur,ED; Sanderson,SC (1992): A comparison between xeroriparian and upland vegetation of Beaver Dam Slope, Utah, as desert tortoise habitat. p.25-31. In: Clary,WP; McArthur,ED; Bedunah,D; Wambolt,CL [comp.]. Proceedings - Symposium on ecology and management of riparian shrub communities. USDA Forest Service. General Technical Report INT-289.

The Beaver Dam Slope of extreme southwestern Utah is historic desert tortoise habital, grazed by livestock for over 100 years. It is composed of a large bajada dissected by intervening arroyos. Of 30 common species - 14 were preferentially associated with xeroriparian habitats, 3 with upland habitats, and 13 were non-preferential. Arroyos with more shrubs and rougher topography serve well as den sites and provide succulent forage during dry periods. The much larger uplands, under favorable moisture conditions, provide an abundance of accessible forage.

[DESERT TORTOISE; RIPARIAN HABITAT; UPLAND VEGETATION; XERORIPARIAN]

1103. McBride,JR; Strahan,J (1984):

Establishment and survival of woody riparian species on gravel bars of an intermittent stream. The American Midland Naturalist 112(2), 235-245.

Seedling establishment and survival were studied on gravel bars of Dry Creek, California. Gravel bar species become established from May to July. Establishment was correlated with sediment texture. Salix spp. established preferentially on areas where surface sediment size was less than $0.2 \mathrm{~cm}$. Populus fremontii established more densely on areas of intermediate and large-sized sediments $(0.2-1.0$ $\mathrm{cm})$. Baccharis viminea dominated on the larger sediment sizes. Mortality resulting from drought was highest on bars where the stream had dried up prior to Sept 1. Seedlings which established in areas protected from the swiftest current were able to withstand the winter flows. At some locations, changes of gravel bar landforms resulted in significant losses of established trees as well as saplings and seedlings.
[RIPARIAN RESTORATION; RIPARIAN

SHRUBS; RIPARIAN VEGETATION; STREAM FLOW]

1104. McCall,JD; Knox,RF (1978): Riparian habitats in channelization projects. p.125-128. In: Proceedings of the national symposium on strategies for protection and management of floodplains, wetlands and other riparian ecosystems. 11-13 December 1978. Galloway Gardens, GA.

A joint Memorandum of Understanding (MOU) between state and federal agencies has fostered development and implementation of project features designed to protect or mitigate losses of fish, wildlife, and riparian habitats on constructed channels in Indiana. Successful implementation of such features has expanded their use to channel modification caused by highway bridge construction and legal county drain maintenance.

[CHANNEL DYNAMICS; RIPARIAN HABITAT]

1105. McClusky,DC; Brown,J; Bornholdt,D; Duff,DA; Winward,AH (1983): Willow planting for riparian habitat improvement. USDI Bureau of Land Management Technical Note 363. Denver, Co. $21 \mathrm{p}$.

This report is intended for field personnel who are interested in employing willow (Salix spp.)

planting as a technique for riparian habitat improvement. The technique discussed here deals only with vegetative cuttings of willows because they are the easiest to obtain, lowest in cost, usually locally acclimated, and provide a good project benefit/cost ratio.

[CUTTINGS; PLANTINGS; RIPARIAN RESTORA'IION; WILLOW]

1106. McComb,WC; McGarigal,K; Anthony,RG (1993): Small mammal and amphibian abundance in streamside and upslope habitats of mature Douglas-fir stands, western Oregon. Northwest Science 67(1), 7-15.

Capture rates of small mammals and amphibians were compared between streamside and upslope habitats along 700-m transects in each of six mature Douglas-fir stands, 1988. Equitability and diversity of small mammal communities were higher along streamside than upslope transects. There was no difference in small mammal or amphibian species richness per transect between streamside and upslope transects. Capture rates of marsh shrews, Pacific jumping mice, long-tailed voles, white-footed voles, and Dunn's salamanders were higher along 
streamside than upslope transects. Capture rates of western red-backed voles, Townsend's chipmunks, crecping voles, Trowbridge's shrews, and Ensatina salamanders were higher along upslope than streamside transects. Capture rates of marsh shrews, Pacific jumping mice, deer mice, shrew-moles, and Pacific shrews, decreased with distance from the stream along transriparian transects. Capture rates of western red-backed voles increased with distance from the stream.

[AMPHIBIANS; RIPARIAN HABITAT; SMALL MAMMALS]

1107. McComb,WC; Sedell,JR; Buchholz,TD (1990): Dam-site selection by beavers in an eastern Oregon Basin. Great Basin Naturalist 50(3), 273-281.

The authors compared physical and vegetative characteristics at 14 dam sites occupied by beaver with those at 41 unoccupied reaches to identify features important to dam-site selection in eastern Oregon. Stream reaches with dams were shallower and had a lower gradient than unoccupied reaches. Beaver did not build dams at sites with a rock substrate. Bank slopes at occupied reaches were not as steep as unoccupied reaches; and occupied stream reaches had greater tree canopy cover, especially of thin-leaf alder, than did unused reaches. Four habitat suitability models for beaver were also tested with positive results.

[BEAVER; CLASSIFICATION; RIPARIAN HABITAT]

1108. McConnell,CA (1979): Stream channel renovation methods to mitigate natural resource losses. p.611-614. Swanson, GA [ed.]. In: The mitigation symposium: A national workshop for mitigating losses of fish and wildlife habitat. USDA Forest Service. General Technical Report RM-65.

Stream channel renovation methods, using a blend of hand labor crews with light equipment where possible and heavy equipment where necessary, were used to minimize damages to natural resources on the Wolf River in Tennessee. Methods, work guidelines, and results are discussed.

[CHANNEL DYNAMICS; HABITAT MANAGEMENT; RIPARIAN RESTORATION]

1109. McCurdy,MK (1989): Public trust protection for wetlands. Environmental Law 19, 683-721.

The speed and scale at which man can harm the environment today calls for legal tools that are flexible and comprehensive in their application. The public trust doctrine offers courts a common-law method for protecting changing public expectations in natural resources. Traditionally, courts applied the doctrine to protect certain public uses of navigable waterways. The evolution of the doctrine within the water area reflects judicial willingness to apply it to new situations. The next logical extension of the trust is to wetlands.

[PUBLIC TRUST DOCTRINE; RIPARIAN HABITAT; WETLANDS]

1110. McDermid, $R$ (1993): A view of the lower Deschutes River planning process. p.311-315. In: Tellman,B; Cortner,HJ; Wallace,MG; DeBano,LF; Hamre, RH [tech. coord.]. Riparian management: Common threads and shared interests. USDA Forest Service. General Technical Report RM-226.

These certain factors encountered in the process were critical to success: 1) embark on a well-defined mission; 2) all participants must bring honesty and credibility into the process and maintain it throughout; 3) continuity of personnel must be maintained; 4) in a public process, the public matters; 5) do not rush important decisions; and 6) a plan serves no purpose unless it is successfully implemented.

[PLANNING; RIPARIAN HABITAT; RIVER ECOLOGY]

1111. McDevitt,H (1979): Public users' perspective of the grazing issue. p.71-74. In: Cope,OB [ed.]. Forum -- Grazing and riparian/stream ecosystems. 3-4 November 1979.

Denver, CO. Trout Unlimited, Inc.

Many publics do not understand the use of the public domain, but others understand it very well. They are beginning to ask questions like, "Why should a man inherit and then deed to his children semi-exclusive use of public land at less than the market price?" Most western groups are more interested in keeping everybody on the public lands than in foreclosing someone's future or trying to go back to the old dominant-use theory. [GRAZING IMPACTS; PUBLIC COMMENT; RIPARIAN ISSUES]

1112. McGarigal,K; McComb,WC (1992): Streamside versus upslope breeding bird communities in the central Oregon Coast Range. Journal of Wildlife Management 56(1), 10-23.

Despite perceived ecological and management significance of streamside areas in the coniferous and 
mixed deciduous-coniferous forests of the Pacific Northwest, there is little empirical data on the relative importance of streamside habitat to area avifauna. This paper examines breeding bird species diversity, richness, evenness, and individual species' abundance between streamside and upslope areas in mature, unmanaged forest stands. Bird community composition and structure differed between streamside and upslope areas. Streamsides exclusively contributed only 9 percent of the species versus 33 percent in the uplands. Vegetation structure and composition may have been responsible for observed bird distributions. Management of riparian areas alone may not meet the needs of several bird species. The authors suggest that a landscape-level approach addressing both upslope and riparian habitat may be more effective in meeting the needs of breeding bird communities.

[AVIAN ECOLOGY; RIPARIAN HABITAT]

1113. McGinnies,WG; McComb,AL; Fletcher,JE (1963): Role of watersheds and forests in the arid west. American Association for the Advancement of Science Pub. 74, 277-307.

The problems of increasing streamflow from watersheds are discussed. Snow as a streamflow source, interception of rain, evapotranspiration and transpiration losses, phreatophyte problems, vegetation and floods, management to increase yields, flood control, wind erosion and shelter belts, water erosion and sedimentation, and research in forest management problems are all considered. [EROSION CONTROL; HYDROLOGY; SEDIMENTATION; STREAM FLOW; WATERSHED]

1114. McIntosh,BA; Sedell,JR; Smith,JE; Wissmar,RC; Clarke,SE; Reeves,GH; Brown,LA (1994): Historical changes in fish habitat for select river basins of Eastern Oregon and Washington. Northwest Science 68, 36-53.

From 1934 to 1942 the Bureau of Fisheries surveyed more than $8,000 \mathrm{~km}$ of streams in the Columbia River Basin to determine the condition of fish habitat. Changes in fish habitat over time were evaluated by resurveying a subset of the historically surveyed streams from 1990 to 1992. Many streams were as degraded from past use practices (e.g. timber harvest, splash dams, stream channelization, livestock grazing, and mining) as before the 1930's. Differences in land-use histories partially explain current fish habitat conditions and declines in anadromous fish runs. Strategies to protect, restore, and maintain anadromous and resident fish habitat need ecosystem approaches that protect as well as restore the remaining habitats.

[ANADROMOUS FISH; LAND USE; RIPARIAN

HABITAT; RIPARIAN RESTORATION]

1115. McKee,A; Means,JE; Moir,WH; Franklin,JF (1987): First-year recovery of upland and riparian vegetation in the devastated area around Mount St. Helens. p. 168-187. In: Mount St Helens 1980: Botanical consequences of the explosive eruption. [Ed: Bilderback,DE] University of California Press, Berkeley, CA. In the first growing season following the 1980 eruption of Mount Saint Helens, no vascular plants were found in the regions subjected to pyuroclastic flows. Clear-cut sites showed the highest plant cover. Riparian areas had the greatest species richness, probably because of more favorable microsites found along streams. Favorable microsites were also critical for plant survival and regrowth in upland habitats. Virtually all the live plants were perennials that had sprouted from the pre-eruption soil and had penetrated the ash or been protected by a snow pack. [PLANT COMMUNITIES; RIPARIAN HABITAT; RIPARIAN RESTORATION]

1116. McKinstry,MC; Anderson,SH (1999): Attitudes of private- and public-land managers in Wyoming, USA, toward beaver. Environmental Management 23(1), 95-101.

A mail survey concerning beaver was disseminated during 1993. Primary concerns about beaver damage centered on: blocked irrigation ditches, girdled timber, blocked culverts, and flooded roads, pastures and crops (decreasing order of importance). Primary benefits perceived were: elevated water tables, increased riparian vegetation, and increased stock watering opportunities (increasing order of importance). [BEAVER; RIPARIAN HABITAT]

1117. McLemore,CE; Meehan,WR (1988): Invertebrates of Meadow Creek, Union County, Orcgon, and their use as food by trout. USDA Forest Service Research Paper PNW-RP-394. Portland, OR. 13 p.

From 1976 to 1980 , invertebrates were collected from several reaches of Meadow Creek in eastern Oregon. Five sampling methods were used: benthos, drift, sticky traps, water traps and fish stomachs. A total of 372 taxa were identified, of which 239 were used as food by rainbow trout and steelhead (Salmo gairdneri Richardson). Of the taxa found in trout stomachs, 71 (29.5 percent) were terrestrial. 
[AQUATIC ECOSYSTEMS; INVERTEBRATES; RIPARIAN HABITAT; SALMONIDS; TROUT]

1118. McNatt,RM; Hallock,RJ; Anderson,AW (1980): Riparian habitat and instream flow studies; Lower Verde River: Fort McDowell Reservation, Arizona. Riparian Habitat Analysis Group. USDI Fish and Wildlife Service.

Albuquerque, NM.

Riparian habitats are the most biologically productive areas in the Southwest. Only about 15 percent of the original riparian habitat remains in Arizona. This proportion is even smaller when only Sonoran Desert riparian areas are considered. The Lower Verde River is unique for its assemblage of mixed habitats and its outstanding productivity. [FISHERIES; RIPARIAN HABITAT; STREAM FLOW]

1119. Meador,MR; Layher,AO (1998): Instream sand and gravel mining: Environmental issues and regulatory process in the United States. Fisheries 23(11), 6 p.

The extraction of sand and gravel can significantly affect the physical, chemical, and biological characteristics of mined streams. This paper presents an overview of a symposium held by the American Fisheries Society in San Antonio, Texas. Conclusions from that symposium suggest that complex physiochemical and biotic responses to disturbances such as channel incision and alteration of riparian vegetation determine the effects of instream mining. Understanding geomorphic processes can provide insight into the effects of mining on stream function. Multidisciplinary empirical studies are needed to determine the relative effects of mining vs. other natural human-induced stream alterations. Mining regulations are frequently complicated, conflictive, or unclear. Dialogue between experts is a necessary first step to protective policies.

[MINING IMPACTS; POLICY; RIPARIAN VEGETATION]

1120. Medin,DE; Clary,WP (1980): Bird and small mammal populations in a grazed and ungrazed riparian habitat in Idaho. USDA Forest Service Research Paper INT-425. Ogden, UT. 8 p.

A survey of bird and small mammal populations (spring and later summer, respectively, in 1988 and 1989) in two 9 ha plots, one placed at the upstream end of a 122 ha grazing exclosure (grazing excluded from 1975), the other placed in the adjacent upstream grazed riparian zone. The Summit Creek study area is located in Custer County, Idaho, in the Little Lost River drainage. In 1989, there was little difference between grazed and ungrazed habitats in total breeding bird density, but presence of shorebirds in the grazed area caused the tendency for greater species richness, bird biomass and bird species diversity in the grazed habitat as compared with the ungrazed habitat. Small mammal populations were higher on the grazed than the ungrazed plots but species richness and diversity of the small mammal communities were higher in the ungrazed habitat. IAVIFAUNA; BIODIVERSITY; GRAZING IMPACTS; RIPARIAN HABITAT; SMALL MAMMALS]

1121. Medin,DE; Clary,WP (1989): Small mammal populations in a grazed and ungrazed riparian habitat in Nevada. Res.Pap. INT-413. Ogden, UT. USDA Forest Service. Research paper INT-413. 6p.

Community composition and relative abundance of small mammal populations in grazed and exclosed riparian zones at $6200 \mathrm{ft}$, northeastern Nevada, were monitored in late summer. The numbers of species trapped and the total numbers of individuals trapped were greater inside the protected areas than in the grazed areas. Species observed: deer mouse (Peromyscus maniculatus), western jumping mouse (Zapus princeps), least chipmunk (Tamias minimus), Great Basin pocket mouse (Perognathus parvus), golden-mantled ground squirrel (Spermophilus lateralis), vagrant shrew (Sorex vagrans), long-tailed vole (Microtus longiclaudus), montane vole (Microtus montanus), Townsend's ground squirrel (Spermophilus townsendii), northern pocket gopher (Thomomys talpoides), and bushy-tailed woodrat (Neotoma cinerea).

[BIODIVERSITY; GRAZING IMPACTS; RIPARIAN HABITAT; SMALL MAMMALS]

1122. Medin,DE; Clary,WP (1990): Bird populations in and adjacent to a beaver pond ecosystem in Idaho. USDA Forest Service. Research Paper INT-432. 6 p.

Breeding bird populations and community organizations were compared between a bcaver pond habitat dominated by willows and an adjacent riparian habitat. Total bird density in the ponded habitat was three times that of the nonponded habitat. Bird biomass, bird species richness, and bird species diversity were $3.49,3.25$, and 1.67 times higher, respectively, in the beaver pond habitat. [AVIAN ECOLOGY; BEAVER; RIPARIAN HABITAT] 
1123. Medin,DE; Clary,WP (1991): Small mammals of a beaver pond ecosystem and adjacent riparian habitat in Idaho. USDA Forest Service. Research Paper INT-445. 4 p.

Small mammal populations and community organization were compared between a beaver pond habitat dominated by willows and an adjacent non-willow riparian habitat. Small mammal relative density was 3.06 times higher and standing crop biomass was 2.71 times higher in the beaver pond habitat than in the adjacent non-ponded habitat. There were no pronounced differences between the two habitats in small mammal species richness or species diversity.

[BEAVER; RIPARIAN HABITAT; SMALL MAMMALS; WILLOW]

\section{Medin,DE; Clary,WP (1991): Breeding} bird populations in a grazed and ungrazed riparian habitat in Nevada. USDA Forest Service. Research Paper INT-441. 7 p.

Breeding bird populations and bird community organization were compared between a grazed and ungrazed aspen-willow riparian habitat. There were no differences between the two sites in bird density, species richness, species composition, or other attributes. There were also no pronounced differences between the sites in total density or total standing crop biomass of a nine-species guild of riparian birds. There were no obvious relationships between the responses of individual bird species and any physiognomic differences in the vegetation of the two habitats.

[AVIAN ECOLOGY; GRAZING IMPACTS; RIPARIAN HABITAT]

1125. Medin,DE; Torquemada,KE (1988): Beaver in western North America: An annotated bibliography, 1966 to 1986. USDA Forest Service. General Technical Report INT-242.18 p.

This annotated bibliography of 206 references is provided as a working tool for natural resource specialists, land-use planners and others charged with managing beavers and their habitats.

[BEAVER; BIBLIOGRAPHY; RIPARIAN HABITAT; RIPARIAN RESTORATION]

1126. Medina,AL (1990): Possible effects of residential development on streamflow, riparian plant communities, and fisheries on small mountain streams in central Arizona. Forest Ecology and Management 33/34, 351-361.

Increased residential development along small mountain streams within pine forests in central
Arizona has surged in the last 20 years and presents a potential threat to riparian plant communities because it can alter the nature of streamflow from perennial to ephemeral. The change in streamflow increases water stress on riparian plants along those streams. Cultural activities associated with residential development that alter streamflows are water diversions, groundwater pumping, and changes in land use. Measurements of tree densities and stand composition of Arizona alder and box elder showed that perennial streams had greater tree densities in all diameter classes, compared with ephemeral streams where small-diameter trees were absent. Xylem water potential measurements decreased more rapidly on trees occupying ephemeral reaches than on trees of comparable reaches of perennial strcams during the summer. The increase in water stress in trees growing along ephemeral stream reaches may be responsible for the lower plant densities and lack of seedling establishment measured. Trout populations also declined when streamflow changed from perennial to ephemeral.

[FISHERIES; RIPARIAN PLANTS; STREAM FLOW; TROUT]

1127. Medina,AL (1996): Native aquatic plants and ecological conditions of southwestern wetlands and riparian areas. p.329-335. In: Shaw,DW; Finch,DM [tech. coord.]. Desired future conditions for Southwestern riparian ecosystems: Bringing interests and concerns together. USDA Forest Service. General Technical Report RM-GTR-272.

The determination of the ecological condition of wetland and riparian habitats has been the focus of research by many scientists, because of the importance to understand the processes and related functions of these systems. Research on montane woodland and riparian systems has shown the relative importance of native aquatic plants in maintaining these systems in a functional condition. The presence or absence of key species is used as an indicator of the ecological condition, and desired ecological condition of wetlands and riparian habitat can be expressed in terms of the species composition and abundance of native aquatic plants. This type of information is needed by resource managers in defining the endpoint of their management actions. Information is presented on the functional role of these species in sustaining the biological and physical integrity of these habitats.

[AQUA'IIC PLANTS; ECOLOGICAL CONDITION; RIPARIAN HABITAT; WETLANDS] 
1128. Medina,AL; Baker,Jr,MB; Neary,DG (1996): Desirable functional processes: $A$ conceptual approach for evaluating ecological condition. p.302-311. In: Shaw, DW; Finch, DM [tech. coord.]. Desired future conditions for Southwestern riparian ecosystems. USDA Forest Service. General Technical Report RM-GTR-272.

Determining what "desired future condition" actually means has been viewed as a moving target approach for developing ecosystem management plans. The difficulty arises from trying to define what the desired conditions are for any given site. In addition, definitions may be plagued with inconsistencies, contention and argument, indeterminate time frames, and less than the best knowledge available. Herein, we propose a conceptual approach called "Desirable Functional Processcs", or DFP, for cvaluating the ecological condition of an ecosystem or parts thereof. It is founded on the premise that ecosystems and their components display varied degrees of functionality. It is based on the degree to which one can observe the interaction of ongoing processes involving the vegetation, soils, and hydrological components that determine the functionality of a system. Hence, an ecosystem or its components are considered functional if the processes observed are those that move the system to a higher stale of dynamic equilibrium, as opposed to a state that is dysfunctional and demonstrates a trend toward system degradation. The identification of processes and their functional status requires a multidisciplinary approach, wherein most elements of the environment are examined to determine functioning condition. Examples using a watershed approach are used to illustrate the concept and its framework. As a concept, it recognizes the public's needs in the decision-making process, and as such provides a mechanism by which the resource managers can communicate environmental concerns in a non-argumentative manner.

[DESIRED FUTURE CONDITIONS; ECOLOGICAL CONDITION; PLANNING; RIPARIAN HABITAT]

1129. Medina,AL; Clark,SC (1988): Stream channel and vegetation changes in sections of McKnight Creek, New Mexico. Great Basin Naturalist 48(3), 373-381.

The effects of grazing on stream channel morphology and riparian vegetation were insignificant compared with channel adjustments caused by wildfire in the headwaters, high amounts of sedimentation in the upper channel and storm events. This result exemplifies the importance of overall watershed condition to channel stability and plant communities in the riparian zone. [CHANNEL MORPHOLOGY; GRAZING IMPACTS; RIPARIAN VEGETATION]

1130. Meehan,WE; Swanson,FJ; Sedell,JR (1977): Influence of riparian vegetation on aquatic ecosystems with particular reference to salmonid fishes and their food supply. p.137-145. In: Johnson,RR; Jones,DA [tech.coord.|. Importance, preservation, and management of riparian habitats: A symposium. 9 July 1977 . Tucson, AZ. USDA Forest Service. General Technical Report RM-43.

The total stream ecosystem including the habitat of salmonids is profoundly influenced by the riparian zonc. Shade and organic debris from the riparian zone control the food base of the stream and the large woody debris influences channel morphology. Temporal and spatial changes in the riparian zone, the indirect influences of riparian vegetation on salmonids, and the effects of man's activities are addressed.

[FISHERIES; RIPARIAN HABITAT; SALMONIDS; WOODY DEBRIS]

1131. Meehan,WR (1996): Influence of riparian canopy on macroinvertebrate composition and food habits of juvenile salmonids in several Oregon streams. USDA Forest Service. Research Paper PNW-RP-496. 14 p.

The community composition of macroinvertebrates and the feeding habits of juvenile salmonids were studied in eight Oregon streams. Benthic, drift, sticky trap, and water trap samples were taken over a period of three years, along with stomach samples of the fish. Samples were taken in stream reaches with and without canopy. The main effects, fish diet vs. macroinvertebrate composition and canopied vs. noncanopied stream conditions, were highly significant.

[CANOPY; MACROINVERTEBRATES; RIPARIAN HABITAT; SALMONIDS]

1132. Meehan,WR; Platts,WS (1978): Livestock grazing and the aquatic environment. Journal of Soil and Water Conservation 33(6), 274-278.

Contemporary grazing systems seek to improve livestock production while protecting resources. Resource managers need to know how these grazing systems influence other resources, including anadromous and resident cold water fish populations. Researchers also need to know what the pristine or 
natural conditions of streams were prior to these uses. Such areas could be preserved as study areas to furnish baseline data. The result of such studies may be guidelines for predicting the effects of various grazing strategies on the condition and productivity of stream/riparian systems.

[FISHERIES; GRAZING IMPACTS; RIPARIAN HABITAT]

1133. Meehan,WR; Swanson,FJ; Sedell,JR (1977): Influences of riparian vegetation on aquatic ecosystems with particular reference to salmonid fishes and their food supply. p.137-145. In: Johnson,RR; Jones,DA [tech. coord.]. Symposium on the importance, preservation and management of the riparian habitat. 9 July 1977. Tucson, AZ. USDA Forest Service. General Technical Report RM-43.

Riparian zones have important influences on the total stream ecosystem including salmonid habitat. Shade and organic detritus from the riparian zone control the food base of the stream and large, woody debris influences channel morphology. Temporal and spatial changes in the riparian zone, the indirect influences of riparian vegetation on salmonids, and the effects of man's activities are discussed. [FISHERIES; RIPARIAN HABITAT; RIPARIAN VEGETATION; STREAM ECOLOGY]

1134. Meents,JK; Anderson,BW; Ohmart,RD (1981): Sensitivity of riparian birds to habitat loss. p.619-625. In: Warner,RE; Hendrix,KM |eds.|. Proceedings of the California riparian systems conference. 17-19 September 1981. Davis, CA.

The extent and composition of riparian plant communities in the Lower Colorado River valley have historically been altered, primarily by man. Some of these communities are disappearing (cottonwood and mesquite) and others are expanding (salt-cedar and arrow-weed). In this study, the avian community associated with riparian vegetation was examined and avian habitat specialists were identified. Nearly all specialists were concentrated in cottonwood/willow or honey mesquite communities. Salt-cedar generally supported no avian species with narrow habitat breadth.

[AVIAN ECOLOGY; CLASSIFICATION; RIPARIAN HABITAT]

1135. Megahan,WF (1982): Channel sediment storage behind obstructions in forested drainage basins draining the granitic bedrock of the Idaho batholith. p.114-121. In: Proceedings of the workshop on sediment budgets and routing in forested drainage basins. USDA Forest Service. General Technical Report PNW-141.

The total volume of sediment stored behind obstructions varied between drainage basins and years in response to changes in bankfull channel width and annual peak-flow rates, respectively. Logs were the most important type of obstruction because they had the greatest longevity and stored the greatest amount of sediment. An average of 15 times more sediment was stored behind obstructions than was delivered to the mouths of the drainages as annual average sediment yield. Logging reduced total channel-sediment storage behind obstructions because many natural obstructions were destroyed by felling and subsequent clearing operations to remove logging debris from channels. Storage behind obstructions is an important component of the overall sediment routing through forested drainage basins. [CHANNEL MORPHOLOGY; SEDIMENTATION; SEDIMENT TRANSPORT]

1136. Megahan,WF (1985): Evaluating effects of land use on sedimentation - a case for sediment budgeting. Hydrological Science and Technology 1(1), 13-16.

Understanding the linkages between erosion and sedimentation could help meet present needs for water quality monitoring and evaluation of environmental impacts. Development of sediment budgets to account for watershed erosion processes and zones of sediment storage is an approach to provide this understanding. A sediment budget for forested watersheds in the mountainous zone of the interior US is presented along with data to quantify selected budget components. The sediment budget, with certain modifications, is applicable to watersheds anywhere.

[CHANNEL MORPHOLOGY; SEDIMENTATION; SEDIMENT TRANSPORT]

\section{Megahan,WF (1987): Increased} sedimentation following helicopter logging and prescribed burning on granitic soil. p.259-260. In: Erosion and sedimentation in the Pacific Rim: Proceedings of the International Association of Hydrological Sciences. 3-7 August 1987. Oregon State University; Corvallis, OR. IAHS publication No.165.

This paper describes a study of the effects of clear-cut logging by helicopter, and associated prescribed burning on sediment yields. Annual sediment yields averaged a 100 percent increase resulting from the timber harvest. Accelerated sedimentation continued to persist nine years after 
logging. Accelerated sedimentation was apparently caused by active erosion within the cutting units. [HYDROLOGY; LOGGING IMPACTS; SEDIMENTATION; SOILS]

1138. Megahan,WF; Kidd,WF (1972): Effects of logging and logging roads on erosion and sediment deposition from steep terrain. Journal of Forestry 70(3):136-141.

Five years of data collection indicated that there were no differences in the erosion resulting from jammer and skyline logging, respectively. However, sediment dam data obtained concurrently showed that logging operations alone, not including roads, increased sediment production by a factor of approximately 0.6 over the natural sedimentation rate. Roads associated with the jammer logging system increased sediment production an average of about 750 times the natural rate for six years following production.

[EROSION; LOGGING IMPACTS; ROAD IMPACTS; SEDIMENTATION]

1139. Megahan,WF; King,JG; Scyedbagheri,KA (1995): Hydrologic and erosional responses of a granitic watershed to helicopter logging and broadcast burning. Forest Science 41(4), 777-795.

Effects of helicopter logging and prescribed burning on streamflow and sediment yields from headwater drainages in the Idaho Batholith were evaluated, using paired watersheds monitored from 1966 to 1986. In the fall of 1976,23 percent of a 162 ha watershed was clear-cut. All the cutting units were on south-facing slupes. Helicopter logging was followed by broadcast burning on cutting units. Streamflow parameters showed little change in response to logging and burning. However, total annual sediment yields increased an average of 97 percent in the 10 years following logging, with the largest increases occurring in the years of highest sediment yields. About 94 percent of the increased sediment yields was attributed to accelerated surface erosion on the cutting units. Accelerated erosion persisted on the cutting units throughout the study period. The accelerated surface erosion occurred primarily as a result of the prescribed burning rather than the helicopter logging; surface erosion rates on the burned areas were about 66 times greater than those on undisturbed slopes.

[EROSION; HY DROLOGY; LOGGING IMPACTS; PRESCRIBED BURNING; SEDIMENTATION; STREAM FLOW]

1140. Megahan,WF; King,PN (1985):
Identification of critical areas on forest lands for control of non-point sources of pollution. Environmental Management 9(1), 7-17.

Pollution associated with forest lands is of a nonpoint character and is of two general types. One type involves changes in naturally occurring water constituents caused by the disruption of the ecosystem by various practices. This includes changes in sediment, dissolved chemical transport, and water temperature. The second type of pollutant consists of exotic substances introduced by management practices and includes bacteriological pollutants and chemicals such as pesticides, fertilizers, and fire retardants. Most non-point pollution problems on forest lands can be controlled by careful planning and management of specific control areas. Critical areas include sites with high mass and surface erosion hazards, overland flow areas, and the riparian zone.

[LOGGING IMPACTS; NON-POINT SOURCE POLLUTION; SOILS; WATER QUALITY]

1141. Megahan,WF; Nowlin,RA (1976): Sediment storage in channels draining small forested watersheds in the mountains of central Idaho. p .4-115 to 4-126. In: Proceedings of the 3rd federal interagency sediment conference. Denver, $\mathbf{C O}$.

The role of sediment storage was studied in channels draining seven small forested watersheds in central Idaho. Data collection included an inventory of sediment deposited behind channel obstructions, detailed surveys of channel cross sections, and measurements of annual sediment yields in sediment detention reservoirs. The channel cross sections were used in evaluating annual changes in the total volume of sediment stored on channel bottoms. Annual watershed erosion was determined by entering the annual sediment yields and the annual change in stored sediment into a continuity equation. [GEOMORPHOLOGY; SEDIMENTATION; SEDIMENT TRANSPORT]

1142. Megahan,WF; Potyondy,JP; Seyedbagheri,KA (1992): Best management practices and cumulative effects from sedimentation in the South Fork Salmon River: An Idaho case study. p. 401-414. In: Watershed management: Balancing sustainability and environmental change. [Ed: Naiman,RJ]. Springer-Verlag.

Poor land use, including intensive unregulated logging from 1940 through the mid-1960s, contributed to massive cumulative effects from 
sedimentation in Idaho's South Fork Salmon River (SFSR) by 1965 . Severe damage to valuable salmon and steelhead habitat resulted. Present-day management practices, properly implemented, have the potential of reducing sediment yields by about 45 to 95 percent compared with yields caused by historical land use. Cumulative effects analysis is a useful tool for evaluating management alternatives. Some increases in sedimentation are unavoidable even using the most cautious logging and roading methods. However, much of the sedimentation in the SFSR and other drainages could have been avoided if logging and road construction had followed best management practices.

[BEST MANAGEMENT PRACTICES; LOGGING IMPACTS; RIPARIAN RESTORATION; ROAD IMPACTS; SEDIMENTATION]

1143. Melton,BL; Hoover,RL; Moore,RL; Pfankuch, D.J (1984): Aquatic and riparian wildlife. Chapter 6. p.261-301.In: Managing forested lands for wildlife. [Fds: Hoover,RI; Wills, DL/ Colorado Division of Wildlife in cooperation with USDA Forest Service, Rocky Mountain Region. Denver, CO.

Riparian/aquatic ecosystems are important areas for both man and wildlife. The unique characteristics of riparian zones result in a greater use by a larger variety of users than occurs in any other ecosystem. The ecological roles between riparian, aquatic, and upland ecosystems are so complex that these interrelationships have not been completely determined or defined. The high degree of connectedness and intertwining links between these ecosystems makes them highly sensitive to disturbance. It takes knowledge and appreciation of the structure and functions of aquatic/riparian ecosystems in order to exercise the deliberate management needed to protect and enhance these very limited and unique landscapes.

[AQUATIC ECOSYSTEMS; RIPARIAN ECOLOGY; RIPARIAN HABITAT]

1144. Mentor,Jr.,J. (1998): Trading water. p.325-333. In: Potts, DF [ed.]. Range management and water resources: Proceedings of the AWRA specialty conference. American Water Resources Association. 27-29 May 1998. Reno, NV.

Water transfers reflect greater efficiencies in agricultural water use, conversion of farm land to other uses, and demographic trends toward increased urbanization. Moreover, many significant environmental impacts caused by developing new water sources can be avoided by transfers. This paper describes history, legal bases, methods of reallocation, and case studies.

[WATER LAW; WATER RIGHTS]

\section{Merendino,MT; Smith,LM; Murkin,HR;} Pederson, RL (1990): The response of prairie wetland vegetation to seasonality of drawdown. Wildlife Society Bulletin 18, 245-251.

Diversity and productivity of prairie wetland flora are maintained by cyclic wet and dry periods that can be either natural or man-induced. This study evaluated the effects of four drawdown dates on recruitment of species from the seed bank. Season of drawdown affected the abundance, species richness, and flowering of wetland vegetation. Overall shoot densities were highest for a May 15 drawdown, with alkali bulrush the dominant species. The number of flowering shoots was highest in the June 15 drawdown. Cattail dominated the June 15 drawdown and purple loosestrife reached maximum densities. Mid-summer drawdowns (July 15) and late summer drawdowns (August 15) were characterized by low species abundance and absence of seed production. [RIPARIAN HABITAT; WATER CYCLES; WETLANDS]

1146. Merigliano,M (1997): Flood-plain and vegetation dynamics along the Upper Snake River, Idaho. Ph.D. Dissertation, University of Idaho, Moscow, ID.

Flood control has been the main factor limiting cottonwood regeneration on the South Fork of the Snake River. Hydrologic, geomorphic, and botanical evidence indicates that most cottonwood regeneration occurred soon after flood events having a 10-year flood interval. Sediment deposits that originated after the Palisades dam closure are less extensive and have less topographic relief than those deposited under natural conditions. This change has resulted in smaller cottonwood patches and a slow but definite decline in forest extent. Successional processes have a strong influence during the first few decades after initial colonization, but edaphic factors, which vary greatly over space, result in large shifts in understory species composition independent of deposit age and succession.

[CHANNEL MORPHOLOGY; COTTONWOOD; IIYDROLOGY; SUCCESSION]

1147. Merigliano,MF (1996): Ecology and management of the South Fork Snake River cottonwood forest. Technical Bulletin 96-9. Idaho BLM Technical Bulletin. USDI Bureau of Land Management. Boise, ID. 79 p. 
This report summarizes an investigation of the cottonwood ecosystem along the South Fork Snake River from Palisades Dam to Heise, Idaho. Vegetation dynamics, with emphasis on the cottonwood component, were the primary foci of this project, in which the relationship between riparian vegetation and the physical processes of the river were examined. Water flow at this location is dominated by snowmelt and sediment load is strongly influenced by glacial deposits. Usually stable, the primary channel can migrate considerable distances during very high discharges. Floods were the dominant disturbance factor before the dam closure and most of the cottonwood forest established on sediment deposited during large floods. Smaller floods since dam closure have been less conducive to cottonwood/willow regeneration so that the forest area is shrinking and becoming relatively older. [COTTONWOOD; FLOOD IMPACTS; GALLERY FOREST; RIPARIAN HABITAT; STREAM FLOW]

1148. Merritt,RW; Lawson,DL (1978): Leaf litter processing in floodplain stream communities. p. 93-105. In: Proceedings of the Symposium on national riparian ecosystems: Strategies for the protection and management of floodplain wetlands and other riparian ecosystems. 11-13 December 1978. Callaway Gardens, GA.

This research was based on the hypothesis that the floodplain serves as a preprocessing area for stream allocthonous flow. The major season for leaf litter processing in the floodplain was in the spring which was related to abiotic and biotic factors. Tethered leaves and coarse mesh bags containing confined litter degraded at a significantly faster rate than leaf litter in medium or fine mesh bags. The major time for stream litter processing occurred in the fall. Overall ecological processes occurring in the floodplain were similar to those occurring in the stream, although the timing of leaf litter processing activity differed.

[AQUATIC ECOSYSTEMS; MACROINVERTEBRATES; RIPARIAN ECOLOGY; RIPARIAN HABITAT]

1149. Meyer,JL (1990): A blackwater perspective of riverine ecosystems. BioScience 40(9), 643-651.

Streams and rivers are vital natural resources. They provide fresh water to support a growing human population as well as transport and treatment of waste water. They are valuable for recreation and fisheries, providing an essential source of protein in many countries. Streams and their riparian wetlands are the habitat for diverse assemblages of species. When Europeans first colonized this North America, streams and rivers were used for transportation and were the arteries of the continent. Today they are used instead as kidneys - processing and purifying the wastes of an industrialized society. More complete understanding of these systems in the future would be facilitated by the following studies: 1) quantification of rates of exchange of nutrients and organic matter between different components of stream ecosystems plus an assessment of factors controlling those rates; 2) assessments of the significance of the microbial food web as a pathway of organic carbon transfer and nutrient spiraling in flowing waters; and 3) whole system experimental manipulations to develop an understanding of factors controlling lotic ecosystem function and structure.

[FOOD WEBS; LOTIC ECOSYSTEMS; NUTRIENT CYCLES; RESEARCH; RIPARIAN RESTORATION; RIVER ECOLOGY; WETLANDS]

1150. Meyer,K (1993): The Mt. Shasta Meadows Restoration Project. p.189-190. In: Tellman,B; Cortner,HJ; Wallace, G; DeBano,LF; Hamre,RH [tech. coord.|. Riparian management: Common threads and shared interests. USDA Forest Service. General Technical Report RM-226.

The project was initiated to halt human induced degradation and reclaim the ecological and cultural integrity of fragile sub-alpine meadow systems on Mt. Shasta. This paper describes the creative solutions and managerial implications of restoring sub-alpine meadows while understanding and cducating a varied and diverse user public. [ECOLOGICAL INTEGRITY; MEADOWS; RIPARIAN RESTORATION]

1151. Meyer,PA (1985): Public values for riparian ecosystems: Experimental results in the West and implications for the Grand Canyon. p.417-20. In: Johnson,RR; Ziebell,CD; Patton,DR; Ffolliott,PF; Hamre,RH [tech. coord.]. Riparian ecosystems and their management: Reconciling conflicting uses. 16-18 April 1985. Tucson, AZ. USDA Forest Service. General Technical Report RM-120.

Economic, psychological, and legal arguments are presented for use of compensatory procedures in valuing riparian resource protection and restoration activities. Values from studies in California and Washington are reported and implications of those for the Grand Canyon are considered. 
[HUMAN IMPACTS; RIPARIAN HABITAT; RIPARIAN VALUES]

1152. Meyer,PA (1986): Valuing riparian habitat. A presentation to the USDA Forest Service. Philip A. Meyer, Consultant. P.O. Box 1152, Davis, CA, 95617. 10 p.

Economic importance of riparian habitat for Indian peoples can be established by again identifying impacting linkages, with ceremonial use, subsistence and commerce, and then placing those impacts in the dual contexts of cultural significance and tribal resource capability.

[ECONOMICS; RIPARIAN HABITAT]

1153. Meyer,PA (draft): Valuing habitat supportive of fish and wildlife. Meyer Resources, Inc; Davis, CA; 24 p. [ECONOMICS; FISHERIES; RIPARIAN HABITAT]

1154. Meyers,LH (draft - 1984): Woody riparian survey. USDI Bureau of Land Management, Dillon Resource Area; Dillon, MT. 16 p. [INVENTORY; MONITORING; RIPARIAN HABITAT]

1155. Meyers, LH (draft): Impacts of livestock grazing systems on riparian habitats in southwestern Montana. USDI Bureau of Land Management, Dillon Resource Area; Dillon, MT. $19 \mathrm{p}$.

[GRAZING IMPACTS; GRAZING TREATMENTS; RIPARIAN HABITAT]

1156. Michael,ED (1987): Creating wetlands along highways. p.50-55. In: Proceedings of the Fourth symposium on environmental concerns in rights-of-way management. 25-28 October 1987. Indianapolis, IN.

This paper describes guidelines for creating wetlands along highways. Studies were conducted in WV but findings apply to any areas having hilly terrain. Sites conducive to wetland creation are: 1) waste areas; 2) old streambeds; 3) existing streams perpendicular to the highway; 4) drainage channels parallel to the highway; 5) interchanges; and 6) rest areas. For site selection, the following guidelines should be used: 1) size of at least one acre; 2) site should be visible to passing motorists; 3 ) other wetlands should be nearby; 4) site should be bordered by shrubs or trees; and 5) site should have a dependable water source. Wetlands associated with highways reduce pollution and make travel more enjoyable due to the diversity of scenery and wildlife provided.

[CREATED WETLANDS; RIPARIAN HABITAT; WETLANDS]

1157. Michael,Jr.,JH, (1998): Pacific salmon spawner escapement goals for the Skagit River watershed as determined by nutrient cycling considerations. Northwest Science 72(4), 239-248.

Habitat loss, introduction of non-native stocks and species, and over fishing have all contributed to the decline of Pacific Salmon. Historically, huge numbers of salmon carcasses provided entire watersheds with nutrients derived from the ocean. Diminished populations and transport of these nutrients out of the watersheds has caused a nutrient deficiency compared to times when populations were large. This nutrient deficiency may be hampering recovery of salmon and other animal populations. The author estimated the biomass of salmon carcasses necessary to support nesting song birds, wintering bald eagles, and salmonid smolt production in the Skagit River watershed in Washington. The proposed spawner escapement goals thus estimated were 150 percent to 680 percent higher than the current spawner escapement goals for salmon in the watershed.

[FISH HABITAT; NUTRIENT CYCLES; SKAGIT RIVER]

1158. Michael,JL; Neary,DG; Wells,MJM (1989): Picloram movement in soil solution and streamflow from a coastal plain forest. Journal of Environmental Quality 18, 89-95.

A study of the movement, on- and off-site, of the herbicide picloram and its residues, following aerial application of picloram to four forested watersheds. Movement was monitored in the mineral soil, soil solution, groundwater and streams. Most of the initial off-site movement came from a perennial stream that had been inadvertently treated, but subsequent storm runoff was the largest contributor to stream contamination.

[HERBICIDES; RIPARIAN FOREST; RIPARIAN HABITAT; WATER QUALITY]

1159. Mih,WC; Bailey,GC (1979): A machine for mitigation of salmonid spawning habitat from silting. p.645-648. In: Swanson,GA |ed.]. The mitigation symposium: A national workshop on mitigating losses of fish and wildlife habitat. USDA Forest Service. General Technical Report RM-65.

A machine developed to remove silt and 
sediments from spawning gravels utilizes high-velocity hydraulic jets, a suction system, and separation system. The unit travels in the streams during the cleaning operation, and sprays the removed silt on the stream banks above the high water level.

[RIPARIAN RESTORAIION; SALMONIDS; SILT REMOVAL; SPAWNING HABITAT]

1160. Miller,LK; Schneller-McDonald,K (1988): Wetland bibliographic data bases. p.43-48. In: Mutz,KM; Cooper,DJ; Scott,ML; Miller,LK [eds.]. Restoration, creation, and management of wetland and riparian ecosystems in the American West. Proceedings of the symposium. 14-16 November 1988. Denver, CO. Rocky Mountain Chapter of the Society of Wetland Scientists.

The paper is an overview of the structure of the Wetland Values Citation Data Base (WVCDB) and the Wetland Creation/Restoration Data Base (CREATE). [BIBLIOGRAPHY; CREATED WETLANDS; WETLANDS]

1161. Miller,RK; Enote,JE; Martinez,CL (1996): Tribal experiences and lessons learned in riparian ecosystem restoration. p.198-202. In: Shaw,DW; Finch,DM [tech. coord.]. Desired future condition of Southwestern riparian ecosystems: Bringing interests and concerns together. USDA Forest Service. General Technical Report RM-GTR-272.

Riparian ecosystems have been part of the culture of land use of native peoples in the Southwest United States for thousands of years. The experiences of tribal riparian initiatives to incorporate modern elements of environment and development with cultural needs are relatively few. This paper describes tribal case histories and examples in riparian management which may advance discussions of cultural values in resource management for rural and developing communities such as those on tribal lands in the United States.

[CULTURAL VALUES; RIPARIAN HABITAT; RIPARIAN MANAGEMENT ZONE; TRIBAL LANDS]

1162. Miller,TB; Johnson,FD (1986): Sampling and data analyses of narrow, variable-width gallery forests over environmental gradients. Tropical Ecology 27, 132-142.

A system for sampling and data analyses for narrow, variable-width gallery forests is described. Gallery forests studies were along steep tributary streams of a deep river canyon in the western US. A series of transects, perpendicular to the stream, was designed to sample riparian vegetation plus that of adjacent vegetation types. Data analysis consisted of two-dimensional ordination, discriminant analysis, and polythetic-agglomerative classification. Results showed that species can be related to environmental parameters and to each other and that community types can be designated and similarly related.

Authors suggest that this sampling/data analysis system can be successfully applied to gallery forests or other riparian vegetation in narrow stream courses. [CLASSIFICATION; GALLERY FOREST; RIPARIAN HABITAT; RIPARIAN VEGETATION]

1163. Miller,WW; Blank,RR; Marcus,JA (1998): Inorganic $\mathbf{N}$ and $P$ from post-snowmelt Sierran riparian and upland soil cores. p.447-455. In: Potts, DF [ed.]. Rangeland management and water resources: Proceedings of the AWRA specialty conference. American Water Resources Association. 27-29 May 1998. Reno, NV.

Watershed disturbance has been suggested as a possible mechanism for accelerated nutrient input into Lake Tahoe, Nevada and California. This study investigated the interaction of site (riparian, upland non-forested, and upland forested) and soil depth on magnitude of $\mathrm{N}$ and $\mathrm{P}$ discharge. Leachate from the riparian soil cores had higher $(\mathrm{P}<0.05)$ concentrations and total discharge of $\mathrm{N}$ either of the other two site types. Soil core leachate from non-forested sites contained greater $P$ than the forested or riparian sites. Differences among parameter discharge characteristics are indicative of the complexities of inorganic nutrient transport in watersheds of the Sierra Nevada.

[NUTRIENT CYCLES; WATER QUALITY; WATERSHED]

1164. Mills,BM (1995): Cows and creeks. Range Magazine 3(1), 52-54.

Meadow Creek, in eastern Oregon's Blue Mountains, has made a remarkable comeback since 1953 when it was overused, overgrazed, and over logged. Various trials tested the results of timing and intensity of grazing. Grass production was increased 1 to 4 times in response to grazing treatments. Riparian areas are resilient and can recover with good management. Grazing, if done properly, can be a compatible use of riparian areas. [GRAZING IMPACTS; LIVESTOCK EFFECTS; RIPARIAN]

1165. Milon,JW (1987): Optimizing non-point source controls in water quality regulation. Water 
Resources Bulletin 23(3), 387-396.

A stochastic programming framework was developed to evaluate the economic implications of reliability criteria and multiple effluent controls on non-point source pollution. An integrated watershed simulation model was used to generate probability distributions for agricultural practices. Results from the planning model indicate that reliability and multiple effluent constraints significantly increase the cost of non-point controls but the effects vary by control alternative. An evaluation of water quality objectives can be an important planning tool for designing non-point source controls for water quality regulation.

[BEST MANAGEMENT PRACTICES; NON-POINT SOURCE POLLUTION; WATER QUALITY]

1166. Minckley,WL; Rinne,JN (1985): Large woody debris in hot-desert streams: A historical review. Desert Plants 7(3), 142-153.

Large-particulate organic debris is denied to present-day desert streams because of interception by impoundments and as a result of decimation of formerly extensive riparian vegetation. Historical records indicate a substantial, but sporadic, input of coarse debris (from high-elevation forests), which was reduced to finer particles through molar action in canyon-bound reaches of desert rivers. Historical changes, functions of large debris in the systems, and probable future conditions are reviewed.

[HISTORIC RECORDS; RIPARIAN HABITAT; SOUTHWESTERN DESERT STREAMS; WOODY DEBRIS]

1167. Mink,LL (1993): Water banking in Idaho. p.248-252. In: Tellman,B; Cortner,HJ;

Wallace,MG; DeBano,LF; Hamre, RH [tech. coord. |. Riparian management: Common threads and shared interests. USDA Forest Service. General Technical Report RM-226.

The water banking process has undergone many changes in the last $60+$ years in Idaho. More modifications are necessary to make these water banks more responsive to the needs of each basin. [WATER BANKS; WATER QUALITY; WATER RIGHTS]

1168. Mink,LL; Belt,GH (1993): Idaho riparian cooperative - is Idaho ready? History of starting a riparian cooperative. p.247. In: Tellman,B; Cortner, HJ; Wallace,MG; BeBano,LF; Hamre, RH [tech. coord.]. Riparian management: Common threads and shared interests. USDA
Forest Service. General Technical Report RM-226.

The Idaho Water Resources Research Institute, University of Idaho, coordinated meetings with state and federal agencies and user groups, which led to the establishment of the Idaho Riparian Cooperative. The mission of the IRC is to provide information to improve the management of riparian-wetland systems in Idaho.

[PARTNERSHIPS; RIPARIAN HABITAT; RIPARIAN MANAGEMENT ZONE]

1169. Minkley,WL; Clark,TO (1984): Formation and destruction of a Gila River mesquite bosque community. Desert Plants 6(1), 23-30.

Evidence is presented for repeated formation and destruction of a Mesquite bosque community on a Gila River terrace in eastern Arizona. Terrace formation was induced by coarse alluvial cone produced by flooding in an ephemeral tributary, followed by vegetative colonization culminating in mesquite. Destruction was accomplished by sustained flooding in the mainstream Gila River.

[BOSQUE; FLOOD IMPACTS; RIPARIAN

HABITAT; RIPARIAN VEGETATION]

1170. Minshall,GW; Brock,JT; Varley,JD (1989): Wildfires and Yellowstone's stream ecosystems. BioScience 39(10), 707-715.

Fires of the magnitude such as those that burned during 1988 in the Greater Yellowstone Area can have profound effects on the ecology of streams. The extent of the near-term effects of fire on stream ecosystems and the rates of return to pre-fire conditions are largely dependent on the degree of disruption of the watershed and stream channel in the first few years after fire. The difference appears to be due primarily to the size of the watershed and the intensity of the fire. The chance occurrence of intense summer thunder storms is also a factor. Three scenarios or alternative trajectories are presented for potential responses to the different degrees of disturbance resulting from the fire.

[FIRE IMPACTS; RIPARIAN HABITAT]

\section{Minshall,GW; Jensen,SE; Platts,WS} (1989): The ecology of stream and riparian habitats of the Great Basin region: A community profile. USDI Fish and Wildlife Service. Biological Report 85. 7-24, 142.

Proposes a hierarchical framework for classification of riparian ecosystems of the Great Basin hydrographic region: hydrologic unit (e.g. region, subregion, basin, subbasin, and tributary 
basin); geomorphic valley form (e.g. glacial valleys, fluvial valleys, alluvial valleys, and lacustrine basins); water regime (e.g. permanently flooded, semi-permanently flooded, saturated, seasonally flooded, and sub-irrigated); physiognomy of the community (e.g. forest, shrub, herb, and moss/lichen, and non-vegetated physionomic classes such as cobble, gravel, and silt bars); community type, based on floristic similarities in both the understory and overstory; and descriptors, based on the functional attributes of the riparian ecosystems.

[CLASSIFICATION; GEOMORPHOLOGY; HYDROLOGY; RIPARIAN HABITAT; SOILS; SPATIAL SCALE]

1172. Minshall,GW; Peterson,RC; Cummins,KW; Bott,TL; Sedell,JR; Cushing,CE; Vannote,RL (1983): Interbiome comparison of stream ecosystem dynamics. Ecological

Monographs 53(2), 1-25.

Studies were conducted in four distinct geographical areas in northern United States to examine changes in key ecosystem parameters: benthic organic matter (BOM), transported organic matter (TOM), community production and respiration, leaf pack decomposition, and functional feeding-group composition along gradients of increasing stream size. The results for each parameter are presented and compared between sites. The postulated gradual change in a stream's ecosystem structure and function is supported by this study. Regional and local deviations are explained by: 1) watershed climate and geology; 2) riparian conditions; 3 ) tributaries; and 4) location specific lithology and geomorphology.

[AQUATIC ECOSYSTEMS; BENTHIC BIOMASS; GEOMORPHOLOGY; NUTRIENT CYCLES; ORGANIC DEBRIS; STREAM ECOLOGY]

1173. Moerlins,JE; Herndon,RC; Lambou,VW; Gebhard,RL (1990): Proximity of Washington landfills to wetlands and deep water habitats: Data on individual landfills. US Environmental Protection Agency. EPA/600/07. Las Vegas, NV.

Sanitary landfills can cause considerable harm to sensitive ecosystems if they are not properly located, designed, and managed. This study in Washington documents the proximity of sanitary landfills to wetlands and deep water habitats. The nearness or proximity of landfills was determined by drawing three concentric regions around each landfill at $1 / 4$ $\mathrm{mi}, 1 / 2 \mathrm{mi}$, and $1 \mathrm{mile}$. Sensitive ecosystems can be affected directly by habitat alteration or, indirectly, through the migration of contaminants from landfills.
[CONTAMINATION; POLLUTION; RIPARIAN

HABITAT; SANITARY LANDFILLS; WETLANDS]

1174. Mollard,JD (1973): Air photo interpretation of fluvial features. p.341. In: Fluvial processes and sedimentation. Proceedings of hydrology symposium. 8-9 May 1973. Edmonton, Alberta. National Research Council. Canada.

This paper discusses the approach and techniques used by the photo interpreter studying river patterns and features - what might be termed "riverscape morphology". Emphasis is placed on the air photo distinguishing features of different river channel and floodplain patterns and on the variables influencing them. The paper contains examples of a wide variety of stream types where air photo interpretation studies have been carried out. [AERIAL PHOTO; GEOMORPHOLOGY; HYDROLOGY]

1175. Molles,Jr.,MC; Crawford,CS; Ellis,LM; Valett,HM; Dahm,CN (1987): Managed floods: Restoration of riparian forest ecosystem structure and function along the Rio Grande. p.24. In: Abstracts. 1997 annual meeting of the Ecological Society of America jointly with the Nature Conservancy. Changing ecosystems: Natural and human influences. 10-14 August 1997. Albuquerque, NM.

Managed floods may be used to partially restore the structure and function of riparian forest ecosystems that have been isolated from historical flooding. Experimental floods were timed to coincide with historic spring "flood pulse"on the upper Rio Grande. Flooding reduced soil and air temperatures and altered soil-moisture dynamics during nonflooding periods. Flooding also increased the activity of decomposer and mycorrhizal fungi, increased rates of mass loss by leaves and wood, and increased forest floor respiration by three orders of magnitude. Floods reduced populations of exotic arthropods, while increasing numbers of native arthropods. The authors concluded that resuming the historic flood pulse initiated a process of riparian ecosystem reorganization.

[ARTHROPODS; DECOMPOSER FOOD CHAIN; FLOOD IMPACTS; RIPARIAN ECOLOGY]

1176. Molloy,DP; Struble,RH (1988): A simple and inexpensive method for determining stream discharge from a streambank. Journal of Freshwater Ecology 4(4), 477-481. 
A detailed protocol for the determination of stream discharge is presented which requires neither a current meter nor actual entry into stream water. The proposed flotation method (a 10-20 minute procedure) could be used with reasonable accuracy to determine discharge in small to moderate-sized streams.

[HYDROLOGY; STREAM ECOLOGY; STREAM FLOW]

1177. Monks, V (1996): The beauty of wetlands. National Wildlife June/July, 20-27.

Science is steadily advancing our understanding of the functions of wetlands and their benefits to society. If changes in laws such as the Clean Water $A c t$, however, already approved by the House of Representatives, are endorsed by the 104th Congress, as much as 95 percent of the remaining U.S. wetlands could be opened for development. Proposed legislation could also hinder efforts to preserve habitat for wide-ranging species. [BIODIVERSITY; CLEAN WATER ACT; RIPARIAN HABITAT; WETLANDS]

1178. Monsen,SB; McArthur,ED (1995): Implications of early Intermountain range and watershed restoration practices. p.16-25. In: Proceedings: Wildland shrub and arid land symposium. 19-21 October, 1993. Las Vegas, NV. USDA Forest Service. General Technical Report INT-GTR-315.

Ecological restoration of disturbed wildlands continues to gain acceptance as the most desirable approach to site improvement. However, some disturbed sites have been so seriously altered that native communities cannot recover. In addition, weeds are dominant over large areas, and appear more persistent and resilient than many native species. In these and related situations, introduced species and altered plant communities will have to be maintained to protect all resources. Previous site rehabilitation practices provide information to better restore disturbed watersheds, rangelands, and weed-infested sites. Previous research and project plantings have provided information to better identify sites that are suitable for restoration, and to define more appropriate planting practices. Native species and ecotypes have been identified and tested to define their range of adaptation and use in reconstructing native communities. Equipment has been developed to culture plants, prepare seedbeds, control weeds, and seed a variety of species. Considerable information can be gained by examining previous rehabilitation practices, including documentation of secondary succession of seeded as well as protected natural sites. This information is essential in developing sound restoration measures.

[DISTURBED WILDLANDS; RIPARIAN

RESTORATION; WATERSHED]

1179. Montana Department of Environmental Quality (1998): Montana stream management guide: 1998 revised edition. 34 p.

This guide provides information for landowners and managers, resource professionals, state and local decision-makers, and others interested in streams. Section 1 addresses the characteristics and behavior of healthy streams. Section 2 discusses management and restoration decisions, permits, and the involved agencies. Section 3 focuses on specific stream problems that are commonly encountered. [PERMITTING; RIPARIAN MANAGEMENT ZONE; RIPARIAN RESTORATION; STREAM ECOLOGY]

1180. Montana Riparian Association. (1987): Montana Riparian Association bibliography. University of Montana. Missoula, MT. 66 p.

This bibliography contains over 500 references on riparian management arranged alphabetically, without annotations. It was designed to be an open data base to accommodate future additions. [BIBLIOGRAPHY; RIPARIAN HABITAT; RIPARIAN MANAGEMENT ZONE]

1181. Montana Riparian Association. (1990): Management of riparian and wetland forested ecosystems in Montana. Fourth annual Montana Riparian Association workshop. 5-7 September 1990. Whitefish, MT.

The Montana Riparian Association published the proceedings of its 1990 workshop which consisted of twelve technical papers. Topics included: fisheries, forestry, streamside management zones, biodiversity, global warming effects, riparian classification and inventory.

[FISHERIES; RIPARIAN FOREST; RIPARIAN HABITAT; WETLANDS]

1182. Montgomery,DR; Grant,GE; Sullivan,K (1995): Watershed analysis as a framework for implementing ecosystem management. Water Resources Bulletin 31(3), 3.

Implementing ecosystem approaches to land use decision making and land management requires new methods for linking science and planning. Greater integration is critical because under ecosystem 
management sustainable levels of resource use are determined by coupling management objectives to landscape capabilities and capacities. Recent proposals for implementing ecosystem management employ analyses organized at a hierarchy of scales for analysis and planning. [ECOSYSTEM MANAGEMENT; RIPARIAN RESTORATION; SPATIAL SCALE; SUSTAINABILITY; WATERSHED]

1183. Montgomery,JM (1985): Bear Valley Creek, Idaho fish habitat enhancement project feasibility study. Prepared for the Shoshone-Bannock Tribes, Funded hy BPA Contract No. 83-359. (Prepared by James $M$. Montogomery, Consulting Engineers, Inc. 1301 Vista Ave., Boise, ID 83705). [HABITAT MANAGEMENT; RIPARIAN HABITAT]

1184. Moore,DRJ; Keddy,PA; Gaudet,CL; Wisheu,IC (1988): Conservation of wetlands: do infertile wetlands deserve a higher priority? Biological Conservation 47, 203-217. Infertile wetlands had higher species richness and many more rare species than fertile wetlands. Further, infertile wetlands had a greater range of vegetation types than did fertile wetlands. It is also probable that infertile wetlands are more sensitive to human disturbances. Therefore, infertile wetlands are more desirable for conservation than previously believed.

[BIODIVERSITY; RIPARIAN HABITAT; WETLANDS]

1185. Moore, $R$ (1993): River protection and rural communities. p.98-101. In: Tellman,B; Cortner,HJ; Wallace,MG; DeBano,LF; Hamre, RH [tech. coord.]. Riparian management: Common threads and shared interests. USDA Forest Service. General Technical Report RM-226.

This paper discusses creative financing. Before beginning a search for funds, project sponsors should have the total duration and scope of the project in order to determine who will benefit. Those individuals or groups can be pulled together for both the processes of decision-making and fund-raising. [RIPARIAN MANAGEMENT ZONE; RIPARIAN RESTORATION]

1186. Moreau,JK (1996): Placing large wood debris to restore salmonid habitat. p.58-64. In: National hydrology workshop proceedings. 27
April-1 May 1992. Phoenix, AZ. USDA Forest Service. General Technical Report RM-GTR-279.

Fishery managers are placing large wood debris to restore habitats in salmonid streams in the Pacific Northwest. Desirable skills for habitat restoration practitioners are described. A process is presented to plan, implement, and monitor fish habitat restoration projects to maximize the potential for success. Innovative technologies adapted for large woody debris projects are described and sources for tools and materials are presented.

[FISHERIES; RIPARIAN RESTORATION; SALMONIDS; STREAM IMPROVEMENTS]

1187. Morganweck, $R$ (1989): Status and trends of wetlands in the conterminous U.S. Renewable Resources Journal 7(3), 6-7.

A summary of wetland area, ownership, conservation and losses is presented that demonstrates the demographic trends in U.S. wetlands.

[WETLAND LOSSES; WETLANDS]

1188. Morgenson, G (1992): Vegetative propagation of poplar and willow. p.84-86. In: Proceedings, Intermountain Forest Nursery Association. 12-16 August 1991. Park City, Utah. USDA Forest Service. Gencral Technical Report RM-211.

This paper discusses the processes involved in the propagation of poplar and willow from hardwood cuttings including stooling block establishment, cutting planting, growth, use of equipment, and chemical inputs.

[PLANT MATERIALS; PLANT PROPAGATION; RIPARIAN RESTORATION; RIPARIAN SHRUBS]

1189. Morris,J (1987): Evaluating the wetland resource. Journal of Environmental Management 24, 147-156.

This article provides an economic framework for examining the competition between agriculture and the environment. With particular reference to wetlands, it reviews possible methods for identifying and measuring costs, benefits, and impacts, and considers their contribution to resource decisions. [DRAINAGES; ECONOMICS; RIPARIAN HABITAT; WETLANDS]

1190. Morris,S; Moses, T (1999): Urban stream rehabilitation: A design and construction case study. Environmental Management 23(2), 165-177. 
In this case study, a meandering channel pattern was reestablished for about $280 \mathrm{~m}$ of straightened, dredged channel, a new floodplain was excavated, and a new riparian zone was replanted. The project was coordinated by a local nonprofit environmental organization, utilizing donated materials and a largely volunteer work force. The most important lesson learned from the project was that sponsoring agencies and clients need to be informed of the many steps and sequencing of properly constructed, complex stream rehabilitation projects and the time and cost requirements.

[RIPARIAN RESTORATION; VOLUNTEERS]

1191. Moseley,RK (1998): Riparian and wetland communities of 14 reference areas in southwestern Idaho. USDI Bureau of Land Management. Boise, ID. Technical Bulletin No. 98-5.

The purpose of this project was to assess the diversity of wetland and riparian communities of southwestern Idaho through field inventory and sampling, using high quality reference area, such as BLM Areas of Critical Environmental Concern and Research Natural Areas, and private conservation lands. The inventory was used to prepare a preliminary guide to riparian types of this region, including a key to their identification and supporting descriptive material. This guide can be expanded as additional material becomes available. [CLASSIFICATION; INVENTORY; RIPARIAN VEGETATION]

1192. Mosko,TL; Jeffers,BL; King,JG; Megahan,WF (1990):Streamflow data for undisturbed forested watersheds in central Idaho. USDA Forcst Service. Intermountain Research Station. General Technical Report INT-272. 334 p.

This report contains a summary of daily streamflows from 29 undisturbed, forested watersheds at Silver Creek, Tailholt Creek, and Horse Creek in the headwaters of the Idaho batholith region. Data sets span up to 20 years. Watersheds are described. These data provide baselines for quantifying the effects of subsequent timber harvest. [HYDROLOGY; RUNOFF; WATER YILLD; WATERSHED]

1193. Mosley,JC; Cook,PS; Griffis,AJ; O'Laughlin,JO (1997): Guideline for managing cattle grazing in riparian areas to protect water quality: Review of research and best management practices policy. Idaho Forest, Wildlife, and Range Policy Analysis Group Report No. 15.
University of Idaho.

Protecting water quality and providing forage for cattle are only two of the many functions of land area adjacent to water. This report addresses the water quality functions of riparian zones. It's purpose is to provide the management guidelines that will help livestock producers meet the goals of the Clean Water Act while grazing cattle in riparian areas. Depending upon the current condition of the particular riparian area, this could mean that the producer may have to change the timing, frequency, and intensity of grazing to maintain conditions that will protect water quality. These guidelines are based on a review of research results published in the scientific literature. The report addresses three fundamental questions about riparian grazing: 1) What management strategies are indicated by research? 2) How are Best Management Practices administered? 3) How does the state policy protect water quality?

[BEST MANAGEMENT PRACTICES; CLEAN WATER ACT; GRAZING IMPACTS; LIVESTOCK EFFECTS; RIPARIAN MANAGEMENT ZONE; WATFR QUALITY]

1194. Mount,J; Krausman,W; Finch,DM (1996): Riparian habitat change along the Isleta-Belen reach of the Rio Grande. p.58-61. In: Shaw,DW; Finch,DM [tech. coord.]. Desired future conditions for Southwestern riparian ecosystems: Bringing interests and concerns together. USDA Forest Service. General Technical Report RM-GTR-272.

The paper provides a summary of vegetation changes over an 11-year period (1984-1995) in the middle reach of the Rio Grande. Hink and Ohmart (1984) surveyed and mapped riparian vegetation along the middle Rio Grande as part of an extensive biological inventory conducted for the Army Corps of Engineers. The Isleta-Belen reach was field-assessed and remapped in 1995 to determine whether vegetation classes had changed substantially since the original survey. Over the past 11 years, the Rio Grande bosque vegetation has changed, and an assessment of structural types documents this aging process. In addition, the exotic woody species saltcedar and Russian olive have increased in cover, appearing as understories in Rio Grande cottonwood galleries and as independent vegetational communities. In some cases, these introduced species have replaced other vegetation such as the coyote willow. There was evidence of 31 fire events that altered vegetation.

[HISTORIC RECORDS; INVENTORY; RIO GRANDE; RIPARIAN HABITAT; RIPARIAN 


\section{VEGETATION]}

1195. Moyer,DL; Dahm,CN; Valett,HM; Thibault,JR; Marshall,MC (1998): Effects of livestock grazing on morphology, hydrology, and nutrient retention in four southwestern stream ecosystems. p.397-408. In: Potts,DF [ed.]. Rangeland management and water resources: Proceedings of the AWRA specialty conference. American Water Resources Association. 27-29 May 1998. Reno, NV.

Four streams in New Mexico were selected to determine how livestock grazing influences solute transport and nutrient retention. Comparisons were made of paired stream reaches where one reach was exposed to livestock grazing and complementary reach was protected. For each stream, morphology, hydrology, and nutrient retention were compared between grazed and non-grazed reaches. Grazed reaches exhibited increased dispersion and transient storage, and decreased surface water velocity. Nutrient retention associated with each reach type was determined by co-injecting a biologically active tracer (NaNO3) along with the conservative tracer. Nitrate uptake lengths were shorter in the grazed reaches. Decreased surface water velocities and increased width:depth ratios in the grazed reaches increased nitrate utilization in grazed reaches of these streams.

[GEOMORPHOLOGY; GRAZING IMPACTS; LIVESTOCK EFFECTS; NUTRIENT CYCLES; RIPARIAN ECOLOGY]

1196. Moyle,PB; Marchetti,MP; Baldridge,J; Taylor,TL (1998): Fish health and diversity: Justifying flows for a California stream. Fisheries 23(7), 6 p.

An advocacy group called the Putah Creek Council contributed to a successful court trial supporting fish conservation. California Fish and Wildlife Codes require that fish must be maintained in good condition below a dam. Good condition was defined to mean that there had to be healthy individual fish in healthy populations that were part of a healthy biotic community. This led to a conceptual model for instream flows for the creek that favored native resident and anadromous fishes. Recommendations from this model had four components: living space flows for the entire creek, resident native fish spawning and rearing flows, anadromous fish flows, and habitat maintenance flows. The trial judge, attempting to balance competing demands, ordered the implementation of the first two recommendations.
[FISH HABITAT; STREAM FLOW; WATER LAW]

1197. Munther,GL (1982): Beaver management in grazed riparian ecosystems. p.234-241. In: Proceedings of the Symposium on wildife-livestock relationships. 20-22 April 1981. Coeur d'Alene, ID.

Beaver activity has substantially influenced the structure of many low gradient streams and valley bottoms in western Montana. These areas, with their flat valley bottoms and low gradient streams, have high wildlife, fisheries, and livestock values. Because riparian zones are in delicate equilibrium with their surroundings, the removal of beaver through the elimination of habitat or over harvest often leads to dramatic changes in the valley bottom and its stream channel. Reductions in wildlife and fisheries habitat can result. Continued livestock grazing in the absence of beaver in some valley types eliminates shrubs, causes stream channel changes, and lowers water tables. Once the channel has eroded and the water table has lowered, livestock forage production is usually reduced, and vegetative type changes result in a less diverse wildlife community. The lower vegetative productivity in combination with a more active stream channel inhibit riparian recovery and necessitates substantial livestock management changes for recovery. Riparian management practices that increase the quality of this zone include: grazing systems that favor shrub production, regulation of beaver harvest, transplants, and reduction of livestock grazing.

[BEAVER; RIPARIAN IIABITAT; RIPARIAN RESTORATION]

1198. Murphy,HW; Albertson,J (1987): Fish Lake wildlife habitat: Study for silviculture treatment. In: Streamside management: Riparian wildlife and forestry interactions. An interdisciplinary symposium. 11-13 February 1987. University of Washington. Seattle, WA.

This poster paper compared managed and unmanaged riparian forest communities and emphasized the interrelationships of various wildlife species.

[RIPARIAN FOREST; RIPARIAN HABITAT]

1199. Murphy,ML; Koski,KV (1989): Input and depletion of woody debris in Alaska streams and implications for streamside management. North American Journal Fisheries Management 9, 427-436.

Natural rates of input and depletion of large 
woody debris (LWD) in southeast Alaska streams studied to provide a basis for managing streamside zones to maintain LWD for fish habitat after timber harvest. Because nearly all LWD is derived from within $30 \mathrm{~m}$ of the stream, the use of a $30-\mathrm{m}$ wide, unlogged buffer strip along both sides of the stream during timber harvest was recommended to maintain LWD.

[BUFFER STRIPS; LARGE WOODY DEBRIS; RIPARIAN FOREST; RIPARIAN HABITAT; SALMONIDS]

1200. Murphy,PJ; Agiurre,EJ (1985): Bed load or suspended loss. Hydraulic Engineer 111(1), 93-552.

The difference between the sediment transport and suspended load is explained and quantified. The mean and fluctuating components of the particle motion are studied by examining both components of the particle's dynamics in open channel flows. For sand particles, the time required for particles leaving the bed to attain the free fall velocity is shown to be the critical parameter for their saltation-suspension distinction. Examples are given.

[CHANNEL DYNAMICS; SEDIMENT

TRANSPORT]

1201. Mustard,EW; Rector,CD (1979):

Wetlands, irrigation, and salinity control: Lower Gunnison River Basin, Colorado. p.310-317. In:

Swanson,GA [ed.]. The mitigation symposium: A national workshop on mitigating losses of fish and wildlife habitats. USDA Forest Service. General Technical Report RM-65.

A total of 8,773 ha of wetlands was inventoried on a 72,800 ha area as part of an environmental assessment for a salinity control project in the Lower Gunnison River Basin, Colorado. Wetlands were evaluated for wildlife habitat value and use. Implementing measures to reduce salt loading to the Colorado River will cause wetland losses. Mitigation recommendations are provided.

[MITIGATION; RIPARIAN HABITAT;

SALINITY; WETLANDS]

1202. Mutz,KM; Cooper,DJ; Scott,ML; Miller,LK (1988): Restoration, creation, and management of wetland and riparian ecosystems in the American West. Proceedings of the Symposium. 14-16 November 1988. Denver, CO. Rocky Mountain Chapter of the Society of Wetland Scientists.

Plenary addresses were: public policy and Colorado wetlands; wetlands protection and water rights; a stream classification system; the influence of riparian/wetland systems on surface water quality; riparian wildlife habitats: more, worth less, and under invasion; and, mountain wetland vegetation dynamics.

[CREATED WETLANDS; POLICY; RIPARIAN

HABITAT; RIPARIAN RESTORATION; WATER

QUALITY; WATER RIGHTS; WETLAND

MITIGATION; WETLANDS]

1203. Myers,LH (1981): Grazing on stream riparian habitats in southwestern Montana. In: Proceedings of the 34th annual meeting of the Society for Range Management. 9-13 February 1981. Tulsa, OK.

Livestock grazing and riparian habitat management can be compatible on some streams if grazing systems are properly designed. No single type of grazing system has an apparent advantage but the frequency of heavy use and rest treatments seems to be the key factors. Grazing systems with hot season use (July 10 - September 1 in Montana) in more than one year out of three or four met riparian habitat goals in only 24 percent of sampled streams. Grazing systems lacking hot season use, or with no more than one hot season treatment in three or four years met riparian habitat management goals on 90 percent of evaluated streams. Livestock use may be incompatible with riparian management on some streams because of exceptional or unique biological values, frail channels, or rangeland phenology. The extended summer green season may be a key factor to success of grazing systems in southwest Montana. In areas with hot and dry summers, where green forage is largely limited to the riparian zone, grazing may have to be more restricted. In wetter areas of the West, riparian grazing management is more successful with less intensive management. [GRAZING IMPACTS; GRAZING TREATMENTS; LIVESTOCK EFFECTS]

1204. Myers,LH (1991): Managing livestock to minimize impacts on riparian areas. p.24-30. In: Roth,D; Bridges,C; Zimmerman,C [eds.]. What does riparian mean to me? Proceedings of the third annual convention. Colorado Riparian Association. 6-8 November 1991. Pueblo, CO.

Many factors must be considered in managing grazing on stream riparian sites. Some stream systems may be too frail or unstable to warrant grazing use either temporarily or permanently. Special riparian management pastures give the manager much more control in meeting recovery needs, while still allowing livestock use and 
simplifying upland site management.

[GRAZING IMPACTS; RIPARIAN

MANAGEMENT ZONE]

1205. Myers,LH (1987): Riparian inventory and monitoring. Montana BLM Riparian Technical Bulletin No.1. 38 p.

This bulletin describes the techniques used for inventorying and monitoring riparian sites in the Dillon Resource Area in southwestern Montana. The condition and vigor or deciduous, woody, wetland species were found to be valid indicators of general riparian site conditions and trend and provided adequate data for most management situations. [INVENTORY; MONITORING]

1206. Myers,LH (1989): Grazing and riparian management in southwestern Montana. p.117-120. In: Gresswell,RE; Barton,BA; Kershner,JL [eds.]. Riparian resource management. An educational workshop. USDI Bureau of Land Management. Billings, MT.

Standardized approaches to riparian grazing management are not practical. The results of 34 grazing systems in riparian zones are analyzed in terms of riparian recovery and important factors that apply to management in Montana are discussed. [GRAZING IMPACTS; GRAZING TREATMENTS]

1207. Myers,LH (1989): Riparian area management: Inventory and monitoring riparian areas. USDI Bureau of Land Management. Technical Reference 1737-3. 79 p.

The reference contains suggested techniques and procedures for riparian inventory and monitoring. It is intended to assist managers in determining needs. Extensive inventories utilize remote sensing, maps, existing data, and limited field analyses. Based on that information, the manager can decide to pursue intensive inventories based on resource values and site characters. Intensive inventories require detailed field examinations and data collection.

[INVENTORY; MONITORING; RIPARIAN HABITAT]

1208. Myers,LH; Thomas,A; Hines, B; Stalder,R; Wagner,R; Eshelman,K; Cooperrider,A; Boyd,R (1987): Riparian area management - inventory and monitoring. Review Draft. BLM Technical Reference TR-1737-2.92 p.

This document describes the techniques used for inventory and monitoring riparian sites in southwest Montana. The condition and vigor of deciduous, woody, wetland species were found to be valid indicators of general riparian site conditions and provided adequate data for most management situations. The techniques described here were specifically designed for application in southwest Montana.

[MONITORING; RIPARIAN HABITAT; RIPARIAN MANAGEMENT ZONE; TECHNIQUES]

1209. Myers, M (1993): Nichols Meadow

Restoration Project, Mariposa Ranger District, Sierra National Forest. p.191. In: Tellman,B;

Cortner,HJ; Wallace,MG; DeBano,LF;

Hamre, RH [tech. coord.]. Riparian management:

Common threads and shared interests. USDA

Forest Service. General Technical Report

RM-226.

Using contributed labor from the California Native Plant Society and European volunteers, the project stabilized head and sidewalls of a large gully, re-established ground cover, and replanted riparian vegetation along the stream channel. Structural work utilized a cellular soil confinement material called Geoweb to form retaining walls.

[CHANNEL DYNAMICS; RIPARIAN

RESTORATION; VOLUNTEERS]

1210. Myers,TJ; Swanson,S (1991): Aquatic habitat condition index, stream type, and livestock bank damage in northern Nevada. Water

Resources Bulletin 27(4), 667-677.

The quality of stream habitat varies for a variety of natural and anthropogenic reasons not identified by a condition index. However, many people use condition indices to indicate management needs or even direction. Stream types and levels of ungulate bank damage were related to estimates of aquatic habitat condition index and stream width parameters in a large data base. Soil and vegetation stability were highly correlated. Riparian area width did not vary significantly with either stream type or ungulate bank damage. Variation among stream types indicates that riparian management and monitoring should be stream type and reach specific.

[MONITORING; RIPARIAN CONDITION; RIPARIAN HABITAT]

1211. Nabhan,GP (1985): Riparian vegetation and indigenous Southwestern agriculture: Control of erosion, pests, and microclimate. p.232- 235. In: Johnson,RR; Ziebell,CD; Patton,DR; Ffolliott, PF; Hamre,RH [tech. coord.|. Riparian ecosystems and their management: Reconciling 
conflicting uses. 16-18 April 1985. Tucson, AZ. USDA Forest Service. General Technical Report RM-120.

Indigenous farmers in the American Southwest managed riparian vegetation adjacent to their agricultural fields for centuries. They planted, pruned, and encouraged phreatophytic tree species for flood and erosion control; soil fertility renewal; buffered field microclimates; and produced fuelwood. Those practices benefitted wildlife and plant genetic diversity.

[AGRICULTURAL IMPACTS; RIPARIAN HABITAT; RIPARIAN VEGETATION]

1212. Nachlinger,JL (1988): Soil-vegetation correlations in riparian and emergent wetlands, Lyon County, Nevada. USDI Fish and Wildlife Service Biological Report 88(17), 39.

The study tests a system for delineating wetlands by correlation of vegetation indices with soil types. Each plant was assigned a wetland indicator number, based on prepared plant lists or a provisional number for species not previously listed for the area. Vegetation indices included the wetland indicator and either the plant density or percent cover. See Eicher (1988) and Baad (1988) for similar studies in California and explanation of methods.

[CLASSIFICATION; PLANT COMMUNITIES; RIPARIAN HABITAT; SOILS]

1213. Nader,G; Tate,KW; Atwill,ER; Bushnell,J (1998): Water quality effect of rangeland beef cattle excrement. Rangelands 20(5), 19-25.

The evaluation of rangeland cattle excrement impacts on water quality require consideration of natural variability in the hydrologic cycle, the nutrient cycle, and the pathogen cycle, as well as how grazing modifies each of these processes. In order to understand and quantify the fate of nitrogen, as an example, on a grazed rangeland watershed several things must be considered: 1) quality and quantity of the forage; 2) retention by the animal; 3) losses through volatilization; 4) soil incorporation; 5) plant incorporation; and 6) spatial distribution of the feces and urine. All such factors make it difficult to quantify the amount of nutrient and pathogen loading that is attributable to rangeland beef cattle on a watershed.

[GRAZING IMPACTS; LIVESTOCK EFFECTS; NON-POINT SOURCE POLLUTION; NUTRIENT CYCLES; PATHOGENS; WATER QUALITY]

1214. Nader,GA; Tate,KW; Connor,MJ; AllenDiaz,B; Atwill,ER (1998): Evaluation of buffer zones to attenuate nutrient and sediment transport from hillslope pasture. p. 133. In: Potts,DF [ed.|. Rangeland management and water resources: Proceedings of the AWRA specialty conference. American Water Resources Association. 27-29 May 1998. Reno, NV.

Nutrient and total suspended solid (TSS) levels in runoff from hillslope pastures were analyzed to evaluate the effectiveness of $10 \mathrm{~m}$ buffer strips for attenuating these contaminants. Buffers were established by fencing the lower $10 \mathrm{~m}$ of the field, adjacent to the stream channel. There appeared to be limited reduction in $\mathrm{NO} 3$ and total $\mathrm{P}$ as a result of the buffer. There did appear to be a reduction of TSS, due more to the exclusion of livestock than to filtering action from the buffer.

[BUFFER STRIPS; GRAZING IMPACTS; LIVESTOCK EFFECTS; NON-POINT SOURCE POLLUTION; WATER QUALITY]

1215. Naiman,RJ; Johnston,CA; Kelley,JC (1988): Alteration of North Amcrican streams by beaver. BioScience 38(11), 753-762.

A review of changes that occur in the structure and dynamics of streams and related wetlands as beaver recolonize their historic habitat. These and other studies have produced two conceptual advances. These address the organizational patterns of drainage networks with beaver populations and the role of the beaver in the complex, dynamic pattern of vegetative patches on the landscape.

[BEAVER; CREATED WETLANDS; HYDROLOGY; RIPARIAN HABITAT]

1216. Naiman,RJ; Melillo,JM (1984): Nitrogen budget of a sub-aretic stream altered by beaver (Castor canadensis). Oecologia 62, 150-155.

Beaver influence stream ecosystems through their wood cutting and dam building activities. The authors measured rates of nitrogen dynamics to construct a nitrogen budget for a section of a second order stream and a beaver dam in that stream. The budget demonstrated the importance of sediment accumulations and an expanded wetted area to the annual nitrogen economy and to pathways of nitrogen cycling. After impoundment, changes included a reduction in allochthonous and an increase in nitrogen fixation by sediment microbes. Overall, the beaver-modified section accumulated 10 to the 3rd power more $\mathrm{N}$ than before modification. [BEAVER; NUTRIENT CYCLES; RIPARIAN HABITAT]

1217. Nanson,GC; Beach,HF (1977): Forest 
succession and sedimentation on a meandering river floodplain, northeast British Columbia, Canada. Journal of Biogeography 4, 229-251.

Examination of primary forest succession within two migrating bends of a river in northeast British Columbia provides information on the interrelationships between the geomorphic and biotic components of a meandering floodplain. Rapid sedimentation on the youngest ridges favors the establishment of a dense, nonreproducing balsam poplar stand of uniform age, and prevents the establishment of white spruce seedlings. Following an abrupt decline in overbank sedimentation on surfaces approximately 50 years old, white spruce rapidly colonize the bare mineral soil beneath the poplar canopy and form a dense, relatively even-aged stand. With the death of mature poplars on surfaces 100-150 years old, the spruce seedlings are released and develop into a mature, nonreproducing stand. This stand persists until its senescence on ridges 350400 years old. Here, a second similar but less evenaged spruce stand establishes, maturing in a like manner to the first, to eventually decline on ridges 500-550 years of age. Tree densities and overbank sedimentation achieve minimum values on floodplain surfaces greater than approximately 200 years in age. Negligible sediment deposition on these older surfaces is explained by the more open trunk density which permits relatively rapid overland flow which prevents the deposition of suspended sediment load. Sedimentation and vegetation appear to be strongly interrelated components within the total floodplain system.

[FOREST SUCCESSION; GEOMORPHOLOGY; RIPARIAN VEGETATION]

1218. Natural Resources Defense Council (1987): Citizen's handbook on water quality standards. NRDC. 1350 New York Ave. NW \#300, Washington, DC. 20005. 35 p. [CLEAN WATER ACT; WATER LAW; WATER QUALITY]

1219. Neale,CMU (1997): Classification and mapping of riparian systems using airborne multispcetral vidcography. Restoration Ecology 45(5), 103-112.

Multispectral airborne videography has become a useful tool for classifying and mapping riparian vegetation because its spectral and digital format has high spatial resolution. A description of the Utah State University airborne system is provided, along with the image processing steps used for developing finalized products. Examples of riparian applications using high resolution imagery are included. [MODELING; REMOTE SENSING; RIPARIAN RESTORATION]

1220. Neary,D; Ross,KC; Coleman,SS (1996): National hydrology workshop proceedings. 27 April -1 May 1992. Phoenix, AZ. USDA Forest Service. General Technical Report RM-279.

This publication contains 30 papers from the USDA Forest Service's National Hydrology Conference. Topics include: cumulative effects, external responsibilities, aquatic ecology, monitoring, large woody debris, non-point source pollution, riparian areas, water rights, fluvial geomorphology, land management planning, coastal zone management,channel maintenance, sediment modeling, wetlands, watershed rehabilitation, data management, and marketing hydrology programs. [HYDROLOGY; RIPARIAN VEGETATION; WATERSHED]

1221 Neary,DG; Medina,AL (1996): Geomorphic response of a montane riparian habitat to interactions of ungulates, vegetation, and hydrology. p.143-147. In: Shaw,DW; Finch,DM [tech. coord.]. Desired future conditions for Southwestern riparian ecosystems: Bringing interests and concerns together. USDA Forest Service. General Technical Report RM-GTR-272.

Wildcat Creek, a tributary of the Black River on the Apache-Sitgreaves National Forest is being studied to determine the impacts of cattle and elk grazing on riparian wet meadows. An intensive survey of a selected stream reach revealed a unique channel development involving an aggradation/degradation process in a pool-riffle sequence of an E-6 stream channel. Grazing and trampling impacts of elk and cattle were found to affect the process in two ways: 1) overgrazing of stream banks resulted in exposure of the soil fabric and loss during high flows, sloughing of banks, channel widening, and a reduction in the ability of plants to trap sediments; and 2) trampling at animal crossings initiated initiated a degradation of riffles by breaking down the armoring gravels which are held in place by native aquatic plants of the genera (Carex, Cyperus, Juncus, Glyceria, Scirpus, etc.) The importance of the aggradation/degradation process is in the long-term maintenance of montane cienegas in a quasi-stable condition with fully functional processes. [ELK GRAZING; GEOMORPHOLOGY; GRAZING IMPACTS; LIVESTOCK EFFECTS; RIPARIAN HABITAT] 
1222. Neary,DG; Michael,JL (1989): Effect of sulfometuron methyl on ground water and stream quality in coastal plain forest watersheds. Water Resources Bulletin 25, 617-623.

Sampling of a shallow ground water aquifer, $<1.5 \mathrm{~m}$ below ground surface, did not detect any sulfometuron methyl residues for 203 days after herbicide application. Lack of herbicide residue was attributed to low application rates, rapid hydrolysis in acidic soils and water, and dilution in streamflow. [GROUNDWATER; HERBICIDES; RIPARIAN HABITAT; WATER QUALITY]

1223. Nedeff,N (1989): Cooperative resource management on the Muleshoe Ranch Preserve. p.7-9. In: Gresswell,RE; Barton,BA; Kershner,JL [eds.]. Practical approaches to riparian resource management. An educational workshop. 8-11 May 1989. USDI Bureau of Land Management. Billings,MT.

The Muleshoe Ranch (22,182 ha) is a historic cattle ranch owned jointly by the Arizona Nature Conservancy, the Bureau of Land Management, and the Forest Service. One of the best watered areas in southern Arizona, the ranch supports seven perennial strcams and five spccies of rare native species.

Riparian forests and mesic shrublands also provide habitat to uncommon bird and mammal species. Riparian and watershed protection and enhancement are among the most important biological management objectives and serve to focus cooperative management activities between the three operating agencies.

[RIPARIAN HABITAT; RIPARIAN MANAGEMENT ZONE]

1224. Neely,BE (1991): Riparian communities of Colorado. p.42-45. In: Roth,D; Bridges, $C$; Zimmerman, $\mathrm{C}$ [eds.]. What does riparian mean to me? Proceedings of the third annual convention. Colorado Riparian Association. 6-8 November 1991. Pueblo, CO.

This presentation described the formation, by the Nature Conservancy, of the Rivers of the Rockies fund raising campaign. The initiative is responsive to the Conservancy's sense of urgency regarding loss of riparian and wetland areas and has identified approximately 30 sites along Colorado rivers for inventory and classification.

[INVENTORY; RIPARIAN HABITAT; RIPARIAN MANAGEMENT ZONE]

1225. Neff,DJ (1957): Ecological effects of beaver habitat abandonment in the Colorado Rockies.
Journal of Wildlife Management 21(1), 80-84.

The results of this study indicate that even on the most stable and physically suitable locations, the abandonment of a colony by beavers means the loss of aquatic habitat that is necessary for the survival of the trout fishery and the successful breeding of waterfowl. On streams where beaver ponds make possible a valuable trout fishing area, all due consideration should be given to maintaining the beaver population. Since food depletion is a primary cause of abandonment, effective methods of perpetuating the aspen type adjacent to such streams should be developed. Beaver populations should be kept well within the limits of available food supply and competition with big game and livestock should be minimized.

[BEAVER; RIPARIAN HABITAT]

\section{Negri,S (1989): The San Pedro riparian} area. In: Arizona Highways. April 1989, 18-33.

This is a topical article describing the geography, geology, hydrology, and ecology of the San Pedro Riparian Area. In 1986, the BLM acquired 36 miles of streamside habitat, which has since been designated as a natural preserve. [RIPARIAN HABITAT; SOUTHWESTERN DESERT STREAMS]

1227. Nehlsen, Willa (1997): Prioritizing watersheds in Oregon for salmon restoration. Restoration Ecology 5(4), 25-33.

The paper describes an ecosystem approach (the Bradbury framework) to prioritizing watersheds for restoration, and salmon recovery, and illustrates the approach with an example. The framework was applied at 3 spatial scales: 1) river basins within the north coast geographic area of Oregon; 2) watersheds within Tillamook Bay Basin; and 3) restoration activities at the watershed level. The sample application demonstrates that an ecosystem approach is particularly advantageous when data are limited. [RIPARIAN RESTORATION; SALMONIDS; SPATIAL SCALE; WATERSHED]

1228. Neill,CR; Mollard,JD (1982): Erosional processes and sediment yield in the upper Oldman River basin, Alberta, Canada. p.183-191. In: Recent developments in the explanation and prediction of erosion and sediment yield (Proceedings of the Exeter Symposium, July 1982). IAHS Publication No. 137.

This paper discusses the sediment yield and associated erosional processes in the upper Oldman basin, located in southwest Alberta. Suspended 
sediment yield averages $70 \mathrm{t} / \mathrm{km} /$ year, but varies greatly from year to year. Principal erosional features identified include stream channel instability, ravine erosion, grassland gullying, wind erosion, and gravity-induced mass movements. In general, they interpreted that erosional features are generally local in extent and erosion is associated with streams and rivers. The main source of man-made erosion appeared to arise from public roads and associated interference with the natural drainage. A potential for accelerated erosion appears to exist on grazing lands on substantial slopes. Erosion is minor in forested areas compared with agricultural areas.

[GEOMORPHOLOGY; LAND USE; SEDIMENT TRANSPORT; SOILS]

\section{Nelson,RW; Weller,EC (1984): A better} rationale for wetland management.

Environmental Management 8(4), 295-308.

Present federal wetland management strategy

(Section 404 of the Clean Water Act) does not account for the differences in the natural values of wetlands and their different vulnerability to development pressure. The strategy, aimed at reducing the regulatory burden, provides for different levels of wetland protection, primarily by designating certain activities in or affecting wetlands as essentially harmless, having only minor impacts even when considered for their cumulative effects. Such activities are authorized under general permits precluding any evaluation of project impacts. A sounder, yet practical, rationale for wetland management and regulatory relief should be linked to the scarcity of certain wetland habitats, the habitat diversity or carrying capacity, and the incremental losses already incurred from past development, and the incremental losses already incurred within the same wetland ecosystem. The regulatory effort should be concentrated where these characteristics indicate high value wetlands.

[RIPARIAN HABITAT; WETLANDS]

1230. Nelson,RL; Platts,WS; Casey,O (1987): Evidence for variability in spawning behavior of interior cutthroat trout in response to environmental uncertainty. Great Basin Naturalist 47(3), 480-487.

The fluctuating characteristics (numbers, biomass, condition, and young-adult ratios) of the Lahontan cutthroat trout population in Chimney Creek, Nevada, are discussed in relationship to the unpredictable and unstable habitat in which the population occurs. One possible means of adapting to environmental capriciousness, staggcred spawning, occurred during 1982, and clues to the cause of this unusual event are sought by examining the runoff hydrographs of a nearby watershed for 1981 through 1984. The management values of the environmental tolerance of these trout with respect to sectoring viable trout fisheries in degraded Great Basin streams are also considered.

[FISHERIES; RIPARIAN HABITAT; SPAWNING HABITAT]

1231. Nelson,SM; Anderson,DC (1994): An assessment of riparian environmental quality by using butterflies and disturbance susceptibility scores. The Southwestern Naturalist 39(2), 137142.

The butterfly community at a revegetated riparian site on the lower Colorado River near Parker, Arizona, was compared to that found in a reference riparian site. Data indicated that the herbaceous plant community, which was lacking at the revegetated site, was important to several butterfly taxa. An index using butterfly sensitivity to habitat change (species classified into risk groups) and number of taxa was developed to monitor revegetation projects and to determine restoration effectiveness.

[BUTTERFLIES; RIPARIAN RESTORATION]

1232. Nelson,W; Horak,G; Soloman,J (1978): Instream flow strategies for Idaho. USDI Fish and Wildlife Service OBS-78/38. 95 p.

[FISHERIES; HYDROLOGY; STREAM FLOW; WATER LAW; WATER RESOURCE MANAGEMENT]

1233. Nepf, HM (1999): Drag, turbulence, and diffusion in flow through emergent vegetation. Water Resources Research 35(2), 479-489.

At the scale of the plant stems and branches, aquatic plants convert mean kinetic energy into turbulent kinetic energy. The transfer of energy affects drag and turbulence intensity. A model was developed to describe the drag, turbulence, and diffusion for flow through emergent vegetation. This model was supported by laboratory and field observations.

[EMERGENT VEGETATION; MODELING; STREAM FLOW; WETLANDS]

1234. Newson,M (1994): Hydrology and the river environment. 1st ed. Oxford University Press, Cary, NC. 240 p.

This book presents a current account of environmental hydrology, a contemporary means of describing basic patterns of runoff, and a discussion 
of how hydrology is altered by development and industry. [HYDROLOGY; RUNOFF; WATERSHED]

1235. Newton,J (1984): Fifteen mile Creek riparian recovery, Wasco County, Oregon. p.8083. In: Bedell,TE [ed.]. Proceedings of 1984 Pacific Northwest range management short course; Range watersheds, riparian zones and economics: Interrelationships in management and use. 25-27 January 1984. Pendleton, OR. Oregon State University

Riparian recovery occurred after fencing and extended protection from livestock access and grazing.

[EXCLOSURES; GRAZING IMPACTS; RIPARIAN RESTORATION]

1236. Newton,M; Willis; WJ; Cole,E; Chan,S (1996): Enhancing riparian habitat for fish, wildlife, and timber in managed forests. Weed Technology 10, 429-438.

Riparian site production in managed forests can be focused to provide fish and wildlife habitat while yielding most of its productive capacity for other than amenity values. Establishment of habitat protection goals and objectives permits flexible means of implementing them. Once protection standards are set, intensive management of the woody cover depends on minimum disturbance methods for vegetation management and harvest. Several currently registered chemical products and nonchemical methods are helpful and safe for achieving yield and protective goals.

[RIPARIAN HABITAT; RIPARIAN RESTORATION; STREAM FLOW; WOODY DEBRIS]

1237. Niering,WA (1990): Vegetation dynamics in relation to wetland creation. p.479-486. In: Kusler,JA; Kentula,ME [eds.]. Wetland creation and restoration. Island Press, Washington, DC.,

The understanding of ecological processes involved in wetland vegetation development is essential to wetland managers concerned with wetland creation. Ascertaining a sound hydologic system is basic in any attempt to recreate a wetland system since the vegetation and associated fauna are dependent upon a consistent but usually fluctuating hydrologic regime. Any hydrologic manipulations can also greatly modify what species will become established in a given site or those that may decline in abundance. Traditional succession-climax dogma has limited usefulness in interpreting vegetative change. Thus, an understanding of the complex of factors involved in the process, including chance and coincidence, makes management more challenging. Since vegetation change is not necessarily predictable and orderly, as is sometimes thought, it is often difficult to predict the ultimate vegetation of a given site. Some wetland communities once created may be relatively stable; others may undergo directional or cyclic change. One of the major goals of wetland creation should be the persistence of the wetland as a self-perpetuating oscillating system, which is assured by assuring a sound hydrologic regime.

[HYDROLOGY; RIPARIAN VEGETATION; WETLANDS]

1238. Nilsson,C (1987): Distribution of stream edge vegetation along a gradient of current velocity. Ecology 75(2), 513-522. [CHANNEL DYNAMICS; GEOMORPHOLOGY; RIPARIAN VEGETATION; STREAM VELOCITY]

1239. Nilsson,C; Grelsson,G; Johansson,M; Sperens, $U$ (1989): Patterns of plant species richness along riverbanks. Ecology 70(1), 77-84.

Total species richness along two rivers increased with substrate heterogeneity and was at a maximum at intermediate levels of substrate fineness.

Observation coincides with the hypothesis that species diversity and environmental heterogeneity should be closely related along rivers. On the rivers studied, ice scour was most likely a cause of substrate heterogeneity, causing patchiness by erosion, transport and deposition of soil material, by affecting bank height (flood height) and channel width. [BIODIVERSITY; PLANT COMMUNITIES; RIPARIAN ECOLOGY; RIPARIAN HABITAT]

1240. Noh,L (1979): Grazing riparian/stream ecosystems on Federal lands --the livestock producers' viewpoint. p.3-4. In: Cope, OB [ed.]. Forum -- Grazing and riparian/stream ecosystems. 3-4 November 1978. Denver, CO. Trout Unlimited, Inc.

Most ranchers have realized that there can be problems with livestock grazing and riparian habitat. Often, he just doesn't know what to do. We should emphasize education programs for stockmen. There is no reason why livestock conventions and meetings on grazing management to enhance wildlife habitat could not be jointly sponsored by conservation organizations.

[ECONOMICS; GRAZING IMPACTS]

1241. Noon,KF (1989): Major implementation 
issues in protection of nation's wetlands.

Renewable Resources Journal 7(3), 14-15.

Major wetlands protection implementation issues are described that were derived from practical experience in Michigan. The six major issues are as follows: 1) lack of appreciation for wetlands benefits; 2) conflict between the goals of a wetlands protection policy and the economic goals of the landowner; 3 ) wetlands mapping inventories cannot substitute for onsite boundary determinations; 4) problems can arise during the implementation process; 5) define and standardize the methods used in determining the types and quantity of benefits derived from wetlands; and 6) lack of understanding of the actual success of mitigation efforts.

[POLICY; WETLANDS]

1242. Norcross, E; Calvo,G (1993): Private lands river protection: balancing private and public concerns. p.53-69. In: Tellman,B;

Cortner,HJ; Wallace,MG, DeBano,LF;

Hamre,RH [tech. coord.]. Riparian management: Common threads and shared interests. USDA Forest Service. General Technical Report RM226.

Rivers on private land have traditionally been protected by an assortment of state and federal legislation/programs. The authors present a summary and description of river protection and related environmental laws. They have also included a review of alternative river protection strategies and programs.

[POLICY; RIPARIAN HABITAT; RIVER ECOLOGY]

1243. Novak,MA; White,RG (1989): Impact of fire and flood on the trout population of Beaver Creek, Upper Missouri Basin, Montana. p.120126. In: Richardson,F; Hamre,RH [eds.]. Wild trout IV. Proceedings of the symposium. 18-19 September 1989. Mammoth, WY.

A 100-year flood in the Beaver Creek drainage was caused by a forest fire followed by an intense convectional rainstorm. The study documented changes in resident trout populations and use of the stream by spawning fish. Two months after the event, trout populations in the impacted portion of the stream were nearly eliminated. Within two years, numbers and biomass of rainbow trout had increased to 55 percent and 51 percent greater, respectively, than before the event. Rapid recovery of the rainbow trout population resulted from large spawning runs from the Missouri River.

[FIRE IMPACTS; FISHERIES; FLOOD IMPACTS;
RIPARIAN HABITAT; [ROUT]

1244. Nunnally,NR (1978): Improving channel efficiency without sacrificing fish and wildlife habitat: 'The case for stream restoration. p. 394399. In: Proceedings of the national riparian ecosystems symposium. 11-13 December 1978. Calloway Gardens, GA.

Stream restoration is a much more efficient means for improving hydraulic efficiency of streams than conventional channelization and is less expensive and less environmentally damaging. Restoration creates a more stable channel by removing debris, providing fairly uniform cross sections, and stabilizing stream banks with minimal disturbance of the streambed and riparian vegetation. [RIPARIAN RESTORATION]

1245. Oakley,A (1987): Kiparian management practices of the Bureau of Land Management. In: p. 191-196. Streamside management: Riparian wildlife and forestry interactions. An interdisciplinary symposium. 11-13 February 1987. University of Washington. Seattle, WA.

Current management practices for forest lands managed by Bureau of Land Management (BLM) in Oregon and Washington were developed through the land use planning process, including full public involvement under the National Environmental Policy Act. Environmental impact statements were prepared in which effects of planned forest management activities were analyzed and final decisions for managing riparian areas were subsequently made for each plan. The policies for preparing plans and managing BLM lands and resources are based on applicable federal laws, Executive Orders, regulations, manuals, policy statements and other guidance.

[POLICY; RIPARIAN FOREST; RIPARIAN HABITAT]

1246. Oakley,AL; Collins,JA; Everson,LB; Heller,DA; Howerton,JC; Vincent,RE (1985): Riparian zones and freshwater wetlands. p.57-80. In: Management of wildlife and fish habitats in forests of western Oregon and Washington. USDA Forest Service. Pacific Northwest Region.

When riparian zones and wetlands are in satisfactory condition for wildlife, the best management generally is to allow the natural ecosystems to function with minimal disruption. Rehabilitation of altered habitats can be hastened by various techniques which promote natural recovery to desired conditions and prevent further 
deterioration. Enhancement of habitat can often be accomplished by creating more diversity, but a thorough field examination should precede any plans to enhance or restore riparian and wetland habitats. Managers, with the advice of resource specialists, should seek creative ways to manage or improve these habitats.

[RIPARIAN HABITAT; RIPARIAN

VEGETATION; WETLANDS]

1247. Odgaard,AJ; Moscone,CE (1987): Streambank protection by submerged vanes. Hydraulic Engineer 113(4), 520-536.

A summary is given of the design, installation and performance of a system of submerged vanes

("lowa Vanes") for erosion protection in a bend of East Nishnabotna River, lowa. The vanes are small aspect ratio foils emplaced along the outer bank, at angles of 10-15 degrees with the mean flow, to direct the near bed current outward toward the bank. The system functions by eliminating, or reducing, the centrifugally induced helical motion of the flow (the root cause of bank undermining). The system was installed during the summer of 1985 . Its performance was evaluated with data obtained in surveys in the spring of 1986 . The system was found to effectively reduce velocity and scour along the bank without changing the energy slope of the channel. Areas of design improvements were identified. The summary includes a brief description of the theoretical and experimental background for the design. [RIPARIAN RESTORATION; SOILS; STREAMBANK PROTECTION; TECHNIQUES]

1248. Odum, EP (1985): Trends expected in stressed ecosystems. BioScience 35:419-422.

Ecosystems not suffering from unusual external perturbations nevertheless demonstrate certain well defined developmental trends. Disturbance tends to arrest or reverse these autogenic developments. Therefore, we can anticipate some ecosystem responses to stress - a syndrome comprising both input and output, stimulus and response. Trends expected in stresses ecosystems include changes in energetics, nutrient cycling, and community structure and function.

[ECOSYSTEM MANAGEMENT; NUTRIENT CYCLES; STRESS]

1249. Odum,WE (1988): Predicting ecosystem development following creation and restoration of wetlands. p.67-70. In: Zelazny,J; Feierbend,JS [eds.]. Increasing our wetland resources. National Wildlife Federation Proceedings. October 1987.
Washington DC.

Created wetlands offer an opportunity via monitoring and study to understand the processes of wetland development. Few projects have been followed for more than several years. Implementation of long-term monitoring may enable us to predict artificial wetland development and change with better precision.

[CREATED WETLANDS; ECOSYSTEM MANAGEMENT; MONITORING; RIPARIAN RESTORATION]

1250. Ogle,D (1990): Willow poles help restore streambanks. Idaho Range News, April, 1990. USDA Soil Conservation Service (Boise).

Willow cuttings and willow poles were planted to stabilize streambanks in the Henry's Lake area. Vertical banks on straight stream sections and meanders were planted. Snowmelt causing bank failure appeared to maintain the steep angles of unvegetated banks. Willow establishment reduced failures and resulted in shallower bank angles. [RIPARIAN RESTORATION; SOILS; STREAMBANK STABILITY]

1251. Ohlenbusch,PD; Jones,RD; Fuchs,EH (1998): A grazing land water quality education program for producers. p. 335-339. In: Potts,DF [ed.]. Rangeland management and water resources: Proceedings of the AWRA specialty conference. American Water Resources Association. 27-29 May 1998. Reno, NV.

Education programs are needed to assist producers and landowners in understanding and implementing strategies that have the potential to improve water quality while maintaining the livestock operation as a viable, profitable business. A physical inventory, management profile, and economic analysis of producer volunteered operations is being developed as a database. Potential water quality impacts will be prioritized and alternative management strategies will be prepared for consideration by the cooperator.

[GRAZING IMPACTS; PLANNING; WATER QUALITY]

1252. Ohmart,RD (1996): Ecological condition of the East Fork of the Gila River and selected tributaries: Gila National Forest, New Mexico. p.312-317. In: Shaw,DW; Finch,DM [tech. coord.] Desired future conditions for Southwestern riparian ecosystems: Bringing interests and concerns together. USDA Forest Service. General Technical Report RM-GTR-272. 
Ecological condition of riparian habitats along the East Fork of the Gila River, Main Diamond Creek, lower South Diamond Creek, and Black Canyon Creek are all in very heavily degraded condition. Channel cross sections show extensive entrenchment, high width-to-depth ratios, and numerous reaches where banks are sloughing into the stream, especially on the East Fork of the Gila River. Species of floodplain vegetation typifies degraded channel conditions. Absence of woody species disallows bank stabilization except where entrenched to large cobble. Data from channel cross-sections and vegetation sampling validate these conditions.

Numerous anthropogenic factors have been involved in the degradation of these riparian streams to their current condition, but the major degrading force has been unmanaged domestic livestock grazing either seasonlong or yearlong. Potential to recover these fluvial systems to proper functioning condition is high with management intervention. Stream gradients are moderate to low and sediment loads sufficient for bank formation. All stream reaches are in wilderness areas. Wildlife values of these habitats are presently very low because of the heavily degraded stream channel, poor herbaceous ground cover, and the virtual absence of understory and canopy foliage layers. Historically, these were habitats for the endangered Gila trout and southwestern willow flycatcher. [ECOLOGICAL CONDITION; FLUVIAL PROCESSES; GRAZING IMPACTS; PROPER FUNCTIONING CONDITION; RIPARIAN HABITAT; WILDERNESS]

1253. Ohmart,RD; Anderson,BW; Hunter,WC (1985): Influence of agriculture on waterbird, wader, and shorebird use along the lower Colorado River. p.117-122. In: Johnson,RR; Ziebell,CD; Patton,DR; Ffolliott,PF; Hamre,RH [tech. coord]. Riparian ecosystems and their management: Reconciling contlicting uses. 16-18 April 1985. Tucson, AZ. USDA Forest Service. General Technical Report RM-120.

Waterbird, wader, and shorebird use was restricted to habitats in or immediately adjacent to the Colorado River prior to agricultural development. Agricultural habitats were systematically studied for 3 years in order to identify those settings that were most important for species and groups. [AGRICULTURAL IMPACTS; AVIFAUNA; RIPARIAN HABITAT]

1254. Ohmart,RD; Deason,WO; Burke,C (1977): A riparian case history: the Colorado River. p.35-
47. In: Johnson,RR; Jones,DA [tech. coord.]. Importance, preservation, and management of riparian habitat: A symposium. 9 July 1977. Tucson, AZ. USDA Forest Service. General Technical Report RM-43.

Cottonwood communities have historically declined in abundance along the lower Colorado River to a condition that makes the future of this species precarious. Avian species showing strong specialization to cottonwood communities may be extirpated should the cottonwood community be lost. Concern and action will assure the persistence of this resource.

[AVIFAUNA; COTTONWOOD; GALLERY FORESI; RIPARIAN HABITAT]

1255. Okagbue,CO; Abam,TKS (1986): An analysis of stratigraphic control on river bank failure. Engineering Geology 22, 231-245.

Erosion and recession of the Niger River banks have constituted a threat to many villages in the area. Analyses of the recessional mechanisms indicate that bank failure is initiated by a fluvial erosion of the lower cohesionless bank layer at a much faster rate than the upper cohesive bank layer. This leads to development of overhangs of the upper cohesive materials. 'The failure mechanism of the river bank is complex, ranging from slip failures in high banks to shearing and toppling failures in low banks. The use of the common slip circle model for stability evaluation appears to be adequate only for high banks. This model tended to yield misleading results for stability analyses of low banks.

[GEOMORPHOLOGY; STREAMBANK PROTECTION]

1256. Oliphant,JO (1947): The cattle herds and ranches of the Oregon country, 1860-1890.

Agricultural History 21, 217-238.

Cattle breeding on open ranges in Oregon in the nineteenth century was highly speculative. Ranges could and did become crowded; herds of sheep could and did come upon the ranges and ruin them for cattle. Farmers could and did appropriate the grasslands for their own purposes; markets could and did fail cattlemen. Many made handsome profits and many suffered severe losses. During the depression of the $1870 \mathrm{~s}$, few, if any, made money on cattle. Boom years followed this period, however, and many took good advantage of this rising market. The cattle industry was both widespread and important to the regional economy during this period.

[GRAZING IMPACTS; HISTORIC RECORDS] 
1257. Olsen,DS; Wenger,DC (1998): Riparianwetland assessment: Applying hydrogeomorphic (HGM) concepts to riparian rangeland management. p.25-34. In: Potts, DF [ed.]. Rangeland management and water resources: Proceedings of the AWRA specialty conference. American Water Resources Association. 27-29 May 1998. Reno, NV.

The US Army Corps of Engineers has been developing the hydrogeomorphic (HGM) approach for riparian-wetlands assessments since 1993. This technique quantifies hydrologic, geomorphic, and ecologic functions by measuring variables and applying them in algorithms. Each algorithm product is termed the functional capacity index (FCI), which is the estimated ability of the riparian-wetland to perform a given function. The purpose of this approach has been to standardize methods to quantify functions of wetlands within the jurisdiction of the agency. Based on various applications, the HGM approach was evaluated to be a relatively accurate and rapid method of assessing the functions of riparian-wetland areas in rangelands.

[ASSESSMENTS; EVALUATION; HYDROGEOMORPHIC; RIPARIAN MANAGEMENT ZONE]

1258. Olson,C; Harris,R (1997): Applying a twostage system to prioritize riparian restoration at the San Luis Rey River, San Diego County, California. Restoration Ecology 45(5), 43-55.

This system was applied to an area of southern California in order to prioritize riparian restoration projects. In the first stage, data from topographic quadrangles and aerial photographs were analyzed to define and classify reaches. These analyses concluded that: 1) $28 \mathrm{~km}$ of the river and adjacent floodplain were suitable for second-stage evaluation of restoration needs; and 2) $32 \mathrm{~km}$ met criteria for reference conditions at the stream reach scale and should be protected from further impacts. The approach was developed for streams in the semi-arid western United States but could be adapted for use elsewhere.

[EVALUAIIION; PLANNING; RIPARIAN RESTORATION]

1259. Olson,JE; Horak,GC (1979): Successful and potentially successful measures to protect and improve fish and wildlife habitats. p.429-433. In: Swanson,GA [ed.]. The mitigation symposium: A national workshop on mitigating losses of fish and wildlife habitats. USDA Forest Service. General Technical Report RM-65.
This paper presents information from the new Western Reservoir and Stream Habitat Improvements Handbook on habitat improvement measures. Measures discussed involve improvement possibilities for reservoir water level management, fish propagation and control, wildlife protection at canals, and others. Specifics concerning design, implementation, cost, and effectiveness will be presented.

[RESERVOIRS; RIPARIAN HABITAT; RIPARIAN RESTORATION]

1260. Olson,RW; Armour,CL (1978): Economic considerations for improved livestock management approaches for fish and wildlife in riparian/stream areas. p.67-71. In: $\mathrm{Cope,OB} \mathrm{[ed.].}$ Proceedings of the Forum - Grazing and riparian/stream ecosystems. 3-4 November 1978. Denver, $\mathbf{C O}$. Trout Unlimited, Inc.

This paper conceptualizes complex interrelationships between various range uses. Monetary values of rangeland use for ranchers, consumers, and hunters are presented. Economic ramifications of the implementation and improved riparian management techniques on fish and wildlife are addressed.

[ECONOMICS; GRAZING IMPACTS; RIPARIAN HABITAT]

1261. Olson,TE; Knopf,FL (1988): Patterns of relative diversity within riparian small mammal communities, Platte River watershed, Colorado. p.379-386. In: Szaro,RC; Severson,KE; Patton,DR [tech. coord.] Management of amphibians, reptiles, and small mammals in North America: Proceedings of the symposium. 19-21 July 1988. Flagstaff, AZ. USDA Forest Service. General Technical Report RM-166.

Focus of the study was to analyze patterns of small mammal similarity within and between riparian and adjacent upland sites in the same watershed and across the elevational gradient. In accordance with avifaunal studies in the same watershed (Knopf, 1985), riparian sites at the higher elevations contributed substantially to the regional diversity of small mammal populations. In order to conserve regional integrity in native small mammal faunas, the authors recommend that land uses allowed in and adjacent to high elevation riparian zones should be considered as carefully as those in lowland floodplains.

[BIODIVERSITY; PLATTE RIVER; RIPARIAN HABITAT; SMALL MAMMALS] 
1262. O'Malley, R (1989): Wetlands protection: Perspective of the states in long-term policy direction. Renewable Resources Journal 7(3), 811.

The major issues discussed in this presentation were: 1) the perspective of states toward wetlands protection; and 2) long-term policy with respect to wetlands. The author urges congressional jurisdiction initiatives on an order of complexity to match that of wetland issues.

[POLICY; WETLANDS]

1263. Omernik,JM; Abernathy,AR; Male, LM (1981): Stream nutrient levels and proximity of agricultural and forest land to streams: Some relationships. Journal of Soil and Range Conservation 36: 227-231.

Forested buffer strips have been used to control nutrient loss from agricultural land to streams but the effect is not well documented. In this application, the authors attempted to determine whether the proximity of two land use types (agricultural and forest) to streams improved the ability to predict nutrient levels over simply using the proportion of watersheds occupied by each land use. Results indicated that proximity did not improve the predictive ability. One reason may be that the longterm effects of near-stream vegetation in reducing nutrient levels is negligible.

[BUFFER ZONES; NON-POINT SOURCE POLLUTION; NUTRIENT CYCLES; RIPARIAN FOREST]

1264. O'Neill,MP; Schmidt,JC; Dobrowolski,JP; Hawkins, CP; Neale,CMU (1997): Identifying sites for riparian wetland restoration: Application of a model to the Upper Arkansas River Basin. Restoration Ecology 45(5), 85-102.

A conceptual model for identifying restoration sites for riparian wetlands is presented with a specific application in Colorado. The model utilizes a Geographic Information System (GIS) to analyze a variety of spatial data useful in characterizing geomorphology, hydrology, and vegetation of riparian wetland sites. The model focuses on three basic properties of riparian wetland sites: relative soil moisture, disturbance regime, and vegetative characteristics. Restoration potential is evaluated as a combination of nominal scores from wetness, land cover, and disturbance indices.

[HYDROLOGY; MODELING; RIPARIAN RESTORATION]

1265. Onuf,CP; Zedler,JB (1988): Pattern and process in arid region salt marshes - southern California. p. 570-581. In: The ecology and management of wetlands. Volume 1: Ecology of wetlands. [Eds: Hook,DD.] Croom Helm, London and Sydney.

Salt marshes of the moist eastern United States have been long and often the subject of studies of ecosystem function. In comparison, ecological investigations of arid region salt marshes are recent and limited. This review relies primarily on research from the last decade in southern California. The results contradict several paradigms of ecosystem function that have emerged from research in the eastern United States. Key differences in the salt marshes between the regions provide insights about the governing process.

[RIPARIAN HABITAT; SALT MARSHES; WETLANDS]

1266. Oregon State University (1991): Watershed management guide for the interior Northwest. Oregon State University Extension Service.

EM8436. September, 1991. 45 p.

Riparian zones are important focal points for most of the products and uses associated with natural ecosystems. Abusive land use practices can degrade these areas but their inherent capacity for recovery is remarkable. This may be because Kentucky bluegrass is exceptionally tolerant of heavy use and provides stability or it may be a function of the rich nutrient and soil resource or the relatively higher moisture. By exercising the appropriate tools of the range manager, livestock can be compatible with other uses and values of these areas.

[GRAZING IMPACTS; LIVESTOCK EFFECTS; RIPARIAN VEGETATION]

1267. Oregon State University Extension Service (1991): Watershed management guide for the interior Northwest. Oregon State University Extension Service. EM 8436. 38 p.

This report summarizes numerous case studies and concludes: 1) riparian zones are important focal points for most of the products and uses associated with many natural ecosystems; 2) abusive land practices can easily degrade these areas; 3 ) the inherent capacity for recovery of degraded riparian zones is remarkable, perhaps because of grazing tolerant species, the rich nutrient and soil resource, or the relatively higher available moisture in these areas; and 4) managers can exercise the appropriate tools and allow levels of livestock grazing that are compatible with other uses and values.

[GRAZING IMPACTS; LIVESTOCK EFFECTS; 


\section{WATERSHED]}

1268. Oregon/Washington Riparian Habitat Subcommittee. Interagency Wildlife Committee. (1979): Managing riparian ecosystems (zones) for fish and wildlife in eastern Oregon and eastern Washington. $44 \mathrm{p}$.

Riparian ecosystems are defined as streams, lakes, and wet areas, and adjacent vegetative communities which are predominantly influenced by their association with water. Optimum fish and wildlife habitat conditions are described for this ecosystem in eastern Oregon and Washington. A process is outlined to evaluate the present conditions of riparian ecosystems, to project potentials for enhancement, and to establish recommended habitat conditions for managing fish and wildlife within riparian ecosystems.

[RIPARIAN HABITAT; RIPARIAN

MANAGEMENT ZONE; RIPARIAN VEGETATION]

1269. Orsborn,JF; Anderson,JW (1986): Stream improvements and fish response: $A$ bioengineering assessment. Water Resources Bulletin 22(3), 381388.

Human modifications of natural streams in the name of habitat improvement take various forms, and the impacts of those improvements, both positive and negative, vary by orders of magnitude from stream to stream. The positive impacts are achieved by careful and timely planning, design, installation, and monitoring of projects. Negative impacts are the result of rush jobs dictated by available money, a lack of consideration for limiting factors, untrained and inexperienced personnel, force-fitting structures instead of bending the flow, lack of a watershed plan, poor communication and cooperation among disciplines, not using the team approach, and single habitat solutions which neglect diversity and artificial constraints. A general systems approach is presented which uses a common language for interdisciplinary communication. Various conceptual models are discussed to describe system complexities and factors.

[BIOENGINEERING; CHANNEL DYNAMICS; FISHERIES; RIPARIAN HABITAT; RIPARIAN RESTORATION]

1270. Osborn,HB; Simanton,JR (1986): Gully migration on a southwest rangeland watershed. Journal of Range Management 39(6), 558-561.

On southwestern rangelands, most rainfall and almost all runoff are products of intense summer thunderstorms. Head-cutting and gully growth characterize the region. Runoff at a head-cut in southern Arizona was estimated using a kinematic cascade rainfall-runoff model. The head-cut sediment contribution was about 25 percent of the total sediment load measured downstream from the headcut. The sediment contribution from the swale drainage above the head-cut was about the same. More data was needed but the total contribution from gully banks and headcuts in this study had to be an important portion of the total sediment load. [GEOMORPHOLOGY; GULLY CONTROL; SEDIMENT TRANSPORT]

1271. Osborn,HB; Simanton,JR (1989): Gullies and sediment yield. Rangelands 11(2), 51-56.

Estimates of total sediment yield, over a nineyear period, for a small gullied watershed, were partitioned to account for main gully contribution, tributary gully contribution, and upland erosion. The main gully contributed about 50 percent of the total sediment yield. Estimates of upland erosion ranged from about 20 percent of the total based on the USLE to 40 percent based on comparison with an adjacent ungullied watershed. The remainder ( 10 to 30 percent) was attributed to contribution from tributary gullies.

[EROSION CONTROL; GULLY CONTROL; RIPARIAN RESTORATION; SEDIMENTATION]

1272. Osterkamp,WR; Hedman,ER (1977): Variation of width and discharge for natural highgradient stream channels. Water Resources Bulletin 13(2), 256-258.

This study defines a width-discharge relationship for natural perennial alluvial stream channels with gradients exceeding $.0080 \mathrm{~m} / \mathrm{m}(.0080 \mathrm{ft} / \mathrm{tt})$. A standard exponent of 2.0 is suggested for studies relating mean discharge to active channel width. The results are in close agreement with studies by Leopold and Maddock (1953) and confirm their "b" exponent. Workers currently using active channel width measurements as a means of estimating average discharge from ungaged basins should consider 2.0 as a standard exponent of the regression relation.

[CHANNEL DYNAMICS; HYDRAULICS; HYDROLOGY]

1273. O'Toole,R (1987): Social and economic benefits of riparian forests other than for timber. In: Streamside management: Riparian wildlife and forestry interactions. An interdisciplinary symposium. 11-13 February 1987. University of 
Washington. Seattle, WA.

Major changes in public forest management and water laws are needed to protect riparian resources. Public land managers should charge fair market value for all forms of recreation. Collection of as little as ten percent of the values the USDA Forest Service claims for recreation would cover all costs plus enforcement. Riparian management would also be improved if water rights were freely transferable, giving landowners an incentive to protect water quality by making it more valuable.

[ECONOMICS; RIPARIAN HABITAT; RIPARIAN MANAGEMENT ZONE]

1274. O'Toole,R (1988): Economic protection for riparian forests. p.259-269. In: Streamside management: Riparian wildlife and forestry interactions. An interdisciplinary symposium. University of Washington, Institute of Forest Resources, Seattle, WA.

Riparian systems are economically valuable primarily because the majority of forest recreation takes place there. They are also important for protecting high quality watersheds and may be the most cost effective method for filtering water, maintaining cool temperatures for fish, and dissipating runoff. They are also the most productive timber areas. Traditionally, timber has been regarded as a market resource, while watershed, wildlife, and recreation have been categorized as nonmarket resources. The solutions to riparian management require the acceptance of the fact that restrictive or prescriptive legislation will not work as long as incentives remain unchanged. Incentives to crosssubsidize timber or sell it below cost should be eliminated. Finally, managers should charge fair market value for recreation and other "nonmarket" resources. In short, most nonmarket resources can be market resources.

[ECONOMICS; RIPARIAN FOREST; RIPARIAN HABITAT]

1275. Ottenbreit,KA; Staniforth,RJ (1992): Life cycle and age structure of ramets in an expanding population of Salix exigua (sandbar willow). Canadian Journal of Botany 70, 1141-1146.

The sandbar willow is a dominant woody pioneer and stabilizer of riverbanks and sand dunes over much of North America. A population growing on a point bar in Manitoba was assessed. Average annual height increments were $29.7 \mathrm{~cm}$, and the average annual girth increments were $2.6 \mathrm{~mm} /$ year. There were no significant differences between sexes. Significant linear correlations existed between basal stem diameter and age and between stem height and age. Flowering occurred in a few 2- and 3-year-old stems, regardless of sex. Flowering frequency increased to 93 percent at the age of 9 years. Stem mortality was highest in 3-, 4-, and 6-year-old ramets, and senescence was first observed at about 12 years. Few stems were over 12 years old but the oldest stem encountered was 31 years old. The sex ratio of 1.7:1.0 significantly favored males.

[RIPARIAN HABITAT; RIPARIAN PLANTS; WILLOW]

1276. Overton,KC; Chandler,GL; Pisano,JA (1994): Northern/Intermountain Region's fish habitat inventory: Grazed, rested, and ungrazed reference stream reaches, Silver King Creek, CA. USDA Forest Service. General Technical Report INT-GTR-311.27 p.

Stream reaches that have been rested from livestock grazing appear to have stable banks and more bank undercuts than grazed stream sections. Ungrazed reference streams that are similar in parent geology, precipitation, channel type, habitat types, drainage area, and stream width had greater bank stability values and lower width-to-depth ratios than those of grazed and rested management sections of Silver King Creek. Power curve analysis was used to suggest the sample sizes required to monitor progress toward the desired condition.

[DESIRED FUTURE CONDITIONS; GRAZING

IMPACTS; INVENTORY; MONITORING; SAMPLING]

1277. Overton,KC; McIntyre,JD; Armstrong,R; Whitwell,SL; Duncan,KA (1995): User's guide to fish habitat: Descriptions that represent natural conditions in the Salmon River Basin, ID. USDA Forest Service. General Technical Report INTGTR-322. 142 p.

This user's guide and reference document describes the physical features of the Salmon River Basin, Idaho, stream channels that represent "natural conditions" for fish habitat; that is, streams that have not been influenced by major human disturbances. The data base was created to assist biologists and resource managers. It describes resource conditions that can be achieved through management objeclives. [CHANNEL MORPHOLOGY; DESIRED FUTURE CONDITIONS; FISH HABITAT; MULTISCALE ANALYSIS; RIPARIAN HABITAT]

1278. Overton,KC; Radko,MA; Nelson,RL (1993): Fish habitat conditions: Using the Northern/Intermountain Regions' inventory 
procedures for detecting differences on two differently managed watersheds. USDA Forest Service. Intermountain Research Station. General Technical Report INT-300. 14 p.

Differences in land management may produce differences in habitat variables between two studied watersheds. In using the R1/R4 Watershed Scale Fish Habitat Inventory Process, for most habitat variables, evaluations of at least 30 habitat units were adequate. Such variables as channel morphology, substrate, large woody debris, and bank conditions can be detected using the guidelines provided for determining sample sizes required to determine differences.

[CHANNEL MORPHOLOGY; FISH HABITAT; [NVENTORY; SMZ]

1279. Overton,KC; Wollrab,SP; Roberts,BC; Radko,MA (1997): R1/R4 (Northern/Intermountain Regions) fish and fish habitat standard inventory procedures. USDA Forest Service. General Technical Report INTGTR-346. 73 p.

Standard inventory procedures for collecting fish habitat and salmonid fish species data for streams in USDA Forest Service R1 and R4 are described. Procedures are designed to define and quantify the structure, pattern, and dimensions of fish habitat; describe salmonid species composition distribution, and relative abundance; and facilitate the calculation of summary statistics for habitat descriptors.

[CHANNEL DYNAMICS; FISH HABITAT; INVENTORY]

1280. Padgett,WG; Youngblood,AP; Winward,AH (1989): Riparian community type classification of Utah and southeastern Idaho. R4Ecol-89-01. USDA Forest Service. 191 p.

A community type classification system, based on approximately 600 sample stands. Distribution, vegetation composition, soils and successional status are described.

[CLASSIFICATION; PLANT COMMUNITIES; RIPARIAN HABITAT; RIPARIAN MANAGEMENT ZONE; SOILS]

1281. Pall,R; Dickinson,WT; Green,D; McGirr,R (1982): Impacts of soil characteristics on soil erodibility. In: Recent developments in the explanation and prediction of erosion and sediment yield. Proceedings of the Exeter symposium. July 1982. IAHS Publication No. 137, 39-47.

Field observations from two small drainage basins in the temperate climate of southern Ontario have been laboratory tested to identify key soil characteristics affecting soil erodibility. High soil erosion and transport rates during and immediately following spring thaw temperature and soil water conditions appeared to be linked to the presence of low soil density, high soil water content, and resulting low shear strength values in the surface soils. Lab tests on agricultural soil samples from the area verified the vulnerability of the soils to such density and water content conditions. The existing data base is acknowledged to be sparse. However, it is hypothesized that further examinations of surface soil shear characteristics may be useful in clarifying erosion processes.

[GEOMORPHOLOGY; SOIL-WATER CONDITIONS; SOILS]

1282. Palmquist,DE; Blank;RR; Young,JA (1992): To krige or not to krige: a spatial variability study of a Great Basin saline playa. p.186-189. In: Clary,WP; McArthur,ED; Bedunah,D; Wambolt,CL [comp.]. Proceedings Symposium on ecology and management of riparian shrub communities. USDA Forest Service. General Technical Report INT-289.

Coarse-textured soil mounds dotting the edges of playas are characteristic features of the Great Basin. These mounds sustain a sparse, salt tolerant plant community that consists of allenrolfea, greasewood, and Torrey saltbush. Spatial variability techniques from two different disciplines were adapted to explore patterns of distributions and relationships between these soil mounds and the vegetation occurring on them. [GEOMORPHOLOGY; PLAYAS; SALTTOLERANCE; SPATIAL SCALE]

1283. Park,CC (1977): Man-induced changes in stream channel capacity. p. 121-144. In: River channel changes. [Ed: Gregory,KJ]. John Wiley and Sons. New York. NY. [CHANNEL MORPHOLOGY; GEOMORPHOLOGY; TECHNIQUES]

1284. Parker,M (1986): Beaver, water quality, and riparian systems. In: Proceedings of the streamside zones conference. Wyoming Water Research Center. 28-30 April 1986. Laramie, WY.

A complex of beaver dams can improve the quality of water flowing through them. Compared to stream sections above or below the dams, export from the complexes was estimated to be less than by 50-75 percent for suspended solids, less than 20-65 
percent for total $\mathrm{P}$ and total Kjeldahl $\mathrm{N}$, and less by 20-25 percent for nitrate-nitrogen. Work is also summarized that suggests that the presence of beaver dams can protect riparian areas from erosive perturbations, if they are not too great.

[BEAVER; RIPARIAN HABITAT; WATER QUALI'I'Y]

1285. Parker,M; Wood,FJ,Jr; Smith,BH; Elder,RG (1985): Erosional down-cutting in lower order riparian ecosystems: Have historical changes been caused by the removal of beaver? $p$. 35-38. In: Johnson,RR; Ziebell,CD; Patton,DR ;Ffolliott,PF; Hamre,RH. [tech. coord.]. Riparian ecosystems and their management: Reconciling conflicting uses. 16-18 April 1985. Tucson, AZ. USDA Forest Service. General Technical Report RM-120.

The authors hypothesize that, in lower order streams, beaver may be able to resist perturbations to a state of dynamic equilibrium if the perturbations are not too great. They suggest the thermodynamic and mechanistic bases and propose a simple model by which potential beaver perturbation resistance can be quantified. The model may be applicable to a number of management problems.

[BEAVER; EROSION CONTROL; MODELING; RIPARIAN HABITAT]

1286. Parsons,SC; Hudson,S (1985): Channel cross section surveys data analysis. USDI Bureau of Land Management. Denver Service Center. Technical Reference TR-4341. 48 p.

This report describes two computer programs which reduce and analyze stream channel crosssection survey data collected by either a rod and level survey or a sag tape survey. Data may be entered from the keyboard or a file. Cross sections are plotted on $x-y$ coordinates and discharge rating curves are developed using Manning's equation given a usersupplied value for Manning's " $n$ ". Output tables include values for average flow velocity (for each discharge increment), cross-section area, wetted perimeter, and hydraulic radius.

[CHANNEL DYNAMICS; CHANNEL MORPHOLOGY; TECHNIQUES]

1287. Pase,CP; Layser,EF (1977): Classification of riparian habitat in the Southwest. p.5-9. In: Johnson,RR; Jones,DA [tech. coord.] Symposium on the importance, preservation and management of the riparian habitat. 9 July 1977. Tucson, AZ. USDA Forest Service. General Technical Report RM-43.
Riparian areas in Arizona and New Mexico are uniquely productive for wildlife. A tentative classification for riparian vegetation based on the Brown and Pase model is proposed. Six biomes, nine series, and 23 associations are tentatively recognized. Classification of riparian vegetation can provide a strong management tool.

[CLASSIFICATION; INVENTORY; RIPARIAN HABITAT]

1288. Passey,HB; Hugie,VK; Williams,EW; Ball,DE (1982): Relationships between soil, plant community, and climate on rangelands of the Intermountain West. USDA Technical Bulletin. No. 1669. 123 p.

Studies were done to determine the range of soil, climate, and vegetation characteristics consistently associated under natural conditions. Eighty five study sites were selected within 32 relict areas in northern Utah, southern Idaho, northeastern Nevada, and westcentral Wyoming. Studies were confined to climax plant communities characterized by associations of sagebrush, bluebunch wheatgrass, Sandberg bluegrass, and Idaho fescue and Entisol, Aridisol, and Mollisol soil orders. Soil subgroups provided the most meaningful level of soil classification for correlation with broad plant associations. The presence of different species or subspecies of sagebrush provided the most meaningful grouping of plant communities. Vegetation production and composition data were recorded and analyzed for 10 consecutive years on 17 key study sites. Annual and periodic fluctuations in total production and yield of individual species in response to climatic variations were analyzed. Soil properties modified the effects of climate on plant communities. Effects of soil, plant, and climate relationships on relict areas may be used to approximate productive potential of other areas of the same or similar soils.

[CLIMATE; GRAZING IMPACTS; PLANT

COMMUNITIES; SAGEBRUSH; SOILS]

1289. Patrick,DM; Smith,LM; Whitten,CB (1982): Methods for studying accelerated fluvial change. p.783-815. In: Gravel bed rivers. [Eds: Hey,RD; Bathurst,JC; Thorne,CR|. John Wiley and Sons Ltd. New York, NY.

Human activities, both site-specific and regional, may adversely affect streambank stability, navigation, flood frequency, and wildlife habitats. To develop and manage a river basin and fluvial system effectively it is necessary to identify and minimize the adverse effects of existing structures and activities and to predict and take into account the 
potential adverse effects of proposed schemes. This requires data on the factors that control the mechanics of the fluvial system. The data should cover the basin characteristics, relations between geomorphology and river mechanics, erodibility of the drainage basin and temporal effects. In this paper, some of the techniques and methods for studying accelerated fluvial change are described. Particular emphasis is placed on the importance of information of basin characteristics and on geomorphological processes, to project studies.

[CHANNEL MORPHOLOGY; FLUVIAL PROCESSES; GEOMORPHOLOGY; REMOTE SENSING; SOILS; STREAMBANK PROTECTION; TECHNIQUES]

1290. Patton,BD; Nyren,PE (1998): The effect of grazing intensity on soil water and rangeland productivity in south-central South Dakota. p.219228. In: Potts, DF [ed.] .Rangeland management and water resources: Proceedings of the AWRA specialty conference. American Water Resources Association. 27-29 May 1998. Reno, NV.

Responses to no grazing, light, moderate, heavy, and extreme grazing were monitored in south-central South Dakota to measure changes in available soil water and biomass production. Significant differences have occurred during both periods of soil water recharge and discharge indicating increased runoff and evapotranspiration from the soil surface on the heavily grazed treatments. Plants on the ungrazed treatment on silty sites had more leaf area than plants on the moderate treatment and appear to remove more water through transpiration. Biomass production has been reduced on both the extreme and ungrazed treatments compared to the moderate treatment on all sites.

[BIOMASS; EVAPOTRANSPIRATION; GRAZING IMPACTS; LIVESTOCK EFFECTS; RUNOFF; SOIL-WATER CONDITIONS]

\section{Patton,DR (1977): Riparian research} needs. p.80-82. In: Johnson,RR; Jones, DA [tech. coord.]. Proceedings of the symposium on importance, preservation, and management of riparian habitats. 9 July 1977 . Tucson, AZ.

In 1977, approximately 22 studies on riparian habitat were in progress in the western United States. Six categories of studies were identified as needed to provide managers with data for making decisions about the riparian ecosystem. The concept of "validation sites" was suggested for use in a team approach to solve plant and animal problems in the riparian zone.

\section{[RESEARCH; RIPARIAN STUDIES]}

1292. Patton,DR (1993): Integrating science and decision making. p.167-172. In: Tellman,B; Cortner,HJ; Wallace,MG; DeBano,LF;

Hamre, RH [tech. coord.]. Riparian management: Common threads and shared interests. USDA Forest Service. General Technical Report RM226.

The author points to a conclusion that it is not the quantity of scientific information that leads to integration of science into decision making, but how useful decision makers perceive that information to be. Credible scientists need to develop documents or presentations to make technical information available. Scientific input requires time, a willing audience, and an adaptive management style that allows science to refine it's information. The alternative is to allow emotionalism, lobbying, and non-factual public perceptions to be the data base used by managers who make decisions regarding our natural resources. [ADAPTIVE MANAGEMENT; DECISION MAKING; RIPARIAN HABITAT; SCIENCE]

1293. Patton,PC; Schumm,SA (1981): Ephemeral stream processes: Implications for studies of Quaternary Valley fills. Quaternary Research 15, 24-43.

Three unstable ephemeral stream channels were resurveyed to provide data on the mechanics of erosion and sedimentation processes during 14-22 year periods. Channel morphology changed significantly. Erosion occurred through nick-point recession and bank collapse, but erosional reaches are separated by aggrading or stable channel reaches. In general, sediment that is eroded, as the nick-point recedes upstream, is trapped in the widened channel downstream. In this manner sediment is transported episodically out of these basins during a series of cutand-fill cycles. The manner by which the channels aggrade and the morphology of the aggraded stable channels are controlled by the sediment type. [CHANNEL MORPHOLOGY; GULLY CONTROL; SEDIMENTATION]

1294. Payne,NF; Copes,F (eds.) (1986): Wildlife and fisheries habitat improvement handbook. (USDA Forest Service, Wildlife and Fisheries Administrative Report. December 1986. 403 p. [HABITAT MANAGEMENT; RIPARIAN HABITAT; RIPARIAN RESTORATION; TECHNIQUES] 
1295. Payne,NF; Munger,GP; Matthews,JW; Taber,RD (1975): Inventory of vegetation and wildlife in riparian and other habitats along the upper Columbia River. U.S. Army Corps of Engineers, North Pacific Division (1976).

An extensive descriptive inventory of riparian habitats occurring along the upper Columbia River. Manuscript contains 36 maps and 560 pages of narrative.

[COLUMBIA RIVER; INVENTORY; RIPARIAN HABITAT]

1296. Pearce,RA; Frasier,GW; Lieninger,WC; Trlica,MJ (1998): Sediment movement and filtration in riparian vegetation. p.167-177. In:

Potts,DF [ed.]. Rangeland management and water resources: Proceedings of the AWRA specialty conference. American Water Resources Association. 27-29 May 1998. Reno, NV.

This paper addresses a combined field and laboratory rainfall simulation study conducted to determine the influence of vegetation characteristics on sediment transport and filtration through vegetated filter strips. Sediment yield was not affected by vegetation height or community. Coarse sediment (>200 um) movement was affected by vegetation height. The coarse material traveled farther down slope in the clipped to the soil surface treatment than in either the $10 \mathrm{~cm}$ or natural height vegetation treatments. The study results indicated that vegetation height was not an important variable affecting sediment yield, but that vegetation height may be important on a small scale for coarse particle movement.

[EROSION; NON-POINT SOURCE POLLUTION; RUNOFF; SEDIMENTATION; STUBBLE HEIGHT]

1297. Pearce,RA; Frasier,GW; Trlica,MJ; Leininger,WC; Stednick,JD; Smith,JL (1998): Sediment filtration in a montane riparian zone under simulated rainfall. Journal of Range Management 51(3), 309-314.

The effectiveness of riparian vegetation to filter sediment from overland water flow was tested over two years. Sediment yields at the downslope end of the plots were greater when finer silica sediment was introduced into overland flow as compared with sediment derived from sandy loam soil. Sediment yiclds, measured at the outlets of plots, did not increase or decrease as vegetation heights increased. Accurate prediction of sediment filtration from shallow flow in riparian zones required consideration of a combination of vegetation and soil surface factors.

[EROSION; GRAZING IMPACTS; NON-POINT

SOURCE POLLUTION; RIPARIAN

VEGETATION; SEDIMENTATION; STUBBLE HEIGHT]

1298. Pearse,RA; Trlica,MJ; Leininger,WC; Mergen,DE; Frasier,G (1998): Sediment movement through riparian vegetation under simulated rainfall and overland flow. Journal of Range Management 51(3), 301-308.

A 2-year simulation study was conducted to evaluate the effectiveness of riparian vegetation at three vegetation heights to reduce sediment movement. Results of the first experiment showed a significant increase in the sand movement downslope when vegetation was clipped to the soil surface compared with undisturbed vegetation. In the second experiment, most significant differences in movement for finer particles occurred in the $2-10$ micron particle ranges. The study showed that additional variables (percent surface vegetation cover, aboveground biomass, percent shrubs, surface roughness coefficient, soil texture of introduced sediment, percent bare ground, distance downslope, vegetative density, grass species and sedge species), besides vegetation height, influenced sediment movement.

[EROSION; GRAZING IMPACTS; RIPARIAN VEGFTATION; SEDIMENTATION]

1299. Peart,MR; Walling,DE (1982): Particle size characteristics of fluvial suspended sediment. p.397-407. In: Proceedings of the Exeter Symposium. Recent developments in the explanation and prediction of erosion and sediment yield. IAHS Publ. No. 137.

The relationship between the particle size characteristics of source and sediment is investigated by considering data from a small number of small drainage basins in the USA and from two small basins in Devon, England. These demonstrate the importance of soil type and catchment characteristics in controlling this relationship. Temporal variations in the particle size distribution of suspended sediment are considered by highlighting the varied evidence presented in existing studies and by considering in detail, data from the two small drainage basins in Devon which exhibit markedly different responses. [CHANNEL DYNAMICS; GEOMORPHOLOGY; SEDIMENTATION; SEDIMENT TRANSPORT]

1300. Pence, L (1991): Riparian restoration using beaver. p.32-34. In: Roth,D; Bridges, $C$; 
Zimmerman, $\mathrm{C}$ [eds.]. What does riparian mean to me? Proceedings of the convention. Colorado Riparian Association. 6-8 November 1991. Pueblo, CO.

Using beavers is one of the many tools and techniques available to us for improving riparian areas. A case study in Blaine County, Idaho, is described.

[BEAVER; RIPARIAN RESTORATION]

1301. Periman, RD (1996): The influence of prehistoric Anasazi cobble mulch agricultural features on northern Rio Grande landscapes. p.181-188. In: Shaw,DW; Finch,DM [tech. coord.] Desired future conditions for Southwestern riparian ecosystems: Bringing interests and concerns together. USDA Forest Service. General Technical Report RM- GTR- 272.

Research concerning ancient Pueblo Indian farming, specifically the innovation of cobble mulch gardens, suggests a manipulation of the local environment on a landscape level that helped create existing ecosystems. This agricultural technology, which consisted of a protective layer of gravel covering the productive soil, trapped seasonal runoff moisture in field areas, retained it, and guarded against evaporation. These water trapping features are usually found on terraces and slopes above riparian areas. The effect of this lithic mulch technology on available water, drainage patterns, and general system dynamics is explored.

[COBBLE MULCH AGRICULTURE; DRAINAGES; PUEBLO INDIANS; RIPARIAN HABITAT; RUNOFF; WATER TRAPPING]

1302. Pess,GR; Pollock,MM (1997): A processbased watershed restoration strategy derived from historic conditions. p.161. Abstracts. 1997 Annual meeting of the Ecological Society of America jointly with The Nature Conservancy. 10-14 August 1997. Albuquerque, NM.

Historic condition of physical and ecological processes can be assessed to provide critical information to protect and restore freshwater (salmonid) habitat. For this study, the riparian habitat (past and present) in the Stillaguamish river in Washington was assessed. In the past century, most riparian zones adjacent to anadromous salmonid habitat have been degraded. Logging has converted late seral coniferous forests to deciduous forests. The latter have little conifer regeneration, indicating that these forests arc relatively stable. Beaver populations have been reduced to less than 10 percent of original numbers. Increasing beaver populations and actively managing riparian forests for conifer production are important steps toward restoring freshwater habitat and declining salmon runs.

[AQUATIC ECOSYSTEMS; ASSESSMENTS; FISH HABITAT; HISTORIC RECORDS; LOGGING IMPACTS; SALMONIDS]

1303. Peterjohn,WT; Correll,DL (1984):

Nutrient dynamics in an agricultural watershed: Observations on the role of a riparian forest. Ecology 65, 1466-1475.

Nutrient concentration changes were measured in surface runoff and shallow groundwater as they moved through a small agricultural watershed. Cropland appeared to retain fewer nutrients than riparian forest and was thought to incur the majority of its nutrient losses in harvested crop. The dominant pathway of total-N loss from the riparian forest seemed to be subsurface flux. $P$ loss from the riparian forest appeared almost evenly divided between surface and subsurface losses. Nutrient removals in the riparian forest are thought to be of ecological significance to receiving waters and indicate that coupling natural systems and managed habitats within a watershed may reduce diffuse-source pollution.

[DIFFUSE-SOURCE POLLUTION; NUTRIENT CYCLES; RIPARIAN HABITAT; RIPARIAN VEGETATION; WATER QUALITY]

1304. Petersen,RC; Cummins, KW (1974): Leaf processing in a woodland stream. Freshwater Biology 4, 343-368.

Detritus processing by a small woodland stream is analyzed by following the loss of weight of a measured unit of single species accumulation of riparian leaves. The response of the invertebrate community to differences in leaf species is also investigated using controlled, artificial streams where significant differences in the effect of the invertebrates are related to the ability of the leaf to be processed. Evidence suggests that differential invertebrate colonization of leaf packs is a function of microbial colonization and conditioning. The data are used to develop a general scheme of leaf pack processing.

[AQUATIC ECOSYSTEMS; MACROINVERTEBRATES; RIPARIAN HABITAT]

1305. Peterson,MM; Somerville,DJ; Sennet,RF (1992): Preliminary riparian classification system for private and state owned lands in Utah. p.7982. In: Clary,WP; McArthur,ED; Bedunah,D; 
Wambolt,CL [comp.]. Proceedings - Symposium on ecology and management of riparian shrub communities. USDA Forest Service. General Technical Report INT-289.

A classification system for riparian areas in Utah was developed by the USDA Natural Resources Conservation Service in cooperation with the Utah State Department of Agriculture and the Utah Riparian Management Coalition. This is a hierarchical system beginning at broad levels of physiographic classifications and proceeding to more specific levels.

[CLASSIFICATION; RIPARIAN HABITAT; RIPARIAN VEGETATION]

1306. Peterson,WT; Correll,DL (1984): Nutrient dynamics in an agricultural watershed:

Observations on the role of a riparian forest. Ecology 65(5), 1466-1475.

Nutrient $(C, N$, and $P)$ concentration changes were measured in surface runoff and shallow groundwater as they moved through a small agricultural watershed. The crop land appeared to retain fewer nutrients than the riparian forests and is thought to incur the majority of its nutrient losses in harvested crop. The dominant pathway of total- $\mathrm{N}$ loss from the riparian forests seemed to be subsurface flux. P loss from the riparian forest appeared almost evenly divided between surface and subsurface losses. Nutrient removals in the riparian forest were thought to be of ecological significance to receiving waters and indicate that coupling natural systems and managed habitats within a watershed may reduce diffuse-source pollution.

[NUTRIENT CYCLES; RIPARIAN FOREST; RIPARIAN HABITAT; WATERSHED]

1307. Pettit,PI (1996): Discussion of future cooperative actions and closing remarks. p.351353. In: Shaw,DW; Finch,DM [tech. coord.]. Desired future conditions for Southwestern riparian ecosystems: Bringing interests and concerns together. USDA Forest Service. General Technical Report RM-GTR-272.

A discussion of brainstorming sessions and written feedback forms received at the conclusion of the symposium. Sponsors of the symposium will work as a coalition to implement the the most promising and effective ideas and comments. [COLLABORATION; RIPARIAN HABITAT]

1308. Pfankuch,DJ (1978): Stream reach inventory and channel stability evaluation. USDA Forest Service, Northern Region, Missoula, MT.
$26 \mathrm{p}$.

[GEOMORPHOLOGY; INVENTORY; STREAMBANK STABILITY]

1309. Pfister,RD (1990): Streamside management zones (SMZ)-- Delineation criteria and management guidelines. In: Management of riparian and wetland forested ecosystems in Montana. Fourth annual Montana Riparian Association workshop. University of Montana. Missoula, MT. 5-7 September 1990. Whitefish, MT.

The Montana Riparian Association Management Guidelines Working Group has been working on a matrix of soil erosion hazards relative to management practices; SMZ width guidelines for substrates of high, medium and low erodibility classes; and for various slope classes presented.

[RIPARIAN FOREST; RIPARIAN HABITAT; SMZ]

1310. Pfister,RD; Boggs,KW (1990): Methodology for riparian inventory and streamside management zone delineation on the Kootenai National Forest. In: Management of riparian and wetland forested ecosystems in Montana. University of Montana. Missoula, MT. Fourth annual Montana Riparian Association workshop. 5-7 September 1990. Whitefish, MT.

A brief overview was provided of a contract study with the Kootenai National Forest. The objective was to develop and demonstrate techniques for mapping wetlands and streamside management zones in heavily forested areas.

[INVENTORY; RIPARIAN FOREST; RIPARIAN HABITAT]

1311. Phinn,SR; Stow,DA; Zedler,JB (1996): Monitoring wetland habitat restoration in southern California using airborne multispectral video data. Restoration Ecology 4(4), 412-422.

Remote sensing provides a complementary approach to field sampling to assess whether restored wetland areas provide suitable habitat. This paper describes the application of image classification techniques to high-spatial-resolution digital video imagery to delimit patches of different marsh vegetation. Preliminary field checking results indicate that this approach is an accurate, noninvasive, and cost efficient means of providing ecological information for restoration monitoring. [MONITORING; REMOTE SENSING; RIPARIAN HABITAT; WETLANDS] 
1312. Phinney,DE; Deusen,MS; Keller,SM; Knudsen,PA (1989): A new approach to riparian management in Washington State. p.11-15. In: Gresswell,RE; Barton,BA; Kershner,JL [eds.]. Practical approaches to riparian resource management. An educational workshop. 8-11 May 1989. USDI Bureau of Land Management. Billings,MT.

The 1974 State Forest Practices Act regulates forest practices on state and private forest lands in Washington in order to protect public resources and maintain a viable forest industry. New conflicts between industries, tribes, environmentalists, and state agencies have evolved as revisions to the Act have been adopted. In 1986, when riparian management regulations were proposed, rampant controversy erupted. With the assistance of a nonprofit organization, the State brought all representatives of interests into a negotiating process. The Timber, Fish, and Wildlife Agreement has successfully resolved previous conflicts by providing positive benefits to all parties while sustaining regulatory integrity.

[CONFLICT RESOLUTION; RIPARIAN HABITAT; RIPARIAN MANAGEMENT ZONE]

1313. Piest,RF; Bradford,JM; Wyatt,GM (1975): Soil erosion and sediment transport from gullies. Journal of the Hydraulics Division, Procedures of the American Society of Civil Engineers. 101(No. HY1 January 1975), 65-80.

The processes that cause gullying are analyzed by reviewing data from watersheds around lowa. Tractive forces acting on the gully boundary, mass wasting of gully banks and scarps and gully clean out of wasted soil debris are some of the processes considered. Processes of mass wasting of gully banks and scarps were mainly responsible for their growth. The loose soil debris represented the prime sediment source in the gullies. Causes of gullying vary according to the boundary restraints (base level, channel slope, and resistant soils) that are typical of given region.

[GEOMORPHOLOGY; GULLY CONTROL; SEDIMENT TRANSPORT; SOILS]

1314. Pionke,HB; Hoover,JR; Schnabel,RR; Gburek,JB; Urban,JB; Rogowski,AS (1988): Chemical-hydrologic interactions in the nearstream zone. Water Resources Research 24(7), 1101-1110.

The chemical and hydrologic responses of a hilly watershed to a typical summer storm event were determined and compared. Patterns and the relative magnitudes of $\mathrm{NO} 3, \mathrm{NH} 4$, phosphorus, and $\mathrm{PO} 4$ concentrations observed in seepage, surface runoff, storm flow, base flow, and rainfall, fit those hypothesized in the storm hydrograph and associated water table responses observed in the near-stream zone. Nitrate concentrations in seepage and base flow were similar and, typically, exceeded those in surface runoff, rainfall, and peak storm flow by 5-20 times. Conversely, NH4, $\mathrm{P}$, and $\mathrm{PO} 4$ concentrations in surface runoff from the seep zone and in peak storm flows exceeded those in seepage and base flow by 220 times.

[CHEMICAL RESPONSES; HYDROLOGY; WATERSHED]

1315. Plantico, $\mathrm{RC}$ (1981): The value of riparian ecosystems: Institutional and methodological considerations. p.233-240. In: Warner,RE; Hendrix,KM [eds.]. California riparian systems conference. 17-19 September 1981. University of California. Davis, CA.

[ECONOMICS; RESEARCH; RIPARIAN HABITAT]

1316. Platts, WS (1976): Validity of methodologies to document stream environments for evaluating fishery conditions. p.267-284. In: Proceedings of the Symposium and specific conference on instream flow needs. Western Division of the American Fisheries Society. 3-6 May 1976. Boise, ID.

Studies conducted from 1970-1972 addressed: 1) the relationship of the physical structural components of aquatic environments to each other; 2) the relationship of stream structure and fish populations; 3) the importance of multiple variables in controlling fish populations; and 4) the validity of using present methodologies to evaluate fishery productivity. A large area in the upper South Fork Salmon River was evaluated for environment-fishery relationships. Certain valid interpretations were made concerning aquatic variable control of fish populations, but the overall observed variation was low. Instream conditions controlled the density of the fish populations and the composition of fish species. Control was not isolated to any one variable. Stream width, depth, and the elevation of the stream channel were the most important evaluated variables controlling the fish populations. [FISHERIES; RIPARIAN HABITAT; STREAM ECOLOGY]

1317. Platts, WS (1978): Livestock interactions with fish and aquatic environments: problems in 
evaluation. p.498-504. In: Transactions of the 43rd North American wildlife and natural resources conference. 18-22 March 1978. Phoenix, AZ. Wildlife Management Institute; Washington, DC.

In the past, our methodology for measuring the condition of the stream environment has rarely been tested. Biologists must be able to measure small environmental changes and to differentiate between natural variation in environmental conditions and treatment effects (grazing and nongrazing). This must be done without observer error. Only then, biologists will be able to evaluate existing grazing systems and to develop better grazing strategies.

[FISHERIES; GRAZING IMPACTS; RIPARIAN HABITAT]

1318. Platts, WS (1978): Livestock interactions with fish and their environments. p.92-96. In: Proceedings of the Cal-Neva Wildlife Transactions, 1978.

[FISHERIES; GRAZING IMPACTS; RIPARIAN HABITAT]

1319. Platts, WS (1979): Livestock grazing and riparian/stream ecosystems -- an overview. p.3945. In: Cope,OB [ed.]. Forum -- grazing and riparian/stream ecosystems. 3-4 November 1979. Denver, CO. Trout Unlimited, Inc.

The problem is that past management practices have allowed streamside environments to deteriorate and that land managers do not have the information to correct the problems. Fishery biologists and range managers must concentrate on finding solutions to problems and providing these to land managers. [GRAZING IMPACTS; RIPARIAN ECOLOGY]

1320. Platts, WS (1979): Relationships among stream order, fish populations, and aquatic geomorphology in an Idaho river drainage. Fisheries 4(2), 5-9. [CLASSIFICATION; FISHERIES; GEOMORPHOLOGY]

1321. Platts, WS (1981): Effects of livestock grazing. In: Influence of forest and rangeland management on anadromous fish habitat in western North America. USDA Forest Service. General Technical Report PNW-124. 25 p.

This paper documents current knowledge on interactions of livestock and fish habitat. Included are discussions of incompatibility and compatibility between livestock grazing and fisheries, present management guidelines, information needed for problem solving, and future research needs. [GRAZING IMPACTS; LIVESTOCK EFFECTS; RIPARIAN HABITAT]

1322. Platts,WS (1981): Effects of sheep grazing on a riparian-stream environment. USDA Forest Service. Research Note INT-307. 6 p.

A stream section in a meadow receiving high intensity grazing from sheep was almost five times as wide and only $1 / 5$ as deep as an adjoining stream section where the meadow received light or no grazing. In the heavily grazed area, undercut banks were eliminated, streambanks were outsloped, and water depth at the stream surface-stream channel interface was only $1 / 13$ as deep as in the lightly or nongrazed areas. Prolonged holding of sheep on meadows for long periods of time is apparently detrimental to the riparian-stream ecosystem. [EROSION; GRAZING IMPACTS; LIVESTOCK EFFECTS]

1323. Platts, WS (1981): Impairment, protection and rehabilitation of Pacific salmonoid habitats on sheep and cattle ranges. p.82-92. In: Hassler, TJ [ed.]. Proceedings: Propagation, enhancement, and rehabilitation of anadromous salmonid populations and habitat in the Pacific Northwest. 15-17 October1981. Arcata, CA. Humboldt State University.

With proper grazing intensity, timing, and distribution of animals, forage can be utilized without undue stress on the stream and riparian environment. Rest rotation and 25 percent or less riparian herbage utilization will effectively protect a stream. Although rehabilitation of riparian vegetation may occur within 5 years, benefit to aquatic systems are slower. Rest rotation may not improve a badly degraded meadow with cattle, but may with sheep since they are not as hard on the landscape.

[FISHERIES; GRAZING IMPACTS; RIPARIAN HABITAT]

1324. Platts, WS (1981): Protection and enhancement of Pacific salmonids on ranges grazed by livestock: an overview. p.62-64. In: Hassler, TJ [ed.].Proceedings of the propagation, enhancement, and rehabilitation of anadromous salmonid populations and habitat in the Pacific Northwest. 15-17 October 1981. Arcata, CA. Humboldt State University.

Since the mid-1800s, there has been a dramatic decline in the quality of salmonid habitat in the Pacific Northwest. One land use responsible for part of this decline has been improper grazing by cattle 
and sheep. The solutions to reverse this decline reside with range and fishery specialists, who need to work together and coordinate their studies. These specialists must determine the suitability of each habilat type for grazing and the correct grazing strategy for proper animal distribution. [FISHERIES; GRAZING IMPACTS; RIPARIAN HABITAT]

1325. Platts,WS (1981): Sheep and cattle grazing strategies on riparian-stream environments. $p$. 251-270. In: Proceedings of wildlife-livestock relationships. 20-22 April 1981. Coeur d'Alene, ID. University of Idaho. Moscow, ID.

This paper addresses the effects of cattle and sheep grazing on stream riparian habitat. Initial results indicate that herded sheep grazing may have little effect on stream/riparian environment. The effects of cattle grazing first appear on streambanks and riparian vegetation. At utilization rates of 65 percent or more, habitat alteration occurs. Alteration is insignificant at utilization rates of 25 percent or less. Research to identify grazing strategies compatible with riparian values is needed. [GRAZING IMPACTS; GRAZING TREATMENTS; RIPARIAN HABITAT]

1326. Platts, WS (1981): Sheep and streams. Rangelands 3(4), 158-160.

Whenever sheep were forced to concentrate in the past on a riparian-stream area, they adversely affected the stream environment. Since sheep, however, are classified as animals that prefer slopes and upland sites for grazing, they would not be expected to have major on-site effects on riparianstream environments. Under grazing strategies such as deferred use plus active herding, there should be no detrimental effects on the fishery.

[GRAZING IMPACTS; LIVESTOCK EFFECTS]

1327. Platts, WS (1981): Stream inventory garbage in -- reliable analysis out: Only in fairy tales. p.75-84. In: Armantrout,NB [ed.]. Acquisition and utilization of aquatic habitat inventory information: Proceedings of a symposium. 28-30 October 1981. Portland, OR.

The success or failure of stream inventories depends on the suitability, accuracy, and combination of the selected habitat measurements. Accuracy is difficult to evaluate and seldom do we know what the true mean of the measured variable is in stream habitat assessment. This report defines the precision and repeatability that can be expected when measuring selected aquatic habitat conditions in
Intermountain West streams. [INVENTORY; MONITORING; RIPARIAN HABITAT]

1328. Platts, WS (1981): Riparian system/livestock grazing interaction research in the Intermountain West. p.424-428. In: Proceedings of the California riparian systems conference. 17-19 September 1981. Davis, CA.

Actual research that identifies the influences of livestock grazing has on riparian and aquatic ecosystems is limited. A research study initiated by the USDA Forest Service in 1975 studied these influences and was seeking to find solutions so that managers would have better information to evaluate range management alternatives. Continuous and rest rotation grazing systems on riparian ecosystems were compared and described.

[GRAZING IMPACTS; GRAZING TREATMENTS; LIVESTOCK EFFECTS]

1329. Platts, WS (1982): Livestock and riparian fishery interactions: What are the facts? p.507515. In: Transactions of the 47th North American wildlife and natural resources conference. 26-31 March 1982. Portland, OR. Wildlife Management Institute. Washington, DC.

In most livestock-fishery interaction studies, there is a bias because of poor study design, poor data collection. or erroneous interpretations and seldom have the authors known the exact location of the study area prior to the grazed conditions. Those studies confounded by stream improvement structures, other land uses, or fish stocking programs may have just as much bias. Regardless of biases in these studies, there is evidence that past grazing practices have degraded riparian habitats and decreased fish populations.

[FISHERIES; GRAZING IMPACTS; RIPARIAN HABITAT]

1330. Platts, WS (1983): How many stream habitat evaluation systems do we need? -- Less than a million. p.212-220. In: Proceedings, 63rd annual conference of the Western Association of Fish and Wildlife Agencies. 10-14 July 1983. Teton Village, WY.

There are about as many stream habitat evaluation systems as there are fisheries biologists. There is currently no concentrated effort to bring the systems together or to standardize the way that variables are being used. It is impossible at this time to construct one comprehensive system, but it is possible to build and standardize several specific 
evaluation systems that will accurately and fully evaluate specific parts of the environmental spectrum selected for analysis. A habitat evaluation system is proposed that has 10 different process steps beginning with the acquisition of the data base and ending with the interpretation and decision making stages.

[EVALUATION; RIPARIAN HABITAT; TECHNIQUES]

1331. Platts,WS (1983): Those vital streambanks. Western Wildlands 3(9), 7-10. [RIPARIAN HABITAT; RIPARIAN VEGETATION; STREAMBANK STABILITY]

1332. Platts, WS (1983): Vegetation requirements for fisheries habitats. p.184-188. In: Proceedings of the Symposia on managing intermountain rangelands - improvement of range and wildlife habitats. 15-17 September 1981; Twin Falls, ID. 22-24 June 1982; Elko, NV. USDA Forest Service General Technical Report INT-57.

The paper discusses the importance of streamside vegetation to each of the four habitat components that make up the aquatic environment. The effects of changes in riparian vegetation on stream temperatures, streambank stability, stream nutrients, fish cover, and fish food are discussed. Questions are presented to help land managers make intelligent decisions concerning management of riparian vegetation.

[AQUATIC ECOSYSTEMS; FISHERIES; RIPARIAN HABITAT; RIPARIAN VEGETATION]

1333. Platts, WS (1984): Compatibility of livestock grazing strategies with riparian-stream systems. p.67-74. In: Bedell,TE [ed.|. Proceedings of 1984 Pacific Northwest range management short course; Range watersheds, riparian zones and economics: Interrelationships in management and use. 25-27 January 1984. Pendleton, OR. Oregon State University Corvallis, $\mathbf{O R}$.

Livestock grazing strategies/techniques have been developed to increase plant and litter cover, encourage growth of favorable plant species, improve species composition, increase plant vigor. and prevent soil erosion on upland ranges. The same objectives must be met when riparian areas are used for grazing. This paper evaluates grazing strategies for their compatibility with stream/riparian zones and productive fisheries. Fishery specialists should understand these procedures in order to work more effectively with range conservationists.

[GRAZING IMPACTS; GRAZING TREATMENTS;
RIPARIAN HABITAT]

1334. Platts,WS (1984): Determining and evaluating riparian-stream enhancement needs and fish response. p.181-190. In: Hassler, TJ [ed.]. Pacific Northwest stream habitat management workshop. 10-12 October 1984. Arcata, CA. Humboldt State University

Many presently degraded riparian environments reached this condition over a 100 -year period, so that immediate enhancement will not likely occur. Riparian enhancement will probably be necessary for improvement and/or a extended period of time. The paper discusses riparian structure and integrity and enhancement procedures for rehabilitating riparian habitats.

[AQUATIC ECOSYSTEMS; FISHERIES; RIPARIAN HABITAT; RIPARIAN RESTORATION]

1335. Platts, WS (1984): Progress in range riparian-stream research at the Intermountain Forest and Range Experiment Station. p.78-84. In: Proceedings of the Bonneville Chapter of the American Fisheries Society. 8-9 February 1984. Logan, UT.

Eight options were presented for land managers to use in managing riparian-stream habitats, These options vary from the elimination of grazing to complicated grazing strategies. Options with the best opportunity for maintaining and improving these habitats are the inclusion of a riparian pasture, fencing streamside corridors, changing the kind of livestock, and adding more rest to the grazing cycle. [GRAZING IMPACTS; GRAZING TREATMENTS; RESEARCH]

1336. Platts, WS (1986)): Livestock grazing strategies and fisheries compatibility. North American Journal of Fisheries Management 34 p.

Livestock grazing strategies have been developed for upland ranges to increase plant and litter cover, encourage growth of favorable plant species, improve plant species composition, increase plant vigor, and protect soil from erosion. These same objectives must be met in the stream riparian zone. Grazing strategies are discussed and preliminarily evaluated with respect to how they satisfy the requirements of the stream riparian zone and related fisheries. Better understanding of rangeland management strategies may help fishery specialists work closer and more effectively with range conservationists in rangeland management. [FISHERIES; GRAZING IMPACTS] 
1337. Platts, WS (1986): Managing fish and livestock on Idaho rangelands. Rangelands 8(5), 213-221.

Improper livestock grazing can degrade all four components that make up the fisheries habitat: streamside vegetation, stream channel condition, shape and quality of the water column, and the structure of the soil portion of the streambank. Improving the riparian portion of the rangeland allows these stream components a to begin to rehabilitate. Where streamside vegetation is abundant and vigorous, flood impacts are minimized.

Rehabilitating riparian environments through grazing offers a productive and efficient way to increase wild trout populations in Idaho.

[FISHERIES; GRAZING IMPACTS]

\section{Platts, WS (1986): Managing riparian} stream habitats. p.59-62. In: Proceedings of the Wyoming water and streamside zone conference.28-30 April 1986. Casper, WY. University of Wyoming. Laramie, WY. Improved grazing management strategies are recommended. Riparian pasture and stream corridor fencing methods for managing the riparian zones are described. The effects of grazing time and species on riparian vegetation and stream health are discussed. Resilience to rare hydrologic events is an attribute of 'healthy' riparian zones. Riparian management should anticipate the rare event, particularly given the rapid climate changes predicted for the next century. [GRAZING IMPACTS; GRAZING TREATMENTS; RIPARIAN HABITAT]

1339. Platts,WS (1986): Using a hydrogeologic, historic and futuristic approach to stream riparian management. Fisheries, 27 p.

National assessments and planning to provide for the future management of stream riparian habitats are required by law. Analytical prognostic models are now being developed to guide future decisions. There is a need for these models to come from the hydrologic-historic past in order to better predict the future.

[FISHERIES; GFOMORPHOLOGY; RIPARIAN MANAGEMENT ZONE]

1340. Platts,WS (1989): Compatibility of livestock grazing strategies with fisheries. p.103110. In: Gresswell,RE; Barton,BA; Kershner,JL leds.] Riparian resource management. An educational workshop. USDI Bureau of Land Management. Billings, MT.

This paper reviews the effects of grazing on the stream condition and the practice of various grazing strategies on the riparian ecosystem. Fisheries can be damaged by physical destruction of habitat including loss of streambank overhang. Increases in sediment loads can create changes in channel morphology and substrate composition causing detrimental conditions for fish. Grazing systems can change the intensity and duration of impacts to fish habitat.

[FISHERIES; GRAZING IMPACTS; GRAZING TREATMENTS]

1341. Platts, WS (1990): Managing fisheries and wildlife on rangelands grazed by livestock: $A$ guidance and reference document for biologists. Nevada Department of Wildlife. $114 \mathrm{p}$.

If progress is to be made in rehabilitating western streams, rangeland management has to be improved greatly over that being practiced today. This document is dedicated to seeing that the field biologist has the tools, background, methods, and input necessary to turn this system around. If the present body of knowledge were only put on the ground, western streams would rehabilitate quite rapidly.

[GRAZING IMPACTS; LIVESTOCK EFFECTS; RIPARIAN HABITAT]

1342. Platts, WS (1991): Livestock grazing. p.389423. In: Influences of forest and rangeland management on salmonid fishes and their habitats. American Fisheries Society Special Publication 19.

The range environment includes 485.6 million hectares in the USA. Sixty nine percent of this rangeland was grazed by livestock in 1970 , furnishing 213 million animal unit months of forage. Much of this rangeland has become depleted of natural and desirable vegetation, adversely affecting runoff and altering sediment recruitment and transport to and within streams. Even though livestock use on western ranges has passed the 100year mark, the importance of grazing effects on aquatic resources is just beginning to be understood. Research has not fully identified these problems, described their magnitude, or provided methods for their solution.

[FISHERIES; GRAZING IMPACTS; LIVESTOCK EFFECTS; RIPARIAN VEGETATION]

1343. Platts, WS; Armour,C; Booth,G; Bryant,M; Bufford,JL; Cuplin,P; Jensen,S; Lienkaemper,G; Minshall,GW; Monsen,S; Nelson,RL; Sedell,JR; Tuhy,JS (1987): Methods for evaluating riparian habitats with applications 
to management. USDA Forest Service. General

Technical Report INT-221. 177 p.

This report proposes a standard way of measuring and evaluating riparian conditions. The methods will be helpful to persons documenting, monitoring, predicting, or evaluating riparian, stream or range conditions, and how this relates to their biotic resources, especially those conditions needed to relate to impacts from land uses.

[CHANNEL DYNAMICS; ORGANIC DEBRIS;

RIPARIAN HABITAT; RIPARIAN

MANAGEMENT ZONE; RIPARIAN

VEGETATION]

1344. Platts,WS; Behake,RJ; Buckhouse,JC; Casey,OE; Claire,EW; Cooper,J; Duff,DA;

Evans,WA; Haugen,G; Marcuson,PE; Meehan,WR; Phillipes,RW; Raleigh,RF; Skovlin,JM (1977): Livestock interactions with fish and their environments. p.36-41. In: Proceedings of the workshop on livestock and wildlife-fisheries relationships in the Great Basin. Sparks, NV. University of California; Berkeley, CA. Spec. Publ. 3301.

This report assesses the influences livestock have on aquatic and riparian environments, provides recommendations for more compatibility between livestock grazing and fisheries, lists management objectives for protecting, restoring or enhancing fish and riparian habitats, and describes beneficial management practices. The importance of recognizing the riparian ecosystem as a separate management unit within the range system, as defined by the USDA Forest Service, is emphasized. [FISHERIES; GRAZING IMPACTS; RIPARIAN HABITAT]

1345. Platts,WS; Gebhardt,KA; Jackson,WL (1985): The effects of large storm events on basinrange riparian stream habitats. p. 30-34. In: Johnson,RR; Ziebell,CD; Patton,DR; Ffolliott,PF; Hamre, RH [tech. coord.]. Riparian ecosystems and their management; Reconciling conflicting uses. 16-18 April 1985. Tucson, AZ. USDA Forest Service. General Technical Report RM-120.

When stream riparian reaches received heavy livestock grazing, large storm events had major impacts. One ungrazed rehabilitated stream reach improved in habitat condition while two adjacently grazed stream reaches decreased. Each stream reacted differently to channel erosion, with two streams showing mainly lateral channel movement and the third vertical channel movement. [AQUATIC ECOSYSTEMS; GRAZING IMPACTS;
RIPARIAN HABITAT; STORM EVENTS]

1346. Platts, WS; Johnson,SJ (1982): Impacts of domestic livestock grazing on small mammals of forest grazing allotments in southeastern Idaho. p.242-250. In: Proceedings of the symposium on wildlife-livestock relationships. 20-21 April 1981. University of Idaho. Coeur d'Alene, ID.

Small mammals were sampled in a wide variety of habitats on the Targhee National Forest in 1974, 1977. Significant differences were found in small mammal communities between grazed and ungrazed sites in both riparian and nonriparian areas. Grazing may have been producing an increase in species which require low levels of cover while reducing species which need higher levels of cover.

Specialized species limited to high cover within riparian areas may be eliminated from localized areas. In order to maintain a diversity of small mammal species, coordination is needed to maintain varied utilization levels.

[GRAZING IMPACTS; SMALL MAMMALS; UTILIZATION]

1347. Platts,WS; Martin,SB (1978):

Hydrochemical influences on the fishery within the phosphate mining area of eastern Idaho. USDA Forest Service. Research Note INT-246.

Hydrochemical analysis of selected streams in the upper Blackfoot River drainage showed waters in these streams were in a near natural state, with possible modification from surrounding land uses. Stream hydrochemistry and physical condition of fish indicated the fishery was in good condition. No influences from present phosphate mining were found that threatened fish health or survival. Hydrochemically, the Blackfoot system is capable of producing a good cutthroat trout fishery, but high levels of nutrients probably restrict optimum cutthroat trout populations.

[FISHERIES; HYDROCHEMICAL INFLUENCES; HYDROLOGY; MINING IMPACTS]

1348. Platts, WS; Martin,SB (1980): Livestock grazing and logging effects on trout. p. 34-46. In: Proceedings of wild trout II. 24-25 September 1980. Yellowstone National Park, WY. Trout Unlimited, Inc. and the Federation of Fly Fishermen.

This paper discusses the influence of livestock grazing and timber harvesting activities on trout and their environments. Specific pollution effects on stream habitat and water quality resulting from such development are discussed. Present and future 
management of the resource is summarized, and suggestions for future management of both livestock and logging are suggested.

[FISHERIES; GRAZING IMPACTS; LOGGING IMPACTS]

1349. Platts,WS; Martin,SB; Primbs,ERJ (1979): Water quality in an Idaho stream degraded by acid mine waters. USDA Forest Service. General Technical Report INT-67. 19 p.

Studies from 1967 through 1977 are discussed that show seepage from the no longer operating Blackbird Mine in east Idaho has resulted in acidic waters high in sediment and heavy metals. High concentrations of cobalt, copper, iron, manganese, lead, and zinc in the Panther Creek drainage are the probable cause of diminished insect and fish populations in the area. Pollution from the mined area will remain a problem in the drainage until rehabilitative measures are taken.

[MINING IMPACTS; POLLUTION; WA'TER QUALITY]

1350. Platts,WS; Meehan,WR (1983): Livestock grazing and fish environments: situation and needs. p.30-34. In: Menke, JW [ed.]. Proceedings of the workshop on wildlife-fisheries relationships in the Great Basin. 3-5 May 1977. Sparks, NV. University of California. Berkeley, CA. Spec. Publ. No. 3301.

[FISHERIES; GRAZING IMPACTS]

1351. Platts,WS; Megahan,WF; Minshall,GW (1983): Methods for evaluating stream, riparian, and biotic conditions. USDA Forest Service. General Technical Report INT-138. 70 p.

This publication prescribes standard ways of measuring stream, riparian, and biotic conditions and evaluates the validity of the recommended measurements. Accuracy and precision of most measurements are defined. This report will be of value to those persons documenting, monitoring, or predicting stream conditions and their biotic resources, especially those related to impacts from land uses.

[EVALUATION; MONITORING; RESEARCH; RIPARIAN HABITAT]

1352. Platts, WS; Nelson,RL (1983): The electronic capacitance meter: A tool for evaluating riparian fishery habitat. North American Journal of Fisheries Management 3(3), 219-227.

The use of an electronic capacitance probe to measure riparian biomass is described.
[RESEARCH; RIPARIAN HABITAT]

1353. Platts,WS; Nelson,RL (1985): Impacts of rest rotation grazing on streambanks in forested watersheds in Idaho. North American Journal of Fisheries Management 5, 547-556.

In Idaho, rest rotation grazing allowed forage in the streamside zone to be used at a higher rate than on either immediately adjacent range or the overall grazing allotment. Complete rest was difficult to achieve because of unauthorized use. Cattle appeared to graze streamside at high elevations with less intensity during the early grazing period when vegetation was lush than during the late grazing season. Streambank alteration occurred soon after cattle were turned into ungrazed meadows. [GRAZING IMPACTS; GRAZING TREATMEN'TS; STREAMBANK STABILITY; WATERSHED]

1354. Platts,WS; Nelson,RL (1985): Stream habitat and fisheries response to livestock grazing and instream improvement structures. Big Creek, Utah. Journal of Soil and Water Conservation 40(4), 374-379.

Fisheries habitat and response were compared on an area protected from grazing for 11 years and on adjacent, heavily grazed areas of similar structural and riparian character. Prohibiting grazing dramatically improved riparian vegetation, streambanks, and stream channel conditions. But this improvement was countered by off-site, upstream influences and on-site, instream improvement structures that functioned as fine sediment traps. Fish populations did not respond to improving habitat conditions because the relatively small size of the livestock exclosure did not reduce the incoming, limiting influences created by upstream conditions and the artificial nature of the fishery. [AQUATIC ECOSYSTEMS; FISHERIES; GRAZING IMPACTS; RIPARIAN HABITAT; STREAM IMPROVEMENTS]

1355. Platts,WS; Nelson,RL (1985): Streamside and upland vegetation use by cattle. Rangelands 7(1), 5-7.

Proper grazing of streamside vegetation requires controlled animal distribution. It is usually not feasible to fence every streamside corridor to create separate riparian pastures for specialized management. Therefore, grazing strategies that regulate animal distribution and forage use must be developed. Some strategies that appear promising include: winter grazing, separate riparian pastures, total closure of vulnerable areas, longer rest periods, 
and deferred grazing that allows protective vegetation to be maintained during critical runoff periods.

[GRAZING IMPACTS; LIVESTOCK EFFECTS; RIPARI $\Lambda N$ VEGETATION]

1356. Platts,WS; Nelson,RL (1985): Will the riparian pasture build good streams? Rangelands 7(1), 7-10.

Studies show that, on conventionally managed allotments using rotation, rest rotation, deferred, and season long continuous cattle grazing strategies, cattle graze riparian range types more heavily than the uplands. Fencing streamside corridors to exclude grazing is expensive and a large amount of forage is lost. Special management pastures will also be cxpensive, but the forage can be efficiently utilized. Eliminating grazing from certain allotments is not sociologically, economically, or politically acceptable. The special riparian pasture is a promising alternative.

[GRAZING IMPACTS; RIPARIAN

ENHANCEMENT; RIP $\Lambda$ RI $\Lambda$ N P $\Lambda$ STURES]

1357. Platts,WS; Nelson,RL (1989):

Characteristics of riparian plant communities and streambanks with respect to grazing in northeastern Utah. p.73-81. In: Gresswell,RE; Barton,BA; Kcrshncr, JL [cds.]. Riparian resource management: An educational workshop. USDI Bureau of Land Management. Billings, MT.

Streambanks and associated riparian vegetation were studied in grazed and ungrazed pastures along Big Creek in Utah to determine whether differences in streamside community type, composition, and condition were related to differences in streambank morphology. Streambank stability was related to the community type and grazed condition. Root systems, sod formation, horizontal rooting and depth extent affect the stability of vegetated streambanks. Where sedges become dominant they clearly create the most optimal streambank structure. Managers must ensure moderate grazing on these so that Carex spp. communities do not revert to less favorable communities like bluegrass.

[EXCLOSURES; GRAZING IMPACTS; PLANT

COMMUNITIES; STREAMBANK STABILITY]

1358. Platts,WS; Nelson,RL (1989): Stream canopy and its relationship to salmonid biomass in the Intcrmountain West. North American Journal of Fisheries Management 9, 446-457.

Salmonid biomass and stream canopy characteristics that affect thermal input were measured for streams in the Rocky Mountains and Great Basin. Relationships between salmonid biomass and overstory attributes differed between streams of the two regions. Salmonid biomass was strongly correlated with canopy density $(+v c)$, light intensity (-ve) and sun arc (-ve) in the more productive Great Basin streams, but the same correlations were weak for the Rocky Mountain streams. Insolation is likely to be a limiting factor in the Great Basin streams studied, whereas other factors moderate its effect in the Rocky Mountain study streams.

[C $\Lambda$ NOPY; FISHERIES; RIP $\Lambda$ RI $\Lambda$ N HABITAT; STREAMBANK STABILITY]

1359. Platts,WS; Nelson,RL; Casey, $O$; Crispin,V (1983): Riparian-strcam habitat conditions on Taber Creek, Nevada, under grazed and ungrazed conditions. In: Proceedings of the 63rd annual conference of the western fish and wildlife agencies. 10-14 July 1983. Teton Village, WY.

On a previously grazed riparian stream in northeastern Nevada, habitat improved when completely rested for about 14 years. Improvements were observed in water columns (stream width/depth/pools), stream bank, and riparian vegetation. In comparison, continuous grazing proved to be detrimental to riparian stream habitat. [ $\Lambda$ QUATIC ECOSYSTEMS; EXCLOSURES; GRAZING IMPACTS; RIPARIAN HABITAT]

1360. Platts,WS; Nelson,RL; Minshall,GW (1985): Development of aquatic methodology to evaluate impacts from livestock grazing; methodology testing. USDA Forest Service. Intermountain Forest and Range Experiment Station. Progress Report \#4. 42 p. BLM, Idaho Falls District, Idaho Falls, ID. [GRAZING IMPACTS; RESEARCH]

1361. Platts,WS; Raleigh,RF (1984): Impacts of grazing on wetlands and riparian habitat. p. 1105 1117. In: Developing strategies for rangeland management. National Research Council/National Academy of Sciences, Boulder, CO. Westview Press.

This chapter discusses a paper presented by Jon Skovlin at the workshop on "The Impacts of Grazing Intensity and Specialized Grazing Systems" held in El Paso, Texas, in March, 1981. Further, it expands on the function and value of riparian systems, on grazing systems, and on management alternatives available.

[GRAZING IMPACTS; GRAZING TREATMENTS; 
1362. Platts,WS; Rinne,JN (1985): Riparian ahd stream enhancement management and research in the Rocky Mountains. North American Journal of Fisheries Management 5(2A), 115-125.

Past stream enhancement research in the Rocky Mountains is reviewed. Research is lacking on straam improvement in a watershed context on a long-term basis. Not all streams can be enhanced. Enhancem ent should be attempted only after techniques describ \&d in the literature have been carefully considered as appropriate for the site.

[RESEARCH; RIPARIAN MANAGEMENT ZONE; RIPARIAN RESTORATION]

1363. Platts,WS; Torquemada,RJ; McHenry,ML; Graham,CK (1989): Changes in salmon spawning and rearing habitat from increased delivery of fine sediment to the South Fork Salmon River, Idaho. Transactions of the American Fisheries Society 118, 274-283.

Levels of surface and subsurface fine sediment $(<4.75 \mathrm{~mm}$ in diameter) were measured annually from 1965 to 1985 in spawning and rearing areas for chinook salmon (Oncorhynchus tschawytscha) and steelhead (O. mykiss) (formerly Salmo gairdneri) in the South Fork Salmon River, Idaho. A logging moratorium initialed in 1965, coupled with natural recovery and watershed rehabilitation, led to significant decreases in the amounts of fine sediments delivered to and stored in the South Fork

Salmon River; this reduction led to a limited resumption to logging operations within the watershed in 1978. By 1985, surface and subsurface sediment levels in chinook salmon spawning areas averaged 19.2 percent of the surface area and 25.4 percent of the volume, respectively. However, additional recovery to pre-logging fine sediment levels is probably contingent on both further watershed recovery and the occurrence of flood flows capable of transporting material downstream. An equilibrium between incoming sediment from th $\phi$ watershed and outgoing sediment from the river appears to have been reached under flow regime that have occurred since 1975.

[RIPARIAN HABITAT; SALMONIDS; SEDIMENTATION; STREAM FLOW]

1364. Platts,WS; Wagstaff,FJ (1984): Fencing to control livestock grazing on riparian habitats along streams: Is it a viable alternative? North American Journal of Fisheries Management 4(3), 266-272.
Fencing riparian areas along streams to exclude livestock grazing is a management alternative in many areas of the West, but cost frequently exceeds the gains in fishery values. However, there are few alternatives to fencing that are economically and sociologically acceptable, i.e. no grazing. Fencing costs about $\$ 6,000$ per stream mile. Maintenance costs $\$ 60-200$ per stream mile, and about 12 AUMs per fenced stream mile are lost. If fisheries were the only economic factor considered, it would require an increase of 47 fisherman days per mile to justify the costs.

[ECONOMICS; EXCLOSURES; GRAZING IMPACTS]

1365. Platts,WS; Wagstaff,FJ; Chaney,E (1989): Cattle and fish on the Henry's Fork. Rangelands 11, 58-62.

A synopsis of the historic uses of the Henry's Fork of the Snake River, Idaho, and of present uses, and a summary of a streambank rehabilitation project along approximately 6 miles of the Henry's Fork. The study employs a stuttered deferred grazing rotation with selected rest. Electric fencing technology was employed. Data describing streambanks and vegetation for 1985 (grazed) and 1986 (rested) indicates potential for vegetation improvement with rest from grazing but does not yet indicate changes in streambank characteristics.

[GRAZING IMPACTS; GRAZING TREATMENTS; LIVESTOCK EFFECTS; RIPARIAN RESTORATION]

1366. Poel,P,; Spooner,RG; Piest,RF (1986): Slope indicator measurements of subsurface movement in gully walls. Transactions of the American Society of Agricultural Engineers 29, 982-987.

Slope indicator access tubes were installed in gully banks along an actively eroding channel and upstream of an actively advancing gully head-cut in western Iowa. Deflection of these aluminum tubes due to soil movement was measured with a slope indicator probe capable of sensing small horizontal displacement. Surfacc soil movement adjacent to the channel was toward the channel; deflections of the tubes at greater depths were gencrally toward the channel and indicated slab or topping failure. Bank failure was related to high peak flows and passing channel scarps that decreased bank stability, especially during spring runoff. All recorded bank failures showed greatest displacement at the surface with most of the movement occurring above a depth of 3 to $4 \mathrm{~m}$. 
[CHANNEL DYNAMICS; GEOMORPHOLOGY; GULLY CONTROL; STREAMBANK STABILITY]

1367. Pogacnik,TM; Marlow,CB (1983): The effects of time of grazing on stream channel stability and suspended sediment loading. Proceedings of the annual meeting of the Society for Range Management. 14-16 February 1983. Albuquerque, NM.

The effects of cattle grazing in riparian zones during different periods of the growing season we e investigated on a small watershed in southwest Montana. The study was initiated to quantify changes in stream channel stability and suspended sediment loads due to grazing impacts. Stream channel stability by taking cross-sectional diagrams at 5 stations within the grazed area. Suspended sediment and streamflow were measured concurrently. Results of 2 ycars investigation indicated significant difference between early and late season grazing treatments. Alterations in the strcam channel and increases in suspended sediments were most significant during the grazing scason Junc 28-July 12. Minimal alteration and sedimentation occurred from September 22- October 6.

[CHANNEL MORPHOLOGY; GRAZING IMPACTS; SEDIMENTATION]

1368. Pollock,MM; Naiman,RJ; Hanlcy,TA (1998): Plant species richness in riparian wetlands - A test of biodiversity theory. Ecology 79(1), 94105.

Flood frequency, productivity, and spatial heterogeneity were correlated with plant species richness among wetlands on a coastal island in Alaska. Sites with intermediate flood frequencies and high spatial variation of flood frequencies (SVFF) were species rich, while sites frequently, rarely, or permanently flooded and with low SVFF were species-poor. The data suggest that small scale spatial variation can dramatically alter the impact of the disturbance. Species rich sites had low to intermediate levels of productivity and intermediate flood frequencies, and species-poor sites had ver, low or high flood frequencies and low productivities. [FLOOD IMPACTS; RIPARIAN HABITAT; RIPARIAN VEGETATION; SPECIES RICHNASS]

1369. Ponce, VC (1978): Generalized stability analysis of channel banks. Journal of Irrigation and Drainage Engineering. Procedures of the American Society of Civil Engineers 104(4), 343350.

Stability of alluvial banks is important in relation to the study of bank erosion and channel morphology. The problem of an initially stable channel bank subject to undermining at the toe is considered in this paper. Undermining at the toe is usually caused by the flow impingement originating in the curvature of the flow pattern. A generalized slope stability analysis is presented, the objective being to relate the lowering of the base level to the change in the factor of safety against failure of the bank, as a function of the slope geometry and soil characteristics. The effect of the water table on the soil characteristics is not explicitly taken into account in the analysis. Rather, slope stability calculations arc carried out for homogeneous earth banks for which average soil properties can be assumed, underscoring the qualitative nature of this study.

[CHANNEL DYNAMICS; CHANNEL MORPHOLOGY; EROSION; STREAMBANK STABILITY]

1370. Poplizio,CA; Goetz,H; Chapman,PL (1994): Short-term response of riparian vegetation to 4 grazing treatments. Journal of Range Management 47(1), 48-53.

Three replications of each of the following treatments were applied on Sheep Creek in northcentral Colorado: long-term grazing, protection from livestock grazing since 1956, recent protection after long-term grazing, and recent livestock grazing following protection. When percent foliar cover means were paired using Sorensen's similarity index, long-term grazing and short-term grazing treatments were least similar in late summer, 1988. Long-term protection and short-term grazing were most similar in early summer, 1989. Average percent cover of bare ground, common dandelion, white Dutch clover, and legumes grouped as life forms were significantly different among treatments, with long-term grazing being significantly different from long-term protection. Average sedge and forb cover was least affected. Average percent grass cover increased under short-term protection after a history of longterm grazing. Short-term grazing stimulated foliar cover of forbs, grasses, and sedges after more than 30 years of cattle exclusion. [GRAZING IMPACTS; INVENTORY; LIVESTOCK EFFECTS; RIPARIAN MANAGEMENT ZONE]

1371. Potter,DA; Finch,DM (1996): Rio Grande Basin Consortium: Mission, goals, and activities. p.203-207. In: Shaw,DW; Finch,DM [tech. coord.]. Desired future condition of Southwestern riparian ecosystems: Bringing shared interests and 
concerns together. USDA Forest Service. General Technical Report RM-GTR-272.

The Rio Grande Basin Consortium (RGBC) serves as a networking group and clearinghouse for scientific information pertaining to the Rio Grande Basin. Its membership consists of natural and social scientists from New Mexico's three research universities, administrators, and resource managers from federal, state, and local government agencies, members of community and advocacy groups, and private citizens. Members share an interest in better understanding the physical, ecological, economic, social, and cultural dynamics of this drainage area. This report briefly describes the history, mission, goals and objectives, past and current projects and partnerships, and funding of the Consortium. [PARTNERSHIPS; RIO GRANDE; RIPARIAN HABITAT]

1372. Potter,DU; Gorman,SM (1996): Spatial relationships among lightning, precipitation, and vegetative cover in watersheds of the Rio Puerco Basin: An introduction. p.113-127. In: Shaw,DW; Finch,DM [tech. coord.]. Desired future condition for Southwestern riparian ecosystems: Bringing interests and concerns together. USDA Forest Service. General Technical Report RM-GTR-272.

This paper explores the question "is there a relationship between seasonal precipitation amounts and vegetative cover at a specific site near Grants, New Mexico?" Several hypotheses are investigated. One is that the organizing factor for vegetative response to precipitation is the amount of summer precipitation from convective thunderstorms. The variable winter precipitation (high in El Nino years and low in La Nina years) does not provide a dependable amount of moisture, and plant cover or basal areas are not well correlated with it.

Alternatively, winter or annual precipitation may be the organizing factor for vegetation response. Otherwise, factors such as land use activities, soil type, geological features, temperatures, etc., could be the primary organizers of vegetation pattern within the study site. A Geographic Information System (GIS/ARC/Info) vector data structure will be used to organize, analyze and display the data. Final products will include GIS thematic maps of the study area that display precipitation and vegetation data. The results of statistical and spatial operations such as linear regressions, interpolations, and kriging will be presented and discussed in subsequent publications. [COVER; GIS; PLANT COMMUNITIES; PRECIPITATION; RIPARIAN HABITAT; SPATIAL SCALE; WATERSHED]
1373. Potyondy,JP (1987): Some techniques for using frequency analysis and real time data to interpret flood potential data. Water Resources Bulletin 23(1), 139-145. [FLOOD IMPACTS; HYDROLOGY; STREAM FLOW; WATER SUPPLY]

1374. Potyondy,JP (1996): Technical issues related to non-point source management. p.65-73. In: National hydrology workshop proceedings. 27 April - 1 May 1992; Phoenix, AZ. USDA Forest Service. General Technical Report RM-GTR-279.

Non-point source pollution is a major water quality problem. Because of inherent differences between point sources and non-point sources, different control strategies are required. Non-point source control strategies rely primarily on the application of Best Management Practices (BMPs) as the means to achieve protection of designated beneficial uses. Increasingly, environmental groups and regulatory agencies are looking toward instream numeric water quality criteria as a regulatory mechanism for controlling non-point sources. Numerous technical problems exist with this approach. The most significant being the highly variable and poorly understood relationships between land use and the beneficial uses that have to be protected. The continued use of BMPs appears to offer important advantages over instream water quality standards and their continued use is suggested. In the long term, monitoring data accumulated to evaluate BMPs can be used to build a sound scientific basis for eventual evolution to water quality based approaches.

[BEST MANAGEMENT PRACTICES; NONPOINT SOURCE POLLUTION; WATER QUALITY]

1375. Power,ME; Sun,A; Parker,G; Dietrich,WE; Wootton,JT (1995): Hydraulic food chain models. BioScience 45(3), 159-167.

Modeling efforts can be particularly effective in guiding field studies in large, dynamic, riverine systems, where sampling and experimental manipulations are difficult. The authors see the interaction of modeling and field investigation as the best approach to understanding the complex environmental problems such as those that arise when levees eliminate the floodplain and the flood pulse, or regulation eliminates, alters or dampens seasonal changes in discharge - the master variable that limits and resets river populations throughout entire drainage networks. Future research is likely to support the basic ecological paradox of rivers: that 
large, frequent hydrologic perturbations are crucial for long-term maintenance of their biodiversity, their enormous productivity, and the higher trophic levels, which include the biological populations most prized by humans.

[BIODIVERSITY; FLOOD IMPACTS; FLOODPLAIN MANAGEMENT; HYDROLOGY; MODELING; RESEARCH]

1376. Prange,R (1993): Duck Creek riparian habitat restoration project, Henry's Lake, Idaho. p.395-396. In: Tellman,B; Cortner,HJ; Wallace,MG; DeBano,DF; Hamre, KH |tech. coord.|. Riparian management: Common threads and shared values. USDA Forest Service. General Technical Report RM-226.

This project demonstrated that the traditional barriers between ranchers and fishery interests could be overcome for common gain. A modest project was initially undertaken with one rancher/cooperator. The success of that first project proved contagious and caused other ranchers to become voluntarily involved.

[COLLABORATION; RIPARIAN HABITAT; RIPARIAN RESTORATION]

1377. Pratt,J; Garcia,J; Orloff,S (1987): Riparian habitat assessment techniques. In: Streamside management: Riparian wildlife and forestry interactions. An interdisciplinary symposium. 11-13 February 1987. University of Washington. Seattle, WA.

A new method for comprehensive inventory and evaluation of stream corridors was developed for the purpose of identifying riparian and riverine areas of high value to fish and wildlife. The method, the Stream Corridor Inventory and Evaluation System (SCIES), is capable of integrating Instream Flow Incremental Method evaluations and Habitat Evaluation Procedures evaluations or may be used independently.

[INVENTORY; RIPARIAN HABITAT]

1378. Price,KP; Ridd,MK (1983): Riparian habitat on the Humbolt River, Deeth to Elko, Nevada. Center for Remote Sensing and Cartography. CRCS Report 83-3. University of Utah Research Institute; Salt Lake City, UT. 48 p.

This study was conducted to provide Nevada Department of Wildlife with a map inventory of the major habitat types existing along the Humboldt River riparian zone. It was also initiated to describe the ecological relationships that exist between habitat types and their surrounding environment, and to report impacts to the habitat due to management practices along the river. The principal source of data for this study was a variety aerial photographs with trips to the field for verification of vegetation types. Management practices such as willow eradication, river damming, bridges and bank stabilization, and channelization were mapped and their environmental impacts discussed.

[AERIAL PHOTO; CHANNEL DYNAMICS; INVENTORY; REMOTE SENSING; RIPARIAN HABITAT; RIVER ECOLOGY; STREAMBANK PROTECTION; WILLOW]

\section{Prichard,D (1998): Riparian area} management: A user guide to assessing proper functioning condition and the supporting science for lotic areas. USDI Bureau of Land

Management Technical Reference 1737-15. 136 p.

A method that was developed by an interagency work group is presented for evaluating the condition of riparian wetland areas. The method determines if an area is in proper functioning condition. The process is both qualitative and science-based and considers biotic and abiotic factors relating to physical function. A standard checklist is used to ensure consistency in reporting condition. When quantification is necessary, numerous methods of quantification are provided.

[HYDROLOGY; PROPER FUNCTIONING CONDITION; RIPARIAN VEGETATION; WETLANDS]

1380. Prichard,D; Barrett,H; Cagney,J; Clark,R; Fogg,J; Gebhardt,K; Hansen,PL; Mitchell,B; Tippy,D (1993): Riparian area management: Process for assessing proper functioning condition. USDI Bureau of Land Management. Technical Reference 1737-9. $60 \mathrm{p}$.

I'his technical reference outlines the BLM's process for assessing the functioning condition of riparian areas on public lands. Emphasis is placed on the interaction of vegetation, landform/soils, and hydrology in defining capability and potential of an area. The importance of using an interdisciplinary team is also stressed. The document describes four categories of functioning condition: proper functioning condition, functional at risk, nonfunctional and unknown, and discusses management strategies for each.

[HYDROLOGY; PLANT COMMUNITIES; PROPER FUNCTIONING CONDITION; RIPARIAN HABITAT; SOILS; WETLANDS]

1381. Prichard,D; Bridges,C; Knapf,R; 
Leonard,S; Hagenbuck,W (1994): Riparian area management: Process for assessing proper functioning condition for lentic riparian-wetland areas. USDI Bureau of Land Management. Technical Reference 1737-11. 46 p.

This report outlines the BLM's process for assessing the functioning condition of lentic riparianwetland areas on public lands. Emphasis is placed on the interaction of vegetation, landform/soils, and hydrology in defining capability and potential of an area. The importance of using an interdisciplinary team is also stressed.

[HYDROLOGY; PROPER FUNCTIONING CONDITION; RIPARIAN; SOILS; WETLANDS]

1382. Prichard,DE; Upham,LL (1985): Texas Creek riparian enhancement study. USDI Bureau of Land Management. Colorado State Office. Technical Bulletin. 13 p.

This study in southcentral Colorado concludes that enhancement of riparian habitat can occur by implementing any of the three manipulated factors: 1) deferred livestock grazing; 2) protective fencing; and 3) habitat treatments. The most dramatic improvements occurred where livestock grazing was excluded in combination with intensive habitat treatment projects.

[GRAZING IMPACTS; RIPARIAN HABITAT; RIPARIAN ENHANCEMENT]

1383. Prichard,D; Upham,LL (1986): Enhancement of riparian areas in Texas Creek, Colorado. In: Proceedings of the 51st North American wildlife and natural resources conference. 21-26 March 1986. Reno, NV. The Wildlife Management Institute.

This study demonstrated that enhancement of riparian habitat can occur with: 1) deferred livestock grazing; 2) protective fencing; and 3) extensive habitat treatment, but the level of improvement varied. The most noticeable improvement occurred in a segment where livestock grazing was excluded in combination with extensive habitat treatment projects.

[EXCLOSURES; GRAZING IMPACTS; RIPARIAN MANAGEMENT ZONE; RIPARIAN RESTORATION]

1384. Protasel,G (1987): How institutional laws, rules, policies, and objectives influence on-theground riparian forest management. In: Streamside management: Riparian wildlife and forestry interactions. An interdisciplinary symposium. 11-13 February 1987. University of
Washington. Seattle, WA.

Riparian forest management is most directly influenced by statutes which articulate substantive policy and by objectives which are defined by mandatory rules. The burden is presently on the forester to get the technical assistance needed from wildlife biologists in order to wisely manage the riparian habitat.

[RIPARIAN FORESI; RIPARIAN HABITAT]

1385. Prouty,M (1987): A new program for riparian research. p.7-10. In: USDA Forest Service, Intermountain Region. Forest Research West.

A topical article describing the charter of the new "Riparian-Stream Ecology and Management" research work team based in Boise, Idaho. The team was formed to improve the understanding of riparian and stream habitats and improve methods of managing them for the conservation of resources and production of livestock, fish, and wildlife.

[RESEARCH; RIPARIAN HABITAT; RIPARIAN MANAGEMENT ZONE]

1386. Pruitt,'IA; Nadeau,KL (1978):

Recommended stream resource maintenance flows on seven southern Idaho streams. USDI Fish and Wildlife Service. Instream Flow Information Paper No. 8. OBS-78/68. 60 p. [FISHERIES; HYDROLOGY; STREAM FLOW; WATER RESOURCE MANAGEMENT']

1387. Purvis, A (1995): Ecosystem management: Where did the concept come from? Why and how is it influencing the public policy process? p.458-9. In: Proceedings of the fifth international rangeland congress. 23-28 July 1995. Salt Lake City, UT.

Ecosystem management is profiled as an evolving policy concept. Alternative definitions of the term and schemes for implementation are discussed. A fundamental ethical conflict which poses dilemmas for an operational paradigm is discussed. The role of the concept in ameliorating endangered species is addressed and future options for development/implementation are suggested. [ECOSYSTEM MANAGEMENT; GRAZING IMPACTS; POLICY]

1388. Quigley,TM (1981): Estimating contribution of overstory vegetation to stream surface shade. Wildlife Society Bulletin 9(1), 2227.

A method for estimating the contribution of 
forest overstory to stream surface shade is presented. Characteristics measured are stream width, distance from vegetation to stream, orientation of stream, height of overstory, density of vegetation, crown measurement, location, date, and time. Examples are given.

[AQUATIC ECOSYSTEMS; RIPARIAN FOREST; RIPARIAN HABITAT; SHADING]

1389. Quinn,NWT; Clyde,JR (1998): Wetlands and aquatic processes: $A$ bed sediment and detritus sampler for precise profiling of contaminant concentrations in aquatic environments. Journal of Environmental Quality 27, 64-67.

A bed and detritus sampler has been developed for use in aquatic environments, such as canals, rivers or lakes, for determining precise depth profiles of contaminants. The sampler has been used recently to determine a profile of bed sediment Selenium concentrations with an earth-lined canal, alternatively used for conveyance of agricultural drainage and wetland water supply.

[CONTAMINATION; RIPARIAN HABITAT; SEDIMENTATION]

1390. Rabe,F; Elzinga,C; Breckenridge,R (1994): Classification of meandering glide and spring stream natural areas in Idaho. Natural Areas Journal 14(3), 188-202.

The authors present a classification of meandering glide and spring stream types in Idaho that effectively identifies potential sites as additional natural areas in a statewide network of those reserves. These two stream types are defined by water source, sinuosity, substrate, and other physical characteristics. The first level of the hierarchical classification separates streams based on geomorphologic landscape characteristics. Further subdivisions consider water chemistry and plant communities. Modifying terms provide detail but are not essential in the classification scheme. This classification approach is compared to others and describes 16 sites representing the two stream types. Photographs and captions describing the classification are shown for each stream site. [CLASSIFICATION; GEOMORPHOLOGY; NATURAL AREAS]

1391. Rabe,FW; Biggam,RC; Breckenridge,RM; Naskali,RJ (1986): A limnological description of selected peatland lakes in Idaho. Journal of the Idaho Academy of Science 22(2), 63-85.

Six peatland lakes in northern and central Idaho that occur in terrain glaciated during the Pleistocene Epoch were sampled. Three lakes were formed in glacial deposits and three lakes formed in ice-scoured depressions. The dominant plants comprising the peat mats were Carex spp. and Sphagnum spp. The mats were located either peripherally along shore, midway between a lagg zone open water, or in the center of the lake. Only a few flowering plant species were observed on sphagnum bogs. Two species of insectivorous plants (Drosera spp.) were common along with other species able to tolerate low nitrogen conditions. Seventy species of aquatic insects were identified. Low acidity in some bogs limited the number of insects that respire cutaneously or by gills. [NATURAL AREAS; PEATLANDS; RIPARIAN HABITAT; WETLANDS]

1392. Rabe,FW; Chadde,SW (1994): Classification of aquatic and semi-aquatic wetland natural areas in Idaho and western Montana. Natural Areas Journal 14(3), 175-187.

A hierarchical classification of aquatic and semiaquatic zones associated with lentic (standing water) systems in Idaho and western Montana is proposed. This classification is structured like Cowardin et al. (1979), but is modified to apply to conditions in the Northern Rocky Mountains. Aquatic or open water sites are defined as having a depth greater than $0.5 \mathrm{~m}$. Sites less than $0.5 \mathrm{~m}$ were considered semiaquatic. Wetland types found in Idaho and Montana such as peatlands, marshes, potholes, swamps, and vernal pools are described and classified. Photos of selected study sites illustrate the classification process. [AQUATIC ECOSYSTEMS; CLASSIFICATION; NATURAL AREAS; PEATLANDS; RIPARIAN HABITAT]

1393. Race,MS (1985): Critique of present wetlands policies in the United States based on an analysis of past restoration projects in San Francisco Bay. Environmental Management 9(1), 71-82.

On the basis of an evaluation of past wetland resturation projects in San Francisco Bay, California, the author concludes that it is debatable that any of those sites can be described as completed, active, or successful restoration projects. Wetland creation/restoration has been adopted in the permit process as mitigation to offset environmental damage or loss of habitat. Since the technology is still largely experimental, however, there is no assurance that manmade wetlands will persist as substitutes for sacrificed natural habitats. Policies that encourage the 
exchange of natural wetlands with manmade replacements should proceed with caution. Present technology and management are many steps ahead of the necessary supporting documentation. [CREATED WETLANDS; MITIGATION; RIPARIAN RESTORATION; WETLANDS]

\section{Radko,MA (1997): Spatially linking} basinwide stream inventories to arcs representing streams in a Geographic Information System. USDA Forest Service. General Technical Report INT-345. 22 p.

Basinwide stream habitat inventories were linked to arcs representing streams in a Geographic Information System (GIS). The creation of a fish habitat GIS layer provides fisheries and land managers additional data that can be queried in relation to other landscape features and processes (i.e. vegetation, roads, erosion, etc.) in a GIS for analytical or planning purposes. GIS offers enormous organizational and information sharing capabilities in a corporate database environment.

[FISHERIES; GIS; INVENTORY; RIPARIAN HABITAT]

1395. Raish,C (1996): Historic land use and grazing patterns in northern New Mexico. p. 189197. In: Shaw,DW; Finch,DM [tech. tech.]. Desired future condition of Southwestern riparian ecosystems: Bringing interests and concerns together. USDA Forest Service. General Technical Report RM-GTR-272.

The entrance of the Spanish into what is now New Mexico in the 1500 s permanently altered aboriginal land use and subsistence patterns by the introduction of domesticated animals such as cattle, horses, sheep, goats, and pigs. During the Spanish Colonial and Mexican periods, both the Puebloan groups and Hispanic settlers practiced mixed farming featuring small numbers of livestock pastured in communal grazing areas. After New Mexico became a United States Territory, large scale ranching ventures also developed in the area. The rapid rise in stock numbers associated with the commercial ranching ventures, combined with 250 years of grazing around the existing small communities, led to degradation of land and water resources both in the uplands and in riparian areas. Large scale efforts to reduce livestock and restore degraded lands have been undertaken by the federal government since the early 1900s. Yet grazing on public lands remains a topic of controversy and debate, as well as an important aspect of the liteway of the small Hispanic communities of the region. If the traditional lifeways of these communities are to survive, means must be found to balance the goals of ecosystem restoration with the stock raising needs of the small villages. [CULTURAL IMPACTS; GRAZING IMPACTS; LIVESTOCK EFFECTS; PUBLIC LAND; RIPARIAN RESTORATION]

1396. Rait,K (1993): The Virgin River: An institutional nightmare of opportunity. p.336-340. In: Tellman,B; Cortner,HJ; Wallace,MG; DeBano,LF; Hamre,RH [tech. coord.]. Riparian management: Common threads and shared interests. USDA Forest Service. General Technical Report RM-226.

Consumptive use interests and environmental advocates are polarized regarding future applications of resources in the Virgin River watershed in Utah, Arizona, and Nevada. Relegation of water adjudication authority has been given to the states, however, US Department of Interior has wide management authority in the Basin. Presently, the decision making authority is fragmented by the disparate jurisdictions of Interior agencies. Integrated and coordinated watershed management by Interior agencies could make the Virgin Basin a pilot project for the Ecosystem Management initiative. [ECOSYSTEM MANAGEMENT; RIPARIAN HABITAT; WATERSHED]

1397. Raleigh,RF (1979): Closing remarks. p.8990. In: Cope,OB [ed.|. Forum on Grazing and riparian/stream ecosystems. 3-4 November 1978. Denver, $\mathrm{CO}$.

At this point in time, we simply do not know how to safely graze riparian habitats. Resolution will require well designed studies in which all interest groups have a part. We also need to look at the whole array of management options that will ensure the health of the riparian habitat.

[RIPARIAN HABITAT; RIPARIAN ISSUES]

1398. Raleigh,RF; Duff,DA (1979): Trout stream habitat improvement: Ecology and hydrology. Paper presented at Wild trout II symposium. Mammoth, WY. 24-25 September.

An objective procedure to evaluate stream structural needs is presented that is based on the habitat requirements of trout species by life stage. Effective stream improvement projects involve two essential steps: a diagnosis of stream structural deficiencies and the installation of stream structures designed to meet the biological and hydraulic features of the stream. Failure to address either step can result in the failure of the improvement project. 
[AQUATIC ECOSYSTEMS; FISHERIES; RIPARIAN HABITAT; RIPARIAN

RESTORATION]

1399. Ramsey,EW, III; Spell,RE; Day,RM (1994): GIS and remote sensing as wetland resource management tools: The fire monitoring example. p.133-145. In: Proceedings of an international workshop on requirements for integrated geographic information systems. 2-3 February 1994. New Orleans, LA.

In a preliminary analysis of burn monitoring, site-specific canopy reflectance spectra and light attenuation curves were acquired for a number of fresh marsh sites in coastal Louisiana. Near the time of reflectance acquisitions, thematic mapper scenes were obtained for winter, spring, and summer analysis. Three sites chosen for monitoring canopy reflectance depicted changes in unburned, winterburned, and spring-burned marsh. Comparison among all images indicated that winter-early spring burns were identifiable on the spring image, but not all winter-early burns were identifiable in summer. Spring burns (post-spring image) were detectable on the summer image, as were some winter-early spring burns; however, the two burn ages were not separable.

[CANOPY; GIS; REMOTE SENSING; RIPARIAN HABITAT; WETLANDS]

1400. Randall,KE (1993): Protection and management of riparian areas through water quality programs in Arizona. p.107-111. In: Tellman,B; Cortner,HJ; Wallace,MG; DeBano,LF; Hamre, RH [tech. coord.]. Riparian management: Common threads and shared interests. USDA Forest Service. General Technical Report RM-226.

This paper discusses four programs that have been implemented by Arizona Department of Environmental Quality: the Non-point Source, Point Source, Monitoring, and Water Quality Standards Programs. The relationship between these programs and the kinds of protection they provide to riparian areas is described. Future programs will require the evaluation of the effects of groundwater pumping, surface water diversions, and land use activities on riparian areas.

[NON-POINT SOURCE POLLUTION; POINT SOURCE POLLUTION; RIPARIAN MANAGEMENT ZONE; WATER QUALITY]

1401. Randall,KE (1996): The Arizona Riparian Area Advisory Committee: An experience in defining desired conditions. p.216-226. In: Shaw, DW; Finch, DM [tech. coord.]. Desired future conditions in Southwestern riparian ecosystems: Bringing interests and concerns together. USDA Forest Service. General Technical Report RMGTR-272.

Created in 1992 by the state legislature, the Riparian Area Advisory Committee (RAAC) developed recommendations for protecting, maintaining, and restoring riparian areas in Arizona. These recommendations were submitted to the Legislature and to the Governor after concluding a two-year period of discussion and study. The RAAC, consisting of 34 members broadly representative of federal and state agencies, tribal government, counties, municipalities, major economic resource user groups as well as environmental and recreational organizations, agreed on a Conservation Goal and on the broad outline of a riparian protection strategy that took a watershed approach. The adopted Goal was to sustain and enhance Arizona's riparian areas by managing land, water, and resource uses to protect ecological integrity and functionality. [DESIRED FUTURE CONDITIONS; ECOLOGICAL INTEGRITY; RIPARIAN HABITAT; RIPARIAN MANAGEMENT ZONE]

1402. Range Inventory Standardization Committee (RISC). Society for Range Management. (1983): Guidelines and terminology for range inventories and monitoring. Presented to Board of Directors of SRM. Albuquerque, NM. February 1983. 13 p. [DEFINITIONS; INVENTORY; MONITORING]

\section{Rango,A (1985): Assessment of remote} sensing input to hydrologic models. Water Resources Bulletin 21(3), 423-432.

Remotely sensed variables such as land cover type and snow cover extent can currently be used directly and effectively in a few specific hydrologic models. Regression models can also be developed using physiographic and snow cover data to permit estimation of discharge characteristics over extended periods such as a season or year. Most models, however, are not of an appropriate design to readily accept as input the various types of remote sensing parameters that can be obtained now or in the future. Efforts should be devoted now to either modifying existing models or developing new models that can use this data.

[HYDROLOGY; MODELING; REMOTE SENSING; WATER RESOURCE MANAGEMENT] 
1404. Ratliff, KD (1983): Nebraska sedge (Carex nebraskensis Dewey): Observations on shoot life history and management. Journal of Range Management 36(4), 429-430.

Nebraska sedge, a valuable and distinct species, can withstand a high degree of defoliation by livestock without being seriously damaged. Shoot life history was studied on the Sierra National Forest, California. Initial results indicated that: 1) Nebraska sedge roots live longer than one year; 2) a high proportion of vegetative shoots overwinter; 3 ) overwintering shoots have cores of live leaf tissue which can develop rapidly in spring; and 4) about half of the shoots surviving winter become reproductive and die. As a culmless species, it is better able to withstand defoliation. Reproduction appears to be mainly vegetative, and a management goal of producing an abundance of healthy rhizomes is suggested.

[GRAZING IMPACTS; RIPARIAN PLANTS; SEDGES]

1405. Ratliff,RD; George,MR; McDougald,NK (1987): Managing livestock grazing on meadows of California's Sierra Nevada: A manager - user guide. University of California. Berkeley, CA. Cooperative Extension Leaflet No. 21421.9 p.

A management guide with recommendations for herbage productivity, timing, and length of grazing period for mountain meadows.

[GRAZING IMPACTS; GRAZING TREATMENTS; MEADOWS; RIPARIAN MANAGEMENT ZONE]

1406. Reaser,JK (1996): Spotted frog: Catalyst for sharing common ground in the riparian ecosystems of Nevada's range landscape. p.32-39. In: Evans, KE [comp.]. Sharing common ground on western rangelands: Proceedings of a livestock/big game symposium. 26-28 February 1996. Sparks, NV. USDA Forest Service. General Technical Report INT-GTR-343. 164 p.

An action plan was developed to empower multisector partnerships for the purpose of identifying rangeland management strategies compatible with the needs of both regional biota and the human population. The spotted frog (Rana pretiosa), a candidate for protection under the Endangered Species Act, can serve as a valuable indicator of ecosystem health. The range of the action plan is such that it addresses grazing and other human impacts to the loss of diversity issue, using amphibians as indicators of ecosystem health. [AMPHIBIANS; BIODIVERSITY; GRAZING IMPACTS; RIPARIAN HABITAT]
1407. Reece,PE; Nichols,JT; Brummer,JE; Engel,RK; Eskridge,KM (1994): Harvest date and fertilizer effects on native and interseeded wetland meadows. Journal of Range Management 47(3), 178-183.

Forage quality, dry matter yield, and response to spring-applied $\mathrm{N}$ were similar for native wetland meadow vegetation and interseeded areas over a range of harvest dates. Native vegetation was dominated by sedges. Interseeded sites were dominated by Garrison creeping foxtail. Within levels of $\mathrm{N}$, first cutting yield was about 60 percent of peak standing crop on June 15 and 90 percent on July 15 compared with August 15. Regrowth dry matter yield was not affected by spring-applied $\mathrm{N}$. Sedge dominated, prairie meadows are productive and provide predictable forage and wildlife habitat management alternatives.

[FERTILIZATION; RIPARIAN HABITAT;

SEDGES; WETLANDS]

1408. Reed,J (1979): Resources -- use, abuse, and management. p.64-65. In: Cope,OB [ed.]. Forum on Grazing and riparian/stream ecosystems. 3-4 November 1978. Trout Unlimited, Inc.

Public land need to be managed for the benefit of many elements. The three systems that make up the riparian ecosystem - the atmospheric, the surface, and the underground - need to be protected by strong, well financed multiple use management.

[GRAZING IMPAC'IS; MULTIPLE USE; RIPARIAN MANAGEMENT ZONE]

1409. Reed,Jr.,PB (1988): National list of plant species that occur in wetlands: National summary. USDI Fish and Wildlife Service Biological Report 88(24), 244.

Plant species that occur in wetlands, as used in the National List, are species that have demonstrated an ability to achieve maturity and reproduce in an environment where all or portions of soil within the root zone become, periodically or continuously, saturated or inundated during the growing season. [RIPARIAN HABITAT; RIPARIAN VEGETATION]

1410. Reed,Jr.,PB (1988): National list of plant species that occur in wetlands: Intermountain Region (Region 8). USDI Fish and Wildlife Service Bioligical Report 88(26.8), 76.

This plant list for the Intermountain Region (Region 8) is a subset of the National List. Plant species that occur in wetlands, as used in the National List, are species that have demonstrated an ability to 
achieve maturity and reproduce in an environment where all or portions of the soil within the root zone become, periodically or continuously, saturated or inundated during the growing season.

[INVENTORY; RIPARIAN HABITAT; RIPARIAN VEGETATION]

1411. Reeves,GH; Hall,JD; Roelofs,TD; Hickman,TL; Baker,CO (1991): Rehabilitating and modifying stream habitats. In: Influences of forest and rangeland management of salmonid fishes and their habitats. American Fisheries Society Special Publication 19:519-557.

Techniques for rehabilitating and modifying habitats have been used for over 50 years in fishery management, but they have been applied to a relatively small degree in the management of western salmonids, particularly anadromous stocks. Increased rates of harvest and other threats to the survival of many wild populations of salmon and trout call for intensified fishery management. Intensified logging, grazing, irrigation, agriculture, and urbanization have diminished the quality and quantity of habitats available to wild salmonid stocks. In principle, rehabilitation and modification of habitats are attractive means to restore the abundance of these salmonids.

[FISHFRIES; RIPARIAN HABITAT; RIPARIAN RESTORATION]

1412. Regional Interagency Executive Committee. (1995): Fcosystem analysis at the watershed scale. Federal guide for watershed analysis. Regional Ecosystem Office. Portland, OR 97208 - 3623. 26 p.

Watershed analysis is essentially ecosystem analysis at the watershed scale. Watershed analysis is a procedure to characterize the human, aquatic, riparian and terrestrial conditions, processes, and interactions collectively referred to as "ecosystem" elements, within a watershed.

[CLASSIFICATION; ECOSYSTEM MANAGEMENT; RIPARIAN HABITAT; SPATIAL SCALE]

1413. Reichard, $N$ (1984): Riparian habitat restoration: Some techniques for dealing with landowncrs, livestock, and eroding streambanks. p.128-137. In: Hassler,TJ [ed.]. The Pacific Northwest habitat management workshop. 10-12 October 1984. Humboldt State University. Arcata, CA.

Landowners cooperation is necessary for successful habitat restoration on private land.
Livestock exclusion can be accomplished using a variety of fencing materials and layouts. Stock water access, stream crossings, and impacts of flooding should be considered. Living material can be incorporated into streambank stabilization measures to enhance physical and biological utility. Several biotechnical stabilization methods are illustrated. Planting vegetation on protected streamside land may significantly accelerate riparian thicket recovery. Moisture stress and competition from pasture grasses may limit the rate of establishment of desired riparian plant species.

[RIPARIAN HABITAT; RIPARIAN

RESTORATION]

1414. Reichenbacher,Frank W (1984): Ecology and evolution of southwestern riparian plant communities. Desert Plants 6(1), 15-22.

This article addresses the relationship between the distributions of plants in the floodplain and a set of physical site factors. The plant-floodplain relationship does have an important evolutionary basis and its understanding contributes to useful perspectives on the nature of riparian plant communities. Data from Trout Creek, Arizona, on grazed vs. ungrazed riparian communities lead to the general conclusion that "grazing impact is everywhere negative, and locally disastrous". The critical features of the floodplain environment to which riparian plants are adapted, are a relatively high plant available soil moisture in an unstable substratum. The gradients created by the movement of the stream across its floodplain result in a dynamic successional sequence in a riparian habitat continuum.

[GRAZING IMPACTS; HISTORIC RECORDS; RIPARIAN HABITAT; RIPARIAN VEGETATION]

1415. Reichmuth,DR (1990): Salmon River habitat structures evaluation of past work and proposals for future work. (Report prepared by GEOMAX. Bozeman, MT.)

This is a report to the USDA Forest Service from a private consultant regarding an evaluation of the management of the Salmon River near Stanley, Idaho. Past and proposed work focused on controlling sediment production and movement while promoting fish habitat development. Instream structures were examined and evaluated. [CHANNEL DYNAMICS; INSTREAM STRUCTURES; RIPARIAN HABITAT]

1416. Rendall,WB; Robertson, RJ (1990): Influence of forest edge on nest site selection by 
tree swallows. Wilson's Bulletin 102(4), 634-644.

This study examined the influence of forest edge on nest site selection by tree swallows at nest box grids in uniform habitats. Tree swallows occupied nest sites 3-100 $\mathrm{m}$ from the forest edge, while house wrens and most eastern bluebirds used boxes within $30 \mathrm{~m}$ of the forest edge. Mean distance to forest edge for distribution of nest boxes used by tree swallows was greater than those means for house wrens and eastern bluebirds, but mean distances to forest edge for nest boxes occupied by the latter two species were not different. Tree swallows may select nest sites farther from the forest edge to avoid the costs of aggression or nest destruction that may be incurred during interactions with competitors.

[AVIFAUNA; FOREST EDGE; RIPARIAN FOREST; RIPARIAN HABITAT]

1417. Resource Systems, Inc. (1983): Boise River fish and wildlife habitat study/wetland inventory and management guidelines. Final Report prepared for the City of Boise, ID. December 1983. 158 p. Boise, ID.

[INVENTORY; RIPARIAN HABITAT; RIPARIAN MANAGEMENT ZONE; WETLANDS]

1418. Rex,KD; Malanson,GP (1990): The fractal shape of riparian forest patches. Landscape Ecology 4(4), 249-258.

Remnant patches of a forest corridor were examined in lowa. A fractal dimension was found for these patches which was incorporated with the perimeter:area ratio in an index of shape. The index was then regressed on five hydrogeomorphic variables hypothesized to represent processes which might control patch dimensions, plus a variable to represent human impact. Results indicate that in this landscape the hydrogeomorphic structures play a role, but that human impact is more significant in its effect on the shape of the forest patches. Other structures, such as regional topography, may account for the unexplained variance. The index of shape used in this paper may be useful as an independent variable in studies of ecological processes affected by patch shape and form and as a guide to conservation. [FLOODPLAIN MANAGEMENT; LANDSCAPE ECOLOGY; RIPARIAN FOREST; RIPARIAN HABITAT]

1419. Rhodes,BJ; Marlow,CB; Sherwood,HW (1995): Monitoring streambank stability: Grazing impacts or stream variability? Montana

Agricultural Research 12(2), 3-8.

Stream channel monitoring and management efforts should be directed toward specific areas of concern, rather than the grazing unit as a whole. Riparian grazing standards must be developed for the specific reach or stream conditions. Widespread use of the same set of grazing standards over large areas and entire allotments can not be considered a reliable basis for monitoring efforts because of the natural variation occurring within and between streams in the same watershed. The use of regional or national standards may not be beneficial to either the natural resource base or local economic uses.

[GRAZING IMPACTS; MONITORING; STANDARDS AND GUIDELINES]

1420. Rhodes,J; Skau,CM; Greenlee,D; Brown,DL (1985): Quantifcation of nitrate uptake by riparian forests and wetlands in an undisturbed headwaters watershed. p.175-179. In: Johnson,RR; Ziebell,CD; Patton,DR; Ffolliott,PF; Hamre, RH [tech. coord.]. Riparian ecosystems and their management: Reconciling conflicting uses. USDA Forest Service. General Technical Report RM-120. 16-18 April 1985. Tucson, AZ.

During three years of research on a headwaters watershed, the area was shown to be capable of removing over 99 percent of the incoming nitrate nitrogen. Riparian vegetation nitrate uptake and output, and microbial denitrification will be incorporated into hydrologically-based nutrient transport models.

[MODELING; NUTRIENT CYCLES; WATER QUALITY; WATERSHED]

1421. Ribaudo,MO; Young,CE (1989): Estimating the water quality benefits from soil erosion control. Water Resources Bulletin 25, 7178.

A framework for estimating the water quality benefits from soil erosion was developed, based on the linkages between soil erosion and off-site damages. The linkages were: erosion on the field, movement of eroded materials to waterways, impact of discharged material on water quality parameters, impact of water quality changes on ability of water to provide economic services, and the economic value of the changes in water use. Linkages were modeled in order to estimate water quality benefits from reductions in soil erosion. A number of simplifying assumptions were made to represent links that could not be modeled.

[HYDROLOGY; NON-POINT SOURCE POLLUTION; SOILS; WATER QUALITY]

1422. Ricciardi,A (1998): The exotic species 
problem and freshwater conservation. Wild Earth 8(1), 44-49.

The author describes the origin and course of exotic plant and animal invasions. The problem has expanded to affect almost everyone and the only recourse is a dependence on personal responsibility. He advocates political support for preventative exotic species legislation; opposition to dubious aquaculture schemes; routine inspection of boating and fishing gear; and, making intelligent decisions about the use of live bait or disposal of aquarium pets.

[AQUACULTURE; EXOTICS; FRESHWATER CONSERVATION]

1423. Rice,J; Ohmart,RD; Anderson,BW (1983): Habitat selection attributes of an avian community: A discriminant analysis investigation. Ecological Monographs 53(3), 263-290.

Habitat use characteristics of all bird species in the Lower Colorado River valley were studied. Mean habitat disciminability of all species varied from a low of 86 percent in summer to a high of 91 percent in late summer. Most species showed extensive variability among seasons in both the degree of habitat selectivity and criteria used in habitat selection. The variability reflected both changes in the population structure of the species and responses to changing resource and climatic pressures. The mix of habitat generalists and specialists and the habitat selectivity of individual species varied seasonally, implying that the organization of habitat use of the community is the dynamic product of many interacting factors. Species showed preferences for particular habitat attributes more frequently than they avoided habitat attributes. Foliage height diversity was the most frequently important variable in differentiating areas uses from areas not used. Proportions of honey mesquite, cottonwood, and willow in the vegetation were also frequently important variables in the selection of habitat by avian species.

[AVIAN ECOLOGY; RIPARIAN HABITAT]

\section{Rich,LR (1952): Forest and range} vegetation. American Society of Civil Engineering Transactions 117, 974-990.

Few areas in the western United States have unlimitcd water available or for full potential consumptive use. Water use has varied from 77 percent to 90 percent on forested watersheds, and is generally higher on rangelands. A method for describing consumptive use of forest and range vegetation is to divide the water year into four periods: 1) soil moisture recharge, 2) water surplus,
3) soil moisture utilization, and 4) water deficit. Consumptive use is dependent on total precipitation less the amount of surface runoff. [HYDROLOGY; WATER RESOURCE MANAGEMENT; WATERSHED]

1425. Richards, K (1982): Rivers - Form and process in alluvial channels. Metheun, New York, NY. $358 \mathrm{p}$.

[CHANNEL DYNAMICS; GEOMORPHOLOGY; HYDRAULICS]

1426. Richards,MT; Wood,DB (1985): The economic value of sport fishing at Lee's Ferry, Arizona. p.219-222. In: Johnson,RR; Ziebell,CD; Patton,DR; Ffolliott,PF; Hamre,RH [tech. coord.|. Riparian ecosystems and their management: Reconciling conflicting uses. 16-18 April 1985. Tucson, AZ. USDA Forest Service. General Technical Report RM-120.

Economic analysis of trophy and non-trophy sport fishing was conducted at Lee's Ferry, Arizona, to determine values. Based on those values, management recommendations were made that permitted discrimination between users of the riparian environment and among fishermen specifically.

[ECONOMICS; RECREATION IMPACTS; RIPARIAN HABITAT]

1427. Rickard,WH; Cushing,CE (1982):

Recovery of streamside woody vegetation after exclusion of livestock grazing. Journal of Range

Management 35(3), 360-361.

Removal of livestock grazing along a small, perennial desert stream in southern Washington allowed the reestablishment of woody vegetation (Salix amygdaloides) in the riparian zone within 10 years.

[EXCLOSURES; GRAZING IMPACTS; RIPARIAN RESTORATION]

1428. Rickard,WH; Price,KR (1989): Uptake of tritiated groundwater by black locust trees. Northwest Science 63(3), 87-89.

Artificially planted trees have survived for four decades in the dry climate of south-central Washington without irrigation. It was believed that tree survival depended on root contact with groundwater but this assumption had never been tested. Leaf water from trees growing at a location where groundwater was $7.7 \mathrm{~m}$ below the surface had elevated levels of tritium. Well water also had elevated levels of tritium indicating that some of the 
tritium measured in leaf water was obtained from root contact with tritiated groundwater.

Concentrations in leaf water were greatest in August when sources of tritium other than groundwater were least abundant, suggesting that the trees relied most heavily on groundwater during the dry season. [GROUNDWATER; HYDROLOGY; RIPARIAN PI.ANTS]

1429. Rickard,WH; Rogers,LE; Vaughan,BE; Liebetrau,SF (Eds.) (1988): Shrub-steppe balance and change in a semi-arid terrestrial ecosystem. Developments in agricultural and managed forest ecology series. Vol. 20. Elsevier Science Publishing Company Inc. New York, NY. 272 p.

The text includes eight bibliographic chapters which focus on research conducted at the Arid Land Ecological Reserve, at the Hanford Site of the Lower Columbia River: 1) introduction: shrub-steppe lands; 2) climate of the Hanford Site; 3 ) soils: carbon and mineral cycling processes; 4) water balance; 5) springs and streams; 6) plant communitics: characteristics and responses; 7) terrestrial animal habitats and population responses; 8) theoretical perspective on ecosystem disturbance and recovery. Topics covered which are relevant to the riparian ecosystem include bird populations, hydrology of springs and streams and associated vegetation, and effects of land uses on the sagebrush-bunchgrass uplands.

[AVIFAUNA; BIBLIOGRAPHY; HYDROLOGY; PLANT COMMUNITIES; RIPARIAN HABITAT; SOILS]

1430. Riegel,GM; Sjejcar,TJ; Trent,JD (1991): Seasonal physiologic and community response to a riparian montane meadow water table gradient. In: Abstracts of the sixty fourth annual meeting of the Northwest Scientific Association. 20-22 March 1991. Boise State University. Boise, ID.

Highly productive meadows may lose much of their productivity when stream channels become eroded or down cut. Mesic communities that once dominated the floodplain or meadow may now be restricted to the zone adjacent to the stream. In this study, the objective was to determine the influence on graminoid physiology of northern Sierra Nevada montane meadow species by a decrease in water table depth caused from down cutting. There were no differences in photosynthesis between wet and dry locations. Transpiration and conductance rates were not different by location but were different by species later in the growing season. Differences in pre-dawn xylem potentials by location occurred early to midseason while midday xylem potential differences occurred from early through middle of the growing season.

[HYDROLOGY; MEADOWS; PLANT PHYSIOLOGY; RIPARIAN PLANTS; WATER TARI.E EFFECTS]

1431. Rieman,BE; McIntyre,JD (1993): Demographic and habitat requirements for conservation of bull trout. USDA Forest Service. Intermountain Research Station. General Technical Report INT-302. 38 p.

This report identified elements in bull trout biology, population dynamics, habitat, and biotic interactions important to conservation of the species. Even though bull trout appear to have more specific habitat requirements than other salmonids, no critical thresholds of acceptable habitat condition were found. Size, temporal variation, and spatial distribution are likely to influence the stability of local and regional populations. Isolated populations are not likely to persist indefinitely because disruption of key habitat characteristics threatens these numbers. Conservation of this species will require maintenance and restoration of high quality, connected habitats.

[BULL TROUT; FISH HABITAT; POPULATION DYNAMICS; SALMONIDS]

1432. Riley, AL (1998): Restoring streams in cities: A guide for planners, policymakers, and citizens. Island Press. Covelo, CA. 450 p.

The book presents alternatives to traditional practices that respond to problems of flooding and erosion in natural environments. Suggested options are proposed to repair existing environmental damage and prevent that damage from happening. The concept here is to de-emphasize "control" and recognize stream as natural landscape features in the urban environment. Land use planning, site design, and watershed restoration measures are presented along with stream channel modifications and floodproofing strategies. More than 100 photos are included.

[CHANNEL DYNAMICS; RIPARIAN RESTORATION; URBAN IMPACTS]

1433. Rink,LP; Wikndell,JR (1988): Riparian wetland enhancement in the San Miguel River Valley, Telluride, CO. p.102-105. In: Mutz,K; Cooper,DJ; Scott,ML; Miller,LK [eds.]. Restoration, creation, and management of wetland and riparian ecosystems in the American West. A symposium of the Rocky Mountain Chapter of the 
Society of Wetland Scientists.

Historically, the San Miguel River corridor had been severely impacted by channelization, mine tailing deposition, and livestock grazing. The mitigation project involves replacement of riparian vegetation, streambank stabilization through willow plantings, creating riparian wetland buffer zones, and enhanced control of non-point source pollution control.

\section{[RIPARIAN RESTORATION; WETLANDS]}

1434. Rinne,J (1998): Grazing and fishes in the Southwest: Confounding factors for research. p.75-84. In: Potts,DF [ed.]. Range management and water resources: Proceedings of the AWRA specialty conference. American Water Resources Association. 27-29 May 1998. Reno, NV.

There is little information available regarding the relationships and interactions of livestock and fishes in the southwestern US. Moreover, there are certain factors that render research difficult. These include: 1) the species of fish under consideration; 2) temporal-spatial factors; 3) habitat influences; and 4) fishery management practices. Acquisition of valid, defensible data must address these factors.

[FISHERIES; GRAZING IMPACTS; LIVESTOCK EFFECTS; RIPARIAN MANAGEMENT ZONE]

1435. Rinne,JN (1985): Livestock grazing effects on Southwestern streams: a complex research problem. p.295-299. In: Johnson,RR; Ziebell,CD; Patton,DR; Ffolliott,PF; Hamre,RH [tech. coord.]. Riparian ecosystems and their management: Reconciling conflicting uses. 16-18 April 1985. Tucson, AZ. USDA Forest Service. General Technical Report RM-120.

It is problematical to conduct research on the effects of domestic livestock grazing on stream environments and biota in southwestern national forests. The multiple use concept, spatial temporal factors, inadequate control and replication, and changes in land management objectives and direction render it difficult to effectively study grazing impacts.

[GRAZING IMPACTS; RESEARCH]

\section{Rinne,JN (1988): Effects of livestock} grazing exclosure on aquatic macroinvertebrates in a montane stream, New Mexico. Great Basin Naturalist 48(2), 146-153.

Based on a limited literature and this study, the author concludes that aquatic macroinvertebrates are useful biological indicators of grazing impacts on stream ecosystems. The author emphasizes the importance of collecting baseline data and of defining the variability of factors within study areas prior to implementing treatments. Linear changes in stream habitat may affect water quality and biota in the stream quite apart from the effects of grazing and exclosure.

[AQUATIC ECOSYSTEMS; EXPERIMENTAL DESIGN; GRAZING IMPACTS; INVERTEBRATES]

1437. Rinne,JN (1988): Grazing effects on stream habitat and fishes: research design considerations. North American Journal of Fisheries

Management 8, 240-247.

A 4-year study of a montane stream from which cattle grazing had been excluded for 10 years indicated that stream bank vegetation and stability were markedly improved and that stream substrate fines were somewhat reduced, but it indicated that fish populations were unaffected. Shortcomings of this case history study are common to similarly designed studies of grazing effects on fishes and their habitats. Three major deficiencies in research design are (1) lack of pretreatment data, (2) improper consideration of fishery management principles, and, (3) linear positioning of treatments along a stream. Future research on riparian grazing effects must address these factors in addition to designs of longterm (10+ years) ecosystem (watershed) studies. [EXPERIMENTAL DESIGN; FISHERIES; GRAZING IMPACTS; GRAZING TREATMENTS; RESEARCH]

1438. Rinne,JN (1990): The utility of stream habitat and biota for identifying potential conflicting forest land uses: Montane riparian areas. Forest Ecology and Management 33/34, 363-383.

Recent investigations on the effects of land management practices on riparian stream systems have often produced contradictory results.

Inconsistencies have occurred, in part, because of efforts that have not been totally comprehensive and, in part, because of poor study design and/or procedure. This paper reviews the literature on the use of fine sediment, aquatic macroinvertebrates, and fishes as indicators for identifying and describing the effects of various land use practices on riparian stream systems. The results of research on the effects of land management practices on these three variables is also presented. The author suggests it is valid to use these variables to detect the effects of multiple use practices on riparian stream systems, although other variables such as solar radiation, water 
quality, water temperature, riparian vegetation, and others may also be useful. More reliable definition of effects will require the collection of baseline data, protracted ecosystem scale studies, and consideration of multiple physical and biotic features.

[LAND USE; MACROINVERTEBRATES; MONITORING; RIPARIAN HABITAT]

1439. Rinne,JN (1993): A wild life viewpoint southwestern riparian areas: Habitats for fishes. p.46-53. In: Tellman,B; Cortner,HJ; Wallace,MG; DeBano,LF; Hamre, RH [tech. coord.]. Riparian management: Common threads and shared interests. USDA Forest Service. General Technical Report RM-226.

Riparian stream areas, that are critical aquatic habitats for fishes, have become markedly altered by off-site land management and on-site instream alteration of flows. In order to sustain fish populations, future management must be on a watershed or ecosystem basis.

[RIPARIAN HABITAT; RIPARIAN MANAGEMENT ZONE; SPATIAL SCALE]

1440. Rinne,JN (1996): Desired future condition: Fish habitat in southwestern riparian-stream habitats. p.336-345. In: Shaw, DW; Finch, DM |tech. coord.]. Desired future conditions for southwestern riparian ecosystems: Bringing interests and concerns together. USDA Forest Service. General Technical Report RM-GTR-272.

Riparian ecosystems in the southwestern United States provide valuable habitats for many living organisms including native fishes. An analysis of habitat components important to native fishes was made based on the literature, case histories, and unpublished and observational data. Results suggest a natural, surface water hydrograph and lack of introduced species of fishes being the two most critical habitat components delimiting sustainability of native fishes in the Southwest. Vegetation, channel characteristics and instream hydrological features (i.e. depth, velocity, and substrate) are important in distribution and sustainability of native fishes but secondary to the first two and are more important or relevant as management activities affect them. Desired future condition for native southwestern fishes ultimately depends on proper or desirable functioning of riparian ecosystems. [DESIRED FUTURE CONDITIONS; NATIVE FISHES; RIPARIAN HABITAT]

1441. Rinne,JN; LaFayette,RA (1991): Southwestern riparian stream ecosystems:
Research design, complexity, and opportunity. USDA Forest Service. Research Paper RM-299. 8 p.

Two basic approaches to research design in riparian areas - intrastream and interstream - and their merits are evaluated based on physical, chemical, and biological data from streams in central Arizona and northern New Mexico. For effective generation of dependable, and applicable information for future management of forest lands, a partnership: 1) characterized by constant and intimate interaction of research and management personnel; 2) operating within the framework of daily forest land management activity; and 3) vigilant of research opportunity - is proposed.

[FISHERIES; MONITORING; RESEARCH; RIPARIAN ECOLOGY; RIPARIAN HABITAT]

1442. Rinne,JN; Tharlson, T (1986): Effects of domestic livestock grazing on montane streams: Aquatic macroinvertebrates. p.91-98. In: Proceedings of the Western Fish and Wildlife Agencies. Western Division American Fisheries Society. 20-23 July 1986. Portland, OR.

Aquatic macroinvertebrate populations in reaches of a montane stream within areas removed from domestic grazing were lower than in reaches of the stream where cattle grazing was present. Differences were not consistently significant $(P<0.05)$ and could be casily attributed to lack of pretreatment data and linear changes in stream habitat as to the presence or absence of cattle grazing. [GRAZING IMPACTS; LIVESTOCK EFFECTS; MACROINVERTEBRATES; RIPARIAN HABITAT]

1443. Risenhoover,KL (1987): Intraspecific variation in moose preference for willows. p.58-63. In: Proceedings - Symposium on plant-herbivore interactions. USDA Forest Service. General Technical Report INT-222.

Moose preference for Alaskan felt-leaf willow and gray-leaf willow were observed and compared among different habitats in and around Denali National Park, Alaska. Observations during the winter-spring searching phase of diet selection indicate that moose are selective browsers, and feed on only a fraction of the plant stems available. Moose preferences for individual willow species varied considerably among habilat types, and did not appear to be related to the availability of biomass. Observed variations in willow preference could not be attributed to plant nutritional quality, or to the amounts of phenols and condensed tannins they 
contained.

[BROWSING EFFECTS; GRAZING IMPACTS; MOOSE; WILLOW]

1444. Ritchie,JC; Rango,A; Kustas,WP; Schmugge,TJ; Havstad,KM; Everitt,JH; Hipps,LE; Ramaingham,K (1998): Jornex: A remote sensing campaign to study plant community response to hydrologic fluxes in desert grasslands. p. 65-74. In: Potts, DF [ed.]. Rangeland management and water resources: Proceedings of the AWRA specialty conference. American Water Resources Association. 27-29 May 1998. Reno, NV.

Long-term investigations at Jornada Experimental Range in southern New Mexico have yielded a wealth of ground data about the basin characteristics, ecosystem dynamics, and vegetation response to changing hydrologic and atmospheric events. To complement these programs, a campaign called JORNEX was begun to collect remotely sensed data from aircraft and satellite platforms to provide spatial and temporal data. Different platforms allow the evaluation of the landscape at different scales. These measurements are being used to quantify the hydrologic budgets and plant response to change in components of the water and energy balance at the Jornada.

[HYDROLOGY; RANGE MANAGEMENT; REMOTE SENSING]

1445. Ritzi,RW; Bouwer,H; Sorooshian,S (1985): Water resource conservation by reducing phreatophyte transpiration. p. 191-196. In: Johnson,RR; Ziebell,CD; Patton,DR; Ffolliott,PF; Hamre, RH [tech. coord.]. Riparian ecosystems and their management: Reconciling conflicting uses. 16-18 April 1985. USDA Forest Service. General Technical Report RM-120.

Managing the magnitude of depth to the water table below floodplains may affect supporting phreatophytes and water conservation due to reductions in the evapotranspiration. Meanwhile, the integrity of the riparian ecosystem is maintained. The paper describes a phreatophyte - floodplain system model for analysis of economic feasibility. [MODELING; PHREATOPHYTES; RIPARIAN HABITAT; STREAM FLOW]

1446. Roath,LR; Kreuger,WC (1982): Cattle grazing and behavior on a forested range. Journal of Range Management 35(3), 332-338.

Environmental and topographic parameters on a mountainous forested range were analyzed to establish causes of cattle behavioral response.

Distinct home range groups of cattle were identified through examination of quality and patterns of range use, cattle distribution, herd social activities, and cattle activities. The home range of one group encompassed only upland areas. Water and vegetation type were important parameters in determining area and degree of use. Vertical distance above water was the most important factor in determining vegetation utilization on moderately steep slopes. Time after sunrise and relative humidity factors were key in determining the kind and timing of cattle activity.

[GRAZING IMPACTS; LIVESTOCK FFFECTS]

1447. Roath,LR; Kreuger,WC (1982): Cattle grazing influence on a montane riparian zone. Journal of Range Management 35(1), 100-103.

A combination of management and physical topographic features caused cattle to concentrate on the riparian zone early in the grazing season. A large percentage of the cattle days and vegetation utilization of the riparian zone occurred in the first 4 weeks of the grazing period. Utilization on herbaceous vegetation was 72-76 percent. Impact on the most prevalent species, Kentucky bluegrass, was minimal. Shrub use increased with increased maturity of herbaceous vegetation. Utilization of major shrubs was not excessive and had no long-term effects on vigor or abundance of shrubs.

[GRAZING IMPACTS; RIPARIAN VEGETATION; RIPARIAN SHRUBS]

1448. Roberts,BC; White,RG (1992): Effects of angler wading on survival of trout eggs and preemergent fry. North American Journal of Fisheries Management 12, 450-459.

Multiple wadings during cgg development killed up to 96 percent of eggs and pre-emergent fry. Single wading killed up to 43 percent of eggs. Death occurred by crushing or physical disturbance to redds, spread of fungi, substrate compaction, intergravel flows, and oxygen reductions to trout eggs. It is reasonable to assume that wading by cattle would result in mortality of eggs and pre-emergent fry at least equal to that demonstrated for human wading. [FISHERIES; GRAZING IMPACTS; HUMAN IMPACTS]

1449. Roberts,Jr.,TC (1992): Political and social aspects of riparian area management. p.120-122. In: Clary,WP; McArthur,ED; Bedunah,D; Wambolt,CL [comp.]. Proceedings -Symposium 
on ecology and management of riparian shrub communities. USDA Forest Service. General Technical Report INT-289.

Impediments to riparian area improvements are institutional and natural resistance to change, mixed land ownership, and lack of incentives. Management changes that are suggested include improved career tracks, adoption of holistic philosophies, use of volunteers, consensual problem solving techniques, and better incentives for improving management programs.

[PUBLIC COMMENT; RIPARIAN

RESTORATION; SOCIAL VALUES; VOLUNTEERS]

1450. Robertson,D; Garcia,R; Piwowar,K (1987): Comparison of wetland habitat in undisturbed and reclaimed phosphate surfacemined wetlands. p.180-193. In: Proceedings of the 14th annual conference on wetlands restoration and creation. Institute of Florida Studies. 14-15 May 1987. Plant City, Fl.

Macroinvertebrates inhabiting wetlands associated with two intermittent first order tributaries in Florida were qualitatively censused to assess the phosphate industry's ability to reclaim wetland habitat after surface mining. The two stream channels were reclaimed to marshy reaches that retain water year round. Species richness was nearly twice as high in the older reclaimed areas. Results suggest that the richness of the reclaimed lotic sections will match that of undisturbed streams.

[CREATED WETLANDS; MINED LAND RFCI.AMATION; RIPARIAN RESTORATION]

1451. Robinson,CT; Minshall,GW (1998): Regional assessment of wadable streams in Idaho, USA. Great Basin Naturalist 58(1), 54-65.

There has been a resurgence of bio-assessment techniques for evaluating and monitoring biological integrity of stream ecosystems. Biological metrics have been refined to account for regional variation in aquatic habitats and fauna. This study evaluated environmental and macroinvertebrate properties for wadable streams in 3 major ecoregions in Idaho. Multiple discriminant analyses effectively determined habitat and macroinvertebrate differences between reference and test streams within ecoregions. Results support the contention of a multimetric approach for assessing differences among streams. [ $\Lambda$ SSESSMENTS; MACROINVERTEBRATES; RIPARIAN HABITAT]
1452. Robinson,TW (1952): Phreatophytes and their relation to water in the western United States. American Geophysical Union Transactions 33(1), 57-61.

About 15 million acres of phreatophytes occur in the 17 western states and this area is expanding. These plants may waste as much as 20 to 25 millionacre-feet of water by transpiration into the atmosphere. The potential applications of the water that could be reclaimed or salvaged annually are substantial.

[HYDROLOGY; PHREATOPHYTES; WATER RESOURCE MANAGEMENT]

1453. Rochester,H,Jr; Lloyd,T; Farr,M (1984): Physical impacts of small scale hydroelectric facilities and their effects on fish and wildlife. Western Energy and Land Use Team. USDI Fish and Wildlife Service FWS/OBS/-84/19. [FISHERIES; HYDROELECTRIC IMPACTS; RIPARIAN HABITAT; STREAM FLOW]

1454. Rogers, TJ (1996): Insects of the riparian. p.154-156. In: Shaw,DW; Finch,DM [tech. coord.]. Desired future conditions of Southwestern riparian ecosystems: Bringing interests and concerns together. USDA Forest Service. General Technical Report RM-GTR-272.

This paper describes life histories, defoliation problems, and other activities of insects associated with forest tree species growing along high elevation streams and river banks. In addition, examples of insects and diseases associated with lower elevation riparian areas are given.

[INVERTEBRATES; RIPARIAN HABITAT]

1455. Roesser,Jr.,JC (1988): Blue River reclamation project, Breckenridge, $C O$. p.94-101. In: Mutz,K; Cooper,DJ; Scott,ML; MillerLK [eds.]. Restoration, creation, and management of wetland and riparian ecosystems in the American West. A symposium of the Rocky Mountain Chapter of the Society of Wetland Scientists. 1416 November 1988. Denver, $C O$.

An assemblage of partnerships has been instrumental in recreating a river and wetland environment that was lost years ago to gold mining operations. One-half-mile of river, including a new river channel, drop structures, and revegetation has been reconstructed at approximately $1 / 2$ the cost of typical riparian reclamation.

[MINED LAND RECLAMATION; MINING IMPACTS; RIPARIAN RESTORATION] 
1456. Rogers,WF; Singh,VP (1986): Some geomorphic relationships and hydrograph analysis. Water Resources Bulletin 22(5), 777-784.

Each first order channel acts as a source area for surface runoff. The distribution of first order channel distances from the gage determines the timing of water to the gage. A comparison of the frequency histogram of the first order channel distances for drainage basins and their hydrographs of runoff from general storms showed similarity. This correspondence indicated the shape of the surface runoff hydrograph and was largely controlled by the distribution of first order channel distances.

[GEOMORPHOLOGY; HYDROLOGY; RUNOFF]

1457. Rood,SB; Mahoney,JM (1993): River damming and riparian cottonwoods: Management opportunities and problems. p.134-143. In: Tellman,B; Cortner,HJ; Wallace,MG; DeBano,LF; Hamre, RH [tech. coord.]. Riparian management: Common threads and shared interests. USDA Forest Service. General Technical Report RM-226.

Cottonwoods (Populus spp.) are the principal trees in the riparian areas of the semi-arid regions of western North America. Loss of cottonwoods is not compensated by enrichment from other tree species. The entire gallery forest ecosystem collapses when cottonwoods are killed. In the southwestern United States, only small remnants of cottonwood forests survive. Among majors factors contributing to cottonwood forests decline are livestock grazing, clearing for crop production, and river damming and water diversions. Studies have demonstrated that asexual recruitment (vs. sexual recruitment) is an extensive and even dominant form of reproduction. Moreover, it is the riparian water table depth rather than river stage that determines moisture available for cottonwoods.

[COTTONWOOD; DAMS; GALLERY FOREST; RIPARIAN HABITAT; RIVER ECOLOGY]

1458. Rood,SB; Mahoney,JM (1995): River damming and riparian cottonwoods along the Marias River, Montana. Rivers 5(3), 195-207.

There is severe deficiency of cottonwood seedlings downstream from the Tiber Dam that probably results from stabilized river flows. Descriptive analyses of riparian cottonwoods and quantitative analyses of streamflow patterns were conducted to investigate the factors that influence the regeneration of riparian cottonwoods. Findings suggest that: 1) without exclusion due to flooding, zones of dense grass, shrubs, and sedges have encroached to the river's edge, competing with cottonwood seedlings; 2) the hydrological pattern of spring flooding and subsequent gradual flow decline required for seedling establishment is lacking; 3 ) erosional and depositional processes are reduced, limiting the formation of point and lateral bars that are seedling recruitment sites; 4) suspended silt settles out in the reservoir and consequently the downstream discharge carries little sediment that would contribute to bar expansion; and 5) the combined lack of flooding and impoverishment of suspended material may have resulted in an entrenched channel, further degrading the cottonwood recruitment zone. [CHANNEL MORPHOLOGY; COTTONWOOD; DAMS; FLOOD IMPACTS; RIPARIAN FOREST; STREAM FLOW]

1459. Rooseboom,A; Mulke,FJ (1982): Erosion initiation. p.59-66. In: the Proceedings of the Exeter Symposium. Recent developments in the explanation and prediction of erosion and sediment yield. IAHS Publ. No. 137.

Critical conditions for both cohesionless and cohesive materials are analyzed in terms of applied power. Power applied by a stream along its bed in maintaining motion is compared to the power required to dislodge bed particles. In the case of cohesionless materials, unique mathematical relationships have been derived for both laminar and turbulent flow conditions. A theoretical relationship has also been established for cohesive matcrials. This relationship was calibrated with field data for cases of crosion on steep slopes.

[CHANNEL MORPHOLOGY; EROSION; SEDIMENT TRANSPORT; SOILS]

1460. Root,AL; Berry,KA; Markee,NL; Giewat,GR (1998): Representing ranching communities: Comparing the water policy making environment of county commissioners with and without ranching constituencies. p.317-324. In: Potts,DF [ed.]. Range management and water resources: Proceedings of the AWRA specialty conference. American Water Resources Association. 27-29 May 1998. Reno, NV.

Results from this survey indicate that county commissioners share certain characteristics such as a high participation in water related policy decisions, a preference for local sources of information, and limited training in technical courses related to water. [PLANNING; POLICY; WATER RIGHTS]

1461. Roper,BB; Dose,JJ; Williams,JE (1997): 
Stream restoration: Is fisheries biology enough?

Fisheries 22(5), 6-11.

The fisheries profession plays a key role in planning and implementing stream restoration projects throughout the world. To date, however, few examples exist of effective stream restoration programs/projects. One of the primary reasons that stream restoration projects have not succeeded has been that projects have been implemented on a small scale, site-specific basis. The authors suggest that stream restoration would have a better chance of success if planned and implemented at a watershed scale. For this to happen, stream restoration projects must be expanded beyond instream work to include modification of upslope and riparian conditions that cause stream habitats to decline. Such efforts must incorporate other disciplines.

[FISHERIFS; RIPARIAN RESTORATION; STREAM IMPROVEMENTS]

1462. Roper,BB; Konnoff,D; Heller,D; Wieman,K (1998): Durability of Pacific Northwest instream structures following floods. North American Journal of Fisheries Management.18:686-693.

The authors assessed the durability of 3,946 instream structures in 94 streams after flood events. General durability was high and less than 20 percent of the structures had been removed from its original placement. Magnitude of flood events had a significant effect on structure durability. Stream order also affected durability, with structures in large streams 20 times more likely to be removed than structures in smaller streams. Other conditions that affected durability included location of the structure within the stream channel, whether the structure was anchored or not, structure material, and upslope landslide frequency. Such structures are most effective when used in degraded stream conditions while the activities that caused the habitat degradation are simultaneously ameliorated. [FLOOD IMPACTS; INSTREAM STRUCTURES; STREAM IMPROVEMENTS]

1463. Roseboom, $D$ (1994): Case studies on biotechnical streambank protection. p.57-65. In: Riparian area management: Proceedings of the 46th annual meeting, Forestry Committee, Great Plains Agricultural Council. 20-23 June 1994. Manhattan, KS.

This paper showed biotechnical stabilization and instream habitat enhancement techniques that had been field tested and were already in use by federal and state agencies. Methods described were willow post bank stabilization, "lunker" instream habitat enhancement, and A-Jack structural and vegetative bank stabilization.

[RIPARIAN HABITAT; STREAM

IMPROVEMENTS; STREAMBANK STABILITY]

1464. Roseboom,D; Russell,K (1985): Riparian vegetation reduces stream bank and row crop flood damage. p.241-244. In: Johnson, RR; Ziebell,CD; Patton,DR; Ffolliott,PF; Hamre,RH [tech. coord.|. Riparian ecosystems and their management: Reconciling conflicting uses. 16-18 April 1985. Tucson, AZ. USDA Forest Service. General Technical Report RM-120.

Channelization is frequently used by farmers to divert flood waters from eroding into floodplains fields. Erosion from these fields also occurs as scour in areas away from the stream bank. Channelization may frequently be the only method the landowner has to limit flood damages to fields. Studies suggest that this is only a short-term solution that results in long-term damages to streams and fields. Moreover, fish surveys documented the elimination of large game fish in old channelized stream segments. Sediment eliminated much of the instream habitat. [AGRICULTURAL IMPACTS; CHANNEL MORPHOLOGY; FISHERIES; RIPARIAN HABITAT]

1465. Rosentreter, $R$ (1991): High water indicator plants along Idaho waterways. p.18-24. In: Proceedings of the symposium on ecology and management of riparian shrub communities. 29 31 May 1991. Sun Valley, ID. USDA Forest Service. General Technical Report INT-289.

Plants restricted to and common under seasonally flooded conditions along Idaho waterways can be useful for managing and monitoring riparian areas. They can function as indicator plants that relate topography and channel capacity to annually fluctuating water levels. Indicator plants can also be useful in evaluating present and past stream hydrology conditions. The presence of these indicator species can help determine mean flood levels relative to the current water level. Stream channel geometry is highly variable over the length of a stream, and estimating mean high water can help one determine the sites available for rehabilitation.

[FLOOD IMPACTS; MONITORING; RIPARIAN HABITAT; RIPARIAN PLANTS; WATER TABLE EFFECTS]

1466. Rosentreter, $R$ (1992): Camas Prairie and possible evolutionary links with Old World 
Artemisia species: A pre-symposium tour. p.223227. In: Clary,WP; McArthur,ED; Bedunah,D; Wambolt,CL [comp.]. Proceedings - Symposium on ecology and management of riparian shrub communities. USDA Forest Service. General Technical Report INT-289.

The author conducted a field tour for symposium attendees from the Snake River Plains to the Camas Prairie, Idaho, and facilitated discussion on the geology, soils, and native vegetation en route. The field trip concluded with a discussion of the possible evolution of woody sagebrush species in North America.

[EVOLUTION; RIPARIAN HABITAT; SAGEBRUSH]

1467. Rosgen,DL (1973): The use of color infrared photography for the determination of sediment production. p.381-. In : Fluvial processes and sedimentation. Proceedings of hydrology symposium. Edmonton, Alberta. National Research Council. Canada.

The concepts and special techniques for applying color infrared photography in sediment studies were presented. The techniques were developed and evaluated through a low elevation color infrared photography flight conducted on 100 miles of streams over the West Fork of the Madison River in southeastern Montana. The photographic analysis indicated that the majority of the suspended sediment sources were primarily from channel erosion. Fluvial interpretations derived from photo analysis were also presented and discussed.

[AERIAL PHOTO; EROSION; GEOMORPHOLOGY; SEDIMENTATION]

1468. Rosgen,DL (1985): A stream classification system. p. 91-95. In: Johnson,RR; Ziebell,CD; Patton,DR; Ffolliott,PF; Hamre, RH [tech. coord.].Riparian ecosystems and their management: Reconciling conflicting uses. 16-18 April 1985. USDA Forest Service. General Technical Report RM-120.

This paper describes a stream classification system that categorizes various stream types by morphological characteristics. Criteria include: stream gradient, sinuosity, width/depth ratio, channel materials, entrenchment, confinement, and soil/landform features. Applications include: riparian management guidelines, fisheries habitat interpretations, hydraulic geometry, and sediment transport relationships.

[CHANNEL MORPHOLOGY; CLASSIFICATION; STREAM ECOLOGY]
1469. Rosgen,DL (1988): A stream classification system. p.10-16. In: Mutz,K; Cooper,DJ;

Scott,ML; Miller,LK [eds.]. Restoration, creation, and management of wetland and riparian ecosystems in the American West. A symposium of the Rocky Mountain Chapter of the Society of Wetland Scientists. 14-16 November 1988. Denver, CO.

A stream classification is presented which categorizes various stream types by morphological characteristics. Delineation criteria are stream gradient, sinuosity, width/depth ration, channel materials, entrenchment, confinement, and soil/landform features. Applications include riparian management guidelines, fishery habitat interpretations, hydraulic geometry, and sediment transport relationships.

[CHANNEL MORPHOLOGY; CLASSIFICATION; FISH HABITAT]

1470. Rosgen,DL (1993): Overview of the rivers in the west. p.8-15. In: Tellman,B; Cortner,HJ; Wallace,MG; DeBano,LF; Hamre,RH [tech. coord.]. Riparian management: Common threads and shared interests. USDA Forest Service.

General Technical Report RM-226.

Floodplains and riparian areas need to be restored to their proper function. Federal agencies are increasingly aware of the need for "environmental engineering" and are actively pursuing technical expertise to incorporate into river design works. Recent restoration work by the author in California, Colorado, and Nevada has demonstrated the effectiveness of restoring the dimension, patterns and profiles of the natural, stable river form. Once restored, on-going management to maintain their function is critical. Grazing practices, for example, have been demonstrated to actually improve stream and riparian condition. The collective efforts by persons of diverse background and experience are needed to maintain functional river systems and provide associated resource values.

[GRAZING IMPACTS; PROPER FUNCTIONING CONDITION; RIPARIAN RESTORATION; SEDIMENTATION; STREAM FLOW]

1471. Rosgen,DL; Silvey,HL; Potyondy,JP (1986): The use of channel maintenance flow concepts in the Forest Service. American Institute of Hydrology 2(1, March), 19-26.

A channel maintenance flow procedure developed by USDA Forest Service is described. Channel maintenance flows consist of a specified range and duration of flows designed to provide for 
the self-maintenance of stream channels. If such flows are not available, stream channels will in the long term accumulate sediment, accelerate bank erosion, and increase the potential for vegetation encroachment and other processes which reduce their capacity to pass flood flows.

[CHANNEL DYNAMICS; CHANNEL

MORPHOLOGY; STREAM FLOW]

1472. Rosner, $U$ (1998): Effects of historical mining on surface water and groundwater - an example from northwest Arizona. Environmental Geology 33(4), 2240230.

The surface water in the mining areas of northwest Arizona was found to be contaminated by various combinations and concentrations of heavy metals. Elevated arsenic, cadmium, and iron concentrations were detected in most surface water samples while lead, copper, and zinc contamination differed from region to region, depending on the ore mined. The groundwater was seriously polluted by arsenic, cadmium, lead, zinc, iron, and manganese in the immediate vicinity of mines that processed ore on the site.

[GROUNDWATER; MINING IMPACTS; POLLUTION; RIPARIAN HABITAT; SURFACE WATER-GROUNDWATER INTERACTION]

1473. Roth,D; Bridges,C; Zimmerman,C (eds.) (1991): Riparian: What does it mean to me? Proceedings of the third annual convention of the Colorado Riparian Association. The Nature Conservancy, Boulder, CO. 48 p.

A compilation of 16 topical and technical papers addressing riparian management in Colorado. Most of the latter are syntheses of presentations offered in more technical detail during the proceedings. Much of the information contained herein has been published in greater detail in more formal contexts. [RIPARIAN HABITAT; RIPARIAN MANAGEMENT ZONE]

1474. Roundy,BA; Young,JA; Cluff,GJ; Evans, RA (1983): Measurement of soil water on rangelands. USDA Agricultural Research Service. Agricultural research results. ARS-W-31. September 1983.

Measurements of soil water content are useful in determining effects of precipitation or treatments on soil water storage. Gravimetric moisture determination by weighing and drying samples is inexpensive and simple. Soil water content is rapidly determined using gas pressure chambers. Neutron probes permit rapid and repeatable measurements of soil water content in the same location. Gypsum blocks work well for determining matric potentials of nonsaline soils down to -15 bars. Psychrometers can be used to measure total soil water potential of saline soils and matric potentials of nonsaline soils down to about -70 bars.

[HYDROLOGY; MONITORING; SOIL-WATER CONDITIONS]

1475. Rovey, CEK (1975): Numerical model of flow in a stream aquifer system. Hydrology Paper No. 74, August 1975. Colorado State University; Ft. Collins, $\mathbf{C O}$.

A three-dimensional, finite difference model was developed for simulating steady and unsteady, saturated and unsaturated flow in a stream aquifer system. The basis of this model is the finite difference form of Richard's equation for unsaturated and saturated subsurface flow. Effects of streamflow on groundwater movement are treated by applying the appropriate boundary conditions to Richard's equation. Contributions of groundwater to river flow are quantified by including seepage rates in the computation of river discharge. The threedimensional model was developed for use in this study to interact with two-dimensional model segments, which were interfaced with the threedimensional model on its upstream and downstream ends. Computed estimates of river discharge at each end of the study area and water table elevations throughout the region agreed reasonably well with observed data.

[HYDROLOGY; MODELING; SURFACE WATER-GROUNDWATER INTERACTION]

1476. Rowley,WD (1985): US Forest Service grazing and rangelands - $A$ history. Texas $A$ \& M University Press, College Station, TX. 270 p.

This book reviews the history of grazing on national forest system lands from the open lands of the 19th century to the current times. The evolution of USDA Forest Service land management policies and the science of range management are carefully explained. The history of the agency and the development of public attitudes are positively correlated.

[GRAZING IMPACTS; HISTORIC RECORDS]

1477. Rupp,CW (1979): Management and policy for grazing riparian ecosystems on national forest system lands. p.17-19. In: Cope,OB [ed.|. The forum on grazing and riparian/stream ecosystems. 3-4 November 1978. Denver, CO. Trout Unlimited, Inc. 
We must manage our riparian areas with no impairment of their basic productivity. Managers do not have all the answers for riparian ecosystems but intend to be innovative. The immediate objective is to improve riparian habitat while retaining livestock use.

[GRAZING IMPACTS; POLICY; RIPARIAN HABITAT; EVALUATION]

1478. Russell,GD; Hawkins,CP; O'Neill,MP (1997): The role of GIS in selecting sites for riparian restoration based on hydrology and land use. Restoration Ecology 45(5), 56-68.

Successful long-term restoration efforts require consideration of hydrology and surrounding land use during the site selection process. This paper describes an approach to initial site selection in the San Luis Rey River watershed in southern California that uses watershed-level information on basin topography and land cover to rank the potential suitability of all sites within a watershed for either preservation or restoration. This approach requires the use of a geographic information system (GIS) to map relative wetness and land cover within a watershed. [GIS; HYDROLOGY; LAND USE; RIPARIAN RESTORATION]

1479. Russell,IC (1903): Preliminary report on artesian basins in southwestern Idaho and southeastern Oregon. USDI Geological Survey. Water and Irrigation Paper No.78. [HISTORIC RECORDS; HYDROLOGY; WATER RESOURCE MANAGEMENT]

1480. Russell,IC (1905): Preliminary report on the geology and water resources of central Oregon. USDI Geological Survey Bulletin No. 252. [GEOLOGY; HISTORIC RECORDS; HYDROLOGY; WATER RESOURCE MANAGEMENT]

1481. Ryder,RA (1980): Effects of grazing on bird habitats. p.51-65. In: Workshop proceedings, Management of western forests and grasslands for nongame birds. 11-14 February 1980. Salt Lake City, UT. USDA Forest Service. General Technical Report INT-86.

Feeding on plants by various herbivores, especially livestock and big game but also by rodents, lagomorphs, insects and even some birds and reptiles, can alter vegetative communities as habitat for birds. Species composition of plants, density of stands, vigor, seed and insect production, and growth form of plants often change due to grazing. Removal of vegetative cover as well as trampling may expose soils to increased wind and water erosion.

Differences in effects of grazing on vegetation and soils by various classes of livestock, species of big game, different levels of intensity and seasons of use are discussed with stress on examples from western forest and grassland types.

[AVIFAUNA; GRAZING IMPACTS; PLANT

COMMUNITIES; RIPARIAN HABITAT $]$

1482. Saab,V (1999): Importance of spatial scale to habitat use by breeding birds in riparian forests: A hierarchical analysis. Ecological Applications 9(1), 135-151.

Patterns of habitat use by breeding birds were studied in cottonwood riparian forests of the South Fork of the Snake River in southeastern Idaho. A hierarchical approach was used to examine habitat use at three spatial scales: microhabitat, macrohabitat, and landscape. The most significant predictor of species occurrence was the landscape component: increases in upland natural vegetation with decreases in agriculture. Both interior and edge specialists were found in arid land, cottonwood riparian forests that were linear in nature, with large amounts of edge. Nest predators, brood parasites, and exotic species responded positively to human-altered landscapes. Landscape patterns were the primary influence on distribution and occurrence of most bird species, whereas macrohabitat and microhabitat were of secondary importance. Surrounding landscape features should be a primary consideration for selecting riparian reserve areas.

[AVIFAUNA; COTTONWOOD; LANDSCAPE ECOLOGY; RIPARIAN FOREST; RIPARIAN HABITAT; SPATIAL SCALE; SPECIES RICHNESS]

1483. Sadeghipour,J; Dracup,JA (1985): Regional frequency analysis of hydrologic multiyear droughts. Water Resources Bulletin 21(3), 481-487.

The authors propose a method to standardize drought severities to enable comparison among drought events. A multivariate simulation model is used to estimate exceedence probabilities associated with regional drought maxima. This method, named the regional extreme drought method, is capable of generating a series of drought events which, although they have not occurred historically, are more severe than historic events.

[DROUGHT EFFECTS; HYDROLOGY]

1484. Sagers,CL; Lyon,J (1997): Gradient 
analysis in a riparian landscape: Contrasts among forest layers. Forest Ecology and Management 96, 13-26.

Standard vegetation sampling techniques were used to characterize species associations in a riparian forest of the Buffalo River, Arkansas. Environmental gradients dominated by $\mathrm{pH}$ and elevation influenced species associations, but secondary gradients differed among forest layers. The number and composition of vegetation clusters did not correspond well among forest layers. Independence of forest layers may be promoted by response to different patterns of environmental factors operating at different levels of the forest. Species associations in the overstory were not good predictors of understory associations. Traditional use of canopy dominants as community indicators may be inaccurate and imprecise for the majority of the forest species.

[CANOPY; FOREST LAYERS; PLANT

COMMUNITIES; RIPARIAN FOREST]

1485. Salmond,GR; Croft,AR (1955): The management of public watersheds. p.191-198. In: Water: The yearbook of agriculture. 84th Congress. House document No. 32. [EROSION; HISTORIC RECORDS; WATER RESOURCE MANAGEMENT; WATERSHED]

1486. Salwasser,H; Shimamoto,K (1981): Pronghorn, cattle, and feral horse use of wetland and upland habitats. p.210-213. In: Warner,RE; Hendrix,KM [eds.]. Proceedings of the California Riparian Systems Conference. 17-19 September 1981. Davis, CA.

Developed wetlands play a critical role in habitat quality for pronghorn, domestic livestock, and feral horses in Great Basin range types. Wetlands provide abundant summer forage for pronghorn when cattle and horse grazing has removed coarse, grasslike plants, making forbs available. Wetland creation should be balanced with needs for existing habitats on ranges.

[GRAZING IMPACTS; RIPARIAN HABITAT; WETLANDS]

1487. Sammis, G (1993): A rancher's view of the river. In: Tellman,B; Cortner,HJ; Wallace;MG; DeBano,LF; Hamre,RH [tech. coord.]. Riparian management: Common threads and shared interests. USDA Forest Service. General Technical Report RM-226. 419 p.

There could be no agriculture without rivers. On the Chase Ranch operated by the author, livestock co-exist with numerous species of wildlife, although there are occasions when conflicts occur. The river can also be destructive to physical improvements and infrastructure. Ranchers who are caretakers for rivers "must do our best to protect its watersheds and riparian areas and make it a better river as it goes on its way".

[RIPARIAN HABITAT; RIPARIAN MANAGEMENT ZONE; RIVER ECOLOGY; STEWARDSHIP]

1488. Samson,FB (1980): Use of montane meadows by birds. p.113-129. In: Workshop proceedings, Management of western forests and grasslands for nongame birds. 11-14 February 1980. Salt Lake City, UT. USDA Forest Service. General Technical Report INT-86.

Relatively few species of birds breed on montane meadows, but meadows serve as important foraging areas for avian communities associated with nearby riparian or forest habitats. Recommendations for management of montane meadows include: 1) care should be exercised in grazing or other land use prescriptions such as fire, considering their apparent accelerative effect on meadow succession; 2) information is needed on the effect of meadow size on the diversity of breeding and foraging birds to fully predict the effect of land use changes; and 3) detailed studies involving marked individuals rather than singing male counts are needed to ensure accurate estimates of densities and essential habitat needs of breeding birds.

[AVIFAUNA; MEADOWS; RIPARIAN HABITAT]

1489. Samson, FB (1987): Characteristics of natural riparian forest systems. In: Streamside management: Riparian, wildlife, and forestry interactions. An interdisciplinary symposium. 1113 February 1987 . University of Washington. Seattle, WA.

Riverine systems are characterized by two major attributes: differences between high and low flows and storm handling properties, which may be characterized by $25-50-100$ year floods. This dynamic, extremely variable, high energy water system is a unique, integral part of the riverine riparian environmental system. It directly changes stream beds, adjacent vegetation, bordering land, and is the major component of the aquatic system. [CLASSIFICATION; INVENTORY; RIPARIAN FOREST; RIPARIAN HABITAT]

1490. Samson,FB; Knopf,FB; Hass,LB (1988): Small mammal response to the introduction of cattle into a cottonwood floodplain. p.432-438. In: 
Proceedings of the symposium: Management of amphibians, reptiles, and small mammals in North America. USDA Forest Service, General Technical Report RM-166.

Few differences between pastures in small mammal communities were evident prior to grazing, 1 month following grazing, and no differences in numbers or distribution of small mammals were observed 5 months following grazing. Each small mammal species exhibited different habitat use compared to availability and few habitat variables differed on grazed versus ungrazed pastures. Grazing at USDA Soil Conservation Service recommended levels in winter did not appear to have an initial effect on small mammal populations or their habitats in a Colorado floodplain.

[COTTONWOOD; FLOODPLAIN

MANAGEMENT; GRAZING IMPACTS; RIPARIAN HABITAT]

1491. Sands, A; Howe,G (1977): An overview of riparian forests in California: Their ecology and conservation. p.98-115. In: Johnson,RR; Jones,DA [tech. coord.]. Importance, preservation, and management of riparian habitats: A symposium. 9 July 1977. Tucson, AZ. USDA Forest Service. General Technical Report RM-43.

This paper brings together abstracts of presentations made at the Symposium on riparian forests: Their ecology and conservation, which was held in Davis, California on May 14, 1977. Sponsors of that symposium intended to encourage a strong alliance of individuals and agencies that could work together to establish protection for the endangered riparian ecosystems of California.

[RIPARIAN ECOLOGY; RIPARIAN HABITAT]

1492. Sanville,WD; Eilers,HP; Boss,TR; Pfleeger,TG (1986): Environmental gradients in northwest freshwater wetlands. Environmental Management 10(1), 125-134.

Representative physical, hydrological, and edaphic properties were periodically measured in micro-plots along upland/wetland transects. A multivariate approach was utilized in the data analysis applying correlation, cluster analysis, and principal components analysis. Results indicated that the environmental characteristics change in a quantifiable manner both spatially and temporally. The controlling mechanism is moisture spatially in terms of the upland/wetland transect and temporally with respect to seasonal response. These changes do not correlate with vegetation.

[ENVIRONMENTAL MANAGEMENT;

\section{RIPARIAN HABITAT; WETLANDS]}

1493. Sather,JH; Smith,RD (1984): An overview of major wetland functions and values. Western Energy and Land Use Team. USDI Fish and Wildlife Service FWS/OBS-84/18. 68 p.

This report was prepared to provide background information for participants at the National Wetland Values Assessment Workshop held at Alexandria, Virginia, in May, 1983. The Wetlands Values Bibliographic Database was used to access citations in the literature search. Annotations of each referenced document can be found in the Database. [BIBLIOGRAPHY; RIPARIAN HABITAT; WEILANDS]

1494. Savabi,MR; Gifford,GF (1987): Application of selected soil loss equations to trampled soil conditions. Water Resources Bulletin 23(4), 709-715.

Soil loss prediction equations (Universal Soil Loss Equation, Modified USLE, and Onstad-Foster Method) were modified to reflect the impact of trampling on soil erosion. The erosion control factor, $\mathrm{P}$, was replaced by a trampling ratio, $\mathrm{Tr}$, which is a function of the change in soil erosion due to animal trampling. Trampling impact on soil erosion varied with soil type. The data are a preliminary attempt to account for the impact of trampling on soil erosion. [COMPACTION; GEOMORPHOLOGY; LIVESTOCK EFFECTS; SOILS]

1495. Schade,JD; Fisher,SG; Grimm,NB (1997): The impact of riparian shrubs on subsurface nitrogen patterns in a Sonoran Desert stream. p.178. Abstracts. 1997 annual meeting of the Ecological Society of America jointly with The Nature Conservancy. 10-14 August 1997. Albuquerque, NM.

The effect of colonization by a riparian shrub (Baccharis salicifolia) on nitrogen patterns of subsurface water in a desert stream was investigated. Organic matter and respiration were higher under $B$. salicifolia, but denitrification was not. Higher organic matter and low nitrite under shrubs suggest nitrite limitation. Sandbars colonized with $B$. salicifolia may represent nitrogen sinks in this ecosystem and potentially influence primary production of algae in the N-limited surface stream.

[NUTRIENT CYCLES; ORGANIC DEBRIS; RIPARIAN SHRUBS]

1496. Schlesinger, WH; Abrahams, AD (1997): Runoff losses of nitrogen and phophorous from 
grassland and shrubland plots in the Chihuahuan Desert of New Mexico. p.179. In: Abstracts. 1997 annual meeting of the Ecological Society of America jointly with The Nature Conservancy. 10-14 August 1997. Albuquerque, NM.

Rainfall simulation experiments at the Jornada LTER, Las Cruces, New Mexico, measured runoff losses of water, sediment, and forms of dissolved $\mathrm{N}$ and P. Dissolved organic forms dominated the loss of $\mathrm{N}$ from all areas. The total yield of $\mathrm{N}$ was positively correlated to discharge among all plots. $\mathrm{N}$ discharge was negatively correlated to surface litter. Dissolved organic $\mathrm{P}$ dominated $\mathrm{P}$ losses in the grassland. Total yield of $P$ was positively correlated to discharge and to the $P$ concentration in runoff.

[NUTRIENT CYCLES; RUNOFF]

1497. Schlosser, IJ (1987): The role of predation in age and size related habitat use by stream fishes. Ecology 68:651-659.

In a natural second order, warm water stream, predators were restricted to pool habitats so that riffles and raceways were effective refugia. In the absence of bass, juveniles of all taxa preferred structurally complex or structurally simple pools, even though benthic insect densities were higher in riffles than pools. In the presence of bass, juveniles of all taxa were largely restricted to shallow riffle or raceway refugia. Results suggest that the high density and extensive overlap in habitat overlap in habitat use of small fishes in shallow habitats of small warm water streams is related to the increased risk of predation by centrarchids in pools.

[FISH HABITAT; PREDATION; WARM WATER STRE.AMS]

1498. Schlosser,IJ (1991): Stream fish ecology: a landscape perspective. BioScience 41(10), 704-711.

Various life stages and species of stream fish require different kinds of physical habitats. Spatial heterogeneity and the maintenance of connectivity between habitat patches is critical for reproduction and survival of fish in lotic ecosystems. The terrestrial-aquatic interface in upstream areas is the most critical area of the landscape, where most fish reproduction occurs. This interface also experiences extreme fluctuations and variability and is most vulnerable to land use activities which are concentrated there. Alterations at this location may cause severe reductions in fish diversity, trophic structure, and fish abundance. The predictive capability of stream fish ecologists would be greatly enhanced by the use of evolving quantitative techniques to establish relationships between environmental heterogeneity and critical biological processes.

[AQUATIC ECOSYSTEMS; LANDSCAPE ECOLOGY; RIPARIAN HABITAT]

1499. Schlosser,IJ (1995): Dispersal, boundary processes, and trophic-level interactions in streams adjacent to beaver ponds. Ecology 76(3), 908-925.

In Minnesota, experiments conducted in an artificial stream located below a beaver pond indicated discharge and fish predation have potentially strong and interactive effects on invertebrate colonization in stream ecosystems. Differences in colonization of riffles and pools under low vs. elevated discharge and fish vs. no-fish treatments suggested, however, that the interactive effects of these factors on invertebrate was variable over even small spatial scales. Elevated discharge increased invertebrate colonization in riffles but decreased invertebrate colonization in pools. Contrary to expectations, fish predation reduced invertebrate colonization more under elevated than low discharge conditions, particularly in pool habitats. Results suggest that: 1) beaver ponds act as reproductive sources for fish on the landscape, while adjacent stream environments act as potential reproductive "sinks"; 2) large scale spatial relationships between beaver ponds and streams, along with the influence of discharge on the permeability of the boundaries between these habitats, are critical in controlling fish dispersal between ponds and streams and the subsequent abundance and composition of fish in lotic ecosystems; and 3) fish predation and discharge have potentially cascading effects on invertebrate colonization in lotic ecosystems.

[BEAVER; FISH DISPERSAL; INVERTEBRATES; PREDATION; RIPARIAN HABITAT; STREAM ECOLOGY]

1500. Schlosser,IJ; Karr,JR (1981): Riparian vegetation and channel morphology impact on spatial patterns of water quality in agricultural watersheds. Environmental Management 5(3): 233-243.

The Universal Soil Loss Equation (USLE) may not adequately predict relative water quality conditions within a watershed when variation in channel morphology and riparian vegetation exists. The authors offer the following recommendations: 1) models to predict water quality effects of management programs should combine a terrestrial phase (hydrologic and erosion processes associated 
with surface runoff) with an aquatic phase (hydrological processes of scour and sediment transport); 2) sampling schemes should be designed to account for the impact of water quality of both watershed land surface and in- and near-channel processes; and 3) best management practices or systems for improving the broadest range of water resources in agricultural watersheds need to be based on an expanded "critical area" approach, which includes identification of critical erosive and depositional areas in both terrestrial and aquatic environments.

[AGRICULTURAL IMPACTS; CHANNEL MORPHOLOGY; RIPARIAN VEGETATION; WATER QUALITY]

1501. Schmeitzer,SH; Finch,DM; Leslie,DM,Jr (1998): The brown-headed cowbird and its riparian-dependent hosts in New Mexico. USDA Forest Service. Rocky Mountain Research Station. General Technical Report RMRS-GTR-1.

Brown-headed cowbirds (Molothrus ater) are increasing in some areas of North America while certain populations of neotropical migratory songbirds (NTMs) are declining. In the Southwest, several species of NTMs nest only in riparian habitats, some of which have seen significant declines. Brood parasitism by the brown-headed cowbird and loss of riparian habitat may be the primary causes of these declines. The authors hypothesized that increased human use of riparian habitats in New Mexico had resulted in increased abundance of brown-headed cowbirds and their parasitism on riparian-dependent NTMs. Results suggested that quantitative studies should be conducted to determine the distribution, density, and rates of parasitism of brown-headed cowbirds in New Mexico's riparian habitat because existing data is inadequate.

IAVIAN ECOLOGY; PARASITISM; NEOTROPICAL BIRDS; RIO GRANDE; RIPARIAN HABITAT]

1502. Schmidt,JC; Webb,RH; Valdez,RA; Marzolf,GR; Stevens,LC (1997): The role of science and value judgement in restoring the Colorado River in Grand Canyon. p.34. In: Abstracts. 1997 annual meeting of the Ecological Society of America jointly with The Nature Conservancy. Changing ecosystems: Natural and human influences. 10-14 August 1997. Albuquerque, NM.

The completion of the Glen Canyon Dam created profound river corridor changes in Grand
Canyon. Ecological impacts of the dam have included reduction of frequency and magnitude of floods, sediment transport, and variability of water temperature. The dam's tailwaters created a trout fishery. Camping beaches have eroded. Debris flows have increased navigation difficulty. Native fish populations have declined and exotic fish populations have increased. Marsh and riparian vegetation has increased, woody debris has disappeared, and sand contributed by the tributaries is deposited in the river channel rather than on the channel margins or in eddies. In these circumstances, science can identify problems and tradeoffs but the ultimate choices regarding restoration and management belong to society.

[FISHERIES; FLOOD IMPACTS; RIPARIAN RESTORATION; WOODY DEBRIS]

1503. Schmidt,LJ (1996): The national riparian policy. p.81-84. In: National hydrology workshop proceedings. 27 April - 1 May 1992; Phoenix, AZ. USDA Forest Service. General Technical Report RM-GTR-279.

In 1989, the USDA Forest Service initiated a national effort to make riparian area management a prominent part of the on-going forest planning and management process. The approach involved: 1) developing an integrated approach to implementing riparian standards and guidelines; 2) setting national, regional, and forest goals for on-the-ground accomplishment; 3) using an integrated basinwide approach to accomplish priority goals with demonstration areas on every district; 4) conducting an inventory of current riparian ecological conditions; and 5) building increased internal and external support for the initiative. [EVALUATION; POLICY; RIPARIAN HABITAT; RIPARIAN MANAGEMENT ZONE]

1504. Schmidt,RH (1991): Defining and refining value for riparian systems. Rangelands $13(2), 80-$ 82.

This article explores the costs and benefits of: 1) increasing the benefits of riparian systems or their products; and 2) decreasing the costs associated with preserving riparian systems. Economic models for distributing the economic values to landowners have not been fully developed.

[ECONOMICS; RIPARIAN; RIPARIAN

HABITAT]

1505. Schneller-McDonald,K; Ischinger,LS; Auble,GT (1990): Wetland creation and management: Description and summary of the 
literature. USDI Fish and Wildlife Service. Biological Report 90(3). 198 p.

This report provides bibliographic information contained in the Wetland Creation/Restoration data base. One thousand one hundred records are included. Each record represents one article, report, or other publication dealing with the data subjects. Information contained in the records is: 1) introduced in a description of all fields and key words, 2) summarized in terms of findings in a set of graphs and tables, and 3 ) accessible through a crossreferenced index.

[BIBLIOGRAPHY; CREATED WETLANDS; RIPARIAN HABITAT; WETLANDS]

1506. Schrader,TA (1955): Waterfowl and the potholes of the North Central States. p.596-604. In: Water: The yearbook of agriculture. 84th Congress. House Document No. 32.

The prairie pothole region of the Dakotas and Minnesota is the most important waterfowl nesting area in the United States. Formerly, it produced up 15 million ducks (by 1955, production had dropped to about 5 million ducks annually). Pothole drainage for agricultural development was the primary cause. An acceptable program to save wetlands would have involved two factors. Subsidies to provide farmers with incomes equitable with that which could be achieved by drainage and/or compensation for the problems caused by undrained potholes. Another desirable but impractical alternative would be direct purchase of such lands by the federal government. [RIPARIAN HABITAT; WATERFOWL MANAGEMENT; WETLANDS]

\section{Schroeder,K; Savonen,C (1997): Lessons} from floods. Fisheries 22(9), 14-16.

Human activities have contributed to the increased intensity of floods. Long-term goals should address the reestablishment of stability and resilience of watersheds in the face of natural disturbances without the need for continued human intervention such as constructing instream habitat or repairing flood damage to streams. Riparian and upland management can also be altered to more closely mimic the spatial and temporal scales of natural disturbances. For example, increased protection of riparian habitat and longer timber harvest rotations can help return natural flow regimes to forested watersheds and can establish natural delivery of wood into streams to maintain complex habitats. [FLOOD IMPACTS; HUMAN IMPACTS; ORGANIC DEBRIS; RIPARIAN HABITAT; SPATIAL SCALE; WATERSHED]
1508. Schultz,TT; Leininger,WC (1990): Differences in riparian vegetation between grazed areas and exclosures. Journal of Range Management 43(4), 295-299.

Differences in vegetation structure were examined in a montane riparian zone in north-central Colorado after 30 years of cattle exclusion and continued, but reduced, grazing pressure. Total vascular vegetation, shrub, and graminoid canopy cover was greater in the exclosures as compared to grazed areas, while forb canopy cover was similar between treatments. Exclosures had nearly 2 times the litter cover, while grazed areas had 4 times more bare ground. The mean peak standing crop over the 2 years of the study in the exclosures was about 5 times that in the grazed areas. Cattle utilized about 65 percent of the current years growth of vegetation. [EXCLOSURES; GRAZING IMPACTS; PLANT COMMUNITIES]

1509. Schultze,RF; Wilcox,GI (1985): Emergency measures for streambank stabilization: an evaluation. p. 59-61. In: Johnson,RR; Ziebell,CD; Patton,DR; Ffolliott,PF; Hamre,RH [tech. coord.]. Riparian ecosystems and their management: Reconciling conflicting uses. 16-18 April 1985. Tucson, AZ. USDA Forest Service. General Technical Report RM-120.

Streams in California were severely damaged by severe storms in 1978-1983. USDA Soil Conservation Service used several mechanical and revegetation techniques to stabilize streambanks and re-establish riparian vegetation. Results of evaluations of 29 separate projects were discussed and evaluated.

[RIPARIAN RESTORATION; STORM EVENTS]

1510. Schultz,TT; Leininger,WC (1991): Nongame wildlife communities in grazed and ungrazed montane riparian sites. Great Basin Naturalist 51(3), 286-292.

Livestock grazing can alter vegetative structure and composition of riparian habitat for nongame species. This study, in north central Colorado, suggests that previous heavy cattle grazing changed the bird and small mammal community composition through reduction of shrub and herbaceous cover. More research is indicated for the intensities and season of grazing. [AVIFAUNA; GRAZING IMPACTS; RIPARIAN HABITAT; SMALL MAMMALS]

1511. Schumaker,J (1995): Riparian grazing successes on Montana ranches. Conservation 
Districts Bureau. Helena, MT. 30 p.

A compilation of successful case studies of riparian restoration projects and practices on Montana ranches. In this booklet, ranchers and grazing associations have benefitted by: increased abundance and diversity of vegetation along streambanks; reduced streambank erosion and property loss; increased forage quality and production; fewer weeds; higher weaning weights; healthier livestock; higher conception rates; lower calf mortality; improved water quality and fisheries; improved range and riparian condition; reduced livestock injury on icy or muddy streambanks; increased streamflows; and, better cooperation from public land management agencies.

[GRAZING IMPACTS; RIPARIAN MANAGEMENT ZONE]

1512. Schumann, R (1989): Morphology of Red Creek, Wyoming, an arid region anastomosing channel system. Earth Surface Processes and Landforms 14, 277-288.

Red Creek is an arid region anastomosing stream. A steep, deep, sinuous main channel is flanked by anastomosing flood channels or anabranches. Anabranch enlargement occurs by headward erosion and anabranches serve as distributary channels during floods. During periods of low discharges, the anabranches act as tributaries to the main channel, transporting runoff. [CHANNEL DYNAMICS; CHANNEL MORPHOLOGY; SEDIMENTATION]

\section{Schumm,SA (1960): Effect of sediment} characteristics on erosion and deposition in ephemeral stream channels. p. 31-70. USDI Geological Survey Prof. Paper 352-C.

This study suggests that preventive conservation may be the most practical solution to some erosion problems, such as gully cutting. Deposition, if it is desired to fill a trenched channel, should be induced in reaches where conditions are most favorable for natural aggradation. Conservation measures should be modified depending on the character of the valley and its alluvium. Only certain critical reaches of a channel need to be controlled over larger areas. [CHANNEL MORPHOLOGY; EROSION CONTROL; SEDIMENTATION]

1514. Schumm,SA (1973): Geomorphic thresholds and complex response of drainage systems. p.299-310. In: Fluvial geomorphology. Binghampton symposium series \#4. Binghamton, New York.
The alluvial and morphological details of drainage systems are too complex to be explained by progressive erosion alone. Within the context of the erosion cycle such complexities as terraces or alluvial deposits must be explained by external variables such as climatic, tectonic, isostatic or land use changes. Some abrupt modifications of such a system can be inherent in its erosional development and that two additional concepts are required for comprehension of drainage system evolution: 1) geomorphic thresholds and 2) complex response of drainage systems.

[CHANNEL DYNAMICS; GEOMORPHOLOGY; GULLY CONTROL; STREAM ECOLOGY]

1515. Schumm,SA; Harvey,MD; Watson,CC (1984): Incised channels: Morphology, dynamics and control. Water Resources Publications, Littleton, $\mathrm{CO}$.

Within any area, erosional activity will be variable and the smaller components of the landscape may not be in the same stage of erosional or depositional development. This scenario is widely replicated in the semiarid regions of the western US. The relations developed in this book indicate that the distribution of erosional features can be explained and that the sites of additional erosion may be predictable.

[CHANNEL DYNAMICS; CHANNEL MORPHOLOGY; GEOMORPHOLOGY; GULLY CONTROL]

1516. Schumm,SA; Lichty,RW (1965): Time, space, and causality in geomorphology. American Journal of Science 263, 110-119.

During a long period of time a drainage system or its components can be considered as an open system which is progressively losing potential energy and mass (erosion cycle), but over shorter spans of time self-regulation is important, and components of the system may be graded or in dynamic equilibrium. During an even shorter time span a steady state may exist. Therefore, depending on the temporal and special dimensions of the system under consideration, landforms can be considered as either a stage in a cycle of erosion or as a system in dynamic equilibrium.

[CHANNEL DYNAMICS; GEOMORPHOLOGY; STREAM ECOLOGY]

1517. Schweitzer,SH; Finch,DM; Leslie,Jr,DM (1996): Reducing impacts of brood parasitism by Brown-headed cowbirds on riparian-nesting migratory songbirds. p.267-276. In: Shaw,DW; 
Finch,DM [tech. coord.]. Desired future conditions for Southwestern riparian ecosystems: Bringing interests and concerns together. USDA Forest Service. General Technical Report RM-GTR-272.

Riparian habitats throughout the Southwest have been altered directly and indirectly by human activities. Many migrant songbird species specific to riparian communities during the breeding season are experiencing population declines. Conversely, the Brown-headed cowbird benefits from fragmentation of habitat and livestock grazing in and near riparian habitat. Brood parasitism by cowbirds may accelerate the process of local extirpation of small, remnant populations of migratory songbirds. Cowbird trapping programs have successfully reduced brood parasitism of the Least Bell's Vireo and Southwestern Willow Flycatcher in riparian habitats of California. This removal technique has not been used commonly in riparian habitats of other states but may be beneficial if a significant problem is identified. Preliminary surveys should be conducted to determine abundance and distribution of cowbirds, and nests of potential hosts should be monitored to assess rates of parasitism. It is not likely that remnant populations of migratory songbirds can sustain parasitism rates of more than 30 percent. Trapping, habitat restoration, and research suggestions are presented.

[AVIAN ECOLOGY; AVIFAUNA; PARASITISM; NEOTROPICAL BIRDS; RIPARIAN HABITAT; RIPARIAN RESTORATION]

1518. Schweitzer,SH; Finch,DM; Leslie,Jr.,DM (1998): The brown-headed cowbird and its riparian-dependent hosts in New Mexico. USDA Forest Service. General Technical Report RMRSGTR-1. 23 p.

In some regions of North America, brownheaded cowbirds are increasing at the same time that some populations of neotropical migratory songbirds (NTMs) are declining. Significant declines of the southwestern willow flycatcher and the least Bell's vireo are of great concern. In this study, existing data on the brown-headed cowbird was collected and analyzed and compared to data from other states. Results suggest that quantitative studies should be conducted to determine the distribution, abundance, density, and rates of parasitism of brown-headed cowbirds in New Mexico riparian habitat because the existing data are inadequate.

[BROWN-HEADED COWBIRD; NEOTROPICAL BIRDS; PARASITISM; RIPARIAN HABITAT]

1519. Schwien,J (1991): A pitch for Badger
Creek. Rangelands 13(4), 181-182.

In Colorado, 18 federal, state, and local agencies are cooperating to restore Badger Creek to its original status as the premier spawning stream for German brown trout on the Arkansas River. Periodic flooding and sediment damage to gravel beds had reduced the stream's fishery value. Treatments include the implementation of best management practices and short duration grazing.

[COLLABORATION; GRAZING IMPACTS; GRAZING TREATMENTS]

1520. Scott,JM; Csuti,B; Jacobi,JD; Estes,JE (1987): Species richness: A geographic approach to protecting future biological diversity.

BioScience 37(11), 782-788.

The authors propose that the most efficient and cost effective way to retain maximal biological diversity in the minimal area is to focus efforts on species-rich areas. A geographical information systems mapping approach has identified unexpected inequities in present time wildlife/nature preserves and the extent of protection of species-rich habitats. [BIODIVERSITY; GIS; RIPARIAN HABITAT]

1521. Scott,JM; Scott,MJ; Davis,F; Csuti,B; Butterfield,B; Noss,R; Caicco,S; Anderson,H; Ulliman,J; D'Erchia,F; Groves,C (1990): Gap analysis: Protecting biodiversity using geographic information systems. A handbook for a workshop held at the University of Idaho, 29-31 October 1990. Moscow, ID. 176 p.

A handbook providing a detailed framework for instruction in the gap analysis concept. Chapters included are: Introduction to biodiversity and conservation planning; mapping actual vegetation to predict regional biodiversity; GIS data layers and mapping of biodiversity; and interpreting the data. A section on the mapping of wetland and aquatic habitats (riparian areas) indicates the difficulties of dealing with small but species-rich land areas. [BIODIVERSITY; CONSERVATION; GAP ANALYSIS; GIS; RIPARIAN HABITAT]

1522. Scott,ML; Auble,GT (1997): The influence of floods, ice, and grazing on riparian cottonwood establishment along the Missouri River, Montana, USA. p.182. Abstracts. 1977 annual meeting of the Ecological Society of America jointly with The Nature Conservancy. 10-14 August 1997. Albuquerque, NM.

This study documented the importance of flowrelated channel change in the establishment of plains cottonwood along with the quantification of ice and 
grazing related mortality along the Missouri River. Most excavated trees ( 72 percent) established in the year of a flow exceeding $1400 \mathrm{cu} \mathrm{m} / \mathrm{s}$ or in the following two years. Flows of this magnitude create establishment sites for cottonwood sites at high elevations. Frequent ice scour and cattle grazing appear to limit cottonwood survival at lower elevations. In nonflood years, cottonwood establishment is largely confined to a narrow elevational zone below the annual high stage. [COTTONWOOD; FLOOD IMPACTS; GRAZING IMPACTS; RIPARIAN FOREST]

1523. Scott,ML; Auble,GT; Friedman,JM (1997): Flood dependency of cottonwood establishment along the Missouri River, Montana, USA. Ecological Applications 7(2), 677-690.

The physical environment of riverine ecosystems is largely structured by natural flow variability. The latter, however, has been modified in many rivers by water management practices. The authors quantified the relationship between flow and establishment of the dominant tree (plains cottonwood) along one of the least hydrologically altered alluvial reaches of the Missouri River. The date and elevation of tree establishment relative to peak stage and discharge were determined over a 112-year hydrologic record. Flows at a magnitude recurring every 9.3 years created the necessary bare, moist establishment sites at an elevation high enough to allow cottonwoods to survive subsequent floods and ice jams. Almost all cottonwoods that survived the most recent floods were established $>1.2 \mathrm{~m}$ above the lower limit of perennial vegetation. Most younger individuals were established between 0 and $1.2 \mathrm{~m}$ and were unlikely to survive over the long term. In this case, a relatively narrow valley constrains lateral channel movement that might otherwise facilitate cottonwood recruitment at lower flows. Understanding locally dominant fluvial geomorphic processes contributes to effective management of flows to maintain cottonwood recruitment. [COTTONWOOD; FLOOD IMPACTS; FLUVIAL PROCESSES; GEOMORPHOLOGY; RIPARIAN FOREST; RIVER ECOLOGY]

1524. Scott,ML; Horak,GC; Slauson,WL (1988): Landscape analysis of woody riparian vegetation along a portion of the Cache La Poudre River, CO. p.63-70. In: Mutz,K; Cooper,DJ; Scott,ML; Miller,LK [eds.]. Restoration, creation, and management of wetland and riparian ecosystems in the American West. A symposium of the Rocky Mountain Chapter of the Society of Wetland
Scientists. 14-16 November 1988. Denver, CO.

Infrared aerial photography was used to assess the extent of woody riparian vegetation along a gradient from urban to agricultural areas on the Cache La Poudre River, Colorado. Although the aerial extent of riparian vegetation in the urban area is not significantly different than that in the agricultural area, detailed examinations of land use patterns indicated a change in occurrence and nature of riparian vegetation from urban to agricultural land uses. In urban areas, riparian vegetation is associated with gravel mined areas or narrow alluvial terraces between the channel and channel rip-rap. In contrast, riparian vegetation in agricultural areas with unconfined channels is found on point bars and low, uncultivated alluvial terraces along the channel edge. Decisions regarding the values and management of ecosystems should be made in view of landscape level changes in hydrology, vegetation dynamics, and land uses.

[AERIAL PHOTO; LAND USE; LANDSCAPE ECOLOGY; RIPARIAN HABITAT; RIPARIAN VEGETATION]

1525. Scurlock,D (1998): From the rio to the sierra: An environmental history of the Middle Rio Grande Basin. USDA Forest Service. General Technical Report RMRS-GTR-5. $440 \mathrm{p}$.

The processes and evolution of the Middle Rio Grande Basin ecosystems, especially riparian zones, have been profoundly affected by human groups from A.D. 1540 to the present. Overgrazing, clearcutting, irrigation farming, fire suppression, intensive hunting, and introduction of exotic plants have interacted with droughts and floods to bring about environmental and associated cultural changes. In response, public laws and agencies were created to mitigate or reverse various environmental problems. Restoration and remedial programs have somewhat improved some issues but most environmental problems persist.

[ENVIRONMENTAL MANAGEMENT; HISTORIC RECORDS; RIO GRANDE]

1526. (USDA) Soil Conservation Service and USDI Bureau of Land Management (1985): Little Lost River Flood Control Measure Plan and Environmental Impact Statement. Howe, Butte County, Idaho. $67 \mathrm{p}$.

The USDA Soil Conservation Service and other entities proposed to reduce winter flooding in and around the community of Howe, Idaho. Low winter flows in the winter freeze, blocking the channel. Subsequent flows are forced out of the channel onto 
surrounding crop land, causing flooding on $>1500$ acres. Five alternatives for addressing the flooding problem were evaluated. The proposed measure would divert low winter flows from the channel into an infiltration trench. The stream channel would remain free of ice, allowing normal passage of spring runoff. Approximately 10.5 miles of stream will be dewatered from about December to March. [FLOOD IMPACTS; HABITAT MANAGEMENT; RIPARIAN RESTORATION]

1527. Sedell,JR; Everest,FH; Gibbons,DR (1989): Streamside vegetation management for aquatic habitat. p.115-125. In: Proceedings of the national silviculture workshop: Silviculture for all resources. 11-14 May 1987. Sacramento, CA. USDA Forest Service.

The authors discuss three aspects of silvicultural management of Riparian Management Areas (RMAs); 1) effects of extended timber rotations or permissible rates of entry into RMAs; 2) organic debris standards; and 3) RMA width and shading requirements.

[RIPARIAN FOREST; RIPARIAN HABITAT; SHADING; WOODY DEBRIS]

1528. Sedell,JR; Froggatt,JL (1984): Importance of streamside forests to large rivers: The isolation of the Willamette River, Oregon, U.S.A., from its floodplain by snagging and streamside forest removal. For. Science Lab., USDA-Forest Service, Corvallis, OR. Verhandlungen der Internationalen Vereinigung fur Theoretische und Angenwandte Limnologie 22, 1828-1834.

This pristine riparian forest in western Oregon extended $1.5-3 \mathrm{~km}$ on either side of the river. The pristine river was a series of multiple channels, sloughs, and backwater areas. Historically, the floodplain and valley had extensive marshes. Numerous downed trees helped to create and maintain shoals, multiple channels, oxbow lakes, and complex aquatic habitats at the outside bends of the river. After 80 years of snag removal and riparian forest destruction, there now exists one channel, few downed trees, relatively simple and homogeneous habitat for aquatic vertebrates, and over a four-fold decrease in river shoreline. The few floodplain areas with extensive riparian forests along our major rivers must be treated as the last reserves of species and habitats approximating the condition of pristine rivers.

[HISTORIC RECORDS; RIPARIAN HABITAT; RIPARIAN VEGETATION]
1529. Sedgwick,JA; Knopf,FL (1987): Breeding bird response to cattle grazing of a cottonwood bottomland. Journal of Wildlife Management 51(1), 230-237.

Habitat use by migratory bird species utilizing the grass-herb-shrub layer of vegetation in a riparian community (South Platte River, Colorado) subjected to late fall, early winter cattle grazing. Breeding bird populations on ungrazed control plots and fall grazed plots (16 ha) were censused over a 10-day period in spring of 1982, 1984, and 1985. Ordination of six species on axes of forb cover and mid-level shrub density cover suggested different susceptibilities to grazing.

[AVIFAUNA; GRAZING IMPACTS; PLATTE

RIVER; RIPARIAN HABITAT]

1530. Sedgwick,JA; Knopf,FL (1990): Habitat relationships and nest site characteristics of cavity-nesting birds in cottonwood floodplains. Journal of Wildlife Management 54(1), 112-124.

Lack of regeneration of cottonwood, decline in the dead limb lengths, trees with more than $1 \mathrm{~m}$ length of dead limb ( $>10 \mathrm{~cm}$ diam.), and snag density along the South Platte River will probably result in the decline of cavity-nesting birds. Redheaded woodpeckers and American kestrels have the most particular cavity requirements for nesting. An aging overstory with a lower percentage of small trees and a lack of regeneration, resulting in lower small tree densities, could adversely affect chickadees. A mosaic of sites of differing age structures in cottonwood floodplains accommodates a greater variety of cavity-nesting species. [AVIFAUNA; BIODIVERSITY; RIPARIAN FOREST; RIPARIAN HABITAT]

1531. Sedgewick,JA; Knopf,FL (1991): Prescribed grazing as a secondary impact in a western riparian floodplain. Journal of Range Management 44(4), 369-373.

The effect of late autumn cattle grazing on plant biomass was examined in a western Great Plains cottonwood riparian zone prone to catastrophic flooding every $5-8$ years. Five 16 -ha pastures were grazed and compared to 5 control pastures within the South Platte River Floodplain in northeastern Colorado. At a prescribed grazing level of 0.46 ha/AUM, riparian vegetation proved to be resilient to the impacts of grazing. Willows responded negatively to grazing whereas biomass of prairie cordgrass was greater on grazed plots. Periodic, catastrophic flooding is a major perturbation to that ecosystem and dormant season grazing within 
prescribed guidelines is a comparatively minor impact within the floodplain. Grazing impacts were probably further mitigated by a major forage supplement of cottonwood leaves available at the time of cattle introductions. This forage supplement created a lighter grazing treatment than that originally prescribed.

[COTTONWOOD; FORAGE PRODUCTION; GRAZING IMPACTS; PRESCRIBED GRAZING; WILLOW]

1532. Sedgewick,JA; Knopf,FL (1992): Cavity turnover and equilibrium cavity densities in a cottonwood bottomland. Journal of Wildlife Management 56(3), 477-484.

A fundamental factor in regulating the numbers of secondary cavity nesting ( $\mathrm{SCN}$ ) birds is the number of extant cavities available for nesting. The number of available cavities may be thought of as being the in an approximate equilibrium maintained by a very rough balance between recruitment and loss of cavities. Based on estimates of recruitment and loss, cavity densities in a mature plains cottonwood bottomland along the South Platte River in northeastern Colorado were ascertained. Equilibrium cavity density along the South Platte River was estimated to be 238-289 cavities/100 ha. [AVIAN ECOLOGY; COTTONWOOD; PLATTE RIVER; RIPARIAN HABITAT]

1533. Sedgwick,JA; Leininger,WC (1991): Prescribed grazing as a secondary impact in a western riparian floodplain. Journal of Range Management 44(4), 369-373.

The effect of late autumn grazing on plant biomass was examined in a western Great Plains cottonwood riparian zone prone to catastrophic flooding every 5-8 years. At the prescribed level of $0.46 \mathrm{ha} / \mathrm{AUM}$, riparian grazing proved to be resilient to the impacts of grazing. Willows responded negatively to grazing whereas biomass of prairie cordgrass was greater on grazed plots. Periodic, catastrophic flooding is a major perturbation to the ecosystem and dormant season grazing within prescribed guidelines is a relatively minor impact within the floodplain. Grazing impacts were probably further mitigated by a major forage supplement of cottonwood leaves available at the time of cattle use. [COTTONWOOD; FLOOD IMPACTS; GRAZING IMPACTS; LIVESTOCK EFFECTS]

1534. Seery,D (1993): Riparian restoration projects in Arizona, Soil Conservation Service. p. 193-194. In: Tellman,B; Cortner,HJ;
Wallace,MG; DeBano,LF; Hamre,RH [tech. coord.|. Riparian management: Common threads and shared interests. USDA Forest Service. General Technical Report RM-226.

Five successful riparian restoration projects completed by the USDA Soil Conservation Service in Arizona were photographically displayed and discussed. All projects returned the functions and values that were lost back to the original ecosystems. [RIPARIAN RESTORATION]

1535. Sewards,MA; Valett,HM (1996): Effects of livestock grazing on nutrient retention in a headwater stream of the Rio Puerco Basin. p.135142. In: Shaw,DW; Finch,DM [tech. coord.]. Desired future conditions of Southwestern riparian ecosystems: Bringing interests and concerns together. USDA Forest Service. General Technical Report RM-GTR-272.

Sediment and nutrient loss from headwater streams of sedimentary basins in the semi-arid Southwest have been attributed to both over-grazing by livestock and to climatic cycles that influence arroyo formation. Considerable effort has been directed toward the influence of livestock grazing on riparian species abundance and diversity, Less work has concentrated on the influence of livestock on instream processes and communities. In contrast, considerable research has described the importance of floods as ecological organizers of riparian and benthic communities in lotic ecosystems. The focus on this project was the interaction of flooding and livestock grazing on hydrologic and nutrient retention in a headwater stream of the Rio Puerco Basin, New Mexico. Authors propose that grazing decreases retention of water, nutrients, and sediments by changing physical and biological features of the stream that cause the system to be less resistant to natural floods and by decreasing recovery rates when floods do occur. This project represents initial studies of differing nutrient and hydrologic environments created by cattle exclosures. Preliminary results indicate that benthic biomass and transient hydraulic storage are greater in reaches protected from cattle influences.

[BENTHIC BIOMASS; CLIMATE; GRAZING IMPACTS; HYDROLOGY; NUTRIENT CYCLES; SEDIMENTATION]

1536. Seyedbagheri,KA; McHenry,ML; Platts, WS (1987): An annotated bibliography of the hydrology and fisheries studies of the South Fork Salmon River. USDA Forest Service. General Technical Report INT-235. Ogden, UT. 
27 p.

A brief summary of the land management history of the South Fork Salmon River (Idaho) watershed that includes citations and annotations of published and unpublished reports of fishery and hydrology studies conducted in the drainage from 1960 to 1986.

[BIBLIOGRAPHY; FISHERIES; HYDROLOGY; RIPARIAN HABITAT]

1537. Seyhan,E; Hope,AS; Schulze,RE (1983):

Estimation of stream flow loss by evapotranspiration from a riparian zone. South African Journal of Science 79(3), 88-90.

Recession hydrographs from a small research catchment in South Africa exhibited diurnal fluctuations in streamflow which were superimposed on the general recession trend. The daily additional reduction in flow may be the result of greater evapotranspiration losses in the riparian zone during the day.

[EVAPOTRANSPIRATION; HYDROLOGY; STREAM FLOW]

1538. Shabman,L (1979): Mitigation planning under the principles and standards framework. p.196-202. In: Swanson,GA [ed.]. The mitigation symposium: A national workshop on mitigating losses of fish and wildlife habitats.

Recent water policy reforms stress improved economic and environmental assessment and stricter application of the Principles and Standards framework. While there are practical limits on the use of the assessment tools being developed, the result will be improved mitigation analysis and increased mitigation at federal projects. [IMPACT MITIGATION; POLICY; WATER QUALITY]

1539. Sharitz,RR; Lee,LC (1985): Limits on regeneration processes in southeastern riverine systems. p.139-143. In: Johnson,RR; Ziebell,CD; Patton,DR; Ffolliott,PF; Hamre,RH [tech. coord.]. Riparian ecosystems and their management: Reconciling conflicting uses. 16-18 April 1985. Tucson, AZ. USDA Forest Service. General Technical Report RM-120.

Principal factors affecting recruitment in cypress-tupelo forests were seed production, microsite availability, and hydrologic regime. Management of water levels on regulated streams must account for species regeneration requirements to maintain floodplain community structure. [RIPARIAN FOREST; RIPARIAN HABITAT]
1540. Sharitz,RR; Lee,LC (1985): Recovery processes in southeastern riverine wetlands. p.499501. In: Johnson,RR; Ziebell,CD; Patton,DR; Ffolliott,PF; Hamre, RH [tech. coord.]. Riparian ecosystems and their management: Reconciling conflicting uses. 16-18 April 1985. Tucson, AZ. USDA Forest Service. General Technical Report RM-120.

Perturbations to riverine wetlands often degrade existing communities or change the potential for wetland sites to support those communities.

Disturbances that are in scale with wetland ecosystems can lead to normal recovery processes. The greatest changes to wetlands occur when the magnitude of the disturbance exceeds or is asynchronous with natural environmental limits [ECOLOGICAL PERTURBATIONS; RIPARIAN RESTORATION; RIVER ECOLOGY; WETLANDS]

1541. Sharma,KD; Dhir,RP; Murthy,JSR (1992): Modeling suspended sediment flow in arid upland basins. Hydrological Sciences 37(5), 481-490.

A conceptual basin model of the instantaneous unit sediment graph was developed for sediment graph prediction from arid upland basins by routing mobilized sediments through a series of linear reservoirs. The mobilized sediment during a storm was related to effective precipitation and the parameters of the model were estimated from observed events.

[HYDROI.OGY; MODELING; SEDIMENTATION]

1542. Sharp,B (1987): Management guidelines for the willow flycatcher. USDI Fish and Wildlife Service. Portland, OR. 21 p.

The guidelines present existing information on the willow flycatcher (Empidonax trailii) and its regional status. They identify problems affecting the population, propose management considerations, and summarize management oriented information for affected and interested parties. Also presented are strategies to overcome or compensate for some of the identified problems.

[AVIAN ECOLOGY; AVIFAUNA; RIPARIAN HABITAT]

1543. Sharpe,WE (1975): Timber management influences on aquatic ecosystems and recommendations for future research. Water Resources Bulletin 11(3), 546-550.

Many timber management practices have profound effects on the water quality of small headwater streams. Such streams frequently support 
fisheries of high value. The status of current knowledge indicates that there are definite potentials for symbiotic relationships between timber and fisheries management. Future research efforts must recognize the mutually benefitting aspects of these heretofore separate disciplines and must carefully examine the complex interrelationships between aquatic ecosystems and the riparian forest environment. [FISHERIES; IOGGING IMPACTS; RIPARIAN FOREST; WATER QUALITY; WATERSHED]

1544. Shaw,DC; Bible,K (1996): An overview of forest canopy functions with reference to urban and riparian systems. Northwest Science 70, 1-6.

Functions of forest canopy ecosystems generally include photosynthesis; sexual reproduction of trees; light absorption, modification, and shading; atmospheric interaction; hydrologic interaction; and biodiversity. This paper reviews some of those functions and draws comparisons from two specialized systems, the urban and the riparian. Urban forest canopies abate noise, ameliorate urban temperature increases, conserve energy by shading buildings, and capture particulate matter, pollutants, and carbon dioxide, which make cities more habitable for humans. Riparian and wetland forest canopies affect temperature and primary production of aquatic habitat by shading, influence productivity by controlling allochthonous inputs, including coarse woody debris, and provide unique habitat for wildlife and other biota.

[CANOPY; RIPARIAN FOREST; RIPARIAN HABITAT]

1545. Shaw,DW; Finch,DM [Eds.] (1996): Desired future conditions for Southwestern riparian ecosystems: Bringing interests and concerns together. USDA Forest Service. General Technical Report RM-GTR-272. 359 p.

This proceedings represents scientific and applied papers presented at a symposium of the same title held 18-22 September 1995 at the Four Seasons Hotel in Albuquerque, New Mexico. The symposium brought together scientists, natural resource managers, conservationists, and representatives from the private sector to share their findings, ideas, and visions for managing, conserving, and restoring riparian ecosystems in the Southwest. [DESIRED FUIURE CONDITIONS; RIPARIAN HABITAT; RIPARIAN RESTORATION]

1546. Shaw,NL; Clary,WP (1996): Willow establishment in relation to cattle grazing on an eastern Oregon stream. p.148-153. In: Shaw,DW; Finch,DM [tech. coord.]. Desired future conditions for Southwestern riparian ecosystems: Bringing interests and concerns together. USDA Forest Service. General Technical Report RM-GTR-272.

Natural establishment and growth of coyote willow and whiplash willow were monitored from 1987 to 1993 on a low elevation eastern Oregon stream degraded by more than a century of heavy livestock grazing. Treatments were no grazing, moderate spring grazing, moderate fall grazing, and continued, heavy, season long grazing by cattle. Fresh sediments deposited by a May 1987 flood provided moist, open seedbed conditions for willow recruitment from off-site seed sources. Initial establishment of coyote willow was limited, but density increased through 1990 with some fluctuation thereafter. Over the 7-year period, density was greatest in pastures grazed moderately in spring and least in pastures grazed moderately in fall or heavily season long. By contrast, large numbers of whiplash willows established in 1987, but densities declined through 1990 and remained stable thereafter. Densitics were greater in ungrazed or moderately grazed pastures compared to those grazed season long. Height of both willow species generally increased over time in all pastures and was greater in ungrazed or moderately grazed pastures compared to those grazed season long. Browsing by deer each summer substantially reduced willow growth in all pastures, possibly masking treatment differences. Few willows have grown beyond browsing height to increase site stability and begin providing on-site seed sources.

[BROWSING EFFECTS; GRAZING IMPACTS; RIPARIAN HABITAT; WILLOW]

1547. Shaw,SP; Crissey,WF (1955): Wetlands and the management of waterfowl. p.604-614. In: Water: The yearbook of agriculture. 84th Congress. House Document No. 32.

During the preceding one or two decades, the accepted method of encouraging necessary conservation measures had been the use of incentive payments to private landowners. Since the use of public funds for such purposes is in the long-term public interest, there should be little opposition to the use of public monies to benefit the waterfowl resource. Land use planners should have public support to preserve and improve wetlands on private lands, especially if they can assure the availability of technical and financial assistance.

[PLANNING; RIPARIAN HABITAT; WATERFOWL MANAGEMENT; WETLANDS] 
1548. Sheeter,GR; Claire,EW (1981): Use of juniper trees to stabilize eroding streambanks on the South Fork John Day River. USDI Bureau of Land Management. Oregon State Office.

Technical Note OR-1.

Cut juniper trees anchored along eroded banks proved beneficial in stabilizing them, often during the first year. Juniper revetment was a successful substitute for costly rock structures on straight or slightly curved banks. Failures, associated with improper anchoring and placement of trees on outside curves, occurred on only 4 percent of the treated banks.

[EROSION CONTROL; RIPARIAN RESTORATION; STREAMBANK STABILITY]

1549. Sheeter,G; Svejcar,T (1997): Streamside vegetation regrowth after clipping. Rangelands 19(1), 30-31.

This study was designed to quantify the amount of regrowth occurring on a stream associated riparian zone in southeastern Oregon following defoliation. There was very little regrowth of the riparian community when clipping occurred after mid-July. Managers should be cautious in their assumptions about regrowth in riparian areas. Most have assumed that because riparian areas are relatively wet, they will regrow vigorously. This study suggested that significant regrowth after mid-summer would not be expected.

[GRAZING IMPACTS; RIPARIAN VEGETATION]

1550. Sheley,RL; Mullin,BH; Fay,PK (1995): Managing riparian weeds. Rangelands 17(5), 154157.

Riparian areas should be protected from invasion by noxious weeds because of the extreme natural values of these sites. Invasive weed species, such as purple loosestrife, can be hyper-competitive in a riparian setting, crowding out native species. Studies have shown that weeds often do not stabilize soils as well as native vegetation, which can lead to soil erosion and degradation of the stream channel. Managing weeds in riparian zones is difficult and requires an integrated, well planncd, and coordinated strategy based on the way an area is used. Riparian weed management includes the integration of control methods to prevent weed introductions, detection and eradication of existing infestations, the proper management of livestock, and revegetation. [EXOTICS; RIPARIAN HABITAT]

1551. Shelton, ML (1998): Modeled runoff and climate change for a central Oregon rangeland watershed. p. 375-384. In: Potts, DF [ed.]. Rangeland management and water resources: Proceedings of the AWRA specialty conference. American Water Resources Association. 27-29 May 1998. Reno, NV.

Future runoff in the Upper Crooked River Basin in central Oregon is modeled assuming current land use and grazing practices and using a previously developed hydro-climatic model calibrated for present day watershed conditions. Greatest monthly changes in water availability to plants were due to increases in evapotranspiration. The sensitivity of the rangeland watershed to evapotranspiration was attributable to the cool season concentration of rainfall and evapotranspiration increases in all months that magnify moisture deficiency and drought in the summer. Modeled future hydroclimate indicates that mitigation will be needed for adverse impacts on water diversion practices and water allocation strategies in the watershed. [FVAPOTRANSPIRATION; MODFI.ING; PRECIPITATION; RUNOFF; WATERSHED]

1552. Shepard,BB (1989): Evaluation of the U.S. Forest Service "COWFISH" model for assessing livestock impacts on fisheries in the Beaverhead National Forest, Montana. p.22-33. In: Gresswell,RE; Barton,BA; Kershner,JL [eds.]. Riparian resource management: An educational workshop. USDI Bureau of Land Management. Billings, MT.

The 'COWFISH' model is useful for increasing awareness of the effects of livestock grazing on aquatic resources but does not replace the need for physically sampling fish populations in streams impacted by livestock grazing. [COWFISH MODEL; FISHERIES; GRAZING IMPACTS; MODELING]

1553. Shinn,DA (1976): Land use habits and changes in vegetation on eastern Oregon rangelands: An historic perspective. p.1135-1141. In: Proceedings of the first conference on scientific research in the National Parks. 9-12 November 1976. USDI National Park Service Transactions and Procedures Series No. 5.

Ecological and historical data concerning wildlife populations, changing vegetation and livestock grazing were coordinated with ecological, historical, and anthropological data concerning fire and man. This combination is an integrated research program called "historical ecology". The best projected application of this approach is in restorative 
management.

[HISTORIC RECORDS; LAND USE;

RANGELAND HEALTH; RIPARIAN HABITAT]

1554. Short,HL (1985): Management goals and habitat structure. p.257-262. In: Johnson,RR; Ziebell,CD; Patton,DR; Ffolliott,PF; Hamre,RH [tech. coord.]. Riparian ecosystems and their management: Reconciling conflicting uses. 16-18 April 1985. Tucson, AZ. USDA Forest Service. General Technical Report RM-120.

Management goals for riparian habitats can be developed that dictate different management policies, strategies, and tactics and result in different impacts on wildlife. Habitat structure expressed as habitat layers can provide a framework for developing effective strategies for achieving goals because many different land uses can be associated with habitat layers. Realistic goals are essential for both management and monitoring.

[RIPARIAN HABITAT; RIPARIAN MANAGEMENT ZONE]

1555. Shroeder,RL; Allen,AW (1992): Assessment of habitat of wildlife communities on the Snake River, Jackson, Wyoming. USDI - USDI Fish and Wildlife Service. Resource Publication 190.

The composition of wildlife communities in western riparian habitats is influenced by the horizontal and vertical distribution of vegetation, the physical complexity of the channel, and barriers to movement along the corridor. Based on existing information, a model was developed to evaluate wildlife communities along the Snake River. The model, which compares new information to pre-1956 conditions (before levees were constructed), may be applied with remotely sensed data and is compatible with GIS analysis. The model evaluates floodplain and channel complexity and assesses anthropogenic disturbance and its potential effect on the quality of wildlife habitat and movement in the riparian corridor.

[GIS; MODELING; RIPARIAN HABITAT]

1556. Shwien,J (1991): A pitch for Badger Creek. Rangelands 13(4), 181-182.

Best management practices are being implemented on the Stirrup Ranch near Canon City, Colorado. State of Colorado, USDA Forest Service, USDI Bureau of Land Management, and the Sangre de Cristo RC \& D are cost-sharing the improvements. The project will cut erosion and sediment in Upper Badger Creek by half within three years.
[BEST MANAGEMENT PRACTICES; GRAZING

IMPACTS; RIPARIAN; WATER QUALITY]

1557. Sidle, RC (1990): Overview of cumulative effects concepts and issues. p.103-107. In: Forestry on the frontier; Proceedings of the 1989 American Foresters annual convention. Bethesda, MD.

Human activities within a watershed and natural processes interact in a cumulative way to affect downstream water quality, particularly as they effect the rates of erosion and sediment transport. Major emphasis of this paper was on water quality, nutrient cycling, and chemical transport.

[CUMULATIVE IMPACTS; HYDROLOGY; SEDIMENT TRANSPORT; WATER QUALITY; WATERSHED]

1558. Sidle,RC (1990): Cumulative effects of forest practices on erosion and sedimentation. $p$. 108-112. In: Forestry on the frontier; Proceedings of the 1989 American Foresters annual convention. Bethesda, MD.

Various logging activities can accelerate the rates of sediment transport and erosion. Multiple human activities may occur within a forested drainage basin. Land managers are being asked to mitigate and predict the cumulative effects of these land uses distributed over the scale of a watershed and over long periods. The cumulative effects of multiple uses of forest lands and the interaction with natural processes present complex problems for managers.

[COMPACTION; CUMULATIVE IMPACTS; EROSION; HYDROLOGY; IOGGING IMPACTS; SEDIMENT TRANSPORT]

1559. Sidle,RC; Amacher,MC (1990): Effects of mining, grazing and roads on sediment and water chemistry in Birch Creek, Nevada. p.463-472. In: Watershed planning and analysis in action, Symposium. Proceedings of American Society of Civil Engineers. 9-11 July 1990. Durango, CO.

Assessment of the cumulative effects of mining and other land uses on water quality of Birch Creek showed that mine dumps and roads increased fine sediment deposits in some reaches. Fine sediments were trapped by woody debris. Grazing appeared to have more adverse impacts on water chemistry than did mining activities.

[CUMULATIVE IMPACTS; GRAZING IMPACTS; SEDIMENT TRANSPORT; WATER QUALITY; WOODY DEBRIS]

1560. Sidle, RC; Hornbeck,JW (1991): 
Cumulative effects: A broader approach to water quality research. Journal of Soil and Water Conservation 46(4), 268-271.

Research on cumulative watershed effects requires significant departures from traditional procedures/approaches. Research questions are usually divided into their component parts with each part being intensively studied by its respective disciplines. The cumulative effects approach requires a look at ecological changes in the broadest context over varying scales of time and space. The issue demands the continuing participation of many disciplines and enhanced interaction and cooperation among those participants.

[CUMULATIVE IMPACTS; MONITORING; RIPARIAN ECOLOGY; SPATIAL SCALE; WATER QUALITY; WATERSHED]

1561. Siekert,RE; Skinner,QD; Smith,MA; Dodd,JL; Rodgers,JD (1985): Channel response of an ephemeral stream in Wyoming to selected grazing treatments. p. 276-278. In: Johnson, RR; Ziebell, CD; Patton,DR; Ffolliott,PF; Hamre,RH [tech. coord.]. Riparian ecosystems and their management: Reconciling conflicting uses. 16-18 April 1985. Tucson, AZ. USDA Forest Service. General Technical Report RM-120.

The effects of seasonal grazing on ephemeral stream morphology were studied. Results indicated that spring grazing has no significant impact on stream morphology. Summer and fall grazing was associated with increases in channel cross-sectional area. These impacts were mitigated or exacerbated by climatic differences. Seasonal grazing was seen as a potential management tool for promoting channel stability. [EPHEMERAL STREAMS; GRAZING IMPACTS; GRA7ING TRF.ATMENTS; STREAM ECOLOGY]

1562. Siekert,RE; Smith,MA; Rodgers,JD; Dodd,JL; Skinner,QD (1987): Change in stream channel morphology with grazing of an ephemeral stream in Wyoming. Abstracts. 40th annual meeting, Society for Range Management. [CHANNEL MORPHOLOGY; GRAZING IMPACTS]

1563. Silverman,AJ; Tomlinson,WD (1984): Biohydrology of mountain fluvial systems: the Yellowstone, Parts I and II. Montana Water Resources Resources Center Completion Report 147. December 1984. $91 \mathrm{p}$.

This is a compilation of research performed on the Yellowstone River. The report text consists of nine chapters pertaining to: 1) general riparian zone properties, form, and function; 2) geology and geomorphology of the river; 3 ) history of cultural activity and resources; $4 \& 5$ ) riparian vegetation and wildlife; 6 ) the river's fisheries; 7) river-based recreational use and trends; 8 ) threats to the Yellowstone River and its riparian zone; and 9) riparian protective or mitigative measures. [FISHERIES; GEOMORPHOLOGY; RIPARIAN HABITAT; RIPARIAN VEGETATION; YELLOWSTONE RIVER]

1564. Silvey,HL (1993): Accommodating issues of scale. p.275. In: Tellman, B; Cortner,HJ; Wallace,MG; Ffolliott,PF; Hamre,RH [tech. coord.]. Riparian management: Common threads and shared interests. USDA Forest Service. General Technical Report RM-226.

The condition or integrity of the land area located adjacent to, or upstream of a particular riparian area of concern becomes as equally important to riparian health and welfare as does the condition of the riparian area itself. Impact magnitude may have widely different rankings in terms of scale but be of equal importance to individual resource users.

[HYDROLOGY; RIPARIAN MANAGEMENT ZONE; SPATIAL SCALE]

1565. Simcox,DE; Zube,EH (1985): Arizona riparian areas: A bibliography. School of Renewable Natural Resources. University of Arizona, Tucson, AZ. 38 p. [EVALUATION; RESEARCH; RIPARIAN HABITAT; TECHNIQUES]

1566. Simons,DB (1975): The geomorphic and hydraulic response of rivers. p.209-219. In: Transactions of the Wildlife Management Institute; 40th North American wildlife and natural resources conference. March 1975. Pittsburg, PA.

Increasing interest in conserving and improving our environment has identified a need for methods to predict river response due to various changes resulting from water resource planning. River response is an unsteady phenomenon in nature. For the study of transient phenomena in natural alluvial channels, the equations of motion and continuity can be used. Understanding the physical process governing river response is the first step toward successful water resources utilization and management. [HYDROLOGY; MONITORING; WATER 


\section{RESOURCE MANAGEMENT]}

1567. Simons,DB; Ruh-Ming,L (1982): Bank erosion on regulated rivers. p. 717-747. In: Gravel bed rivers. [Eds: Hey,RD; Bathurst,JC; Thorne,CR|. John Wiley and Sons, Ltd. New York, NY.

Bank erosion and channel instability result from a wide variety of processes and causes. The factors and forces that control the processes of erosion and deposition are discussed in this chapter. A semiquantitative method for ranking the processes of bank erosion is presented. The different erosion processes may be grouped into two divisions: those related to pool level fluctuations behind hydropower dams and those related to natural fluvial erosion during major floods. The former tend to operate at the water surface and produce a berm and set back vertical bank. The latter operate over the whole bank but are concentrated at depth. They cause retreat of the whole bank profile and tend to destroy the berm. It is concluded that retreat due to pool level fluctuations alone will be limited to a narrow zone only $3-5 \mathrm{~m}$ wide and that natural fluvial erosion is in fact responsible for serious bank erosion and lateral shifting of the channel.

[CHANNEL DYNAMICS; CHANNEL MORPHOLOGY; STREAMBANK PROTECTION]

1568. Simons, LH (1985): Small mammal community structure in old growth and logged riparian habitat. p.505-506. Johnson, RR; Ziebell,CD; Patton,DR; Ffolliott,PF; Hamre,RH [tech. coord.]. Riparian ecosystems and their management: Reconciling conflicting uses. 16-18 April 1985. Tucson, AZ. USDA Forest Service. General Technical Report RM-120.

Small mammal populations in old growth and logged riparian habitat were measured for species richness and evenness. Six species occurred in both habitats but the red-backed vole was present only in old growth. Similarities in understory vegetation and proximity of old growth to logged areas may promote similar small mammal populations.

[LOGGING IMPACTS; RIPARIAN HABITAT; SMALL MAMMAIS]

1569. Sims,B; Piatt,J; Johnson,L; Purchase, $C$; Phillips,J (1996): Channel bed particle size distribution procedure used to evaluate watershed cumulative effects for range permit re-issuance on the Santa Fe National Forest. p.318-326. In: Shaw,DW; Finch,DM [tech coord.]. Desired future conditions for Southwestern riparian ecosystems:
Bringing interests and concerns together. USDA Forest Service. General Technical Report RMGTR-272.

Personnel on the Santa Fe National Forest used methodologies adapted from Bevenger and Kin (1995) to collect baseline particle size data on streams within grazing allotments currently scheduled for permit re-issuance. This information was used to determine the relative current health of the watersheds as well as being used in the development of potential alternatives to current grazing practices, where deemed necessary. [GRAZING IMPACTS; PARTICLE SIZE; WATERSHED]

1570. Sims,BD; Johnson,LD (1985): Structural anadromous fishery habitat improvement on the Siskiyou National Forest. p. 502-504. In: Johnson,RR; Ziebell,CD; Patton,DR; Ffolliott,PF; Hamre, RH [tech. coord.]. Riparian ecosystems and their management: Reconciling conflicting uses. 16-18 April 1985. Tucson, AZ. USDA Forest Service. General Technical Report RM-120.

Three strategies for allowing fish passage through culverts were described: 1) construction of stepped log weirs to raise the pool level at the outlet; 2) retrofitting circular culverts with a baffle system; and 3) use of an open-bottomed arch-type culvert. Additionally, $\log$ and gabion structures were used to create pool habitat. All structures survived several seasons and were proved effective. [FISHERIES; RIPARIAN HABITAT; RIPARIAN RESTORATION; RIPARIAN STRUCTURES]

1571. Singer,FJ; Mark,LC; Cates,RC (1994): Ungulate herbivory of willows on Yellowstone's northern winter range. Journal of Range Management 47(6), 435-443.

Effects of large unmanaged populations of large, mammalian herbivores on vegetation, especially elk, is a concern in Yellowstone National Park. The issue is amplified by the extirpation of wolves from the region, the alterations of ungulate migrations by human activities, and other disruptions of the natural process. Stands of low, hedged (height-suppressed) willows are observed throughout the greater Yellowstone National Park where high densities of wintering elk or moose exist. The height of 47 percent of the willow stands surveyed on Yellowstone's northern winter range has been suppressed. Tall and intermediate height willows contained higher concentrations of nitrogen and they exhibited more water stress than height-suppressed willows. The authors suggest that a more xeric 
climate and locally reduced water tables likely contributed to the willow declines on the northern winter range, but that the proximate factor in the declines was herbivory by native ungulates.

[ELK GRAZING; GRAZING IMPACTS; NATIVE UNGULATES; WATER STRESS; WILLOW; YELLOWSTONE NATIONAL PARK]

1572. Sinning,JA; Andrew,JW (1979): Habitat enhancement for Colorado squawfish in the Yampa River in conjunction with railroad construction. p.553-555. In: Swanson,GA [ed.]. The mitigation symposium: A national workshop on mitigating losses of fish and wildlife habitat. USDA Forest Service. General Technical Report RM-65.

Impact assessments for the Colowyo Coal Company's Yampa River railroad spur determined that no adverse effect to the Colorado squawfish would result from construction and adverse effect was only a remote possibility resulting from operation. The company and its consultants decided to construct additional backwater habitat suitable for rearing Colorado squawfish in two locations during railroad construction as a habitat enhancement feature. The authors discuss design criteria for the backwaters, applications, and some problems. [BACKWATERS; COLORADO SQUAWFISH; RIPARIAN HABITAT]

1573. Skinner,QD (1998): Stubble height and function of riparian communities. p.29-46. In: Stubble height and utilization measures: Uses and misuses. Oregon State University. Corvallis, $O R$. Agricultural Experiment Station Bulletin 682.

Stubble height is discussed as it influences attributes of channels and floodplains, sediment deposition, plant vigor, physical stability of riparian zones, and use of woody plant species. Sediment deposition from growing vegetation may change water relationships of plants along banks over time and channel succession. As channel banks build, plant species composition of the near-bank riparian zone may also change. Plants that require high water tables most of the growing season may be at a disadvantage in competing with plants that can withstand rapid declines. In mature channel systems, the latter may become dominant. Stubble height required to maintain plant vigor may also decrease when plant succession occurs. Higher stubble heights of all plants may be required to maintain channel bank integrity and to reduce grazing of other desired woody species.

[GRAZING IMPACTS; LIVESTOCK EFFECTS;
RIPARIAN MANAGEMENT ZONE; RIPARIAN SHRUBS; STUBBLE HEIGHT; UTILIZATION]

1574. Skinner,QD; Adams,JC; Hussey,MR (1984): Distribution of denitrifying and sulfate reducing bacteria within a riparian zone along a mountain stream. USDI Geological Survey Water Resources Division. Reston, VA. Report No. USGS/G-879-07. $22 \mathrm{p}$.

The presence or absence of denitrifying bacteria as well as bacteria capable of reducing sulfate in soils of a mountain watershed were studied. Bacteria were enumerated from soil samples collected during summer along transects placed perpendicular to stream flow. Samples were taken at 3 depths. Higher counts of total heterotrophic aerobic bacteria, denitrifying bacteria and denitrification potential existed in the upper 5 to $15 \mathrm{~cm}$ of soil than at $30 \mathrm{~cm}$. Soils located close to the stream edge tended to have more bacterial activity than those farther from the stream indicating that these soils may be important sites for sulfate and nitrate reduction. Soil organic matter and water content decreased with depth at all communities, and those closer to the stream contained more organic matter and water than those further from the stream.

[MICROBIOLOGY; RIPARIAN HABITAT; SOILS]

1575. Skinner,QD; Smith,MA; Dodd,JL; Rodgers,JD (1985): Reclamation of riparian zones and water law: first in time -- first in right. p. 374 - 378. In: Johnson,RR; Ziebell,CD; Patton, DR; Ffolliott,PF; Hamre, RH |tech. coord.|. Riparian ecosystems and their management: Reconciling conflicting uses. 16-18 April 1985. USDA Forest Service. General Technical Report RM-120.

This paper describes research designed to reclaim a degraded desert steppe stream and riparian zones in Wyoming. Use of trash collectors, willows, and beaver dams to trap sediment, and stabilize bedload for creating additional water storage is also discussed. Management in terms of user rights considering multiple users is addressed. [RIPARIAN RESTORATION; WATER LAW; WATER RIGHTS]

1576. Skinner,QD; Smith,MA; Dodd,JL; Rodgers,JD; Siekert,RE (1986): The effects of selected grazing treatment on channel morphology and sediment within the riparian zone of Fifteen Mile Creek. Abstracts. 39th annual meeting, Society for Range Management. [CHANNEL MORPHOLOGY; GRAZING 
TREATMENTS; LIVESTOCK EFFECTS]

1577. Skinner,QD; Speck,JE; Smith,M; Adams,JC (1984): Stream water quality as influenced by beaver within grazing systems in Wyoming. Journal of Range Management 37(2), 142-146.

Stream water flowing from watersheds subjected to continuous and deferred rotation grazing by livestock was sampled to enumerate bacteria for detecting differences between grazing treatments and streams. Fecal coliforms, fecal streptococci, total counts at 20 degrees $C$, and bacteria capable of fluorescing under long wave radiation were selected as indicators of pollution. Bacteria counts for different indicator groups varied in their ability to detect change between grazing treatments as well as between streams. Fluorescing bacteria and total counts were of little value in explaining non-point source pollution whereas fecal coliform and streptococci were. Variation in counts of fecal coliform and streptococci could not be fully accounted for by differences in grazing management but is partially explained by beaver damming of stream flow. Given that beaver impoundment of selected stream reaches is equal, variation in nonpoint pollution may be caused by grazing treatment differences alone.

[BEAVER; COLIFORM BACTERIA; GRAZING IMPACTS; GRAZING TREATMENTS; NONPOINT SOURCE POLLUTION; WATER QUALITY]

1578. Skinner,QD; Wesche,TA; Smith,MA; Dodd,JD (1988): Restoring/creating cold desert riparian zones. Muddy Creek, Wyoming: A case study. p. 173-178. In: Stuber,PJ [tech. coord.]. Proceedings of the national symposium on protection of wetlands from agricultural impacts. 25-29 April 1988. Ft. Collins, CO. USDI Fish and Wildlife Service. Biological Report 88(16).

The Muddy Creek study evaluates riparian zone response to cost efficient restoration processes using instream structures and diversions. Sediment storage, vegetation production, salt storage in sediment, and groundwater were measured to determine worth of the resturation process. Preliminary results indicate that riparian zones help abate non-point pollution and that their economic value depends on who is using them and for what purpose.

[COLD DESERT SHRUBS; NON-POINT SOURCE POLLUTION; RIPARIAN MANAGEMENT ZONE; RIPARIAN RESTORATION]
1579. Skovlin,JM (1984): Impacts of grazing on wetlands and riparian habitat: A review of our knowledge. p.1001-1103. In: Developing strategies for rangeland management. National Research Council/National Academy of Sciences. Boulder, CO. Westview Press.

This paper reviews impacts on wetland and riparian habitats throughout western North America. It identifies problems, discusses values and functions, and synthesizes study findings. Major topics are the effects of livestock grazing on vegetation, watershed, and fish and wildlife. Specific subjects cover responses of (1) trees, shrubs, and herbaceous plants, (2) water quality, streambank stability, and features of upland erosion, and (3) large and small mammals, birds, and invertebrate organisms. Grazing strategies to improve habitats are proposed for better decisions in allocating riparian zone uses.

[GRAZING IMPACTS; RIPARIAN HABITAT]

1580. Skovlin,JM; Meehan,WR; Buckhouse,JC; Vavra,M (1977): Determining the influence of grazing on riparian and aquatic habitats in the Blue Mountains of northeastern Oregon. p.164169. In: Proceedings of the workshop on livestock and wildlife-fisheries relationships in the Great Basin. 3-5 May 1977. Sparks, NV. Spec. Publ. 3301; University of California. Berkeley, CA.

The objective of a study to assess the effects of streamside cattle grazing and browsing on the terrestrial and aquatic systems are delineated, study procedures are outlined, and preliminary results of the first year in a five-year integrated pilot study are discussed. The study site was well suited for experiments on the effects of grazing methods on the riparian herbage and shrubs, water quality, fisheries, soils, and cattle production.

[GRAZING IMPACTS; RIPARIAN HABITAT]

1581. Slaughter,CW; Aldrich,JW [comp.] (1989):

Annotated bibliography of soil crosion and erosion control in sub-arctic and high-latitude regions of North America. USDA Forest Service. General Technical Report PNW-GTR-253. Portland, OR. 234 p.

The emphasis of this document is on the physical processes of upland soil erosion, prediction of soil erosion and sediment yield, and erosion control. The bibliography is divided into two sections: (1) references specific to Alaska, the Arctic and subarctic, and similar high-latitude settings; and (2) references relevant to understanding erosion, sediment production, and erosion control. Most of the cited works were published prior to 1981 . 
[BIBLIOGRAPHY; EROSION; HYDROLOGY]

1582. Smelser,MG; Schmidt,JC (1998): An assessment methodology for determining historical changes in mountain streams. USDA Forest Service. General Technical Report RMRSGTR-6. 29 p.

The methodology facilitates the collection/organization of historical records and describes how to organize the data on computer spreadsheets. Further, six techniques are described to quantify the spatial and temporal magnitude of historic channel adjustments. Information thus derived can be used by managers to gage the implications of resource development, and restoration for montane riparian systems. [ASSESSMENTS; HISTORIC RECORDS; MONITORING]

1583. Smirnow, E (1988): Water resources analyses: Flow category analysis for flow duration curves. Unpublished report prepared for USDA Forest Service. Uncompahgre and Gunnison National Forests. Delta, CO.

A report that discusses a method to facilitate the development of flow category analysis and flow duration data for streams having unstable channels and/or considerable daily range in stage during spring runoff. It is intended to provide investigators with a tool to expedite and refine generation of flow duration curves/tables, flow regime frequencies, and sediment yields.

[HYDROLOGY; RUNOFF; STREAM FLOW]

1584. Smith,B; Prichard,D (1992): Riparian area management: Management techniques in riparian areas. USDI Bureau of Land Management.

Technical Reference 1737-6. $44 \mathrm{p}$.

Large numbers of techniques have been developed to assist in managing riparian areas. These management treatments and techniques can be as varied as the multiple uses that occur within riparian zones. The application in this document focuses on riparian areas but some can be applied to other forms of wetlands. The following management techniques and their associated concepts are described: fencing, prescribed burns, forestry practices, vegetation plantings, opportunities from mineral activities, structures, beaver, bank stabilization, recreation planning, and road construction and maintenance. [BEAVER; RIPARIAN HABITAT; RIPARIAN MANAGEMENT ZONE; VEGETATION MANIPULATION; WETLANDS]
1585. Smith,BH (1977): Recent findings on the condition of aquatic habitat on national resource lands and its potential for future management within the concept of multiple use. p.7. In: Proceedings of the 12th annual meeting. Colorado-Wyoming Chapter. American Fisheries Society. 2-3 March 1977. Cheyenne, WY. A major role of BLM biologists is in the environmental analysis process, identifying and attempting to mitigate the numerous impacts to wildlife habitats that multiple use activities incur. But how long or how far can habitat be mitigated? Reduction of impacts on sequential actions still produces a cumulative effect that reduces the quantity and quality of habitat.

[CUMULATIVE IMPACTS; MULTIPLE USE; RIPARIAN HABITAT]

1586. Smith, BH (1980): Not all beavers are bad; or, an ecosystem approach to stream habitat management, with possible software applications. p.6. In: Proceedings of the 15th annual meeting. Colorado-Wyoming Chapter. American Fisheries Society. 27-28 February 1980. Ft. Collins, CO. Pilot studies in the Rock Springs District, Wyoming, have indicated the establishment of stream habitat improvements can be achieved through a "software" approach of providing environmental limiting factors for beaver, i.e., necessary material and food supplies. When applied within a multi-use management framework, this approach could prove to be highly compatible with other programs (e.g. aspen thinning to stimulate browse regeneration). [BEAVER; ECOSYSTEM MANAGEMENT; RIPARIAN HABITAT; RIPARIAN RESTORATION]

1587. Smith,BH (1980): Riparian willow management: Its problems and potentials, within the scope of multiple use on public lands. p. 15-20. In: Proceedings of the ninth Wyoming shrub ecology workshop. 5-6 June 1980. Lander, WY. [MULTIPLE USE; RIPARIAN HABITAT; WILLOW]

1588. Smith,BH (1981): The ecosystem approach to stream habitat management. p. 5. In:

Proceedings of the Rocky Mountain regional soil, water, and air workshop. 2-6 Fcbruary 1981. Jackson Hole, WY.

With increasing awareness of the value and importance of stream and riparian ecosystems, it is necessary to achieve a more effective interdisciplinary approach toward total watershed 
management. The numerous impacts and problems presently experienced by stream ecosystems are indicators of greater soil or water resource problems associated with the management of public lands. As habitat values are reduced for the aquatic ecosystem, resource productivity is also reduced for all programs. Effective application of "ecosystem engineering" principles can result in improvements in aquatic habitat and in improved watershed management for all resources.

[ECOSYSTEM MANAGEMENT; RIPARIAN HABITAT]

1589. Smith,BH (1982): Livestock-riparianfisheries interrelationships; or, functional applications of adaptation for personal survival. p.4. Proceedings of the 17 th annual meeting. Colorado-Wyoming Chapter. American Fisheries Society. 3-4 March 1982. Ft. Collins, CO. [FISHERIES; GRAZING IMPACTS]

1590. Smith,BH (1983): Restoration of riparian habitats within the BLM's Rock Springs District. p.8. In: Wildlife habitat rehabilitation and reclamation. Proceedings of the symposium by Native Plants, Inc. 10-11 January 1983. Salt Lake City, UT.

A summary of riparian rehabilitation programs currently underway in the Rock Springs District (Wyoming) is presented. Initially focused on stream habitat improvement to enhance survival of $\mathrm{T} \& \mathrm{E}$ species, the principles of these programs are now receiving broader multiple use applications. Present riparian improvement efforts are testing the utilization of both special beaver and livestock management relationships in restoring degraded habitats.

[AQUATIC ECOSYSTEMS; RIPARIAN RESTORATION]

1591. Smith,BH; Dunder,JD (1984): Bone Draw: Riparian rehabilitation for development of a seasonal sport fishery. p.9. In: Proceedings of the American Fisheries Society/Wildlife Society joint chapter meeting. 8-10 February 1984. Logan, UT. [FISHERIES; RIPARIAN RESTORATION]

1592. Smith,BN; Lytle,CM; Hansen,LD; Lipp,J; Ziegler,H (1992): Respiration and growth in seedlings of cold desert shrubs. p.190-193. In: Clary,WP; McArthur,ED; Bedunah,D; Wambolt,CL [comp.|. Proceedings - Symposium on ecology and management of riparian shrub communities. USDA Forest Service. General
Technical Report INT-289.

Plants from geographic races (subspecies) of four species of cold desert shrubs (Artemisia tridentata, Atriplex canescans, Chrysothamnus nauseosus, and Kochia prostata) were grown from seed in the greenhouse. After four months, the seedlings were compared for shoot and root growth. No correlation between growth and carbon and hydrogen isotopic values was found. However, a strong correlation was found between growth and plant respiration.

[COLD DESERT SHRUBS; RIPARIAN

RESTORATION; SEED PRODUCTION]

1593. Smith,CM (1992): Riparian afforestation effects on water yield and water quality in pasture catchments. Journal of Environmental Quality 21, 237-245.

Flow records for two pasture catchments for nine years before and nine years after riparian afforestation were compared. Mean precipitation was $1021 \mathrm{~mm} /$ year. Riparian afforestation reduced water yields $21-55$ percent when the pine stand was 8 to 10 years old. Delayed runoff declined 27-63 percent. Afforestation reduced the quick flow yield in one year by 40 percent. Peak flows declined in small events, were not affected in medium-sized events, and may have increased in large events.

Consequences of riparian afforestation may not be readily predicted from the impacts of complete afforestation.

[RIPARIAN FOREST; RUNOFF; WATER QUALITY; WATER YIELD]

1594. Smith,DG (1976): Effect of vegetation on lateral migration of anastomosed channels of a glacier meltwater river. Geological Society of America Bulletin 87, 857-860.

This paper describes a series of experiments performed on bank materials of anastomosed channels in floodplain silt deposits to determine the effect of vegetation roots on bank erodibility and lateral migration of channels. In cool environments with aggrading river conditions, where overbank deposition of silt, clay, and fine sand dominate the valley fill, vegetation roots are able to rapidly accumulate and decay very slowly, thereby affording protection to banks from erosion in deeper parts of the channels.

[GEOMORPHOLOGY; RIPARIAN VEGETATION; SOILS; STREAMBANK STABILITY]

1595. Smith,DG (1980): River ice processes: thresholds and geomorphological effects in 
northern and mountain rivers. p.323-343. In: Thresholds in geomorphology. Geomorphology symposium series. Binghamton, NY. [Eds: Coates,DR; Vitek,JD]. George Allen \& Unwi, Boston,MS.

Rivers located in northern and mountain environments are severely affected by winter and associated accumulations of river ice. Several types of ice accumulations can occur, depending on channel characteristics, weather conditions, and volume of river discharge. This chapter shows how the concept of a geomorphic threshold can be applied to river ice processes and describes the various river ice processes common to northern rivers. [CHANNEL DYNAMICS; CHANNEL MORPHOLOGY; GEOMORPHOLOGY; RIVER ECOLOGY]

1596. Smith,LM; Kadlec,JA (1985): Fire and herbivory in a Great Salt Lake Marsh. Ecology 66(1), 259-265.

The effects of fire and of herbivory by vertebrates on the standing crop and aboveground net primary production of Typha latifolia, Scirpus lacustris, S.maritimus, and Distichlis spicata investigated in a freshwater marsh adjacent to the Great Salt Lake. Production of T.latifolia, S.lacustris, and S.maritimus vegetation responding after fire was not different from control areas, but flooding following fire eliminated D.spicata. Grazing by wetland vertebrates reduced net primary production of marsh macrophytes. Significant reductions occurred in previously burned areas of T.latifolia (48 percent), S.lacustris (25 percent), and S.maritimus (9 percent), illustrating the importance of the herbivory food chain for inland marshes. Evidence of increased protein in vegetation responding after fire and preferential grazing was consistent with the hypothesis that wetland vertebrates select vegetation of higher nutritive quality.

[FIRE IMPACTS; GRAZING IMPACTS; PRIMARY PRODUCTION; WETLANDS]

\section{Smith,LM; Kadlec,JA (1990): Habitat} management for wildlife in marshes of Great Salt Lake. p.222-231. In: Transactions of the 51st North American wildlife and natural resources conference.

The marshes surrounding the Great Salt Lake in Utah have historically been known for their rich and plentiful avifauna. The marshes have provided vital habitat for breeding shorebirds and waterfowl and have also been critical for molting and wintering birds. Substantial changes have occurred in modern times. This study highlights historical, physical, and biological conditions of the Great Salt Lake marshes and relates recent habitat management schemes to vegetation succession and associated wildlife use. [AVIAN ECOLOGY; HABI'IA'T MANAGEMENT; RIPARIAN HABITAT; WETLANDS]

1598. Smith,MA; Dodd,JL; Skinner,QD; Rodgers,JD (1993): Dynamics of vegetation along and adjacent to an ephemeral channel. Journal of Range Management 46(1), 56-64.

Ephemeral channels may be greater contributors to non-point sediment loads than perennial channels because of their abundance and lower vegetative cover. This study examined above- and belowground standing crop responses of selected vegetation classes and density of shrubs to grazing use and yearly weather variation along an ephemeral stream in north-central Wyoming. Perennial grass standing crop in channels did not respond to grazing but decreased up to 73 percent with decreases in frequency and amount of precipitation. On floodplains and uplands, perennial grass standing crop was not responsive to grazing. Shrub density did not increase as much in grazed as in ungrazed pastures. Location on channels influenced root biomass but grazing did not. Lack of general negative grazing influences on vegetation suggest short periods (10 days) of grazing (as used in this study) represent a sustainable management alternative for grazing in a cold desert.

[CHANNEL MORPHOLOGY; CLIMATE; EPHEMERAL STREAMS; GRAZING IMPACTS; RIPARIAN SHRUBS]

1599. Smith,MA; Rodgers,JD; Dodd,JL; Skinner,QD (1992): Habitat selection by cattle along an ephemeral channel. Journal of Range Management 45(4), 385-390.

Higher proportions of cattle selected channel and floodplain habitats than selected upland habitat. Animal preference for channel habitat was attributed to more available forage in the channels. In contrast, selection of floodplains was sue to succulence and high protein content of greasewood. Greater avoidance of upland areas by cattle was likely due to greater distances to drinking water.

[EPHEMERAL STREAMS; GRAZING IMPACTS; RIPARIAN PASTURES]

1600. Smith,MA; Rodgers,JD; Dodd,JL; Skinner,QD (1993): Habitat selection by cattle along an ephemeral channel. Rangelands 15(3), 120-122. 
When adequate livestock water is present, grazing cattle will be more likely to select areas of higher forage quality and quantity. Increased selection did not result in increased utilization in preferred areas. Limited water distribution in large allotments probably increases utilization closer to water. Vegetation in or near channels can best be protected by developing water points in adjacent uplands while monitoring utilization of water channels.

[GRAZING IMPACTS; LIVESTOCK EFFECTS; RIPARIAN HABITAT]

1601. Smith,RD (1996): Geomorphic effects of large woody debris in streams. p.113-127. In: National hydrology workshop proceedings. 27 April - 1 May 1992; Phoenix, AZ. USDA Forest Service. General Technical Report RM-GTR-279.

This paper reviews the geomorphic effects of inchannel obstructions, including large woody debris. It includes discussion of debris flows, debris removal, obstruction pool interactions, obstruction channel morphology interactions, mechanisms of pool scour, and scour in obstruction related pools. There is also a discussion of information needs for widespread application of the turbulent scour model in forest streams.

[GEOMORPHOLOGY; STREAM

IMPROVEMENTS; WOODY DEBRIS]

1602. Smith,SD; Herr,CA; Hokett,SL; Cochran,GF (1992): Effects of a simulated pluvial maximum climate on soil-plant water relations and potential recharge near Yucca Mountain, Nevada. p.171-175. In: Clary,WP; McArthur,ED; Bedunah,D; Wambolt,CL [comp.]. Proceedings Symposium on ecology and management of riparian shrub communities. USDA Forest Service. General Technical Report INT-289.

A simulated pluvial maximum climate was applied to experimental plots near Yucca Mountain, Nevada. Summer dormancy was alleviated in all shrub species tested. Deep soil moisture recharge $(>1.2 \mathrm{~m}$ ) occurred in the first summer on bare plots but not until winter dormancy on vegetated plots. If pluvial climatic conditions return during the life of the proposed nuclear waste facility, deep soil moisture recharge could occur.

[DORMANCY; RIPARIAN HABITAT; SOILS; WATER RELATIONS]
1603. Smith,SD; Murray,KJ; Landau,FH; Sala,AM (1995): Structure of woody riparian vegetation in Great Basin National Park. p.246251. In: Proceedings: Wild land shrub and arid land restoration symposium. USDA Forest Service. General Technical Report INT-GTR-315.

The community composition and population structure of the woody riparian vegetation in Nevada's Great Basin National Park are described. Community analyses were accomplished by sampling 229 plots along an elevational gradient of 8 major stream systems in the Park. TWINSPAN analysis identified 4 primary species groups that were characterized by aspen, white fir, Woods rose, and narrow-leaf cottonwood as dominants, respectively. Detrended Correspondense Analysis (DECORANA) showed that the most important environmental factors associated with the distribution of species were slope and elevation, with flood related physiographic factors having a secondary effect. Analysis of size-class distributions indicated that each of the four dominants showed good recruitment on most watersheds. Overgrazing by domestic livestock and stream diversion were the two primary disturbance factors affecting riparian vegetation in the Park.

[PLANT COMMUNITIES; RIPARIAN HABITAT; RIPARIAN SHRUBS]

1604. Snodgrass,JW; Meffe,GK (1998): Influence of beavers on stream fish assemblages: Effects of pond age and watershed position. Ecology 79(3), 928-942.

There was high species turnover among impounded and previously impounded reaches, therefore beavers affected patterns of species richness at the drainage basin scale. They collected more species in first and second order streams than in third order streams. Studies suggested that: 1) beavers have a positive effect on fish species richness in low order backwater streams but maintenance of this effect requires preservation of both spatial and temporal dynamics of beaver pond creation and abandonment; and 2) the positive relationship between stream fish species richness and drainage area described for many streams may be a recent phenomenon resulting from the extirpation of beavers from much of their historical range. [BEAVER; FISHERIES; RIPARIAN HABITAT]

1605. Snyder,WD (1988): Stem cutting propagation of woody phreatophytes in eastern Colorado. p.151-156. In: Mutz,K; Cooper,DJ; Scott,ML; Miller,LK [eds.]. Restoration, creation, 
and management of wetland and riparian ecosystems in the American West. Proceedings of the symposium. 14-16 November 1988. Denver, CO. Rocky Mountain Chapter of the Society of Wetland Scientists.

Plantings of six native woody phreatophytes and one exotic species are evaluated. Techniques are related to expected survival. Options for establishing trees, shrubs, and vines, within riverbottom floodplains include: removing top soil to near the water table, irrigation to maintain moist soils, planting rooted seedlings, and using polypropylene plastic sheeting as a weed barrier.

[PLANT PROPAGATION; RIPARIAN RESTORATION; RIPARIAN SHRUBS]

1606. Snyder,WD; Miller,GC (1992): Changes in riparian vegetation along the Colorado River and Rio Grande, Colorado. Great Basin Naturalist 52(4), 357-363.

Changes in vegetation including area occupied, canopy cover, and maturity class of cottonwoods within lower elevational zones of the Colorado River and Rio Grande in Colorado were monitored over 25 and 37 years, respectively. Estimated loss of cottonwoods along the Colorado River was 17.5 percent. Cottonwoods along the Rio Grande increased 9.5 percent. Shrubs declined along the Rio Grande but not along the Colorado River. Loss of hay fields declined along both rivers; developed lands increased along the Colorado River. Wildlife habitat deteriorated much more rapidly along the Colorado than along the Rio Grande. [COLORADO RIVER; COTTONWOOD; RIO GRANDE; RIPARIAN HABITAT]

1607. Sokol,C (1993): Rivers from a timber industry perspective. p.37-38. In: Tellman,B; Cortner,HJ; Wallace,MG; DeBano,LF; Hamre, RH [tech. coord.|. Riparian Management: Common threads and shared interests. USDA Forest Service. General Technical Report RM226.

The timber industry's view of riparian management has changed in the past few years. The new role involves participation with various agencies and entities in developing Coordinated Resources Management Plans (CRMP). Pilot projects such as the Spenser Creek CRMP have been very successful. [CRMP; RIPARIAN HABITAT; RIPARIAN MANAGEMENT ZONE]

1608. Sollins,P; Glassman,CA; Dahm,CM (1985): Composition and possible origin of detrital material in headwater streams. Ecology 66, 297299.

Fragmented but otherwise unaltered plant debris did not compose the bulk of the detrital $\mathrm{C}$ and $\mathrm{N}$ in the stream channel and floodplain materials that were sampled. The heaviest fraction accounted for the majority of the $\mathrm{C}$ and $\mathrm{N}$ in the fine detritus from four streams but for only a small to negligible proportion of $\mathrm{C}$ and $\mathrm{N}$ in waterlogged riparian foliage and wood. Even F1 material was substantially different in composition from the original plant material, $\mathrm{Al}$ and Fe having accumulated in large amounts. [NUTRIENT CYCLES; ORGANIC DEBRIS; RIPARIAN HABITAT]

1609. Solomon,JM; Horak,GC (1979): Promising legal and procedural strategies for reserving instream flows in thirteen western states. p.546549. In: Swanson,GA [ed.]. The mitigation symposium: A national workshop on mitigating losses of fish and wildlife habitat. USDA Forest Service. General Technical Report RM-65.

The authors identify, describe, and evaluate the most promising strategies for reserving flows at existing and proposed projects. These strategies were designed to promote the bargaining process between Federal/State resource development and conservation interests.

[STREAM FLOW; WATER CONSERVATION; WATER QUALITY; WATER RIGHTS]

1610. Sonett,ML; Stovall,PL (1998): Small grade control (check dam) function and design in the Embudo Watershed, Albuquerque, New Mexico. p. 417-426. In: Potts,DF [ed.]. Rangeland management and water resources: Proceedings of the AWRA specialty conference. American Water Resources Association. 27-29 May 1998. Reno, NV.

The Embudo Watershed contains 52 grade control structures, built of rock and brush, or rock, or rock, wire, and brush. Evaluation criteria for these structures included: 1) accumulated sediment volume, 2) dam dimensions, 3) performance characteristics, and 4) repair recommendations. Narrative records, regardless of dimensions, indicated that the structures were filled to capacity one year after construction. Although grade control structures trapped sediment for an estimated 1-2 years after construction, they reduce sediment yield more significantly by lowering flow velocities and stabilizing banks. [CHECK DAMS; RUNOFF; SEDIMENTATION; WATERSHED] 
1611. Sotir,RB; Frazier,L (1997): Stream realignment and restoration achieved through partnership. Land and Water, March/April, 1318.

Installation of soil bioengineering stabilization systems has facilitated the foundation for potential long-term success toward the goals of restoring a riparian stream corridor in Tennessee, while also fulfilling aesthetic requirements and economic constraints.

[BIOENGINEERING; FLOOD IMPACTS; RIPARIAN RESTORATION]

1612. Sparks,RE (1995): Need for ecosystem management of large rivers and their floodplains. BioScience 45(3), 168-181.

Most of the 79 large river - floodplain ecosystems in the world have been altered by human activity, the others face alteration soon. These are complex ecosystems that consist of flowing channels, together with the floodplain lakes, backwaters, forests, and wetlands that support much of the Earth's terrestrial and freshwater biodiversity. These systems are characterized by seasonal floods that promote the exchange of nutrients and organisms among a mosaic of habitats. The annual flood pulses are so predictable and long lasting that plants, animals, and human societies have adapted to take advantage of them. Ecosystem management works with such natural processes as erosion, sedimentation, and seasonal flood pulses. Nonstructural approaches to flood management, such as opting not to rebuild damaged structures in flood-prone areas and moving people out of harm's way, are congruent with restoration of floodplains and riparian zones. Over the long term, ecosystem management could save money and enhance economic efficiency, because natural services are restored (e.g. flood storage, conveyance, and moderation; water purification; fish and wildlife production; and biodiversity

preservation) instead of being maintained by human intervention at great costs and considerable risks of failure.

[ECOSYSTEM MANAGEMENT; EROSION; FLOOD IMPACTS; HUMAN IMPACTS; RIPARIAN HABITAT; RIVER ECOLOGY; SEDIMENTATION]

1613. Speaker,R; Moore,K; Gregory,S (1984): Analysis of the process of retention of organic matter in strcam ccosystems. Verhandlung Internationale Vereinigung Limnologie 22(3), 1835-1841.

Lotic ecosystems are substantially different from most other ecosystems as the continuous unidirectional flow through the system tends to transport matter to downstream reaches. The process of retention removes matter from transport and makes it available for utilization by stream biota, thus providing a link between input and storage. A method is described for the quantitative assessment of retention of particulate matter in streams and several major stream retention features are identified that can be influenced by the structure and composition of riparian zones. Short-term leaf retention curves performed well to a negative exponential model. Though leaves were retained at fairly uniform rates at many sites, the presence of wood debris dams had a major influence on reach retention patterns. Retention structures differed greatly in their relative efficiency of trapping leaves. [MATERIAL TRANSFER; ORGANIC DEBRIS; RIPARIAN HABITAT; SEDIMENT TRANSPORT; STREAM ECOLOGY]

1614. Speaker,RW; Luchessa,KJ; Franklin,JF; Gregory,SV (1988): The use of plastic strips to measure leaf retention by riparian vegetation in a coastal Oregon stream. The American Midland Naturalist 120(1), 22-31.

Plastic strips, rather than leaves, were tested in studies estimating the rate of removal of coarse particulate organic matter from low order forested streams. Processes involved in the retention of organic debris, both instream and on bank, are discussed in relation to the results of an experiment comparing the debris retention by streams sections with manipulated bank vegetation densities. [DECOMPOSER FOOD CHAIN; ORGANIC DEBRIS; RIPARIAN FOREST; RIPARIAN HABITAT]

1615. Spear,MJ (1985): Position paper: activities and views of the U.S. Fish and Wild life Service on riparian ecosystems. p.27-29. In: Johnson,RR; Ziebell,CD; Patton,DR; Ffolliott.PF; Hamre,RH [tech. coord.|. Riparian ecosystems and their management: Reconciling conflicting uses. 16-18 April 1985. Tucson, AZ. USDA Forest Service. General Technical Report RM-120.

Riparian habitat is vital to the Nation's fish and wildlife resources. Presently, many activities are adversely impacting this important ecosystem. Programs of the USDI Fish and Wildlife Service that provide protection for riparian zones are discussed. Examples of projects to conserve riparian areas are emphasized.

[RIPARIAN ECOLOGY; RIPARIAN HABITAT] 
1616. Sponholtz,PJ (1997): Effects of grazing on a riparian system: Where have all the fish gone? p.190. Abstracts. 1997 Annual meeting of the Ecological Society of America jointly with The Nature Conservancy. 10-14 August 1997. Albuquerque, NM.

Livestock grazing effects on a riparian ecosystem were examined at sites on the Verde River in Arizona. Streambank vegetation was 60 percent lower, channel width 50 percent greater and flow velocity 85 percent lower at the grazed site. Fish density at the grazed site was 50 percent lower than at the ungrazed site. Results of this study suggest that livestock grazing on the Verde River influences the total fish community by altering near and instream aquatic habitat.

[AQUATIC ECOSYSTEMS; FISHERIES; GRAZING IMPACTS]

1617. Sprugel,DG (1991): Disturbance, equilibrium, and environmental variability: What is "natural vegetation" in a changing environment? Biological Conservation 58, 1-18.

In recent years, the definition of "natural" ecosystems has undergone a change of perspective. It is now realized that in most areas some type of large scale disturbance is indigenous and must be considered in any realistic interpretation of "naturalness". In some areas, an equilibrium may exist in which patchy disturbance is balanced by regrowth, but in others equilibrium may be impossible because: 1) individual disturbances are too large of infrequent; 2) ephemeral events may have long lasting disruptive effects; and/or 3) climate changes interrupt any movement toward equilibrium that does occur. Vegetation may not be stable over long periods of time in a given area even without man's influence. For any given site at any given time, there are several communities that could be the 'natural vegetation".

[NATURAL AREAS; PLANT COMMUNITIES; RIPARIAN HABITAT; RIPARIAN VEGETATION]

1618. Squires, G (1991): Mined land reclamation in riparian areas. $\mathbf{p . 1 8 - 1 9}$. In: What does riparian mean to me? Proceedings of the third annual convention. Colorado Riparian Association. 6-8 November 1991. Pueblo, CO.

The Colorado Mined Land Reclamation Act requires that every mining operation must have a reclamation permit. Among other requirements, the application for the permit must include a mining plan and a reclamation plan plus other requirements. The applicant must also provide a warranty bond to ensure the reclamation of the site disturbance. [MINED LAND RECLAMATION; MINING IMPACTS; RIPARIAN RESTORATION]

1619. Stabler,DF (1985): Increasing summer flow in small streams through management of riparian areas and adjacent vegetation: $A$ synthesis. p.206-210. In: Johnson,RR; Ziebell,CD; Patton, DR; Ffolliott,PF; Hamre,RH [tech. coord.]. Riparian ecosystems and their management: Reconciling conflicting uses. 16-18 April 1985. Tucson, AZ. USDA Forest Service. General Technical Report RM-120.

Summer streamflow increases were obtained by construction of small dams, suppression of woody vegetation in and adjacent to riparian zones, and removal of livestock from streamsides. Potential may exist for managing small valley bottoms for summer flow increase, while maintaining or enhancing riparian habitat, range, and watershed values. [RIPARIAN HABITAT; RIPARIAN MANAGEMENT ZONE; STREAM FLOW]

1620. Stafford,MP (1994): Control of purple loosestrife with herbicides and the effect and subsequent response of wetland plant communities. p.51. In Proceedings of the Idaho Weed Control Association. 49th Annual Meeting. 15-17 February 1994. Boise, ID.

Field studies were conducted to determine the effects of herbicides on the control of purple loosestrife (Lythrum salicaria). The effects of herbicide treatments on the non-target vegetation was documented the year of treatment and the following year. Triclopyr Garlon 3A applied at 3.0, 4.5, and 6.0 pounds / Ac provided excellent selective control of purple loosestrife when applied in the bud to early flowering stage. Reductions in dicot cover were generally observed with purple loosestrife replaced by bedstraw and bladderwort. Monocots such as reed canarygrass, cattail and giant reedgrass increased 3to 4-fold in coverage

[EXOTICS; RIPARIAN HABITAT; RIPARIAN VEGETATION; WETLANDS]

1621. Stahlecker,DW; Kennedy,PL; Cully,AC; Kuykendall,CB (1989): Breeding bird assemblages in the Rio Grande Wild and Scenic River Recreation Area, New Mexico. The Southwestern Naturalist 34(4), 487-498.

Breeding bird assemblages were quantified on a 7,600-ha study area in northern New Mexico. Birds were censused on spot-mapping grids within six of the eight habitats during the spring and summer of 
1985. Population estimates were made for 43 species in at least one habitat while 113 confirmed and potential breeding species were documented in the study area. The riparian habitat had the highest density of breeding birds (203.3 pairs/40 ha) while sagebrush/grasslands had the lowest density (75.6 pairs/40 ha). Sagebrush/grassland habitat had the lowest species richness, and wooded canyon benches had the highest species richness. The greatest similarity in breeding bird species occurred in adjacent and structurally similar habitats.

[AVIAN ECOLOGY; RIPARIAN HABITAT; SPECIES RICHNESS]

1622. Stahr,L (1993): Oregon's watershed enhancement program. p.244. In: Tellman,B; Cortner,HJ; Wallace,MG; DeBano,LF; Hamre, RH [tech. coord.]. Riparian management: Common threads and shared interests. USDA Forest Service. General Technical Report RM226.

The governor's Watershed Enhancement Board provides grants, funds, and technical assistance to Oregonians proposing projects which demonstrate the benefits of improvement or enhancement of riparian or watershed areas.

[WATER QUALITY; WATERSHED]

1623. Stanford,JA (1979): Proliferation of river deltas in reservoirs: A natural mitigative process? p.193-195. In: Swanson,GA [ed.]. The mitigation symposium: A natural workshop on mitigating losses of fish and wildlife habitats. USDA Forest Service. General Technical Report RM-65.

Sedimentary and ecological dynamics of riverine-formed deltas in Texas, Oklahoma, and Montana illustrate importance of alluvial wetlands to river-reservoir ecosystems. Natural creation of deltas may be considered mitigation of habitat lost by reservoir construction. Conversely, destruction of existing delta habitat by mismanagement of lake level regime may present mitigation problems. [RESERVOIRS; RIPARIAN HABITAT; WETLANDS]

1624. Stanley,EH; Buschman,DL; Boulton,AJ; Grimm,NB; Fisher,SG (1994): Invertebrate resistance and resilience to intermittency in a desert stream. American Midland Naturalist 131, 288-300.

During wetting, drying, dry, and rewetting phases in an intermittent Arizona stream, invertebrate responses to water loss were investigated. Some taxa were resistant to drying because they could tolerate changing water quality and move upstream to avoid stranding. Community shifts occurred at one site when it became isolated from up- and down-stream reaches. No community changes were detected at a second site which remained connected with upstream reaches by surface flow. Mortality after water loss was severe as few individuals survived longer than 10 days. Low resistance during the dry phase was associated with rapid moisture loss from sediments. Slower rates of recovery may reflect the composition, reduced size, and remoteness of macroinvertebrate colonist pools. However, invertebrate persistence in desert streams where both flooding and drying are frequent is due largely to their ability to rapidly recolonize disturbed sites.

[DESERT STREAMS; FLOOD IMPACTS; MACROINVERTEBRATES; RIPARIAN HABITAT]

1625. Starlund,S (1993): Public participation in the planning and management of rivers:

Washington State Scenic River System. p.261-272.

In: Tellman,B; Cortner,HJ; Wallace,MG; DeBano,LF, Hamre,RH [tech. coord.]. Riparian management: Common threads and shared interests. USDA Forest Service. General Technical Report RM-226.

Often, public participation in river planning has had the appearance of government planners seeking acceptance and approval of their product.

Acknowledging the value of involving the river community is critical. The integration of social and cultural values/issues is not only important for planning but is also a crucial means of securing longterm commitment for river conservation action. [PLANNING; RIPARIAN HABITAT; RIVER ECOLOGY; SOCIAL VALUES]

1626. Stednick,JD (1988): The influence of riparian/wetland systems on surface water quality. p.17-19. In: Mutz,K; Cooper,DJ; Scott,ML; Miller,LK [eds]. Restoration, creation, and management of wetland and riparian ecosystems in the American West. A symposium by the Rocky Mountain Chapter of the Society of Wetland Scientists. 14-16 November 1988. Denver, CO.

Principles of water quality maintenance or improvement by riparian/wetland systems have been used to wastewater renovation systems. The removal or immobilization of organic or inorganic sediments, nitrogen and phosphorous, and heavy metals has the potential to improve point source and non-point source water quality. Riparian/wetland management must include recognition of the hydrology-soils- 
water quality interrelationships.

[NUTRIENT CYCLES; RIPARIAN ECOLOGY; WATER QUALITY]

1627. Steinblums,IJ; Leven,AA (1985): Riparian area management in the Pacific Southwest Region of the USDA Forest Service. p.507-509. In:

Johnson,RR; Ziebell,CD; Patton,DR; Ffolliott,PF; Hamre, RH [tech. coord.]. Riparian ecosystems and their management: Reconciling conflicting uses. 16-18 April 1985. Tucson, AZ. USDA Forest Service. General Technical Report RM-120.

A brief paper which summarizes the USDA Forest Service direction regarding the management of riparian zones, specifically in the Pacific Southwest.

[EVALUATION; POLICY; RESEARCH; RIPARIAN HABITAT; RIPARIAN MANAGEMENT ZONE]

1628. Steiner,F; Pieart,S; Cook,E; Rich,J; Coltman,V (1995): State wetlands and riparian area protection programs. Environmental Management 18(2), 183-201.

The protection of wetlands and riparian areas has emerged as an important environmental planning issue. In the United States, several federal and state laws have been enacted to protect wetlands and riparian areas. Specifically, the federal Clean Water Act includes protection requirements in Sections 301 and 303 for state water quality standards, Section 401 for state certification of federal actions (projects, permits, and licences), and Section 404 for dredge and fill permits. The Section 401 water quality state certification element has been called the "sleeping giant" of wetlands protection because it empowers state officials to veto or condition federally permitted or licenced activities that do not comply with state water quality standards. State officials have used this power infrequently. Several states have put in place model programs. Consequently, there are many examples to follow for other states. [CLEAN WATER ACT; RIPARIAN HABITAT; WATER QUALITY; WETLANDS]

1629. Stephenson,BA; Woods,L (1993): Transplanting mature riparian trees using a tree spade or crane. p.204-6. Tellman,B; Cortner,HJ; Wallace,MG; DeBano,LF; Hamre,RH [tech. coord.|. Riparian management: Common threads and shared interests. USDA Forest Service. General Technical Report RM-226.

When tree spades are used to transplant mature trees, the major portion of the root-ball remains intact with minimal disturbance to roots within the grab. Soil floral, faunal, and mycorrhizal components move with the tree to the mitigation site, increasing the speed at which they colonize the site.

Transplanting with a crane may not maintain the soil integrity around the root-ball as a tree spade does. [RIPARIAN FOREST; RIPARIAN RESTORATION; RIPARIAN SHRUBS; TRANSPLANTS]

1630. Stern,DH; Stern,MS (1980): Effects of bank stabilization on the physical and chemical characteristics of streams and small rivers: An annotated bibliography. USDI Fish and Wildlife Service. Biological Services Program. FWS/OBS80/12. 78 p.

An annotated bibliography was prepared as part of a project to synthesize and reference available information on the impacts of bank stabilization on physical and chemical characteristics of small streams. The bibliography has 213 references and is indexed by 26 key subject headings. Included papers vary from technical documents to general discussions addressing the physical and chemical changes that result from bank stabilization techniques. [BIBLIOGRAPHY; STREAMBANK STABILITY; WATER QUALITY]

1631. Stevens,LE (1997): Natural and altered patterns of riparian diversity, Grand Canyon, Arizona. p.36. In: Abstracts. 1997 Annual meeting of the Ecological Society of America jointly with The Nature Conservancy. 10-14 October 1997. Albuquerque, NM.

Arid region riparian vegetation provides an excellent opportunity to test whether interactions between productivity $(P)$ and disturbance (D) affect patterns of species richness (S). In this study, maximum species diversity occurred at the intermediate levels of P and D. Geomorphology and life history traits modify the S patterns across $\mathrm{D}$ and $P$ gradients.

[BIODIVERSITY; RIPARIAN VEGETATION; SPECIES RICHNESS]

1632. Stevens,LE; Brown,BT; Simpson,JM; Johnson, RR (1977): The importance of riparian habitat to migrating birds. p.156-164. In: Johnson,RR; Jones,DA [tech. coord.]. Symposium on the importance, preservation, and management of riparian habitat. 9 July 1997 . Tucson, AZ. USDA Forest Service. General Technical Report RM-43.

Paired study sites in riparian and adjacent, 
nonriparian habitats were censused for spring migrant passerines. The riparian plots contained up to 10.6 times the number of migrants per hectare found on adjacent, nonriparian plots. Stop-over habitat selection is indicated by differing migrant densitics and species diversities in various habitats.

[AVIAN ECOLOGY; RIPARIAN HABITAT]

1633. Stevens, M (1990): Between land and water are wetlands of Idaho. Idaho 10(4), 13-24.

This is a nontechnical article describing the history, types, functions, and values of Idaho wetlands. It concludes with a discussion of regulatory protection for riparian areas and wetlands. [RIPARIAN VEGETATION; WETLANDS]

1634. Stevens,R; McArthur,ED; Davis,JN (1992): Reevaluation of vegetative cover changes, erosion, and sedimentation on two watersheds 1912-1983. p.123-128. In: Clary,WP; McArthur,ED; Bedunah,D; Wambolt,CL [tech. coord.|. Proceedings - Symposium on ecology and management of riparian shrub communities. USDA Forest Service. General Technical Report INT-289.

Two adjoining depleted subalpine watersheds near Ephraim, Utah, have been protected from grazing since 1912 and 1920 , respectively. Studies have demonstrated that management practices can stabilize depleted subalpine range through long periods of nonuse or, more rapidly, with restoration techniques.

[COVER; GRAZING IMPACTS; WATERSHED]

1635. Stevens, R; Walker,SC (1998): Salt-cedar control. Rangelands 20(4), 9-12.

Salt-cedar is a facultative phreatophyte which vigorously consumes water and invades riparian areas and lowlands where it competitively replaces native plants. In these studies, salt-cedar control employing a number of herbicides was established within salt-cedar stands with and without various types of bark and stem injuries. These stands were located southwest of Delta, Utah. On poorly drained, silty clay soil, percent of salt-cedar plants killed varied with herbicide, pruning, and age of salt-cedar plants.

[EXOTICS; HERBICIDES; RIPARIAN

VEGETATION; SALT-CEDAR]

1636. Still,DA; Shih,SF (1985): Using Landsat data to classify land use for assessing the basinwide runoff index. Water Resources Bulletin 21(6), 931-940.
Remote sensing data in the form of Landsat computer compatible tapes (CCT) were used to determine land use and land cover as an aid in hydrologic studies that were used to estimate basinwide runoff index. Results showed that Landsat data can be used to monitor the USGS land use Level 1. One advantage of using the Landsat data for land use classification is that new data are periodically available for updating the land use information. [LAND USE; MONITORING; REMOTE SENSING; RIPARIAN HABITAT]

1637. Stinnett,DP; Smith,RW; Conrady,SW (1988): Riparian areas of western Oklahoma: a case study of the Canadian River. p.22-29. In: Stuber,PJ [tech. coord.]. Proceedings of the national symposium on protection of wetlands from agricultural impacts. 25-29 April 1988. Ft. Collins, CO. USDI Fish and Wildlife Service. Biological Report 88(16).

An inventory was conducted for wetland composition on the Canadian River floodplain in 1954-55 and in 1981-84. Eleven palustrine and riverine wetland types were quantified through computer digitization. Results were analyzed for temporal and for trend identification in distribution of wetland types. Total wetlands declined from 38,655 ha to 23,717 ha. Conversion of floodplain land to agriculture and plant colonization of unconsolidated alluvial sediments have occurred. Wetland and associated floodplain changes were principally due to hydrological modifications in the upper Canadian River Basin.

[AGRICULTURAL IMPACTS; CANADIAN RIVER; INVENTORY; MODELING; RIPARIAN HABITAT]

1638. Storch,RL (1979): Livestock/streamside management programs in eastern Oregon. p.5659. In: Cope, $O B$ [ed.]. Forum -- Grazing and Riparian/Stream Ecosystems, Denver, CO. 3-4 November, 1978; Trout Unlimited, Inc.

Uncontrolled livestock grazing has seriously affected the water quality of streams throughout the West. Techniques are described to improve the streamside, including: water deflectors, check dams, shrub planting, grazing systems, fencing, alternative waters, exclosures, etc.

[GRAZING IMPACTS; RIPARIAN RESTORATION]

1639. Storch,RL (1983): The integration of the riparian zone in the grazing management of associated rangelands. p.19-21. In Proceedings of 
Symposium on forestland grazing. 23-25

February, 1983. Washington State University. Spokane, WA.

Riparian and aquatic ecosystems need to be classified using ecological principles that emphasize characteristics of ecosystems rather than resource use. Both ecosystems should be classified by an interdisciplinary team of resource specialists using a system that incorporates the elements of soil, vegetation, water, and land forms. This would allow: 1) linkage of the riparian and aquatic systems with the upland ecological land classification system; and 2) the capability to predict changes in the ecosystems due to natural influences and resource management practices.

[GRAZING IMPACTS; GRAZING TREATMENTS; MULTIPLE USE]

1640. Strahan,J; McBride,JR (1987): The effects of streamflow regulation on riparian vegetation in central California. In: Streamside management: Riparian wildlife and forestry interactions. An interdisciplinary symposium. 11-13 February 1987. University of Washington. Seattle, WA.

The effects of streamflow regulation on riparian vegetation were studied on 30 streams in central California. Differences in seedling establishmentsurvival and size structure-composition of riparian forests were compared on regulated and nonregulated streams segments. Seedlings were found on 90 percent of the nonregulated stream segments but on only 33 percent of the regulated study sites. Densities were generally moderate to high on nonregulated streams and low on many regulated segments. [RIPARIAN HABITAT; RIPARIAN VEGETATION; STREAM FLOW]

1641. Stream Renovation Guidelines Committee. The Wildlife Society and American Fisheries Society (1983): Stream obstruction removal guidelines. American Fisheries Society 9 p. [RIPARIAN RESTORATION; STREAM IMPROVEMENTS]

1642. Stringham,TK; Buckhouse,JC; Krueger,WC (1998): Stream temperatures as related to subsurface water flows originating from irrigation. Journal of Range Management 51, 8890.

Continuous stream temperature data were collected from adjacent reaches of a third order stream in eastern Oregon. The upstream reach was located within a nonirrigated meadow and the downstream reach was located within an irrigated meadow. Daily maximum stream tempcratures in the reach located within the irrigated meadow were found to be 1 to 3 degrees $C$ cooler than the nonirrigated reach. Daily minimum stream tempcrature exhibited the opposite relationship. [GROUNDWATER; HYDROLOGY; IRRIGATION IMPACTS; STREAM TEMPERATURE]

1643. Stringham,TK; Krueger,WC; Thomas,DR (1998): Understanding the relationship between water table depth and plant communities: Implication for riparian management and restoration. p.345. In: Potts,DF [ed.]. Range management and water resources. Proceedings of the AWRA specialty conference. American Water Resources Association. 27-29 May 1998. Reno, NV.

Within an irrigated eastern Oregon riparian valley, water table levels and soil moisture content by plant community type were measured every two weeks during growing season. Results indicated that soil moisture and/or depth to the water table was the dominant variable in determination of the plant community. The relationship between water table depth and soil moisture can be used to determine the impact of a permanent water table change on the existing plant communities. Meadow water table profiles indicated a strong relationship between creek surface, meadow water tables, soil moisture and plant communities enhances managers abilities to predict plant community response to stream restoration or degradation.

[RIPARIAN RESTORATION; RIPARIAN VEGETATION; SOILS; WATER TABLE EFFECTS]

1644. Stromberg,J (1998): Dynamics of Fremont cottonwood (Populus fremontii) and salt-cedar (Tamarix chinensis) populations along the San Pedro River, Arizona. Journal of Arid Environments 40, 133-135.

Exotic salt-cedar woodlands have displaced riparian forests of natives Fremont cottonwood and willows (Salix spp.) along many southwestern rivers. In the middle basin of the San Pedro River, salt-cedar dominates only at the drier sites. At sites with perennial stream flows, salt-cedar is codominant with Fremont cottonwood. Salt-cedar has been declining at those sites, possibly due to frequent winter flooding, high spring stream flows, and exclusion of livestock, all factors that favor cottonwood establishment. Such occurrences are evidence that degraded Sonoran riparian ecosystems have a capacity for self-repair. In contrast, the upper basin is 
showing an increase in salt-cedar abundance at sites that have evidence of groundwater decline. Salt-cedar is still relatively sparse in the upper basin due to the combination of cool temperatures and persistence of perennial stream flows in most areas. Throughout the river bottom, salt-cedar and cottonwood have both been influenced by changing flood patterns. [COTTONWOOD; EXOTICS; HYDROLOGY; RIPARIAN VEGETATION; SALT-CEDAR]

1645. Stromberg,JC (1997): Growth and survivorship of Fremont cottonwood, Goodding willow, and salt-cedar seedlings after large floods in central Arizona. Great Basin Naturalist 57(3), 198-208.

During winter 1993, Arizona experienced regional river flooding. Flood waters eroded floodplains and created 50-m-wide scour zones available for colonization by pioneer plant species. The slow rate and long duration of the flood water recession allowed establishment of springgerminating native trees like Fremont cottonwood and Goodding willow as well as summer-germinating species including the exotic salt cedar. Goodding willow and Fremont cottonwood showed zonation in the floodplain, while salt cedar was equally abundant in zones with saturated and dry surface soils.

Floodplain elevation (and soil moisture) influenced shoot growth rate to different degrees among the 3 species.

[COTTONWOOD; FLOOD IMPACTS; RIPARIAN HABITAT; RIPARIAN VEGETATION; SALTCEDAR; WILLOW]

1646. Stromberg,JC; Patten,DT (1988): Total protection: One management option. p.61-62. In: Mutz,KM; Cooper,DJ; Scott,ML; Miller,LK [eds.]. Restoration, creation, and management of wetland and riparian ecosystems in the American West. Proceedings of the symposium. 14-16 November 1988. Denver, CO. Rocky Mountain Chapter of the Society of Wetland Scientists. Intensive sampling of riparian plots in southern Arizona is providing new information on the establishment requirements of key riparian species. Flood timing in relation to seed dispersal may affect community structure. Floods scour vegetation and provide a seed bed, provide moist conditions, and allow root growth of seedlings to keep pace with declining water levels.

[FLOODPLAIN MANAGEMENT; PLANT COMMUNITIES; RIPARIAN RESTORATION; SEED PRODUCTION]
1647. Stromberg,JC; Patten,DT (1991): Riparian vegetation instream flow requirements: $A$ case study from a diverted stream in the eastern Sierra Nevada, California, USA. Environmental Management 14(2), 185-194.

A methodology is described for determination of instream flow requirements for maintenance of riparian trees. Tree ring data revealed strong relationships between tree growth and stream flow volume for riparian species on an alluvial stream. These relationships allowed development of models that predict growth rates from hydrologic variables. The models can be used to assess instream flow requirements under the assumption that certain levels of growth are necessary to maintain the population. Previous models have focused on aquatic animals and may underestimate the requirements of the entire riparian ecosystem.

[MODELING; RIPARIAN HABITAT; RIPARIAN VEGETATION; STREAM FLOW]

1648. Stromberg,JC; Tiller,R; Richter,B (1996): Effects of groundwater decline on riparian vegetation of semiarid regions: The San Pedro, Arizona. Ecological Applications 6(1), 113-131.

Groundwater depletion threatens many riparian ecosystems in arid and semiarid regions of the world. The aquifer that sustains Arizona's San Pedro River riparian ecosystem, for example, is threatened by regional groundwater declines and localized pumping from the alluvial aquifer. This paper demonstrates the important role of shallow groundwater in structuring the San Pedro River plant community, portions of which function as reference areas that indicate site potential for a globally rare forest type. Several ecological indicators varied with depth to groundwater, including a weighted average wetland indicator score calculated for herbaceous and woody plant species, cover of plants within wetland indicator groups, and frequency of indicator plant species.

[ECOSYSTEM MANAGEMENT; GROUNDWATER; HYDROLOGY; RIPARIAN ECOLOGY]

1649. Stuber,PJ [coord ] (1988): Proceedings of the national symposium on protection of wetlands from agricultural impacts. 25-29 April 1988. Ft. Collins, CO. USDI Fish and Wildlife Service. Biological Report 88(16), 221.

A compilation of papers and discussions presented at the national symposium. Formal papers addressed four main topics: 1) agricultural impacts on wetlands; 2) national legislative wetland 
protection strategies; 3 ) state/regional wetland protection strategies; and 4) management protection strategies.

[POLICY; RIPARIAN HABITAT; WETLANDS]

1650. Stuber,RJ (1985): Trout habitat, abundance, and fishing opportunities in fenced vs. unfenced riparian habitat along Sheep Creek, Colorado. p.310-314. In: Johnson, RR; Ziebell,CD; Patton,DR; Ffolliott,PF; Hamre,RH |tech. coord.]. Riparian ecosystems and their management: Reconciling conflicting uses. 16-18 April 1985. Tucson, AZ. USDA Forest Service. General Technical Report RM-120.

Fencing was constructed to protect 40 ha of riparian habitat in northeastern Colorado from the adverse impacts of recreation use and animal trampling. Within the fenced area, fish habitat was narrower, deeper, had less streambank alteration, and better streamside vegetation than unfenced sections. Estimated trout standing crop was twice as great, and proportional stock density (PSD) was higher than in unfenced sections. There was also a higher proportion of nongame fish present in unfenced sections.

[EXCLOSURES; FISHERIES; GRAZING IMPACTS; RECREATION IMPACTS]

1651. Studenmund,RG (1993): The Nature Conservancy's Sweetwater River project. p.356358. In: Tellman,B; Cortner,HJ; Wallace,MG; DeBano,LF; Hamre,RH [tech. coord.]. Riparian management: Common threads and shared interests. USDA Forest Service. General Technical Report RM-226.

The Nature Conservancy (TNC) has realized that the protection of biological diversity will be achieved most effectively through the conservation of whole ccosystems. Given the geographic scale of most ecosystems, TNC will not be able to protect diversity through land acquisitions alone. Partnerships with both public and private sectors provides a more comprehensive and affordable approach. The Sweetwater River Project can become the kind of model that epitomizes that collaborative concept. [BIODIVERSITY; PARTNERSHIPS; RIPARIAN HABITAT; RIVER ECOLOGY; SWEETWATER RIVER]

1652. Sun,K (1988): Historical perspective of riparian areas along the Oregon Trail. p.71-72. In: Mutz,K; Cooper,DJ; Scott,ml; Miller,LK [eds.]. Restoration, creation, and management of wetland and riparian ecosystems in the American West. A symposium of the Rocky Mountain Chapter of the Society of Wetland Scientists. 14-16 November 1988. Denver, CO.

This paper describes range sites based on photographic and narrative information in the Sweetwater Valley, Wyoming from the 1870 s to the present time. The author projects contemporary technical ratings systems to historical conditions. [CLASSIFICATION; RIPARIAN HABITAT; RIPARIAN VEGETATION; SWEETWATER RIVER]

1653. Surber,G; Williams,K; Manoukian,M (1998): Drinking water quality for beef cattle: An environment friendly and production management enhancement technique. p. 201-208. In: Potts,DF [ed.]. Rangeland management and water resources: Proceedings of the AWRA specialty conference. American Water Resources Association. 27-29 May 1998. Reno, NV.

Evaluations of livestock preferences for dam/pit drinking water compared to tank water showed an 80 percent preference for tank water. [GRAZING IMPACTS; WATER QUALITY]

1654. Suring,LH; Vohs,Jr.,PA (1979): Habitat use by Columbian white-tailed deer. Journal of Wildlife Management 43, 610-619.

The study area was the Columbian White-Tailed Deer (Odocoileus virginianus) National Wildlife Refuge, on the Washington shore of the Columbia River. The climate was wet $(245 \mathrm{~cm})$ and mild, promoting continued growth of forage throughout the year. Communities providing both cover and forage were more heavily utilized than were communities providing cover or foliage alone. Browse was not used, apparently because of the year round availability of green forage. [RIPARIAN HABITAT; WHITE-TAILED DEER]

1655. Sutherland,PL; Knapp,JA (1988): The impacts of limited water: A Colorado case study. Journal of Soil and Water Conservation 43(4), 294-298.

The transfer of irrigation water to other uses in Colorado and the West poses challenges to land resource, economic, and social questions. Since agricultural water is the most readily available source for conversion to other uses, senior water rights, with the greatest potential for transfer and generally the best water quality, have been selected for transfer. Lack of current legal limitations under the "pure" prior appropriation doctrine of water allocation has allowed water transfers without concern for the 
adverse effects of social, economic, and water quality impacts.

[WATER LAW; WATER RIGHTS; WATER QUALITY]

1656. Svejcar,TJ; Riegel,GM; Conroy,SD; Trent,JD (1992): Establishment and growth of riparian shrubs in the northern Sierra Nevada. p.151-154. In: Clary,WP; McArthur,Ed; Bedunah,D; Wambolt,CL [comp.]. Proceedings Symposium on ecology and management of riparian shrub communities. USDA Forest Service. General Technical Report INT-289.

Results from a planting study suggest that successful establishment of Geyer's willow cuttings can be achieved if the base of the cutting is within 30 $\mathrm{cm}$ of the midsummer water table depth. In Lemmon's willow, drought years caused shorter periods of active photosynthesis, plus lower maximum rates. Willow leaves also had very low photosynthetic rates during the first 4 to 6 weeks of growth. Willows can be established successfully, but the delay in active photosynthesis of willow leaves and rapidly changing soil conditions during midsummer may place constraints on willow planting success.

[RIPARIAN RESTORATION; RIPARIAN

SHRUBS; WILLOW]

1657. Swan,B (1979): Riparian habitat -- the cattlemen's viewpoint. p.4-6. In: Cope, OB [ed.]. Forum - Grazing and riparian/stream ecosystems. 3-4 November 1978. Denver, CO. Trout Unlimited, Inc.

The land base of this country consists of 54 percent that has no productive capabilities for food production for man other than by way of grazing animals. Every AUM produced from our range resource releases the equivalent of 8 bushels of corn for human use or export. Because of the pressures to increase food production and livestock grazing, the problems of riparian habitat should be included in the discussion about grazing on public and private lands. [ECONOMICS; GRAZING IMPACTS; RIPARIAN HABITAT]

1658. Swanberg,TR (1997): Movements of and habitat use by fluvial bull trout in the Blackfoot River, Montana. Transactions of the American Fisheries Society 126, 735-746.

The seasonal movements and habitat use by fluvial bull trout (Salvelinus confluetus) were investigated by using radiotelemetry and snorkel surveys. Adult bull trout used deep pools and were positively associated with habitat units containing mountain whitefish (Prosopium williamsoni). Eighty six percent of migrants returned down-river to within $20 \mathrm{~m}$ of sites occupied in the spring. Results suggested that water temperature influenced the movement of fluvial bull trout and that tributary habitat was important for both spawning and nonspawning fish. Results also demonstrated that the large spatial scale and diversity of habitats are required to sustain fluvial bull trout populations. [BULL TROUT; FISHERIES; RIPARIAN HABITAT]

1659. Swank,GW (1985): Streamside management units in the Pacific Northwest. p.435438. In: Johnson,RR; Ziebell,CD; Patton,DR; Ffolliott,PF; Hamre,RH [tech. coord. ]. Riparian ecosystems and their management: Reconciling conflicting uses. 16-18 April 1985. USDA Forest Service. General Technical Report RM-120.

A stream classification system based on use made of the water with specific water quality objectives established for each of four classes of streams was the foundation for streamside management units operating in Washington and Oregon. Inherent in the concept is the underlying premise that the land immediately adjacent to streams is key to protecting water quality but that this land can be managed to protect riparian values and in most cases still achieve a reasonable return of other resource values.

[CLASSIFICATION; MULTIPLE USE; RIPARIAN HABITAT]

1660. Swanson,FJ (1997): Flood disturbance in a mountain landscape, Oregon. p.36. In: Abstracts. 1997 Annual meeting of the Ecological Society of America jointly with The Nature Conservancy. 10-14 August 1997. Albuquerque, NM.

This study addressed flood disturbance in steep, geologically unstable, mountain landscapes.

Disturbance along order 1 to 3 streams is influenced by the patchy pattern of mass movement processes.

Flood disturbance on higher order streams is controlled in part by transport rates of sediment and large woody debris. Such processes influence the extent of channel change and of uprooting, burial, and abrasion of riparian vegetation. Near-stream vegetation in this environment is disturbed primarily by mechanical damage during flood peaks. Management of forest landscapes can significantly affect floods bu altering streamflow, availability and transport rates of sediment and wood, the potential for initiation and runout of mass movements, and the 
resistance and resilience of stream and riparian communities to disturbance.

[FLOOD IMPACTS; RIPARIAN VEGETATION; SEDIMENTATION; STREAM FLOW; WOODY DEBRIS]

1661. Swanson,FJ; Fredrikson,RL; McCorison,FM (1982): Material transfer in a western Oregon forested watershed. p.267-291. In: Edmonds, RL [ed.]. Analysis of coniferous forest ecosystems in the Western United States. (US/IBP Synthesis Series 14.) Hutchinson Ross Publishing Co. Stroudsburg, PA.

This chapter differentiates the erosional processes that occur in uplands (hill slope processes) from the processes that occur in the channel itself (stream channel processes). Definitions for hill slope processes are given for solution transport, litter fall, surface erosion, soil creep, root throw, debris avalanche and slump and earth flow. Definitions included in the stream channel process include solution transport, suspended sediment, bedload transport and debris torrents. Other factors that influence erosion rates include existing vegetation, soil type, slope, type of bedrock, amount, timing and type of precipitation, watershed size, and stream channel characteristics. Erosion is then discussed for a hypothetical watershed as old-growth forest, the same watershed after a wildfire, and the same watershed after a clear-cut. No research data were presented.

[EROSION; GEOMORPHOLOGY; SEDIMENT TRANSPORT; SOILS]

1662. Swanson,FJ; Graham,RL; Grant,GE (1985): Some effects of slope movement on river channels. p.273-278. In: International symposium on erosion debris flow and disaster prevention. 3-5 September 1985. Tsukuba, Japan.

The geomorphic response of a channel to slope movements depends on the rate of colluvium delivery from hillslopes relative to the rate of removal by fluvial processes. For slope movements ranging from extremely slow to slow (less than $1.5 \mathrm{~m} / \mathrm{mo}$ ), the balance between slope and fluvial influences can be considered in terms of the channel constriction ratio, defined as the ratio of slope movement to channel width, expressed as percent/yr. Sites with faster constriction ratios may experience more frequent stream bank instability and sediment production. Rapid slope movements discharging large volumes of colluvium into channel can form dams. Dam volume, river discharge, and size of distribution of dam material determine the potential for dam failure and release of water from impounded lakes. The implications for hazard prediction and mitigation are discussed.

[CHANNEL MORPHOLOGY; DAMS; GEOMORPHOLOGY; SOILS]

1663. Swanson,FJ; Gregory,SV; Sedell,JR; Campbell,AG (1982): Land - water interactions: the riparian zone. p.267-291. In: Analysis of coniferous forest ecosystems in the western United States. [Ed:Edmonds,RL]. US/IBP Synthesis Series 14. Hutchinson Ross Publishing Co. Stroudsburg, PA.

Chapter nine discusses the characteristics of riparian zones in coniferous forests of western Oregon. Riparian zones are the interface between aquatic and terrestrial environments. In the Pacific Northwest they usually, have a herbaceous layer, a shrub layer, and then a coniferous tree over story. Plant communities in the riparian zone are influenced by number of factors including; soils, gradient, light, moisture, amount of large woody debris, stream channel characteristics, as well as the frequency and intensity of flooding and scouring. Possible impacts from wildfire and logging are briefly mentioned. No research data were presented.

[ORGANIC DEBRIS; RIPARIAN ECOLOGY; RIPARIAN HABITAT; RIPARIAN VEGETATION]

1664. Swanson,GA [coord]. (1979): The mitigation symposium; a national workshop on mitigating losses of fish and wildlife habitats. USDA Forest Service. General Technical Report 65. $696 \mathrm{p}$.

This symposium, consisting of 133 papers presented in three concurrent sessions and a poster session, involved 9 private organizations and 8 federal agencies. Subjects were: coastal zone wetlands: inland wetlands; economic considerations; mining, oil, and gas; planning, evaluation, and inventory; surveys; legal and political considerations; transportation systems; and state perspectives. [HYDROELECTRIC IMPACTS; OIL/GAS IMPACTS; RIPARIAN HABITAT; WETLANDS]

1665. Swanson,S (1986): The value of healthy riparian areas. University of Nevada-Reno. College of Agriculture. Cooperative Extension Service Fact Sheet. 3 p.

Riparian areas sustain and attract many species of wildlife. Their vegetation shades/cools the streams, builds stream banks by catching sediment, and holds overhanging streambanks with root systems. Riparian floodplains buffer floods and store 
water for slow release during dry seasons. They also buffer temperature extremes and filter undesirable material from the water.

[RIPARIAN HABITAT; RIPARIAN

VEGETATION; WATER RESOURCE

MANAGEMENT]

1666. Swanson,S (1988): Riparian values as a focus for range management and vegetation science. p.425-445. In: Tueller,PT [ed.]. Vegetation science applications for rangeland analysis and management. Kluwer Academic Publishers. Boston, London.

Riparian vegetation is defined by its association with free or unbound water. The productivity and diversity of riparian vegetation and its relationship with aquatic ecosystems makes it extremely valuable to fish, wildlife, livestock, and people. Intense human and livestock use has accentuated the naturally high disturbance in most riparian areas. This has caused significant alteration to riparian vegetation and hydrologic processes, threatening the quality of riparian habitats. The long process of developing an integrated interdisciplinary and hierarchical riparian classification is just beginning.

[CLASSIFICATION; GRAZING IMPACTS; RIPARIAN VALUES]

1667. Swanson,S (1989): Priorities for riparian management. Rangelands 11(5), 228-230.

Selection of priority stream reaches is the first step toward proper management, particularly in stream valleys that are long and deeply filled with erodible sediments. Classification can be used for selecting the most appropriate management strategy. Grazing strategies may be appropriate in certain circumstances but none of them are a panacea. Each riparian or upland grazing problem is unique and requires a remedy that suits the circumstances. Classification can also be useful for identifying potential responses. Monitoring the problem is also essential.

[GRAZING IMPACTS; GRAZING TREATMENTS; RIPARIAN ENHANCEMENT]

1668. Swanson,S; Franzen,D; Manning, $M$ (1987): Rodero Creek: Rising water on the high desert. Journal of Soil and Water Conservation 42, 405-407.

Whenever structures are required to heal a gully network, the project should proceed upstream from a point of geologic control as near the top of the watershed/gully system as possible. It is ideal to build just below the deterioration so that watershed stabilization comes soon. Without geologic or other durable control, however, it is possible for a downstream head-cut to move upstream and capture the bottom and eventually other dams.

[GULLY CONTROL; RIPARIAN RESTORATION]

1669. Swanson,S; Miles,R; Leonard,S; Genz,K

(1987): Classifying rangeland riparian areas: the Nevada approach. Interagency task force report. Nevada Riparian Management and Research and Management Task Force; Reno, NV. 13 p.

An interagency task force developed a classification of riparian areas to facilitate communication between managers and scientists. This paper presents their classification. The goal was to develop a system that was interdisciplinary, hierarchical, simple yet reliable, useful for management, based on potential, and mappable. The classification begins at a broad level and proceeds through the intermediate steps that focus on the types of associated aquatic ecosystems and the environment of riparian vegetation and its seral communities. Ecological site and riparian community types are not named because they have not been identified.

[CLASSIFICATION; RIPARIAN HABITAT; RIPARIAN MANAGEMENT ZONE]

1670. Swanson,S; Myers, T (1993): Managing for integrated use. p.19-21. In: Tellman,B;

Cortner,HJ; Wallace,MG; DeBano,LF;

Hamre, RH [tech.coord.|. Riparian management: Common threads and shared interests. USDA Forest Service. General Technical Report RM226.

Riparian areas are the linkage connecting deserts and mountains as well as forming the transition from upland to aquatic. The influence of riparian vegetation becomes greater as the stream orders become lower. A river at any point is the sum of it's upstream parts. The key to integrated use of rivers is open communication between all governmental agencies and nongovernmental entities along with overlapping authority.

[CLASSIFICATION; COLLABORATION; INTEGRATED USE; RIPARIAN HABITAT]

1671. Sweep,DH; Zilincar,JM; Smith,BH; Hardy, RV (1985): Integration of riparian systems management strategies within the context of multiple use land management programs in southwestern Wyoming. p.371-373. In: Johnson,RR; Zeibell,CD; Patton,DR; F folliott,PF; Hamre, RH [tech. coord.|. Riparian ecosystems 
and their management: Reconciling conflicting uses. 16-18 April 1985. Tucson, AZ. USDA Forest Service. General Technical Report RM-120.

Extent of multiple use activities on public lands in southwestern Wyoming places significant pressures on riparian ecosystems. Experience indicates that by using an integrated, interdisciplinary management approach, it is possible to maintain existing healthy riparian habitat, and improve or recover lost habitat.

[MULTIPLE USE; RIPARIAN HABITAT; RIPARIAN MANAGEMENT ZONE]

1672. Swenson,EA (1988): Progress in the understanding of how to reestablish native riparian plants in New Mexico. p.144-150. In: Mutz,KM; Cooper,DJ; Scott,ML; Miller,LK [eds.]. Restoration, creation, and management of wetland and riparian ecosystems in the American West. Proceedings of the symposium. Rocky Mountain Chapter of Wetland Scientists. 14-16 November 1988. Denver, $C O$.

The author describes proven techniques for establishing riparian plants. Woody species are best accomplished by dormant pole planting and understory plants are established by containerized plant or rhizome placement. Guidelines are provided. [PLANTINGS; RIPARIAN RESTORATION; RIPARIAN VEGETATION]

1673. Swenson,EA; Mullins, CL (1985):

Revegetating riparian trees in the southwestern floodplains. p.135-138. In: Johnson,RR; Ziebell,CD; Patton,DR; Ffolliott,PF [tech. coord.]. Riparian ecosystems and their management: Reconciling conflicting uses. 16-18 April 1985. Tucson, AZ. USDA Forest Service. General Technical Report RM-120.

Man's activities continue to alter riparian areas. Managers have been generally unsuccessful in using conventional techniques to replace riparian trees. An inexpensive method for reestablishment of Rio Grande cottonwood, narrow-leaf cottonwood, and Goodding willow is now available.

[COTTONWOOD; RIPARIAN HABITAT;

RIPARIAN FOREST; WILLOW]

1674. Swift,BL (1984): Status of riparian ecosystems in the United States. Water Resources Bulletin 20(2), 223-228.

The author attempted to review all of the available data regarding the extent and status of riparian ecosystems in the United States. This review also addressed the amount of land that was originally covered by woody riparian vegetation and how much remains. He concludes that riparian woodlands are one of this country's most heavily modified natural vegetation types and that they have been reduced in many regions by more than 80 percent.

[RIPARIAN ECOLOGY; RIPARIAN HABITAT; RIPARIAN VEGETATION]

1675. Szaro, RC (1980): Factors influencing bird populations in Southwestern riparian forests. p.403-418. In: Proceedings, Management of western forests and grasslands for nongame birds. Salt Lake City, UT. 11-14 February 1980. USDA Forest Service. General Technical Report INT-86.

Riparian forests comprise only a minor portion of the available habitat in the arid Southwest but support extremely high bird populations. Most birds show a remarkable dependency on water related habitat for breeding areas, wintering areas, and migratory corridors. Bird communities in riparian forests are affected by vegetation type, structure, density, adjacent habitat, recreational use, grazing, and location.

[AVIAN ECOLOGY; AVIFAUNA; RIPARIAN HABITAT; WETLANDS]

1676. Szaro,RC (1989): Riparian and scrubland community types of Arizona and New Mexico. Desert Plants 9(3-4), 69-124.

The primary objectives of this study were to: 1) develop the structural framework of a classification system for Arizona and New Mexico based on actual site vegetative data; 2 ) determine tree and shrub densities and species composition of community types; 3) provide a species list of common plants; 4) provide average physical site characteristics by community type; and 5) discuss various factors affecting riparian plant community composition. [CLASSIFICATION; DESERT SCRUB; PLANT COMMUNITIES; RIPARIAN HABITAT]

1677. Szaro,RC (1990): Southwestern riparian plant communities: Site characteristics, tree species distributions, and size-class structures. Forest Ecology and Management 33/34, 315-334.

Elevation, stream direction, stream gradient, and valley cross-sectional area affect the distribution of riparian tree species in the southwestern United States. Canonical discriminant analysis was used to examine variability of physical site characteristics on 153 sites in New Mexico and Arizona. Elevation was the most significant factor for all community types, all riparian forest types, and all riparian shrub community types. Both stream gradient and stream 
direction also correlated significantly, but on a more limited and local level. Tree population size structures and tree species distribution were studied on sites where species were dominant and at other sites where they occurred. The dominance and/or codominance of some species, such as Arizona walnut (Juglans major), was directly related to site characteristics such as elevation and direction of stream flow.

[CLASSIFICATION; RIPARIAN FOREST; RIPARIAN HABITAT]

1678. Szaro,RC (1991): Wildlife communities of southwestern riparian ecosystems. p.173-201. In: Rodick,JE; Bolen,EG [eds.].Wildlife and habitats in managed landscapes: An overview. Island Press, Washington, DC.

Successful management of southwestern riparian communities requires a suite of strategies to enhance and maintain riparian diversity. An ecosystem approach to management of riparian systems should consider goals and standards for the condition of major indicators of plant and animal community health. It should provide for the continued monitoring of habitat indicators and of species' population levels over an extended time period to fully assess the effects of environmental perturbations and the adequacy of management strategies. Ongoing studies address the need for a long-term ecosystem approach. This chapter also discusses: 1) appropriate management actions; 2) factors affecting riparian zone management; 3 ) examples from case studies; and 4) recommendations for future research and development. [RIPARIAN ECOLOGY; RIPARIAN HABITAT; RIPARIAN VEGETATION]

1679. Szaro,RC; Belfit,SC (1986): Herpetofatnal use of a desert riparian island and its adjacent scrub habitat. Journal of Wild life Management 50(4), $752-761$.

The restriction of water flow in 1959 in Queen Creek in Whitlow Ranch Dam, Pinal County, Arizona, has caused the development of a 15-ha riparian island upstream behind the dam. The herpetofaunas of the riparian interior, riparian edge, desert wash, and upland habitats were sampled to assess the value of this type of development for mitigating continued losses of riparian habitat. Total species richness was 4 in the riparian interior, 7 in the riparian edge, 14 in the desert wash, and 15 in the desert upland. Many of the locally expected species were absent. The lack of invasion by typical riparian species probably results more from biogeographic considerations and flooding patterns than from structural and physical conditions of this newly formed riparian habilat. Regression models for species abundance emphasize the importance of using floristic information rather than summary variables in developing animal-habitat relationships. [AMPIIIBIANS; BIODIVERSITY; HERPETOFAUNA; MITIGATION; REPTILES; RIPARIAN IIABITAT]

1680. Szaro,RC; Belfit,SC (1987): Small mammal use of a riparian desert riparian island and its adjacent scrub habitat. USDA Forest Service. Research Note RM-473.

A 15 ha riparian island was created upstream of a dam built in 1959. Small mammal populations in the riparian interior, riparian edge, desert wash and upland habitats surrounding the island were sampled to assess the value of this type of development (water flow restriction by dam) for mitigating continued loss of riparian habitat. The riparian island had few small mammals; more were recorded in the adjacent desert washes and desert upland habitats. Habilat models were developed for the desert shrew, Arizona pocket mouse, and Bailey's pocket mouse. The authors conclude that potential is limited for using the development of a dense willow gallery forest resulting from changes in hydrologic regime to mitigate the loss of more structurally diverse riparian habitats. Canopy opening to increase development of shrub and herbaceous layers and import of riparian fauna from similar islands might improve the value of the mitigation riparian island small mammal habitat. Species studied included: desert shrew (Notiosorex crawfordii), Arizona pocket mouse (Perognathus amplus), Bailey's pocket mouse (Perognathus baileyi).

[MITIGATION; RIPARIAN HABITAT; SMALL MAMMALS]

1681. Szaro,RC; Belfit,SC; Aitken,JK; Babbs,RD (1988): The use of timed fixed-area plots and a mark-recapture technique in assessing riparian garter snake populations. p.239-246. In: Management of amphibians, reptiles, and small mammals in North America. USDA Forest Service. General Technical Report RM-166.

Wandering garter snake populations along a thin-leaf alder riparian community in northern New Mexico were sampled using timed fixed-area plots and a mark-recapture method. Both methods served to determine yearly differences and relative magnitude of snake density between years. Population estimates determined by fixed-area plots, 
however, were inconsistent between study plots in the same year.

[GARTER SNAKES; RIPARIAN; RIPARIAN HABITAT]

1682. Szaro,RC; Belfit,SC; Aitkin,JK; Rinne,JN (1985): Impact of grazing on a riparian garter snake. p.359-363. In: Johnson,RR; Ziebell,CD; Patton,DR; Ffolliott,PF; Hamre,RH [tech. coord. ]. Riparian ecosystems and their management: Reconciling conflicting uses. 16-18 April 1985. Tucson, AZ. USDA Forest Service. General Technical Report RM-120.

The number of wandering garter snakes wete significantly higher where cattle grazing was excluded than along grazed portions of the Rio de las Vacas in northern New Mexico, where the dominant vegetation was a high elevation, thin-leaf alder/willow plant community. Differences were attributed to the regeneration of streamside vegetation and the increased amount of organic debris.

[GARTER SNAKES; GRAZING IMPACTS; HERPETOFAUNA; ORGANIC DEBRIS; RIPARIAN HABITAT]

1683. Szaro,RC; DeBano,LF (1985): The effects of streamflow modification on the development of a riparian ecosystem. p.211-215. In: Johnson,RR; Ziebell,CD; Patton,DR; Ffolliott,PF; Hamre,RH [tech. coord.]. Riparian ecosystems and their management: Reconciling conflicting uses. $16+18$ April 1985. Tucson, AZ. USDA Forest Service. General Technical Report RM-120.

Riparian vegetation development/hydrologic regime interrelationships were examined in southern Arizona. Data indicated that a flood control structure can have a positive impact on riparian ecosystem development and could be used as a mitigation tool to restore critically threatened habitat.

[HYDROLOGY; RIPARIAN VEGETATION; STREAM FLOW]

1684. Szaro,RC; Jakle,MD (1985): Avian use of a desert riparian island and adjacent shrub habitat. The Condor 87, 511-519.

A central Arizona bird community contributed from 23 to 33 percent of the birds along the adjacent desert washes, and from 7 to 15 percent of the birds in the adjacent desert upland. Conversely, the desert bird community contributed only from 1 to 1.5 percent of the birds in the riparian island. Bird density ranged from 336 to 446 birds/40 ha in the riparian core and edge in 1981-1982. Bird density in the adjacent desert decreased with distance from the edge of the riparian island to a low of 101 birds $/ 40$ ha in 1981 , to 137 birds/40 ha in 1982 , in the segment $600-1,000 \mathrm{~m}$ from the riparian edge.

[AVIAN ECOLOGY; RIPARIAN HABITAT; RIPARIAN VEGETATION]

1685. Szaro,RC; King,RM (1990): Sampling intensity and species richness; Effects on delineating southwestern riparian plant communities. Forest Ecology and Management 33/34, 335-349.

Riparian communities in the southwestern United States often occur in patches and isolated pockets along stream corridors, making classifications of community types highly dependant on sampling design and methodology. The authors determined the number of plots $(5 \times 25 \mathrm{~m})$ and tree species richness in estimating density, basal area, and species ranks. Variability in species density ranks for the most frequent species stabilized, with about 10-20 plots. As species richness increased, so did the variability associated with estimating ranks. Studies, which are based on only a few arbitrarily selected sample plots, may not produce reliable results. [CLASSIFICATION; RIPARIAN STUDIES; RIPARIAN VEGETATION]

1686. Szaro,RC; Patton,DR (1986): Riparian habitat classification in the southwestern U.S. In: Proceedings of the 51st North American wildlife and natural resources conference. 21-26 March 1986. Reno, NV.

The classification of riparian vegetation in the southwestern United States has been complicated by the large variety of physical and environmental factors, contributing to a high plant species diversity. The problem is compounded further by the relatively small land areas of most riparian systems. A structural framework of a classification system is presented that incorporates community types based on existing vegetation. 31 riparian community types are delineated and described.

[CLASSIFICATION; RIPARIAN HABITAT; RIPARIAN VEGETATION]

1687. Szaro,RC; Rinne,JN (1988): Ecosystem approach to management of southwestern riparian communities. p.501-511. In: Transactions of the North American wildlife and natural resources conference: 53rd annual meeting. Wildlife Management Institute. Washington, DC.

The paper describes common problems with ecosystem studies, including: riparian area responses 
to grazing exclosures, geographic variation, and water impoundment. The response to grazing on riparian areas can vary depending on the populations measured, whether birds, reptiles, fish, small mammals, etc. Researchers and managers need to act cooperatively in study designs so that testable hypotheses are addressed and proper controls applied. Sufficient preliminary data is frequently lacking.

[BIODIVERSITY; CLASSIFICATION; EXCLOSURES; GRAZING IMPACTS]

1688. Tabacchi,E; Planty-Tabacchi,A-M; Decamps,O (1990): Continuity and discontinuity of the riparian vegetation along a fluvial corridor. Landscape Ecology 5(1), 9-20.

The concept of continuity/discontinuity was applied to the riparian vegetation of the corridor of the River Adour in southwest France, in order to define longitudinal structure, and to test the degree of floristic continuity of the fluvial axis. The measure of floristic connectance along the river course was based on presence/absence data, and was applied to successive stretches of the river, at various resolution levels. Analysis showed that the river corridor could not be assumed to be floristically continuous. Observed discontinuities may correspond to two types of change in the riparian vegetation; zones of slow change (high level of floristic connectance) or zones of sharp change (low level of floristic connectance).

[RIPARIAN HABITAT; RIPARIAN STUDIES; RIPARIAN VEGETATION]

1689. Taber,RD (1987): Ecology of large mammals in riparian systems of the Pacific Northwest. In: Streamside management: Riparian wildlife and forestry interactions. 11-13 February 1987. University of Washington. Seattle, WA.

Based on the review of the species habitat accounts available in the literature, the author has ranked the overall importance of the riparian system in the welfare of each species population in forest environments and grouped them into species dependent upon or finding optimum habitat in riparian areas, species that are more abundant in riparian areas, and species that use riparian areas but are abundant in other habitats as well. The habitat features of riparian systems that are considered to be of cological importance to these large mammal species are: abundance of prey and carrion, productivity of shrub/herb layer, early spring phenological development of food plants, reduced snow accumulations in winter, aquatic habitat, and lineal contiguity.

[MAMMALS; RIPARIAN HABITAT]

1690. Tabor,JE (1976): Inventory of riparian habitats and associated wildlife along the Columbia River. p.352-771. In: Final Report. US Army Corps of Engineers. North Pacific Division. [COLUMBIA RIVER; INVENTORY; RIPARIAN HABITAT; RIPARIAN VEGETATION]

1691. Tainter,JA; Tainter,BB (1996): Riverine settlement in the evolution of prehistoric land use systems in the Middle Rio Grande Valley, NM. p.22-32. In: Shaw,DW; Finch,DM [tech. coord.]. Desired future conditions for Southwestern riparian ecosystems: Bringing interests and concerns together. USDA Forest Service. General Technical Report RM-227.

Ecosystem management should be based on the fullest possible knowledge of ecological structures and processes. In prehistoric North America, the involvement of Indian populations in ecosystem processes ranged from inadvertent alteration of the distribution and abundance of species to large-scale management of landscapes. The knowledge needed to manage ecosystems today is incomplete without understanding past human involvement in ecological processes and the adjustments of ecosystems to human components. Land use processes suggest that there were periods of significant prehistoric disturbance to both upland and valley ecosystems. [HUMAN IMPACTS; LAND USE; PREHISTORIC DISTURBANCE; RIPARIAN HABITAT]

1692. Tallent-halsell,NG; walker,LR (1997): goodding willow ecology in manmade southwestern riparian ecosystems. p.194. Abstracts. 1997 Annual meeting of the Ecological society of America jointly with The Nature Conservancy. 10-14 August 1997. Albuquerque, NM.

Manmade riparian ecosystems in the southwest are adversely affected by water level fluctuations, increased soil salinization, and interspecific competition. Most Goodding willows were found in monospecific stands where individuals were the same height, suggesting cloud reproduction. Survival depends on their ability to withstand 10 months of inundation a year. Invasion of salt-cedar into adjacent willow stands is restricted by the lower flood tolerance of salt-cedar. Results suggest that shifting the water level cycle to correspond to the natural reproductive cycle of the willow may favor establishment of seedlings and artificial cuttings and 
may also increase interspecific competition from saltcedar.

[FLOOD IMPACTS; RIPARIAN VEGETATION; SALT-CEDAR; WATER LEVELS; WILLOW]

1693. Tank,JL; Webersr,JR 1998): Interaction of substrate and nutrient availability on wood biofilm processes in streams. Ecology 79(6), 21682179.

The effects of decomposing leaf litter and dissolved inorganic nutrients on the heterotrophic biofilm of submerged wood were examined in streams with and without leaves. Microbial processes on wood in the litter-excluded stream were compared to a reference stream using microbial respiration, fungal biomass, and extracellular enzyme activity. Exclusion of leaf litter enhanced all of those parameters. It was concluded that nutrients are more available for other heterotrophic processes in the absence of nutrient immobilization by leaves.

Competition for nutrients may regulate heterotrophic microbial processes in streams.

[DECOMPOSER FOOD CHAIN; LITTER FALL; MICROBIOLOGY; NUTRIENT CYCLES]

1694. Tarlock,AD (1991): New water transfer restrictions: The West returns to riparianism. Water Resources Research 27(6), 987-994.

Fundamental shifts in water allocation and management are occurring throughout the West. Changing public values have forced the reallocation of existing water supplies. This reallocation can be accomplished in three ways: 1) the rededication of unallocated or unused blocks of storage water on federal and state reservoirs; 2) the voluntary transfer of existing water rights; and 3) the redefinition of existing rights by judicial decisions and legislation which trim consumptive entitlements. Many emerging new watershed rules, which could make all transfers presumptively suspect, and reintroducing the principal of watershed protection in the form of a premise that river systems should be managed on an ecosystem basis.

[WATER ALLOCATION; WATER QUALITY; WATER RIGHTS; WATERSHED]

1695. Taylor,DM (1986): Effects of cattle grazing on passerine birds nesting in riparian habitat. Journal of Range Management 39(3), 254-258.

Nine transects, in areas with different histories of cattle grazing, were established along the Blitzen River in Oregon. Counts of birds and measurements of vegetation were made in the summers of 1981 and 1982. Increased frequency of grazing on an annual basis correlated significantly with decreases in bird abundance, shrub volume, and shrub heights. Bird abundance increased significantly with increased shrub volume and taller shrub heights. Bird counts were 5 to 7 times higher on an area ungrazed since 1940 than on two areas grazed annually until 1980 , and 11 to 13 times higher than on a transect severely disturbed by extensive grazing and dredging activities.

[AVIFAUNA; GRAZING IMPACTS; RIPARIAN HABITAT]

1696. Taylor,GB; Barnes,JA; Van Lear,DH (1996): Impacts of beavers (Castor canadensis carolinensis) on riparian ecosystems, water quality, and trout habitat in the Chauga River drainage. p.534-535. In: Proceedings of the Society of American Foresters national convention. Indianapolis, IN. 7-10 November 1993.

The Chauga River is located in the extreme northwestern corner of South Carolina, and represents the lower end of southern Appalachian trout habitat. Beaver have impacted, to varying degrees, 60 percent of 62 inventoried streams in the Chauga river drainage. A study was conducted to determine the effects of beaver on riparian ecosystems, water quality, and trout habitat. Beaver, through their herbivory and dam building, have significantly altered riparian forests and aquatic ecosystems to the detriment of trout habitat within the Chauga drainage.

[BEAVER; RIPARIAN HABITAT; TROUT; WATER QUJALITY]

1697. Teaford,JW (1986): Beaver pond management. Section 5.5.2 in: US Army Corps of Engineers wildlife resources manual.

Environmental Impact Research Program.

Technical Report EL-86-10. 10 p.

Ponds created by beavers satisfy many needs for waterfowl, such as habitat for nesting, roosting, resting, and foraging. Therefore, these ponds provide many opportunities for waterfowl management. This report describes a technique for drainage ponds and planting Japanese millet, which has been widely used in the South. Also provided are recommendations for evaluating potential management sites, constructing and installing drainage structures, planting, and reflooding. [AVIAN ECOLOGY; BEAVER; RIPARIAN HABITAT; WATERFOWL MANAGEMENT]

1698. Technical riparian Work Group. (1992): 
Integrated riparian evaluation guide. USDA

Forest Service. Intermountain Region. 60 p.

The guide presents an integrated approach for: a) stratifying and classifying riparian areas according to their natural inherent characteristics and conditions; b) data collection; c) evaluation of riparian areas; d) future development and linkage of a riparian database; e) preparation of a written narrative to interpret the data and suggest management applications; f) providing a process to prioritize or rank riparian areas based on management objectives; and $g$ ) strengthening the riparian management implications of the Forest Land Management Plan. [CLASSIFICATION; EVALUATION; RIPARIAN HABITAT]

1699. Teskey,RO; Hinkley,TM (1977): Plant and soil responses to flooding. Volume 1 in: Impact of water level changes on woody riparian and wetland communities. USDI Fish and Wildlife Service. OBS-77/58. 30 p.

This is a scientific literature review detailing the impact of water level changes on growth and development of important riparian and wetland trees and shrubs and describing physiological mechanisms. It applies to all geographic areas in the contiguous 48 states.

[FLOOD IMPACTS; RIPARIAN HABITAT; SOILS]

1700. Theurer,FD; Lines,I; Nelson, T (1985): Interaction between riparian vegetation, water temperature, and salmonid habitat in the Tucannon River. Water Resources bulletin 21(1), 53-64.

This analysis relates physical process, ecological, and economic models to: 1) analyze the instream water temperatures with respect to existing and proposed riparian vegetation under natural conditions; 2) use these water temperatures to determine salmon and steelhead fish populations that were based upon field count and known temperature preference data; and 3) determine the economic worth based upon the estimated carrying capacity of the river, the estimated number of return spawners, and the economic value of commercially caught and sport caught salmon and steelhead.

[FISHERIES; RIPARIAN HABITAT; RIPARIAN VEGETATION; STREAM TEMPERATURE; WATER QUALITY]

1701. Thomas, AE (1986): Seen a riparian area lately? Good ones are green! P. 8-9. In: Inside Idaho. April ed. USDI Bureau of Land
Management., Idaho State Office, Boise, ID.

Riparian areas are very important to a variety of wildlife, livestock, watershed, and recreation values. Their condition affects stream profiles (width, depth, etc.), water temperature through shading, food supplies for fish, and sediment control. These factors influence numbers, size, species present, and general health of fish in the stream. Wildlife species, from raptors to big game to small rodents, make heavy use of riparian areas for either seasonal or permanent homes, as migration routes, or for casual visits. Less than 0.6 percent of public land in Idaho can be considered riparian, of which over 80 percent appear to be in some stage of degradation.

[GRAZING IMPACTS; RIPARIAN

VEGETATION]

1702. Thomas, AE (1986): Riparian protection/ enhancement in Idaho. Rangelands 8(5), 224-227.

This paper describes a "pilot" riparian management program on public land in Idaho. The fundamental strategy involves the elimination of problem-causing factors from riparian systems. The latter could include ribbon fencing, temporary exclusion of livestock, revegetation, and bank stabilization.

[GRAZING IMPACTS; RIPARIAN

ENHANCEMENT; RIPARIAN RESTORATION]

1703. Thomas, AE (1987): Idaho riparian management, aquatic protection and enhancement program. USDI Bureau of Land Management Technical Bulletin 87-3 (A\&B). Idaho State Office. Boise, ID.

A compilation of statewide information regarding riparian areas and riparian projects being administered by all field offices in Idaho. This report also describes riparian restoration and enhancement efforts that are planned or in progress.

[RIPARIAN ENHANCEMENT; RIPARIAN RESTORATION]

1704. Thomas,AE; Wentzell,C (1986): A bibliography of riparian topics with emphasis on the Intermountain West. Technical Bulletin 86-4. USDI Bureau of Land Management. Idaho State Office. Boise, ID. 69 p.

A bibliography of current literature in the field of riparian management, which is available from Idaho State Office, BLM. [BIBLIOGRAPHY; BLM; RIPARIAN HABITAT; RIPARIAN MANAGEMENT ZONE]

1705. Thomas,JW; Maser,C; Rodiek,JE (1979): 
Edges. In: Wildlife habitats in managed rangelands -- The great basin of southeastern Oregon. USDA Forest Service. Portland, OR. General Technical Report PNW-189.

Edge can be a measure of overall diversity of any area. Diversity is considered as inherent (community/community) edge, induced (successional stage/successional stage) edge and total edge. Size of stands are related to expected wildlife diversity. [BIODIVERSITY; RANGE MANAGEMENT; RIPARIAN HABITAT]

1706. Thomas,JW; Maser,C; Rodeik,JE(1979): Riparian zones in managed rangelands - Their importance to wildlife. In: Cope, $\mathrm{OB}$ [ed.]. Forum - Grazing and riparian/stream ecosystems. 3-4 November 1978. Denver, CO. Trout Unlimited, Inc.

This paper is a modification of Thomas et.al (1979) which dealt with riparian zones in managed forests and has been modified here to apply to riparian zones in managed rangelands.

[RANGE MANAGEMENT; RIPARIAN HABITAT]

1707. Thomas,JR; Maser,C; Rodiek,JR (1979): Riparian zones. In: Wildlife habitats in managed rangelands - The Great Basin of southeastern Oregon. USDA Forest Service. General Technical Report PNW-85.

Riparian zones are the most critical wildlife habitats in managed rangelands. More wildlife species depend entirely on or spend disproportionately more time in this habitat than any other. The zone is also disproportionately important for grazing, recreation, timber production, fisheries production, road location, and water quantity and quality. In this report, the importance of wildlife is examined and guidance given for management. [RIPARIAN HABITAT]

1708. Thomas,JW;Maser,C; Rodiek,JE (1979): Riparian zones. p.40-47. In: Thomas,JW [ed.]. Wildlife habitats in managed forests - The Blue Mountains of Oregon and Washington. USDA Forest Service. Agriculture Handbook 553.

Riparian zones can be identified by the presence of vegetation that requires free or unbound water or conditions that are more moist than normal. Riparian zones can vary considerably in size and vegetative complexity because of the many combinations that can be created between water sources and physical characteristics of a site. Such characteristics include gradient, aspect, topography, soil, type of stream bottom, water quality, elevation, and plant community. In the Blue Mountains of Oregon, riparian zones: 1) create well-defined habitat zones within the much drier surrounding area;2) they make up a minor proportion of the overall area; 3) they are generally more productive in terms of biomass; and 4) they are a critical source of diversity within the ecosystem.

[RIPARIAN HABITAT]

1709. Thompson,DQ (1991): History of Purple Loosestrife (Lythrum salicaria L.) Biological control efforts. Natural Areas Journal 11(3), 148 p.

After a relatively slow beginning on the northeastern maritime coast, purple loosestrife has spread across temperate North America to the Pacific Coast. It has displaced native wetland vegetation in pastures, marshes, and riparian meadows. Thus far, all methods of cultural, mechanical, and chemical controls have proven unsatisfactory for use in natural areas. Since 1968, the beginnings of a purple loosestrife monitoring network have succeeded in obtaining congressional support for the biological control of purple loosestrife.

[BIOLOGICAL CONTROL; EXOTICS; NATURAL AREAS; PURPLE LOOSESTRIFE; RIPARIAN HABITAT; WETLANDS]

1710. Thompson,J; Votk,K; Knapp,C (1994): Trapper Creek aquatic and riparian restoration project. p.169-171. In: Summit showcase displays and ecosystem case studies. USDI Bureau of Land Management Summit. Incline Village, NV. April 1994.

Loss of riparian vegetation along Trapper Creek in western Colorado has resulted in high summer water temperatures, increased width:depth ratios and a lower water table. Colorado cutthroat trout are now found only in lower reaches where steep canyon walls provide shade and deeper channels. This report describes a partnership between BLM and Trout Unlimited, Inc. to rehabilitate the stream channel. Volunteers to date have contributed over 1,000 hours of labor to this project.

[COLLABORATION; RIPARIAN; RIPARIAN RESTORATION; VOLUNTEERS]

1711. Thompson,WH; Ehrhart,RC; Hansen,PL; Parker,TG; Haglan,WC (1998): Assessing health of a riparian site. p.3-12. In: Potts,DF [ed.]. Rangeland management and water resources. Proceedings of the AWRA specialty conference. American Water Resources Association, 27-29 May 1998. Reno, NV. 
Current assessment capability quantifies values that indicate the ability of a riparian system to function. Quantities are weighted to yield a comparative rating. The evaluation can be used to: 1) assess present functional health of a stream segment; 2) identify factors needed for remedial attention; and 3) monitor effectiveness of management change. The method can be used to evaluate a $200 \mathrm{~m}$ stream segment in about 2 hours. It does not require precise measurements, but relies on visual estimation of nine readily observable features.

[EVALUATION; MONITORING; RIPARIAN HEALTH; RIPARIAN MANAGEMENT ZONE; TREND]

1712. Thomson, BL (1987): Land use conflicts in riparian habitats, the British Columbia Interior. Streamside management: Riparian wildlife and forestry interactions. An interdisciplinary symposium. 11-13 February 1987. University of Washington. Seattle, WA.

In the British Columbia southern interior, naturally scarce riparian vegetation has been permanently lost to settlement and road and rail construction. Riparian vegetation is also continually disturbed by agricultural and forestry activities. Lack of planned management actions in past developments in riparian areas has led to the degradation of those sites and has severely impacted wildlife populations. [CONFLICT RESOLUTION; RIPARIAN HABITAT]

1713. Thorn,CE; Darmody,RD (1985): Grainsize distribution of the insoluble component of contemporary eolian deposits in the alpine zone, Front Range, Colorado. Arctic and alpine Rescarch 17(4), 433-442.

Grain-size parameters were used to describe the character of eolian in-fall to the alpine zone of the Indian Peaks section of the Colorado Front Range. In general, the upper valley, although to the Continental Divide, received finer material than the lower valley. Although the samples exhibited the same local, mesoscale variability, this appears to be secondary and the emergent picture in study years was of a thoroughly homogenized, silt rich deposit of relatively uniform grain-size falling onto the entire alpine zone.

[GEOLOGY; GEOMORPHOLOGY; SOILS]

1714. Thornburg, $T$ (1993): Verde River corridor project. p.397-401. In: Tellman,B; Cortner,JH; Wallace,MG; DeBano,LF; Hamre, RH [tech. coord.]. Riparian management: Common threads and shared interests. USDA Forest service. General Technical Report RM-226.

The Verde Watershed Association was established on January 19, 1993, at a conference in Prescott, Arizona. Arizona State Parks staff were involved as facilitators only. The association is the result of local individuals and groups, not state or federal agencies, and is a consensus-based organization. It will oversee the development of a coordinated river corridor manlagement strategy. [RIPARIAN HABITAT; RIPARIAN MANAGEMENT ZONE; RIVER ECOLOGY]

1715. Thorne,CR (1981): Field measurements of rates of bank erosion and bank material strength. p.503-512. In: Proceedings of the Florence symposium: Erosion and sediment transport measurement. IAHS Publication No. 133.

Traditional and new methods of monitoring rates and locations of bank erosion are reviewed. These range from detailed measurements using erosion pins to large scale studies using aerial photos and maps. It is shown that ideally bank erosion should be studied using on-site measurements for detailed erosion data and remote sensing information for large scale and long-term data. Techniques for the evaluation of soil erodability and shear strength are reported. Particular attention as paid to new approaches being developed in the U.S. and to new instruments such as borehole shear tester and unconfined tension tester. [GEOMORPHOLOGY; SEDIMENTATION; STREAMBANK PROTECTION; TECHNIQUES]

1716. Thorne,CR; Tovey,KN (1981): Stability of composite river banks. Earth Surface Processes and Landforms 6, 469-484.

The stability of a river bank depends on the balance of forces, motive and resistive, associated with the most critical mechanism of failure. Many mechanisms are possible and the likelihood of failure occurring by any particular onc depends on the size, geometry and structure of the bank, the engineering properties of the bank material, the hydraulics of flow in the adjacent channel and climatic conditions. Rivers flowing through alluvial deposits often have a composite structure of cohesionless sand and gravel overlain by cohesive silt/clay. Bank erosion occurs by fluvial entrainment of material from the lower, cohesionless bank at a much higher rate than material from the upper, cohesive bank. This leads to undermining that produces cantilevers of cohesive material. Upper bank retreat takes place predominantly by the failure of these cantilevers. Three mechanisms of failure have been identified: 
shear, beam, and tensile failure.

[GEOMORPHOLOGY; SEDIMENTATION; SEDIMENT TRANSPORT; SOILS; STREAMBANK STABILITY]

1717. Thorne,CR; Zevenbergen,LW (1984): Estimating mean velocity in mountain rivers. Hydraulic Engineer. 111(4), 612-624.

It is often necessary to estimate the mean velocity in ungaged mountain rivers, but the flow resistance equations available for this purpose require further testing and development. Such rivers are characterized by coarse bed materials, steep slopes, and low depths. Three equations were recently developed that are specifically intended for large scale roughness and applied to this problem. The errors were systematic and the equations all tended to overestimate mean velocity compared to observed values. Further research is required.

[CHANNEL DYNAMICS; HYDROLOGY; MODELING]

1718. Thorne,CR (1982): Processes and mechanisms of river bank erosion. In: Gravel bed rivers. [Eds: Hey,RD; Bathurst,JC; Thorne,CR]. John Wiley and Sons Ltd. New York, NY, 227271.

The importance of bank erosion to channel hydraulics and sedimentary processes makes it appropriate that a review and investigation of the way in which a river erodes its banks should be undertaken. It is necessary to consider the processes responsible for the erosion of material from a bank and the mechanisms of failure resulting from the instability created by those processes. Erosional processes fall into two groups: fluvial entrainment, and sub-aerial/sub-aqueous weakening and weathering. Usually it is particular combinations of processes which are the most effective in causing erosion. Mechanisms of failure depend on the size, geometry, and structure of the bank and the engineering properties of bank material. Mechanical bank failures provide supply material to the toe. Its removal from there depends on fluvial entrainment. The balance between rates of supply and removal may be described by the state of basal endpoint control.

[CHANNEL DYNAMICS; GEOMORPHOLOGY; SEDIMENTATION; STREAMBANK PROTECTION]

1719. Thurow, R; King,J (1989): Effects of fine sediment on fish populations. p.49-56. In: Proceedings of the third federal intraagency sedimentation conference. March, 1989. Las Vegas, NV. Federal Encrgy Rcgulatory Commission.

The authors cvaluated the particle size distribution of egg pockets, redd pits, and tail-spills, artificially constructed redds, and undisturbed substrate outside redds. Egg pockets were located in upper strata an average of $14.9 \mathrm{~cm}$ below the substrate surface. Egg pockets contained fewer fines $(<6.35 \mathrm{~mm}$ ) than other sites. except in artificial redds. As substrate depth increased, percent fines tended to increase at all sampling sites and variability in percent fines among sites was reduced. They observed no change in percent fines sampled from May to July, except in cleaned intrusion sites where free interstitial areas rapidly accumulated sediments. Dissolved oxygen levels declined in redds during incubation.

[FISHERIES; RIPARIAN HABITAT; SEDIMENTATION]

1720. Thurow, RF (1994): Underwater methods for study of salmonids in the Intermountain West. USDA Forest Service. General Technical Report INT-GTR-307. $28 \mathrm{p}$.

This guide describes underwater methods using snorkeling gear to study fish populations in flowing waters of the Intermountain West. It outlines procedures for estimating salmonid abundance and habitat use and provides criteria for identifying and estimating the size of fish underwater.

[ANADROMOUS FISH; HABITAT MANAGEMENT; POPULATION DYNAMICS; RIPARIAN HABITAT]

1721. Thurow,RF; Lee,DC; Rieman,BE (1997): Distribution and status of seven native salmonids in the interior Columbia River Basin and portions of the Klamath River and Great Basins. North American Journal of Fisheries Management 17, 1094-1110.

The composition, distribution, and status of fishes within the study area is very different than it was historically. Although several of the salmonid taxa are distributed throughout their polential range, declines in abundance and distribution and fragmentation into smaller patches are apparent for all forms. None of the salmonid taxa have known or predicted strong populations in more than 22 percent of their potential ranges, with the exception of Yellowstone cutthroat trout. If current indicators of the taxa are useful indicators, many aquatic systems are remnants of what were larger and more complex, diverse, and connected systems. 
[FISH POPULATIONS; FISHERIES; RIPARIAN HABITAT]

1722. Tiedemann,AR; Helvey,JD; Anderson,TD (1978): Stream chemistry and watershed nutrient economy following wildfire and fertilization in eastern Washington. Journal of Environmental Quality 7(4), 580-588.

During the first 3 years after severe wildfire, maximum concentrations of nitrate- $\mathrm{N}$ in stream water increased from pre-fire levels of $<0.016$ to 0.56 $\mathrm{mg} /$ liter on a burned, unfertilized watershed and to 0.54 and $1.47 \mathrm{mg} /$ liter on two watersheds that were burned and fertilized. Increased levels appear to be primarily a result of increased nitrification. Organic $\mathrm{N}$ concentration in streamflow was nearly doubled during the second year after fire compared to pre-fire levels. Relative to the background conditions and levels observed in the control stream, the fire exerted protracted impacts on the chemistry of these streams. Results, however, indicate that fire and fertilization exerted negligible results on chemical water quality for municipal use.

[FIRE IMPACTS; NUTRIENT CYCLES; WATER QUALITY; WATERSHED]

1723. Tiedemann,AR; Higgins,DA; Quigley,TM; Sanderson,DB; Marx,HR (1987): Responses of fecal coliform in stream water to four grazing strategies. Journal of Range Management 40(4), 322-329.

Concentration and loadings (output, number day(-1) $\mathrm{km}(-2)$ ) of fecal coliform (FC) indicator bacteria were measured from 1979 through 1984 in stream-flow from 13 forested watersheds under the following range management strategies: (A) no grazing; (B) grazing without management for livestock distribution; (C) grazing with management to obtain livestock distribution; and (D) grazing with management to obtain livestock distribution and cultural practices to increase forage. Both FC concentrations (number $/ 100 \mathrm{ml}$ ) and instantaneous loadings differed significantly among strategies, seasons, and water years. Differcnces among strategies for mean concentrations were $\mathrm{A}<\mathrm{C}=\mathrm{B}<\mathrm{D}$. For instantaneous loadings, significant differences were $\mathrm{A}<\mathrm{C}, \mathrm{B}$ or $\mathrm{D}$; and $\mathrm{C}<\mathrm{D}$. FC concentrations were the same for winter and for snow-melt runoff seasons but concentrations of both were significantly lower than during the summer period. Loadings were different for each season with winter<summer<snowmelt runoff. A definite relationship was established between the presence of cattle on the pastures and FC concentrations.
Elevated FC counts in strategy D watersheds and loadings in excess of $10(8)$ organisms day $(-1) \mathrm{km}(-2)$ in the winter season provide evidence that organisms live into and through the winter period in animal feces, sediment, and soil. Results provide evidence that livestock removal may not provide an immediate solution to elevated levels of FC in stream-water. [COLIFORM BACTERIA; GRAZING IMPACTS; NON-POINT SOURCE POLLUTION; WATER QUALITY]

1724. Tiedemann,AR; Higgins,DA; Quigley,TM; Sanderson,HR (1989): Stream chemistry responses to four range management strategies in eastern Oregon. USDA Forest Service. Research Paper PNW-RP-413. Portland, OR. 9 p.

Four grazing management strategies, implemented as part of the Oregon Range Evaluation Project, are described. Nitrate-N, PO4, Ca, Mg, K and $\mathrm{Na}$ levels and $\mathrm{pH}$ were monitored in streamwater. Grazing systems/strategies included seasonlong/no distribution management ( $8.2 \mathrm{ha} / \mathrm{AUM})$, deferred rotation/uniform pasture use (7.7 ha/AUM), deferred rotation/intensive management with pasture improvement (2.8 ha/AUM), and rest rotation/intensive management with pasture improvement ( 2.8 ha/AUM).

[GRAZING IMPACTS; GRAZING TREATMENTS; RIPARIAN FOREST; WATER QUALITY]

1725. Tiedemann,AR; Quigley,TM;

Anderson, TD (1988): Effects of timber harvest on stream nutrient chemistry and dissolved nutrient losses in northeast Oregon. Forest Science 34(2), 344-358.

The study examined stream-water nutrient levels before and after partial clear-cut of Pacific Northwest watersheds. The maximum treatment was clear-cut of 41 percent of the watershed area in two blocks ( 3.6 and 8.5 ha), machine piling and burning of slash with machine scatter of unburned slash. For another watershed, 17 percent of the area was clear-cut in two small blocks ( 0.8 and 2.4 ha). A selective harvest was performed in a third watershed and no harvest in the fourth control watershed.

[LOGGING IMPACTS; RIPARIAN FOREST; WATER QUALITY]

1726. Tiedemann,RB (1988): Development and use of a wetland bank as a mitigation alternative in Idaho. p.55-60. In: Mutz,KM; Cooper,DJ; Scott,ML; Miller,LK [eds.]. Restoration, creation, and management of wetland and riparian ecosystems in the American West. A symposium of 
the Rocky Mountain Chapter of the Society of Wetland Scientists.

Wetlands restoration is, at times, impossible to accomplish on-site, comes with such risk that successful mitigation cannot be assured, or can only be accomplished at extraordinary cost. Use of a previously constructed, off-site wetland may be appropriate in these situations to compensate for wetland losses. This paper documents the development of the wetland banking system in Idaho and the consensus building which has led to a memorandum of agreement with all resource and regulatory agencies with a statutory interest in wetland issues. The Idaho effort is the first to enlarge the scope of wetland banking to an entire state and to all the activities of an single agency (Idaho Transportation Department). [RIPARIAN RESTORATION; WETLAND MITIGATION BANKING; WETLANDS]

1727. Tilley,LJ; Slack,KV; Kennelly,SS (1991): Transport of invertebrates and detritus in streams. p.9-17. In: Proceedings of the fifth federal intraagency sedimentation conference. 1821 March 1991. Las Vegas, NV.

Stream sediment includes living and non-living particulate organic matter along with inorganic particles. I iving organisms range in size from bacteria to large plants and animals. Non-living organic matter is mostly of plant origin. Drift, the downstream movement of invertebrates in the water column is a universal feature of streams and an important component of suspended particulate organic matter. Drift samples, usually collected with nets, contain the invertebrates along with the organic and inorganic particles collectively termed detritus. Particulate organic matter is important to stream ecosystem functioning, and is also involved in the transport and fate of plant nutrients, trace metals, pesticides and other substances. This study describes sampling techniques and the factors affecting drift and detritus abundance in Rocky Mountain streams. [FISHERIES; INVERTEBRATES; ORGANIC DEBRIS; RIPARIAN HABITAT; SEDIMENTATION]

1728. Tiner,RW (1990): Use of high altitude aerial photography for inventorying forested wetlands in the United States. Forest Ecology and Management 33/34, 593-604.

The USDI Fish and Wildlife Service is conducting an inventory of the wetlands of the US through its National Wetlands Inventory Project (NWI). The project selected high-altitude aerial photography $(1: 40,000$ to $1: 130,000$ scale $)$ as its primary data source. Stereoscopic interpretation of this photography is an efficient and cost-effective method for identifying, classifying, and inventorying wetlands on a national, state, or regional level. [AERIAL PHOTO; INVENTORY; RIPARIAN HABITAT; WETLANDS]

\section{Tiner, RW (1991): The concept of a} hydrophyte for wetland identification. BioScience 41(4), 236-246.

Existence of wetland ecotypes lacking distinguishing morphological characteristics to separate them from the typical species and the broad ecological amplitude or wide wetness tolerance of many species make it difficult to rely on plant community composition to identify many wetlands and delineate their boundaries. Consequently, evaluation of soil properties and other hydrological characteristics are essential to accurate identification and delineation of wetlands.

[HYDROPHYTES; PLANT COMMUNITIES; RIPARIAN HABITAT; SOILS; WETLANDS]

1730. Tiner,Jr.,RW (1988): Agricultural impacts on wetlands in the northeastern United States. p.914. In: Stuber,PJ [tech.coord.]. Proceedings of the national symposium on protection of wetlands from agricultural impacts. 25-29 April 1988. Ft. Collins, CO. USDI Fish and Wildlife Service. Biological Report 88(16).

Despite its reputation as a highly industrialized region, the northeastern U.S. is mostly farmland and forests. Consequently, the agricultural impacts to wetlands are more significant than commonly thought. Available information about these impacts is presented.

[AGRICULTURAL IMPACTS; RIPARIAN

HABITAT; WETLANDS]

1731. Todd,AH (1996): Watershed

rehabilitation: A program for Lake Tahoe. p.178186. In: National hydrology workshop proceedings. 27 April - 1 May 1992. Phoenix, AZ. USDA Forest Service. General Technical Report RM-GTR-279.

Watershed rehabilitation has been recognized as a critical element in the programs needed to improve the quality of Lake Tahoe's waters. Erosion control and restoration needs in the Lake Tahoe Basin have been estimated at over $\$ 300$ million on urban and forest lands. The USDA Forest Service developed a comprehensive watershed rehabilitation program for forest land in approximately 1980 and has since 
completed projects on over 3,000 acres of disturbed slopes and stream zones. The program includes holistic watershed problem inventories, cooperative fisheries/stream zone rehabilitation projects, retrofit of forest facilities and roads, harsh site revegetation, $\mathrm{KV}$ and mitigation projects, and erosion control monitoring. Program success stems from institutionalizing the Forest commitment to watershed rehabilitation in the planning/budget process, and the involvement of partners and support groups.

[PARTNERSHIPS; RIPARIAN RESTORATION; WATERSHED]

1732. Todd,PA (1992): Mountain beaver habitat use and management implications in Yosemite National Park. Natural Areas Journal 12(1), 2631.

Sierra Nevada mountain beavers were studied in Yosemite National Park, California to describe current and historic distributions and habitat use, and to evaluate the need for state or federal protection. A survey of eight riparian areas, each $15 \mathrm{~km}$ long, conducted during the summers of 1988 and 1989 indicated that distribution has changed over the past 100 years partly from human impacts. Development pressures have impacted several active sites. Four variables characterizing mountain beaver habitat, which may be useful in distinguishing potential habitat, were shrub and herbaceous plant abundance, stream depth, and stream gradient. Techniques used in this investigation may be applicable to species of concern in other natural areas.

[BEAVER; CLASSIFICATION; NATURAL AREAS; RIPARIAN HABITAT]

1733. Todd,R; Buckhouse,JC (1998): Management effects on water temperatures in the Sprague River water. p.440. In: Potts, DF [ed.]. Range management and water resources: Proceedings of the AWRA specialty conference. American Water Resources Association. 27-29 May 1998. Reno, NV.

Tributaries to the Sprague River in Oregon provide irrigation water to irrigated mountain meadows which support seasonal catle grazing. Temperature data were collected above and below these diversions at selected grazed and forested stream reaches. Collected data suggest that ambient air temperatures were more significant than management activities in influencing stream temperature. Water temperatures of return flows were not significantly higher than main channel temperatures. Temperatures mostly exceeded Oregon water quality standards. Proper management may result in beneficial effects on stream temperatures. [GRAZING IMPACTS; RANGE MANAGEMENT; STREAM TEMPERATURE; WATER QUALITY]

\section{Toliver,J (1993): What are wetlands?} Journal of Forestry 91(5), 12-14.

Managers, scientists, and administrators must play an important role in the future of wetland forests. The official policy of the U.S. EPA is no net loss of wetlands area in the U.S. Riparian zones have their greatest value as buffers and filters between urban and agricultural developments and our most vital life support - water. Preservation of public riparian rights provides an effective hedge against over-development of urban sprawl and agriculture or forest monoculture.

[HUMAN IMPACTS; RIPARIAN HABITAT; RIPARIAN ZONES; WETLANDS]

1735. Toliver,JR (1996): Multiple use values of forested wetlands - policy and management implications. p.168-173. In: National hydrology workshop proceedings. 27 April - 1 May 1992. Phoenix, AZ. USDA Forest Service. General Technical Report RM-GTR-279.

Applying "normal silvicultural activities" through state-of-the-art "Best Management Practices" is crucial to maintaining and enhancing the multipleuse benefits and values of forested wetlands. The 1977 Clean Water Act permitting normal silvicultural activities or practices in forested wetlands allows managers the opportunity to manage these wetlands for values such as timber, wildlife habitat, and clean water. Silvicultural practices and how they are applied to maintain or enhance the multiple-use benefits of forested wetlands are discussed. [BEST MANAGEMENT PRACTICES; CLEAN WATER ACT; FORESTRY MANAGEMENT; RIPARIAN HABITAT; WETLANDS]

1736. Tremble,M (1993): The Littlc Colorado River. p.283-289. In: Tellman,B; Cortner,HJ; Wallace,MG; DeBano,LF; Hamre,RH [tech. coord.]. Riparian management: Common threads and shared interests. USDA Forest Service.

\section{General Technical Report RM-226.}

Issues of scale have received increased attention from the scientific community. In effective riparian management planning, organizational and cultural perspectives must also be considered. The author addresses differences between the Navajo world view and mainstream Anglo world view and cites problems arising from those differences. Managers 
need to address problems or goals by examining processes that operate over many spatial and temporal scales.

[ENDANGERED SPECIES ACT; PLANNING; RIPARIAN HABITAT; WETLANDS]

1737. Tribe,S; Church,M (1999): Simulations of cobble structure on a gravel streambed. Water Resources Research 35(1), 311-318.

The authors present a two-dimensional, time dependent, kinematic simulation of a gravel streambed that models impacts between clasts as elastic collisions without momentum transfer between discrete, circular discs. The basic algorithm causes simulated stones to cluster into longitudinal structures that resemble such gravel bed forms as imbricate clusters and cluster bed forms. A modified algorithm incorporating programming rules such as stone rotation, entrainment probability inversely proportional to stone size, and the shielding effects of neighbors causes simulated stones to cluster into structures that resemble transverse ribs. The number of stones seems to have the most control on the development of an extended surface structure. [MODELING; STREAMBEDS]

1738. Triquet,AM; McPeek,GA; McComb,WC (1987): Songbird diversity in clear-cuts with and without a riparian buffer strip. Journal of Soil and Water Conservation 42: 500-503.

The following community parameters were monitored on four watersheds in 1983 and 1986; equitability, richness, and diversity. Parameters were similar among all watersheds before treatment of two with different harvest methods in 1983. Bird abundance increased 21 percent and 23 percent on the two clear-cuts during the second growing season after cutting. Bird species richness and bird diversity were highest on an uncut control area of mature forest and a best management practices harvest unit with a riparian buffer strip. Bird diversity and species equitability were lowest on a logger's choice unit with no buffer strip. Clear-cutting with best management practices provided habitat for some species of mature forest birds that logger's choice clear-cutting did not.

[AVIAN ECOLOGY; BEST MANAGEMENT PRACTICES; BUFFER ZONES; LOGGING [MPACTS」

1739. Triska,FJ (1984): Role of wood debris in modifying channel geomorphology and riparian areas of a large lowland river under pristine conditions: a historical case study. Verhandlung
Internationale Vereinigung Limnologie 22(3), 1876-1892.

The author reviewed historical records to estimate the impact of woody debris on a $400-500$ $\mathrm{km}$ reach of the Red River, Louisiana. In a primal condition, the banks consisted of unstable alluvial deposits which were easily eroded. Sediment and riparian trees formed trees from eroded banks formed organic debris dams which blocked the channel and promoted channel aggradation. At one time, exposed wood covered $80-120 \mathrm{~km}$ of channel. Adjacent riparian areas were impacted by flooded forests and a series of large lakes were formed. After removal of organic debris, the most recently formed lakes drained over a period of 30 years. Wood debris reduced the river's width from $185 \mathrm{~m}$ to approximately $40 \mathrm{~m}$ and aggraded the river bed to a maximum of $7 \mathrm{~m}$. Tributary channels were dammed or tilled with organic debris and the river was permanently opened to navigation in 1873. By the early 1900's, dam and snag removal, levees, dredging and removal of bank-side trees resulted in a cleared, meandering channel, which might today be mistaken as typical of a pristine lowland river.

¿CHANNEL MORPHOLOGY; GEOMORPHOLOGY; HISTORIC RECORDS; RIPARIAN ECOLOGY]

\section{Troendle,CA; King,RM (1987): Effect of} partial and clear-cutting on stream-flow at Deadhorse Creek, CO. Journal of Hydrology 90, 145-157.

Two subalpine sub-drainages were used to demonstrate the comparable impact on water yield of two tree harvesting practices. Thirty six percent of one subdrainage was clear-cut commercially using five-tree height circular openings. In contrast 40 percent of the basal area of the other subdrainage was removed by partial cutting in the first step of a threestep shelterwood cut. Annual flow and peak flow from the clear-cut watershed were increased significantly. The partial cut resulted in a significant in total water equivalent in the winter snow-pack and an apparent increase in total annual streamflow that was comparable to the clear-cut.

[HYDROLOGY; LOGGING IMPACTS; STREAM FLOW]

1741. 'Tubbs,AA (1980): Riparian bird communities of the Great Plains. p.419-433. In: Proceedings: Management of western forests and grasslands for non-game birds. 11-14 February 1980. Salt Lake City, UT. USDA Forest Service. General Technical Report INT-86. 
One hundred thirty six birds utilizing riparian communities in the Great Plains are identified and categorized. Breeding birds restricted to riparian vegetation may outnumber obligates of other grassland communities sevenfold. Grazing, water diversion, land conversion, and wood-harvesting are destructive impacts in the region. Sensitive and decreasing species are discussed. [AVIFAUNA; RIPARIAN HABITAT]

1742. Tucker,TL; Leininger,WC (1987): Livestock grazing affects fish habitat and nongame wildlife populations in a mountainous riparian area. Abstracts of the 40th Annual meeting of the Society for Range Management, Boise, ID.

[FISHERIES; GRAZING IMPACTS; LIVESTOCK EFFECTS; RIPARIAN HABITAT]

1743. Tucker-Schulz, T; Leininger,WC (1990): Differences in riparian vegetation structure between grazed areas and exclosures. Journal of Range Management 43(4), 295-299.

Differences in vegetation structure were examined in a montane riparian zone in north-central Colorado after 30 years of cattle exclusion and continued, but reduced, grazing pressure. In order to assess the changes in the riparian community, canopy coverage, density, and standing crop of riparian species were measured in 1985 and 1986 . Total vascular canopy cover was greater $(\mathrm{P}<0.05)$ in the exclosures as compared to grazed areas, while forb canopy cover was similar $(\mathrm{P}<0.05)$ between treatments. Exclosures had nearly 2 times the litter cover, while grazed areas had 4 times as much bare ground. Willow canopy cover was 8.5 times greater in protected areas than in grazed areas. Kentucky bluegrass cover was 4 times greater in grazed areas than exclosures, while the cover of fowl bluegrass was 6 times greater in protected sites. Mean peak standing crop over two years of the study was 2,410 $\mathrm{kg} / \mathrm{ha}$ in the exclosures and $1,217 \mathrm{~kg} / \mathrm{ha}$ in caged plots within grazed areas. Cattle utilized approximately 65 percent of the current year's growth of vegetation during the 1985 and 1986 grazing seasons.

[EXCLOSURES; GRAZING IMPACTS; RIPARIAN; WILLOW]

1744. Tufford,DL; McKellar,HN,Jr; Hussey,JR (1998): Instream non-point source nutrient prediction with land-use proximity and seasonality. Journal of Environmental Quality 27, 100-111.
This study developed multiple regression models relating land use to in-stream concentrations of total nitrogen (TOTN) and total phosphorous (TOTP) in eight, low-order watersheds. The study area included dominant land-use categories of agriculture, forest, urban, and wetland. Land-use data were obtained from a pre-existing GIS database derived by classification of satellite images. The models partitioned land-use categories according to distance from stream channels using a series of buffer zones around each stream. Effects of point source contributions were removed from observed in-stream concentrations so that non-point source effects could be more clearly delineated. Land close to the stream channel $(<150 \mathrm{~m})$ was a better predictor of nutrient concentrations than land away from the channel. Land use change scenarios (converting forest and wetland to agriculture) support the conclusion that management of stream water quality will be the most effective with emphasis on riparian and adjacent land.

[LAND USE; NON-POINT SOURCE POLLUTION; NUTRIENT CYCLES; RIPARIAN HABITAT]

1745. Tung,YK; Hathhorn,WE (1989):

Determination of the critical locations in a stochastic stream environment. Ecological Monitoring 45, 43-61.

Due to the existence of many uncertainties in a stream environment the determination of the critical location is important. This is complicated by the lack of a universally acceptable definition for critical stream location in a stochastic stream environment. Four potentially usable criteria for defining critical location are discussed. Techniques are presented to find these critical locations.

[HYDROLOGY; MONITORING; WATER QUALITY]

1746. Tupa,M; Olgeirson,E; Stevens,M (1988): Beaver Creek stream relocation and restoration, Beaver Creek Ski Area, Avon, CO. p.112-114. In: Mutz,KM; Cooper,DJ; Scott,ML; Miller,LK [eds.]. Restoration, creation, and management of wetland riparian ecosystems in the American West. A symposium of the Rocky Mountain Chapter of the Society of Wetland Scientists.

This paper describes an interdisciplinary team approach to designing and constructing a stream reach in the central Rocky Mountains. Pooled skills and backgrounds contributed to the overall success of this project.

[RIPARIAN RESTORATION] 
1747. Turner,RE (1988): Secondary production in riparian wetlands. p.491-501. In: Transactions of the 53rd North American wildlife and natural resources conference.

Riparian wetlands have high primary production that is available to consumers, a fluctuating environment, and an aquatic/terrestrial food web or chain, which results in secondary production. Riparian ecosystems, therefore, have more trophic levels per number of trophic links than do nonwetland ecosystems. No apparent large differences were anticipated between the number of trophic species to number of trophic links and mean chain length for wetland and non-wetland ecosystems. Numbers of predator-prey and predator-to-predator links should be lower in wetland than in stable ecosystems. Vegetation canopy of riparian wetlands adds to maximum ecosystem dimension resulting in relatively longer food chains compared to other wetland ecosystems.

[ECOSYSTEM MANAGEMENT; RIPARIAN ECOLOGY; RIPARIAN HABITAT]

1748. Twitchell,M (1987): Fish and wildlife preservation, environmental protection, and the Northwest's electric power system: a panel of views. Anadromous Fish Law Memo, Issue No 42, August 1987.27 p. Natural Resources Law Institute, Lewis and Clark College; Portland, $O R$.

This memo contains edited and footnoted versions of speeches given at the 5th Annual Public Interest Law Conference held in Eugene, Oregon in March 1987. It includes speakers who have been involved with the preservation and restoration of the Northwest anadromous fish runs. Topics covered are: 1) the Northwest Power Act and Indian treaty fishing rights; 2) proposals to expand the Pacific Interstate lines; 3) Federal Energy Regulatory Commission's (FERC) activities; and 4) status of the controversial Winchester Dam on Oregon's North Umpqua River. It concludes with a question and answer session. [FEDERAL ENERGY REGULATORY COMMISSION; INDIAN TREATY FISHING RIGHTS; RIPARIAN HABITAT; WATER LAW]

1749. University of Washington (1987): Streamside Management - Riparian, wildlife interactions. Proceedings of the symposium. College of Forest Resources, University of Washington. 11-13 February 1987. Seattle, WA.

This collection of 28 papers was presented in their original form at a program initiated by the University of Washington's College of Forest Resources and other departments to address the production and protection of forest, fish, and water resources in Pacific Northwest watersheds. [RIPARIAN FOREST; RIPARIAN HABITAT; RIPARIAN MANAGEMENT ZONE]

1750. USDA (1944): The history of western range research. Agricultural History 18, 127-143.

During World War I, there was a patriotic but illadvised expansion of cattle and sheep numbers that failed to accomplish the desired increase in essential livestock products. By 1944, there was a better understanding of the basic principles of range management: proper kind and class of livestock, proper season of grazing, proper distribution of livestock, and proper numbers of animals. Also, by this time, there was general acceptance of conservative grazing standards. Emphasis by this time was turning to range betterment and more economic livestock production, and the application of research to expand that knowledge.

[GRAZING IMPACTS; HISTORIC RECORDS; RANGE MANAGEMENT]

1751. USDA Forest Service (1990): Integrated riparian evaluation guide. Technical riparian work group. Intermountain Region. Ogden, UT. $102 \mathrm{p}$.

The guide provides an integrated approach for: 1) a process to stratify and classify riparian areas according to their natural inherent characteristics, and their respective existing conditions; 2) data collection; 3) evaluation of riparian areas; 4) development and linkage of a riparian data base; 5) preparation of a written narrative to interpret the data and suggest management applications; 6) providing a process to prioritize or rank riparian areas based on management objectives; and 7) strengthening the riparian management implications for Forest Management Plans.

[EVALUATION; MONITORING; RIPARIAN HABITAT; RIPARIAN MANAGEMENT ZONE]

1752. USDA Forest Service, Region 4 (19??): Identification of riparian areas in the planning process. An administrative report. Ogden, UT. [PLANNING; RIPARIAN ZONES]

1753. USDA Soil Conservation Service, Camas Soil Conservation District and USDA Forest Service (1987): Idaho Cooperative River Basin Study: Camas Creek erosion and sediment study. $116 \mathrm{p}$. [RIPARIAN RESTORATION; STREAMBANK STABILITY] 
1754. US Department of the Interior (1992): Wetlands stewardship. 50 p.

Wetlands have crucial ecological values and functions. More than one-third of the threatened or endangered plants and animals in the U.S. utilize wetland habitats during some portion of their life cycle. Wetlands have critical roles in maintaining the hydrology and serving as reservoirs and groundwater recharge areas. They can reduce flood peaks in flood plains by 80 percent. They filter water, maintain water quality, control erosion, and remove pollutants. Wetlands are also vital to the commercial and recreational secturs. This document outlines the plan the USDI has developed to implement the President's wetland goals.

[ECONOMICS; EROSION CONTROL; GROUNDWATER; HYDROLOGY; POLLUTION; WATER QUALITY]

1755. USDI Bureau of Land Management (1975): Birch Creek aquatic habitat management plan. Idaho Falls District Office; Idaho Falls, ID. 86 p.

Birch creek occurs in a closed basin in northeastern Idaho. The water originates from scattered springs in the upper valley and sinks into the Snake River Aquifer in the lower basin elevations. The stream is the life support system for aquatic and terrestrial wildlife, domestic animals, and humans in the basin. Riparian areas and aquatic habitat here have been severely abused. Man has altered the channel and historic overgrazing by livestock has adversely affected vegetation and damaged stream banks. The habitat management plan described was designed to enhance and protect riparian and aquatic habitat.

[EXCLOSURES; GRAZING IMPACTS; SNAKE RIVER; STREAM IMPROVEMENTS]

1756. USDI Bureau of Land Management (1984): Riparian zones -- life support systems of the desert. Arizona Public Lands Update, Special Issue. Phoenix, AZ. BLM Arizona State Office. 4 p.

[RIPARIAN HABITAT; SMZ]

1757. USDI Bureau of Land Management (1985): Riparian aquatic information data summary RAIDS. Division of Resource Systems, Denver Service Center; Denver, CO. 35 p. [INVENTORY; MONITORING; RIPARIAN HABITAT; TECHNIQUES]

1758. USDI Bureau of Land Management (1986): Selected riparian area management strategies for:
Arizona, California, Colorado, Idaho, Montana, Nevada, Wyoming. Unpublished report on file, BLM State Office, Boise, ID. 55 p.

Riparian management strategies for several western states are discussed. Plans for all of the states are similar, calling for inventory of riparian areas, modifying land use plans, and establishing long term monitoring. This was a planning document for riparian pilot projects. Cost estimates are provided in some instances for pilot projects. No management strategies are presented or discussed in detail. This is a general informational riparian planning report. No research data presented. No literature cited.

[MONITORING; RIPARIAN HABITAI']

1759. USDI Bureau of Land Management (1989): Wyoming riparian management activity guide 1989. Bureau of Land Management. Wyoming State Office. Cheyenne, WY. 58 p.

This document presents the Wyoming riparian management strategy for public lands. It provides a listing and description of riparian projects, including planned actions, projects, monitoring, research, training, information transfer, and funding options. [BLM; GRAZING IMPACTS; POLICY]

1760. USDI Bureau of Land Management. (1990): Fish and Wildlife 2000. Annual progress report. Washington, DC. 29p.

This report summarizes those projects implemented under BLM's "Fish and Wildlife 2000 a plan for the future." Planned fish and wildlife projects, including habitat management and restoration, are included.

[BLM; RIPARIAN HABITAT]

1761. USDI Bureau of Land Management. (1991): Riparian-wetlands initiative for the 1990's. BLM/WO/GI-91/001+4340.50 p.

The riparian-wetland initiative for the 1990's provides a blueprint for management and restoration of riparian-wetland areas encompassing 23.7 million acres of BLM lands. Four national goals have been established: 1) restore and maintain riparian-wetland areas so that 75 percent or more are in proper functioning condition by 1997 ; 2) protect riparianwetland areas and associated uplands through proper land management and avoid or mitigate negative impacts 3) ensure an aggressive riparian-wetland information/outreach program; and 4) improve partnerships and cooperative restoration and management processes in implementing the riparianwetland initiative. 
[RIPARIAN MANAGEMENT ZONE; RIPARIAN RESTORATION; RIPARIAN-WETLAND INITIATIVE]

1762. USDI Bureau of Land Management. New Mexico State Office. (1990): New Mexico Riparian - Wetland 2000: A management strategy. Santa Fe, NM.

This document was intended to identify and consolidate planning decisions and to determine the needs for future planning development related to riparian-wetland area resource management. It also identifies issues not addressed in land use plans that may be essential for meeting legal obligations and management prescriptions. Monitoring programs are also proposed including the use of permanent photo points, vegetation transects, and the cyclic collection of large scale aerial photography and other techniques.

[MONITORING; PLANNING; RIPARIAN

MANAGEMENT ZONE; WETLANDS]

1763. USDI Fish and Wildlife Service (1980):

Riparian ecosystems: a preliminary assessment of their importance, status and needs. Eastern Energy and Land Use Team. Kearneyville, WV. 13 p.

A majority of the nation's wildlife, including a relatively large proportion of endangered species, depend on riparian habitats for their survival. Most riparian areas are jeopardized by intensive economic pressures for a variety of alternative land and water uses. As much as 70 to 90 percent of all original riparian communities in the U.S. have already been destroyed. High fish and wildlife values, multiple intrinsic values, and high economic values of natural riparian ecosystems argue for their protection and management. Present conservation efforts have proven to be ineffective.

[RIPARIAN ECOLOGY; RIPARIAN HABITAT]

1764. USDI Fish and Wildlife Service (1980): Summaries of riparian and stream alteration studies completed by the Eastern Energy and Land Use Team. Eastern Energy and Land Use Team and National Water Resources Analysis Group. 38 p.

[RIPARIAN HABITAT; WATER RESOURCE MANAGEMENT]

1765. USDI Fish and Wildlife Service (1980): Stream-side areas --management dividends. Biological Services Program, FWS/OBS-80/55. 10 p.
[MULTIPLE USE; RIPARIAN HABITAT; RIPARIAN VEGETATION]

1766. USDI Fish and Wildlife Service (1990): Wetlands. Meeting the president's challenge. 1990 Wetlands Action Plan. 64 p.

A mandate from the President has prescribed a policy of "no net loss" for the nation's wetlands. The role of the USDI Fish and Wildlife Service in achieving that goal is discussed in detail. [POLICY; RIPARIAN HABII'AT; WETLANDS]

1767. USDI Bureau of Land Management. (1999). Photographic guide to median stubble heights. Idaho BLM Technical Bulletin No. 99-01.

A photographic field guide prepared by the BLM Challis Field Office to provide a practical monitoring tool for determining the stubble heights on riparian areas.

[RIPARIAN VEGETATION; STUBBLE HEIGHT; UTILIZATION]

1768. US Environmental Protection Agency - US Department of Agriculture (1998): Clean water action plan: Restoring and protecting American waters. 89 p.

In the 25 years since the passage of the 1972 Clean Water Act, much progress has been made toward reducing water pollution and restoring waterways. Restoration of water quality has had dramatic benefits but serious problems persist. States report that about 40 percent of their waters do not meet water quality standards. About $1 / 2$ of the nations's over 2,000 major watersheds have serious or moderate water quality problems. This action plan provides a blueprint for restoring and protecting the nation's water resources and proposes aggressive new actions to strengthen the program.

[CLEAN WATER ACT; PLANNING; WATER QUALITY; WATERSHED]

1769. US General Accounting Office. (1988): Public Rangelands. Some riparian areas restored but widespread improvement will be slow. GAO/RCED-88-105: Report to congressional requesters. Washington, DC. 85.

This report examines federal efforts to restore degraded riparian areas on public rangelands, achievements to date, the extent of the problem remaining, and the factors that will impede more widespread progress in the future.

[POLICY; RIPARIAN RESTORATION]

1770. Vale, TR (1975): Pre-settlement vegetation 
in the sagebrush-grass area of the Intermountain West. Journal of Range Management 28(1), 32-36.

A total of 29 journals and dairies were reviewed for their vegetative descriptions of the sagebrushgrass area in an attempt to assess the vegetation conditions in the northern Intermountain West. Early writings suggest that a pristine vegetation was visually dominated by shrubs. Stands of grass apparently were confined to wet valley bottoms, moist canyons, and mountain slopes. Most of the area was covered by thick stands of brush.

[GRAZING IMPACTS; HISTORIC RECORDS; RANGELAND HEALTH]

1771. Valencia,R (1993): Arizona riparian inventory and mapping project. p.242. In: Tellman,B; Cortner,HJ; Wallace,MG; DeBano,LF; Hamre, RH [tech. coord.]. Riparian management: common threads and shared interests. USDA Forest Service. General Technical Report RM-226.

The Arizona Game and Fish Department has initiated a statewide inventory of riparian areas in response to recent legislation and in order to better understand the functions and values of riparian ecosystems in the arid Southwest. [INVENTORY; RIPARIAN HABITAT]

1772. Valiela,D; Whitfield,PH (1989): Monitoring strategies to determine compliance with water quality objectives. Water Resources Bulletin 25, 63-69.

Two sampling techniques designed to test for compliance with water quality objectives were examined. Those objectives based on long-term mean requirements are best met by fixed frequency sampling at frequent intervals. For those objectives based on maximum allowable concentrations, effective sampling strategies increase the likelihood of detecting noncompliance.

[HYDROLOGY; MONITORING; WATER QUALITY]

1773. Vance,L; Tate,K (1998): Assessment of the air-water temperature relationship under differing conditions in several northern California streams. p.439. In: Potts,DF [ed.]. Range management and water resources: Proceedings of the AWRA specialty Conference. American Water Resources Association. 27-29 May 1998.

The observed relationship between air and water temperatures has suggested the potential for predicting water temperatures from air temperature data. In this study, they hypothesized that although strong linear correlations could be found in many sites when monthly mean temperatures were compared, diurnal relationships would not be equally correlated. Results of the analysis are discussed.

[AIR TEMPERATURE; STREAM TEMPERATURE; WATER QUALITY]

1774. Vance, $M$ (1986): Wetland conservation: a bibliography. Vance Bibliographies; P.O. Box 229, Monticello, IL 61856; Public Administration Series: Bibiliography \#P 2058, ISSN: 0193-970X, ISBN: 1-55590-118-2. 20 p.

Lists 196 technical and scientific articles on the subject of conservation of wetlands and riparian areas. Bibliography is not annotated.

[BIBLIOGRAPHY; RIPARIAN HABITAT; WETLANDS]

1775. Vander Haegen,GE; Tipping,JM; Hammer,SA (1998): Consumption of juvenile salmonids by adult steelhead in the Cowlitz River, Washington. California Fish and Game 84, 48-50.

This study was conducted to add information to that known about the frequency of adult steelhead predation on juvenile salmonids. Observed low incidence of juvenile salmonids in the stomachs of adult summer steelhead suggests that the hatchery program on the Cowlitz River does not impair sympatric populations of juvenile salmonids through predation. Observations suggest that adult summer steelhead sampled from June through October had sufficient energy reserves to carry them through December spawning and that they infrequently fed in fresh water.

[FISH HABITAT; PREDATION; SALMONIDS; STEELHEAD]

1776. Vander Haegen,WM; Degraaf,RM (1996): Predation on artificial nests in forested riparian buffer strips. Journal of Wildlife Management 60(3), 542-550.

Artificial nests were used to examine predation in riparian buffer strips created by commercial clearcutting and in unharvested control areas on industrial forest-lands in eastern Maine. Nests in riparian buffer strips were deprecated more often than those in intact riparian areas. The pattern was similar for both ground and shrub nests and for both trials. Predation rate for nests in control stands was 15 percent, compared to 31 percent in $20-40 \mathrm{~m}$ wide buffer strips along tributary streams and 23 percent in $60-80 \mathrm{~m}$ wide buffer strips along main-stem streams $(\mathrm{P}=0.045)$. Predation rates were similar $(\mathrm{P}=0.41)$ in main-stem and tributary buffer strips. Greater 
predation rates documented for nests in riparian buffer strips likely resulted from an elevated number and diversity of predators associated with the narrow, linear forest stands. Red squirrels and blue jays were responsible for $>50$ percent of the identified depredations. Managers should leave wide buffer strips $(>150 \mathrm{~m})$ buffer strips along riparian zones to reduce edge related nest predation, especially in landscapes where buffer strips are an important component of the existing mature forest.

[AVIAN ECOLOGY; LOGGING IMPACTS; PREDATION; RIPARIAN HABITAT]

1777. Vanderheyden,J (1985): Managing for multiple resources in western Cascades forest riparian areas: an example. $\mathrm{p.448-452}$. In: Johnson,RR; Ziebell,CD; Patton,DR; Ffolliott,PF; Hamre, RH [tech. coord.]. Riparian ecosystems and their management: Reconciling conflicting uses. 16-18 April 1985. USDA Forest Service. General Technical Report RM-120.

Concepts of multiple use and riparian area dependent resources were incorporated into a district level riparian area management policy. The linkage of riparian areas to the aquatic resource and cumulative watershed processes is integrated into the policy designed to provide consistent direction for on-the-ground management.

[MULTIPLE USE; RIPARIAN HABITAT; RIPARIAN MANAGEMENT ZONE]

1778. Van Dyne,GM; Burch,W; Fairfax,S; Huey, W (1984): Forage allocation on arid and semi arid public grazing lands: summary and recommendations. p.1-25. In: Developing strategies for rangeland management: A report prepared by the committee on developing strategies for rangeland management. (:) National Research Council/National Academy of Sciences. Westview Press, Boulder and London.

This summary focuses on the physical and biological aspects of forage allocation, including the large domestic and wild herbivores and the plants on which they graze. Recent legislation has broadened the concept of forage allocation considerably. To meet legislated mandates of multiple use and sustained yield, livestock and other grazing animals must be considered as only one of many uses of the public resource in the West.

[FORAGE PRODUCTION; GRAZING IMPACTS; LIVESTOCK EFFECTS]

1779. Van Haveren,B; Janes,EB; Jackson,W (1985): Non-point pollution control on public lands. Journal of Soil and Water Conservation 40(1), 92-94.

BLM meets its water quality responsibilities in various ways: water quality improvement objectives are integrated into land use plans; funding for soil and water programs is used mainly for project activities; and many watershed rehabilitation projects are implemented. Other resource management strategies, including improved grazing systems, intensive riparian management practices, and good forest management, all contribute directly to improved water quality.

[NON-POINT SOURCE POLLUTION; SEDIMENT TRANSPORT; WATER QUALITY]

1780. Van Haveren,BP (1986): Management of instream flows through runoff detention and retention. Water Resources Bulletin 22(3), 399. 404.

The use of reservoirs and land treatments to manage stream flow for the maintenance or enhancement of instream flow values is a valid concept. Historically, large reservoirs have been used for flood control and water-supply regulation. Smaller structures have enjoyed widespread use for soil and water conservation in headwater areas. Where reservoir releases can be controlled, it is technically feasible to regulate flows for the enhancement of instream values. However, institutional and political obstacles may preclude the operation of some reservoirs for this purpose. Retention and detention structures and land treatments, implemented for soil and water conservation purposes, have often had favorable effects on the stream flow hydrograph. Decreases in peak flows and increases in low flows have been documented. Design concepts for runoff control structures are discussed in relation to in stream flow management objectives. Hydrological simulation is offered as a potential tool for project design and feasibility analysis.

[HYDROLOGY; MODELING; RUNOFF; STREAM FLOW]

1781. Van Haveren,BP; Jackson,WL (1986): Rehabilitating riparian ecosystems in semiarid environments. p.280-289. In: Proceedings of the 51st North American wildlife and natural resources conference. 21-26 March 1986. Reno, NV. The Wildlife Management Institute.

Proper hydrological function of the floodplain, stream-dependent water table, and stream channel erosion and deposition processes are all necessary for a healthy riparian ecosystem. These factors and 
interrelationships are brought to bear in a discussion of rehabilitation principles and approaches for use on degraded riparian areas. Channel conditions such as incised streams and laterally unstable streams which are commonly associated with degraded riparian areas are discussed. Proper identification of the causes of degradation and stage of channel evolution is required before developing a rehabilitation plan.

Stream riparian systems undergoing major geomorphic or hydrological adjustments should not be treated with habitat improvements until the channel has reached a new dynamic equilibrium. The stream riparian zone is defined as the entire active channel area, including the portion of the flood-plain that supports a riparian vegetation community.

[CHANNEL DYNAMICS; GEOMORPHOLOGY; HYDROLOGY; RIPARIAN ECOLOGY; RIPARIAN RESTORATION]

1782. Van Hees,WWS (1990): Boreal forested wetlands - What and where in Alaska. Forest Ecology and Management 33/34, 425-438.

There are extensive areas of forested wetlands throughout interior Alaska. Tree cover on these sites is composed primarily of black spruce (Picea mariana) but also includes stands of poplar (Populus sp.). The Forest Inventory and Analysis method developed by USDA Forest Service shows promise for low cost/unit area estimation. Current utilization of the resource is minimal due to low human population levels, inadequate economic and physical infrastructures, and the dispersed nature of the resource.

[BOREAL FOREST; RIPARIAN HABITAT; WETLANDS]

1783. Van Sickle,J; Gregory,SV (1990): Modeling inputs of large woody debris to streams from falling trees. Journal of Canadian Forest Resources 20, 1593-1601.

A probabilistic model predicts means and variances of the total number and volume of large woody debris pieces falling into a stream reach per unit time. The estimates of debris input are based on the density (trees/area), tree size distribution, and tree-fall probability of the riparian stand adjacent to the reach. Distributions of volume, length, and orientation of delivered debris pieces are also predicted. Applied to an old-growth conifer stand in Oregon, the observed inputs from the riparian stand exceeded estimated inputs; debris pieces observed in the stream were generally smaller than predicted. [MODELING; RIPARIAN FOREST; RIPARIAN

\section{HABITAT; WOODY DEBRIS]}

1784. Van te Chow (1964): Handbook of applied hydrology. McGraw-Hill Inc.

[GEOMORPHOLOGY; HYDROLOGY; WATER

RESOURCE MANAGEMENT]

1785. Van Velson,R (1979): Effects of livestock grazing upon rainbow trout in Utter Creek, Nebraska. p. 53-55. In: Cope,OB |ed.|. Forum -Grazing and riparian/stream ecosystems.3-4 November 1978. Denver, CO. Trout Unlimited, Inc.

Prior to implementation of this case study, impaired habitat conditions exemplified the damage that improper livestock management practices can impose on trout. Results of the habitat improvement project are indicative of the rewards in terms of fish production that can result from stream restoration. [FISHERIES; GRAZING IMPACTS; RIPARIAN RESTORATION; TROUT]

1786. Varela-Romero,A (1993): The role of the Centro Ecologico de Sonora in the protection and conservation of wetlands in Sonora. p.276-282. In: Tellman,B; Cortner,MG; Ffolliott,PF; Hamre,RH [tech. coord.]. Riparian management: Common threads and shared interests. USDA Forest Service. General Technical Report RM-226.

The paper describes a collaboration between the Centro Ecologico de Sonora (CES) and the Nature Conservancy to protect and preserve natural resources in a region across international boundaries. The program includes the study of areas with significant biodiversity, economic, social, and scenic interest and the development of substantive management strategies.

[INTERNATIONAL RELATIONS; RIPARIAN RESTORATION; WETLANDS]

1787. Vasiliev,OF (1987): System modeling of the interaction between surface and ground waters in problems of hydrology. Journal of Hydrological Sciences 32(3), 297-311.

A largely theoretical paper on modeling the interactions between ground and surface waters. The model has five subcomponents which are complex, with formulae for determining several of the subcomponent sections. Submodels are interception evapotranspiration; vertical one dimensional moisture transport in the root zone and underlying unsaturaled zone; horizontal two-dimensional groundwater saturated flows; horizontal lwo-dimensional overland-channel flow; and a snowmelt submodel. 
The model was primarily developed for engineers and hydrologists.

[HYDROLOGY; MODELING; SURFACE WATER-GROUNDWATER INTERACTION]

1788. Vavra,M (1984): Livestock production possibilities on stream-side meadows. p.35-44. In: Bedell,TE [ed.]. Proceedings of 1984 Pacific Northwest range management short course: Range watersheds, riparian zones and economics: Interrelationships in management and use. 25-27 January 1984. Pendleton, OR. Oregon State University. [ECONOMICS; GRAZING IMPACTS; RIPARIAN VEGETATION]

1789. Vellidis,G; Lowrance,R; Smith,MC; Hubbard,RK (1993): Methods to assess the water quality impact of a restored riparian wetland. Journal of Soil and Water Conservation 48(3), 223-230.

The feasibility and effectiveness of restoring a riparian wetland and using it as a bioremediation site for nutrients moving downslope from an animal waste application site is being evaluated. In question is the short term effectiveness of the restored wetland in enhancing the quality of water leaving the site. The wetland was restored by reintroducing a combination of native trees that will be harvested for pulpwood or timberwood. Native grasses and forbs were allowed to reestablish themselves among the trees. An intensive monitoring system using a network of shallow groundwater wells and automated surface runoff collectors was established to measure nutrient movement through the wetland in shallow groundwater and surface runoff. Soil samples are collected for nutrient analysis and denitrification measurements. Details of wetland restoration, instrumentation, and sampling strategies are discussed.

[ASSESSMENTS; BIOREMEDIATION; RIPARIAN RESTORATION; WETLANDS]

1790. Vincent,D (1996): Riparian restoration of Senorito Canyon, a tributary of the Rio Puerco. p.253-257. In: Shaw,DW; Finch,DM [tech. coord.]. Desired future conditions of Southwestern riparian ecosystems: Bringing together interests and concerns. USDA Forest Service. General Technical Report RM-GTR-272.

Senorito Canyon, a non-functional, degraded tributary stream of the Rio Puerco in New Mexico, has begun to respond to management strategies by the USDI Bureau of Land Management. Restoration of the riparian ecosystem has been accomplished principally through livestock grazing management and planting and reestablishment of the native cottonwood/willow communities. [COTTONWOOD; GRAZING IMPACTS; LIVESTOCK EFFECTS; RIPARIAN RESTORATION; WILLOW]

1791. Vinebrooke,RD; Leavitt,PR (1999): Differential responses of littoral communities to ultraviolet radiation in an alpine lake. Ecology 80(1), 223-237.

Differences in habitat conditions may affect differential sensitivities of benthic and planktonic communities to UV radiation. Results of this study indicated that UV radiation affects shallow-water communities in cold and unproductive systems mainly through direct effects, rather than by indirect effects mediated by the food-web processes. Access to physical refuges was evidently a key factor determining habitat-specific responses to UV radiation. UV radiation did not adversely affect motile epepelon and zoobenthos that could seek refuge in sediments, but it did suppress attached epilithic taxa. In habitats devoid of physical refuge, UV tolerance was associated with photo-protective pigmentation (e.g. zooplankton) and possibly a capacity for DNA repair. UV exposure can affect abiotic regulation of littoral food webs in extreme environments, such as alpine, polar, and anthropogenically acidified ponds and lakes. [ALPINE LAKES; MICROBIOLOGY; UV RADIATION]

1792. Vinson, MR (1988): Sediment dynamics in meandering and straight sections of a relocated stream channel. p.76-87. In: Mutz,KM; Cooper,DJ; Scott,ML; Miller,LK [eds.]. Restoration, creation, and management of wetland and riparian ecosystems in the American West. Proceedings of the symposium. 14-16 November 1988. Denver, CO. Rocky Mountain Chapter of the Society of Wetland Scientists.

Sediment dynamics were analyzed in meandering and straight sections of a relocated stream channel in coarse alluvium. Although both sections had similar substrate distributions prior to the introduction of water, the meandering section exhibited greater particle size segregation, less instream fine sediment, and more over-bank fine sediment than did the chanmelized section ten months after the introduction of water to the new channel. Sediment deposition in the form of point bars was inversely related to meander radius of curvature. 
Within the meandering channel, sediment was deposited almost exclusively along the channel banks. Sediment deposition within the straight channel was uniformly distributed over the channel bed and banks.

[CHANNEL DYNAMICS; CHANNEL MORPHOLOGY; SEDIMENTATION; SEDIMENT TRANSPORT]

1793. Von Guerard,P (1991): Variation in streambed material, bedload, and benthic invertebrates. Unreferenced, p.13-1 to 13-8. Grain-size distribution of streambed material and bed-load and the occurrence of benthic invertebrates were determined at two sites in SE Colorado. Grain-size distribution of streambed material differed noticeably at the upstream sample site but were similar at the downstream sample site. There were significant differences between the two sites for mean density values for all major taxa of benthic invertebrates. Median density of all organisms was $9,500 / \mathrm{sq} \mathrm{m}$ at the upstream site and $370 / \mathrm{sq} \mathrm{m}$ at the downstream site. Even though other factors affected the density of benthic invertebrates, analysis indicated that as the grain-size of the streambed material approaches that of bedload, benthic invertebrate populations might be adversely affected.

[INVERTEBRATES; RIPARIAN HABITAT]

1794. Vowell,Jl (1996): Management issues in forested wetlands. p.174-177. In: National hydrology workshop proceedings. 27 April - 1 May 1992; Phoenix, AZ. USDA Forest Service. General Technical Report RM-GTR-279.

Management issues involving forested wetlands are largely centered around balancing utilization of the timber resource with other wetland functions and values. Because of the nature of timber harvesting activities, forest management issues concerning streamside management zones, bedding, wetland conversion, and wet weather operations are complex and often controversial. These issues are discussed, along with associated regulations, where applicable. [RIPARIAN HABITAT; WETLANDS]

1795. Wagner,FH; Keigley,RB; Wambolt,CL (1995): Comment: Ungulate herbivory of willows on Yelllowstone's northern winter range:

Response to Singer et al (1994). Journal of Range Management 48(5), 475-477.

In a recent Journal of Range Management article, Singer et al. (1994) report results of a willow study on the northern elk winter range of
Yellowstone National Park and the immediate vicinity. The authors measured production, forage quality, moisture stress, and tannin content of growth shoots, all in relation to ungulate browsing, browsing-induced architectural variation, and altitude. The inference that reduced chemical defenses is attracting further heavier browsing is not supported. The prevailing evidence remains that the progressive decline of woody vegetation on the northern range, especially willow, has been induced by a wintering elk herd that has greatly increased since establishment of the Park. [BROWSING EFFECTS; ELK GRAZING; GRAZING IMPACTS; RIPARIAN SHRUBS; WILLOW; YELLOWSTONE NATIONAL PARK]

1796. Wagstaff, FJ (1986): Economic issues in grazing and riparian area management. In: Proceedings of the 51st North American wildlife and natural resources conference. 21-26 March 1986. Reno, NV. The Wildlife Management Institute.

Positive economic benefits from improved riparian conditions may off-set the negative impacts from limiting livestock grazing. Because of intensified management costs, the public may be faced with increased expenditures. Irregularities will be perceived by the many interests involved in riparian habitat management. Many of these problems will lead to costly litigation and social disharmony. However, reasoned approaches could lead to greater net social benefit levels. Issues and problems will not become simpler or easier and economics alone will not resolve the problems. [ECONOMICS; RIPARIAN HABITAT; RIPARIAN MANAGEMENT ZONE]

1797. Wald,J (1979): The BLM and the NEPA process. p.61-63. In: Cope,OB [ed.|. Forum -Grazing and riparian/stream ecosystems. 3-4 November 1979. Denver, CO. Trout Unlimited, Inc.

Delays in EIS preparation and the inadequacies of the statements have left the agency (USDI Bureau of Land Management) vulnerable to legal challenges. More recently, this situation has improved. The implementation of rest-rotation, however, is not a panacea. All entities will have to work together to enlist the support and understanding of the livestock industry for needed changes $\mathrm{kn}$ grazing management. [GRAZING IMPACTS; RIPARIAN MANAGEMENT ZONE]

1798. Walker,JW; Heitschmidt,RK (1986): 
Effect of various grazing systems on type and density of cattle trails. Journal of Range

Management 39(5), 428-430.

Number and kinds of cattle trails may have a dramatic impact on relative amount of bare soil and subsequently on amount and rate of soil erosion. The objective of this study was to quantify the effect of a cell-designed, rotational grazing treatment (RG) on density and kind of cattle trails in relation to other grazing treatments. It was concluded that implementation of a cell-designed, RG system will cause a significant increase in density and number of trails, particularly near the cell center.

[GRAZING IMPACTS; GRAZING TREATMENTS; LIVESTOCK EFFECTS; SOILS]

1799. Walker,MD; Walker,DA; Everett,KR (1989): Wetland soils and vegetation, arctic foothills, Alaska. USDI Fish Wildlife Service. Biological Report 89(7), 89.

Analyses of relationships between hydric soils and wetland plant species in the northern foothills of the Brooks Range, Alaska, were conducted. The site is considered to be representative of broad regions of acidic tussock tundra in the foothills. Seven soil subgroups were identified. Weighted and index averages were calculated for each of 84 samples by weighing each species according to its wetland indicator status in a published list of vascular wetland plants of the U.S. Analysis of variance among soil types using averages based on vascular species alone or in combination with cryptogamic species led to a highly significant distinction between hydric and non-hydric soils. Cryptogams, lichen-moss crusts on the soil surface which have not been reviewed for wetland status, did not separate the soil types properly.

[RIPARI $\Lambda N$ HABITAT; RIPARIAN

VEGETATION; SOILS]

1800. Walker,MJ; Montemgno,CD; Jenkins,MB (1998): Source water assessment and non-point sources of acutely toxic contaminants: A review of research related to survival and transport of Cryptosporidium parvum. p.467. Potts,DF [ed.]. Rangeland management and water resources: Proceedings of the AWRA specialty conference. American Water Resources Association. 27-29 May 1998. Reno, NV.

This review summarizes recent research related to survival and transport of $C$. parvum oocysts, as an acutely toxic conlaminant with non-point sources in animal agriculture. Significance of infected domestic animals as potential sources of C. parvum are discussed. Laboratory and field studies of survival and transport are reported. Source control approaches in the context of public health protection are presented.

[GRAZING IMPACTS; NON-POINT SOURCE POLLUTION; WATER QUALITY]

1801. Wallace,JB; Grubaugh,JW; Whiles,MR (1996): Biotic indices and stream ecosystem processes: Results from an experimental study. Ecological Applications 6(1), 140-151.

The authors investigated the ability of the North Carolina Biotic Index (NCBI) and the Ephemeroptera

+ Plecoptera + Trichoptera (EPT) index to track the experimental manipulation of the invertebrate community and resultant alteration of several ecosystem-level processes in headwater streams in western North Carolina. The FPT index was the easiest to use from both the standpoint of time required for sample processing and ease of application. The EPT index was relatively simple and displayed a remarkable ability to track the secondary production of invertebrates in the treatment stream. [BIOTIC INDICES; MONITORING; RIPARIAN HABITAT]

1802. Wallace, $N$ (1988): Circle irrigation and wetlands. p.166-172. In: Stuber,PJ [tech. coord.].Proceedings of the national symposium on the protection of wetlands from agricultural impacts. 25-29 April 1988. Ft. Collins, CO. . USDI Fish and Wildlife Service. Biological Report 88(16).

The prairie pothole region of the north central states is a major waterfowl producing area with over $1,000,000$ wetland acres under protective easement. The area also provides excellent opportunities for irrigated crops. Problems arise when protected wetlands become impassable quagmires for circle irrigators. During a two-year study, several techniques were developed for crossing wetlands with circle irrigators without biologically degrading wetland values.

[ $\Lambda$ GRICULTURAL IMPACTS; RIPARIAN

HABITAT; WETLANDS]

1803. Wallace,PM; Kent,DM; Rich,DR (1996): Responses to wetland tree species to hydrology and soils. Restoration Ecology 4(1), 33-41.

The authors conducted a study of the flood tolerance of nine wetland tree species on seven soil types in western Florida. Seedlings were subjectcd to 11 months of continuous shallow inundation or moist soil conditions on three mineral soils, two organic 
soils, a manufactured designed to mimic the practice of layering muck over mineral soil, and a stockpiled topsoil. In general, greatest net height and total biomass were achieved on moist organic soils, and least net height and total biomass were achieved on stockpiled top-soils and inundated soils. Findings suggest that transfer of organic soils will benefit restoration and creation efforts, and that layering organic soils over mineral soil is more effective than using mineral soils or stockpiled topsoil. [HYDROLOGY; RIPARIAN FOREST; RIPARIAN VFGFTATION; SOIIS]

1804 Wallin, $P$ (1993): Management of rivers with special designations. p.349-351. In: Tellman,B; Cortner,HJ; Wallace,MG; DeBano,LF; Hamre, RH [tech. coord.]. Riparian management: Common threads and shared interests. USDA Forest Service. General Technical Report RM226.

The author predicts that we will see a new kind of designation for rivers that will address the health of the whole watershed, including the economic health of its human community. The concept will endorse river conservation of all rivers, no matter how ordinary, not just the "crown jewcl" rivers. The new designation will bring all the players into the game, federal, state, and private. It will give local government and business and agriculture some real incentives for buying into watershed protection. It will also give a central role to citizen organizations in working on watershed restoration.

[RIPARIAN HABITAT; RIVER ECOLOGY; WATERSHED]

1805. Walling,DE; Kane,P (1982): Temporal variation of suspended sediment properties. p.409419. In: Proceedings of the Exeter symposium, July 1982. Recent developments in the explanation and prediction of erosion and sediment yield; IAHS Publication No. 137.

Increasing awareness of the role of suspended sediment in the transport of nutrients and contaminants, of the significance of water-sediment interactions as an influence on river water quality and of the importance of sediment in non-point pollution, requires an improved understanding of spatial and temporal variations in suspended sediment properties. A study of suspended sediment yields in the basin of the River Exe, Devon, England, undertaken by the authors, has attempted to provide information on the nature and extent of temporal variations in sediment geochemistry. Results from four measuring stations relating to major element composition, clay mineralogy, and organic constituents are presented. Detailed patterns of storm period variation in sediment properties are illustrated. The implication of these findings are reviewed.

[NON-POINT SOURCE POLLUTION; SEDIMENTATION; SEDIMENT TRANSPORT; WATER QUALITY]

1806. Walling,DE; Webb,BW (1982): Sediment availability and the prediction of storm-period sediment yields. p.327-337. In: Proceedings of the Exeter symposium. July 1982. Recent developments in the explanation and prediction of erosion and sediment yield; IAHS Publication No.137.

The form of the suspended sediment concentration/discharge relationship or rating curve for a drainage basin reflects the overall pattern of erosion and sediment delivery operating in the upstream area. As such it may prove useful in the development of a realistic model of storm-period sediment yield. Several workers have highlighted the existence of 'exhaustion effects' in the form of the relationship and an attempt has been made to evaluate the evidence for temporal variations in sediment availability. Detailed records of suspended sediment concentration provided by continuous recording turbidity sensors installed in several basins in Devon, UK, have been used to study this feature of basin response. The implications for the development of sediment yield models are discussed. [MODELING; SEDIMENT TRANSPORT; WATER QUALITY]

1807. Wallis, C (1993): Keeping the Oldman River rolling along - the courts as a tool for riparian habitat protection. p.341-346. In: Tellman,B; Cortner,HJ; Wallace,MG; DeBano,LF; Hamre, RH [tech.coord.|. Riparian management: Common threads and shared interests. USDA Forest Service. General Technical Report RM-226.

In 1987, the federal and provincial governments of Alberta, Canada, issued licences to construct the Oldman River Dam. Friends of the Oldman River (FOR) was formed to initiate legal action alleging that Alberta did not follow proper procedures in issuing the construction licence. At the time this paper was given, construction had been completed but the reservoir had not been filled. 90 percent of the predicted environmental impacts from dam operations had not occurred. It is still possible that legal actions by FOR might block flooding of the reservoir area. 
[DAMS; LEGAL ACTIONS; RIPARIAN

HABITAT]

1808. Walters,MA; Teskey,R; Hinkley,TM

(1980): Pacific Northwest and Rocky Mountain

Regions. Vol.VII. USDI Fish and Wildlife

Service/OBS-78/93; N; 90; Impact of water level

changes on woody riparian and wetland

communities.

A literature review that synthesizes existing information on the effect of water level changes on woody plants found in riparian and wetland communities. Riparian vegetation in this region is exposed to large fluctuations in water levels. Spring run-off and summer droughts result in large changes in the water status of the vegetation in riparian zones. This review discusses both the impact of flooding and drought on riparian vegetation.

[RIPARIAN HABITAT; RIPARIAN

VEGETATION; WATER STRESS]

1809. Walters,MA; Teskey,R; Hinkley,TM (1980): Pacific Northwest and Rocky Mountain Regions. Vol. VII. In: Impact of water level changes on woody riparian and wetland communities. USDI Fish and Wildlife Service. OBS 78/94. 47 p.

Riparian vegetation in the Pacific Northwest and Rocky Mountain regions of the western United States is exposed to large fluctuations in water levels. Spring runoff and summer droughts result in large changes in the water status of the vegetation that occupies the riparian zone. Coupled with natural fluctuations in water levels are man originated fluctuations. The purpose of this review was to discuss both the impact of flooding and drought on riparian vegetation.

[CLASSIFICATION; IIYDROLOGY; RIPARIAN VEGETATION]

1810. Walters,MA; Teskey,RO; Hinckley,TM (1980): Impact of water level changes on woody riparian and wetland communities. Volume VIII. Pacific Northwest and Rocky Mountain Regions. USDI Fish and Wildlife Service. Biological Services Program: FWS/OBS-78/94. 46 p.

Riparian vegetation in the Pacific Northwest and Rocky Mountain regions of the United States is exposed to large fluctuations in water levels. Spring runoff and summer droughts result in large changes in the water status of the vegetation that occupies riparians zones. Natural fluctuations in the water level are compounded by man's activities. Flooding and drought have profound influences on these sites.
Volume VIII covers the mountainous areas of the Pacific Northwest from northern California through Washington and Oregon and along the Rocky Mountains from Montana and Idaho south through New Mexico and Arizona.

[BIBLIOGRAPHY; GROUNDWATER; PLANT

COMMUNITIES; RIPARIAN HABITAT]

1811. Ward,N (1993): The problem of sediment in water for fish. Ontario Ministry of Natural Resources. Northern Ontario Boreal Forest Management Technical Note-21. 8 p.

Erosion and the resultant input of soil particles to lakes and streams is of particular concern to fish managers. Spring floods and "flushing flows" are necessary to remove sediment from between the rocks, not just from spawning bed surfaces. Problems of having sediment deposited in water can be minimized if contractors use prescribed construction practices. For water crossing sites that may affect critical fish habitat, it is advisable to develop sediment control plans.

[EROSION; FISHERIES; RIPARIAN HABITAT; SEDIMENTATION]

1812. Warner,RE (1979): Fish and wildlife resource needs in riparian ecosystems. USDI Fish and Wildlife Service, National Water Resources Analysis Group. Eastern Energy and Land Use Team.

On May 30-31, 1979, a workshop including 17 member participants, met for two days of discussion and analysis. Among its findings was the conclusion that a national program needed to be: a) system oriented; b) based on long-term perspective; c) based on a public trust doctrine; d) an integration of the activities of federal agencies; e) involved with the public but unresponsive to special interests; $f$ ) avoiding irreversible intrusions into ecosystems; g) laden with integrative and education programs; and h) consisting of research, management, planning, and educational programs.

[FISHERIES; RIPARIAN ECOLOGY; RIPARIAN HABITAT]

1813. Warner,RE; Hendrix,KM |eds.]. (1984): In: Proceedings of California riparian systems: Ecology, conservation, and productive management. University of California. Berkeley, CA. [AQUATIC ECOSYSTEMS; MANAGEMENT PLANS; RIPARIAN HABITAT]

1814. Warner,WS (1990): A PC-based analytical 
stereo-plotter for wetland inventories: An efficient and economical photogrammetric instrument for field offices. Forest Ecology and Management 33/34, 571-581.

Highly flexible photogrammetric systems, controlled entirely by PC technology, can collect primary data from aerial photographs and process these data in a variety of cartographic systems and statistical programs. This paper describes an instrument in use by the USDA Forest Service and other organizations that has relatively low cost and high accuracy that make it suitable for field office use.

[INVENTORY; RIPARIAN HABITAT; WETLANDS]

1815. Warren,PL; Anderson,LS (1985): Gradient analysis of a Sonoran Desert wash. p.150-155. In: Proceedings of the first North American riparian conference. 16-18 April 1985. Tucson, AZ.

Vegetation was sampled along two parallel environmental gradients in the Sonoran Desert - one each in an upland bajada site and in a xeroriparian wash site. The wash gradient was more complex than the upland site, with three areas of plant species turnover compared to zero turnover along the upland gradient. This was likely due to the interactions of three major limiting environmental factors related to watershed area acting in different portions of the wash gradient. The upland gradient is controlled by only one overriding environmental factor.

[RIPARIAN HABITAT; RIPARIAN

VEGETATION; WATERSHED]

1816. Warren,PL; Schwalbe,CR (1985): Herpetofauna in riparian habitats along the Colorado River in Grand Canyon. p.347-354. In: Tellman,B; Cortner,HJ; Wallace,MG; DeBano,LF; Hamre, RH [tech. coord.|. Riparian ecosystems and their management: Reconciling conflicting uses. 16-18 April 1985. Tucson, AZ. USDA Forest Service. General Technical Report RM-120.

Population densities and species composition of lizards were sampled in riparian and non-riparian habitats along the Colorado River. The highest densities were found in shoreline habitats, moderate densities in riparian habitats, and lowest densities in non-riparian densities. Rapidly fluctuating river flow levels may have a deleterious effect on lizard populations by trapping populations on alluvial bars and inundating nest sites.

[HERPETOFAUNA; RIPARIAN HABITAT]
1817. Wauer, R (1977): Significance of Rio Grande riparian systems upon the avifauna. p.165-174. In: Johnson, RR; Jones, DA [tech. coord.|. Importance, preservation, and management of riparian habitats: $A$ symposium. 9 July 1977. Tucson, AZ. USDA Forest Service. General Technical Report RM-43.

The Rio Grande corridor in west Texas serves as a significant migratory and emigration route for avifauna and 38 species are known to nest within the riparian habitat. Nine spccies are discussed as indicators of change within the system and the importance of the Rio Grande area as a refugium is described.

[AVIFAUNA; RIPARIAN HABITAT]

1818. Wear,DN; Turner,MG; Naiman,RJ (1998):

Land cover along an urban-rural gradient:

Implications for water quality. Ecological

Applications 8(3), 619-630.

The pressures of development in rural mountainous areas hold crucial implications for water quality. Simulation modeling was used to examine how position along urban-rural gradients affects landscape patterns in watersheds. Results indicate that position along the gradient has a significant effect on land-cover changes on private but not public lands. Two locations along the urban-rural gradient may hold disproportionate influence over water quality in the future: 1) the most remote portion of the landscape; and 2) at the outer envelope of urban expansion.

[LANDSCAPE ECOLOGY; MODELING; WATER QUALITY]

1819. Weber,CI,et al (1990): Short-term methods for estimating the chronic toxicity of effluents and receiving waters to freshwater organisms. US Environmental Protection Agency. Environmental Monitoring Systems Laboratory. Second edition methods manual. No PB 89-207 013/AS.

Cincinnati, $\mathrm{OH}$.

The manual describes methods for estimating the chronic toxicity levels for certain indicator species, including the fathead minnow (Pimephales promelas), a cladoceran (Ceriodaphnia dubia), and a green algae (Selenastrum capricornutum). [EFFLUENTS; RIPARIAN HABITAT; TOXICOLOGY; WATER QUALITY]

1820. Weber,DJ; Fernandes, GW (1992): Insect galls and chemical composition of white rubber rabbitbrush on riparian and dry sites. p. 203-207. In: Clary,WP; McArthur,ED; Bedunah,D; 
Wambolt,CL [comp.]. Proceedings - Symposium on ecology and management of riparian shrub communities. USDA Forest Service. General Technical Report INT-289.

The total hydrocarbon fraction was higher in leaves from dry hillside sites, but the number of individual components was greater in the hydrocarbon fraction from leaves from riparian sites. That increased number was attributed to the more diverse metabolic activity of riparian sites. A pregnane type of compound was present in higher concentrations in the leaf tissue of plants on the dry sites.

[INVERTEBRATES; PLANT TISSUE; RIPARIAN HABITAT]

1821. Wegner,DL (1985): Dividing the water: Precepts of the Colorado River Law. p.453-455. In: Johnson,RR; Ziebell,CD; Patton,DR; F folliott,PF; Hamre,RH [tech. coord.]. Riparian ecosystems and their management: Reconciling conflicting uses. 16-18 April 1985. Tucson, AZ. USDA Forest Service. General Technical Report RM-120.

The extent of riparian vegetation development along the rivers and streams that comprise the Colorado River System is a function of a myriad of legal and operational factors. Utilization of the Colorado River water can be identified with several key issues, federal acts, and treaties. The paper outlines the major arguments and perceptions that define present day levels of water use and the extent of riparian vegetation.

[RIPARIAN HABITAT; WATER ALLOCATION; WATER RIGHTS]

1822. Weiland,MA; Hayward,RS (1997): Cause for the decline of large rainbow trout in a tailwater fishery: Too much putting or too much taking? Transactions of the American Fisheries Society 126, 758-773.

In this case study, rainbow trout densities have been sustained against increased fishing pressure over the last thirty years mainly by increasing the stocking rates of catchable size fish. Short residence times of rainbow trout resulting from heavy fishing pressure and high vulnerability to angling were generally considered to be the main reason for limited growth after stocking. The authors found that increasing stocking rates have been paralleled by food base degradation, leading to sub-maintenance consumption rates and poor growth conditions. Greater attention to energetic conditions is recommended.
[FISHERIES; RIPARIAN HABITAT; TROUT]

1823. Weiner,AH (1998): Kenai River restoration and management. Fisheries 23(1), 610.

A comprehensive program of restoration, land acquisition, recreation enhancement, and land management is underway on the Kenai River in Alaska. This program is attempting to restore degraded fish habitat in the riparian zone of the mainstem, to acquire land to protect fish habitat, to provide recreational access for anglers, and to manage land in the watershed to prevent development-related harm. Funding for this program, currently in excess of $\$ 21$ million, is provided by the state of Alaska, the Exxon Valdez oil spill civil settlement and criminal restitution funds, National Marine Fisheries Service, Federal Aid for Sport Fish Restoration Fund, Dingell-Johnson Sport Fish Fund, Land and Water Conservation Fund, and the Federal Highway Administration.

[FISHERIES; RIPARIAN RESTORATION]

1824. Welch,R; Jorday,TR (1983): Analytic nonmetric close-range photogrammetry for monitoring stream channel erosion.

Photogrammetric Engineering and Remote

Sensing 49(3), 367-374.

Vertical stereo-pairs are recorded before and after storms with a non-metric $35-\mathrm{mm}$ camera from a platform $(\mathrm{H}=9.5 \mathrm{~m})$ constructed over a gauged stream channel. Image measurements are easily undertaken on positive film enlargements with a cartographic digitizer, and provide the input $x, y$ image coordinates required for an analytical solution. Studies to-date have produced mean errors of approximately $+/-3 \mathrm{~mm}$ in the $\mathrm{X}$ and $\mathrm{Y}$ terrain coordinates and $+/-6.5 \mathrm{~mm}$ in $\mathrm{Z}(1 / 1500 \mathrm{H})$. These accuracies approximate those obtained from measurements on the original negatives undertaken with a stereo-comparator. The procedures described provide accurate results at minimum cost, and can be used to monitor stream channel erosion. Computer graphics routines provide and efficient means of constructing DTMs, contour maps, and threedimensional displays of changes in elevation due to storm runoff. Non-metric close-range photogrammetry appears to provide an inexpensive, efficient, and accurate means for monitoring gully and stream channel erosion.

[CHANNEL MORPHOLOGY; GULLY CONTROL; PHOTO PLOTS; STREAMBANK PROTECTION; TECHNIQUES] 
1825. Weller,MW (1990): Waterfowl management techniques for wetland enhancement, restoration and creation useful in mitigation procedures. p.517-528. In: Wetland creation and restoration: The status of the science. [Eds: Kusler,JA; Kentula,MA] Island Press, Washington, DC.

Wildlife managers have long been involved in wetland restoration and enhancement and have developed functional techniques for management. Most of these procedures use natural processes to tap natural seed banks, modify cover/water ratios, or control weeds via water level control and herbivores. This chapter presents strategies for restoring, creating, or enhancing wetlands to meet mitigation requirements. These procedures may also be used to enhance wetland functions such as water quality, shoreline protection, and esthetic values. [RIPARIAN RESTORATION; WATERFOWL MANAGEMENT; WETLANDS]

1826. Weller,MW (1998): Issues and approaches in assessing cumulative impacts on waterbird habitat in wetlands. Environmental Management 12(5), 695-701.

Vertebrates are commonly used as indicator species after wetlands are subjected to environmental impacts because they are conspicuous. Such impacts may take place at the landscape level where extensive areas are lost; at the wetland level where some units of closely spaced wetlands are modified, or at the level of individual wetland through modification or fragmentation. Vertebrates utilize habitats differently according to age, size, sex, geographic location, and season. Habitat evaluations based on a single observation can be biased. Current wetland evaluation systems incorporate wildlife habitat as a major feature. Several approaches for estimating bird habitat losses are derived from population curves based on natural and experimentally induced population fluctuations. Additional research needs are identified.

[ASSESSMENTS; AVIFAUNA; CUMULATIVE IMPACTS; WETLANDS]

1827. Weller,MW; Griffith,JS,Jr; Noble,RL; Stickney,RL (1986): Aquatic and wetland ecosystems: multifaceted challenges. In: Proceedings of the 51st North American wildlife and natural resources conference.21-26 March 1986. Reno, NV. The Wildlife Management Institute.

The best mechanism for addressing the difficult problems facing aquatic resources may best be met with university programs that are designed for longterm research. Turnover of principal investigators is slower in universities. Moreover, students in many institutions can produce publishable papers. Research in universities is cost effective and can provide more results per dollar. Graduate students can be put into the field at minimal cost and university faculty can be expected to maintain objectivity.

[RFSEARCH; RIPARIAN ECOLOGY; RIPARIAN HABITAT]

1828. Welling,CH; Pederson,RL; van der Valk,AG (1988): Temporal patterns in recruitment from the seed bank during drawdowns in a prairie wetland. Journal of Applied Ecology 25, 999-1007.

This study described seasonal patterns of seedling recruitment and assesses the potential impact on recruitment of environmental conditions during draw-downs. Further, vegetation produced by draw-downs which perseveres for one or two years or longer is compared.

[EMERGENT VEGETATION; WETLANDS SEED BANK]

1829. Wells,MD (1991): Wetlands in watersheds. Journal of Soil and Water Conservation 46(6), 415-416.

Creating numerous small watershed dams, both on crop land and woodland areas, has enhanced wildlife values in Missouri.

[RIPARIAN HABITAT; WATERSHED; WETLANDS]

1830. Wells,RW; Trofymow, JA (1998): Coarse woody debris in the coastal forests of southern Vancouver Island. Northwest Science 72(2), 23-24.

In this study, trends of coarse woody debris abundance across chronoscquence plots established on both the drier east side and the wetter west side were examined. Total biomass of CWD on the east side was substantially lower than on the west side. [ASPECT; LARGE WOODY DEBRIS]

1831. Welsh,Jr.,HH; Ollivier,L (1998): Stream amphibians as indicators of ecosystem stress: $A$ case study from California's Redwoods. Ecological Applications 8(4), 1118-1132.

After road construction released fine sediments into pristine streams during a storm event in northern California, the authors initiated a study of stream amphibians as indicators of stream ecosystem stress. Densities of amphibians (tailed frogs, Pacific giant salamanders, and southern torrent salamanders) were 
significantly lower in streams impacted by sediment. Sediment effects were species-specific and reflected differential use of stream microhabitats. However, the shared vulnerability of these species to infusions of fine sediments is probably the result of common reliance on interstitial spaces in the streambed. Since many stream-dwelling amphibians are long lived and exist in relatively stable populations, these attributes make them more tractable and reliable indicators of potential biotic activity in stream ecosystems than anadromous fish or macroinvertebrates.

[AMPHIBIANS; RIPARIAN ECOLOGY; STRESS; WATER QUALITY]

1832. Weltz,M; Wood,MK (1986): Short duration grazing in New Mexico: effects on sediment production. Journal of Soil and Water Conservation 41(4), 262-266.

A study was conducted to determine the influences of short duration grazing, continuous grazing, and grazing exclusion from cattle on soil erosion as expressed by sediment concentration and total suspended sediment in two range sites in New Mexico. Total sediment concentration was greater on all grazed treatments than on the exclosure; there were no differences among grazed treatments. Doubling the stocking rate and applying a shortduration system resulted in significantly greater sediment concentration. Total sediment production in the grazed, short duration pasture was triple that in the moderate, continuous pasture. These increases were attributed to reduced biomass and increased bare ground.

[GRAZING IMPACTS; GRAZING TREATMENTS; SEDIMENTATION; SOILS]

1833. Wentworth,TR; Johnson,GP; Kologiski,RL (1988): Designation of wetlands by weighted averages of vegetation data: $A$ preliminary evaluation. Water Resources Bulletin 24(2), 389-396.

Weighted averages (WA) of vegetation data proved to be a useful tool for assessing wetland status of the vegetation types included in this study: 1) rankings of vegetation stands by WA correlated well with their positions on environmental moisture gradients, and 2) the results of WA could be used together with a wetland/ upland break-point - to designate areas as wetland or upland but these should be verified with supplemental data on soils and hydrology. [CLASSIFICATION; RIPARIAN HABITAT; WETLANDS]
1834. Wesche,TA; Goertler,CM; Frye,CB (1985): Importance and evaluation of instream and riparian cover in smaller trout streams. p.325-328. In: Johnson,RR; Ziebell,CD; Patton,DR; Ffolliott,RH; Hamre,RH [tech. coord.]. Riparian ecosystems and their management: Reconciling conflicting uses. 16-18 April 1985. Tuscon, AZ. USDA Forest Service. General Technical Report RM-120.

Cover is an important trout habitat component resulting from the geomorphological characteristics of a stream channel, the streambank interface with the riparian community, and the stream flow. The significance of the riparian contribution to the overall stream cover as related to brown trout population size is described.

[COVER; FISHERIES; RIPARIAN HABITAT; RIPARIAN VEGETATION; TROUT]

1835. Wesche,TA; Goertler,CM; Frye,CB (1987): Contribution of riparian vegetation to trout cover in small streams. North American Journal of Fisheries Management 7, 151-153.

Cover is an important trout habitat component resulting from the geomorphologic characteristics of a stream channel, the streambank interface with the riparian community, and the stream flow. By means of regression analysis, this study quantitatively describes the relative importance of three cover parameters (overhead bank cover, rubble-boulderaquatic vegetation areas, and deepwater areas) and two cover models as indicators of trout standing stock in eight small streams in southeast Wyoming. Results indicated that overhead bank cover, provided primarily by riparian vegetation, is the cover parameter that explains the greatest amount of variation in trout population size.

[COVER; FISHFRIFS; RIPARIAN HABITAT; RIPARIAN VEGETATION; TROUT]

1836. Wesche,TA; Reiser,DW; Hasfurther,VR (1986): Development and testing of a new technique for measuring fine sediment in streams. p.49-53. In: The 1986 National symposium on mining, hydrology, sedimentology, and reclamation; University of Kentucky; Lexington, KY.

The collection and analysis of bed material samples has been a standard practice for determining the quantity of fine sediments (less than $3.35 \mathrm{~mm}$ diameter) in stream gravels. However, the sampling techniques currently in use can be labor and equipment intensive. Also, inaccuracy in quantification of the finer fractions can occur 
dependent upon bed material composition. This paper reports on a study which has evaluated the utility of a sediment trapping device for measuring fine sediment in the inter-gravel environment. [GEOMORPHOLOGY; SEDIMENT TRANSPORT; TECHNIQUES]

1837. Wesche,TA; Reiser,DW; Hasfurther,VR; Hubert,WA; Skinner,QD (1989): New technique for measuring fine sediment in streams. North American Journal of Fisheries Management 9, 234-238.

Collection and analysis of bed material samples has been a standard practice for determining the quantity of fine sediments in stream gravels. This technique, however, can be labor and equipment intensive and inaccuracies in quantification of finer materials can occur. This study evaluated the utility of a sediment trapping device for measuring fine sediment in an inter-gravel environment.

[HYDROLOGY; POLLUTION; SEDIMENTATION]

1838. West,RA; Paustian,SJ; Martin,JR (1989): A proposed stream-side riparian mapping system for the Tongass National Forest. p.73-85. In: Proceedings of watershed '89: A conference on the stewardship of soil, air and water resources. 21-23 March 1989. Juneau, Alaska. USDA Forest Service.

A mapping system is proposed that employs a hierarchical inventory utilizing GIS technology. Level I identifies watershed boundaries and areas and is used to estimate the annual precipitation and to compute water budgets. Level II delineates boundaries between the aquatic-riparian ecosystems and the surrounding terrestrial environment by overlaying the soil/plant association layer and the watershed layer. Level III comprises mapping of the aquatic and riparian ecosystems. Level IV maps specific riparian sites as defined by particular plant associations with specific soils and channel types. [CHANNEL MORPHOLOGY; GEOMORPHOLOGY; GIS; INVENTORY; PLANT COMMUNITIES; SOILS; SPATIAL SCALE]

1839. Wheeler,D (1993): The Boulder open space program. p.162-163. In: Tellman, $B$; Cortner,HJ; Wallace,MG; Ffolliott,PF; Hamre,RH [tech. coord.J. Riparian management: Common threads and shared interests. USDA Forest Service. General Technical Report RM-226.

In recent years, desire for outdoor recreation has focused human intrusion further into riparian corridors. Intensified human use, however, has consumed all the remaining wildlife values of stream corridors. The Boulder Creek Trail now accommodates more than 4000 human trips per day. The success of this program has created a public demand for even more trails. Further development will only diminish the available space for wildlife. Long-term cumulative impacts of various uses and preservation options need to be carefully considered before the community can make informed decisions. [OPEN SPACE; RECREATION IMPACTS; RIPARIAN HABITAT]

1840. Whigham,D; Dykyjova,D; Hejny,S (Eds.) (1994): Wetlands of the world: Inventory, ecology, and management. Vol.1. Africa, Australia, Canada and Greenland, Mediterranean, Mexico, Papua, New Guinea, South Asia, Tropical South America, United States. 1st ed. Kluwer Academic Publ., Dordrecht, The Netherlands. 788 p.

In the public mind, wetlands have been transformed in recent years from mosquito-infested swamps suited for ditching, diking, and reclamation into valuable ecosystems with high intrinsic and aesthetic value that provide beneficial services to humans and wildlife. Each chapter in this book corresponds to a common format. Each geographical region and climate is described followed by descriptions of geology, geomorphology, and hydrology; distribution of wetlands within the region; flora, fauna, and ecological attributes; human impacts; and conservation/management recommendations.

[GEOMORPHOLOGY; HYDROLOGY; RIPARIAN HABITAT; WETLANDS]

1841. Whitfield,PH (1998): Reporting scale and the information content of stream flow data.

Northwest Science 72(1), 42-51.

Hydrological metering programs are collected continuously around the world. However, measured signals are usually reported on time scales longer than the original observations (e.g. daily, weekly, monthly, etc.). In this study, records of data from several years from a number of watersheds in British Columbia were analyzed. Results bring into question whether or not reporting of mean daily discharge is appropriate for streams of different size scales or from different hydrological regions. Daily mean discharge is an appropriate reporting scale for watersheds of large area and low precipitation. In smaller watersheds or those receiving heavy rains, a finer time interval is a more relevant scale. [HYDROLOGY; SPATIAL SCALE; STREAM 
FLOW; WATERSHED]

1842. Whitney,JC (1996): The Middle Rio

Grande: Its ecology and management. p.4-21. In: Shaw,DW; Finch,DM [tech. coord.]. Desired future conditions for Southwestern riparian ecosystems: Bringing interests and concerns together. USDA Forest Service. General Technical Report RM-227.

The Middle Rio Grande riparian forest, or "bosque", represents the largest cottonwood gallery riparian forest in the Southwestern United States. This reach of the Rio Grande extends from Cochiti Dam downstream $260 \mathrm{~km}$ to San Marcial, New Mexico. It constitutes 8 percent of the river's total length and 34 percent of it's length in New Mexico. The valley traverses three major biotic communities and it's reach can be subdivided into 4 reaches which coincide roughly with the four geologic basins along this portion of the Rio Grande Rift. This system has been affected by man's activities throughout prehistoric and modern eras. The Rio Grande is regulated for water supply and flood control. The effects of this interaction have contributed to the character of the riparian ecosystem in its current expression. This paper discusses the climate, geology, hydrology, river morphology, and anthropogenic factors that have contributed to past and current expressions of the Middle Rio Grande riparian habitat.

[BOSQUE; GALLERY FOREST; GEOLOGY; GEOMORPHOLOGY; HUMAN IMPACTS; HYDROLOGY; RIO GRANDE; RIPARIAN HABITAT]

1843. Whittaker,JG; Davies,TRH (1982): Erosion and sediment transport processes in steppool torrents. p.99-104. In: Proceedings of the Exeter symposium, July 1982; Recent developments in the explanation and prediction of erosion and sediment yield; IAHS Publication No. 137.

In upland regions, streams often exhibit a steppool morphology where water cascades between relatively deep pools. The capacity of such streams to entrain adjacent slope material depends not only on water flow rate and channel slope, but also on the degree of in-filling of the pools by sediment. This situation has been idealized, using a laboratory channel containing regularly spaced baffles. The results appear consistent with findings of studies of real torrents. The laboratory investigation has revealed that the erosive capacity of step-pool streams reaches a maximum (for a given flow rate) when the pools are almost full of sediment; that is, when sediment transport rates are high. This behavior is conducive to erosion of adjacent slopes and contrasts with that of alluvial strcams. Despite steady inputs, water and sediment outputs from the laboratory channel were often independently unsteady. Step-pool streams thus seem to display intrinsic unsteadiness, particularly of sediment movement. These findings seem to relate also to low-slope alluvial channel processes. Conventional linear analysis may be inappropriate for these situations.

[CHANNEL MORPHOLOGY; SEDIMENT TRANSPORT; SOILS]

1844. Whitten,D (1991): What riparian means to me. p.3. In: Proceedings of the third annual convention." What docs riparian mean to me?" Colorado Riparian Association. 6-8 November 1991. Pueblo, CO.

Animal impact or herd effect can be an effective tool to bring about desircd future condition and improve our watersheds. Despite its complexities, this process can benefit all the resources of a grazing allotment.

[DESIRED FUTURE CONDITIONS; GRAZING IMPACTS; LIVESTOCK EFFECTS]

1845. Wichert,GA; Rapport,DJ (1998): Fish community structure as a measure of degradation and rehabilitation of riparian systems in an agricultural drainage basin. Environmental Management 22(3), 425-443.

In this study, the authors examined fish communities in terms of an array of indicators of structure and related these to changes in riparian vegetation and agricultural practice within a drainage basin. The evidence suggests that management practices designed to foster healthier environments by reestablishing riparian vegetation were associated with positive impacts on the integrity of the fish community. Concurrently, intensification of agricultural practices in parts of the drainage basin had a degrading influence.

[AGRICULTURAL IMPACTS; FISHERIES; RIPARIAN HABITAT; SPATIAL SCALE]

1846. Wight,JR; Pierson,FB; Flerchinger,GN (1992): Influence of sagebrush on the soil microclimate. p.181-185. In: Clary,WP; McArthur,ED; Bedunah,D; Wambolt,WL [comp.|. Proceedings - Symposium on ecology and management of riparian shrub communities. USDA Forest Service. General Technical Report 
INT-289.

Since effective management of sagebrush-grass ranges requires establishment of desirable perennials, this study examined the influence of sagebrush on the near-surface soil microclimate. Maximum soil temperatures at a $1 \mathrm{~cm}$ depth differed by as much as 30 degrees $C$ between interspace and shrub-covered areas. Shrub cover prolonged the periods of soilwater conditions favorable for seedling establishment. Solar radiation was reduced 50 percent or more by sagebrush canopy. Reduced radiation and litter accumulation under sagebrush canopies significantly moderated the extremes in the soil microclimate.

[RIPARIAN HABITAT; SAGEBRUSH; SOILWATER CONDITIONS; SOILS]

1847. Wigley, TB (1995): Wildlife in streamside management zones: What do we really know? p.85-90. In: At the water's edge: The science of riparian forestry conference. 19-20 June 1995. Duluth, MN.

Streamside management zones (SM7s) are strips of forest vegetation maintained along waterways and often contain riparian and upland habitat. Increasingly, SMZ characteristics are being recommended on the basis of their perceived relationship to biodiversity. An overview is presented of results of existing studies that address relationships between characteristics of SMZs and wildlife communities. Bird species richness often increases with SMZ width, but most of the increase is in narrower width classes. Bird species sometimes characterized as forest-interior species can be supported in SMZs, but reproductive success is not understood. Microhabitat features in SMZs appear to be especially important to small mammal communities. Because of the limited number of studies, herpetofauna in SMZs is poorly understood. Many factors, other than the width, affect the value of SMZs as wildlife habitat. For a number of reasons, the database describing wildlife policies in SMZs is limited and not adequate for devising policy. [AVIAN ECOLOGY; EVALUATION; POLICY; RIPARIAN HABITAT; SMZ]

1848. Wild Horse Associates (1992): Classification and inventory of riverine/riparian habitat: Five Mile Creek Basin, Umatilla National Forest, Oregon. Prepared for North Fork John Day Ranger District, Umatilla National Forest, USDA Forest Service. 169 p.

Classification and inventory of riverine/riparian habitat was conducted in the watershed of Five Mile
Creek, an Order 4 tributary of Camas Creek which flows to the North Fork John Day River in Oregon. The focus of the classification was to identify riparian types. These vegetation types were nested in a hierarchical classification so that it could be used to compare this with other watersheds with similar ecological potential. Also assessed was the condition of these sites, which ranged from near natural to severely impacted.

[CLASSIFICATION; GIS; INVENTORY; RIPARIAN HABITAT; TECHNIQUES]

1849. Wilen,BO; Frayer,WE (1990): Status and trends of U.S. wetlands and deepwater habitats. Forest Ecology and Management 33/34, 181-192.

Historically, annual wetland losses have averaged 458,000 acres: 440,000 acres of palustrine losses of which 300,000 acres are forested, and 18,000 acres of estuarine wetland losses of which less than 100 acres are shrubs, scrub trees, or forested. Of these losses, 66 percent are forested wetlands. Agricultural development was responsible for 87 percent of wetland losses and 90 percent of the losses of forested wetlands. Urban development and other development caused only 8 percent and 5 percent of the losses, respectively. Forested-wetland losses caused by urban development and other development were 6 percent and 4 percent, respectively.

[RIPARIAN HABITAT; WETLANDS]

1850. Willard,DE; Willis,JA; Hillegeist,CL (1988): Regional-scale impacts from using agricultural wastewater for wildlife refuges. p.4754. In: Stuber,PJ [tech. coord.]. Proceedings of the national symposium on protection of wetlands from agricultural impacts. 25-29 April 1988. Ft. Collins, $C O$. USDI Fish and Wildlife Service. Biological Report 88(16).

Many western wetlands serve as agricultural wastewater sumps. These will inevitably build up contaminants. Mitigation sites should receive water upstream of agriculture. These upstream refuges will have greater ecological utility if they are available for populations to "spread the risk" before the existing sump refuge becomes hazardous. Time is short! [RIPARIAN HABITAT; WETLANDS]

1851. Williams,JR; Nicks,AD; Arnold,JG (1985): Simulator for water resources in rural basins. Hydraulic Engineer 111(6), 970-986.

A model called SWRRB (Simulator for Water Resources in Rural Basins) was developed for simulating hydrological and related processes in rural 
basins. The objeclive in model development was to predict the effect of management decisions on water and sediment yields with reasonable accuracy for ungaged rural basins throughout the United States. The three major components of SWRRB are weather, hydrology, and sedimentation. Processes considered include surface runoff, percolation, return flow, evapotranspiration, pond and reservoir storage, and sedimentation. Besides water, SWRRB also simulates sediment yield using the Modified Universal Soil Loss Equation (MUSLE) and a sediment routing model. Tests with data from a 538 $\mathrm{km}(2)$ basin in Oklahoma and a $17.7 \mathrm{~km}(2)$ basin in Texas indicate that SWRRB is capable of simulating water and sediment yield realistically. [HYDROLOGY; MODELING; SEDIMENT TRANSPORT]

1852. Williams,KS (1993): Use of terrestrial arthropods to evaluate restored riparian woodlands. Restoration Ecology 1(2), 107-116.

This study was implemented with the goal of using terrestrial arthropods to evaluate the progress of a riparian restoration effort along the San Luis Rey River in California. The evaluation was accomplished by comparing characteristics of the arthropod community at the reconstructed system to those of a naturally occurring riparian woodland used as a reference site. Relative abundances of indicator assemblages were compared between sites to evaluate the establishment and maintenance of processes critical for the natural function of the reconstructed riparian ecosystem. Abundance of certain groups, such as detritivores suggested that arthropods had propagated rapidly at the restoration site, a possible indication of resiliency. Relatively low numbers of other arthropods, such as predators and parasites, at the reconstructed site indicated the need for continucd monitoring. Decline of pollinators and herbivores by the last year of study at the reconstructed site suggested they may have immigrated or been introduced with transplanted vegetation but had difficulty colonizing the site. [ARTHROPODS; MONITORING; RIPARIAN RESTORATION]

1853. Williams,SE; Stahl,PD (1987): Importance of mycorrhizal fungi in land revegetation. p.72-89. In: Proceedings 39th annual meeting, Great Plains agricultural forestry committee. 22-25 June 1987.

Certain fungi, together with plant roots, form structures termed mycorrhizae that are advantageous to both plant and fungi. Sometimes this mutualism is essential to the growth and survival of the host plant.
Numerous shrubs in the western U.S. are highly dependent on mycorrhizae for enhanced survival. [MYCORRHIZAE; RIPARIAN RESTORATION; SOILS]

1854. Wills,L (1993): A grass roots perspective Feather River coordinated resource management. p.316-322. In: Tellman,B; Cortner,HJ; Wallace,MG; DeBano,LF; Hamre,RH [tech. coord.]. Riparian management: Common threads and shared interests. USDA Forest Service. General Technical Report RM-226.

Current public focus has been on the cumulative overuse of resource supplies perpetuated in and by the resource dependent communities. Until the consumer takes some responsibility for one hundred years of cumulative resource problems, the political "quick fix" solution will continue to be reduced multiple use in areas valued by consumers as playgrounds and intensified uses of less visible watersheds to provide products for runaway consumer demand.

[CRMP; PLANNING; RIPARIAN IIABITAT]

\section{Wilms,J; Rood,SB; Wilms,W; Tyree,M} (1998): Branch growth of riparian cottonwoods: A highly sensitive dendroch ronological tool. Trees 12, 215-223.

Conservation of riparian forests relies on the provision of in-stream flows that are sufficient to sustain tree growth. In this study, annual branch growth increments were investigated as an indicator of environmental favorability for riparian cottonwoods. Branch growth increments provided an accurate but short duration ( 1 or 2 decades) record of environmentally favorable conditions for growth. Close correlation between branch growth and stream flow indicated that water was the principal limitation to growth of riparian cottonwoods and that these trees obtained their water from a source linked to a stream, the water table. Branch increment analysis can provide a management for: 1) determining instream flow needs for riparian cottonwoods; and 2) analyzing impacts of stream flow alterations. [COTTONWOOD; DENDROCHRONOLOGY; RIPARIAN FOREST; STREAM FLOW]

1856. Wilson,BN; Barfield,BJ (1986): A detachment model for non-cohesive sediment. Transactions of the American Society of Agricultural Engineers 29(2), 445-449.

A detachment algorithm was developed using Einstein's bed load transport concepts. It was based on the probability of turbulent detachment forces 
exceeding the submerged weight of particles. During the process, a theoretical inconsistency in Einstein's bed load formulation was corrected. The use of the algorithm was demonstrated in predicting the bed scour rate in detention ponds. Results showed that the model predicted values with proper trends.

[GEOMORPHOLOGY; MODELING; SEDIMENT TRANSPORT]

1857. Wilson,L (1962): Observations on the dambuilding behavior of the beaver (Castor fiber $L$.) in a stream tank. Technical Report EOOAR Contract No $>$ AF 61(052)-195. 29 p.

This report summarizes the dam-building activities of young beavers in a 10 by $2 \mathrm{~m}$ stream tank in response to various stimuli. These included stream velocity, water level, rushing water, and building material.

[BEAVER; RIPARIAN HABITAT]

1858. Wilson,L (1987): Riparian boundary determination guidelines. In: Streamside management: Riparian wildlife and forestry interactions. An interdisciplinary symposium. 1113 February 1987. University of Washington. Seattle, WA.

In order to make management decisions regarding riparian resources, boundaries frequently must be delineated and choices must be made. Making these decisions may require information on plant ecology, wildlife ecology, aquatic ecology, topography, and hydrology. A series of questions in each of these areas was compiled to aid decisionmakers in assembling the information necessary to make riparian boundary determinations which protect the critical functions of the riparian zone. [INVENTORY; RIPARIAN HABITAT]

1859. Wilzbach,MA; Cummins,KW; Hall,JD (1986): Influence of habitat manipulations on interactions between cutthroat trout and invertebrate drift. Ecology 67(4), 898-911.

This study cxamined the interactions of the riparian setting (logged vs. forested) and prey availability on the prey capture efficiency and growth of the cutthroat trout, and to determine if the riparian setting influcnces the impact of trout predation on drift composition. Short-term relative growth rates of cutthroat trout, experimentally confined in stream pools, were greater in a logged than in a forested section of stream. Differences in growth rates were attributed to differences among pools in invertebrate drift density, and to differences in trout foraging efficiency that were related to differences between the sections in the amount of overhead shading and substrate crevices. Mean percentages of introduced prey captured by trout were greater in logged control pools and pools of both sections whose bottoms were covered with fiberglass screening to eliminate substrate crevices than in forested control pools and logged pools that were artificially shaded. A logarithmic relationship was found between trout foraging efficiency and surface light of pools. Drift density significantly increased relative to controls in pools from which trout were removed in the logged reach, but not in the forested section.

[FISHERIES; LOGGING IMPACTS; MACROINVERTEBRATES; PREDATION; RIPARIAN HABITAT; TROUT]

1860. Windell,JT; Willard,BE; Cooper,DJ; Foster,SQ; Knud-Hansen,CF; Rink,LP; Kiladis,GN (1986): An ecological characterization of Rocky Mountain Montane and subalpine wetlands. USDI Fish and Wildlife Service. Biological Report 86(11). National Ecology Center. Washington, DC. 295 p.

This report is intended to provide information for the assessment, planning, and permitting activities of federal and state agencies. It is also an educational source document for those interested in the ecological functioning and value of high-elevation wetlands. It draws on all types and sources of scientific information and provides both an analysis and a synthesis. Attempts were also made to recognize and identify gaps in the scientific literature. [RIPARIAN HABITAT; WETLANDS]

1861. Wincgar,HH (1977): Camp Creek channel fencing -- plant, wildlife, soil, and water response. Rangeman's Journal 4(1), 10-12.

This paper argues that, along with flow recovery projections, that natural recovery of western riparian systems will improve water quality, enhance all components of productive fisheries habitat and riparian dependent wildlife habitat and will provide a significant yet undetermined recovery of riparian systems and maintenance of late season flow. Natural recovery should be a prerequisite to other treatments. [EXCLOSURES; RIPARIAN HABITAT; RIPARIAN RESTORATION]

1862. Winger,PW; Schultz,DP; Johnson,WW (1988): Contaminant residues in fish from national wildlife refuges in the Southeast. p.38-46. In: Proceedings of the national symposium on protection of wetlands from agricultural impacts. 25-29 April 1988. Ft. Collins, CO. USDI Fish and 
Wildlife Service. Biological Report 88(16).

In fish from five of twenty refuges sampled, mean residue concentrations of organochlorine chemicals in fish tissue were at levels high enough to pose a threat to fish-eating wildlife. Concentrations of elemental contaminants in fish were considered higher than background levels in only six of twenty refuges surveyed. Potential environmental impacts of the chemicals of the elements at these levels are not known. Most refuges in the Southeast reflect contamination from agricultural chemicals, but only 5 of 20 examined were seriously contaminated. [AGRICULTURAL IMPACTS; POLLUTION; RIPARIAN HABITAT; WETLANDS]

\section{Winsor, $C$ (1977): Methods of improving} small trout streams. Fly Fisherman. Late Season, 1977, 38-41.

This is a topical article that analyzes which methods fit which type of creek and suggests some rules to guide fishing groups/clubs, individual stream owners, and even fish commissions, in their streamimprovement work to provide better fly fishing. Different types of streams demand different methods of improvement. The author presents three rules for stream improvement: 1) never touch a good natural pool; 2) take advantage of any natural conditions when you improve; and 3) drop a boulder or two in the pool at the dam or in the fast water above. [FISHERIES; RIPARIAN RESTORATION; STREAM IMPROVEMLNTS]

1864. Winter,PL (1993): Positives and negatives of recreation in riparian areas. p.155-157. In: Shaw,DW; Finch,DM [tech. coord.]. Riparian management: Common threads and shared interests. USDA Forest Service. General Technical Report RM-226.

Conflicts between recreational users becomes more likely as an area's popularity increases. Conflicts occur between users whose recreational choices are incompatible. Depreciative behaviors are most likely to occur in arcas with high use. Meetings between resource managers and various user groups can be helpful in reducing conflicts.

[CONFLICT RESOLUTION; RECREATION IMPACTS; RIPARI $\Lambda N$ HABITAT; RIPARIAN RESTORATION]

1865. Winward,AH (1984): An ecosystem classification for intermountain riparian areas. p.1-5. In: Bedell,TE [ed.]. Proceedings of 1984 Pacific Northwest range management short course: Range watersheds, riparian ones and economics: Interrelationships in management and use. 25-27 January 1984. Pendleton, OR. Oregon State University.

Riparian areas normally make up about $1-4$ percent of any one geographic region. There has been a tendency to overlook the value or importance of these areas, perhaps because of their small size. However, they provide a majority of the herbaceous forage from a small minority of an allotment. They provide the largest number and density of birds. They are also significant to fisheries, to certain wildlife species, and to numerous recreationists. Riparian areas are more important to more users than any other ecosystem. A proposal for classification of riparian areas is described that shows how riparian areas can be developed at several levels of intensity. [CLASSIFICATION; RIPARIAN ECOLOGY; RIPARIAN HABITAT]

1866. Wirtz,B; Martinez,R; Sims,B (1996): Watershed restoration on the French Mesa Grazing Allotment. p.201-204. In: National hydrology workshop proceedings. 27 April - 1 May 1992; Phoenix, AZ. USDA Forest Service. General Technical Report RM-GTR-279.

A Watershed Condition Inventory was completed on the French Mesa Grazing Allotment on the Santa Fe National Forest in north central New Mexico in 1988. This inventory identified and documented numerous erosional problems which were linked to ongoing land management practices. Meetings were held with allotment permittees and interdisciplinary Forest Service planning tcam. The team was successful in reaching consensus with the permittees and restoration measures were employed. These measures included earth dam gully plugs, sagebrush mowing, fencing which created new pastures, road management, and repair of existing developments. The key to success was in establishing cooperative ties with the permittees and overcoming traditional attitudes.

[CONSENSUS; EROSION CONTROL; GRAZING IMPACTS; WATERSHED]

1867. Wissmar,R; Halbert,C; Chu,J; Doyle,J (1993): Skagit wild and scenic river: management status and issues. p.373-388. In: Tellman, $B$; Cortner,HJ; Wallace,MG; DeBano,LF; Hamre, RH [tech. coord.|. Riparian management: Common threads and shared interests. USDA Forest Service. General Technical Report RM226.

USDA Forest Service has the authority to administer federal land within the Skagit Wild and 
Scenic River but no management authority or enforcement capability over state and private land within the corridor. Funding for management has been sparse and has originated primarily from the recreation program. Other funding has been delayed. These factors have combined to seriously compromise the USDA Forest Service desired management objectives for protecting and enhancing the values that caused the Skagit River to be added to the National Wild \& Scenic Rivers system. Problems are exacerbated by the complications of 26 separate agencies or entities having management responsibilities within the corridor. [COLLABORATION; FRAGMENTATION; RIPARIAN HABITAT; RIVER ECOLOGY; SKAGIT RIVER; WILD AND SCENIC RIVERS]

1868. Wissmar,RC; Smith,JE; McIntosh,BA; Li,HW; Reeves,GH; Sedell,JR (1994): A history of resource use and disturbance in riverine basins of eastern Oregon and Washington (early 1800s1990s). Northwest Science 68(Special Issue), 1-35.

A historical review of human activities influencing stream and riparian ecosystems in eastern Oregon and Washington shows that cumulative effects of resource uses and management over the last two centuries are altering the health of many river basins. Past practices such as livestock grazing and forest harvest near riparian areas and streams became collectively significant over long time periods and are continuing today. Historic cumulative effects on stream and riparian ecosystems include livestock grazing and mining from the 1860s until about 1910 . Timber harvest, roads, fire management, dams, irrigation, and fisheries increased in importance during the 20th century. Continuous dissent from competing entities only compounds this situation as available water and habitats continue to decline. Alternatively, new basin-wide management strategies of federal agencies and environmental organizations offer hope for improving the ecosystem diversity and population levels of fish and wildlife. Intact watersheds function as critical habitats and refugia for fish and wildlife of adjoining ecosystems. [ECOSYSTEM MANAGEMENT; RESOURCE CONFLICTS; RIPARIAN HABITAT; RIPARIAN RESTORATION]

1869. Witt,D; Tate,K; Atwill,ER; McDougald,NK; George,MR (1998): A rapid method for estimating livestock manure deposition on rangeland watersheds. p.135. In: Potts,DF [ed.]. Rangeland management and water resources: Proceedings of the AWRA specialty conference. American Water Resources Association. 27-29 May 1998. Reno, NV.

This study evaluated a double sampling technique to allow estimation of manure loading across a watershed through time. Regression relationships predicting dry weight per plot were highly significant for all trials. ANOVA indicated no difference between actual manure loading (measured by collection) and loadings estimated by observers, indicating the technique was accurate and consistent among observers.

[NON-POINT SOURCE POLLUTION; WATER QUALITY; WATERSHED]

1870. Wolman,MG (1954): A method of sampling coarse river-bed material. Transcripts of the American Geophysical Union. 35(6, Dec. 1954), 951-956.

This determination of the size of material on the bed of a stream is based upon an analysis of the relative area covered by particles of given sizes. The method is applicable to those rivers which flow on coarse material and may be waded during periods of low water. Sampling consists of measuring the intermediate axis of 100 pebbles picked from the bed of the channel on the basis of a grid system. From this sample a frequency distribution is drawn from which the desired size parameters are read. The advantages of the areal sampling procedure over bulk sampling are: 1) that it is applicable to very coarse materials; and 2) that it provides a more representative sample of an entire reach of a stream. [CHANNEL MORPHOLOGY; SAMPLING; SEDIMENTATION]

1871. Wolman,MG (1959): Factors influencing erosion of a cohesive river bank. American Journal of Science 257(March, 1959), 204-216.

The sinuous channel of Watts Branch in Montgomery County, Maryland, traverses a grassy meadow nearly devoid of trees. The creek has a drainage area of four square miles and the river bank is composed primarily of cohesive silt. Re-surveys to cross sections during the five years 1953-1957 have revealed as much as seven feet of lateral crosion. Approximately 85 percent of the observed erosion occurred during the winter months, December through March. Erosion was most severe at the water surface. Second in erosion effectiveness were cold periods during which wet banks, frost action, and low rises in stage combined to produce 0.6 foot of erosion in six weeks during the winter. Significant erosion also resulted from the combination of moist banks and low rises in stage. Lastly, crystallization of ice 
and subsequent thawing, without benefit of changes in stage, also produced some erosion as did flashy summer floods even on hard dry banks. [CHANNEL MORPHOLOGY; EROSION; RIVER ECOLOGY; STREAMBANK PROTECTION]

1872. Wolman,MG; Gerson,R (1978): Relative scales of time and effectiveness of climate in watershed geomorphology. Earth Surface Processes and Landforms 3, 189-208.

River channels in temperate regions widened by floods of recurrence intervals from 50 to more than 200 years may regain their original width in matters of months or years. In semi-arid regions, recovery of channel form depends not only on flows but upon climatic determinants of the growth of bottomland vegetation resulting in variable rates of recovery, on the order of decades, depending on the coincidence of average flows and strengthened vegetalion. In truly arid regions, the absence of vegetation and flow precludes the recovery and the width of channels increases in areas up to $100 \mathrm{~km} 2$, but remains relatively constant at larger drainage areas. Measured recovery times described in the literature vary from less than a decade for some tropical areas to decades or more in temperate regions. Recurrence incidence of high magnitude storms which trigger mass wasting range from 1 to 2 years in some tropical regions, to 3 or 4 per hundred years in some areas of seasonal rainfall and to 100 or more years in some temperate regions.

[CLIMATE; DRAINAGES; GEOMORPHOLOGY]

1873. Wondzell,SM (1997): Debris jams and flooding control long-term dynamics of the hyporheic zone. p.209. Abstracts. 1997 Annual meeting of the Ecological Society of America jointly with The Nature Conservancy. 10-14 August 1997. Albuquerque, NM.

Stream ecosystems are linked to terrestrial ecosystems underlain by shallow water tables via flows of water through the hyporheic zone. Subsurface flows are controlled by the configuration of primary and secondary channels. Floods which change the configuration of channels can profoundly alter subsurface flow paths. In this case study, change in the relative elevation of the primary channel and the abandonment of the secondary channel dramatically altered subsurface flow paths in nearstream locations. Stream reaches vary in their susceptibility to flood induced channel changes depending on the width of the main channel, degree on constraint, longitudinal gradients, and sediment size distribution.
[CHANNEL DYNAMICS; FLOOD IMPACTS; STREAM ECOLOGY]

1874. Wood,JC; Wood,MK (1988): Infiltration and water quality on range sites at Fort Stanton, New Mexico. Water Resources Bulletin 24(2), 317323.

The authors examined soil infiltration rates, sediment concentration and runoff water quality for range sites on a mesa top, hillside slopes and on valley bottom with varied grazing treatments and fertilization (valley bottom only). Soil infiltration on grassland was susceptible to grazing. Short duration grazing of pinyon pine-juniper treatments did not affect infiltration. Fertilization of bottomlands with soil conditions that favored plant growth increased plant biomass and cover. Higher stocking rates can be achieved if plant cover and biomass are sufficient to offset adverse effects of increased animal disturbance. Fertilized bottom-lands have increased chemical nutrient losses.

[GRAZING IMPACTS; GRAZING TREATMENTS; SOILS; WATER QUALITY]

1875. Woods,LG (1966): Multiple use management of mountain riparian vegetation. p.37-43. In: Vegetation management on flood plains and riparian lands: Phreatophyte symposium. Pacific Southwest Interagency Committee 66-3 Meeting. 30 August 1966. Albuquerque, NM.

Streamside zones are usually the sensitive tension areas where conflicts in uses and competition for resources and uses are found. These are also the areas where multiple use restraints limit what can or cannot be done with respect to manipulating vegetation. This does not preclude the possibilities of intensive management of streamside vegetation for increased water yield. Management decisions will require coordinated planning to develop feasible projects that will command public support. [MULTIPLE USE; RIPARIAN HABITAT; RIPARIAN VEGETATION; WATER YIELD]

1876. Wozniak,FE (1996): Iuman impacts on riparian ecosystems of the Middle Rio Grande Valley during historic times. p.33-43. In:

Shaw,DW; Finch,DM [tech. coord.]. Desired future condition for Southwestern riparian ecosystems: Bringing interests and concerns together. USDA Forest Service. General Technical Report RM-GTR-272.

The development of irrigation agriculture in historic times has profoundly impacted riparian 
ecosystems in the Middle Rio Grande Valley of New Mexico. A vital relationship has existed between water resources and settlement in the semi-arid Southwest since prehistoric times. Levels of technology have influenced human generated changes in the riparian ecosystems of the Middle Rio Grande Valley.

[AGRICULTURAL IMPACTS; HUMAN IMPACTS; RIO GRANDE; RIPARIAN ECOLOGY; RIPARIAN HABITAT]

1877. Wozniak,FE (1998): Irrigation in the Rio Grande Valley, New Mexico: A study and annotated bibliography of the development of irrigation systems. USDA Forest Service. Rocky Mountain Research Station. RMRS-P-2. 204 p.

This report describes the development of irrigation systems in the Rio Grande Valley of New Mexico from their origins in prehistoric Puebluan times through the Hispanic and Anglo-American irrigation constructions. Historic settlement and their interconnections to the land grant communities of Spanish and Mexican eras are discussed. The report also includes an annotated bibliography of published and unpublished sources relating to the primary subject matter.

[AGRICULTURAL IMPACTS; BIBLIOGRAPHY; IRRIGATION IMPACTS; RIO GRANDE]

1878. Wunder,L; Carey,AB (1996): Use of forest canopy by bats. Northwest Science 70, 79-85.

Eleven of the 15 species of bats in the Pacific Northwest are known to make regular use of the forest canopy for roosting, foraging, and reproduction. Common roosting sites are in cavities, crevices, and foliage. Several species forage in forest gaps, along forest edges, or in riparian areas. [BAT SPECIES; CANOPY; RIPARIAN HABITAT]

1879. Wunderlich,RC; Winter,BD; Meyer,JH (1994): Restoration of the Elwha River Ecosystem. Fisheries 19, 11-19.

Historically, the Elwha River in western

Washington was renowned for the abundance and diversity of anadromous salmonids. Most of the river system lies within the Olympic National Park and remains in pristine condition, but two dams in the lower river have blocked all anadromous fish for more than 80 years. To restore the Elwha's historic fishery resources and resolve an impasse about federal licensing of the dams, the U.S. Congress passed the Elwha River Ecosystem and Fisheries Restoration Act in 1992. The act required an analysis of alternatives (dam retention with fish passage facilities vs dam removal) to achieve full ecosystem and fishery restoration. Analysis indicates that removal of both dams is the only option that will achieve full restoration, but dam removal and fish restoration efforts could span 20 years and cost $\$ 147$ to $\$ 203$ million. Although fish restoration poses problems because of limited native runs, sediment management presents the most significant environmental challenge and cost. Nevertheless, a unique opportunity to fully restore the ecosystem of a major anadromous-salmonid-producing river is at hand.

[ANADROMOUS FISH; FISHERIES; RIPARIAN RESTORATION; RIVER ECOLOGY]

1880. Xiang,W-N (1996): GIS-based riparian buffer analysis: injecting geographic information into landscape planning. Landscape and urban planning 34(1), 1-10.

Establishment and maintenance of riparian buffer zones along shorelines or streams is a common best management practice in the U.S. These vegetated areas function as sinker, filter, and transformer to delay, absorb, or purify contaminated runoff before it enters surface waters. Their effectiveness for non-point source pollution control has been widely recognized. This paper describes a case study in which a GIS-based buffer analysis was conducted on a North Carolina watershed. This study accomplished a series of tasks that likely could not have been accomplished in conventional ways. These tasks included: 1) calculating and mapping variable riparian buffer zones; 2) identifying inadequately regulated areas; and 3) estimating land acquisition costs associated with unregulated areas.

[BUFFER STRIPS; GIS; INVENTORY; NONPOINT SOURCE POLLUTION; RIPARIAN HABITAT; RIPARIAN MANAGEMENT ZONE]

1881. Yong,W; Finch,DM (1996): Land-bird species composition and relative abundance during migration along the middle Rio Grande. p.77-92. In: Shaw,DW; Finch,DM [tech. coord. ]. Desired future conditions for Southwestern riparian ecosystems: Bringing interests and concerns together. USDA Forest Service. General Technical Report RM-GTR-272.

The authors report species composition and relative abundance of stopover migrants during spring and fall migration along the middle Rio Grande in 1994. They recorded 157 land-bird species using mist-netting and survey methods at sites on the Rio Grande, the Bosque del Apache, and the Rio Grande Nature Center. A total of 6,509 birds was 
captured. Of 157 species, 47 percent were neotropical long distance migrants, 50 percent were short

distance migrants, and the remaining 3 percent were residents or border migrants. Comparisons of relative abundance from the 1994 field research to similar findings from studies conducted in 1981-1983 and 1987-1990 demonstrated that populations of many species have remained relatively stable over approximately 6 or 12 year periods, while some species have become common or rare. [AVIAN ECOLOGY; RIO GRANDE; RIPARIAN HABITAT]

1882. Yoo,KH; Molnau,M (1987): Upland soil erosion simulation for agricultural watersheds. Water Resources Bulletin 23(5), 819-827.

A soil erosion simulation model that considered the physical conditions of agricultural watersheds and interfaced with an existing watershed hydrology model was developed. The model compares the transport capacity of the overland flow to determine the fate account for the free soil particles that have already been detached and are readily available to be transported by overland flow. The model was tested on two agricultural watersheds in the Pacific Northwest and calibrated by trial-and-error to determine coefficients.

[AGRICULTURAL IMPACTS; HYDROLOGY; MODELING; SOILS]

1883. York,J (1991): Riparian restoration plantings. p.35-41. In: Roth,D; Bridges,C; Zimmerman,C. [eds.]. What riparian means to me? Proceedings of the third annual convention. Colorado Riparian Association. 6-8 November 1991. Pueblo, CO.

Vegetative plantings of dormant stubs (logs) have proven to be highly successful means of forming streambank vegetation. The author cites the planting of 40-50,000 stubs from which 95 percent successfully established. Contract specifications and guidelines are included.

[PLANT COMMUNITIES; PLANTINGS; RIPARIAN RESTORATION]

1884. York,JC (1985): Dormant stub planting techniques. p. 513-514. In: Johnson,RR; Ziebell,CD; Patton,DR; Ffolliott,PF; Hamre,RH [tech. coord.]. Riparian ecosystems and their management: Reconciling conflicting uses. 16-18 April 1985. Tucson, AZ. USDA Forest Service. USDA Forest Service. General Technical Report RM-120.

Dormant stubs of black willow and cottonwood successfully stabilized when planted along the toe of banks and levees. 3-6 inch logs, 6-7 feet long, planted into the water table, resulted in exceptionally good survival and first season growth. Original plantings have survived several minor and one major flood and have provided protection to their respective banks and levees.

[PLANTINGS; RIPARIAN RESTORATION; TECHNIQUES]

1885. Young,DA (1988): Development of water management plans to protect waterfowl resources during agricultural drainage. p.121-130. In: Stuber,PJ [tech. coord.]. Proceedings of the national symposium on protection of wetlands from agricultural impacts. 25-29 April 1988. Ft. Collins, CO. USDI Fish and Wildlife Service. Biological Report 88(16).

The interest in expanded drainage activities in Alberta prompted various government agencies to commission water management planning exercises which could accommodate the interest of various water user groups including agriculture and wildlife. [AGRICULTURAL IMPACTS; RIPARIAN HABITAT; WETLANDS]

1886. Young,DW (1998): Hydrology of stock watering rights in Arizona's adjudications. p.305315. In: Potts, DF [ed.|. Range management and water resources: Proceedings of the AWRA specialty conference. American Water Resources Association. 27-29 May 1998. Reno, NV.

Since 1977, the Arizona State Land Department and the Attorney General's Office have conducted research projects to measure the capacity of stock ponds, determine the effective retention of stock ponds, and model the effects of stock ponds on watershed hydrology. Results of this study are summarized.

[HYDROLOGY; STOCK PONDS; WATER RIGHTS; WATERSHED]

1887. Young,JA; Allen,FL (1997): Cheatgrass and range science: 1930 - 1950. Journal of Range Management 50(5), 530-535.

Cheatgrass is currently and historically a serious point of contention among a wide varicty of people interested in sagebrush/bunchgrass. Nowhere are these differences more apparent than in the scientific community. The period $1930-1950$ was a period of awakening interest by range scientists. Cheatgrass both provides the bulk of forage on many ranges and is the symbol of environmental degradation. Trying to cope with the endless ramifications of cheatgrass 
invasion, dominance, persistence, and potential community decline keep forcing scientists to critically evaluate the ecological principles upon which range management is based.

[EXOTICS; GRAZING IMPACTS; SECONDARY SUCCESSION]

1888. Young,JA; Allen,F; Clements,CD (1998): The Wooten Plan - Division of Nevada rangelands based on water. p. 293-298. In: Potts,DF [ed.].

Range management and water resources:

Proceedings of the AWRA specialty conference. American Water Resources Association. 27-29 May 1998. Reno, NV.

Mr. E.O. Wooten was a US Department of Agriculture economist who was assigned, in the 1920 s, to find ways of achieving proper control over federal lands being used by the livestock industry in Nevada. In 1925, the Nevada legislature passed a law to control grazing within a 3-mile radius of recorded water rights. Conflicting and overlapping claims doomed the law to failure.

[GRAZING IMPACTS; PUBLIC LAND; WATER RIGHTS]

1889. Young,JA; Palmquist,DE; Blank,RR; Clements,CD (1998): Perennial pepperweed in riparian ecosystems. p.137-143. In: Potts, DF [ed.]. Rangeland management and water resources: Proceedings of the AWRA specialty conference. American Water Resources Association. 27-29 May 1998. Reno, NV.

Perennial pepperweed (Lepidium latifolium) is an exotic, highly invasive weed that initially infests riparian and wetland areas before invading agricultural fields. The weed forms dense, near mono-specific colonies that reduce forage production, biological diversity, and limits use of these areas by livestock, wildlife, and humans. Persistent accumulations of this species form $1 \mathrm{~m}$ tall entanglements on flood plain meadows, changing flow characteristics and sedimentation during floods. The coarse root system of this plant does not protect stream banks from erosion. [EXOTICS; RIPARIAN ECOLOGY]

1890. Young,MK (1999): Summer diel activity and movement of adult brown trout in highelevation streams in Wyoming, USA. Journal of Fish Biology 54, 181-189.

Implanted transmilters in adult brown trout of various sizes in two montane streams were used to determine variation in diel activity. More fish tended to be active and move greater distances each hour during twilight and night than during the day. Mean hourly light intensity was significantly negatively correlated with activity and distance moved. Maximum water temperature was not correlated with any measure of diel activity. Fish were active an average of 11 hours, had a mean home range of 41 $\mathrm{m}$, and moved an average of $121 \mathrm{~m}$ daily. Fish length and distance moved were also significantly positively correlated.

[FISH HABITAT; RIPARIAN HABITAT; TROUT]

1891. Young,RA; Huntrods, $T$; Anderson, $W$ (1980): Effectiveness of vegetated buffer strips in controlling pollution from feedlot runoff. Journal of Environmental Quality 9(3), 483-497.

Buffer strips were tested for their ability to control pollution from feedlot runoff by using a rainulator. Cropped buffer strips on a 4 percent slope reduced runoff and total solids transported from a feedlot by 67 percent and 79 percent, respectively. Total $\mathrm{N}$ and $\mathrm{P}$ were reduced by an average of 84 percent and 83 percent, respectively. Results indicated that nonstructural discharge control practices are a good alternative for controlling pollution occurring from feedlot runoff. [BUFFER ZONES; COLIFORM BACTERIA; NONPOINT SOURCE POLLUTION]

1892. Young,RA; Onstad,CA (1982): The effect of soil characteristics on erosion and nutrient loss. p.105-113. In: Proceeding of the Exeter symposium, July 1982 . Recent developments in the explanation and prediction of erosion and sediment yield; IAHS Publ. No. 137.

Soil properties which exert a significant influence in the type of erosion occurring, inter-rill or rill, were compared. Those characteristics most influential in determining a soil's susceptibility to inter-rill erosion are the degree of aggregation of the surface soil, the stability of soil aggregates to breakdown under raindrop impact, and the type and amount of clay in the soil. The characteristics influencing susceptibility to rill erosion are organic matter content, aggregate density, bulk dersity of the surface soil, and the dispersion ratio. Some factors affecting the transportability of detached particles were also examined along with their possible effects on nutrient enrichment of sediment.

[GEOMORPHOLOGY; NON-POINT SOURCE POLLUTION; SEDIMENT TRANSPORT; SOILS]

1893. Youngblood,AP; Padgett,WC; Winward,AH (1985): Riparian community type classification in the Intermountain Region. p.510- 
512. In: Johnson,RR; Ziebell,CD; Patton,DR; Ffolliott,PF; Hamre, RH [tech. coord.]. Riparian ecosystems and their management: Reconciling conflicting uses. 16-18 April 1985. Tucson, AZ. USDA Forest Service. General Technical Report RM-120.

Riparian ecosystems in Idaho, Wyoming, and Utah were classified into community types based upon similarities in floristic composition. The method provides a tool for resource management. Diagnostic keys that utilize conspicuous plant species are provided for field identification. Environmental relationships, successional status, and management implications are discussed.

[CLASSIFICATION; RIPARIAN HABITAT]

1894. Yount,JD; Niemi,GJ (1990): Recovery of lotic communities and ecosystems from disturbance - A narrative review of case studies. Environmental Management 14(5), 547-569.

This paper presents a narrative account of case studies on the recovery after disturbance of flowing water systems. In the majority of studies examined, the systems recovered rapidly. The most commonly cited reasons for short recovery times were: 1) life history characteristics that allowed rapid recolonization and repopulation of the affected areas; 2) the availability and accessibility of unaffected upstream and downstream areas as sources of organisms for repopulation; 3) the high flushing rates of lotic systems that allowed them to dilute or replace polluted waters; and 4) the fact that lotic systems are naturally subjected to a variety of disturbances and the biota have evolved the characteristics that favor flexibility or adaptability. Longer recovery times were generally associated with alterations to physical conditions.

[LOTIC SYSTEMS; RIPARIAN RESTORATION]

1895. Yuncevich,GM (1993): The San Pedro National Conservation Area. p.369-372. In: Tellman,B; Cortner,HJ; Wallace,MG; DeBano,LF; Hamre,RH [tech. coord.]. Riparian management: Common threads and shared interests. USDA Forest Service. General Technical Report RM-226.

The San Pedro Riparian National Conservation Area (NCA) was created by passage of the Arizona Conservation Act in 1988. The NCA was established to conserve, protect, and enhance the riparian area and the aquatic, wildlife, archaeological, paleontological, scientific, cultural, educational, and recreational resources of the public land surrounding the San Pedro River.
[NATIONAL CONSERVATION AREA; RIPARIAN HABITAT; RIPARIAN MANAGEMENT ZONE]

1896. Zasada,J; Tappeiner,J; O'Dea,M (1992): Clone structure of salmonberry and vine maple in the Oregon Coast Range. p.56-60. In: Clary,WP; McArthur,ED; Bedunah,D; Wambolt,CL [comp.]. Proceedings - Symposium on ecology and management of riparian shrub communities. USDA Forest Service. General Technical Report INT-289.

Salmonberry and vine maple, both important riparian shrubs in western Oregon, form large clones of varying densities. Salmonberry clones develop in an active process that requires growth of a rhizome into an area followed by ramet production from the rhizome seed bank. Vine maple clones, however, develop by layering when stems are pinned to the ground by falling trees or branches

[PLANT COMMUNITIES; RIPARIAN

RESTORATION; RIPARIAN SHRUBS]

1897. Zedler,JB; Williams,GD; Desmond,JS (1997): Wetland mitigation: Can fishes distinguish between natural and constructed wetlands?

Fisheries 22(3), 26-28.

This paper recommends that plans for mitigating damages to natural wetlands strive to mimic reference systems in all features, including geomorphic heterogeneity and hydrologic complexity (hydroperiod, salinity, currents, and water quality) and that only the most natural wetlands of the region be used as role models. Mitigation banking has the advantage of allowing resource values to be determined in advance of losing habitat, but there must be landscape-level consequences.

[CREATED WETLANDS; MITIGATION

BANKING; WATERSHED; WETLAND MITIGATION]

1898. Zeedyk,B; Romero,B; Albert,SK (1996): Using simple structures for flow dispersion in wet meadow restoration. p.258-259. In: Shaw,DW; Finch,DM [tech. coord.]. Desired future conditions for Southwestern riparian ecosystems: Bringing interests and concerns together. USDA Forest Service. General Technical Report RM-GTR-272.

Historically, wet meadow restoration projects have relied on heavy earth moving equipment to harden nick points and install gully plugs or terraces to trap and detain sediments The authors experimented with a variety of simple hand-built structures fashioned of logs, rocks, geotextile fabrics 
and/or sandbags designed to disperse runoff, re-wet surface and subsurface soils and stimulate the growth of wetland dependent vegetation adapted to erosion control and sediment detention. Workers were utilized from a variety of labor pools.

[EROSION CONTROL; GULLY CONTROL; MEADOWS; RIPARIAN RESTORATION]

1899. Zeedyk,WD (1996): Managing roads for wet meadow ecosystem recovery. USDA Forest Service. FHWA-FLP-96-016.

Riparian and watershed restoration and enhancement have received much attention in recent years. Effective restoration techniques are not often well understood. The focus of this project was to "keep the water on the mountain" and as a result improve riparian habitat. The publication provides a riparian restoration guide which will be used as a reference document for use in understanding wet meadow functions, identifying treatment opportunities, planning and implementing new or remedial treatments, and monitoring results. [EROSION CONTROL; HEADCUTTING; HYDROLOGY; MEADOWS; RIPARIAN RESTORATION]

1900. Zentner,J (1997): Soil considerations in riparian restoration. Restoration \& Management Notes 15(1), 56-59.

Many riparian construction projects begin with excavation to establish required grades. The result is a site on which the planting substrate is a relatively sterile sub-grade. Application of topsoil as a substrate amendment can be extremely beneficial. Many of the concerns about using topsoil relate to the introduction of weeds. This is most germane in areas in which wetland weeds are found. It is then advisable to use only those top-soils contain relatively few adapted weeds. Addition of organic material alone is another means of providing raw nutrients without weed introduction.

[ORGANIC DEBRIS; RIPARIAN RESTORATION; SOILS; TOPSOIL]

1901. Zimmerman,RC; Goodlet,JC; Comer,GH (1967): Influence of vegetation on channel form of small streams. p.255-275. In: International Association of Scientific Hydrology, Publication No. 75. Symposium on river morphology.

Data on channel width of several small streams in the Sleepers River basin of northern Vermont have provided some measure of the influence of vegetation on channel form. In the Sleepers River basin there are apparently two thresholds along streams. In a downstream direction, the first threshold occurs at points with drainage areas of .2 to .8 square mile. Upstream from these points, width does not increase in a downstream direction, living tree roots cross the channel, and dams of organic debris are common. The flow is commonly underground. Points with drainage areas of .2 to .8 square miles have annual high flows of 10 to $20 \mathrm{cfs}$. With drainage areas exceeding .2 to .8 square miles widths increase, but channel form is highly variable, and mean widths may vary by as much as 5 feet depending upon the type of vegetation. Relatively, uniform widths occur, regardless of vegetation, where the drainage area exceeds 4 to 6 square miles. Points with drainage areas of about 5 square miles are apparently the second threshold. These points have annual high flows in the range of 100 to $150 \mathrm{cfs}$. Beyond these points, the influence of vegetation on channel form is marginal compared with that of geological differences and the sinuosity of the flow itself. [CHANNEL MORPHOLOGY; RIPARIAN VEGETATION]

1902. Zonge,L; Swanson,S (1996): Changes on streambanks in the Sierra Nevada Mountains: Perspectives from a dry and a wet year.

Restoration Ecology 4(2), 192-199.

This paper summarizes the findings of a twoyear study of vegetation and stream-bank erosion on incised streams. The first year of the research was conducted during the sixth year of a drought. During the second year of study, precipitation totals ranged from normal to 200 percent of normal. The focus of the study was to determine if vegetation established on a bank affects the erosion of or deposition on that bank. During the drought year, most banks showed relatively litlle change. During the high water year, 27 percent of all vegetation and 32 percent of all bare lower banks retreated more than $250 \mathrm{~mm}$. This similarity between vegetated and unvegetated banks indicates that, on the streams studied, vegetation had little effect on bank erosion.

[CHANNEL DYNAMICS; DROUGHT EFFECTS; RIPARIAN HABITAT; RIPARIAN VEGETATION; STREAMBANK STABILITY]

1903. Zube,EH; Simcox,DE (1987): Arid lands, riparian landscapes and management conflicts. Environmental Management 11(4), 529-535.

The paper reports on a mail survey of the perceptions, attitudes, and opinions of the general public and special interest groups toward a riparian landscape in the Sonoran Descrt. A specific point of enquiry is the relative position of professional 
resource managers compared with other groups on issues such as land use planning, appropriate management prescriptions, and appropriate land uses adjacent to riparian areas. Discriminant analysis of response data reveals significant differences among several special interest groups and the general public, and identifies an important challenge for the managers who are more aware of the fragility of arid lands and riparian ecosystems and of threats to their continued productivity posed by rapid urban expansion. [RIPARIAN HABITAT; RIPARIAN MANAGEMENT ZONE]

1904. Zurowski, W (1979): Preliminary results of European beaver reintroduction in the tributary streams of the Vistula River. Acta Theriologica 24(7), 85-91.

In 1977, there were about 254 beaver families in Poland. Most of them inhabited tributary streams in northeast Poland. In 1976-1977, experimental reintroduction was started into the central portion of the country. Introduced beavers were either removed from the free-living population or taken from a beaver farm at Popielno. In a selected site, artificial lodges or burrows were prepared. Good results were obtained in areas frequented by people.

[BEAVER; RIPARIAN HABITAT]

1905. Zwank,PJ; Sparrowe,RD; Porath,WR; Torgerson, $O$ (1979): Utilization of threatened bottomland habitats by white-tailed deer. Wildlife Society Bulletin 7, 226-232.

White-tailed deer (Odocoileus virginianus) were monitored from 1971 to 1978 to document their utilization of bottomland habitats threatened by water resource development (Swan Lake Nalional Wildlife Refuge, bottomland in north central Missouri). Data collected support other observations that deer in agricultural areas of the Midwest utilize bottomland habitats throughout the year. The destruction of naturally vegetated bottomlands constitutes a threat to viable white-tailed deer populations.

[RIPARIAN HABITAT; WHITE-TAILED DEER] 


\section{KEYWORD INDEX}

$A$

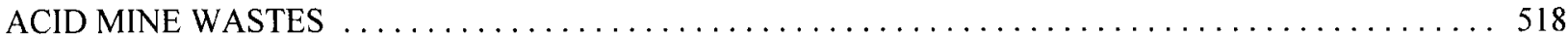

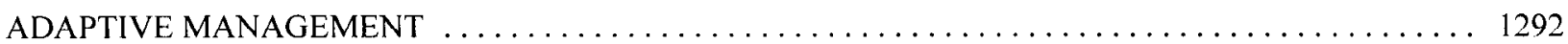

AERIAL PHOTO . . . 45, 108, 115, 345, 391, 405, 407, 408, 516, 545, 637, 702, 709, 771, 998, 1174, 1378, 1467 ,

1524,1728

AGRICULTURAL IMPACTS $\ldots . .43,95,292,427,446,462,606,660,664,745,775,851,881,929,932,1020$, $1051,1052,1211,1253,1464,1500,1637,1730,1802,1845,1862,1876,1877,1882,1885$

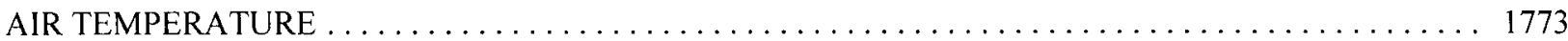

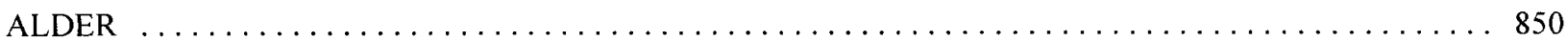

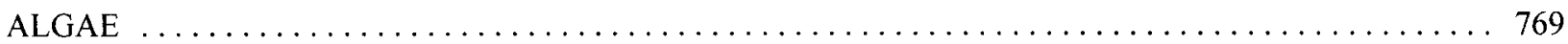

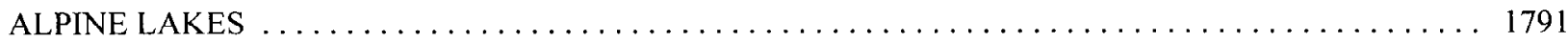

AMPHIBIANS $\ldots \ldots \ldots \ldots \ldots \ldots \ldots \ldots \ldots \ldots \ldots \ldots \ldots \ldots \ldots \ldots \ldots \ldots \ldots \ldots \ldots \ldots \ldots \ldots \ldots, 375,376,610,879,1106,1406,1679,1831$

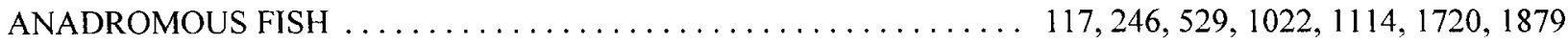

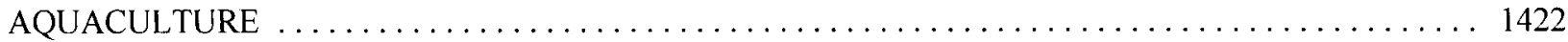

AQUATIC ECOSYSTEMS . . 44, 121, 139, 372, 483, 523, 558, 602, 622, 808, 903, 933, 1025, $1117,1143,1148$,

$1172,1302,1304,1332,1334,1345,1354,1359,1388,1392,1398,1436,1498,1590,1616,1813$

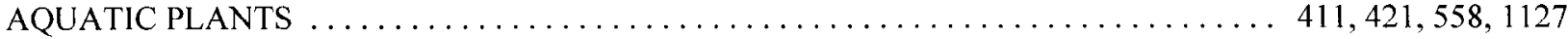

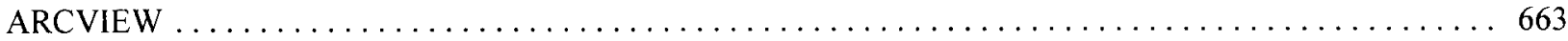

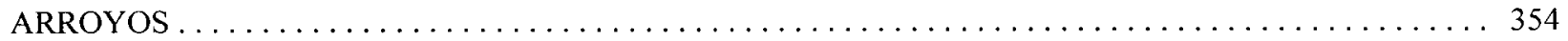

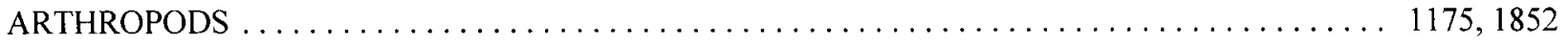

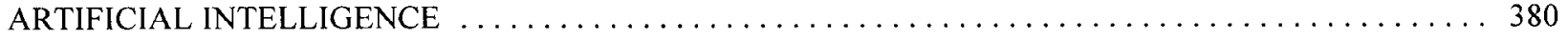

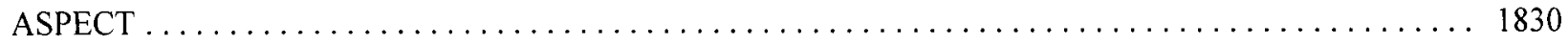

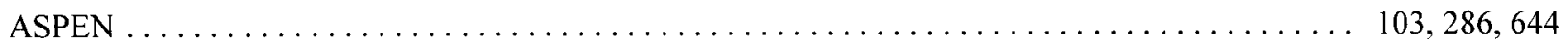

ASSESSMENTS $\ldots \ldots \ldots \ldots \ldots \ldots 297,326,430,471,569,800,889,1257,1302,1451,1582,1789,1826$

AVIAN ECOLOGY . . . 31, 91, 138, 222, 259, 335, 414, 415, 539, 541, 666, 866, 941, 962, 967, 1000, 1034, 1037 ,

$1112,1122,1124,1134,1423,1501,1517,1532,1542,1597,1621,1632,1675,1684,1697,1738,1776$,

1847,1881

AVIFAUNA . . 10, 32-34, 94, 155, 156, 224, 287, 322, 334, 442, 465, 527, 540, 542, 543, 667, 811, 825, 867, 928, $932,939,940,942,943,945,971,1034,1101,1120,1253,1254,1416,1429,1481,1482,1488,1510$,

$1517,1529,1530,1542,1675,1695,1741,1817,1826$

\section{$\boldsymbol{B}$}

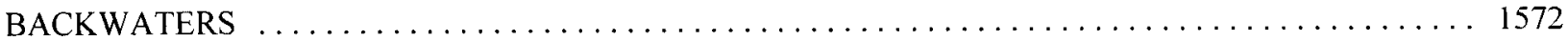

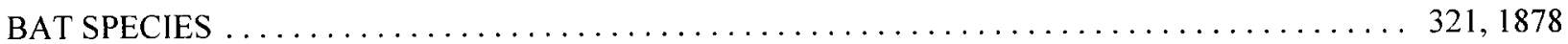
BEAVER . 53, 58-61, 85, 126, 134, 194, 204, 235, 344, 384, 411, 460, 491, 513, 639, 672, 797, 832, 873-875, 923 , $925,951,962,1005,1053,1089,1107,1116,1122,1123,1125,1197,1215,1216,1225,1284,1285$, $1300,1499,1577,1584,1586,1604,1696,1697,1732,1857,1904$

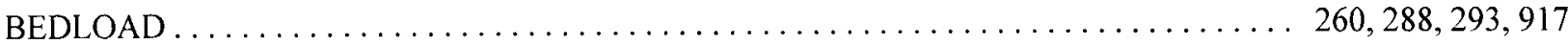

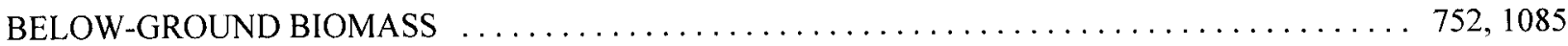

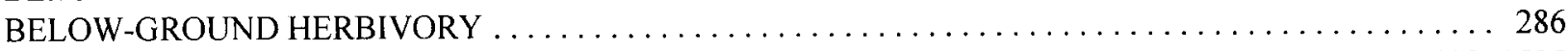

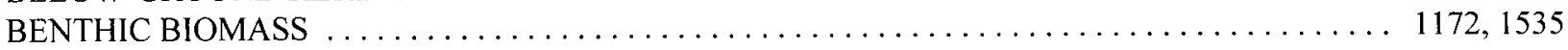

BEST MANAGEMENT PRACTICES .. 341, 361, 627, 717, 718, 720, 725, 773, 809, 821, 921, 1142, 1165, 1193,

$1374,1556,1735,1738$

BIBLIOGRAPHY $\ldots \ldots \ldots 44,164,347,406,421,477,487,488,508,546,595,789,831,887,931,1065,1091$, $1125,1160,1180,1429,1493,1505,1536,1581,1630,1704,1774,1810,1877$

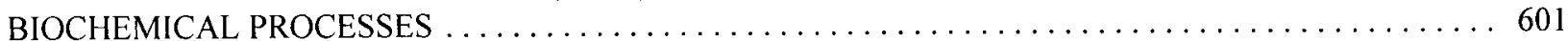


BIODIVERSITY . $13,15,38,54,56,84,94,103,112,186,224,301,371,376,431,500,542,543,590,622,640$, $643,670,701,801,879,892,901,940,943,945,1090,1092,1096,1120,1121,1177,1184,1239,1261$,

$1375,1406,1520,1521,1530,1631,1651,1679,1687,1705$

BIOENGINEERING ................................... 20, 132, 343, 1269, 1611

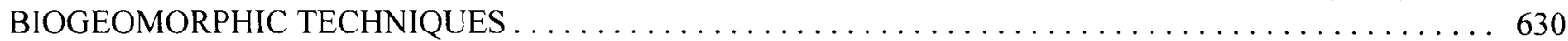

BIOLOGICAL CONTROL . . . . . . . . . . . . . . . . . . . . . . . . . . . . . . . . . 1709

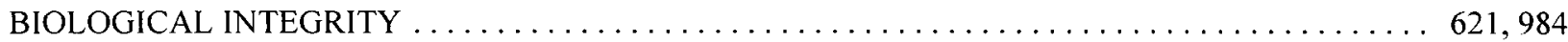

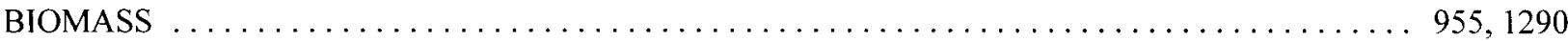

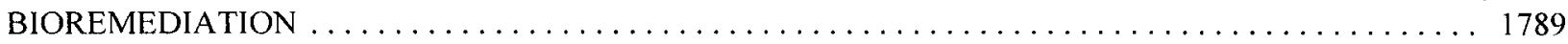

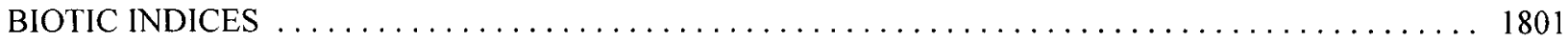

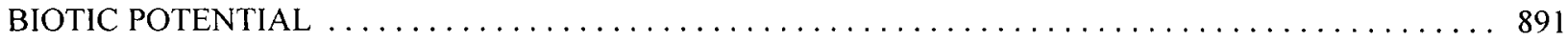

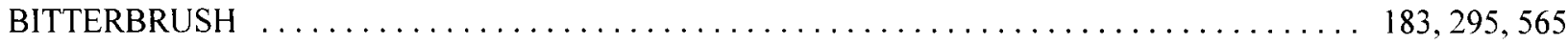

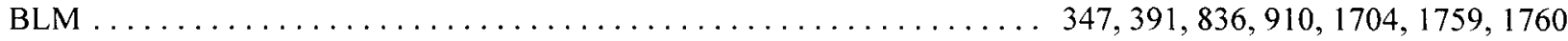

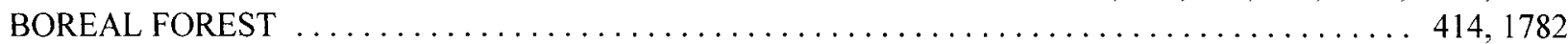

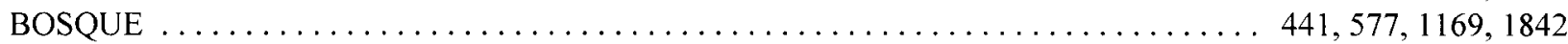

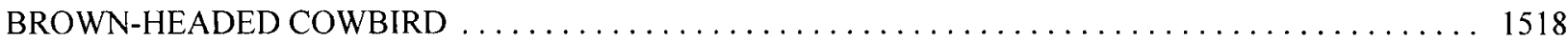

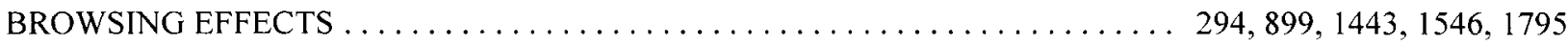

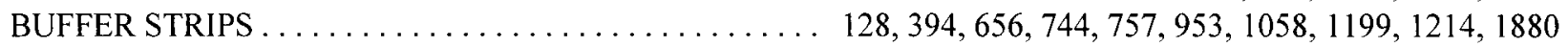

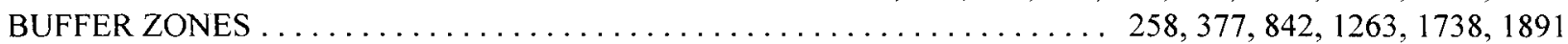

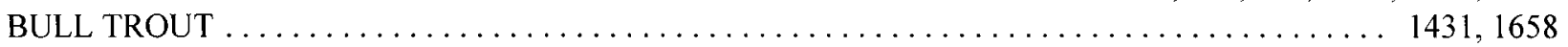

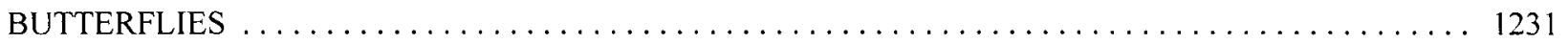

$C$

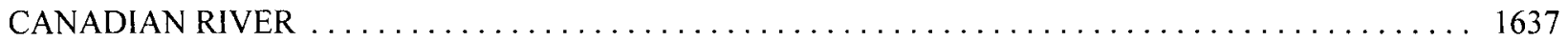

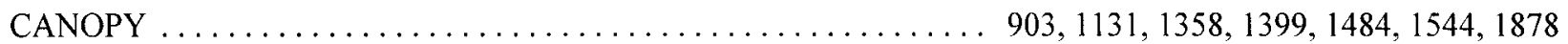

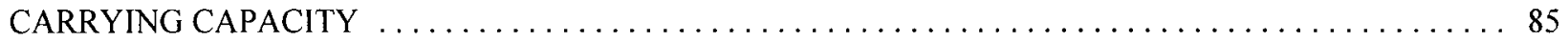

CHANNEL DYNAMICS $\quad 46,48,88,94,97,107,265,314,329,330,356,382,435,439,561,620,630-632,647$, $654,699,712,713,731,736,738-740,756,759,765,771,778,837,839,916,946,948,957,987,1015$, $1016,1030,1031,1095,1104,1108,1200,1209,1238,1269,1272,1279,1286,1299,1343,1366,1369$,

$1378,1415,1425,1432,1471,1512,1514-1516,1567,1595,1717,1718,1781,1792,1873,1902$

CHANNEL MORPHOLOGY . 22, 23, 48, 49, 97, 120, 137, 140, 196, 197, 238, 239, 262, 265, 273, 278, 293, 310 , $313,346,348,356,572,637,654,655,665,693,699,728,736,742,755,756,759,760,778,837,906$, $907,936,957,985,1016,1017,1030,1031,1033,1080,1129,1135,1136,1146,1277,1278,1283,1286$, $1289,1293,1367,1369,1458,1459,1464,1468,1469,1471,1500,1512,1513,1515,1562,1567,1576$, $1595,1598,1662,1739,1792,1824,1838,1843,1870,1871,1901$

CHECK DAMS $96,502,726,727,729,733,737,739,1041,1042,1610$

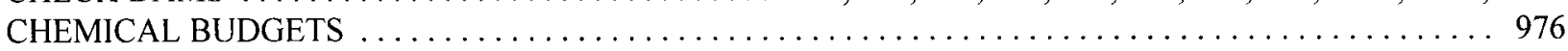

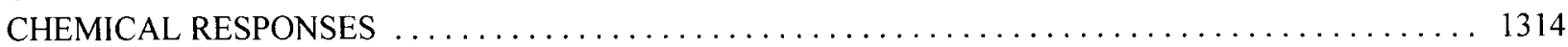

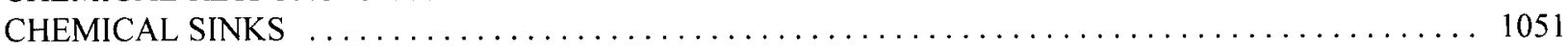

CLASSIFICATION . . 8 80, 83, 89, 130, 153, 167-169, 214, 222, 225, 227, 228, 237, 273, 299, 304, 326, 332, 383, $399,446,447,455,493,495,510,535,536,548,552,574,579,584,587,599,648,680,681,684,686$,

$687,696,723,735,747,804,805,813,848,865,916,954,956,1006,1013,1043,1044,1048,1067$, $1107,1134,1162,1171,1191,1212,1280,1287,1305,1320,1390,1392,1412,1468,1469,1489,1652$, $1659,1666,1669,1670,1676,1677,1685-1687,1698,1732,1809,1833,1848,1865,1893$ CLEAN WATER ACT $\ldots \ldots \ldots \ldots .6,90,184,201,202,430,776,782,1177,1193,1218,1628,1735,1768$ CLIMATE ................. 34, 87, 305, 416, 580, 692, 1012, 1056, 1060, 1288, 1535, 1598, 1872

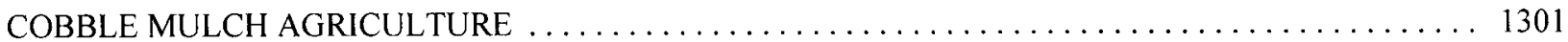

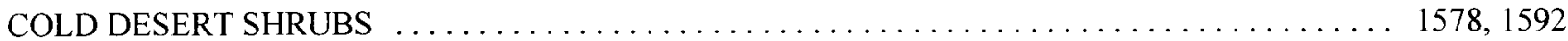
COLIFORM BACTERIA $\ldots \ldots \ldots \ldots \ldots \ldots \ldots \ldots \ldots \ldots \ldots \ldots \ldots \ldots \ldots \ldots \ldots 17,174,175,252,413,1577,1723,1891$ COLLABORATION ... 113, 143, 211, 250, 275, 306, 324, 445, 532, 690, 715, 762, 818, 927, 1307, 1376, 1519, $1670,1710,1867$

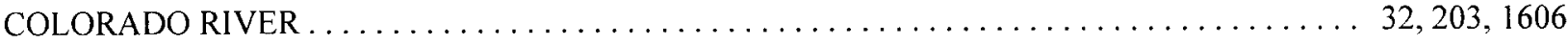

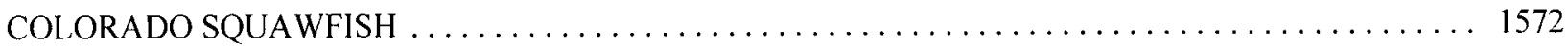


COLUMBIA RIVER

$885,1295,1690$

COMPACTION

1494,1558

CONFLICT RESOLUTION

$818,1312,1712,1864$

CONNECTIVITY

CONSENSUS

$\ldots \ldots \ldots \ldots, 186$

$182,445,716,825,1866$

CONSERVATION

198,1521

CONSERVATION BIOLOGY

CONTAMINATION

............ 280

COTTONWOOD

$38,170,318,342,389,397,415,533,573,613,629,770,772,799,847,867,1059,1089$

$1090,1146,1147,1254,1457,1458,1482,1490,1522,1523,1531-1533,1606,1644,1645,1673,1790$,

1855

COVER

$1372,1634,1834,1835$

COWFISH

363,1035

COWFISH MODEL

CREATED WETLANDS

$1,190,257,431,588,651,751,831,983,994,1021,1065,1156,1160,1202,1215$,

$1249,1393,1450,1505,1897$

CRMP $429,964,1027,1607,1854$

CULTURAL IMPACTS 1395

CULTURAL VALUES

CUMULATIVE IMPACTS

$206,213,316,624,636,701,748,933,934,1557-1560,1585,1826$

CUTTHROAT TROUT

CUTTINGS

D

DAMS $318,416,533,608,1024,1457,1458,1662,1807$

DECISION ........................... 1292

DECISION SUPPORT SYSTEMS $\ldots \ldots \ldots \ldots \ldots \ldots \ldots \ldots$

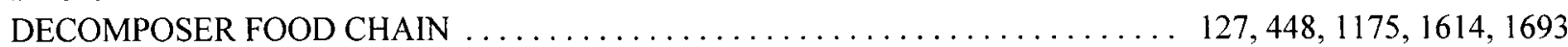

DEER BROWSING . . . . . . . . . . . . . . . . . . . . . . . . . . . . . . . . . . . 820

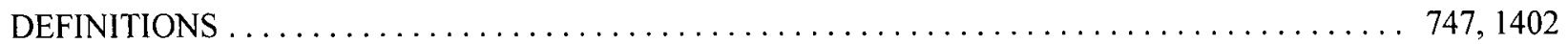

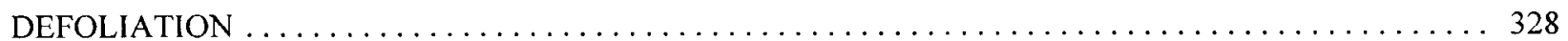

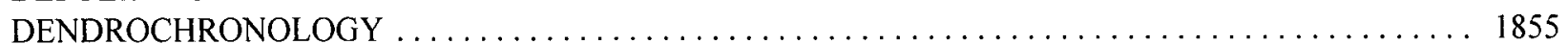

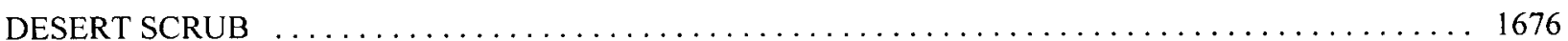

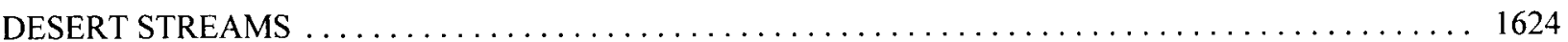

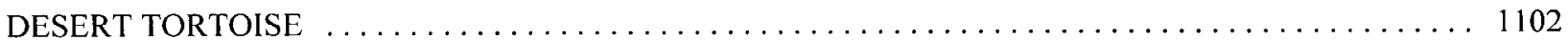

DESIRED FUTURE CONDITIONS . . . . . . . . . . . . 131, 1128, 1276, 1277, 1401, 1440, 1545, 1844

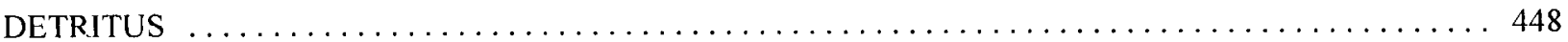

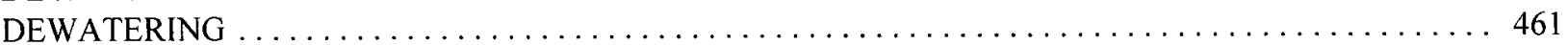

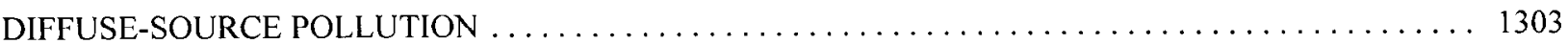

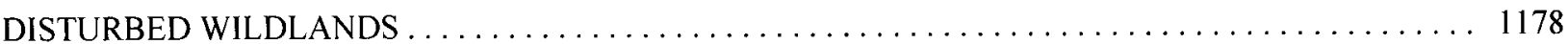

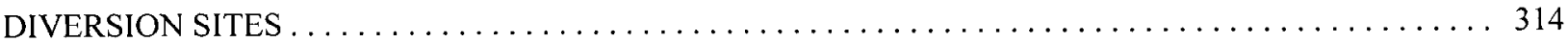

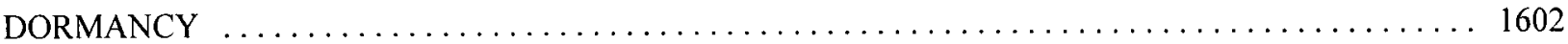

DRAINAGES $\ldots \ldots \ldots \ldots \ldots \ldots \ldots \ldots \ldots \ldots \ldots \ldots \ldots \ldots \ldots \ldots \ldots \ldots \ldots \ldots, 440,695,725,883,1189,1301,1872$

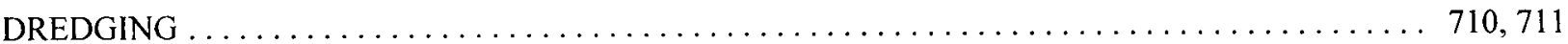

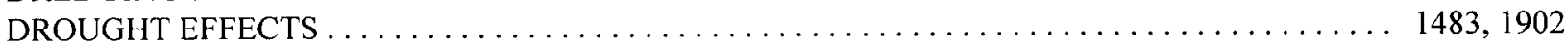

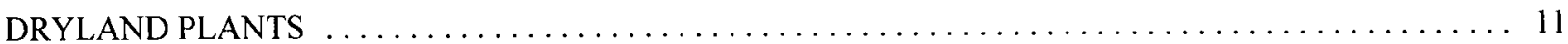

$\boldsymbol{E}$

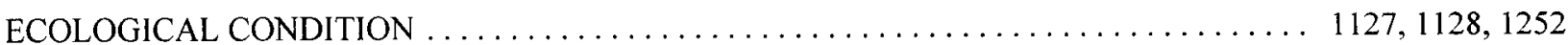

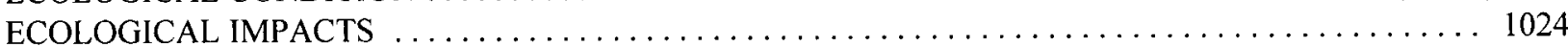

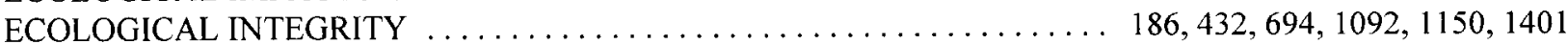

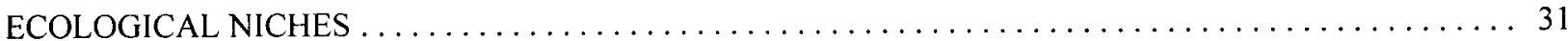

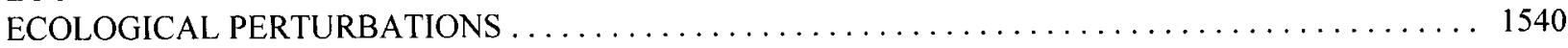




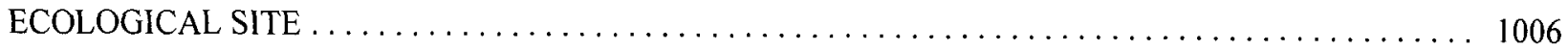

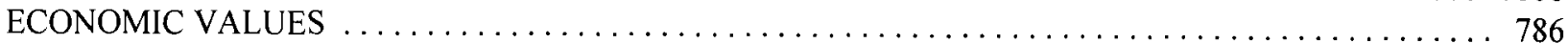
ECONOMICS . . . 16, 112, 118, 133, 154, 212, 266, 388, 412, 426, 471, 477, 526, 781, 1029, 1152, 1153, 1189 , $1240,1260,1273,1274,1315,1364,1426,1504,1657,1754,1788,1796$ ECOSYSTEM MANAGEMENT . 28, 83, 278, 371, 474, 619, 701, 762, 965, 1182, 1248, 1249, 1387, 1396, 1412 ,

EDGE EFFECT $1586,1588,1612,1648,1747,1868$

EDUCATION 975

EFFLUENTS

ELK GRAZING $556,601,1819$

EMERGENT VEGETATION $561,1221,1571,1795$

ENDANGERED SPECIES ACT $557,1233,1828$ ENVIRONMENTAL MANAGEMENT 919,1736 EPHEMERAL STREAMS $440,1561,1598,1599$ EROSION $\ldots 72,88,140,152,254,255,434,439,449,559,623,632,662,742,876,938,990,992,1095,1138$, $1139,1296-1298,1322,1369,1459,1467,1485,1558,1581,1612,1661,1811,1871$ EROSION CONTROL . . 20, 727, 729, 732, 737, 741, 851, 1113, 1271, 1285, 1513, 1548, 1754, 1866, 1898, 1899

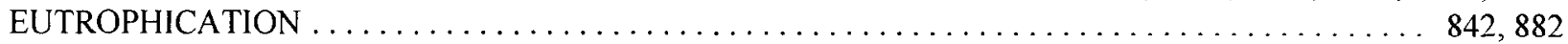
EVALUATION ... 326,369, 569, 626, 947, 1257, 1258, 1330, 1351, 1477, 1503, 1565, 1627, 1698, 1711, 1751, 1847 EVAPOTRANSPIRATION $103,583,1290,1537,1551$

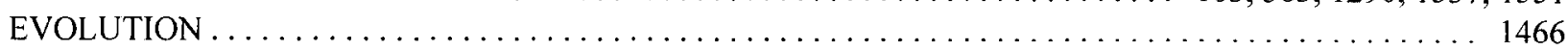
EXCLOSURES ... 241, 298, 333, 484, 485, 561, 847, 905, 985, 997, 1235, 1357, 1359, 1364, 1383, 1427, 1508 , $1650,1687,1743,1755,1861$ EXOTICS . . 270-272, 368, 451, 464, 494, 512, 942, 944, 1000, 1007, 1422, 1550, 1620, 1635, 1644, 1709, 1887 ,

EXPERIMENTAL DESIGN 1889 $993,1436,1437$

\section{$\boldsymbol{F}$}

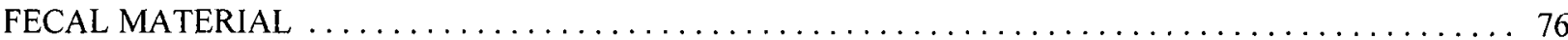
FEDERAL ENERGY REGULATORY COMMISSION $\ldots \ldots \ldots \ldots \ldots \ldots \ldots \ldots \ldots \ldots \ldots \ldots \ldots \ldots 1748$

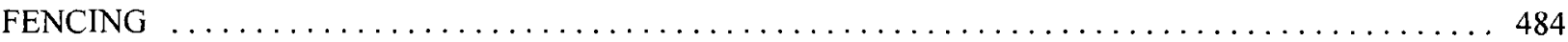

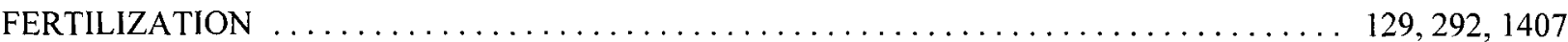

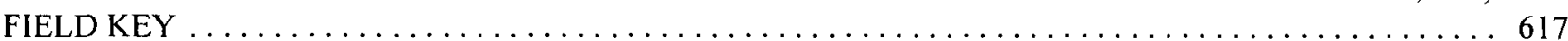
FIRE IMPACTS ....... 26, 67, 157, 215, 234, 270, 272, 332, 386, 519, 565, 661, 931, 1170, 1243, 1596, 1722

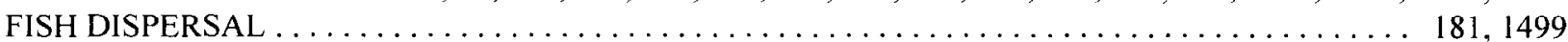
FISH HABITAT . . 1 117, 205, 221, 244, 246, 453, 469, 474, 479, 483, 503, 589, 620, 622, 677, 710, 743, 903, 936, $993,1032,1036,1057,1157,1196,1277-1279,1302,1431,1469,1497,1775,1890$

FISH MANAGEMENT . . . . . . . . . . . . . . . . . . . . . . . . . . . . . . . . 277, 743

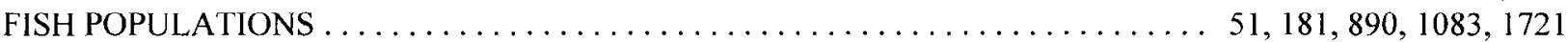
FISHERIES . . 64, 65, 81, 84, 92, 111, 120, 128, 149, 151, 153, 164, 181, 188, 191-193, 245, 277, 280, 291, 311, $363,387,393,412,422,470,473,486-488,522,525,528,529,566,575,582,589,595,622,638,653$, $664,720,723,744,753,768,776,794,795,802,803,828,855,873,885,890,904,905,935,937,946$, $953,968,984,991,1001,1022,1026,1029,1035,1070,1071,1083,1084,1098,1118,1126,1130,1132$, $1133,1153,1181,1186,1230,1232,1243,1269,1316-1318,1320,1323,1324,1329,1332,1334,1336$, $1337,1339,1340,1342,1344,1347,1348,1350,1354,1358,1386,1394,1398,1411,1434,1437,1441$, $1448,1453,1461,1464,1502,1536,1543,1552,1563,1570,1589,1591,1604,1616,1650,1658,1700$, $1719,1721,1727,1742,1785,1811,1812,1822,1823,1834,1835,1845,1859,1863,1879$ FLOOD IMPACTS . 47, 101, 112, 223, 265, 302, 318, 427, 453, 494, 512, 633, 646, 647, 658, 669, 693, 698, 700, $722,829,948,1019,1082,1147,1169,1175,1243,1368,1373,1375,1458,1462,1465,1502,1507$, $1522,1523,1526,1533,1611,1612,1624,1645,1660,1692,1699,1873$ FLOODPLAIN MANAGEMENT . . . . . 5 5, 112, 212, 214, 556, 621, 775, 940, 974, 1019, 1375, 1418, 1490, 1646

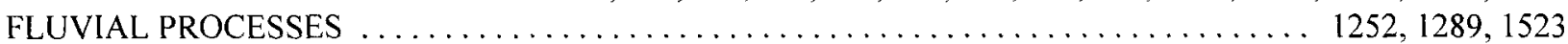


FOOD CHAINS

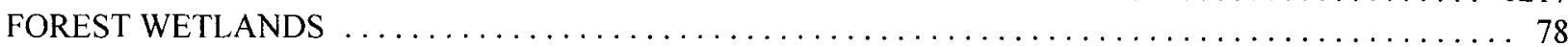

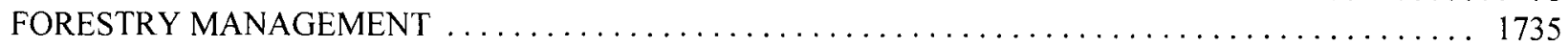

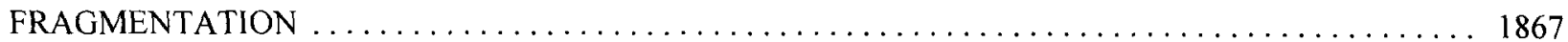

FRESHWATER CONSERVATION

G

GALLERY FOREST

$200,1147,1162,1254,1457,1842$

GAP ANALYSIS $54,301,1521$

GARTER SNAKES

GEOLOGY 1681,1682 GEOMORPHOLOGY .. 46, 47, 72, 73, 141, 178, 238, 239, 260, 305, 314, 379, 384, 416, 436, 443, 492, 505, 520, $550,573,574,589,623,631,632,634,646,647,665,704,706,708,712,713,726,730,731,733,736-$ $739,757,759,760,784,785,817,832,836,857,858,861,876,884,906,907,949,956,968,988,991$, $1006,1015,1017,1018,1024,1033,1064,1080,1095,1141,1171,1172,1174,1195,1217,1221,1228$, $1238,1255,1270,1281-1283,1289,1299,1308,1313,1320,1339,1366,1390,1425,1456,1467,1494$, $1514-1516,1523,1563,1594,1595,1601,1661,1662,1713,1715,1716,1718,1739,1781,1784,1836$, $1838,1840,1842,1856,1872,1892$

GILA RIVER 91 GIS . . 320, 380, 447, 449, 464, 598, 663, 749, 750, 873, 874, 975, 977, 1002, 1372, 1394, 1399, 1478, 1520, 1521, $1555,1838,1848,1880$

GLOBAL WARMING $443,452,779$

GLOSSARY . 747

GRAMINOIDS 813,816 GRAZING IMPACTS . 3, 7, 11, 14, 17, 19, 22, 23, 25, 29, 44, 51, 63-66, 73, 76, 93, 102, 109, 110, 118, 122, 123, $125,131,142,157,170,171,175-177,179,192,194,201,202,215,240-243,247-249,251,252,254$, $255,269,281,284,298,308,309,312,322,323,328,329,331,333,334,336-338,340,341,348,358$, $359,362-364,369,373,378,385,386,390,396,397,410,413,423-425,432,460,467,468,475,478$, $484,485,496,507-509,515,517,554,561,562,568,570,578,581,591,596,603,615,616,627,628$, $642-645,649,650,652,663,664,673-675,682,703,715,725,761,763,764,773,777,780-782,803$, $812,822,838,862,872,893-895,897-899,905,910,920,921,923,930,932,935,936,938,945,962$, $963,965,967,970,992,993,997,999,1003,1007-1009,1011,1035,1036,1042,1070,1073-1076,1078$, $1086,1087,1093,1094,1098-1100,1111,1120,1121,1124,1129,1132,1155,1164,1193,1195,1203$, $1204,1206,1213,1214,1221,1235,1240,1251,1252,1256,1260,1266,1267,1276,1288,1290,1297$, $1298,1317-1319,1321-1326,1328,1329,1333,1335-1338,1340-1342,1344-1346,1348,1350,1353-$ $1357,1359-1361,1364,1365,1367,1370,1382,1383,1387,1395,1404-1406,1408,1414,1419,1427$, 1434-1437, 1442, 1443, 1446-1448, 1470, 1476, 1477, 1481, 1486, 1490, 1508, 1510, 1511, 1519, 1522, $1529,1531,1533,1535,1546,1549,1552,1556,1559,1561,1562,1569,1571,1573,1577,1579,1580$, $1589,1596,1598-1600,1616,1634,1638,1639,1650,1653,1657,1666,1667,1682,1687,1695,1701$, $1702,1723,1724,1733,1742,1743,1750,1755,1759,1770,1778,1785,1788,1790,1795,1797,1798$, $1800,1832,1844,1866,1874,1887,1888$ GRAZING TREATMENTS . 142, 177, 242, 243, 251, 252, 281, 284, 339, 340, 378, 485, 513, 517, 562, 596, 603, $616,715,780,781,862,894,930,938,1073-1075,1086,1094,1155,1203,1206,1325,1328,1333,1335$, $1338,1340,1353,1361,1365,1405,1437,1519,1561,1576,1577,1639,1667,1724,1798,1832,1874$

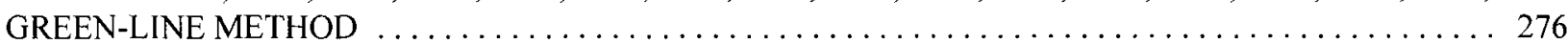

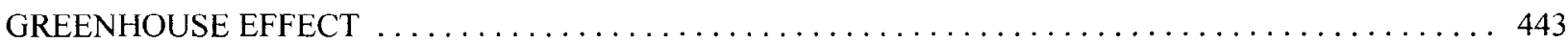
GROUNDWATER . . . 296, 302, 605, 657, 751, 766, 836, 958, 1053, 1222, 1428, 1472, 1642, 1648, 1754, 1810 
GROWING SEASONS

$H$

$1313,1366,1514,1515,1668,1824,1898$

HABITAT MANAGEMENT $\ldots \ldots \ldots \ldots \ldots \ldots$ 487, 677, 691, 797, 920, 1108, 1183, 1294, 1526, 1597, 1720

HEADCUTTING . . . . . . . . . . . . . . . . . . . . . . . . . . . . . . . . . . . . . . . 1899

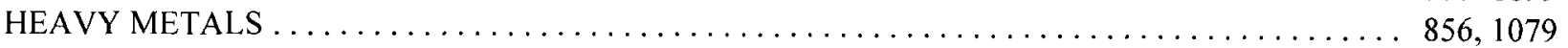

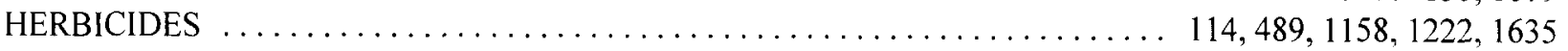

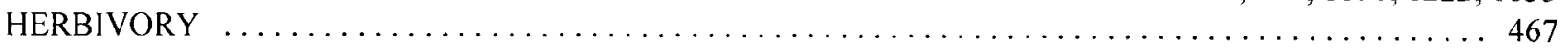

HERPETOFAUNA $\ldots \ldots \ldots \ldots \ldots \ldots \ldots \ldots \ldots \ldots 218,268,610,845,879,880,1047,1679,1682,1816$

HISTORIC RECORDS … 75, 219, 281, 398, 466, 500, 578, 652, 671, 771, 909, 1046, 1166, 1194, 1256, 1302 ,

$1414,1476,1479,1480,1485,1525,1528,1553,1582,1739,1750,1770$

HUMAN IMPACTS .. 21, 219, 250, 317, 374, 400, 537, 624, 641, 767, 908, 1151, 1448, 1507, 1612, 1691, 1734 , 1842,1876

HYDRAULICS $46,49,520,731,759,1016,1017,1272,1425$

HYDROCHEMICAL INFLUENCES 1347

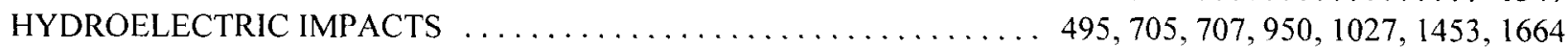

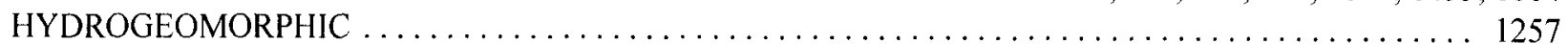

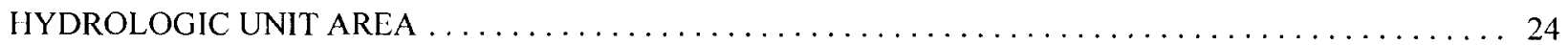
HYDROLOGY . 68, 72, 79, 86-88, 96, 107, 111, 112, 114, 115, 119, 130, 152, 189, 207, 208, 253, 283, 288, 296, $302,353,355,367,379,382,387,392,402,416,431,434,440,444,449,481,490,492,504,505,520$, $525,531,534,538,547,552,553,563,571,585-587,597,605,614,636,646,649,659,693,697,700$, $706,707,724,735,743,751,763,764,766,783,785,789,826,835,852,853,857,859,860,878,882$, $883,886,909,914,917,918,926,950,958,959,976,978,987,990,994,996,1002,1012,1014,1018$, $1026,1031,1045,1048,1052,1054,1063,1082,1097,1113,1137,1139,1146,1171,1174,1176,1192$, $1215,1220,1232,1234,1237,1264,1272,1314,1347,1373,1375,1379-1381,1386,1403,1421,1424$, $1428-1430,1444,1452,1456,1474,1475,1478-1480,1483,1535-1537,1541,1557,1558,1564,1566$, $1581,1583,1642,1644,1648,1683,1717,1740,1745,1754,1772,1780,1781,1784,1787,1803,1809$,

\section{HYDROPHYTES}

$1837,1840-1842,1851,1882,1886,1899$

\section{I}

IMPACT MITIGATION ......................................... 511, 1538

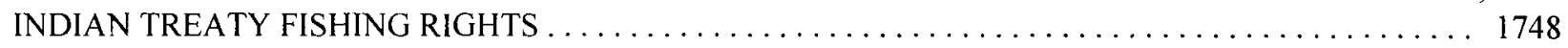

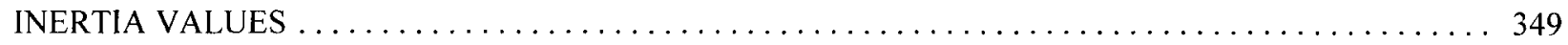

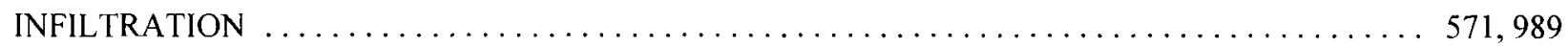

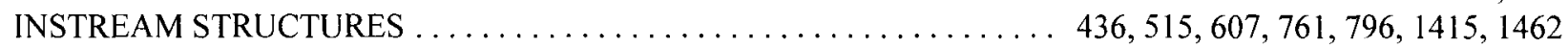

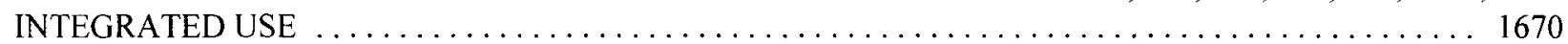

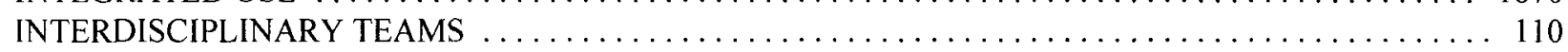

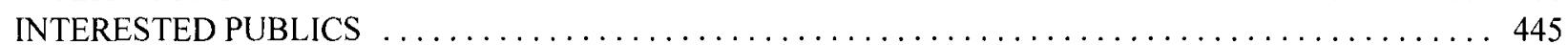

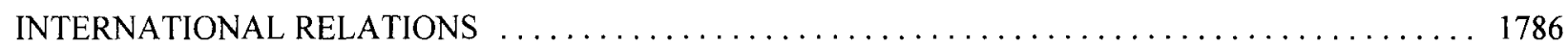

INVENTORY $.9,78,194,226,372,404,405,486,493,516,637,679,683,685,686,709,754,954,1154,1191$, $1194,1205,1207,1224,1276,1278,1279,1287,1295,1308,1310,1327,1370,1377,1378,1394,1402$, $1410,1417,1489,1637,1690,1728,1757,1771,1814,1838,1848,1858,1880$ INVERTEBRATES . $38,300,381,403,456,523,769,779,937,1089,1117,1436,1454,1499,1727,1793,1820$

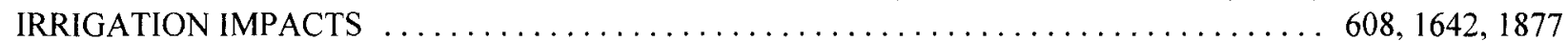

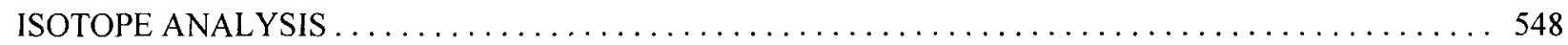

\section{$L$}

LACUSTRINE ECOLOGY

$185,557,831,834,900,910$

LAGOMORPHS .. 820

LAND ETHICS 280,676 
LAND USE ...... 275, 278, 346, 647, 966, 967, 1046, 1114, 1228, 1438, 1478, 1524, 1553, 1636, 1691, 1744 LANDSCAPE ECOLOGY $\ldots \ldots \ldots \ldots \ldots \ldots .70,263,278,465,912,1062,1418,1482,1498,1524,1818$ LARGE WOODY DEBRIS ... 120, 145, 206, 244, 245, 453, 469, 656, 670, 765, 778, 796, 871, 957, 1023, 1199 ,

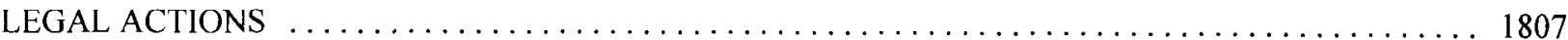

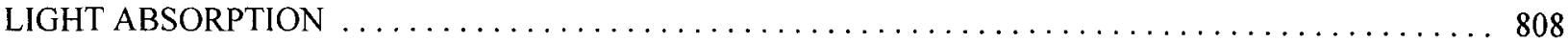

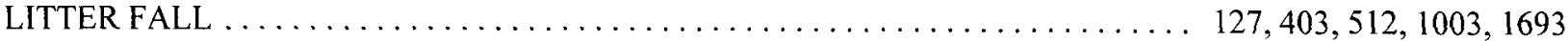

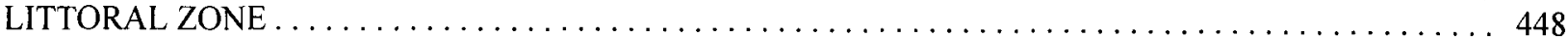

LIVESTOCK EFFECTS . 22, 23, 29, 64, 93, 109, 240, 241, 251, 269, 309, 328, 337, 341, 363, 386, 396, 397, 410, $423,438,502,507,561,627,644,650,663,673,682,703,777,781,847,895,935,952,965,967,993$, $1009,1036,1076-1078,1087,1093,1100,1164,1193,1195,1203,1213,1214,1221,1266,1267,1290$, $1321,1322,1326,1328,1341,1342,1355,1365,1370,1395,1434,1442,1446,1494,1533,1573,1576$, $1600,1742,1778,1790,1798,1844$

LOGGING IMPACTS ... 41, 135, 145, 147, 148, 162, 218, 229, 231, 244-246, 291, 311, 315, 351, 375, 377, 392, $394,490,526,528,529,566,593-595,625,637,638,670,697,744,794,878,926,953,969,1054,1058$, $1083,1137-1140,1142,1302,1348,1543,1558,1568,1725,1738,1740,1776,1859$

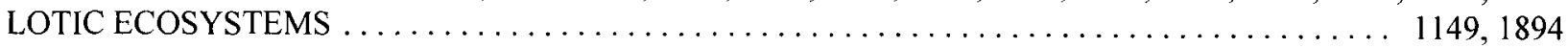

\section{$M$}

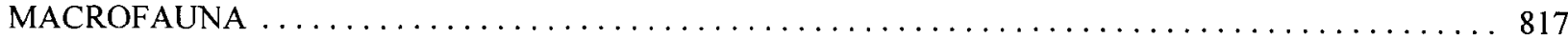

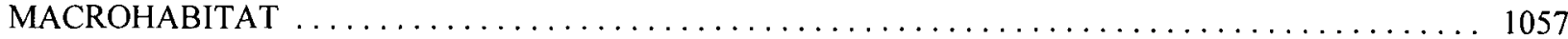

MACROINVERTEBRATES . . . 121, 291, 381, 446, 479, 668, 710, 765, 807, 984, 1131, 1148, 1304, 1438, 1442,

$1451,1624,1859$

MAMMALS .... 94, 1689

MANAGEMENT PLANS $497,870,1813$

MAPPING $679,685,909$

MARSHES 16,888

MATERIAL TRANSFER 1613 MEADOWS .... 69, 130, 157, 215, 216, 286, 304, 322, 431, 501, 596, 780, 1028, 1085, 1101, 1150, 1405, 1430, $1488,1898,1899$

MEDUSAHEAD $819,1574,1693,1791$

MICROBIOLOGY $819,1574,1693,1791$

MICROHABITATS

MIGRATION $\ldots \ldots \ldots \ldots \ldots \ldots \ldots \ldots \ldots \ldots \ldots \ldots \ldots \ldots \ldots \ldots \ldots \ldots \ldots \ldots \ldots \ldots \ldots \ldots \ldots \ldots \ldots \ldots \ldots \ldots \ldots \ldots \ldots \ldots \ldots \ldots \ldots \ldots \ldots \ldots \ldots \ldots$
MINED LAND RECLAMATION $\ldots \ldots \ldots \ldots \ldots \ldots \ldots$ MINING IMPACTS . . . . 207, 221, 285, 297, 518, 553, 632, 710, 711, 807, 1119, 1347, 1349, 1455, 1472, 1618

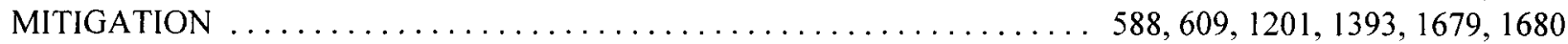

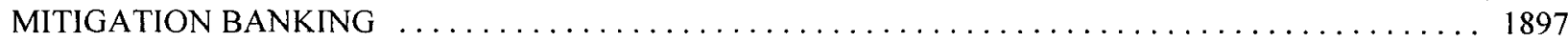
MODELING . . 36, 68, 79, 139, 189, 278, 310, 325, 363, 379, 390, 403, 449, 481, 495, 550, 555, 563, 567, 571, $582,589,659,662,689,691,707,725,755,797,800,835,854,861,876,933,934,968,988,990,1026$, $1035,1044,1052,1219,1233,1264,1285,1375,1403,1420,1445,1475,1541,1551,1552,1555,1637$, $1647,1717,1737,1780,1783,1787,1806,1818,1851,1856,1882$

MONITORING ... 9, 40, 63, 106, 108, 110, 141, 149, 276, 319, 345, 361, 369, 372, 380, 385, 391, 399, 401, 404, $407-409,480,482,499,516,545,562,584,585,591,630,634,645,663,686,688,699,702,706,708$, $709,750,838,846,853,886,889,922,947,978,985,998,1004,1054,1064,1070,1154,1205,1207$, $1208,1210,1249,1276,1311,1327,1351,1402,1419,1438,1441,1465,1474,1560,1566,1582,1636$, $1711,1745,1751,1757,1758,1762,1772,1801,1852$

MOOSE 1443

MOWING 386

MULE DEER 295,961

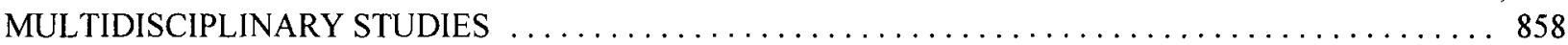
MULTIPLE USE . . ............. 122, 269, 792, 1408, 1585, 1587, 1639, 1659, 1671, 1765, 1777, 1875

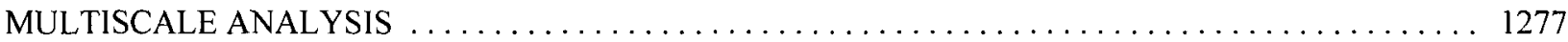


$N$

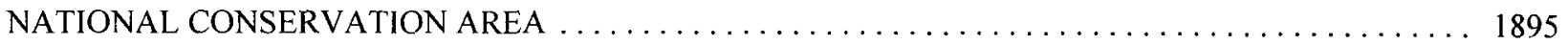

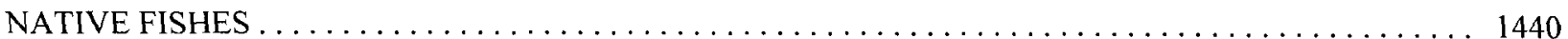

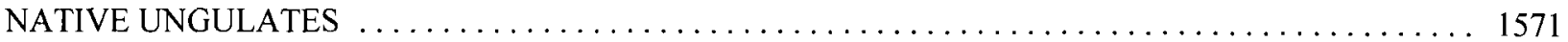

NATURAL AREAS ................................ 997, 1390-1392, 1617, 1709, 1732

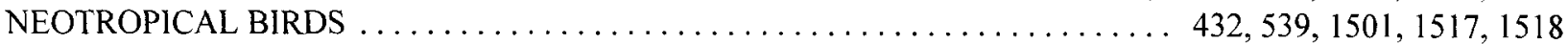

NON-POINT SOURCE POLLUTION . . 6, 7, 76, 125, 171, 174, 175, 252, 292, 297, 339, 377, 413, 429, 430, 446, $456,531,592,598,627,776,782,798,809,821,824,842,872,1050,1140,1165,1213,1214,1263$, $1296,1297,1374,1400,1421,1577,1578,1723,1744,1779,1800,1805,1869,1880,1891,1892$

NUTRIENT CYCLES . . 129, 144, 157, 263, 292, 352, 358, 360, 381, 389, 428, 512, 519, 547, 567, 593, 605, 642, $673,766,798,808,819,833,842,901,1025,1040,1049,1082,1149,1157,1163,1172,1195,1213$, $1216,1248,1263,1303,1306,1420,1495,1496,1535,1608,1626,1693,1722,1744$

$\boldsymbol{O}$

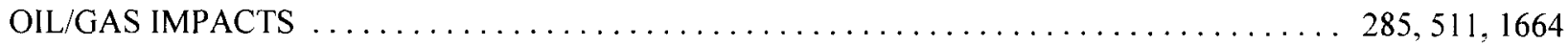

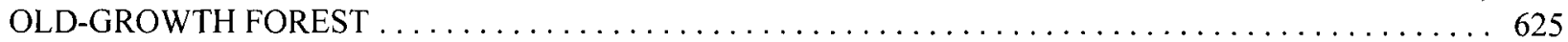

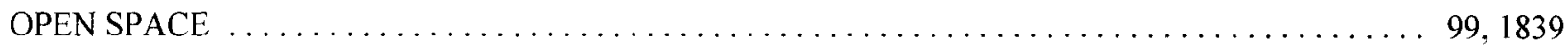

ORGANIC DEBRIS $\ldots . .127,144,147,148,348,351,360,403,448,490,505,646,906,907,1080,1084,1172$, $1343,1495,1507,1608,1613,1614,1663,1682,1727,1900$

$\boldsymbol{P}$

PARASITISM

$415,1501,1517,1518$

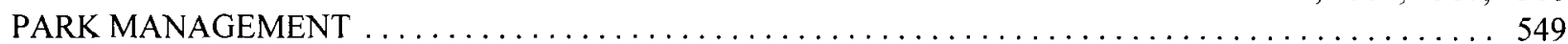

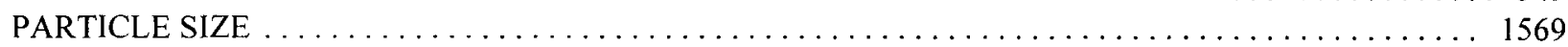

PARTNERSHIPS ......... 113, 199, 324, 437, 475, 612, 715, 716, 806, 858, 1088, 1168, 1371, 1651, 1731

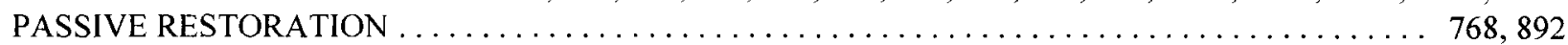

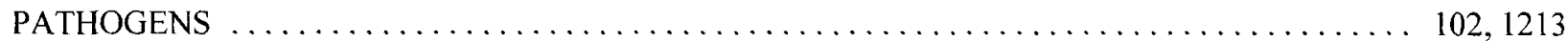

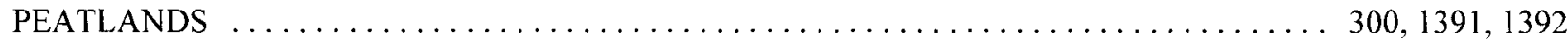

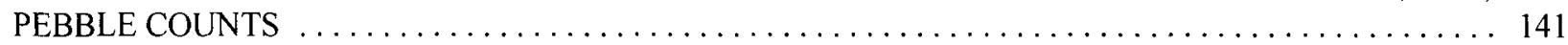

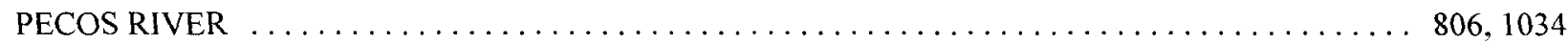

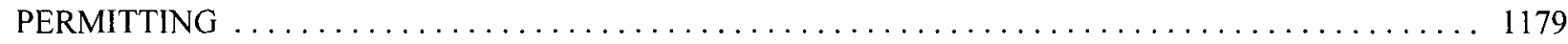

PFANKUCH STREAM CHANNEL EVALUATION $\ldots \ldots \ldots \ldots \ldots \ldots \ldots \ldots \ldots \ldots \ldots \ldots \ldots \ldots \ldots \ldots$

PHOTO PLOTS .................................. 632, 634, 708, 1060, 1064, 1824

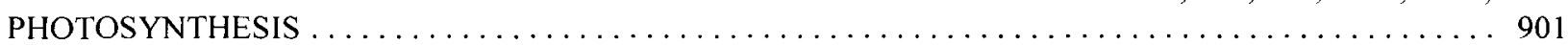

PHREATOPHYTES $\ldots \ldots \ldots \ldots \ldots \ldots \ldots \ldots . \ldots \ldots 2,219,289,303,357,402,461,633,790-793,1445,1452$

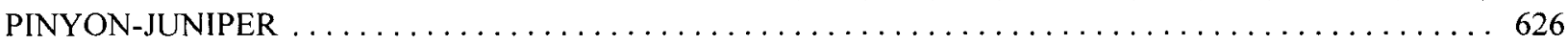

PLANNING . . . 24, 223, 256, 420, 445, 624, 635, 767, 788, 914, 964, 1022, 1110, 1128, 1251, 1258, 1460, 1547,

$1625,1736,1752,1762,1768,1854$

PLANT COMMUNITIES . 33, 80, 89, 168, 169, 276, 333, 365, 493, 510, 565, 683, 687, 696, 721, 771, 960, 1000, $1003,1067,1115,1212,1239,1280,1288,1357,1372,1380,1429,1481,1484,1508,1603,1617,1646$, $1676,1729,1810,1838,1883,1896$

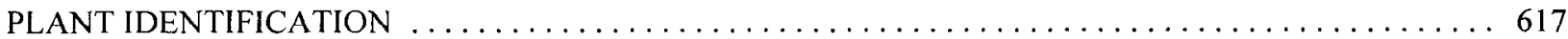

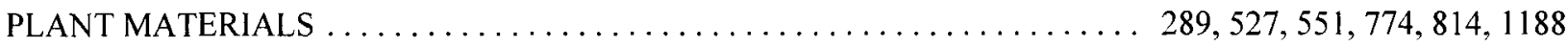

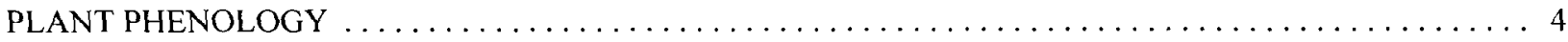

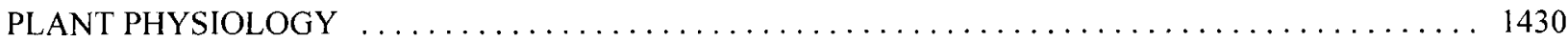

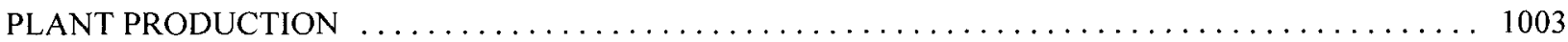

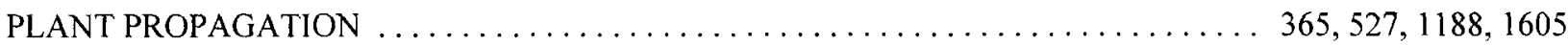

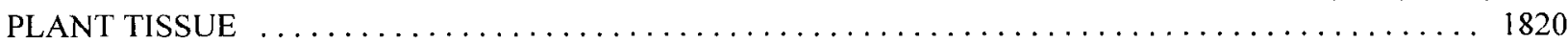

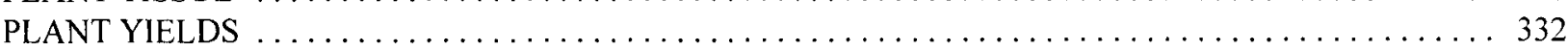

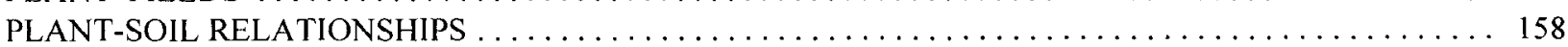


PLANTINGS

$115,275,289,294,337,1105,1672,1883,1884$

PLATTE RIVER

$69,396,398,462,752,939,1261,1529,1532$

PLAYAS

$158,180,721,1282$

POINT SOURCE POLLUTION

400

POLICY . . 82, 90, 125, 161, 233, 526, 560, 602, 827, 843, 863, 943, 972, 973, 986, 1014, $1119,1202,1241,1242$,

$1245,1262,1387,1460,1477,1503,1538,1627,1649,1759,1766,1769,1847$

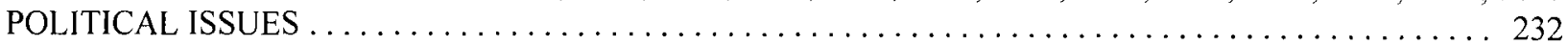

POLLUTION ............... 274, 462, 463, 660, 766, 1029, 1058, 1173, 1349, 1472, 1754, 1837, 1862

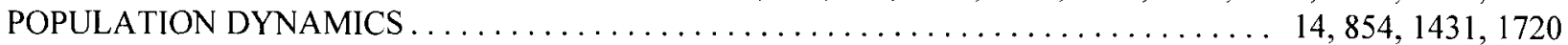

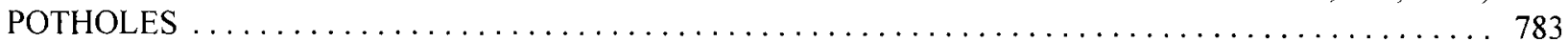

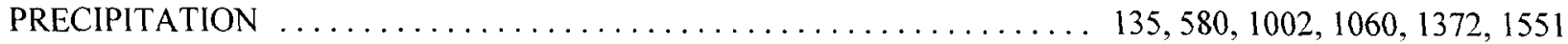

PREDATION . .............................. 415, 658, 1497, 1499, 1775, 1776, 1859

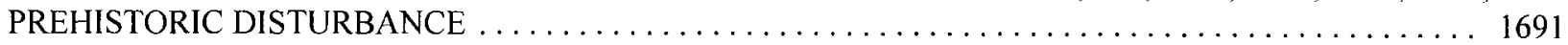

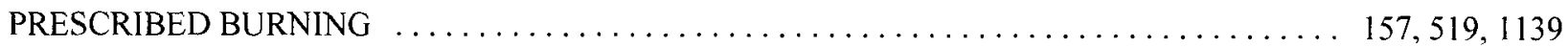

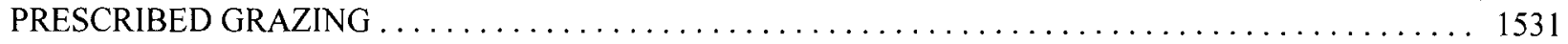

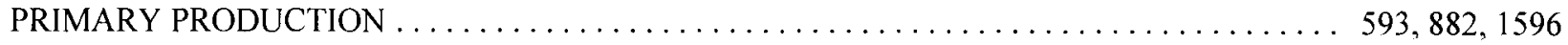

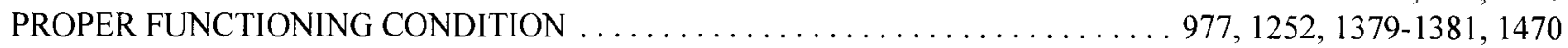

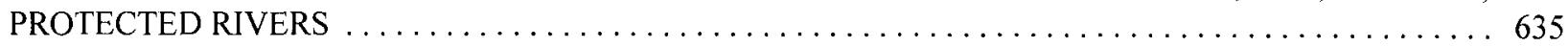

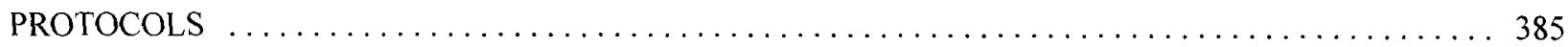

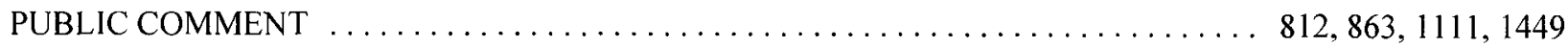

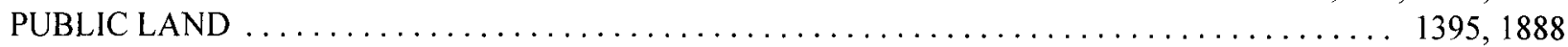

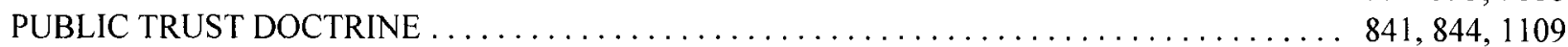

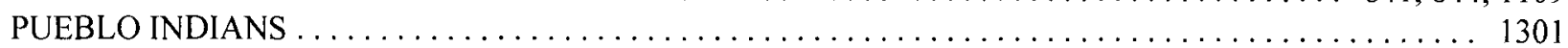

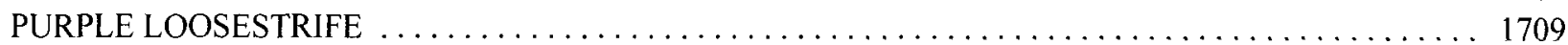

\section{$\boldsymbol{R}$}

RANGE MANAGEMENT ........... 497, 569, 580, 592, 612, 1007, 1060, 1444, 1705, 1706, 1733, 1750

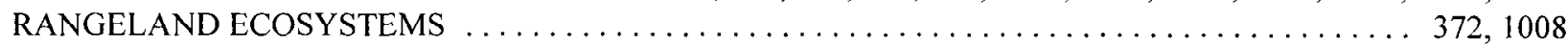

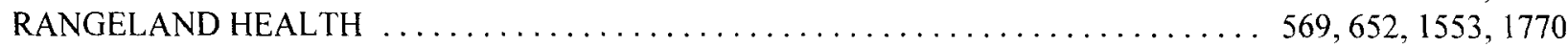

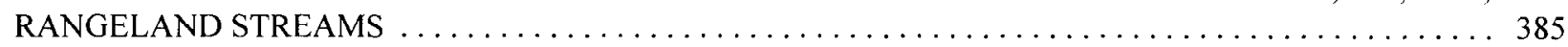

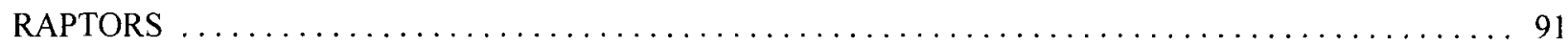

RECREATION IMPACTS ... 21, 66, 124, 156, 199, 317, 537, 549, 577, 641, 786, 864, 1068, 1426, 1650, 1839 ,

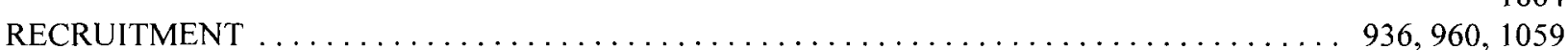

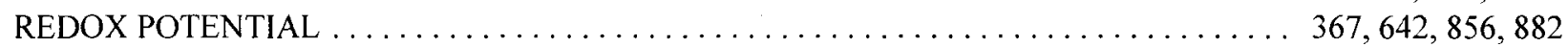

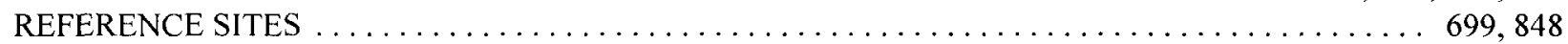

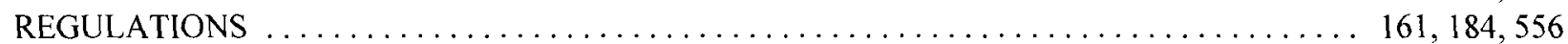

REMOTE SENSING ‥ 108, 273, 345, 407, 481, 754, 835, 977, 1219, 1289, 1311, 1378, 1399, 1403, 1444, 1636

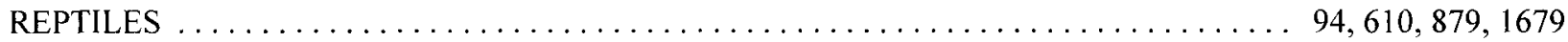

RESEARCH . . 105, 544, 831, 913, 986, 1149, 1291, 1315, 1335, 1351, 1352, 1360, 1362, 1375, 1385, 1435, 1437 ,

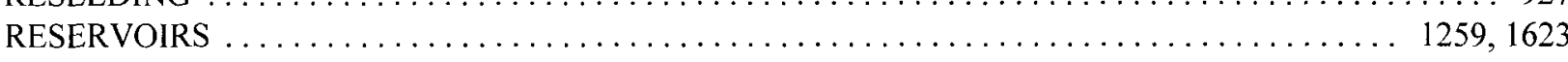

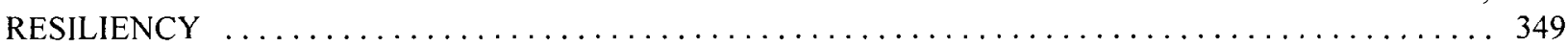

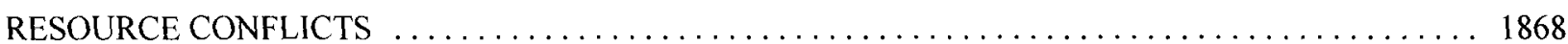

REST ROTATION . . . . . . . . . . . . . . . . . . . . . . . . . . . . . . . . . . . . . . . . . . . . . . . 1094

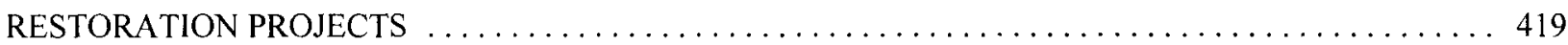

RIO GRANDE . 9 98-100, 321,389,441, 512, 544, 577, 601, 799, 802, 1000, 1194, 1371, 1501, 1525, 1606, 1842,

$1876,1877,1881$

RIPARIAN ...... 39, 309, 467, 507, 761, 848, 921,924, 993, 1012, 1164, 1381, 1504, 1556, 1681, 1710, 1743

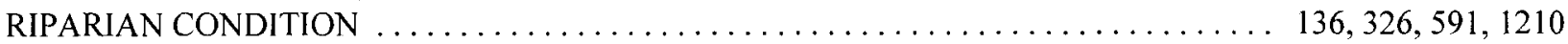

RIPARIAN ECOLOGY . 8 8, 22, 88, 98, 122, 124, 132, 210, 214, 268, 269, 305, 373, 403, 434, 450, 472, 499, 514, $523,543,642,669,685,731,738,784,801,833,843,852,853,865,869,877,896,941,944,954,999$, 
$1009,1028,1051,1065,1143,1148,1175,1195,1239,1319,1441,1491,1560,1615,1626,1648,1663$, $1674,1678,1739,1747,1763,1781,1812,1827,1831,1865,1876,1889$ RIPARIAN ENHANCEMENT ......... 142, 163, 187, 308, 435, 438, 554, 1356, 1382, 1667, 1702, 1703 RIPARIAN FOREST . . . 2, 26, 50, 56, 67, 70, 73, 89, 128, 145, 148, 160, 165, 195, 198, 206, 270, 279, 307, 325, $342,368,376,387,397,414,415,450,452,457,460,473,521,538,567,572,573,605,613,624,626$, $628,629,640,689,757,758,770,772,778,791,796,799,854,867,871,875,891,970,1023,1040$, $1049,1054,1090,1158,1181,1198,1199,1245,1263,1274,1306,1309,1310,1384,1388,1416,1418$, $1458,1482,1484,1489,1522,1523,1527,1530,1539,1543,1544,1593,1614,1629,1673,1677,1724$,

$1725,1749,1783,1803,1855$

RIPARIAN HABITAT $\ldots .3-5,8,10,12,13,15,16,19,21,26,27,29-41,43-45,50,52,54-57,59-63,66,67,69$, $70,74,75,78,80-85,89-92,94,95,98,104-106,108-110,113,116,118,121,124,126,130,133,136-$ $139,143,146,148,149,151,153-156,158-169,172,173,180-187,191-193,195,198-203,205,207,212$, $214,216-219,222-227,232-236,245,250,254,259,263,264,266,268,270-272,274,276,277,279,281$, $282,284-287,291,294,295,299,301,303,311,315,317-322,324,325,327,332,334,335,344,345$, $347,351,353,357,359,360,366,370-372,375-377,380,383,387,388,391,394-396,398-400,402-408$, $411,414,420,421,423,424,427,429,434,437,441,442,447,450-452,454-458,460-462,465,466$, $469,471-473,477,482,484,486-489,491,493,495,496,498-500,510-513,516,523,525-529,532,533$, $535-537,539-549,554-557,560,564-567,574,575,577,579,582-584,588,590,593-595,599,604,606$, $610,611,615,617,618,626,635,638-641,648,651,653,657,660,661,664,666-668,671,672,674$, $676,678-681,683-687,689-691,694,696,698,705,709,716-720,723,744-747,749,750,753,754,757$, $758,767,770,775,779,786,787,790-794,797,798,801,802,804-807,810,811,813,818,819,823$, $825,827-830,832,836,841,843-845,847,851,854,855,863-871,873-875,877,879-881,885,887,888$, $890,891,896,898,900,904,908,911,916,919,920,922,925,928,929,931-933,937,939-946,953-$ $955,957,961,963,964,966,967,971-975,979,984,991,995,998,1000,1004,1005,1010,1013,1020$ $1027,1029,1034,1037-1040,1043,1044,1046-1048,1050,1053,1056,1058,1061,1062,1066-1069$, $1071,1072,1079,1081,1083,1087,1089,1091,1096,1098-1102,1104,1106,1107,1109,1110,1112$, 1114-1118, 1120-1125, 1127, 1128, 1130-1134, 1143, 1145, 1147, 1148, 1151-1156, 1158, 1161, 1162, $1166,1168-1171,1173,1177,1180,1181,1183,1184,1189,1194,1197-1199,1201,1202,1207,1208$, $1210-1212,1215,1216,1221-1226,1229,1230,1236,1239,1242,1243,1245,1246,1252-1254,1259-$ $1261,1265,1268,1269,1273-1275,1277,1280,1284,1285,1287,1292,1294,1295,1301,1303-1307$, $1309-1312,1315-1318,1321,1323-1325,1327,1329-1334,1338,1341,1343-1345,1351,1352,1354$, $1358,1359,1361,1363,1368,1371,1372,1376-1378,1380,1382,1384,1385,1388,1389,1391,1392$, $1394,1396-1399,1401,1406,1407,1409-1418,1423,1426,1429,1438-1442,1445,1451,1453,1454$, $1457,1463-1466,1472,1473,1477,1481,1482,1486-1493,1498,1499,1501,1503-1507,1510,1517$, $1518,1520,1521,1524,1527-1530,1532,1536,1539,1542,1544-1547,1550,1553-1555,1563,1565$, $1568,1570,1572,1574,1579,1580,1584-1588,1597,1600,1602-1604,1606-1608,1612-1615,1617$, $1619-1621,1623-1625,1627,1628,1632,1636,1637,1640,1645,1647,1649,1651,1652,1654,1657-$ $1659,1663-1665,1669-1671,1673-1682,1684,1686,1688-1691,1695-1700,1704-1709,1712,1714$, $1719-1721,1727-1730,1732,1734-1736,1741,1742,1744,1747-1749,1751,1756-1758,1760,1763-$ $1766,1771,1774,1776,1777,1782,1783,1793,1794,1796,1799,1801,1802,1804,1807,1808,1810-$ $1817,1819-1822,1827,1829,1833-1835,1839,1840,1842,1845-1850,1854,1857-1862,1864,1865$, $1867,1868,1875,1876,1878,1880,1881,1885,1890,1893,1895,1902-1905$

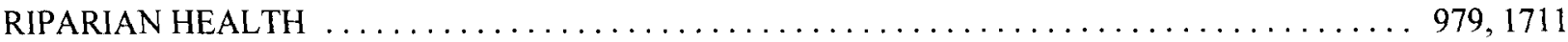

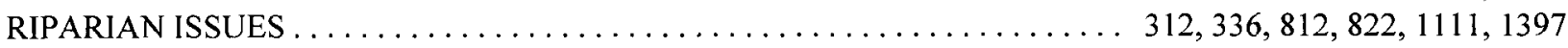
RIPARIAN MANAGEMENT ZONE . . . . 3, 24, 25, 41, 52, 53, 65, 82, 98, 104, 106, 116, 123, 128, 131, 148, 162, $169,193,199,202,203,212,227,234,252,254,283,287,299,308,323,324,340,344,347,361,374$, $406,420,424-426,437,438,441,451,466,475,508,509,514,515,526,544,549,555,560,581,584$, $633,640,643,648,649,675,678,686,687,690,704,711,718-720,735,761,762,771,788,789,826$, $868,893,897,911,952,963,965,966,977,999,1006,1011,1038,1042,1050,1062,1074,1075,1093-$ $1095,1161,1168,1179,1180,1185,1193,1204,1208,1223,1224,1257,1268,1273,1280,1312,1339$, $1343,1362,1370,1383,1385,1400,1401,1405,1408,1417,1434,1439,1473,1487,1503,1511,1554$, $1564,1573,1578,1584,1607,1619,1627,1669,1671,1704,1711,1714,1749,1751,1761,1762,1777$,

$1796,1797,1880,1895,1903$

RIPARIAN PASTURES $17,23,1356,1599$ 
RIPARIAN PLANTS

$4,237,651,684,956,1063,1126,1275,1404,1428,1430,1465$

RIPARIAN RESTORATION . 1, 18, 20, 28, 35, 37, 40, 42, 58-61, 77, 81, 86, 94, 99-101, 132-134, 150, 179, 188 , $190,201,204,209-211,220,243,248,249,257,261,264,273,275,281,289,290,305-307,330,337$, $338,343,349,361,365,389,393,412,419,422,432,433,435,436,438,439,445,453,474,476,480$, $485,489,500-502,506,513,514,517,518,521,522,524,527,530,551,553,575,581,600,607,609$, $613,619-621,629,630,651,688,694,695,698,705,706,714,717,722,726,729,732,740,741,765$, $768,772,774,783,788,795,796,799,806,813-815,831,834,839,840,846,850,855,889,892,902$, 904, 912-915, 923, 924, 927, 947-949, 951, 952, 960, 971, 973, 974, 978, 980-983, 985, 986, 994, 1013, $1019,1021-1023,1028,1039,1041,1059,1065,1084,1085,1088,1091,1092,1103,1105,1108,1114$, $1115,1125,1142,1149,1150,1159,1178,1179,1182,1185,1186,1188,1190,1197,1202,1209,1219$, $1227,1231,1235,1236,1244,1247,1249,1250,1258,1259,1264,1269,1271,1294,1300,1334,1362$, $1365,1376,1383,1393,1395,1398,1411,1413,1427,1432,1433,1449,1450,1455,1461,1470,1478$, $1502,1509,1517,1526,1534,1540,1545,1548,1570,1575,1578,1586,1590-1592,1605,1611,1618$, $1629,1638,1641,1643,1646,1656,1668,1672,1702,1703,1710,1726,1731,1746,1753,1761,1769$, $1781,1785,1786,1789,1790,1823,1825,1852,1853,1861,1863,1864,1868,1879,1883,1884,1894$,

RIPARIAN RIGHTS $1896,1898-1900$

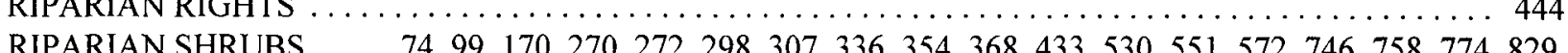
$898,900,925,942,945,962,1103,1188,1447,1495,1573,1598,1603,1605,1629,1656,1795,1896$ RIPARIAN STRUCTURES $506,982,1570$ RIPARIAN STUDIES $1291,1685,1688$

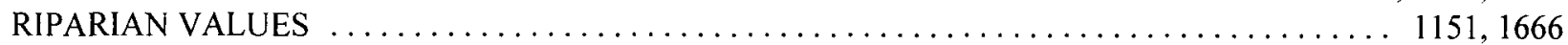
RIPARIAN VEGETATION $\ldots .27,67,75,118,121,123,129,200,237,243,249,251,265,271,273,282,298$, $300,302,326,330,338,343,348,354,357,360,398,399,401,433,464,468,469,482,494,505,507$, $568,591,595,599,604,618,628,631,657,684,704,705,721,722,728,760,775,784,790,792,793$, $805,816,864,866,893,894,937,939,942,944,950,956,958,992,998,1058,1068,1070,1076,1083$, $1084,1099,1103,1119,1129,1133,1162,1169,1191,1194,1211,1217,1220,1237,1238,1246,1266$, $1268,1297,1298,1303,1305,1331,1332,1342,1343,1355,1368,1379,1409,1410,1414,1447,1500$, $1524,1528,1549,1563,1594,1617,1620,1631,1633,1635,1640,1643-1645,1647,1652,1660,1663$, $1665,1672,1674,1678,1683-1686,1688,1690,1692,1700,1701,1765,1767,1788,1799,1803,1808$,

$1809,1815,1834,1835,1875,1901,1902$

RIPARIAN ZONES

$8,75,206,258,290,702,715,975,1082,1734,1752$

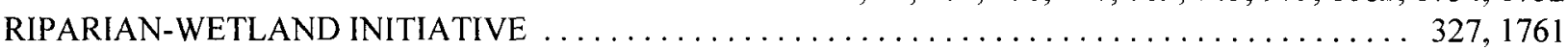
RIVER ECOLOGY $\ldots .15,182,221,232,251,255,416,538,621,841,858,1022,1024,1043,1044,1110,1149$, $1242,1378,1457,1487,1523,1540,1595,1612,1625,1651,1714,1804,1867,1871,1879$

RIVER MEANDERS ROAD IMPACTS $\ldots \ldots \ldots \ldots \ldots \ldots \ldots \ldots \ldots \ldots \ldots \ldots \ldots \ldots \ldots \ldots \ldots \ldots \ldots \ldots, 267,350,490,600,698,981,1138,1142$ ROOT DEPTH 752 RUNOFF ... . 71, 145, 152, 189, 292, 440, 481, 570, 571, 576, 662, 724, 763, 764, 989, 1192, 1234, 1290, 1296, $1301,1456,1496,1551,1583,1593,1610,1780$

RUSHES 813,815

$S$

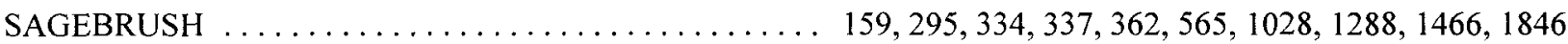

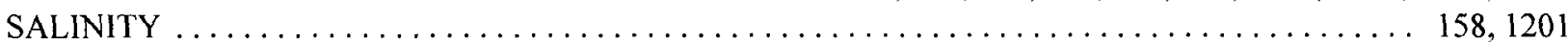

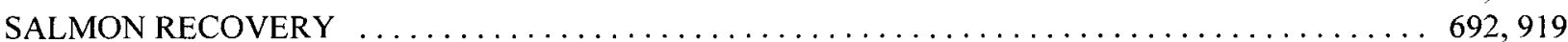

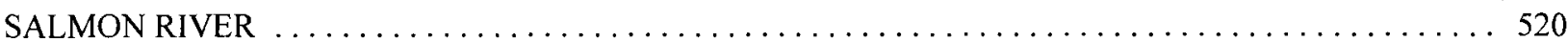
SALMONIDS . . 129, 164, 576, 653, 796, 903, 936, 1117, 1130, 1131, 1159, 1186, 1199, 1227, 1302, 1363, 1431,

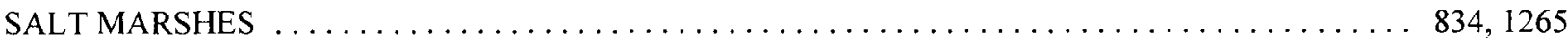
SALT-CEDAR .... 32, 38, 222, 270, 272, 318, 368, 451, 489, 583, 791, 811, 845, 1034, 1635, 1644, 1645, 1692

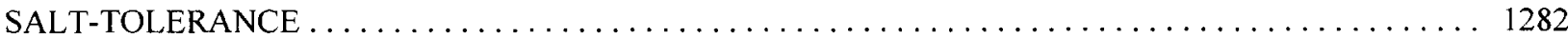

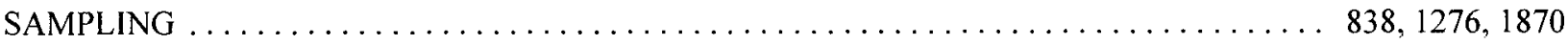




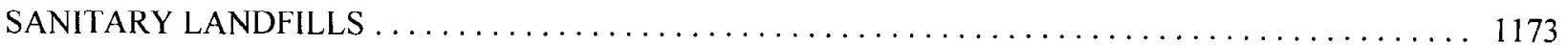

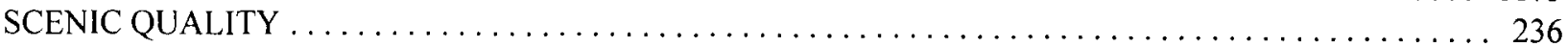

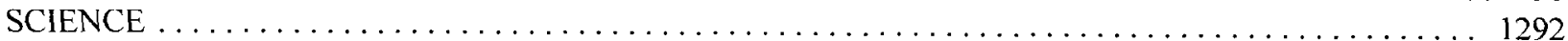

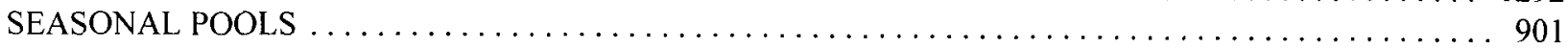

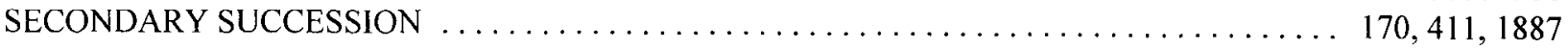

SEDGES ..................................... 14, 17, 816, 1404, 1407

SEDIMENT TRANSPORT . . 47, 49, 71, 96, 293, 310, 338, 490, 550, 742, 756, 837, 857, 859, 861, 876, 917, 988, $989,1030,1033,1051,1079,1135,1136,1141,1200,1228,1270,1299,1313,1459,1557-1559,1613$, $1661,1716,1779,1792,1805,1806,1836,1843,1851,1856,1892$

SEDIMENTATION .. 66, 71, 153, 164, 172, 178, 196, 197, 231, 238, 253, 260, 267, 288, 329, 330, 356, 434, 459, $490,570,623,654,656,662,807,861,918,1032,1033,1058,1063,1113,1135-1139,1141,1142,1271$, $1293,1296-1299,1363,1367,1389,1467,1470,1512,1513,1535,1541,1610,1612,1660,1715,1716$,

$1718,1719,1727,1792,1805,1811,1832,1837,1870$

SEED BANK

SEED PRODUCTION

$101,183,332,689,814,815,899,1059,1081,1592,1646$

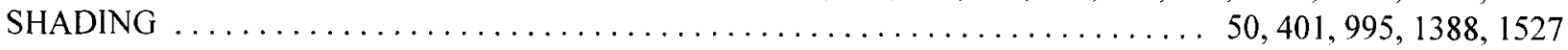

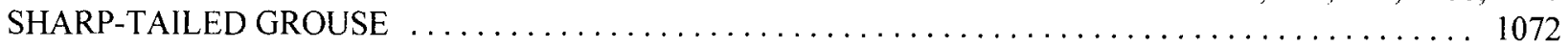

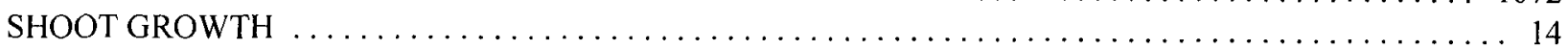

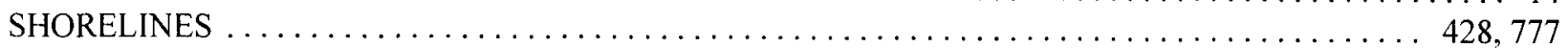

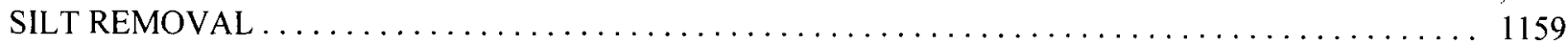

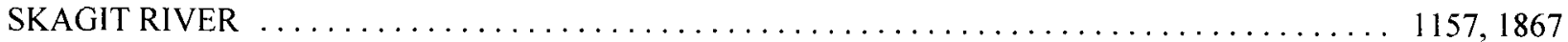

SMALL MAMMALS $\ldots . .30,31,37,56,57,138,166,286,334,335,394,395,457,458,611,810,1101,1106$,

$1120,1121,1123,1261,1346,1510,1568,1680$

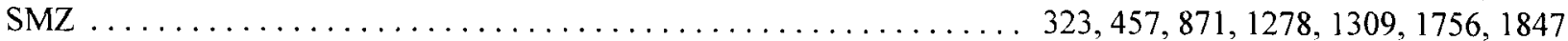

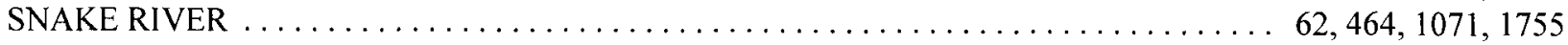

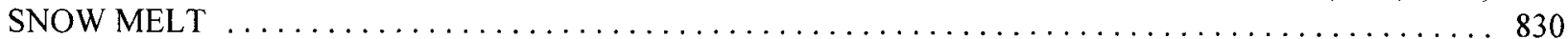

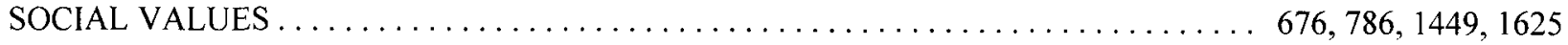

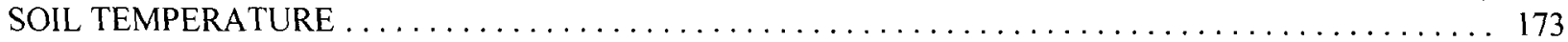

SOIL-WATER CONDITIONS $\ldots \ldots \ldots \ldots \ldots \ldots \ldots \ldots \ldots \ldots \ldots \ldots \ldots \ldots \ldots \ldots, 368,959,1281,1290,1474,1846$

SOILS ... 12, 27, 80, 96, 169, 171, 176, 196, 208, 217, 240, 253, 263, 304, 328, 331, 362, 417, 418, 449, 504, 505, $510,550,566,568,586,641,655,659,687,730,734,740,835,883,990,1012,1137,1140,1171,1212$, $1228,1247,1250,1280,1281,1288,1289,1313,1380,1381,1421,1429,1459,1494,1574,1594,1602$, $1643,1661,1662,1699,1713,1716,1729,1798,1799,1803,1832,1838,1843,1846,1853,1874,1882$,

1892,1900

SOLAR RADIATION

SOUTHWESTERN DESERT STREAMS $\ldots \ldots \ldots \ldots \ldots \ldots \ldots \ldots \ldots \ldots \ldots 142,554,1048,1166,1226$

SPATIAL SCALE . . 8, 167, 370, 379, 403, 440, 574, 667, 706, 915, 916, 934, 984, 1171, $1182,1227,1282,1372$,

$1412,1439,1482,1507,1560,1564,1838,1841,1845$

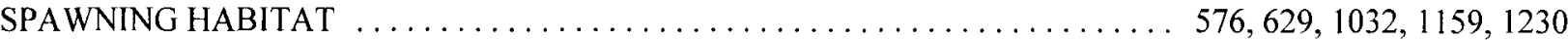

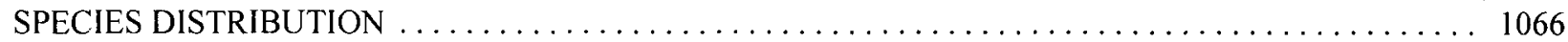

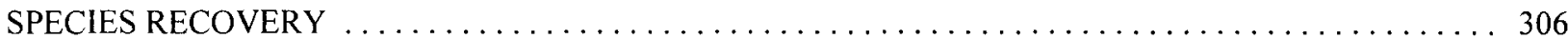

SPECIES RICHNESS ....................... 381, 479, 503, 1000, 1368, 1482, 1621, 1631

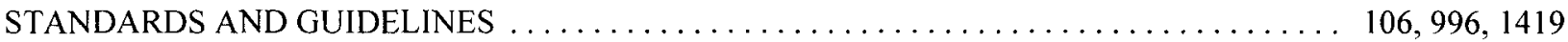

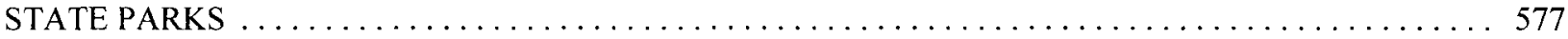

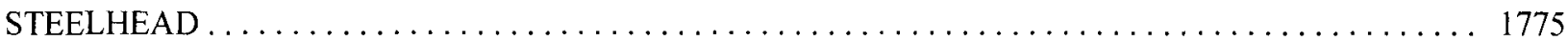

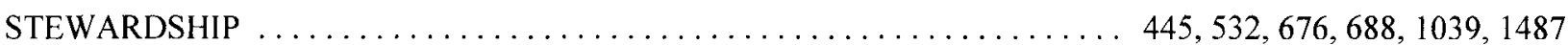

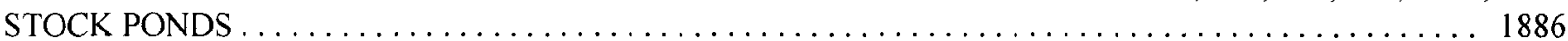

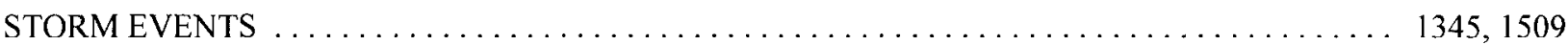

STREAM ECOLOGY . 23, 64, 92, 127, 144, 147, 238, 305, 350, 370, 372, 373, 486, 498, 664, 728, 749, 753, 769, $803,807,817,829,839,840,884,1018,1133,1172,1176,1179,1316,1468,1499,1514,1516,1561$,

1613,1873

STREAM FLOW . $69,84,87,107,111,119,180,191,211,236,288,315,355,368,434,453,454,494,498,525$, $533,572,573,597,615,629,636,658,697,700,753,826,859,878,916-918,926,950,1018,1045,1059$, $1061,1103,1113,1118,1126,1139,1147,1176,1196,1232,1233,1236,1363,1373,1386,1445,1453$, 
$1458,1470,1471,1537,1583,1609,1619,1640,1647,1660,1683,1740,1780,1841,1855$ STREAM IMPROVEMENTS . . 188, 261, 267, 422, 488, 501, 677, 795, 892, 949, 1005, 1186, 1354, 1461-1463, $1601,1641,1755,1863$ STREAM TEMPERATURE $\ldots \ldots \ldots \ldots \ldots 26,117,136,229,779,794,995,1057,1642,1700,1733,1773$

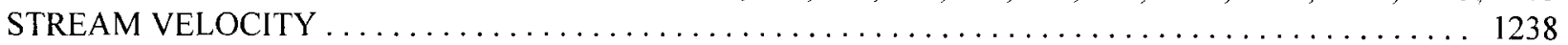
STREAMBANK PROTECTION $\ldots . .72,150,239,254,255,313,343,439,654,655,785,895,980,1031,1073$, $1247,1255,1289,1378,1567,1715,1718,1824,1871$ STREAMBANK STABILITY . . . 20, 48, 132, 172, 173, 177, 197, 247, 262, 385, 538, 623, 657, 987, 1075, 1078 , $1250,1308,1331,1353,1357,1358,1366,1369,1463,1548,1594,1630,1716,1753,1902$

STREAMBEDS ... 1737

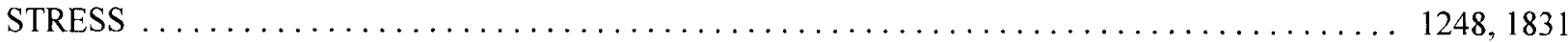

STUBBLE HEIGHT $\ldots \ldots \ldots \ldots \ldots \ldots \ldots \ldots \ldots 131,328,331,338-341,478,675,1296,1297,1573,1767$ SUCCESSION . .................................. 5, 103, 643, 924, 1146 SURFACE WATER-GROUNDWATER INTERACTION $\ldots \ldots \ldots \ldots \ldots \ldots \ldots 262,886,1472,1475,1787$

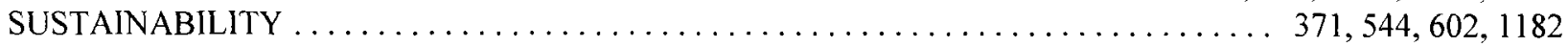

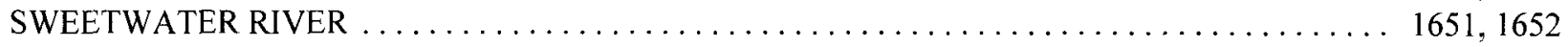

\section{$T$}

TECHNIQUES . .... 586, 645, 859, 860, 886, 922, 1064, 1097, 1208, 1247, 1283, 1286, 1289, 1294, 1330, 1565, $1715,1757,1824,1836,1848,1884$

TERRESTRIAL ECOSYSTEMS 1025

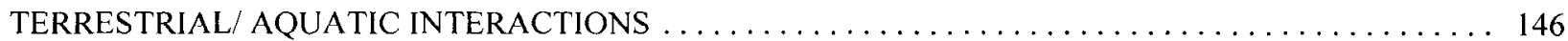

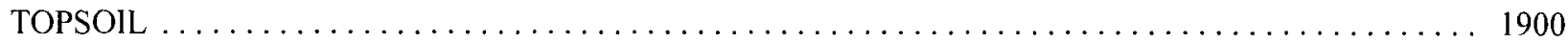

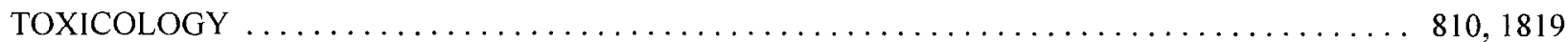

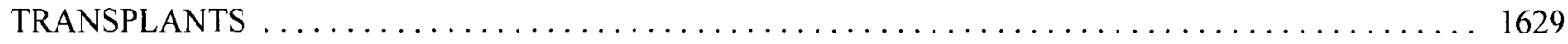

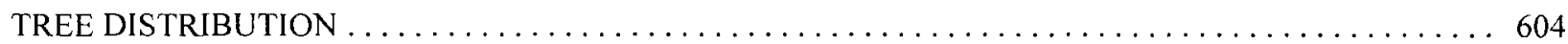

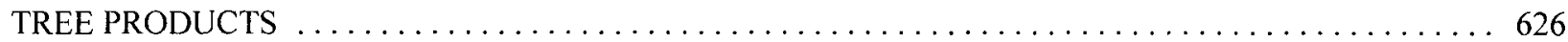

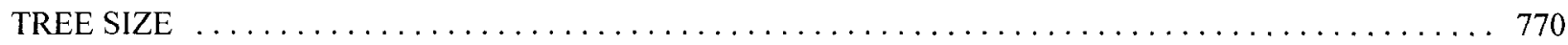

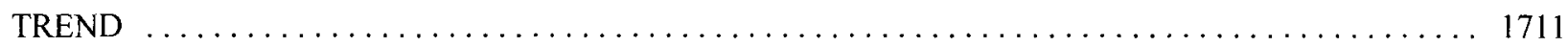

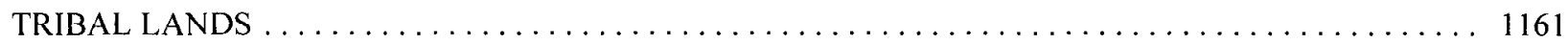
TROUT $\ldots .99,51,64,151,192,193,277,393,412,503,653,716,803,905,951,968,1057,1117,1126,1243$, $1696,1785,1822,1834,1835,1859,1890$

$\boldsymbol{U}$

UPLAND VEGETATION $\ldots \ldots \ldots \ldots \ldots \ldots \ldots \ldots \ldots \ldots \ldots \ldots \ldots \ldots \ldots \ldots \ldots \ldots \ldots \ldots \ldots \ldots \ldots \ldots \ldots \ldots, 1102$

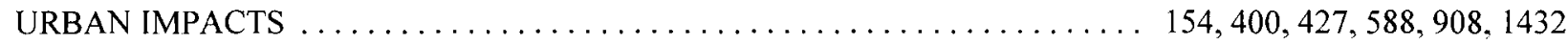
UTILIZATION $\ldots \ldots \ldots \ldots \ldots \ldots \ldots \ldots 109,131,331,339,364,663,675,862,930,1094,1346,1573,1767$

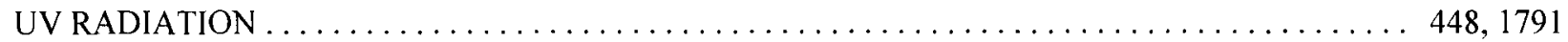

$\boldsymbol{V}$

VEGETATION MANAGEMENT $\ldots \ldots \ldots \ldots \ldots .96,329,346,417,418,502,607,724,727,733,789,887$

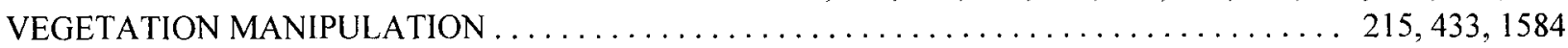

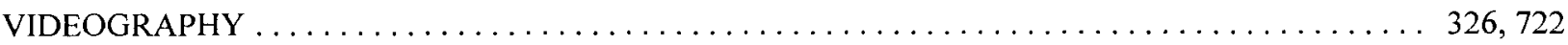

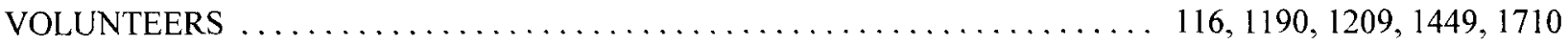

$W$

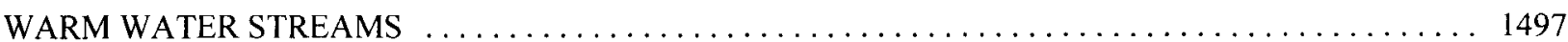

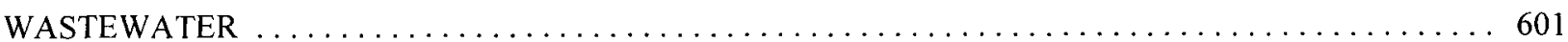

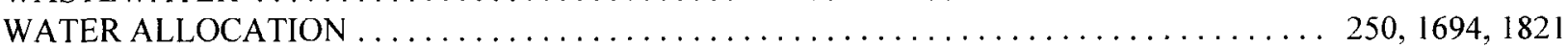

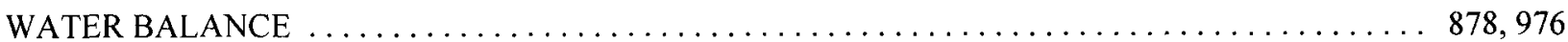

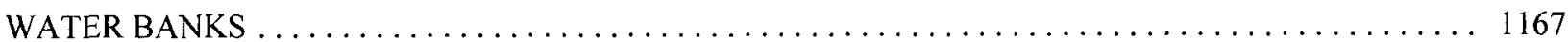

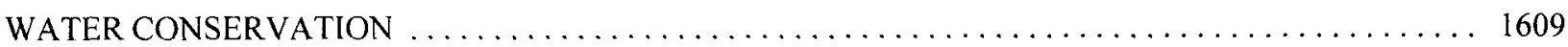




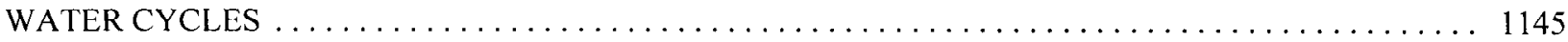

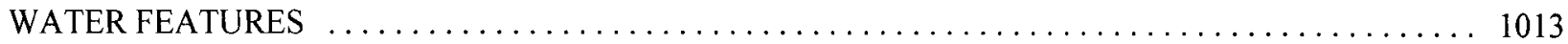

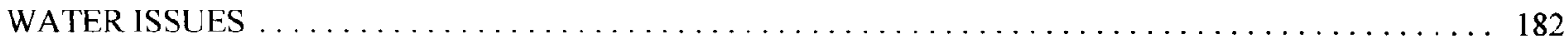

WATER LAW ............ 42, 201, 202, 454, 597, 776, 1069, 1144, 1196, 1218, 1232, 1575, 1655, 1748

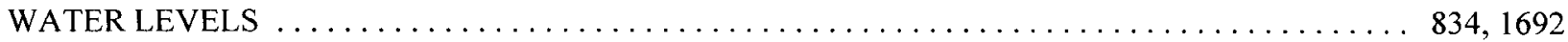

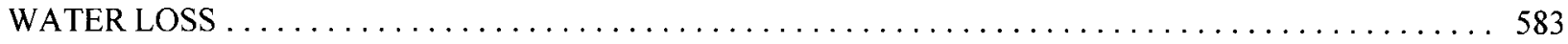

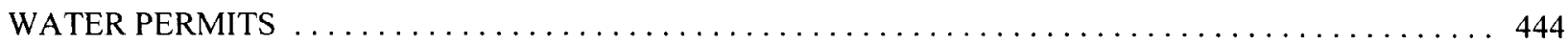

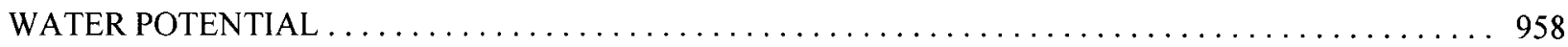

WATER QUALITY . . 6, 7, 15, 22, 24, 102, 110, 114, 125, 128, 171, 174, 175, 177, 205, 221, 230, 247, 252, 267, $297,309,316,350,352,358,366,374,381,413,417,418,421,429,430,456,459,463,470,475,503$, $531,559,592,598,601,602,608,612,615,625,668,748,776,782,809,821,823,824,830,853,856$, $872,890,1001,1050,1051,1054,1055,1079,1140,1158,1163,1165,1167,1193,1202,1213,1214$, $1218,1222,1251,1284,1303,1349,1374,1400,1420,1421,1500,1538,1543,1556,1557,1559,1560$, $1577,1593,1609,1622,1626,1628,1630,1653,1655,1694,1696,1700,1722-1725,1733,1745,1754$,

$1768,1772,1773,1779,1800,1805,1806,1818,1819,1831,1869,1874$

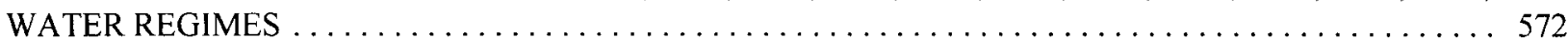

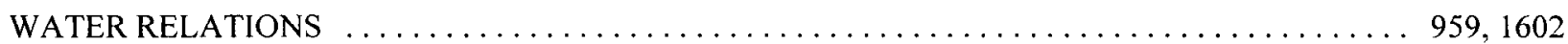

WATER RESOURCE MANAGEMENT . 68, 79, 111, 119, 185, 230, 392, 402, 473, 492, 534, 560, 585, 608, 614, $725,787,789,828,877,1002,1008,1014,1232,1386,1403,1424,1452,1479,1480,1485,1566,1665$,

1764,1784

WATER RIGHTS $\ldots .180,355,444,454,597,836,1055,1061,1144,1167,1202,1460,1575,1609,1655,1694$, $1821,1886,1888$

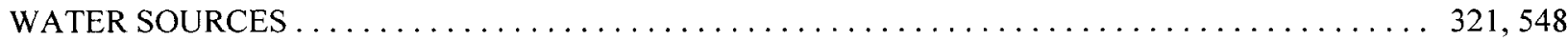

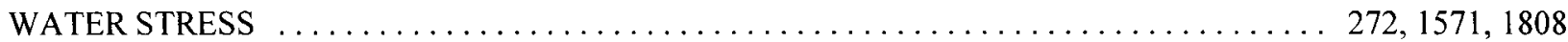

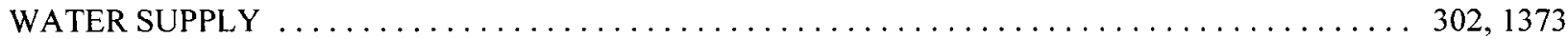

WATER TABLE EFFECTS $\ldots \ldots \ldots$ 208, 304, 342, 362, 367, 431, 434, 451, 752, 852, 1028, 1430, 1465, 1643

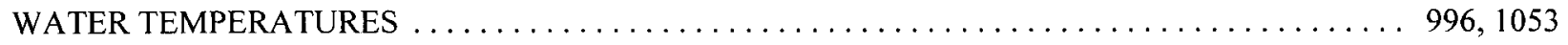

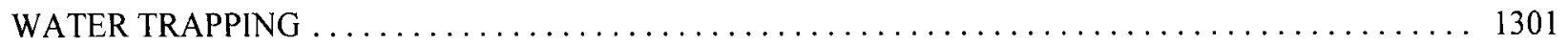

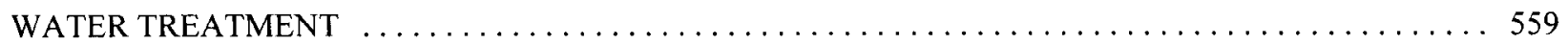

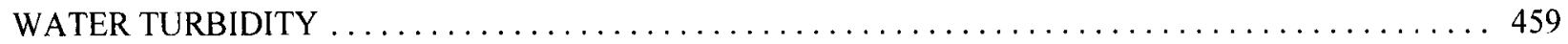

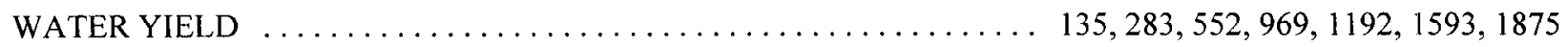

WATERFOWL MANAGEMENT $\ldots \ldots \ldots \ldots \ldots \ldots \ldots 235,660,887,1010,1100,1506,1547,1697,1825$

WATERSHED . . . 13, 15, 22, 28, 40,71, 86-88, 102, 135, 141, 152, 178, 182, 189, 205, 209, 211, 213, 220, 223, $231,246,253,256,258,274,297,304,320,352,357,418,438,439,470,472,474,480,497,519,536$, $552,559,563,574,575,579,593,600,614,615,625,626,636,638,688,695,697,698,727,732,734$, $742,762-764,821,838,853,860,883,911,915,969,974,979,982,989,995,1001,1004,1043,1113$, $1163,1178,1182,1192,1220,1227,1234,1267,1306,1314,1353,1372,1396,1420,1424,1485,1507$, $1543,1551,1557,1560,1569,1610,1622,1634,1694,1722,1731,1768,1804,1815,1829,1841,1866$,

$1869,1886,1897$

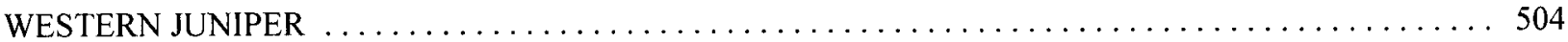

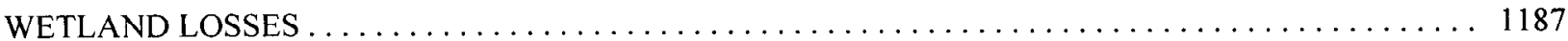

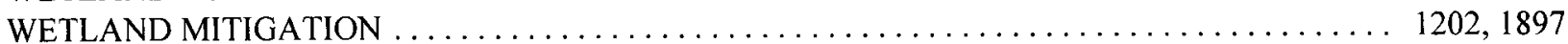

WETLAND MITIGATION BANKING $\ldots \ldots \ldots \ldots \ldots \ldots \ldots \ldots \ldots \ldots \ldots \ldots \ldots \ldots \ldots \ldots \ldots \ldots \ldots \ldots \ldots \ldots, 849,1726$

WETLANDS $\ldots 1,2,16,43,45,77,90,95,105,110,113,143,180,184,190,207,213,215,257,276,287,296$, $300,303,316,345,353,365-367,372,383,389,409,428,443,459,462,477,478,518,524,532,535$, $536,606,609,624,660,682,686,695,701,714,745,748,750,783,800,813,827,830,844,848,849$, $870,881,884,888,900,913,931,934,972,976,983,1010,1012,1020,1021,1045,1056,1061,1096$, $1109,1127,1145,1149,1156,1160,1173,1177,1181,1184,1187,1189,1201,1202,1229,1233,1237$, $1241,1246,1262,1265,1311,1361,1379-1381,1391,1393,1399,1407,1417,1433,1486,1492,1493$, $1505,1506,1540,1547,1584,1596,1597,1620,1623,1628,1633,1649,1664,1675,1709,1726,1728-$ $1730,1734-1736,1762,1766,1774,1782,1786,1789,1794,1802,1814,1825,1826,1829,1833,1840$, $1849,1850,1860,1862,1885$

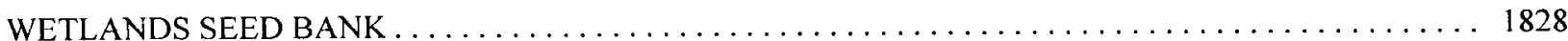

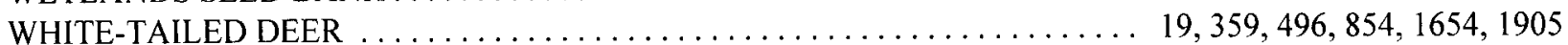




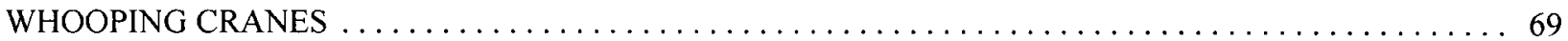

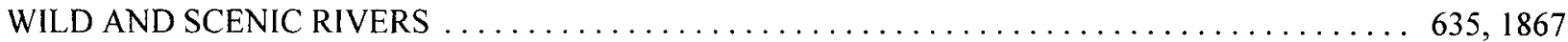

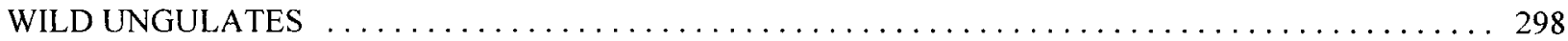

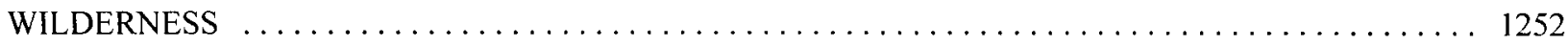

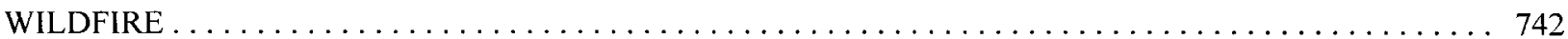

WILLOW . . . 20, 74, 85, 170, 272, 362, 389, 617, 618, 650, 746, 804, 899, 925, 955, 960, 1066, 1081, 1105, 1123 , $1275,1378,1443,1531,1546,1571,1587,1645,1656,1673,1692,1743,1790,1795$

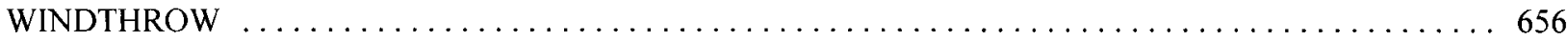

WOODY DEBRIS $\ldots \ldots \ldots \ldots \ldots \ldots 728,1063,1091,1130,1166,1236,1502,1527,1559,1601,1660,1783$

$\boldsymbol{X}$

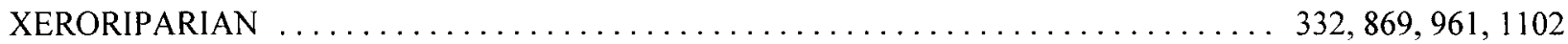

\section{$\boldsymbol{Y}$}

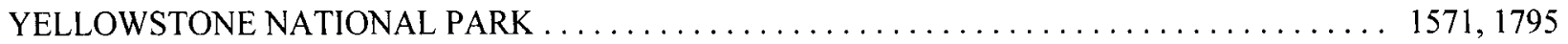

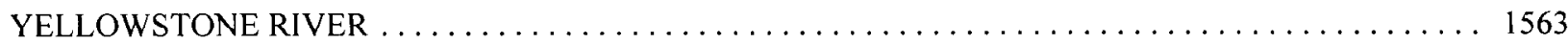

